\title{
Historic Landscape Inventory for Corinth National Cemetery
}

Susan I. Enscore, Ellen R. Hartman, and Adam D. Smith

December 2018
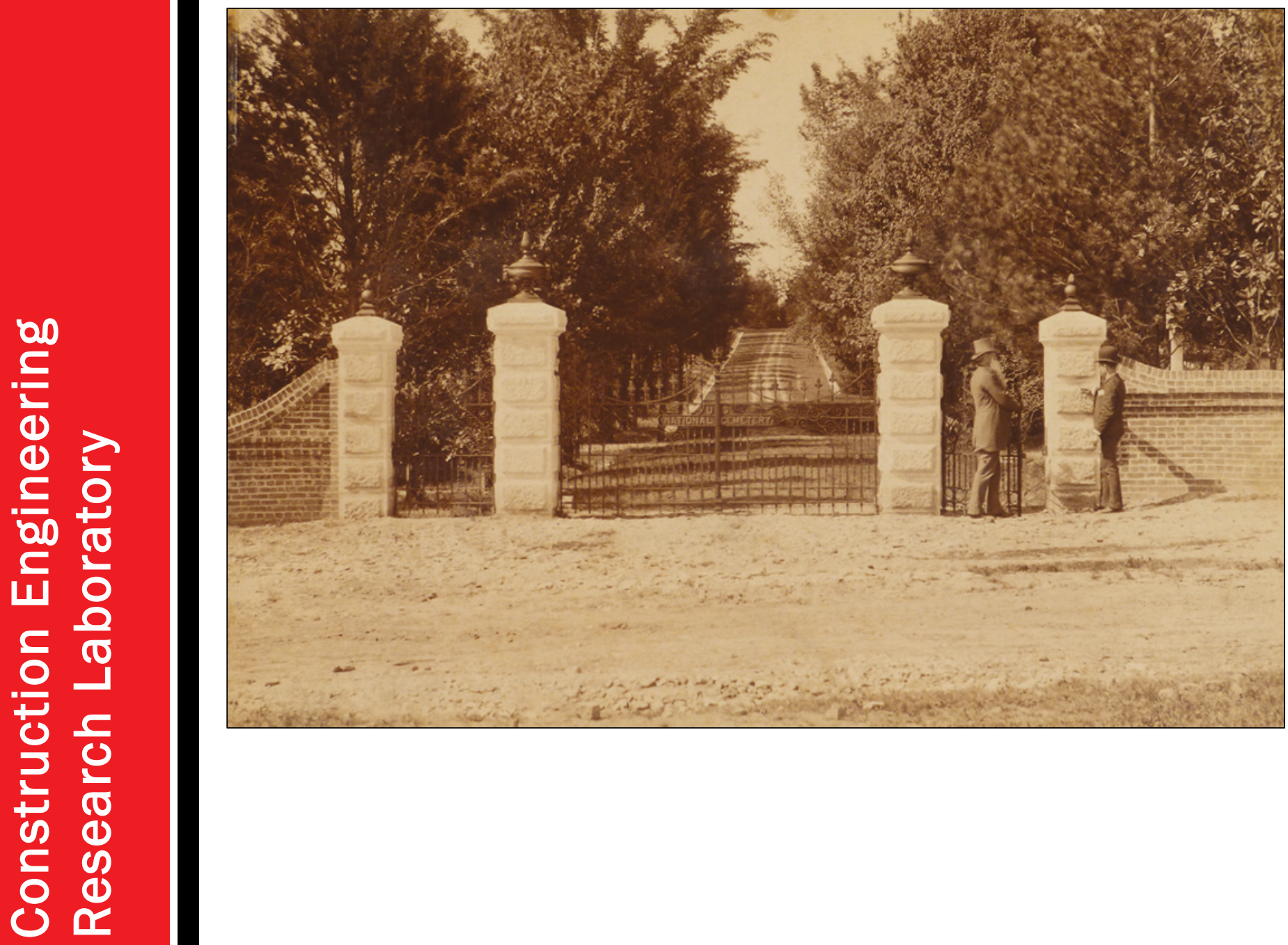
The U.S. Army Engineer Research and Development Center (ERDC) solves the nation's toughest engineering and environmental challenges. ERDC develops innovative solutions in civil and military engineering, geospatial sciences, water resources, and environmental sciences for the Army, the Department of Defense, civilian agencies, and our nation's public good. Find out more at www.erdc.usace.army.mil.

To search for other technical reports published by ERDC, visit the ERDC online library at http://acwc.sdp.sirsi.net/client/default. 


\section{Historic Landscape Inventory for Corinth National Cemetery}

Susan I. Enscore, Ellen R. Hartman, and Adam D. Smith

Construction Engineering Research Laboratory

U.S. Army Engineer Research and Development Center

2902 Newmark Drive

Champaign, IL 61822

Final report

Approved for public release; distribution is unlimited.

Prepared for U.S. Department of Veterans Affairs National Cemetery Administration Washington, DC 20420

Under Project H63F54: “Cultural Landscape Surveys for Chattanooga National Cemetery, Tennessee and Corinth National Cemetery, Mississippi" 


\section{Abstract}

This project was undertaken to provide the U.S. Department of Veterans Affairs National Cemetery Administration with a cultural landscape survey of Corinth National Cemetery. The 20-acre cemetery is located within the city limits of Corinth, Mississippi, and contains 7,892 burials. Corinth National Cemetery was placed on the National Register of Historic Places on 20 November 1996, as part of a multiple-property submission for Civil War Era National Cemeteries.

The National Cemetery Administration tasked the U.S. Army Engineer Research and Development Center-Construction Engineering Research Laboratory (ERDC-CERL) to inventory and assess the cultural landscape at Corinth National Cemetery through creation of a landscape development context, a description of current conditions, and an analysis of changes over time to the cultural landscape. All landscape features were included in the survey because according to federal policy on National Cemeteries, all national cemetery landscape features are considered to be contributing elements.

DISCLAIMER: The contents of this report are not to be used for advertising, publication, or promotional purposes. Citation of trade names does not constitute an official endorsement or approval of the use of such commercial products. All product names and trademarks cited are the property of their respective owners. The findings of this report are not to be construed as an official Department of the Army position unless so designated by other authorized documents. 


\section{Contents}

Abstract.............................................................................................................. ii

Figures and Tables....................................................................................................

Preface .........................................................................................................Xvii

Unit Conversion Factors.................................................................................................xvifi

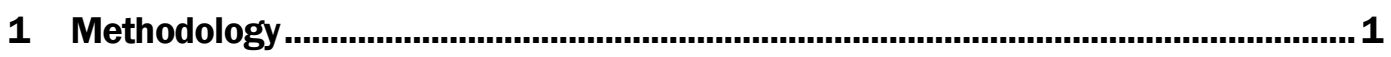

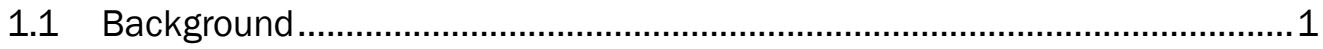

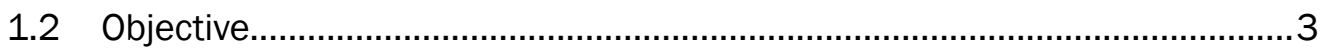

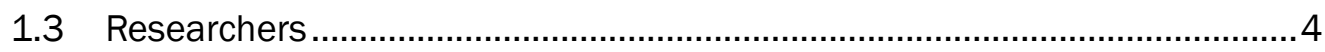

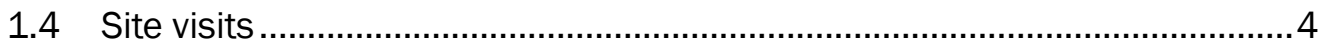

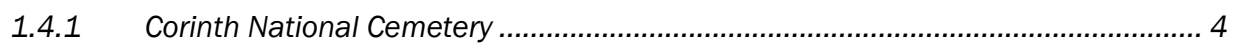

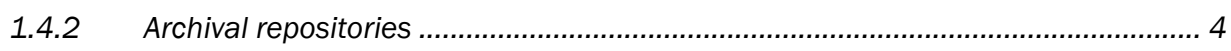

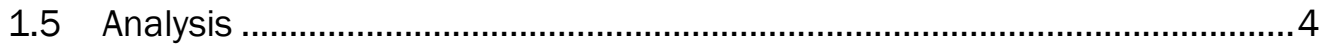

2 Landscape Development History .............................................................................. 6

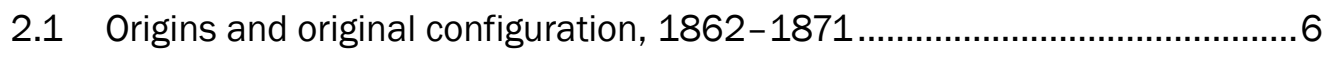

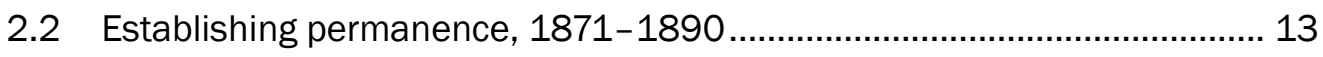

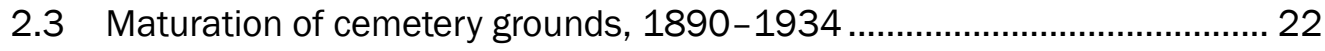

2.4 Modernization period, 1934-1954 ......................................................... 38

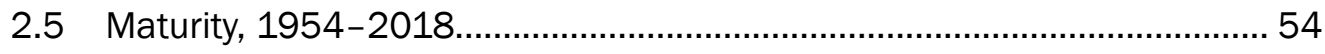

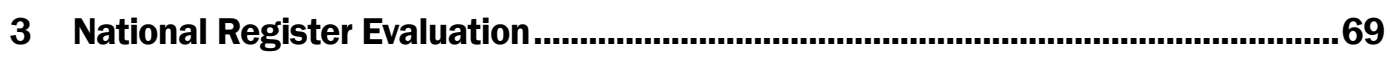

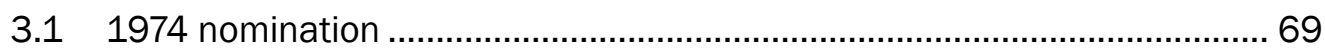

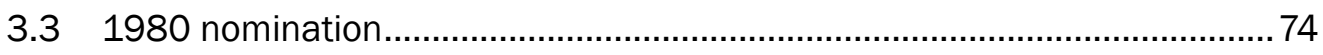

3.5 1991 Siege and Battle of Corinth Sites, National Historic Landmark

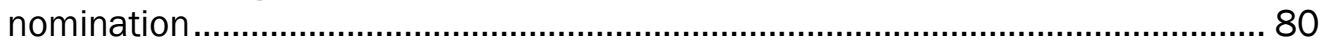

3.61996 nomination................................................................................. 83

3.7 National Register Eligibility of National Cemeteries - a Clarification

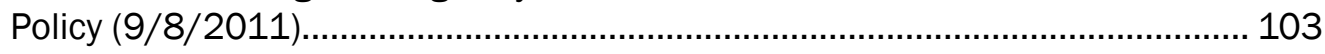

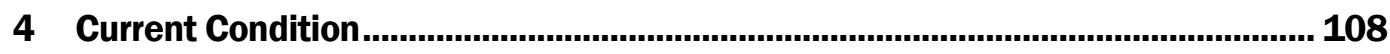

4.1 Ownership and oversight................................................................ 108

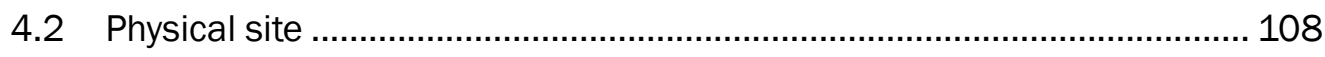

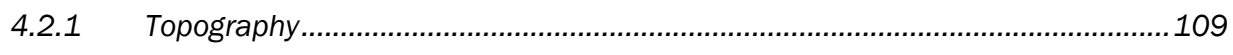

4.2.2 Spatial organization ............................................................................... 111

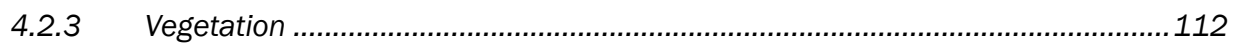

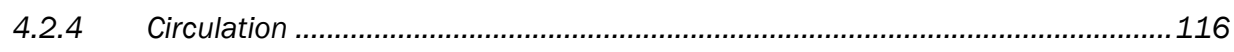

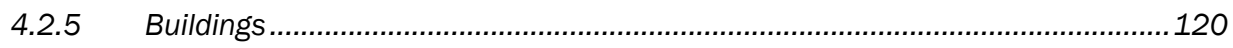

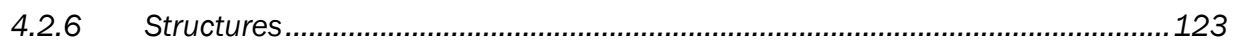

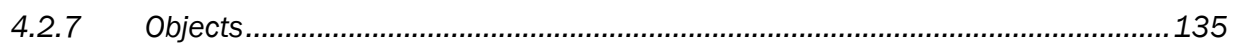

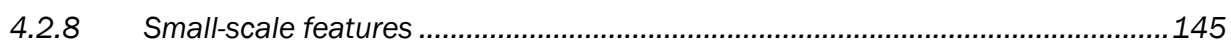




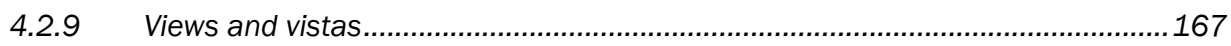

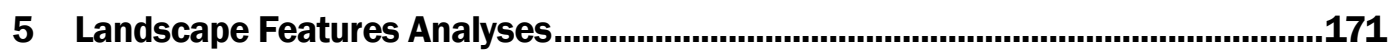

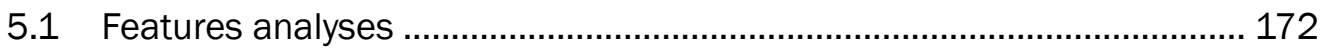

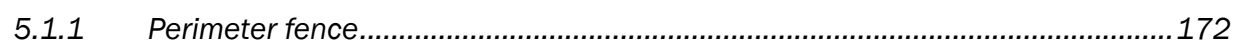

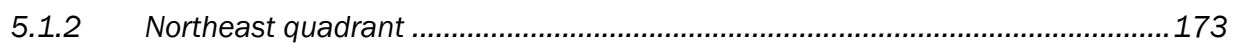

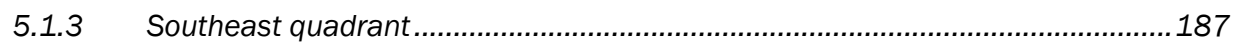

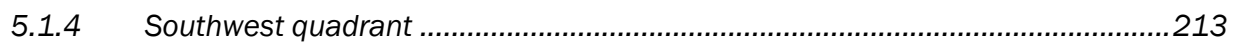

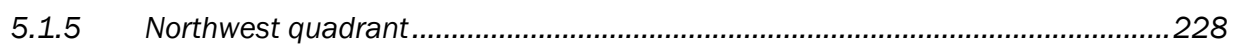

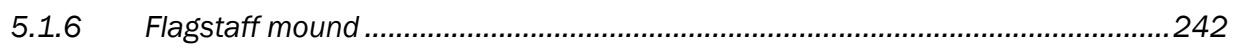

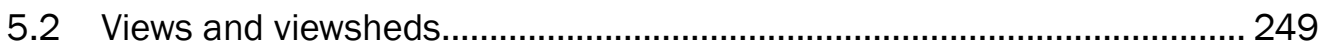

5.3 Same-scale maps ......................................................................... 256

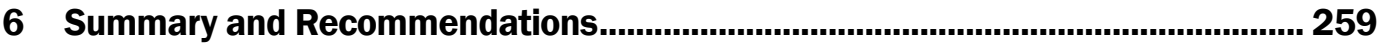

6.1 Landscape features........................................................................... 259

6.1.1 Character-defining landscape features ...........................................................259

6.1.2 Character-defining buildings and structures...................................................260

6.2 Landscape treatment................................................................... 260

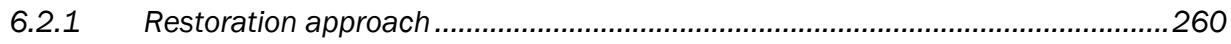

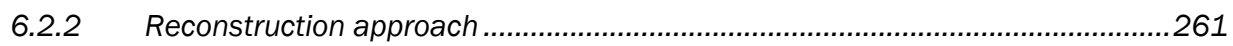

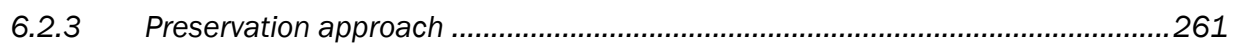

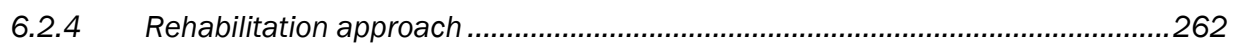

6.3 Management issues and recommendations ......................................... 262

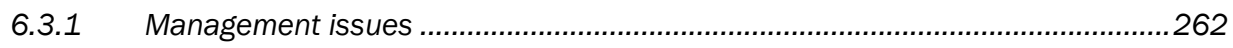

6.3.2 Historic landscape recommendations ............................................................263

Bibliography............................................................................................ 264

\section{Report Documentation Page}




\section{Figures and Tables}

\section{Figures}

Figure 1. Location of Corinth National Cemetery, Corinth, Mississippi (www.openstreetmap.org, accessed 13 September 2018)................................................. 2

Figure 2. Overall layout of Corinth National Cemetery, 2018 (ERDC-CERL).......................... 3

Figure 3. Map of collection area of Union soldier remains for internment at Corinth National Cemetery, 1868 (north is to the right) (NARA, Washington DC)............... 8

Figure 4. Early plan of Corinth National Cemetery, with burial sections and encircling drive, 1867 (NARA, Washington DC).

Figure 5. Sketch map of Corinth National Cemetery showing first lodge, stable (behind lodge), pump house, headboard house (near south fence), wooden picket fence, and original main gate, 1868 (NARA, Washington, DC).................................12

Figure 6. Plan of Corinth National Cemetery, 1868 (NARA, Washington, DC).

Figure 7. Design for Superintendents Lodge, National Cemeteries, Office of the Quartermaster General, U.S. Army, 1871 (NARA, Washington, DC)

Figure 8. National plan for tool house, woodshed, stable, and privy building, 1878 (NARA, Washington, DC).

Figure 9. Elevation and Section, Summer House, ca. 1882 (NARA, Washington, DC).

Figure 10. Section of Summer House, ca. 1882 (NARA, Washington, DC).

Figure 11. View of rostrum shortly after construction, with coursed brickwork, metal posts and railings, and stairs descending to the left, 1892 (NARA, College Park, MD).

Figure 12 . Late $19^{\text {th }}$ or early $20^{\text {th }}$ century view of markers and rostrum, probably around Memorial Day due to flags decorating graves (Cooper Postcard Collection, Mississippi Department of Archives and History).

Figure 13. "National Cemetery Corinth, Miss." 1892, Office of Quartermaster General, U.S. Army (NARA, College Park, MD).

Figure 14. Allées of trees marking the lanes on the cemetery grounds, 1892 (NARA, College Park, MD).

Figure 15. Cemetery grounds with markers, evergreen shrubs, and deciduous and evergreen trees, 1892 (NARA, College Park, MD).

Figure 16. Detail showing Lodge and Stable, map "National Cemetery Corinth, Miss." 1892, Office of Quartermaster General, U.S. Army (NARA, College Park, $\mathrm{MD})$.

Figure 17. 1892 Photograph showing brick walks, dense mixed deciduous and evergreen trees and shrubs, the gravel central avenue, a Bivouac of the Dead plaque (lower right), short brick piers at the ends of the walk, and the second lodge (NARA, College Park, MD).

Figure 18. Photograph of lodge, new south and east wall, stable, and shed with hedge delineating stable yard, and mature trees around the lodge and covering cemetery grounds, 1892 (NARA, College Park, MD). 
Figure 19. Detail showing rostrum and summer house on west side of main avenue, and brick sewer line; map "National Cemetery Corinth, Miss." 1892, Office of Quartermaster General, U.S. Army (NARA, College Park, MD).

Figure 20. Detail showing circular flagstaff area, north entry gate, encircling drive, and two gun memorials, map "National Cemetery Corinth, Miss." 1892, Office of Quartermaster General, U.S. Army (NARA, College Park, MD).

Figure 21. Twentieth-century view of a gun monument at Corinth National Cemetery (Cooper Postcard Collection, Mississippi Department of Archives and History).

Figure 22. South wall, pedestrian gate, and Lodge, 1904 (NARA, College Park, $\mathrm{MD})$.

Figure 23. View of service gate, stable/tool house building, ca. 1900 (NARA, College Park, MD).

Figure 24. South wall service gate, well house, stable/tool house, and grape arbor, ca. 1900 (NARA, College Park, MD).

Figure 25. Gettysburg Address plaque on Superintendent's Lodge at Corinth National Cemetery, 1953 (NCA archives, Washington, DC).

Figure 26. Storm damage to Superintendent's Lodge, 1909 (Cooper Postcard

Collection, Mississippi Department of Archives and History). 36

Figure 27. Photo of damage from same storm, with Lodge in the background (Cooper Postcard Collection, Mississippi Department of Archives and History). 36

Figure 28. 1906 flagpole, 1941 (NARA, Washington, DC).

Figure 29. Stable/tool house and public toilet building, with small oil house adjacent, 1931 (NARA, Washington, DC) 39

Figure 30. Cistern house adjacent to lodge, 1932 (NARA, Washington, DC).

Figure 31. Plan for 1933 standard lodge variation designed for Salisbury, Wilmington, Corinth, Memphis, Marietta, and Nashville national cemeteries (Corinth Lodge Historic Structure Assessment Report [HSAR], NCA archives, Washington, DC).

Figure 32. Elevations for the 1933 standard lodge variation constructed at Corinth National Cemetery (Corinth Lodge HSAR, NCA archives, Washington, DC)

Figure 33. Superintendent's Lodge, ca. 1934 (NCA archives, Washington, DC).

Figure 34. Superintendent's Lodge, ca. 1948, with maturing evergreen shrubs (NCA archives, Washington, DC).

Figure 35. Side view of lodge with family entrance, 1954, showing removal of vegetation around lodge foundation and yard (Corinth Lodge HSAR, NCA archives, Washington, DC).

Figure 36. 1936 Utility Building, ca. 1942 (NARA, Washington, DC).

Figure 37. Addition to right-hand side of Utility Building, as it appeared in 1955 (NARA, Washington, DC).

Figure 38. 1936 section of Utility Building with new overhead door (open at left), 1955 (NARA, Washington, DC).

Figure 39. Rostrum prior to 1942 (NARA, Washington, DC). 46

Figure 40. 1947 flagpole, c. 1953 (NARA, Washington, DC).

Figure 41. Main entrance gate, 1954 (NARA, Washington, DC). 
Figure 42. Central cemetery avenue, ca. 1947 (NARA, Washington, DC)..........................48

Figure 43. Main entrance gate, 1946 (NCA archives, Washington, DC)............................49

Figure 44. New wall, looking east along Horton Street toward the main entrance,

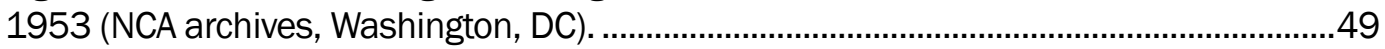

Figure 45. Pedestrian gate in 1946 (NCA archives, Washington, DC) .............................50

Figure 46. Pedestrian gate and walls in 1953 (NCA archives, Washington, DC)...............50

Figure 47. Utility gate in 1946 (NCA archives, Washington, DC)........................................51

Figure 48. Utility gate in 1953 (NCA archives, Washington, DC).......................................51

Figure 49. North entrance gate in 1953 (NCA archives, Washington, DC).........................52

Figure 50. Corinth National Cemetery, 1948 (NCA archives, Washington, DC)..................53

Figure 51. Corinth National Cemetery, spring 1948 (NCA archives, Washington, DC).

Figure 52. Plan of Sections A, E F, I, U, \& V, 1954 (NCA archives, Washington, DC)..........54

Figure 53. Plan of Sections C, L, P \& W, 1954 (NCA archives, Washington, DC).................55

Figure 54. Plan of Sections D, M, N, O \& R, 1954 (NCA archives, Washington, DC).

Figure 55. Plan of Sections B, G, H, K, S \& T, 1954 (NCA archives, Washington,

$\mathrm{DC})$.

Figure 56. Drainage system construction in 1954 (NCA archives, Washington,

$\mathrm{DC})$.

Figure 57. New bronze plaques on pillars of main entrance gates, 1960 (NARA,

Washington, DC). 58

Figure 58. Corinth National Cemetery, May 1963 (NARA, Washington, DC).

Figure 59. Aerial photograph of Corinth National Cemetery, 1963 (Library of Congress, HALS MS-3).

Figure 60. Aerial photograph of Corinth National Cemetery, 1968 (Library of Congress, HALS MS-3).

Figure 61. Lodge at southwest corner, with asphalt shingles, awnings, and mature shrubs, ca. 1970s (Corinth Lodge HSAR, NCA archives, Washington, DC).

Figure 62. East elevation of lodge with awnings, evergreen trees, mature shrubs, and privacy fence, ca. 1970s (Corinth Lodge HSAR, NCA archives, Washington, $\mathrm{DC})$.

Figure 63. South elevation of lodge, 1996 (Corinth Lodge HSAR, NCA archives,

Washington, DC).

Figure 64. Replica Gettysburg Address tablet, 2018 (ERDC-CERL)...................................67

Figure 65. Seabee monument, 2018 (ERDC-CERL).

Figure 66. Reproduction of pages with NRHP nomination of the Corinth National Cemetery, 1974 (NCA, Washington, DC).

Figure 67. Reproduction of pages with NRHP nomination of the Corinth National Cemetery, 1980 (NCA archives, Washington, DC).

Figure 68. Reproduction of pages concerning the Corinth National Cemetery in the NHL registration form for the Siege and Battle of Corinth Sites, 1991 (NCA). 
Figure 69. Reproduction of registration form for Corinth National Cemetery nomination to NRHP, 1996 (NCA).

Figure 70. Reproduction of "A Clarification of Policy" for National Register eligibility of national cemeteries, 2011 (NPS).

Figure 71. Exaggerated topographic section of Corinth National Cemetery, 2018 (ERDC-CERL).

Figure 72. Diagram of tree cover in Corinth National Cemetery, 2018 (ERDC-

CERL).

Figure 73. Crape myrtles line the sidewalk from the main road to the

Superintendent's Lodge, 2018 (ERDC-CERL).

Figure 74. Seating area with shrubs and white rocks, 2018 (ERDC-CERL).

Figure 75. Seating area, view from the north, 2018 (ERDC-CERL). 115

Figure 76. Circulation diagram showing the paved roads in dark yellow, the main grassed drives in green, and the sidewalks in yellow, 2018 (ERDC-CERL).

Figure 77. Asphalt paving in 2018 (ERDC-CERL).

Figure 78. Grass drives and aisles in 2018 (ERDC-CERL). 119

Figure 79. Concrete sidewalks (shaded in yellow) in 2018 (ERDC-CERL). 120

Figure 80. Front facade of the superintendent's lodge-the house faces south, 2018 (ERDC-CERL).

Figure 81. Oblique view of the southeast corner of the superintendent's lodge, 2018 (ERDC-CERL).

Figure 82. North (rear) side of the Superintendent's Lodge, 2018 (ERDC-CERL)............ 122

Figure 83. West side of the Superintendent's lodge, 2018 (ERDC-CERL)......................... 122

Figure 84. Utility building in the maintenance area. The single door is the visitor comfort station, 2018 (ERDC-CERL).

Figure 85. The location of structures at Corinth National Cemetery, 2018 (ERDC-

CERL).

Figure 86. View of the varying heights of the perimeter wall, 2018 (ERDC-CERL)......... 125

Figure 87. Detail of a recent repair to the perimeter wall, 2018 (ERDC-CERL)............... 125

Figure 88. The main gate at Corinth National Cemetery, 2018 (ERDC-CERL). 126

Figure 89. Showing one of two wrought-iron pedestrian gates that are part of the main gate, 2018 (ERDC-CERL).

Figure 90. East side of the wrought-iron road gate, 2018 (ERDC-CERL)......................... 128

Figure 91. West side of the wrought-iron road gate, 2018 (ERDC-CERL).

Figure 92. Example of the decorative urns on the central piers of the main gate, 2018 (ERDC-CERL).

Figure 93. Looking north at bronze plaques on south side of the main gate piers, 2018 (ERDC-CERL).

Figure 94. North gates for vehicles and pedestrian at Corinth National Cemetery, 2018 (ERDC-CERL).

Figure 95. An additional pedestrian gate on the south wall of the cemetery, is located near the Lodge, not adjacent to the main gate entrance as the other two 
pedestrian gates on the south wall are. The wrought-iron gate is propped open in this 2018 photo (ERDC-CERL).

Figure 96 . Gate and post detail on the additional south side's pedestrian-only gate, 2018 (ERDC-CERL).

Figure 97. The service gate on the south wall, 2018 (ERDC-CERL).

Figure 98. Looking south at the committal shelter near the south main gate, 2018 (ERDC-CERL).

Figure 99. Storage shed in the maintenance area, 2018 (ERDC-CERL).

Figure 100. In the maintenance area is an open-air storage shelter for machinery, 2018 (ERDC-CERL).

Figure 101. To the left of the maintenance building is another open-air storage shelter, 2018 (ERDC-CERL).

Figure 102. Rows of Civil War headstones featuring the original dimensions and layout of the markers in the center and right of the photo. Markers on the left show the wider and taller dimensions, 2018 (ERDC-CERL).

Figure 103. Grave markers displaced by tree growth were laid flat to the ground near their original locations, 2018 (ERDC-CERL).

Figure 104. Example of one of the Confederate grave markers in Corinth National Cemetery, 2018 (ERDC/CERL).

Figure 105. Section of Civil War unknown dead, 2018 (ERDC-CERL)

Figure 106. Civil War unknown dead marker, with grave number inscribed on the top face, 2018 (ERDC-CERL).

Figure 107. The Civil War unknown dead grave markers have been raised, 2018 (ERDC-CERL).

Figure 108. The original design of gravestones mixed with the new style of markers, 2018 (ERDC-CERL).

Figure 109. Nonstandard grave marker for Ross Negley, who died in 1862, 2018 (ERDC-CERL).

Figure 110. Grave marker for Rufus Taylor, superintendent of Corinth National Cemetery, who died in 1929, 2018 (ERDC-CERL).

Figure 111. Non-standard grave maker design for Superintendent Rufus Taylor, 2018 (ERDC-CERL).

Figure 112. Non-standard grave marker, 2018 (ERDC-CERL).

Figure 113. View looking south at the flagstaff mound, 2018 (ERDC-CERL).

Figure 114. Grouping of memorial headstones north of the Corinth flagstaff mound, 2018 (ERDC-CERL).

Figure 115. Granite marker with explanatory text for the memorial area in Corinth National Cemetery, 2018 (ERDC-CERL).

Figure 116. Navy Seabee memorial, 2018 (ERDC-CERL).................................................. 145

Figure 117. Concrete bench, 2018 (ERDC-CERL).............................................................. 146

Figure 118. Near the main entrance there are several signs in a variety of designs and materials, 2018 (ERDC-CERL).

Figure 119. Signboard west of the main road with posted informational flyers on both sides, 2018 (ERDC-CERL). 
Figure 120. Sign and mailbox with the grave locator, 2018 (ERDC-CERL)...................... 148

Figure 121. Sign that displays the history behind the formation of the national cemetery system, 2018 (ERDC-CERL). ........................................................................ 148

Figure 122. Sign outlining rules of conduct in the cemetery, 2018 (ERDC-CERL).......... 149

Figure 123. Small sign that directs visitors toward the restrooms, 2018 (ERDCCERL).

Figure 124. One of several signs outside the perimeter wall prohibiting weapons in the cemetery, 2018 (ERDC-CERL).

Figure 125. US Government property, no trespassing sign near the maintenance area, 2018 (ERDC-CERL).

Figure 126. Speed limit sign along the main road, 2018 (ERDC-CERL).

Figure 127. Plaque near the flagstaff mound inscribed with the text from Section

3 of the act that formed the national cemetery system, 2018 (ERDC-CERL). .

Figure 128. Plaque near the flagstaff mound with a passage from the poem, The Bivouac of the Dead, 2018 (ERDC-CERL). .................................................................... 153

Figure 129. The Gettysburg tablet near the main entrance, 2018 (ERDC-CERL)........... 154

Figure 130. Granite section markers for Sections R, S, M, and K, 2018 (ERDCCERL).

Figure 131. Concrete water channel running through the eastern section of the cemetery, 2018 (ERDC-CERL).

Figure 132. Concrete channel and gutter on the east side of the cemetery, 2018 (ERDC-CERL).

Figure 133. Concrete water channel damage revealing the brick underneath, 2018 (ERDC-CERL).

Figure 134. Continuation of the concrete channel west of the main road, 2018 (ERDC-CERL).

Figure 135. Concrete panels over stormwater inlets in the northwest corner of the cemetery, 2018 (ERDC-CERL).

Figure 136. Example of the type of steel grate used near the main entrance, 2018 (ERDC-CERL).

Figure 137. Fire hydrant, 2018 (ERDC-CERL). 160

Figure 138. Water spigot south of the maintenance road, 2018 (ERDC-CERL) .............. 160

Figure 139. Irrigation control box near the main entrance, 2018 (ERDC-CERL). 161

Figure 140. Example of the irrigation system control valve found throughout the site, 2018 (ERDC-CERL).

Figure 141. Example of trash receptacle located near the main entrance and flagstaff mound, 2018 (ERDC-CERL).

Figure 142. Second type of trash receptacle located in the landscaped area east of the main road, 2018 (ERDC-CERL).

Figure 143. LED floodlight on the flagstaff mound, 2018 (ERDC-CERL) .......................... 163

Figure 144. LED floodlight on the flagstaff mound, 2018 (ERDC-CERL).......................... 164

Figure 145. Security light near the main entrance, 2018 (ERDC-CERL)............................ 164

Figure 146. Mailbox near the superintendent's lodge, 2018 (ERDC-CERL)...................... 165 
Figure 147. Receptacle for storing reusable flower stands located along the main road north of the main entrance, 2018 (ERDC-CERL).

Figure 148. Outdoor ashtray made out of brown aggregate. Located near the committal shelter, 2018 (ERDC-CERL).

Figure 149. Survey marker set in concrete, 2018 (ERDC-CERL).

Figure 150. Viewshed from the flagstaff mound looking south toward the main entrance, 2018 (ERDC-CERL).

Figure 151. View from the flagstaff south to the main gate, 2018 (ERDC-CERL)............ 168

Figure 152. Viewshed from the main gate toward the flagstaff mound, 2018 (ERDC-CERL).

Figure 153. View from the main gate looking north toward the flagstaff mound, 2018 (ERDC-CERL).

Figure 154. Secondary viewsheds along allée and towards lodge, 2018 (ERDCCERL).

Figure 155. Corinth National Cemetery divided into quadrants for landscape feature analysis. Gray shading indicates those sections that have burials, 2018 (ERDC/CERL).

Figure 156. The northeast quadrant of an undated preliminary design for the Corinth National Cemetery. Several of the design features were carried through into what was constructed (NARA, College Park, MD).

Figure 157. Photograph of the gun monuments in Corinth National Cemetery,

Sections $A$ and $B$, undated (NCA archives, Washington, DC).

Figure 158. A tall, sphere-topped section marker is shown to the right of the image here, which has been cropped from an undated postcard of Corinth National Cemetery (NCA archives, Washington, DC).

Figure 159. Plan of the northeast quadrant of Corinth National Cemetery, drawn in 1892 (NCA archives, Washington, DC).

Figure 160. Spring 1948, looking across a section of graves for Unknown

Soldiers at Corinth National Cemetery. There are many trees and shrubs arrayed across the site (NCA archives, Washington, DC).

Figure 161. The 1954 plan of the northeast quadrant of Corinth National Cemetery (NCA archives, Washington, DC).

Figure 162. View toward the northeast corner of Corinth National Cemetery in April 1954 (NCA archives, Washington, DC).

Figure 163. View looking east along the north perimeter wall of Corinth National Cemetery in April 1954. Note the size of the deciduous trees along the wall (NCA archives, Washington, DC).

Figure 164. View looking east from flagstaff mound in April 1954. Note the decrease in vegetation across the quadrant (NCA archives, Washington, DC).

Figure 165. 1964 planting plan of the northeast quadrant of Corinth National Cemetery (NCA archives, Washington, DC).

Figure 166. View west through the northeast quadrant of Corinth National Cemetery, toward the flagpole in September 1974 (NCA archives, Washington, $\mathrm{DC})$. 
Figure 167. 1983 plan of the northeast quadrant of Corinth National Cemetery (NCA archives, Washington, DC).

Figure 168. 1983 planting maintenance plan for the northeast quadrant of Corinth National Cemetery (NCA archives, Washington, DC).

Figure 169. Plan of the northeast quadrant of Corinth National Cemetery in 2009

(Veteran's Administration).

Figure 170. Undated design scheme for Corinth National Cemetery southeast quadrant (NCA archives, Washington, DC).

Figure 171. 1892 plan of Corinth National Cemetery southeast quadrant (NCA archives, Washington, DC).

Figure 172. View of the lodge and stable area at Corinth National Cemetery in 1892. There is a hedge that defines the maintenance area. The well has yet to be covered with a structure. Vegetation in various stages of growth frames the background, 1892 (NARA, College Park, MD).

Figure 173. View of the pedestrian gate, wall, and lodge as well as vegetation in 1904 (NARA, College Park, MD).

Figure 174. Maintenance area showing the gate, well, and stable at Corinth National Cemetery. The background on the left is the grape arbor, 1904 (NARA, College Park, MD).

Figure 175. A pedestrian gate at Corinth National Cemetery, 1946. View is from the city street toward lodge at right (NCA archives, Washington, DC).

Figure 176. View of the maintenance gate at Corinth National Cemetery in 1946. In the background are highly manicured shrubs and hedges. Evergreens fill the space between the maintenance area and the lodge (NCA archives, Washington, $\mathrm{DC})$.

Figure 177. Utility building west facade 1946 . The building is framed by vegetation, including a willow to the northeast (NCA archives, Washington, DC).

Figure 178. View at southeast corner of the Corinth National Cemetery, showing the maintenance building surrounded by mature vegetation, August 1947 (NCA archives, Washington, DC).

Figure 179. View of the north façade of the maintenance building at Corinth

National Cemetery in 1946. The walk to the visitor restrooms is lined with vegetation (NCA archives, Washington, DC).

Figure 180. View of the north and west sides of the lodge at Corinth National

Cemetery in October 1946 (NCA archives, Washington, DC).

Figure 181. 1954 plan of the southeast quadrant of Corinth National Cemetery (NCA archives, Washington, DC).

Figure 182. View of the perimeter wall at Corinth National Cemetery. looking east along Horton Street in 1953. There are no street trees in the verge between the street and the wall (NCA archives, Washington, DC).

Figure 183. Single pedestrian gate in in southeast quadrant of Corinth National Cemetery, July 1953. Note the standing plaque inside the gate (NCA archives, Washington, DC).

Figure 184. Maintenance gate in 1953 at Corinth National Cemetery. Note the plaque inside the gate (NCA archives, Washington, DC). 
Figure 185. View north toward the flagpole from the pedestrian entrance at Corinth National Cemetery, April 1954 (NCA archives, Washington, DC).

Figure 186. View northeast across Section $L$ from the north side of the lodge at Corinth National Cemetery, July 1953 (NCA archives, Washington, DC).

Figure 187. View north along east wall at Corinth National Cemetery in April 1954 (NCA archives, Washington, DC).

Figure 188. West façade of the maintenance building and surrounding area at Corinth National Cemetery in July 1953 (NCA archives, Washington, DC).

Figure 189. Rear of maintenance building at Corinth National Cemetery, with new addition in July 1953 (NCA archives, Washington, DC).

Figure 190. East elevation of the lodge at Corinth National Cemetery in July 1953 (NCA archives, Washington, DC).

Figure 191. Concrete walk leading east from Cemetery Drive toward west side of the lodge, with newly planted shrubs lining the walk, July 1953 (NCA archives, Washington, DC).

Figure 192. Looking southeast toward west side of the lodge and surrounding area at Corinth National Cemetery, April 1954 (NCA archives, Washington, DC).

Figure 193. Northeast oblique of lodge at Corinth National Cemetery, April 1954 (NCA archives, Washington, DC).

Figure 194. Metal tablet on south façade of lodge near the front door, July 1953, at Corinth National Cemetery (NCA archives, Washington, DC).

Figure 195. Concrete drainage ditch in the southeast quadrant of Corinth

National Cemetery. View is looking west, July 1953 (NCA archives, Washington, $\mathrm{DC})$.

Figure 196. Drainage ditch along Cemetery Drive, looking north in Corinth National Cemetery, July 1953 (NCA archives, Washington, DC).

Figure 197. Drainage ditch in the southeast quadrant of Corinth National Cemetery, view looking east from Cemetery Drive in April 1954 (NCA archives, Washington, DC).

Figure 198. 1964 planting plan for the southeast quadrant of Corinth National Cemetery (NCA archives, Washington, DC).

Figure 199. Southwest oblique of the lodge in 1977 (NCA archives, Washington, $\mathrm{DC})$.

Figure 200. East elevation of lodge at Corinth National Cemetery in 1977 (NCA archives, Washington, DC).

Figure 201. North elevation of lodge at Corinth National Cemetery, 1977 (NCA archives, Washington, DC).

Figure 202. Burial plan for the southeast quadrant of Corinth National Cemetery, 1983 (NCA archives, Washington, DC).

Figure 203. The tree and shrub maintenance plan from 1883 shows the density of vegetation throughout the southeast quadrant (NCA archives, Washington, $\mathrm{DC})$.

Figure 204. The southeast quadrant burial plan in 2009 (NCA archives, Washington, DC). 
Figure 205. Undated preliminary design for the southwest quadrant of Corinth National Cemetery (NCA archives, Washington, DC).

Figure 206. The 1892 plan of the southwest quadrant showing the spatial layout, headstone patterns of Sections $\mathrm{D}$ and $\mathrm{M}$, and the vegetation patterns (NCA archives, Washington, DC).

Figure 207. View east toward the rostrum, 1892 (NARA, College Park, MD).

Figure 208. Plan of the south entrance and surrounding area, 1892 (NCA archives, Washington, DC).

Figure 209. South entrance in 1892, with pedestrian gates on either side (NARA, College Park, MD).

Figure 210.View east toward the lodge showing the cemetery's main road, brick walks, and vegetation around the south entrance, 1892 (NARA, College Park, $\mathrm{MD})$.

Figure 211. Old main gate in October 1946 (NCA archives, Washington, DC). 218

Figure 212. 1954 burial plan for the southwest quadrant (NCA archives, Washington, DC).

Figure 213. Perimeter wall looking west along Horton Street, April 1954 (NCA archives, Washington, DC).

Figure 214. View toward the southwest corner of the cemetery in April 1954 (NCA archives, Washington, DC).

Figure 215. Drainage ditch running through the southwest quadrant. View looking south from Cemetery Drive, July 1953 (NCA archives, Washington, DC). 221

Figure 216. Planting plan of the southwest quadrant in 1964 (NCA archives, Washington, DC).

Figure 217. View southwest across Section D, showing a fairly mature White Oak in the foreground, May 1964 (NCA archives, Washington, DC).

Figure 218. Southwest corner looking northeast taken in June 1974 (NCA archives, Washington, DC).

Figure 219. Main entrance gate in June 1974 (NCA archives, Washington, DC) 225

Figure 220. 1983 burial plan for the southwest quadrant of Corinth National Cemetery (NCA archives, Washington, DC).

Figure 221. 1983 vegetation maintenance plan for the southwest quadrant (NCA archives, Washington, DC).

Figure 222. 2009 burial plan of the southwest quadrant (Veteran's Administration).

Figure 223. The layout of the northwest quadrant on the preliminary plan for the Corinth National Cemetery (NCA archives, Washington, DC).

Figure 224. Plan of the northwest quadrant of Corinth National Cemetery, 1892 (NCA archives, Washington, DC).

Figure 225. North entrance shown on the 1892 plan for Corinth National Cemetery (NCA archives, Washington, DC).

Figure 226. The layout of the north entrance gate at Corinth National Cemetery, as it appeared in 1892 (NARA, College Park, MD).

Figure 227. View of the north entrance at Corinth National Cemetery, unknown date (NARA, College Park, MD). 
Figure 228. 1954 burial plan for the northwest quadrant (NCA archives, Washington, DC)

Figure 229. View northwest from the flagstaff mound in April 1954 (NCA archives, Washington, DC).

Figure 230. View west showing the north perimeter wall in April 1954 (NCA archives, Washington, DC).

Figure 231. View of the northwest corner in April 1954 (NCA archives, Washington, DC).

Figure 232. The vegetation plan in 1964 (NCA archives, Washington, DC).

Figure 233. Elm tree in Section B looking west in May 1964 (NCA archives, Washington, DC).

Figure 234. Burial plan of the northwest quadrant in 1983 (NCA archives, Washington, DC).

Figure 235. Vegetation plan of the northwest quadrant in 1983 (NCA archives, Washington, DC).

Figure 236. 2009 burial plan for the northwest quadrant (Veteran's Administration)

Figure 237. The undated preliminary design for the roundabout in the main road at Corinth National Cemetery with specified graves for the interior circle (NCA archives, Washington, DC).

Figure 238. Plan of the flagstaff mound on the 1892 cemetery plan (NCA

archives, Washington, DC)

Figure 239. Flagstaff mound in 1954 (NCA archives, Washington, DC).

Figure 240. View looking north toward the flagstaff mound in April 1954 (NCA archives, Washington, DC).

Figure 241. View looking north of the flagstaff mound from Cemetery Drive, April 1954 (NCA archives, Washington, DC).

Figure 242. View from the flagstaff mound south to the main entrance in August 1963 (NCA archives, Washington, DC).

Figure 243. Flagstaff view to the south September 1974 (NCA archives, Washington, DC).

Figure 244. Flagstaff mound view to the north in September 1974 (NCA archives, Washington, DC).

Figure 245. View of the flagstaff mound looking south from the north entrance, 2018 (ERDC/CERL).

Figure 246. View north from the main gate in 1892 and 2018 (NCA archives, Washington, DC and ERDC-CERL).

Figure 247. View south from the flagstaff mound toward the main gate in 1963 and 2018 (NCA archives, Washington, DC and ERDC-CERL).

Figure 248. View east from the southwest corner of Corinth National Cemetery toward the lodge in 1892 and 2018 (NCA archives, Washington, DC and ERDCCERL).

Figure 249. View north across the southwest quadrant between Sections $D$ and $M$ in 1892 and 2018 (NCA archives, Washington, DC and ERDC-CERL). 
Figure 250. Views from same location showing headstone arrangement from 1892 and 2018, using outlined photo as the reference point. Note that headstone facing direction has changed from west to east. (NCA archives, Washington, DC and ERDC-CERL).

Figure 251. Two photos from another location within cemetery of historic photo from 1892 and a 2018 photo, showing comparison of headstone arrangement, using the outlined headstone as the reference point. Note that headstones were facing west and now face east. (NCA archives, Washington, DC and ERDC-CERL)........ 255 Figure 252. Sequence of proposed designs for Corinth National Cemetery in 1864 through a plan of the cemetery in 1892 (NCA archives, Washington, DC)............ 257 Figure 253. Sequence of aerial images from the late 1940s through 2015 (NCA archives, Washington, DC and Google Earth).

\section{Tables}

Table 1. Facilities transferred to the Veterans Administration in 1973 (NCA archives, Washington, DC).

Table 2. List of trees at Corinth National Cemetery in May 2018 (ERDC-CERL).............. 116

Table 3. List of shrubs at Corinth National Cemetery in May 2018 (ERDC-CERL)........... 116 


\section{Preface}

This study was conducted for the U.S. Department of Veterans Affairs National Cemetery Administration under Project H63F54, "IAA with National Cemetery Admin - Cultural Landscape Surveys for Chattanooga National Cemetery and Corinth National Cemetery.” The technical monitor was Mr. W. Edward Hooker III (Historic Architect/Cultural Resources Manager, National Cemetery Administration).

The work was performed by the Land and Heritage Conservation Branch (CNC) of the Installations Division (CN), U.S. Army Engineer Research and Development Center - Construction Engineering Research Laboratory (ERDC-CERL). At the time of publication, Dr. Michael Hargrave was Chief, CEERD-CNC; and Ms. Michelle J. Hanson was Chief, CEERD-CN. The Deputy Director of ERDC-CERL was Dr. Kirankumar V. Topudurti, and the Director was Dr. Lance D. Hansen.

Col. Ivan P. Beckman was the Commander of ERDC, and Dr. David W. Pittman was the Director. 


\section{Unit Conversion Factors}

\begin{tabular}{|c|c|c|}
\hline Multiply & By & To Obtain \\
\hline acres & $4,046.873$ & square meters \\
\hline feet & 0.3048 & meters \\
\hline gallons (U.S. liquid) & 3.785412 E-03 & cubic meters \\
\hline inches & 0.0254 & meters \\
\hline square feet & 0.09290304 & square meters \\
\hline square yards & 0.8361274 & square meters \\
\hline yards & 0.9144 & meters \\
\hline
\end{tabular}




\section{Methodology}

\subsection{Background}

The U.S. Congress codified the National Historic Preservation Act of 1966 (NHPA), which is the nation's most effective cultural resources legislation to date, in order to provide guidelines and requirements for preserving tangible elements of our nation's past. This preservation was done primarily through creation of the National Register of Historic Places (NRHP). Contained within this piece of legislation are requirements for federal agencies to address their cultural resources, defined as any prehistoric or historic district, site, building, structure, or object (NHPA Sections 110 and 106). Section 110 requires federal agencies to inventory and evaluate their cultural resources. Section 106 requires the determination of the effects of federal undertakings on properties deemed eligible or potentially eligible for the NRHP.

The U.S. Department of Veterans Affairs (VA) National Cemetery Administration (NCA) administers 135 of the 149 National Cemeteries in the United States. The NCA was created in 1998 from the National Cemeteries System (NCS). The NCS had been created in 1973and at that time, 83 National Cemeteries were transferred from the Department of the Army to the VA, and those joined the 21 cemeteries located at hospitals and nursing homes that already were being administered by the VA. Corinth National Cemetery was placed on the NRHP in 1991 as a contributing resource in the National Historic Landmark historic district designated as "Siege and Battle of Corinth Sites" under NRHP criteria A and B, and again in 1996 as part of the "Civil War Era National Cemeteries” multiple property submission under Criterion A. ${ }^{1}$

While the nomination of Corinth National Cemetery to the National Register includes some discussion of the important features, no landscape surveys have been completed to date. A landscape survey such as the work outlined in this report details the following: design and layout of the cemetery, any natural and cultural influences, circulation patterns, and

\footnotetext{
1 Paul Hawke, Cecil McKithan, Tom Hensley, Jack Elliot, and Edwin C. Bearss, "Siege and Battle of Corinth Sites," National Register of Historic Places National Historic Landmark Nomination Form, (Washington, DC: National Park Service, 1991). Therese T. Sammartino, "Corinth National Cemetery," National Register of Historic Places Nomination Form, (Washington, DC: National Park Service, 1996).
} 
vegetation. The nomination also did not include documentation of changes to the cemetery over time.

Corinth National Cemetery is located at 1551 Horton Street in Corinth, Mississippi (Figure 1). Corinth is a town of about 15,000 people in northeast Mississippi near the Tennessee border. It is the county seat of Alcorn County. The town was founded in 1853 and developed around the intersection of two rail lines, one running east-west and one running north-south. After the Civil War Siege of Corinth and the Battle of Corinth in 1862, the Corinth National Cemetery was established in 1866. At the time, the location of the cemetery southeast of downtown was on the outskirts of town. But as the town grew, residential neighborhoods encompassed the cemetery. The 20-acre cemetery was designed as a square, bounded by four streets, and bisected by a driveway leading to a circular area containing a flagpole. There is a formal entrance at the center of Horton Street (south boundary) and a secondary entrance at the center of Meigs Street (north boundary). Cemetery Street is the east boundary, and Young Street bounds the cemetery on the west (Figure 2).

Figure 1. Location of Corinth National Cemetery, Corinth, Mississippi (www.openstreetmap.org, accessed 13 September 2018).

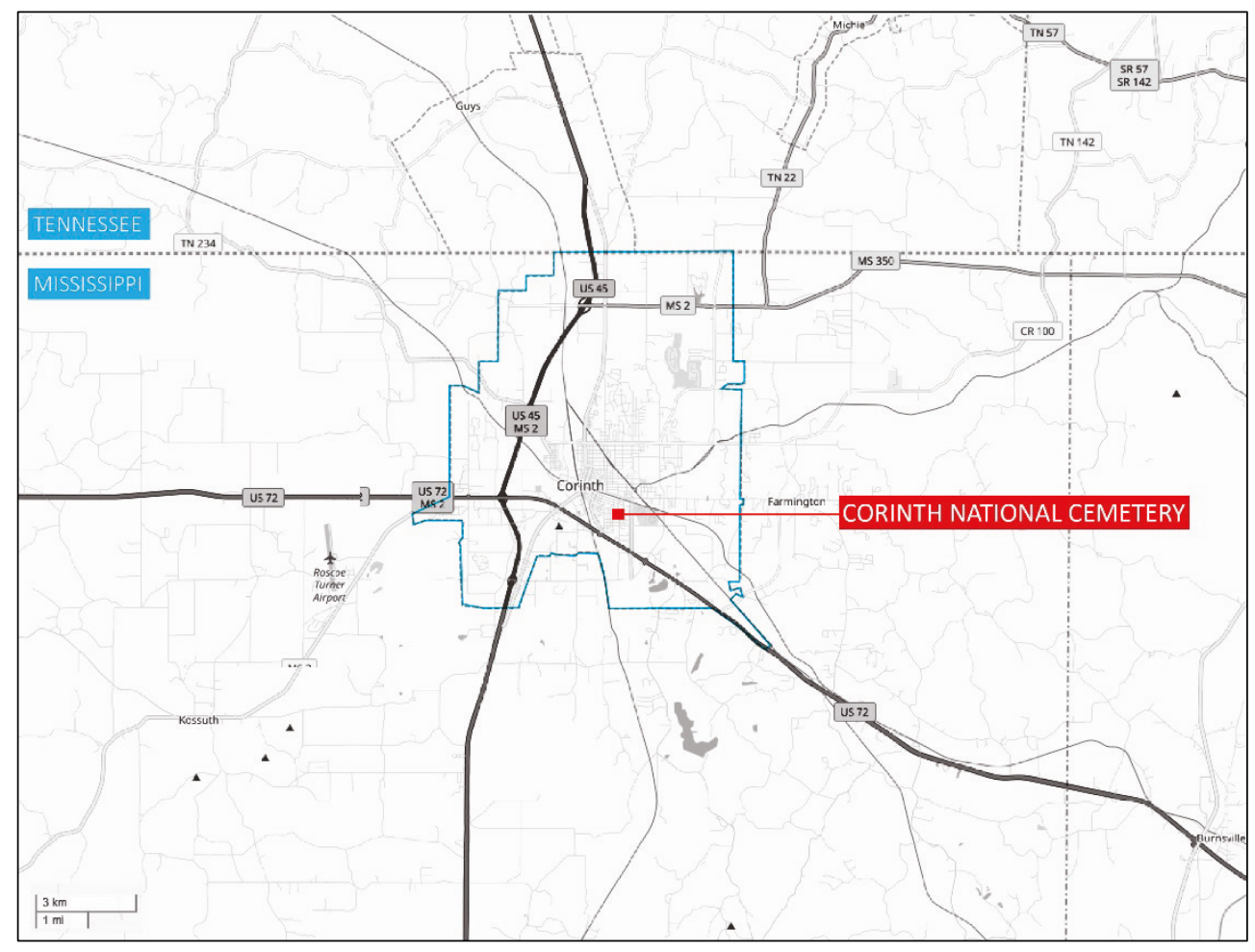


Figure 2. Overall layout of Corinth National Cemetery, 2018 (ERDC-CERL).

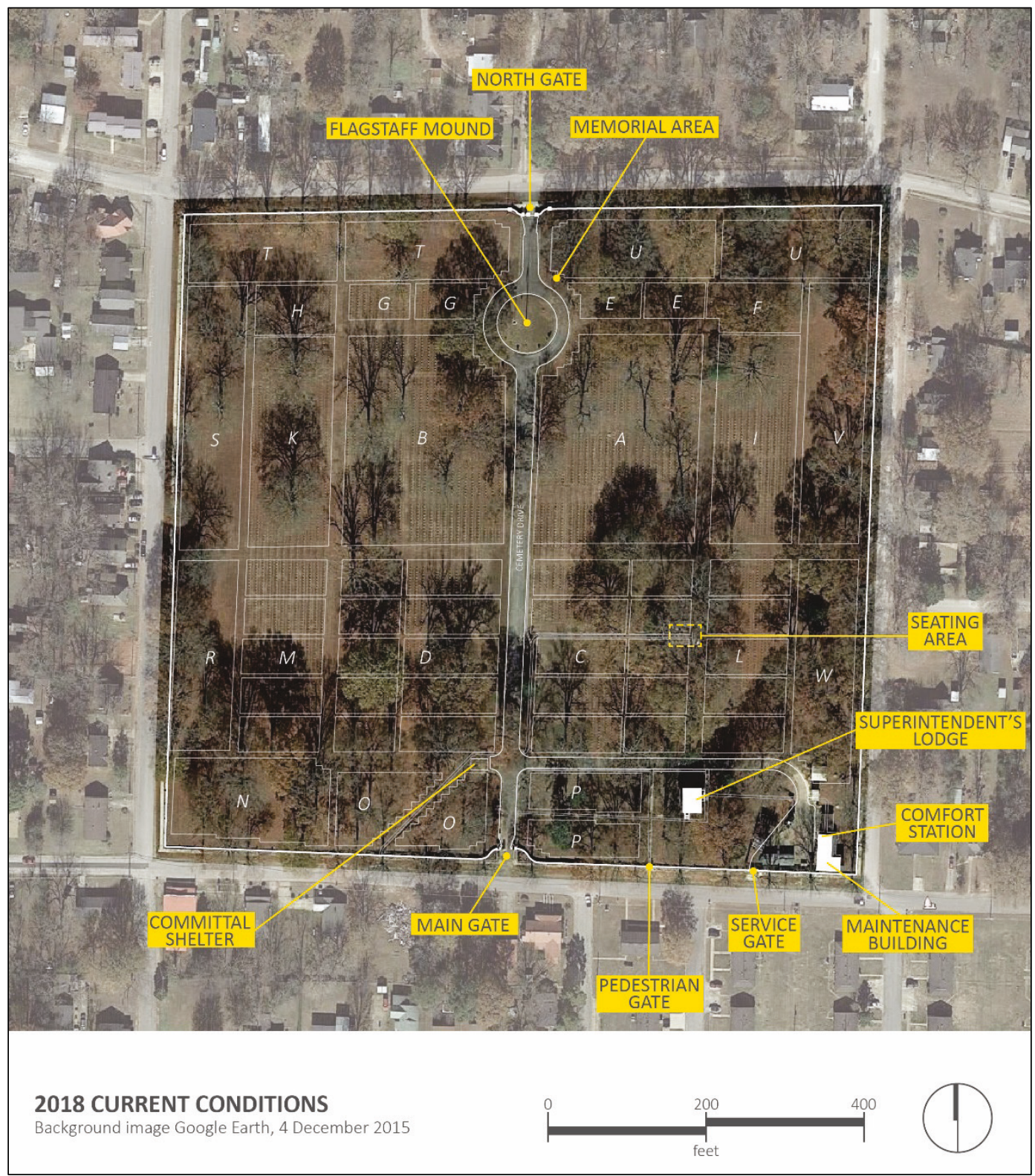

\subsection{Objective}

The objective of this project was to develop a cultural landscape survey for Corinth National Cemetery, MS. The cultural landscape survey provides a historic landscape context, a landscape inventory, a list of character-defining features, and a condition assessment of all features of the cultural landscape to assist the NCA in management of this historic resource. 


\subsection{Researchers}

This project was conducted by the U.S. Army Corps of Engineers, Engineering Research Development Center, Construction and Engineering Research Laboratory (ERDC-CERL), based in Champaign, IL. The research team included Susan Enscore, Doctor of Geography, as project manager and historian with 26 years of experience; Adam D. Smith, Master of Architecture, as architectural historian with 19 years of experience; Megan Tooker, Master of Landscape Architecture, as lead landscape historian with 19 years of experience; and Ellen Hartman, landscape architect with 8 years of experience. All four researchers meet and exceed the Secretary of the Interior's Historic Preservation Professional Qualification Standards.

\subsection{Site visits}

\subsubsection{Corinth National Cemetery}

ERDC-CERL personnel made one trip to Corinth National Cemetery in May 2018 to inventory the landscape. During that week, members of the team inventoried and photographed the landscape features.

\subsubsection{Archival repositories}

ERDC-CERL researchers conducted a review of books, archival repositories, and online resources related to Corinth National Cemetery. The following places were contacted and/or searched:

- NRHP listings and nomination forms (online at https://www.nps.gov/Nr/publications/index.htm)

- Historic drawings, maps, photographs, and information were provided by the VA NCA office in Washington, DC

- National Archives and Records Administration (NARA), College Park, Maryland

- NARA, Washington, DC

- NARA, Atlanta, GA

- Alcorn County Genealogical Society

- Corinth Public Library

\subsection{Analysis}

After initial research was completed, the team analyzed the gathered information. Archival information and field information were integrated 
throughout the course of the project. The information available was contained in text documents, photographs, and historic maps. Using archival sources, the research team extracted relevant historical information. The material was then combined to tell the story in both text and images. 


\section{Landscape Development History}

Corinth National Cemetery is still shaped by the original layout of the property. The cemetery is noted for its geometrical symmetry and mature tree canopy. The bulk of improvements to the cemetery were completed by 1936. Landscape development since then primarily has been notable for the gradual loss of the original vegetation in the cemetery.

\subsection{Origins and original configuration, 1862-1871}

As one of the initial wave of National Cemeteries constructed from 1862 to 1869, Corinth National Cemetery was established in 1866 to shelter the remains of Union soldiers killed in the Siege of Corinth and the Battle of Corinth in $1862 .{ }^{2}$ Corinth was a strategic asset, as it was a crossroad of vital railways. Confederate troops held the city in March 1862, but they were moved out to fight in what became the Battle of Shiloh on 6-7 April. The Confederate troops regrouped in Corinth after the battle and skirmished with Union troops moving south toward the city. The Confederate troops evacuated Corinth on 29 May, moving south. Union forces occupied the city and constructed a new defensive line. Tensions between the two armies remained high in the area, and a reorganized Confederate army attacked the Union troops at Corinth on 3 October 1862. Three waves of soldier charges failed to rout the Union troops before night fell. The Confederate attack resumed the next morning, with brief advances through the Union defenses and into the city before being forced to retreat. The Confederate commander ordered a retreat by mid-day, and the battle was over. There were 355 Union dead and 473 Confederate dead, with an additional total of approximately 6,000 men wounded or missing. Corinth remained a Union base for the next fifteen months. ${ }^{3}$

The many months of fighting in the area, combined with several large battles, resulted in a large number of casualties. Concentrating the remains of Union soldiers from battlefields in the area began in September 1864. A national cemetery was established on 13 April 1866 by an Act of Congress, on land that had been part of the battlefield at Corinth. 4 The property

\footnotetext{
2 For the complete historic context relative to Corinth National Cemetery, see Hawke, et. al., "Siege and Battle of Corinth Sites," 1991 and Sammartino, “Corinth National Cemetery," 1996.

3 Sammartino, “Corinth National Cemetery," 1996, 3-5.

4 Mark E. Maynard, "Corinth National Cemetery," visitor handout, in Corinth Vertical File, National Cemetery Administration, U.S. Department of Veterans Affairs, Washington, DC, 1.
} 
owners, Calvin F. and Margaret Vance, Francis M. and Catherine S. White, and James H. Walker sold the land to the United States by fee simple deed on 17 February 1868 for a payment of $\$ 3,500.5$ The site of the cemetery was selected by Brevet Major E. B. Whitman, Assistant Quartermaster General. ${ }^{6}$ That October, "a battalion of the $16^{\text {th }}$ U.S. Infantry and a small detachment of cavalry" arrived to oversee the work of gathering the remains of fallen Union soldiers. There were approximately 300 freedmen employed in this work.7 Gathered from approximately 20 battlefields in the area, the work of interring soldier remains was basically completed by 1870. ${ }^{8}$ The area from which the Union dead were disinterred for reburial at Corinth National Cemetery was within the shaded red outlined area in Figure 3.

5 Sammartino, “Corinth National Cemetery," 1996, 8-6.

6 Brevet Major E. B. Whitman, Assistant Quarter Master, "Reports on National Cemeteries, Department of the Cumberland, No. 6 Corinth, Miss.," 4 November 1867, in Record Group 92, Entry 576, Box 22, National Archives and Records Administration, Washington, DC.

${ }^{7}$ Article in The Weekly Clarion, 1 November 1866, n.p.

8 Hawke, et. al., “Siege and Battle of Corinth Sites,” 1991, 9. 
Figure 3. Map of collection area of Union soldier remains for internment at Corinth National Cemetery, 1868 (north is to the right) (NARA, Washington DC).

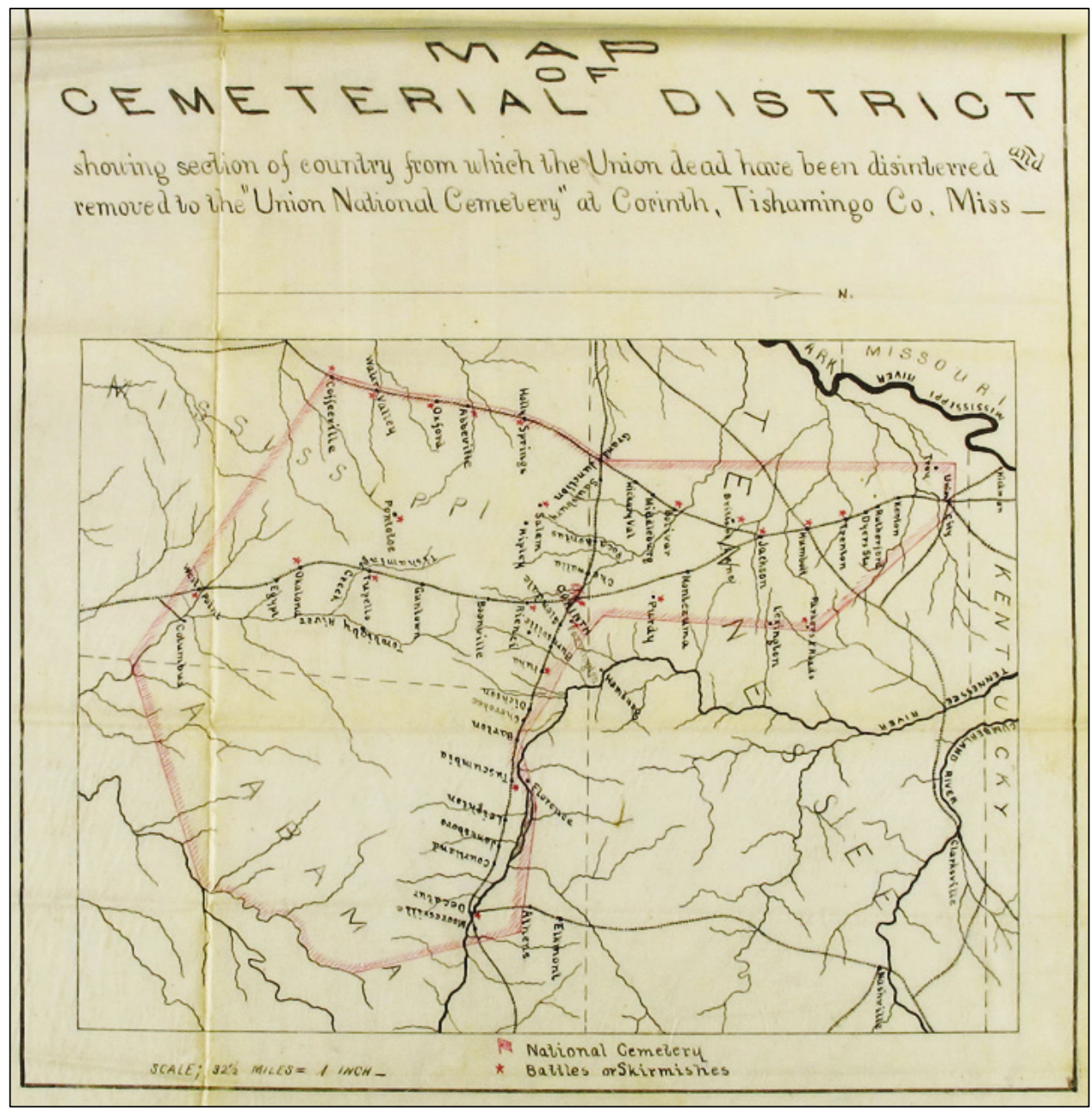

The collection and interment program at Corinth National Cemetery resulted in " 5,688 interments, of which 1,793 were known and 3,895 were unknown. The interred represent 273 regiments from fifteen states." 9 As far as possible, graves were grouped by state. Only three Confederate casualties were included in these interments. ${ }^{10}$ Once the interments were completed in 1870 , Corinth National Cemetery was the sixteenth largest in the nation. ${ }^{11}$

9 Hawke, et. al., "Siege and Battle of Corinth Sites," 1991, 9.

10 "Corinth National Cemetery," typed manuscript, no date, 1, in Corinth Vertical File, National Cemetery Administration, U.S. Department of Veterans Affairs, Washington, DC.

11 Sandra M. Webb, "Corinth National Cemetery National Register of Historic Places Inventory - Nomination Form," Draft, (Washington, DC: Veterans Administration, 1974), 8, in Corinth Vertical File, National Cemetery Administration, U.S. Department of Veterans Affairs, Washington, DC,. 
The author of the cemetery's original design is not clear in the records, but plans and other drawings were contained in a 5 August 1867 report by Brevet Colonel C.W. Folsom, Assistant Quartermaster. ${ }^{12}$ The original layout plan for the cemetery shows a nearly square plot with a winding encircling drive and a central avenue through the grounds (Figure 4). The encircling drive was described in 1867 as "a $20 \mathrm{ft}$ avenue, starting from the central avenue near the South Gate, and going all around the Cemetery, traversing in a serpentine form, a space of 100 feet which has been reserved for it on the West, North and East sides." 13 The land is divided into rectangular sections that are identical on both sides of the avenue. The main avenue widens into a circle close to the northern end of the cemetery, creating a place for a flagstaff. The grounds are subdivided with narrower avenues at right angles. There are four circular areas dedicated to the dead of particular regiments or states (clockwise from upper left: $63^{\text {rd }}$ Ohio, "Four Illinois Regiments," Michigan, and Iowa.) The strip of land closest to the central avenue was reserved as "vacant space." The two sections closest to the north entrance are labeled "miscellaneous," with the west block under that area set aside for troops from Missouri and the eastern block for Indiana. The far southeastern block was reserved for colored Union soldiers. The sections along the perimeter are allotted for graves of unknown soldiers. Also visible in the plan is a drainage that runs from the south middle of the cemetery's east side and exits diagonally slightly west of the main entrance. The drainage system has been a part of the cemetery landscape almost from the beginning.

\footnotetext{
12 Brevet Colonel C. W. Folsom, Assistant Quartermaster, "Report of an Inspection Made of Cemeterial Operations at Corinth, Mississippi," 5 August 1867, in Record Group 92, Entry 576, Box 22, National Archives and Records Administration, Washington, DC.

13 Folsom, "Report of an Inspection Made of Cemeterial Operations at Corinth, Mississippi," 5 August 1867.
} 
Figure 4. Early plan of Corinth National Cemetery, with burial sections and encircling drive, 1867 (NARA, Washington DC).

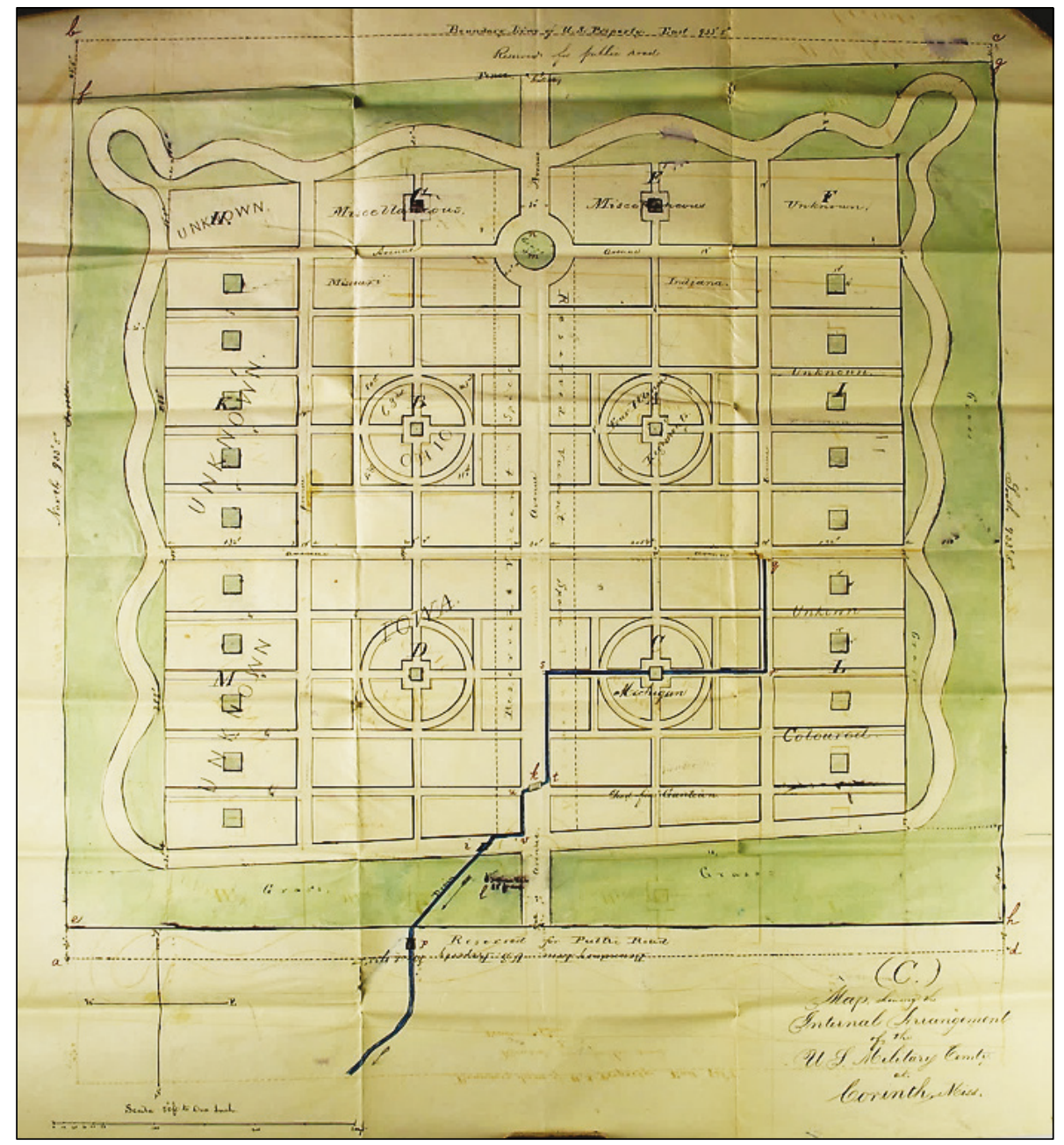

The 1867 "Act to Establish and Protect National Cemeteries"14 included requirements that each cemetery be enclosed by a stone or iron fence and have a lodge for a cemetery manager or superintendent. The person had to be an enlisted veteran, and live on site to provide both protection for the cemetery and information to visitors. 15 The cemetery's first superintendent was Mr. Joseph Berrigan, a discharged private of Company B, 43rd Infantry Regiment, who was appointed to the position on 26 November $1867 .{ }^{16}$

\footnotetext{
14 Public Law 37 was passed by the U.S. Congress on 22 February, 1867.

15 The practice of appointing Civil War veterans was suspended in 1910. Michael R. Harrison (historian), “National Cemeteries, Superintendent's Lodges," Historic American Buildings Survey No. DC-46, (Washington, DC: National Park Service, 2013), 6, 17.

16 Sammartino, “Corinth National Cemetery," 1996, 7-1.
} 
Berrigan's lodging was a single-story, temporary frame building completed in 1868. ${ }^{17}$ Designed by the Quartermaster Department, the initial standard lodges were wood-framed buildings clad in battened board siding, with gable roofs. Covered porches were located at one or both ends, and a central chimney served both fireplaces. ${ }^{18}$ There were two linear rooms, an office and a living room. The two-bedroom lodge was constructed in 1867 and 1868. A three-room version was constructed beginning in 1868 . In addition to the third room, other changes were the addition of a second chimney, a veranda on one side of the office that provided doors into the living room and into the office, and a rear door directly into the kitchen. The three-room lodge was constructed between 1868 and 1870, by which time nearly every other national cemetery had a lodge. ${ }^{19}$

A lodge for Corinth National Cemetery had been ordered by November 1867, and a well had been completed. ${ }^{20}$ The lodge was completed by August 1868, and a small stable had also been constructed. The stable was a frame building, and contained a stable, tool and forage house, and privy. ${ }^{21}$ A small building for storage of headboards had been erected along the fence between the lodge and the stable. The lodge was placed near the main entrance, as stipulated in the 1867 Act. ${ }^{22}$

A depiction of the cemetery was drawn soon after the lodge was constructed, showing a stable, headboard house, lodge, entrance gate, pump house/summer house, and cemetery grounds (Figure 5). The two chimneys and the length of the building depict the three-room lodge design. A grassed allée was lined with trees, and trees also lined the perimeter inside the fence line. The main burial spaces showed little vegetation, while shrubs had been planted around the lodge. An inspection report from the same period states that "the main avenues have been ornamented by excellent shade trees and evergreens and a number of trees have been set out

\footnotetext{
17 Harrison, “National Cemeteries, Superintendent's Lodges,” HABS No. DC-46, 58.

18 Harrison, “National Cemeteries, Superintendent's Lodges," HABS No. DC-46, 18-19.

19 Harrison, “National Cemeteries, Superintendent's Lodges," HABS No. DC-46, 18-19.

20 “Inspection Report," November 1867, in Record Group 92, Entry 576, Box 23, National Archives and Records Administration, Washington, DC.

21 James Gall, Jr., Civil Engineer, War Department, letter to Acting Quartermaster General, 10 February 1876, in Record Group 92, Entry 576, Box 23, NARA, Washington, DC; Major C.H. Carlton, $3^{\text {rd }}$ Cavalry, letter to Quartermaster General, 19 November 1881, in Record Group 92, Entry 576, Box 22, NARA, Washington, DC.

22 Colonel E.B. Whitman, letter to Brevet Major General Thomas Swords, 5 August 1968, Record Group 92, Entry 576, Box 22, NARA, Washington, DC.
} 
at uniform distances around the entire grounds near the fence." 23 Walks and avenues were graveled.

Figure 5. Sketch map of Corinth National Cemetery showing first lodge, stable (behind lodge), pump house, headboard house (near south fence), wooden picket fence, and original main gate, 1868 (NARA, Washington, DC).

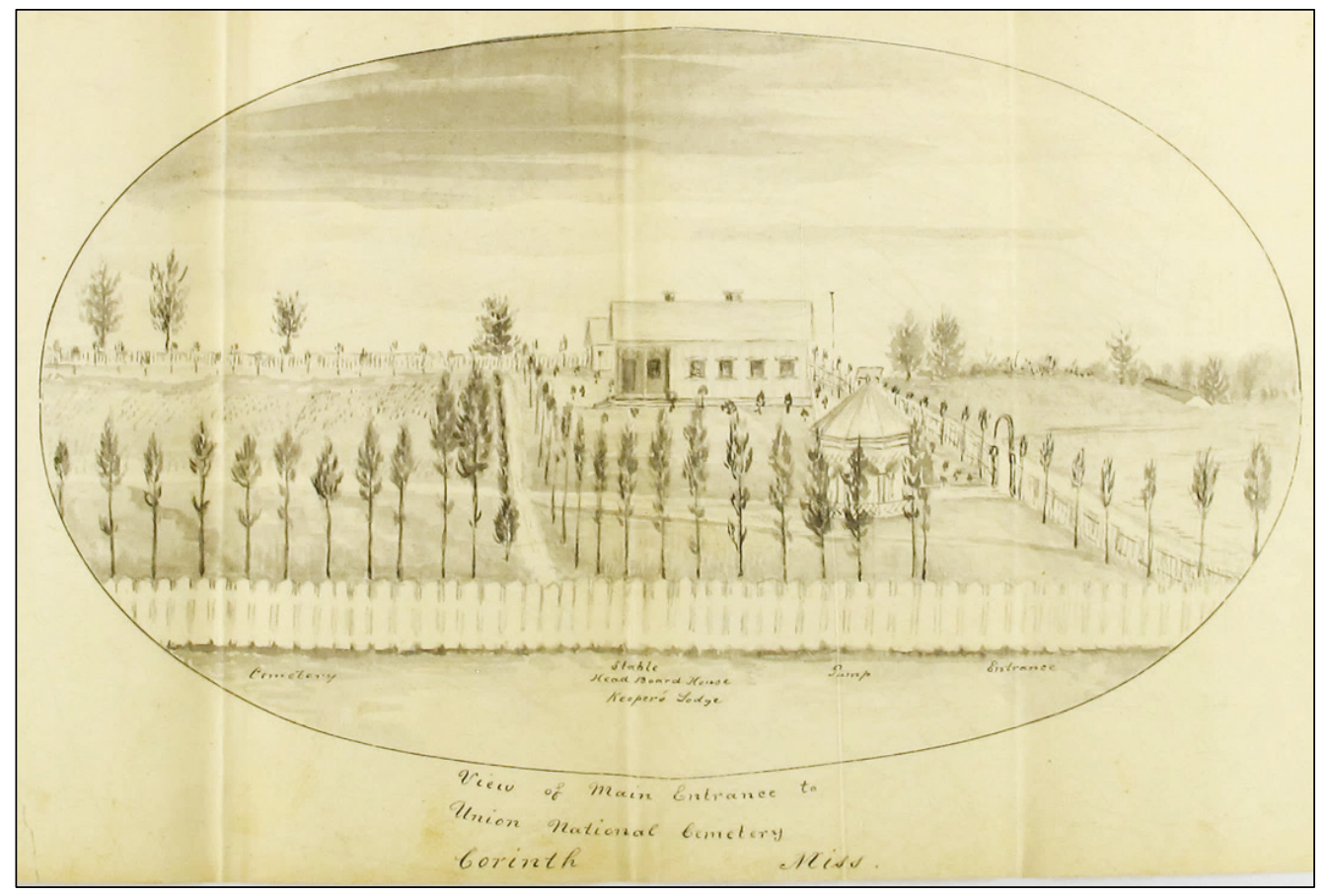

Funds appropriated in 1867 for construction of lodges also covered "land costs, fence construction, grave marking, and other actions." ${ }^{24}$ The individual graves were identified with numbered wooden stakes. These stakes were later replaced with standing marble headstones. ${ }^{25} \mathrm{~A}$ wooden picket fence enclosed the cemetery by November $1867 .{ }^{26}$ An early plan of the cemetery shows the main avenue and the encircling drive lined with trees, as well as trees placed along the southern boundaries of the enclosed area. The main drainage channel is also depicted in the plan (Figure 6). The circular area depicted on the plan is labeled "monument" although it was always the site of the flagstaff, with the first one in place by $1868 .{ }^{27}$ This plan

\footnotetext{
23 “National Cemetery Corinth Miss," undated report circa 1968 or 1869, Record Group 92, Entry 576, Box 23, NARA, Washington, DC.

24 Harrison, “National Cemeteries, Superintendent's Lodges," HABS No. DC-46, 17.

25 Sammartino, “Corinth National Cemetery,” 1996, 7-1.

26 “Inspection Report," November 1867.

27 Colonel E.B. Whitman, letter to Brevet Major General Thomas Swords, 5 August 1968.
} 
is the first to show the buildings in the southeast corner. The geometric arrays of headstones depicted were in fact developed as planned.

Figure 6. Plan of Corinth National Cemetery, 1868 (NARA, Washington, DC).

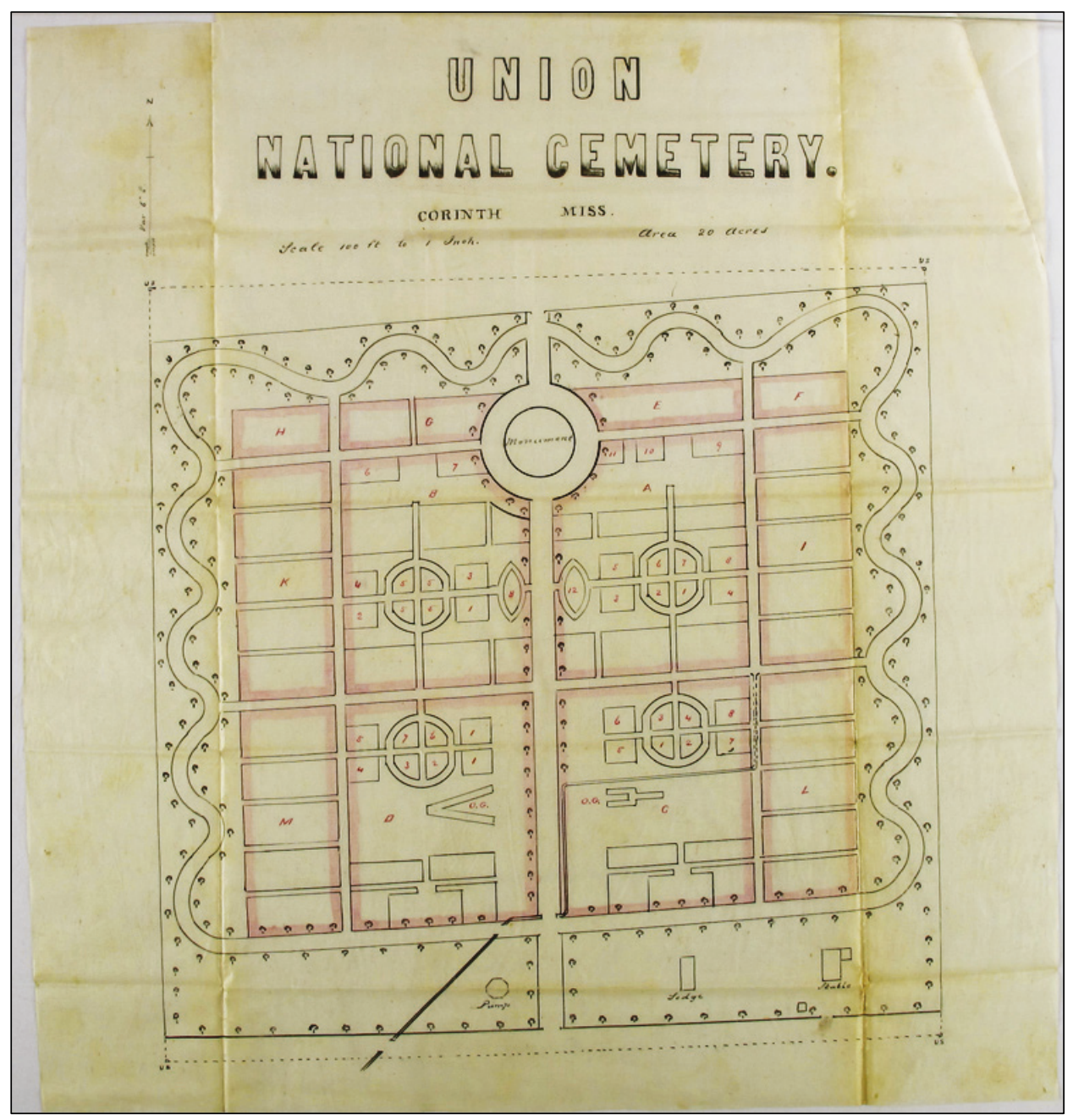

\subsection{Establishing permanence, 1871-1890}

The permanent era of Corinth National Cemetery began in 1871 with plans for a second lodge; construction was completed in 1872 . The $1^{1 / 2}$ story, Lshaped brick masonry building was constructed to what became known as the "Meigs plan" after Quartermaster General Meigs, who acquired it from architect Edward Clark in 1869. As Quartermaster General, Meigs made final decisions on designs for all national cemeteries at that time. ${ }^{28}$

28 Harrison, “National Cemeteries, Superintendent's Lodges,” HABS No. DC-46, 43. 
The design was refined over the next two years, and the resulting standardized plan was constructed in over fifty cemeteries by 1881 . The L-plan provided a more private office area, separated from living quarters with a separate entrance. ${ }^{29}$ The most distinctive feature of the design was a slate and tin mansard roof, most notably associated with the Second Empire architectural style that became popular after the Civil War (Figure 7). ${ }^{30}$

Figure 7. Design for Superintendents Lodge, National Cemeteries, Office of the Quartermaster General, U.S. Army, 1871 (NARA, Washington, DC).

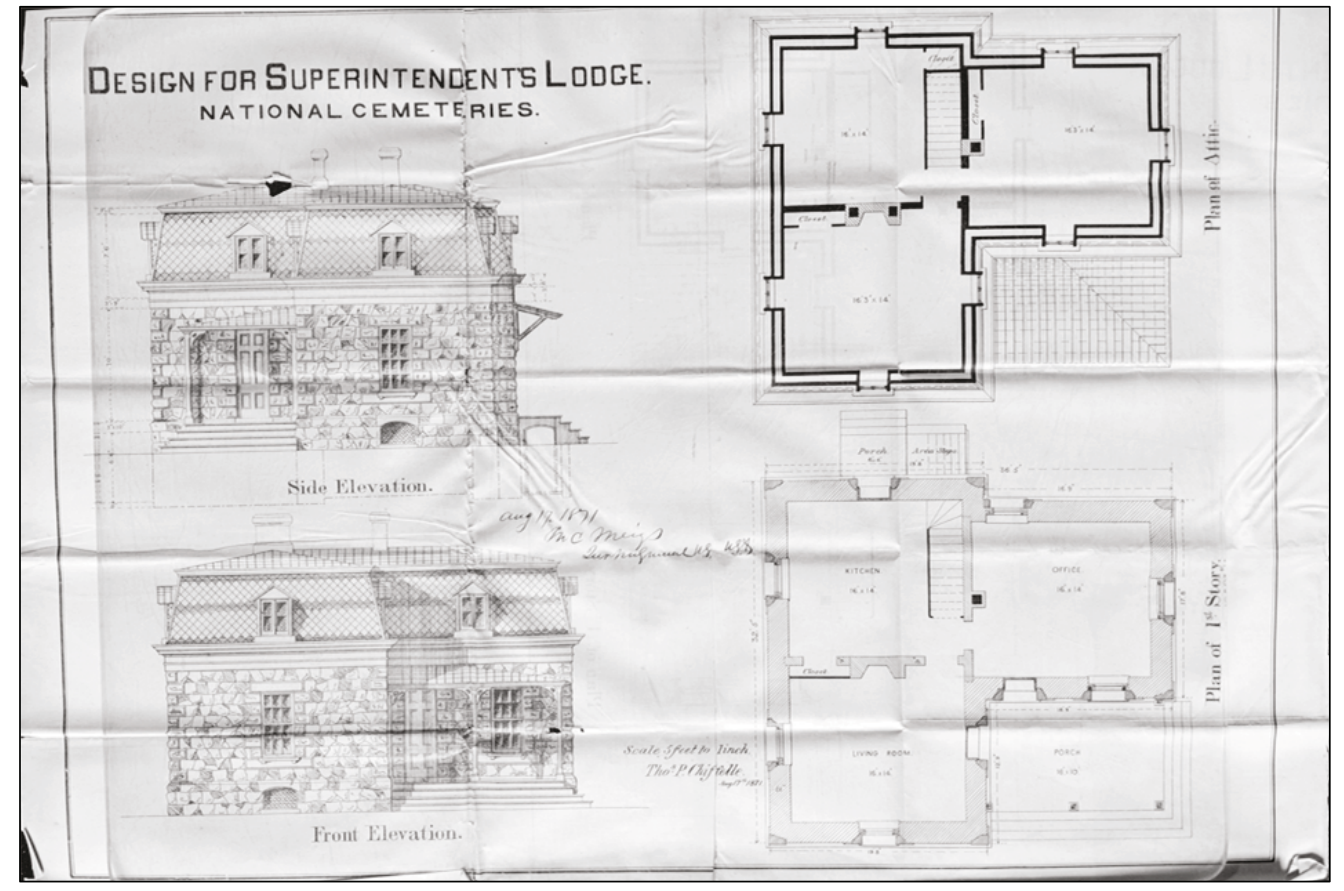

An 1871 inspection report of National Cemeteries reiterated the requirement that they all be enclosed by a wall made of permanent materials and to have a coping on the top of that wall. ${ }^{11}$ The wooden picket fence enclosing the Corinth National Cemetery was replaced by a brick wall in $1871.3^{2}$

\footnotetext{
29 Harrison, “National Cemeteries, Superintendent's Lodges," HABS No. DC-46, 10.

30 Harrison, “National Cemeteries, Superintendent's Lodges," HABS No. DC-46, 2, 11.

31 Bingham to Quartermaster General, letter, September 1871, 11.

32 “Corinth National Cemetery," typed manuscript, 1954.
} 
With the new wall came new gates made of ornamental wrought iron, with double gates for the main entrance, and single gates for the north entrance, pedestrian entrance, and service entrance. 33 The original brick pillars to which the gates were attached were replaced by stone pillars in November 1873.34

Unfortunately, the enclosing brick wall was poorly laid out and constructed. According to an inspection report, the wall was "built without lines and grades, the foundation begins on the surface of the ground, the first course laid dry - many of the bricks are crumbling, being soft and badly made - the mortar also was poor...there are no drainage openings and therefore the surface water forces its way through the foundation gradually undermining it." 35 Another contemporary report noted the following: 36

The cold and the wet of the last winter have disintegrated them [bricks] considerably. This is particularly the case on the west side where there are several panels that will require to be repaired this season. The wall is topped out with hard bricks, the poor ones are mostly near the ground where they readily absorb moisture, and in freezing, burst and crumble away. The buttresses are carried above the wall 8 or 10 inches and sloped up to a point. The mortar covering of the slope caps has come off to a great extent.

As a result, serious problems developed within just a few years. By 1874 , repairs were being carried out that included replacing the soft bricks with sound ones, relaying the coping courses and pilaster caps in lime and cement mortar, and repointing three-quarters of the wall. Drainage outlets were created, and the walls were banked up with earth to protect the foundation. Several buttresses were constructed to support part of the west

\footnotetext{
33 "Repair of Wall and Drainage of Cellar at Corinth National Cemetery," 25 March 1874, in Record Group 92, Entry 576, Box 23, National Archives and Records Administration, Washington, DC.

34 Superintendent, Corinth National Cemetery to Lt. K.B. Sarson, Huntsville, Alabama, 22 May 1874, in Record Group 92, Entry 576, Box 23, National Archives and Records Administration, Washington, DC.

35 Quartermaster General's Office, Memo, 25 March 1874, in Record Group 92, Entry 576, Box 23, NARA, Washington, DC.

36 Major Oscar A. Mack, Inspector National Cemeteries, letter to Quartermaster General, 3 June 1873, in Record Group 92, Entry 576, Box 23, NARA, Washington, DC.
} 
wall. Completing this work and repointing the remaining brick took until the summer of 1876.37

By 1873 , the deteriorating wooden headboards at many National Cemeteries focused attention on the question of replacing them with permanent headstones. On 3 March 1873, Congress appropriated $\$ 1,000,000$ for erecting permanent headstones at all National Cemeteries. $3^{8}$ The government-issued headstones were of two kinds. For known soldiers, the white marble slab was 4 inches thick, 10 inches wide, and 3 feet long (with 12 inches to be above the ground when set). The polished stone was slightly curved on top and was inscribed with the number of the grave, rank and name of the soldier, and his home state. There was a sunken shield on the headstone where the inscription appeared in bas relief. Known as the "Civil War" type, this headstone design was used for Union Army dead. 39 Unknown Soldiers received a marble block 6 inches square and 30 inches long, with only the flat top and upper 4 inches finished. The number of the grave was cut into the flat top. $4^{40}$ At Corinth National Cemetery, headstones were being placed on the graves in lieu of the wooden stakes by $1876 .{ }^{41}$

An inspection report from June 1874 provided the following snapshot of progress on the cemetery: 42

- Lot originally enclosed by wooden fence - square of 933 1/2 feet; acre left outside enclosure on north side.

- Wooden fence replaced by brick wall by June 1874 [1871] (some soft-burnt brick already having been repaired and needing more).

- Front wall on south side is better brick and has the main entrance in the center, closed by double iron gates over the carriage-way. Gates hung on brick piers, but they have been replaced by stone

\footnotetext{
37 James Gall, Jr., Civil Engineer, War Department, letter to Quartermaster General, 12 October 1874, in Record Group 92, Entry 576, Box 23, NARA, Washington, DC.

38 U.S. Secretary of War, "Annual Report of the Secretary of War," 43rd Congress, 1st Session, Ex. Doc. No. 1, Part 6, (Washington, DC: Government Printing Office, 1873); National Cemetery Association, "History of Government Furnished Headstones and Markers," Washington, DC: Department of Veterans Affairs National Cemetery Administration, last updated 2015). https://www.cem.va.gov/history/hmhist.asp.

39 National Cemetery Association, “History of Government Furnished Headstones and Markers,” 2015.

40 U.S. Secretary of War, "Annual Report of the Secretary of War," 1873, 200; National Cemetery Association, "History of Government Furnished Headstones and Markers," 2015.

41 James Gall, Jr. to the Acting Quartermaster General, 10 February 1876, in Record Group 92, Entry 576, Box 23, National Archives and Records Administration, Washington, DC.

42 Inspection report, 25 June 1874, in Record Group 92, Entry 576, Box 23, National Archives and Records Administration, Washington, DC.
} 
posts. [Entrance Gates - 11'9" wide; 5' high; 2 smaller gates - 4' wide, 57 " high]. 43

- Entrance avenue 30 feet wide extends north through lot, passing small circular plat near the north side, with the flag-staff.

- Ground rises gently and irregularly from front to low ridge with flag-staff, then falls off to the north.

- Two large iron-gun monuments placed near flag-staff.

- Drive 16 feet wide laid out on an undulating curve extends around the lot varying 30 to 100 feet from the inside wall.

- Two other 16 foot wide drives, one on each side of the central avenue, and at equal distances from it, cross the lot north and south; and two similar drives cross them at right angles, dividing the grounds into twelve burial sections of difference sizes and shapes

- Area between the interior circular drive and wall used for gardens and grass-plats, besides containing the lodge and out-buildings.

- Row of deciduous trees (mostly soft maples) is planted on each side of the several drives and the main avenue (not growing well). A few evergreens (conifer) are scattered through the grounds. Greater variety of evergreens would improve the appearance, esp in winter.

- Osage-orange hedge along the inside of the wall, growing well.

- Drainage is very good, but large brick gutters need cementing.

- Lodge is on the south front, a little distance to the east of the main entrance.

- A small gateway is opposite the lodge in the front wall.

- Lodge built of brick, $1 \frac{1 / 2}{2}$ stories, French roof, three rooms on ground floor, three chambers over them, also a cellar. Slight repairs needed to walls inside and to chimney-tops.

- Under-ground cistern attached to lodge, covered by an arbor.

- Well near the main entrance protected by large arbor with climbing rose-bushes.

- Stables and out-buildings area east of the lodge, in good order.

- Graves arranged in parallel rows, all levelled, many have fallen in by breaking down of coffins, need to be refilled and well sodded.

- Grass is bunchy. Very little good continuous turf.

- In the center of each section, there was originally a square wooden post painted white, with the letter designating the section put on each side near the top in black. These have been replaced by others made of stone during 1873-74. [In 1889, marker posts were described as " 10 " square cut with beveled corner 5 ' out of ground surmounted by 9 " shells and letter of section cut on the posts."] 44

43 “Entrance Gates," U.S. National Cemetery, Corinth, Mississippi, 1960, Real Property form, Corinth National Cemetery records, National Cemetery Administration, U.S. Department of Veterans Affairs, Washington, DC.

44 James M. Dickey, Superintendent, Corinth National Cemetery, inspection report to Quartermaster General, 18 January 1889, in Record Group 92, Entry 576, Box 23, National Archives and Records Administration, Washington, DC. 
- Expenditures up to that point were $\$ 104,828.20$.

In 1878, Quartermaster General Montgomery C. Meigs designed stables for the cemeteries as a linear row of three rooms (Figure 8). The building functioned as a tool house, woodshed, stable, and privy. According to the building plan, it was a 36 ' long, one-story, brick building with a shed roof. The front elevation had three arched bays, resting on four pilasters. The tool house had an exterior window, and it was enclosed by a rounded-arch wood door. The central room was a woodshed, and it was not enclosed. The third room served as stable and forage room. A corner of this room was blocked off, with only exterior access and a small exterior window. This space was a 2-seat privy, which was used as a public toilet. The building had a tin roof.

Figure 8. National plan for tool house, woodshed, stable, and privy building, 1878 (NARA, Washington, DC).

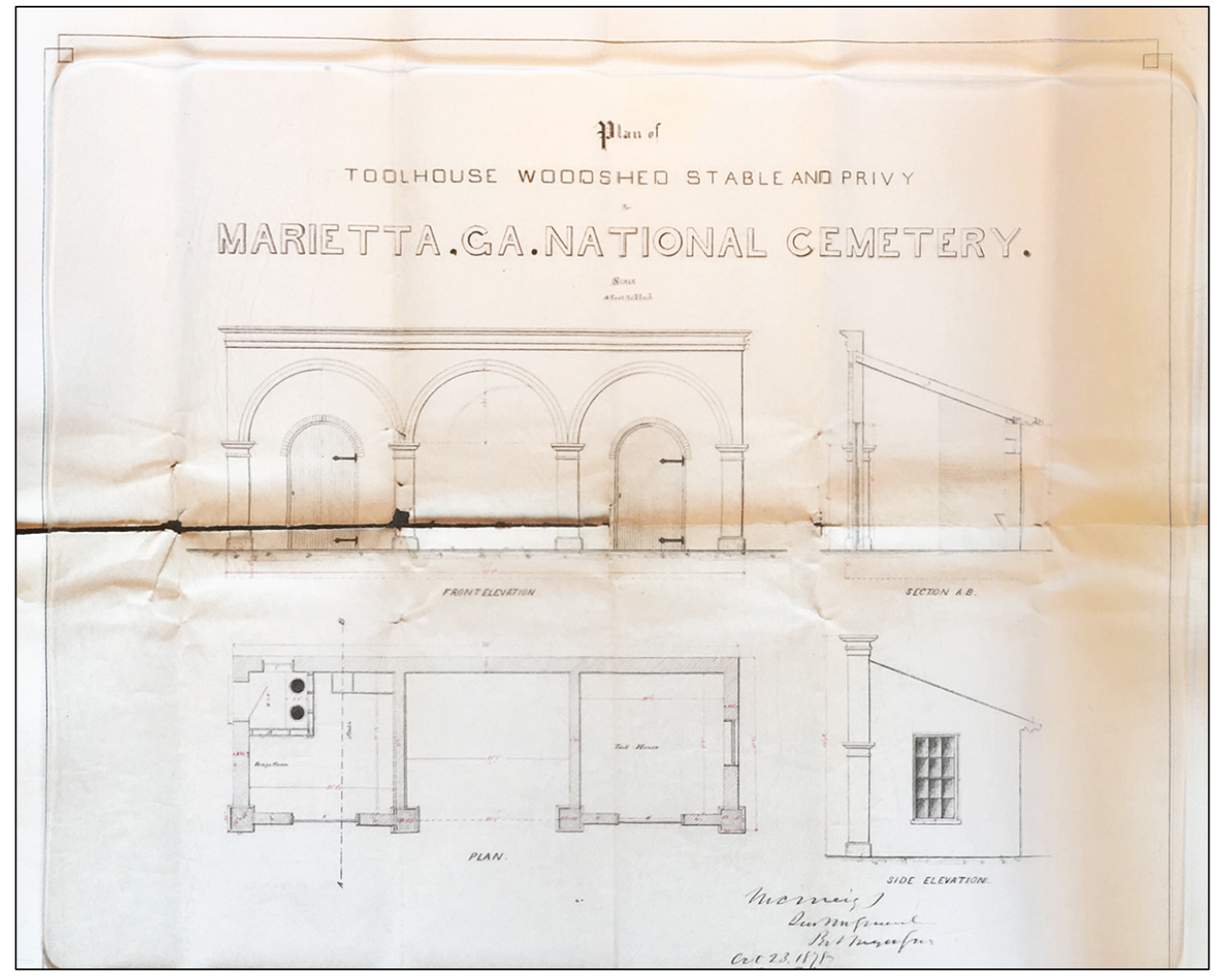

With the current stable at Corinth being deteriorated, estimates for a new stable building were submitted in 1881.45 The site was staked out in March 1882 and located east of the lodge near the wall, where the old stable was

45 Captain A. J. McGonnigle, Depot Quartermaster, New Orleans, Louisiana, letter to Quartermaster General, Washington, D.C., 16 May 1881, in Record Group 92, Entry 576, Box 22, National Archives and Records Administration, Washington, DC. 
located. ${ }^{6}$ Construction was completed that year with the brick building measuring 16' x 39', having a tin roof and three rooms plus privy. $47 \mathrm{By}$ 1888 , requests were being made to add an extension, as the building was not large enough for the needs of two animals plus storage. $4^{8} \mathrm{~A}$ well had been dug in the stable yard in 1881 for the animals and other water needs. 49

The original summer house was in very bad shape by 1882 , so it was demolished and a new one constructed that year, 110 feet southwest of the main entrance. $5^{\circ}$ The octagonal wooden structure was 16' in diameter, with latticed wood work, a shingle roof, and a brick floor that may have been built from a standard plan (Figure 9 and Figure 10). ${ }^{51} \mathrm{~A}$ new cistern house was constructed at the same time, using the same design but scaled down to a 12' diameter. ${ }^{2}$ Both structures were described in 1883 as "most substantial" with the summer house already "a pleasant and attractive place of resort to visitors." 53

\footnotetext{
46 James Gall, Jr., Civil Engineer, letter to letter to General Benjamin C. Card, 25 March 1882, in Record Group 92, Entry 576, Box 22, National Archives and Records Administration, Washington, DC.

47 James M. Dickey, Superintendent, Corinth National Cemetery, inspection report to Quartermaster General, 18 January 1889.

48 W. M. Owen, Civil Engineer, Quartermaster Department, letter to Quartermaster General, 21 May 1888, in Record Group 92, Entry 576, Box 23, NARA, Washington, DC.

49 Captain A. J. McGonnigle, Depot Quartermaster, New Orleans, Louisiana, letter to Quartermaster General, Washington, D.C., 16 May 1881.

50 James Gall, Jr., Civil Engineer, letter to General Benjamin C. Card, 8 January 1882, in Record Group 92, Entry 576, Box 23, NARA, Washington, DC.

51 James M. Dickey, Superintendent, Corinth National Cemetery, inspection report to Quartermaster General, 18 January 1889.

52 James M. Dickey, Superintendent, Corinth National Cemetery, inspection report to Quartermaster General, 18 January 1889.

53 James Gall, Jr., Civil Engineer, letter to Acting Quartermaster General, 10 April 1883, in Record Group 92, Entry 576, Box 22, National Archives and Records Administration, Washington, DC.
} 
Figure 9. Elevation and Section, Summer House, ca. 1882 (NARA, Washington, DC).

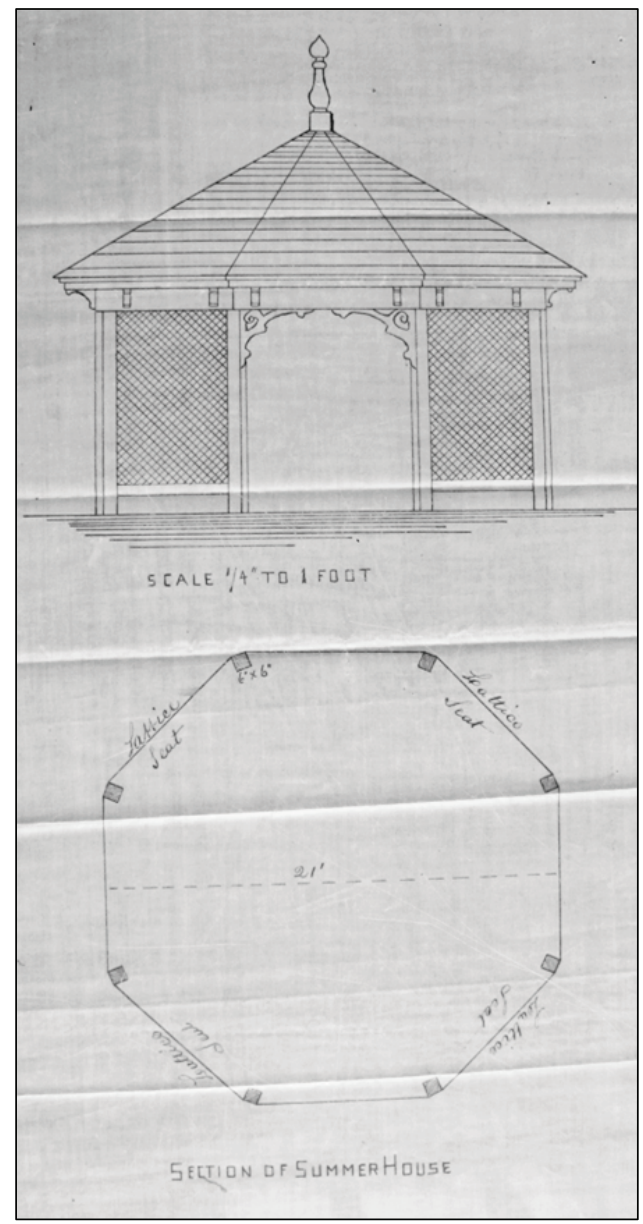

Figure 10. Section of Summer House, ca. 1882 (NARA, Washington, DC).

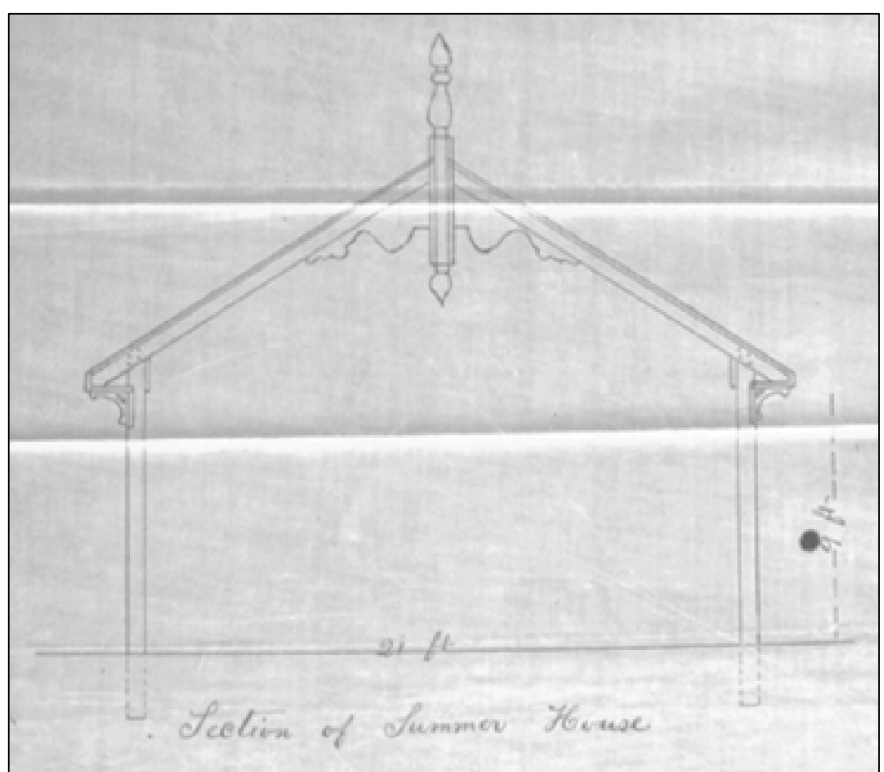


By the early 1880 s, the walks and drives had been sodded or naturally grassed over, except for the graveled Main Avenue.54 In 1884, it was reported that "the strip of ground in the front of the Cemetery, that was formerly the Superintendent's cabbage and potato garden is now the Sylvan Hall, a beautiful piece of lawn, all shaded with handsome young Maples that are rapidly forming a beautiful grove where Decoration Ceremonies may be comfortably and appropriately held." 55

The brick cemetery wall continued to be problematic. In an 1883 letter, a Quartermaster Department civil engineer stated that "all of one side of the wall and part of another would probably have fallen before this had they not been buttressed and banked up on the outside. As it is, these portions of the wall have a heavy outward leaning, and are unstable and unsightly... [it] would be well to rebuild the worst parts of the wall." ${ }^{6}$ Funding did not arrive for rebuilding the wall until 1888, when work began on the north and west walls, as they were most in danger of collapse. The original plan was to replace the north and west walls, while repairing the east and south walls. As work progressed on the north and west walls, the Quartermaster Department decided to go ahead and rebuild the south and east walls. 57 The new walls were set 3 feet inside the original brick wall, as the ground was better, and so the old wall could stand while the new one was being constructed. 58

The new walls were not quite the same size as the old ones, requiring new gates and pillars at the entrances. The north entrance was made wider, and the south wall was curved in toward the entrance. 59 New drive gates and associated walk gates for the north and south entrances, and the walk gate for the lodge entrance were ordered from the Champion Iron Fence Company. The paired drive gates were 12 feet wide and 6 feet high. The walk gates were 4 feet wide and 5 feet high. The 12 foot drive gate pair for the stable entrance was ordered from the Kanaka Iron Fence Company of

\footnotetext{
54 McGonnigle, letter to Quartermaster General, 16 May 1881.

55 James Gall, Jr., Civil Engineer, letter to Deputy Quartermaster General, 22 May 1884, in Record Group 92, Entry 576, Box 22, National Archives and Records Administration, Washington, DC.

56 James Gall, Jr., Civil Engineer, letter to Acting Quartermaster General, 10 April 1883.

57 W. H. Owen, letter to Quartermaster General, 14 May 1888, in Record Group 92, Entry 576, Box 22, National Archives and Records Administration, Washington, DC.

58 W.H. Owen, Civil Engineer, Quartermaster Department, letter to Lieutenant Colonel C.G. Sawtelle, Deputy Quartermaster General, 10 January 1888, in Record Group 92, Entry 576, Box 22, National Archives and Records Administration, Washington, DC.

59 W. H. Owen, letter to Quartermaster General, 16 January 1888, in Record Group 92, Entry 576, Box 22, National Archives and Records Administration, Washington, DC.
} 
Springfield, Ohio. ${ }^{60}$ The drive gates had raised lettering for "U.S. NATIONAL CEMETERY" that was 6 inches high, gilded, placed on metal plates, and attached to the gates at the center, near the top. ${ }^{61}$ New stone gateposts were constructed, and advertisements went out for two cast-iron urns and four cast-iron shell ornaments to be placed on the gateposts, with the urns on the two tallest south entrance posts and the shell ornaments on the smaller posts. ${ }^{62}$ All work on the new wall and entrance gates was completed by the start of 1889.63

\subsection{Maturation of cemetery grounds, 1890-1934}

There was a War Department program in the early 1880 os to provide National Cemeteries with iron tablets inscribed with lines from the Theodore O'Hara poem, "Bivouac of the Dead." Several of these tablets would be placed around the cemetery and when viewed in sequence, they would relate the entire poem. At Corinth, these tablets were installed throughout the grounds. 64

As National Cemeteries took on a more public memorial and ceremonial role in the decades after the Civil War, facilities were created to support those roles. With the growth of the tradition of Decorating Day (what later became Memorial Day), a space was needed to focus the ceremonial activities. The Quartermaster General began a program in 1873 of constructing rostrums, or stands for speakers. ${ }^{65}$ The first design from the Quartermaster's Department was a rectangular structure with a raised floor and an openwork structure that supported climbing vines. A second, less expensive design was created in 1886 that used an octagonal plan that appeared

\footnotetext{
60 Quartermaster General's Office, letter to Major E. B. Kirk, Quartermaster, 22 March 1888, in Record Group 92, Entry 576, Box 22, National Archives and Records Administration, Washington, DC.

61 Deputy Quartermaster General, letter to Major E.B. Kirk, Quartermaster, 17 August 1888, in Record Group 92, Entry 576, Box 22, National Archives and Records Administration, Washington, DC.

62 S.B. Holabird, Quartermaster General, letter to Major E.B. Kirk, Quartermaster, 31 October 1888, in Record Group 92, Entry 576, Box 22, National Archives and Records Administration, Washington, DC; W. M. Owen, Civil Engineer, Quartermaster Department, letter to Quartermaster General, 22 October 1888, in Record Group 92, Entry 576, Box 22, National Archives and Records Administration, Washington, DC.

63 James M. Dickey, Superintendent, Corinth National Cemetery, inspection report to Quartermaster General, 18 January 1889

64 National Cemetery Association, “Bivouac of the Dead," (Washington, DC: National Cemetery Administration, last updated 2015), https://www.cem.va.gov/history/bivouac.asp.

65 Michael R. Harrison (historian), "National Cemeteries, Rostrums," Historic American Buildings Survey (HABS) No. DC-47, (Washington, DC National Park Service, 2013), 28; Historic American Landscapes Survey, "Lodges and Rostrums Data Recorded by HALS," Excel Spreadsheet, in the collection of the National Cemetery Administration, U.S. Department of Veterans Affairs, Washington, DC.
} 
more similar to a gazebo than to the previous rostrum plan. The brick base was topped with an iron railing and four bench seats. The superstructure consisted of eight iron posts about 10' high that supported an iron roof with an iron finial in an orb and flame design. A set of cast-iron steps with railing allowed access to the rostrum. Between 1887 and 1890, the Champion Iron Fence Company of Kenton, Ohio, constructed 18 octagonal rostrums in national cemeteries. 66

A rostrum was constructed at Corinth National Cemetery during 18891890, in the "Sylvan Hall" area of the cemetery near the south entrance. The ornamental structure was built to the standard octagonal design, with a brick foundation/podium and a concrete floor, surmounted by iron columns and a corrugated iron roof. The rostrum was 16' $7^{\prime \prime}$ high and 53' in diameter. The rostrum floor was 4'6" above ground. ${ }^{67}$ Champion Iron Fence Company of Kenton, Ohio, accomplished the construction at an unknown cost. 68 The structure was completed prior to Memorial Day 1890 (Figure 11). 69 The rostrum was described in an inspection report that year as "quite an ornament."70

\footnotetext{
66 Harrison, “National Cemeteries, Rostrums," HABS No. DC-47, 34-37.

67 “Rostrum," U.S. National Cemetery, Corinth, Mississippi, 1941, Real Property form, Corinth National Cemetery records, National Cemetery Administration, U.S. Department of Veterans Affairs, Washington, DC.

68 Historic American Landscapes Survey, "Lodges and Rostrums Data Recorded by HALS," Excel Spreadsheet, in the collection of the National Cemetery Administration, U.S. Department of Veterans Affairs, Washington, DC.

69 Harrison, “National Cemeteries, Rostrums," HABS No. DC-47, 37.

70 J.W. Scully, Quartermaster, letter to Quartermaster General, 20 September 1890, in Record Group 92, Entry 576, Box 22, National Archives and Records Administration, Washington, DC.
} 
Figure 11. View of rostrum shortly after construction, with coursed brickwork, metal posts and railings, and stairs descending to the left, 1892 (NARA, College Park, MD).

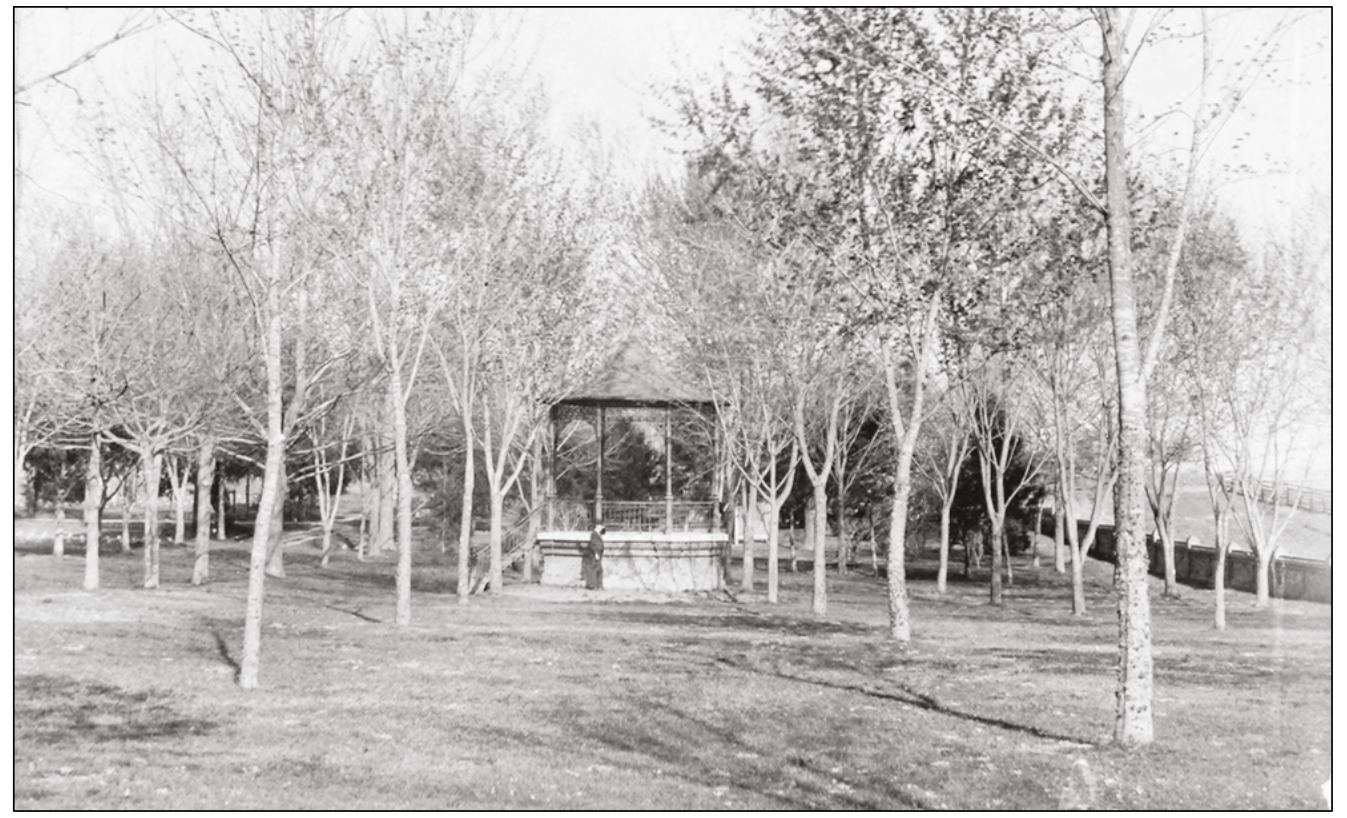

Within a decade or so, the brick part of the rostrum had been covered with vines and surrounded by shrubs and tall deciduous trees, as can be seen in Figure 12. A bench had been placed nearby. The image also shows the extent to which trees and other vegetation had grown to visually enclose and spatially define the perimeter of the cemetery.

Figure 12 . Late $19^{\text {th }}$ or early $20^{\text {th }}$ century view of markers and rostrum, probably around Memorial Day due to flags decorating graves (Cooper Postcard Collection, Mississippi Department of Archives and History).

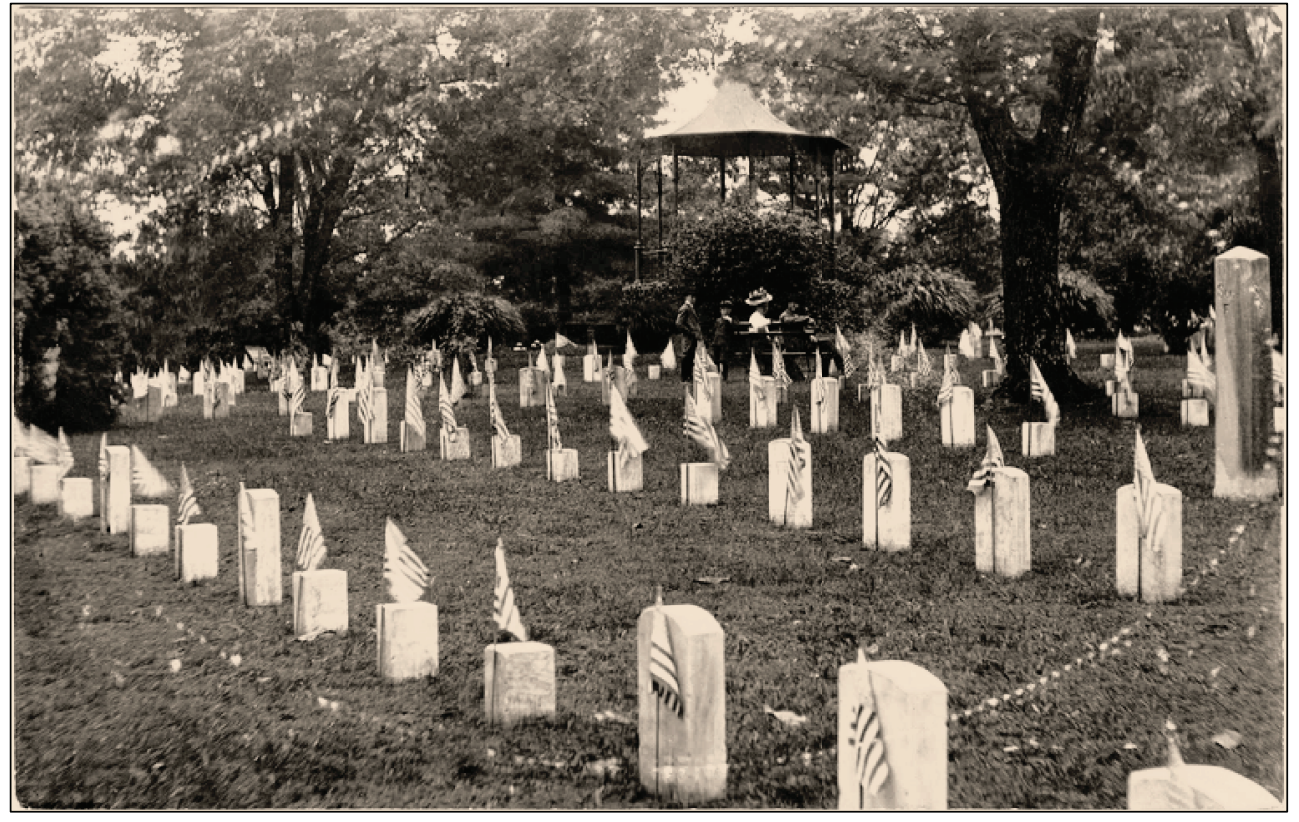


In December 1886, the U.S. Senate passed a bill appropriating $\$ 10,000$ to construct an approach road from the city to the Corinth National Cemetery. The macadamized road was constructed in 1888 and led south from the Memphis \& Charleston railroad track on Fillmore to the cemetery. ${ }^{71}$ The road cost $\$ 9,836$ and was 4,864 feet in length. 72

An 1892 blueprint of the cemetery provided a detailed look at the layout of the burial sections, the roads and walks, buildings and structures, and the type and density of vegetation (Figure 13 through Figure 21). Vestiges of this layout can still be found in the cemetery today. The central avenue was graveled, and the main east-west road was grass covered. The perimeter road was grass covered and lined with trees. There were shrubs lining the brick walk from the central drive to the lodge, and a grape arbor ran from the east side of the lodge to the service drive. The cistern was in place and located northeast of the lodge, and the well was located to the west of the stable. The brick walk continued from the end of the arbor to the stable. The rostrum was on an axis with the western north-south grassed drive. There was vegetation around the interior flagstaff area, and the outer perimeter of the flagstaff area along the road was lined with trees. The early plan for the geometric layout of headstones was evident but in slightly altered form and slightly non-symmetrical patterns. The 1892 plan shows the section marker stones (placed centrally adjacent to but not inside each section) and the two 1874 gun monuments for the first time.

\footnotetext{
71 The Grenada Sentinel, 25 December 1886; Alcorn County Historical Association, The History of Alcorn County Mississippi, (Dallas, TX: National ShareGraphics, Inc., 1983), 18.

72 “Congressman Candler Seeks Improvements for Local Cemetery," The Weekly Corinthian, 20 January 1916.
} 
Figure 13. “National Cemetery Corinth, Miss.” 1892, Office of Quartermaster General, U.S. Army (NARA, College Park, MD).

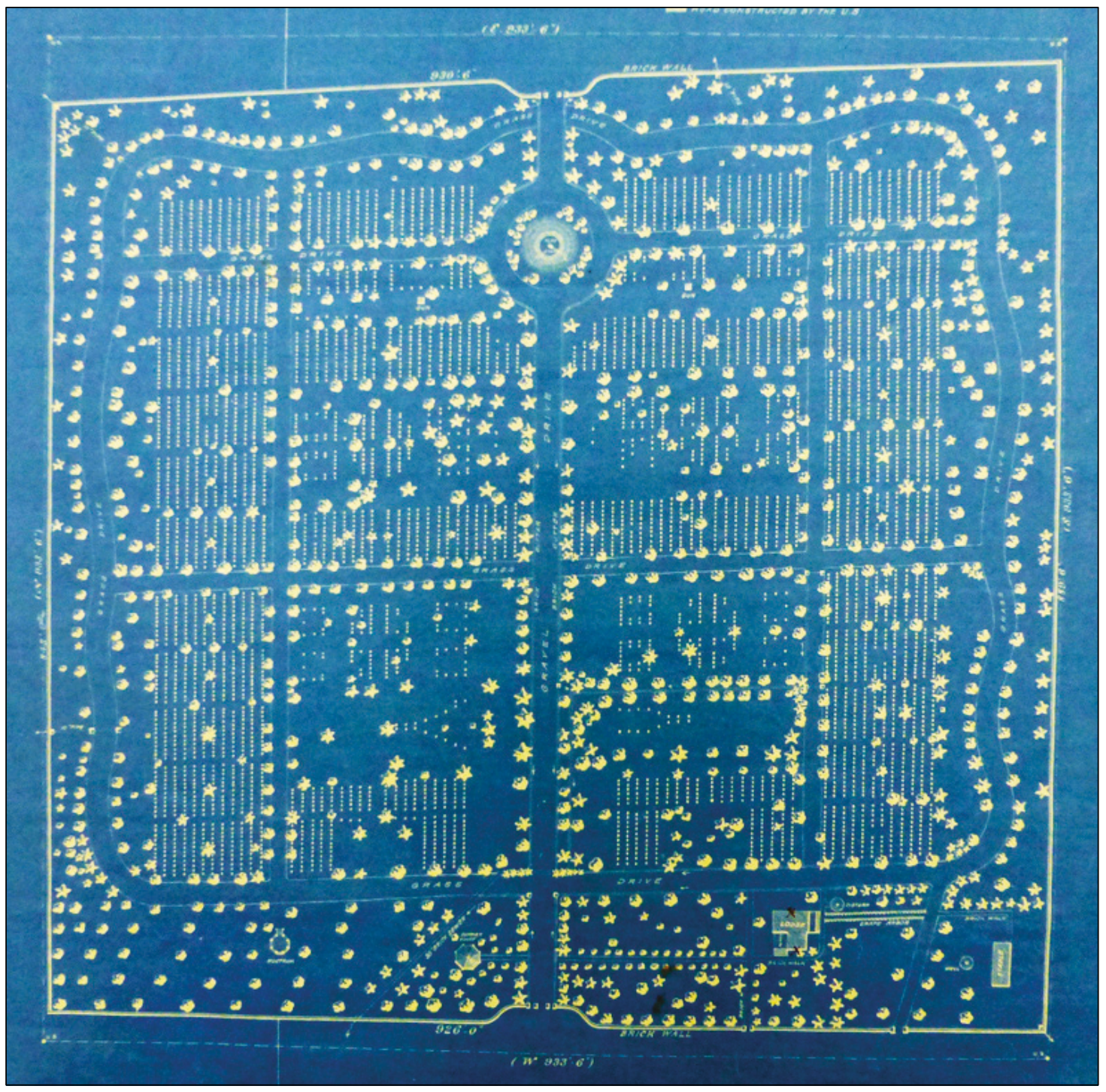


Figure 14. Allées of trees marking the lanes on the cemetery grounds, 1892 (NARA, College Park, MD).

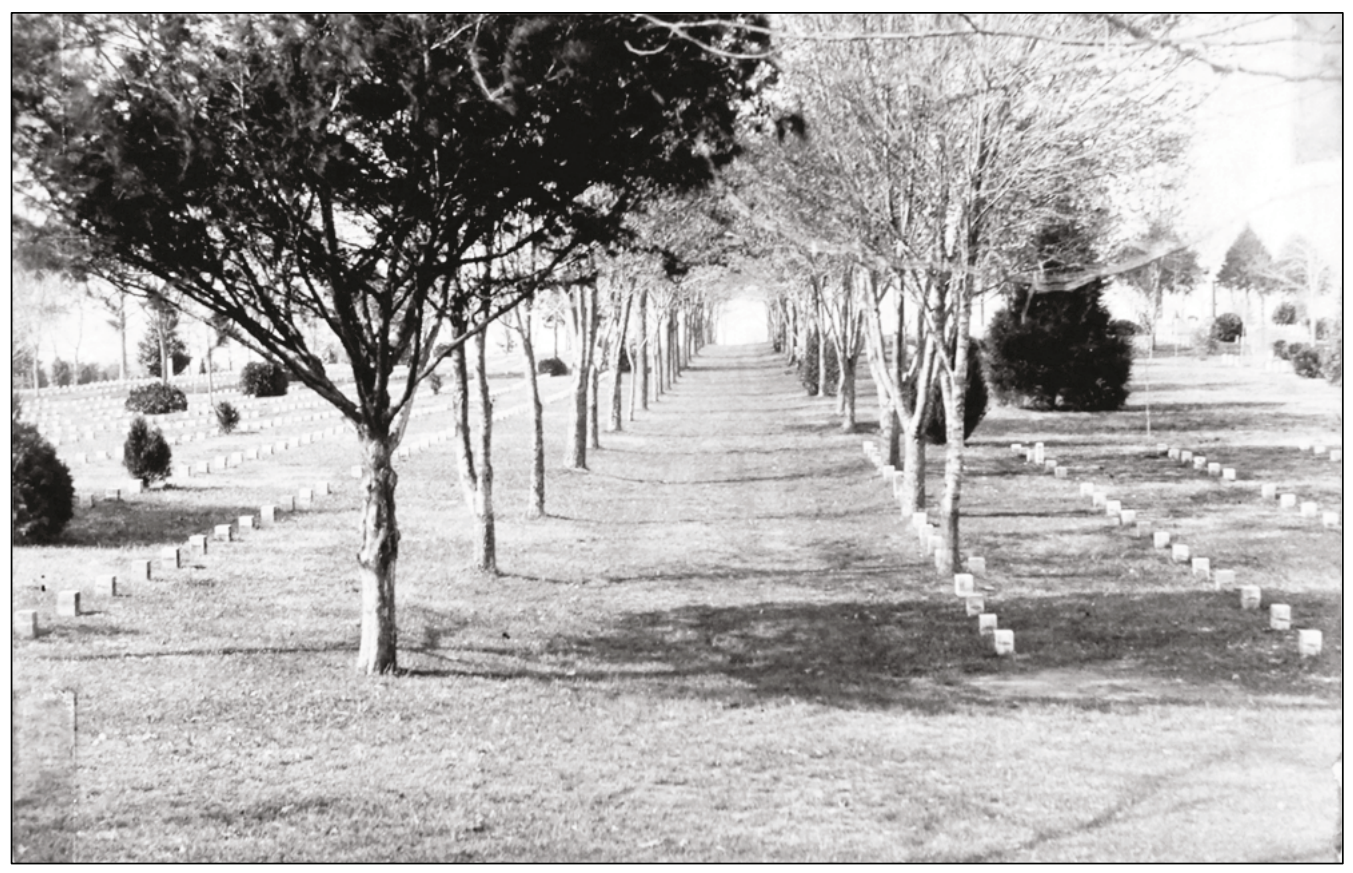

Figure 15. Cemetery grounds with markers, evergreen shrubs, and deciduous and evergreen trees, 1892 (NARA, College Park, MD).

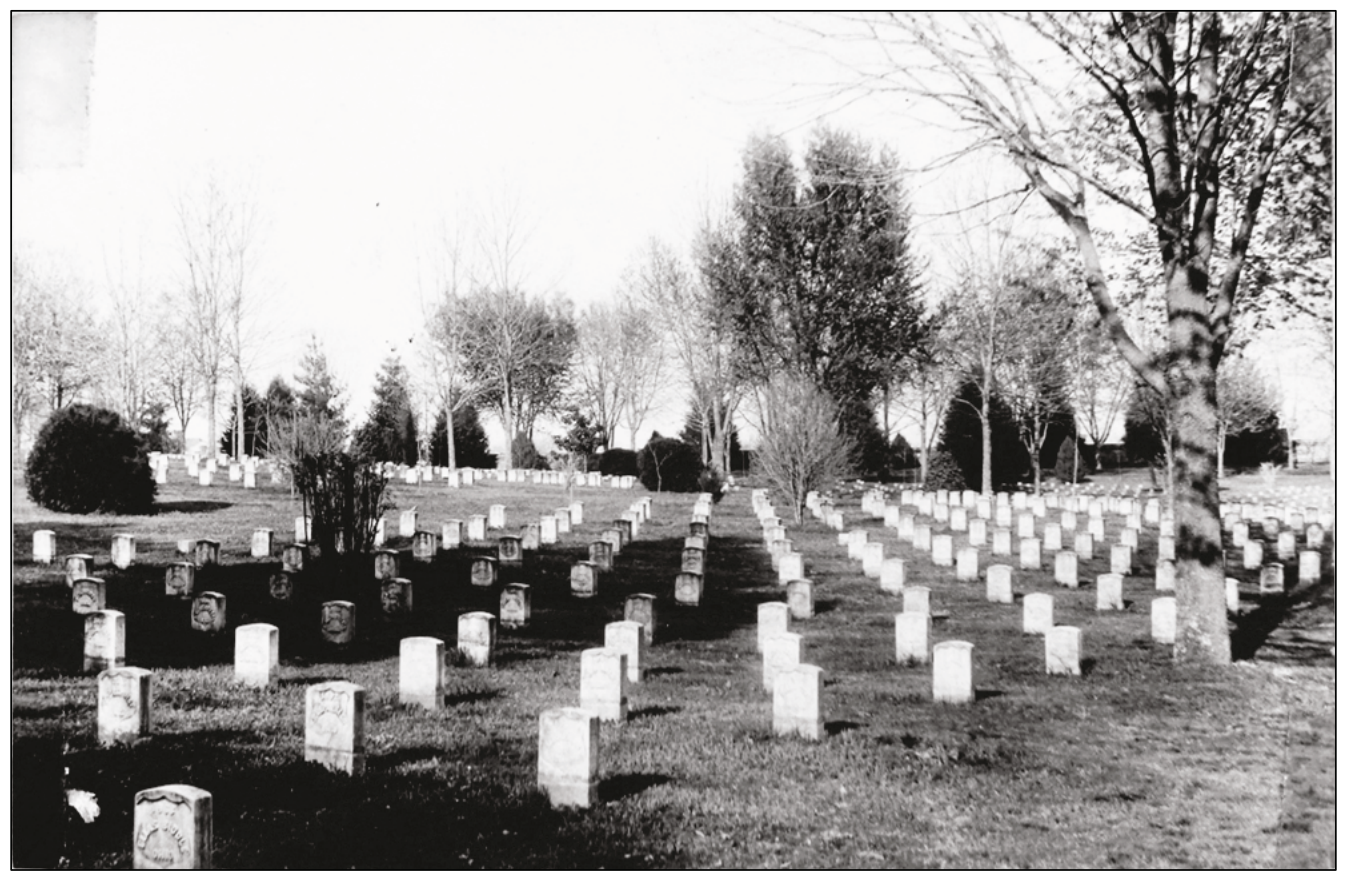


Figure 16. Detail showing Lodge and Stable, map “National Cemetery Corinth, Miss.” 1892, Office of Quartermaster General, U.S. Army (NARA, College Park, MD).

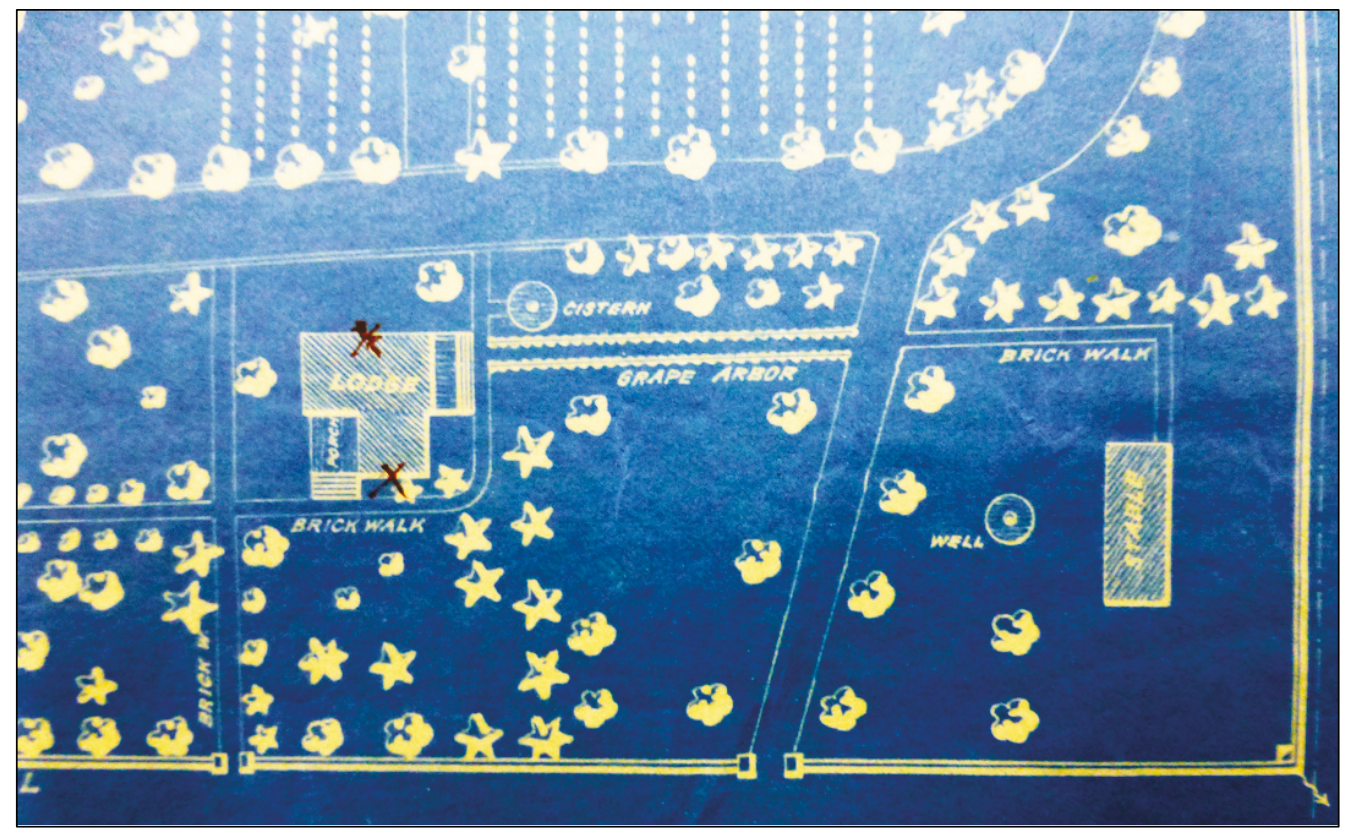

Figure 17. 1892 Photograph showing brick walks, dense mixed deciduous and evergreen trees and shrubs, the gravel central avenue, a Bivouac of the Dead plaque (lower right), short brick piers at the ends of the walk, and the second lodge (NARA, College Park, MD).

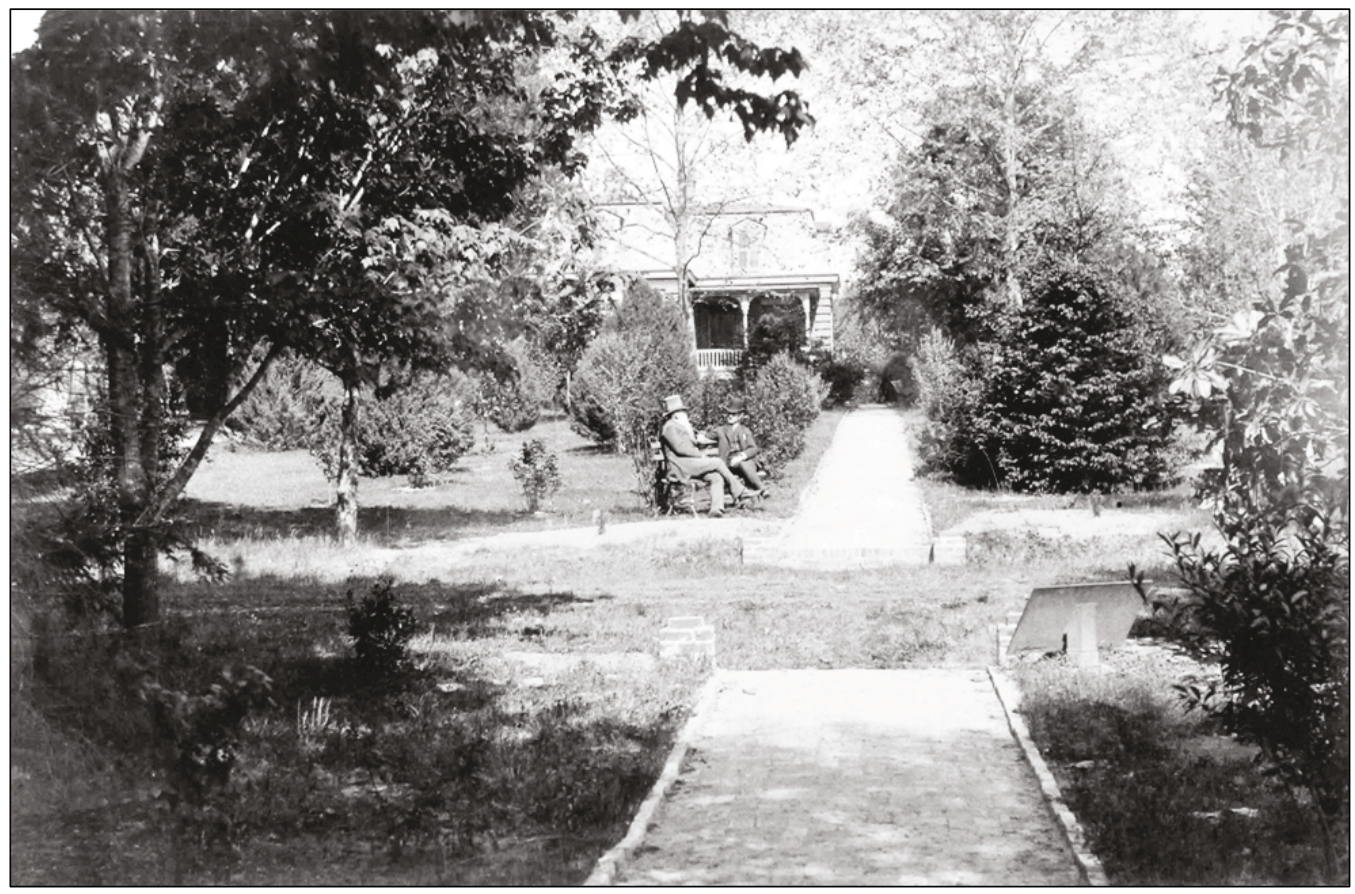


Figure 18. Photograph of lodge, new south and east wall, stable, and shed with hedge delineating stable yard, and mature trees around the lodge and covering cemetery grounds, 1892 (NARA, College Park, MD).

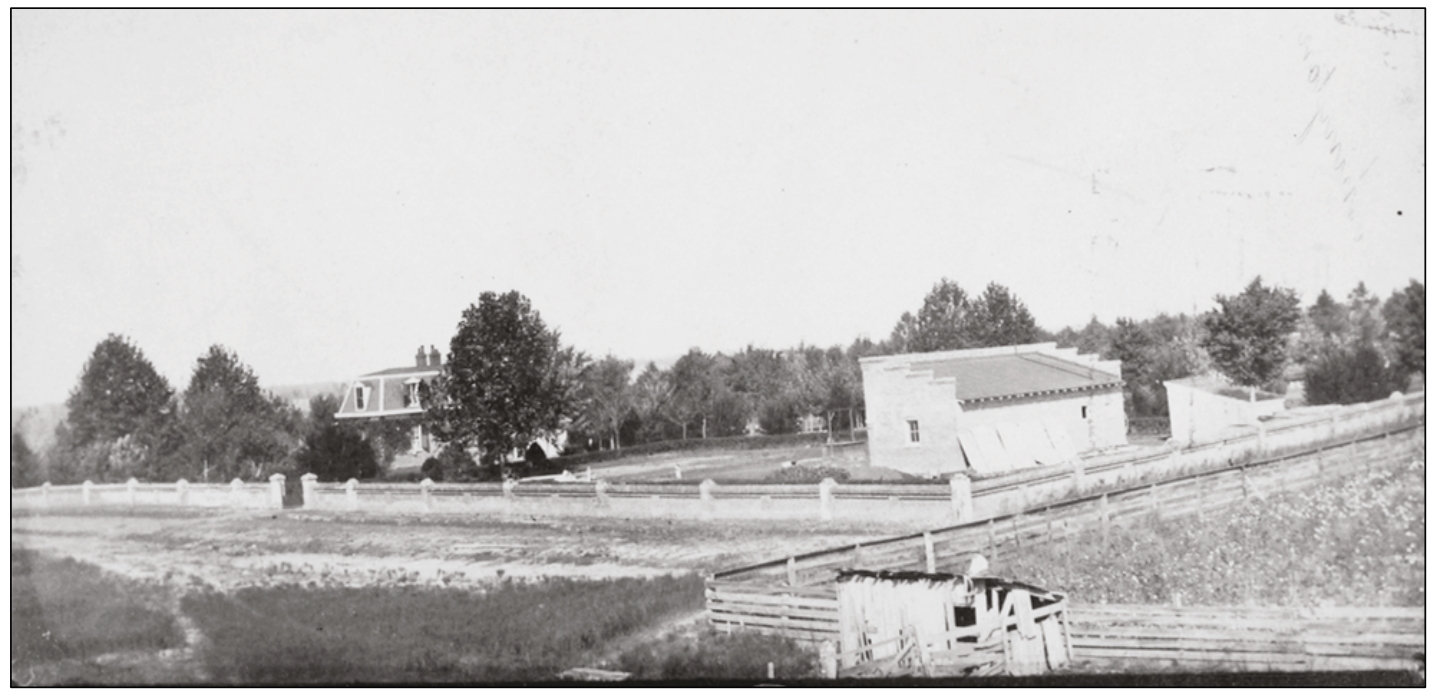

Figure 19. Detail showing rostrum and summer house on west side of main avenue, and brick sewer line; map "National Cemetery Corinth, Miss." 1892, Office of Quartermaster General, U.S. Army (NARA, College Park, MD).

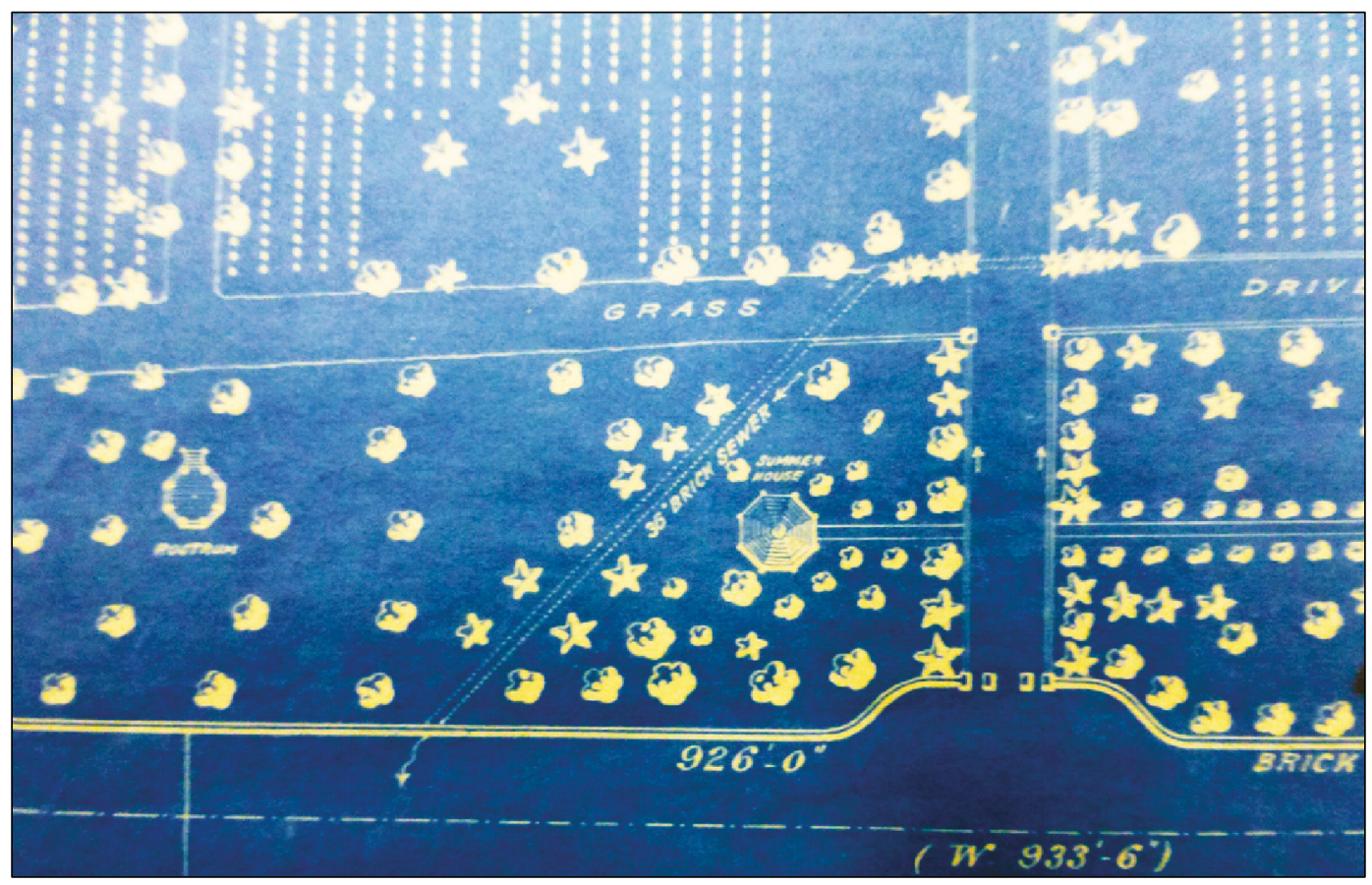


Figure 20. Detail showing circular flagstaff area, north entry gate, encircling drive, and two gun memorials, map “National Cemetery Corinth, Miss." 1892, Office of

Quartermaster General, U.S. Army (NARA, College Park, MD).

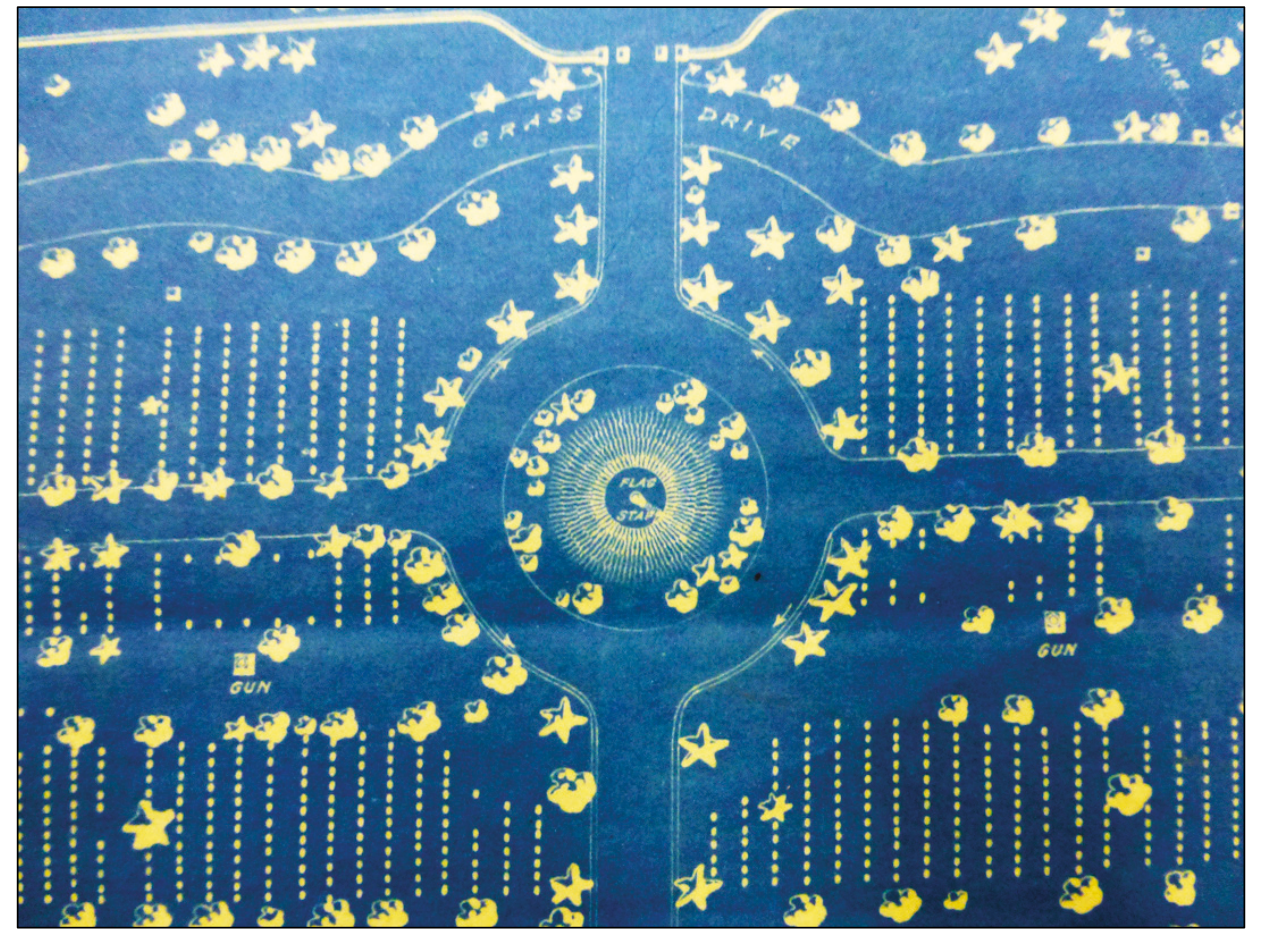

Figure 21. Twentieth-century view of a gun monument at Corinth National Cemetery (Cooper Postcard Collection, Mississippi Department of Archives and History).

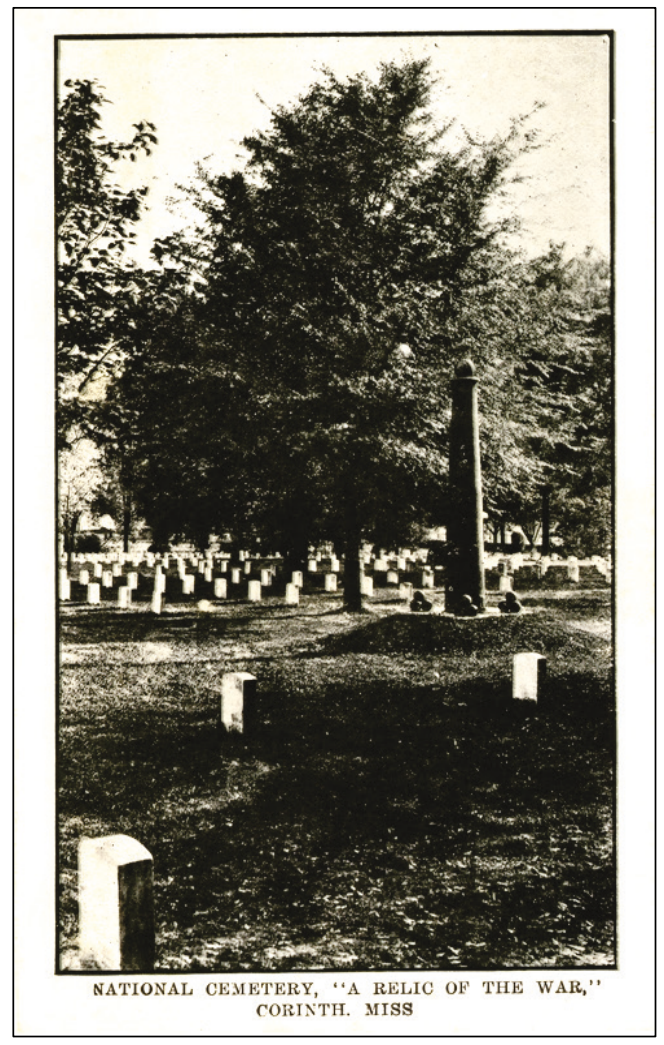


In 1903, the standard size of headstones was modified from that established in 1873. The width of the stone was increased to 12 ", and the aboveground height was changed to 24 " from a total 39 " tall marker. The modified stones had a thickness of $4 "$. Unknown dead who had previously received six-inch-square blocks received the standard headstone, but inscribed with the word "Unknown." 73

A 1909 status report on the cemetery reported a plot of 20 acres, with 19 enclosed. Interments at that time numbered 1,795 known and 3,945 unknown. There were 3,88o headstones consisting of small blocks bearing only the grave number. The land was described as being rolling ground, with the flagstaff located on the highest part and the ground sloping down 28 feet to the south and west. The flagstaff was described at this point as 65 feet tall, double-masted, made from yellow pine, and erected in 1897. The enclosing brick wall was described as being in "very good" condition in 1909.74

The lodge, however, was described as being in "fair" condition. 75 The lodge had not been altered, so it still contained the original three rooms on the first floor, three on the second floor, and a basement (Figure 22).

\footnotetext{
73 National Cemetery Association, "History of Government Furnished Headstones and Markers," 2015.

74 James M. Dickey, Superintendent, “Status Report, Corinth National Cemetery," 18 March 1909, Record Group 92, Entry 576, Box 22, National Archives and Records Administration, Washington, DC.

75 Dickey, “Status Report, Corinth National Cemetery," 18 March 1909.
} 
Figure 22. South wall, pedestrian gate, and Lodge, 1904 (NARA, College Park, MD).

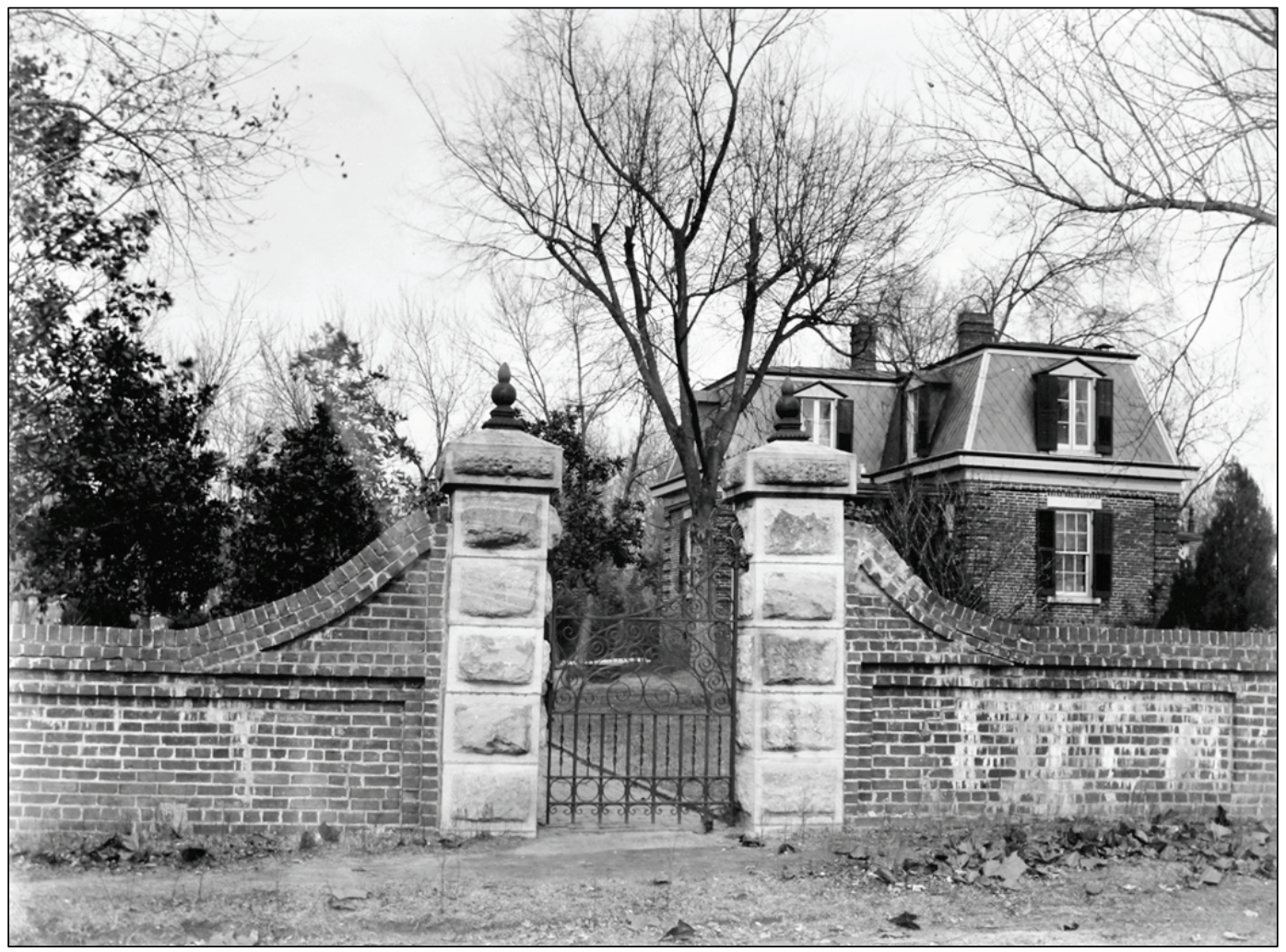

Several outbuildings were described in the 1909 report. There was a onestory building measuring 16' x 39' and containing 3 rooms built in 1882 . An 1894 addition measuring 16'6" x 23' had two stories, and it was connected to the first building by an open shed (Figure 23). The buildings were used as stables ( 3 stalls), and storage for forage, tools, and fuel. The single-story building also contained two privies for the public measuring 4' $\times 5^{\prime}$ and $4^{\prime} \times 6^{\prime} .7^{6}$ It is possible that upon construction of the two-story brick building, it became the stable and the older building was then used for storage.

76 Dickey, “Status Report, Corinth National Cemetery,” 18 March 1909. 
Figure 23. View of service gate, stable/tool house building, ca. 1900 (NARA, College Park, MD).

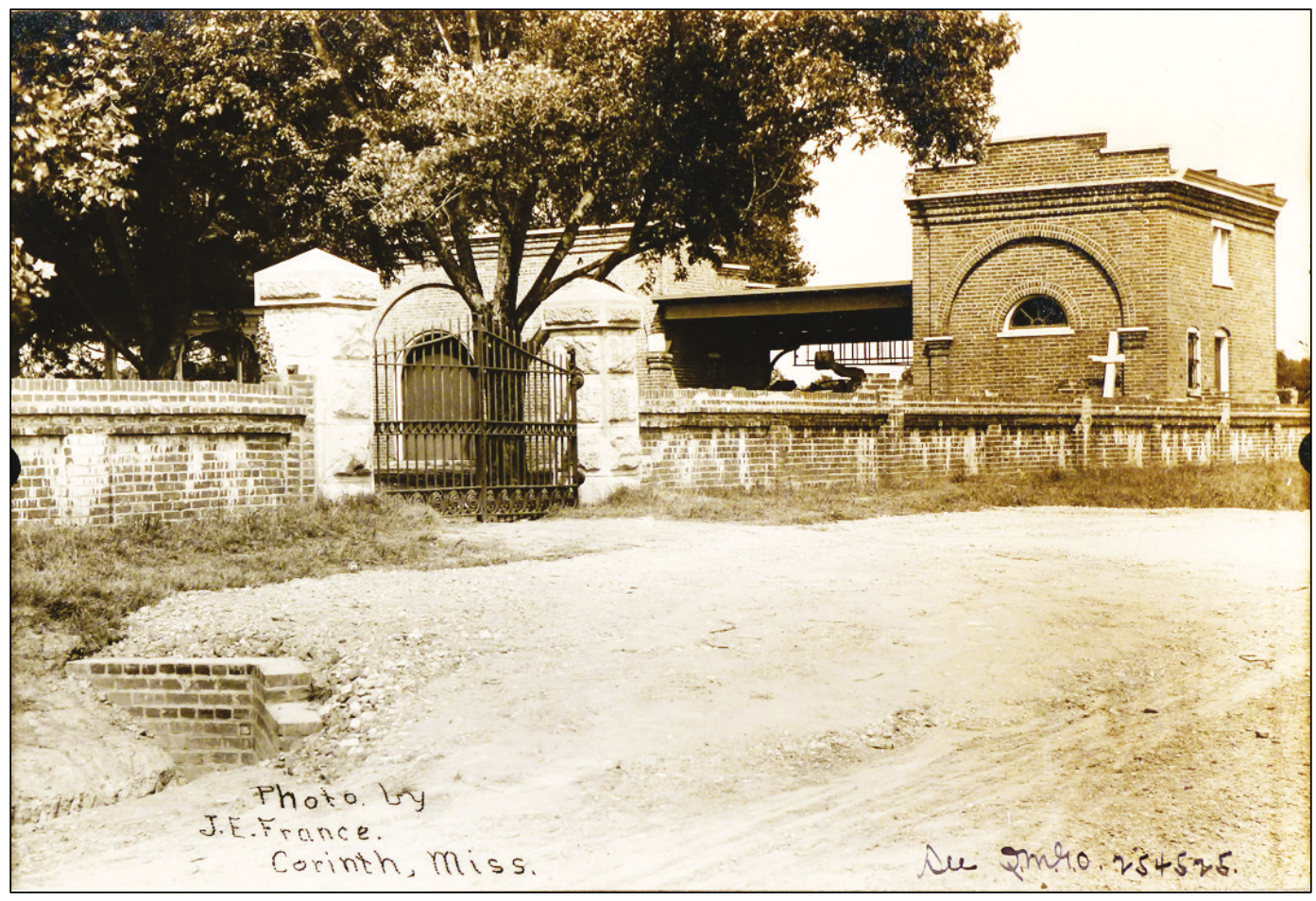

A cistern house, 12 feet in diameter with lattice sides, had been constructed at the rear of the lodge in 1882. It covered a 10,000 gallon capacity cistern for domestic use. The cistern house had lattice walls, a concrete foundation, concrete floor and, at least in 1932, a composition shingle roof. 77 A well house near the stable was built in 1889 with open sides and a $12^{\prime}$ diameter. ${ }^{78}$ The well house can be seen between the right gate pier and the stable in Figure 24. The water from the well was used for the public and the stock. There were cart and wagon sheds in the stable area.79

\footnotetext{
77 “Cistern House," U.S. National Cemetery, Corinth, Mississippi, 1932, Real Property form, Corinth National Cemetery records, National Cemetery Administration, U.S. Department of Veterans Affairs, Washington, DC; Dickey, “Status Report, Corinth National Cemetery,” 18 March 1909.

78 Dickey, “Status Report, Corinth National Cemetery," 18 March 1909.

79 Dickey, “Status Report, Corinth National Cemetery," 18 March 1909.
} 
Figure 24. South wall service gate, well house, stable/tool house, and grape arbor, ca. 1900 (NARA, College Park, MD).

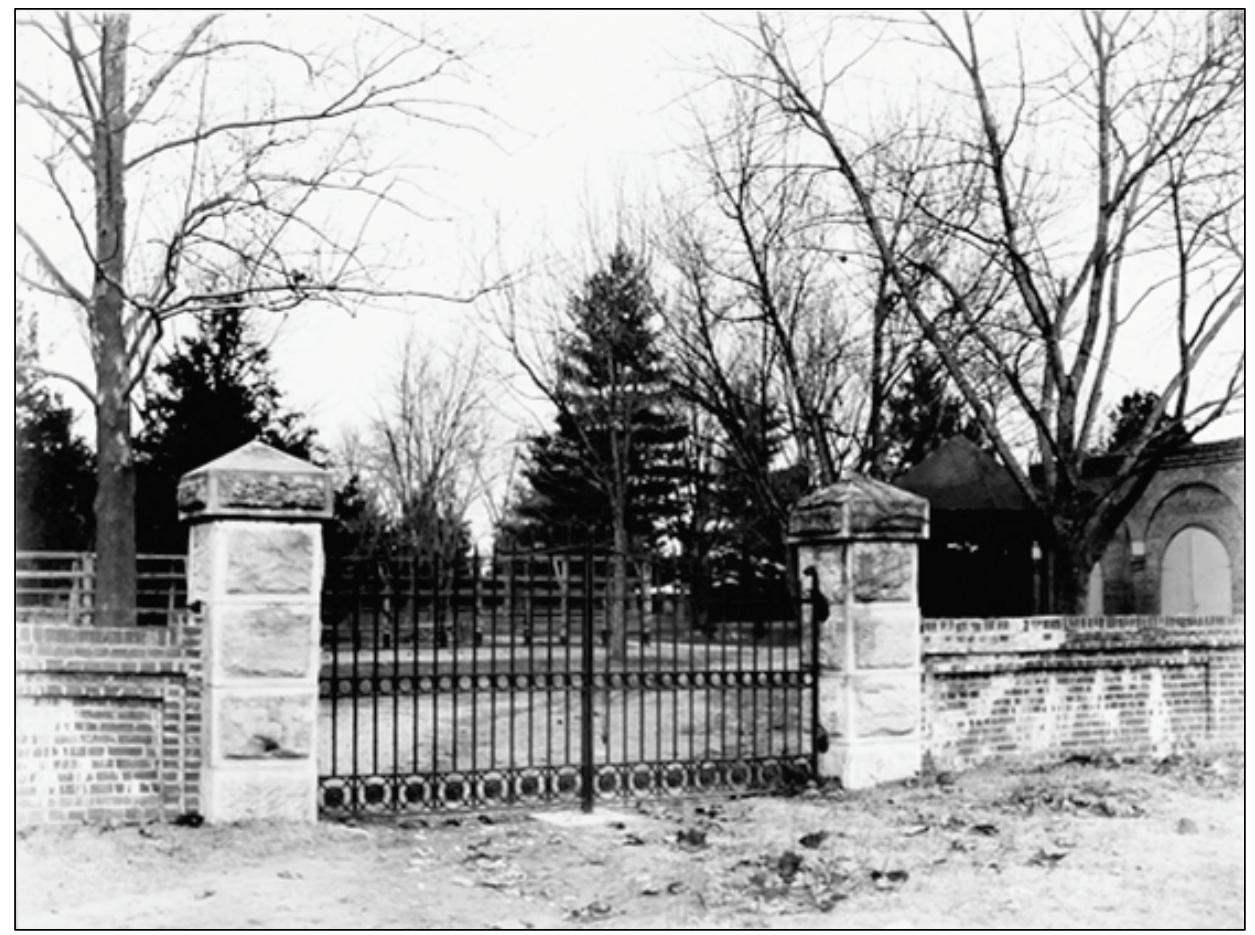

The roads also were described in 1909. The main avenue through the cemetery was 25 ' wide. The circular drive enclosing the burial sections remained, but it had been grassed over although it was "constantly worn by carriage driving." 80 The cemetery at that time contained 15 iron tablets on the grounds, one containing General Order \#80, four providing the text for the 1867 "Act to Establish and protect National Cemeteries," and ten with various verses of Theodore O'Hara's poem, "Bivouac of the Dead." These last tablets were placed in Sections A, B, O, P, R, S, and T.

Tablets in National Cemeteries containing President Lincoln's Gettysburg address were in place by $1909 .{ }^{81}$. This text was chosen because it had previously been featured as a permanent element in national cemetery landscapes as early as 1895, when legislation authorized a monument to the speech at the Soldiers National Cemetery. The original Gettysburg Address

\footnotetext{
80 Dickey, “Status Report, Corinth National Cemetery," 18 March 1909.

81 National Cemetery Administration, "New Gettysburg Address Tables for National Cemeteries to Honor Abraham Lincoln Bicentennial.” https://www.cem.va.gov/history/LincBic.asp, 2015.
} 
cast-iron tablet was produced in 1909 by the U.S. Army Rock Island Arsenal in Illinois and placed in all national cemeteries. ${ }^{82}$ At Corinth, there was some discussion as to where to mount the plaque-on either the north or the south side of the lodge. It was decided to mount it on the south side near the office, so as not to disturb the family's privacy by having visitors looking at it near windows into the family quarters (Figure 25). ${ }^{8}$ It remained there until at least 1953.

Figure 25. Gettysburg Address plaque on Superintendent's Lodge at Corinth National Cemetery, 1953 (NCA archives, Washington, DC).

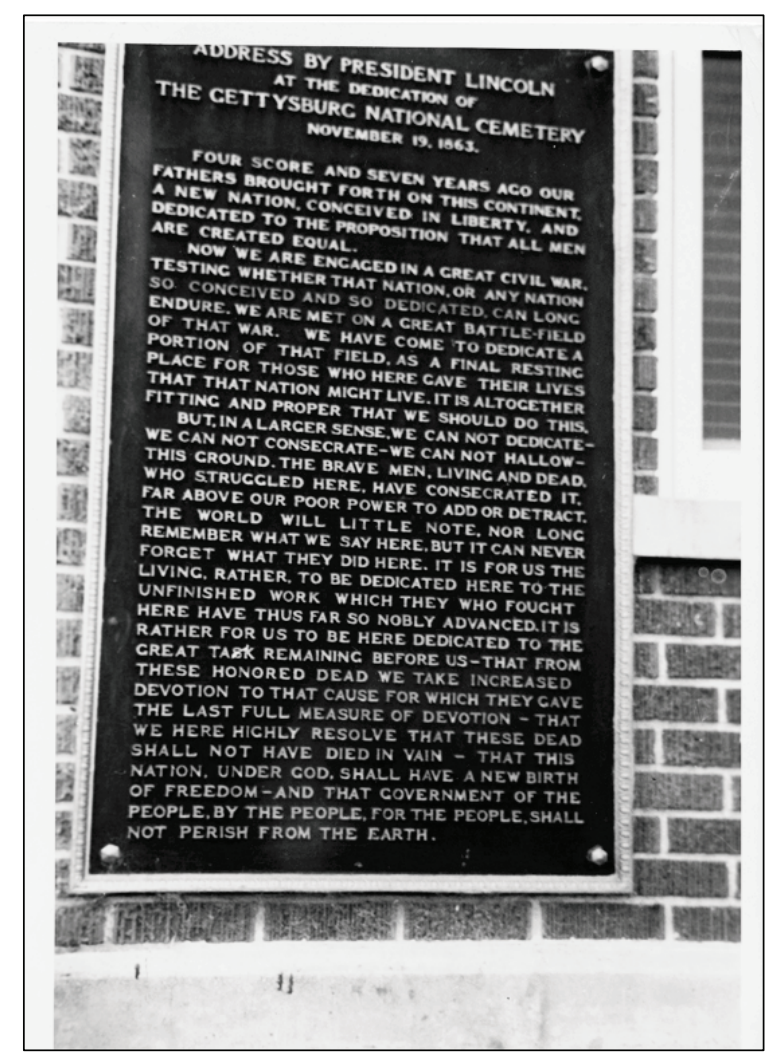

A severe storm tore through the cemetery in 1909, doing considerable damage to the lodge and the vegetation on the cemetery grounds (Figure 26 and Figure 27). It is not known how long it took to repair the damage.

\footnotetext{
82 VA National Cemetery Division, “150 th Anniversary National Cemeteries of the Civil War 2012 planner," (Washington, DC: U.S. Department of Veterans Affairs, National Cemetery Division, 2011); VA National Cemetery Division, "New Gettysburg Address Tablets for National Cemeteries To Honor Abraham Lincoln Bicentennial," (Washington, DC: U.S. Department of Veterans Affairs, National Cemetery Division, last updated 2015), https://www.cem.va.gov/history/LincBic.asp.

83 James M. Dickey, Superintendent, Corinth National Cemetery, letter to the Chief Quartermaster, Department of the Gulf, Atlanta, GA, 10 August 1909, NARA, College Park, MD.
} 
Figure 26. Storm damage to Superintendent's Lodge, 1909 (Cooper Postcard Collection, Mississippi Department of Archives and History).

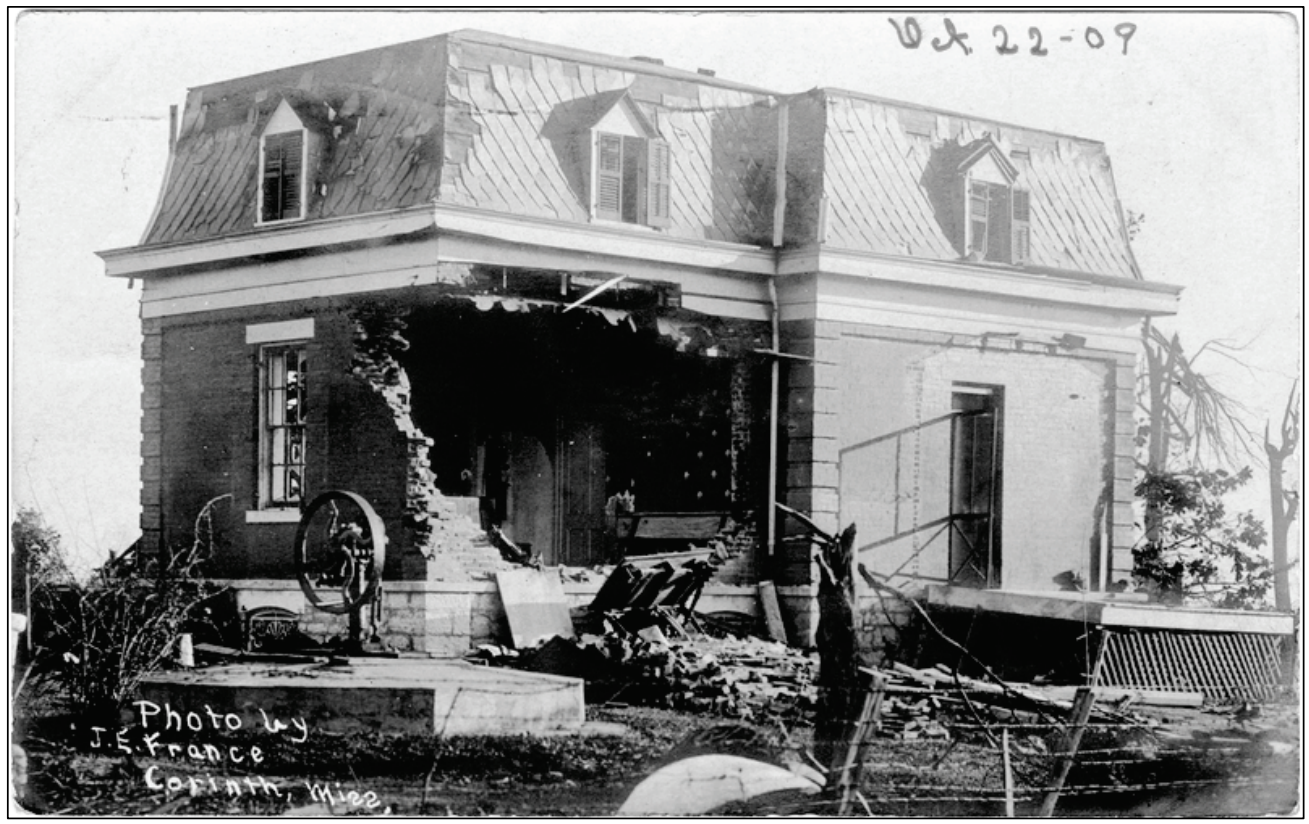

Figure 27. Photo of damage from same storm, with Lodge in the background (Cooper Postcard Collection, Mississippi Department of Archives and History).

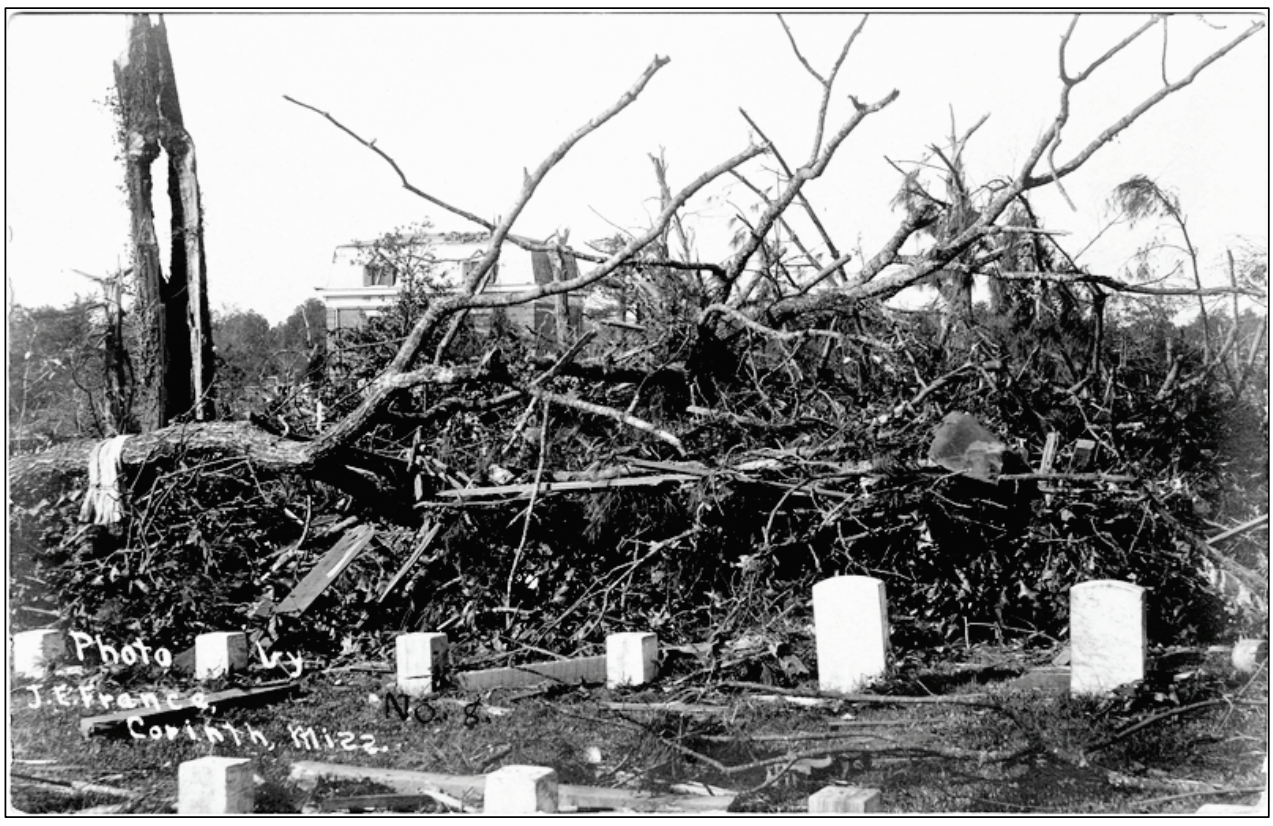

Real property records indicate that a new flagpole was installed in 1906. A 1942 inspection report indicates the iron pole had a concrete foundation 
and was 100' tall (Figure 28). ${ }^{84}$ However, this information contradicts the 1909 report, which still listed the flagpole as being the wooden flagpole erected in 1897; this discrepancy has not been resolved to date by authors of this report.

Figure 28. 1906 flagpole, 1941 (NARA, Washington, DC).

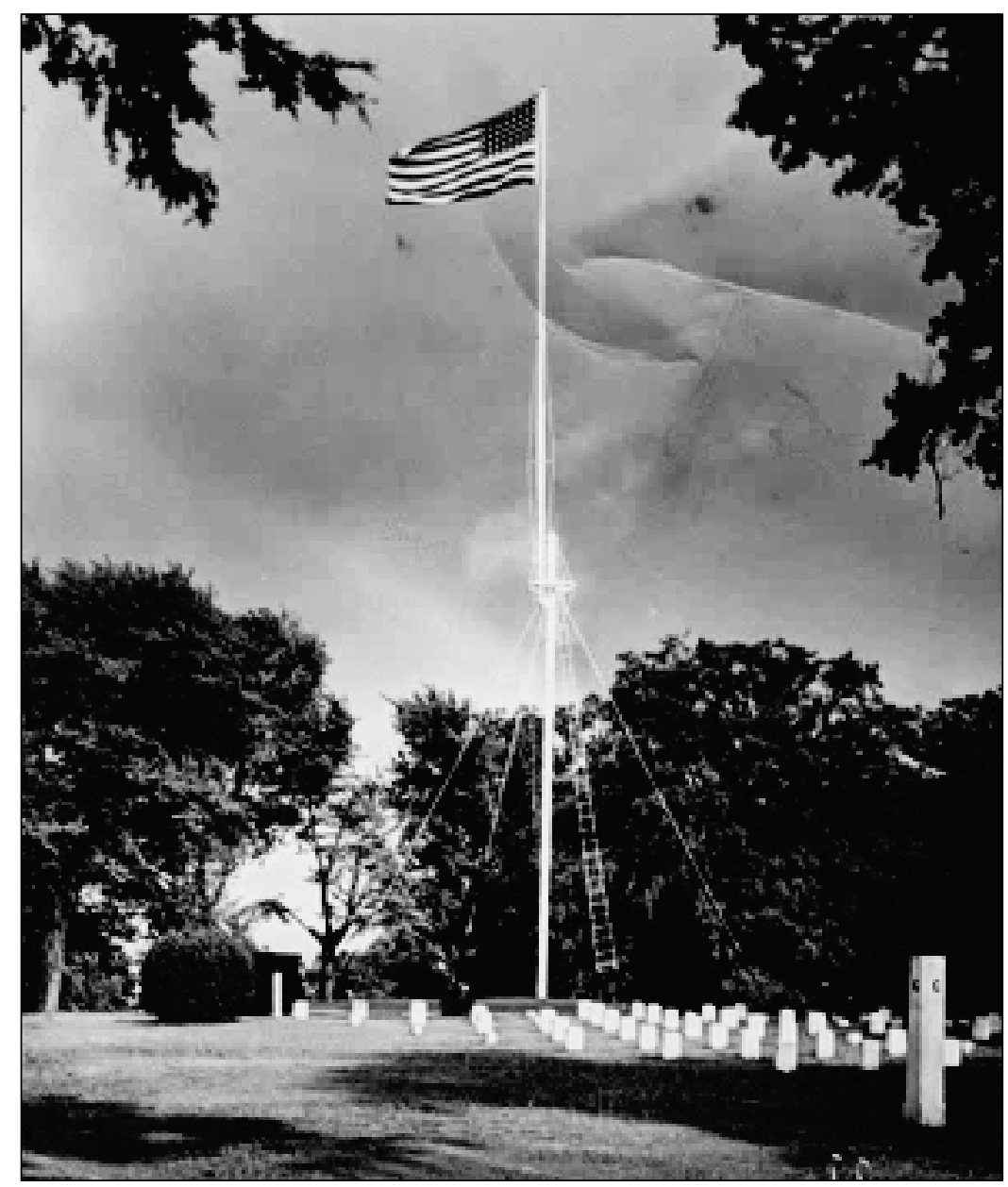

In 1910, the Judge Advocate General of the Army established that the United States government held title to 1,400 feet of the approach road between the cemetery and the old city limits, as a decision on a dispute regarding maintenance responsibilities. A reported agreement between the

\footnotetext{
84 "Flagpole," U.S. National Cemetery, Corinth, Mississippi, 1941, Real Property form, Corinth National Cemetery records, National Cemetery Administration, U.S. Department of Veterans Affairs, Washington, DC.
} 
city and the government in 1911 required the government to maintain its 1,400 feet of the road, and the city would maintain the remainder. ${ }^{85}$

\subsection{Modernization period, 1934-1954}

Headstones were redesigned after World War I, and they were used for all graves except those of Civil War and Spanish-American War veterans. Referred to as the "General" type of headstone, the white marble stone was 42" long, 13" wide, and 4" thick, with a slightly rounded top. The inscription contained a soldier's name, rank, regiment, division, date of death, and home state. For the first time, there was a choice of two religious emblems-a Latin Cross for the Christian faith or the Star of David for the Jewish faith. 86

In 1926, a quitclaim deed from the Acting Secretary of War to the City of Corinth, dated 4 September 1926, formally conveyed the governmentowned or controlled approach road for the cemetery to the city. The road had been originally acquired by the United States through two deeds from M.A. Mitchell and the Mayor of Corinth, resulting from the 1920-11 dispute over maintenance responsibilities. ${ }^{87}$

Construction was completed on the stable building to enclose the existing shelter between the stable and the tool room to create a garage. The 1931 construction cost $\$ 100.88$ The building was described at that time as: 89

Tool House is $17^{\prime} \mathrm{x} 40^{\prime}$ length north and south, 3 rooms with 2 public toilets in north end room. Wood shed 7' x 20' joined to center of east side. Stable $17^{\prime}$ x $32^{\prime}$ across south end of tool house with space between $10^{\prime} \mathrm{x}$ 20 'on east side with weatherboarding, on west by 2 rolling doors. This room is used for a garage.

\footnotetext{
85 “Congressman Candler Seeks Improvements for Local Cemetery," The Weekly Corinthian, 20 January 1916.

86 National Cemetery Association, “History of Government Furnished Headstones and Markers," 2015.

87 United States War Department, “Corinth National Cemetery, Mississippi," Real Property report, 4 August 1937, 1, in Corinth Vertical File, National Cemetery Administration, U.S. Department of Veterans Affairs, Washington, DC.

88 "Stable, tool house \& public toilet," U.S. National Cemetery, Corinth, Mississippi, 1932, Real Property form, Corinth National Cemetery records, National Cemetery Administration, U.S. Department of Veterans Affairs, Washington, DC.

89 "Stable, tool house \& public toilet," 1932.
} 
The old brick stable and tool house was torn down in 1934 as part of a larger project to re-do the living quarters and service area for the cemetery. An existing oil house and the cistern house (Figure 29 and Figure 30) were also removed. ${ }^{90}$ Construction date of the oil house is not known. The small building was constructed of weatherboard walls and a tar-paper roof, and it measured 8' x 8'.91

Figure 29. Stable/tool house and public toilet building, with small oil house adjacent, 1931 (NARA, Washington, DC).

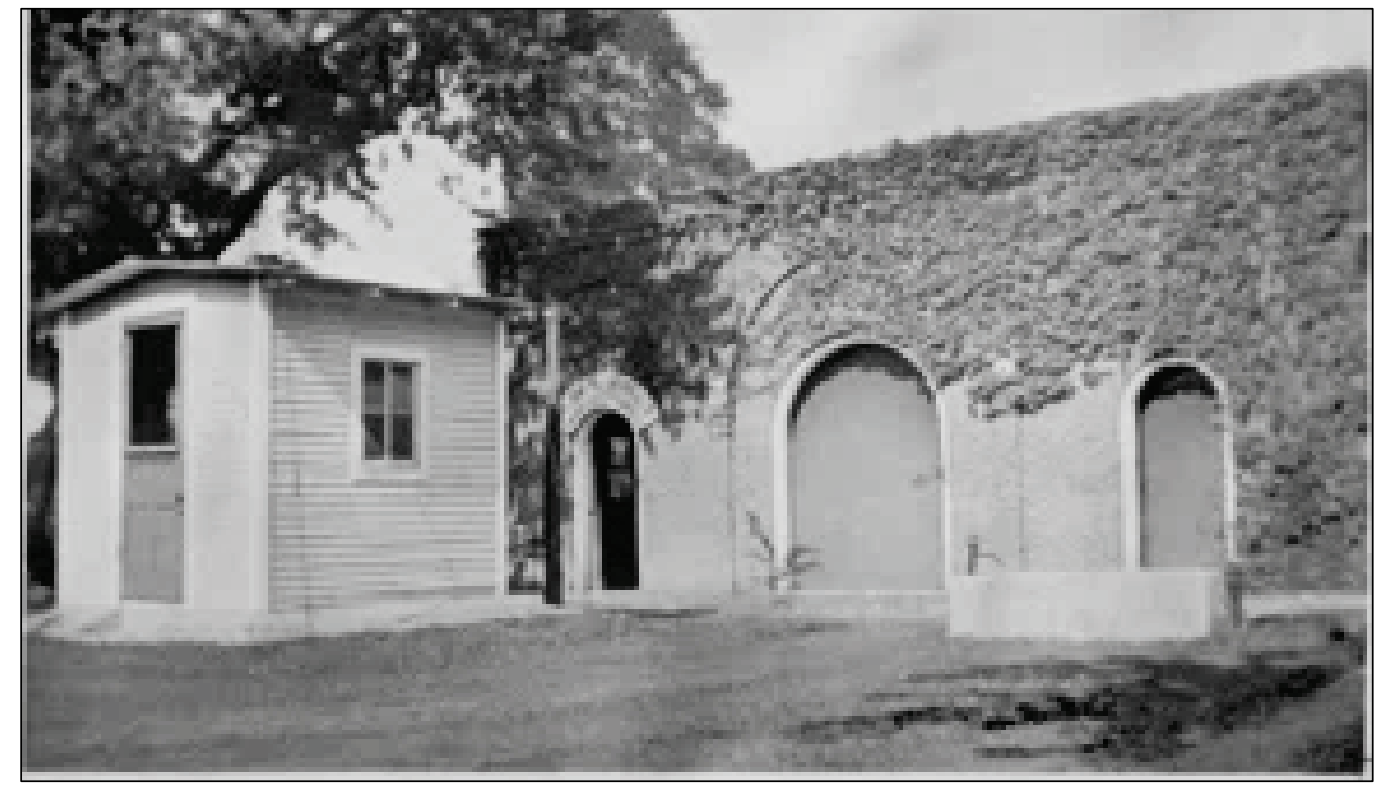

90 Sammartino, “Corinth National Cemetery," 1996, 6.

91 “Oil House," U.S. National Cemetery, Corinth, Mississippi, 1933, Real Property form, Corinth National Cemetery records, National Cemetery Administration, U.S. Department of Veterans Affairs, Washington, DC. 
Figure 30. Cistern house adjacent to lodge, 1932 (NARA, Washington, DC).

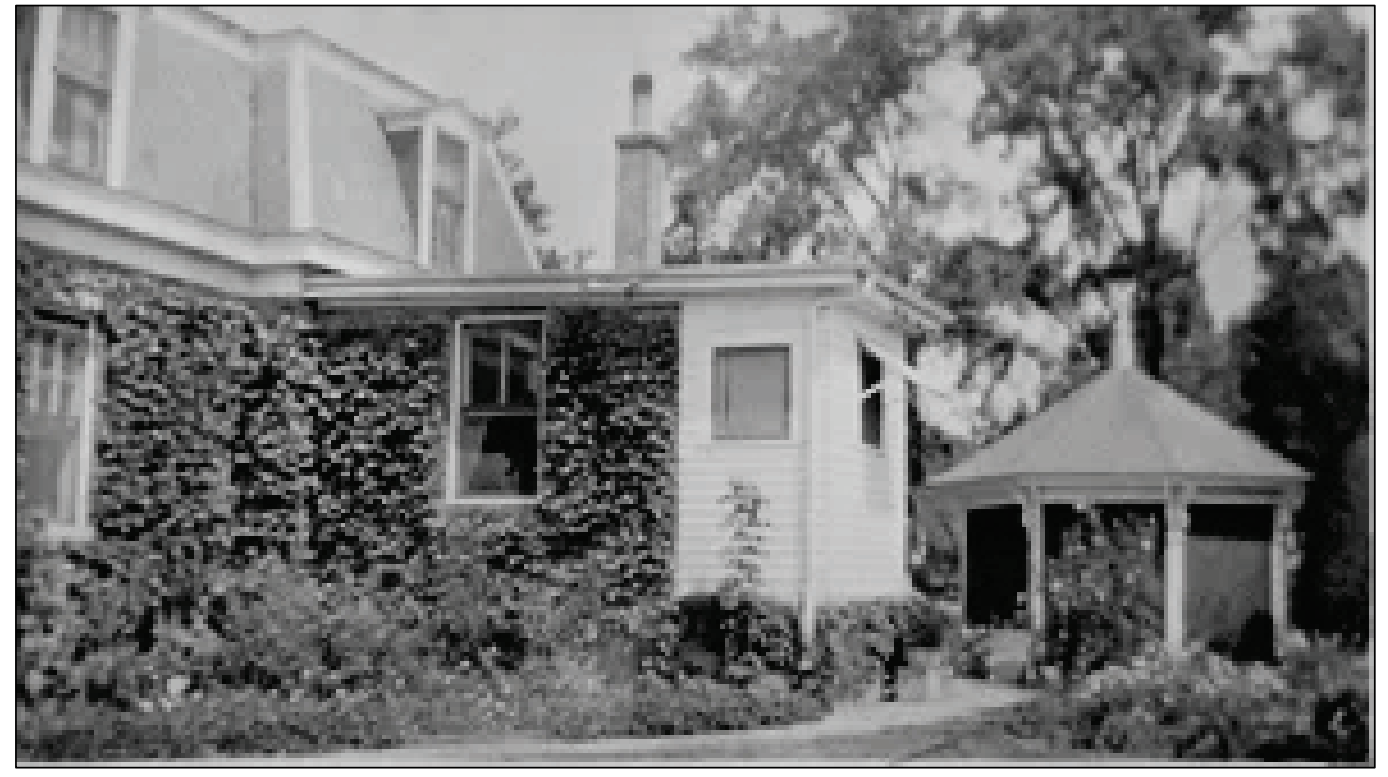

The U.S. Army Quartermaster's Department created a new standard plan for lodges in a Dutch Colonial Revival style, having 1/2 stories and a large gambrel roof. Fourteen Dutch Colonial Revival lodges were constructed between 1921 and 1934, including one at Corinth. "In plan, all the Dutch Colonial Revival lodges were simple rectangles, with an enclosed porch and office in the front; living room and side stair in the middle; and dining room and kitchen toward the rear. The second story contained three bedrooms and a bathroom organized around a central hall."92 The design was changed marginally over the years, and the last version had "brick firstfloor construction and faux-half-timbered or brick gables" with dormers containing four windows. 93

The government made funds available through the Federal Emergency Administration for Public Works (PWA) in fiscal year 1934 for a variety of projects at national cemeteries. Dutch Colonial Revival design lodges constructed in 1934 with PWA funds were located at national cemeteries in Salisbury, Jefferson Barracks, Fort Gibson, Corinth, Philadelphia, Memphis, Wilmington, and Beaufort. 94 The plan for the Corinth lodge is shown in Figure 31, with elevations shown in Figure 32.

\footnotetext{
92 Harrison, “National Cemeteries, Superintendent's Lodges," HABS No. DC-46, 43.

93 Harrison, "National Cemeteries, Superintendent's Lodges," HABS No. DC-46, 43.

94 Harrison, “National Cemeteries, Superintendent's Lodges," HABS No. DC-46, 45.
} 
Figure 31. Plan for 1933 standard lodge variation designed for Salisbury, Wilmington, Corinth, Memphis, Marietta, and Nashville national cemeteries (Corinth Lodge Historic Structure Assessment Report [HSAR], NCA archives, Washington, DC).

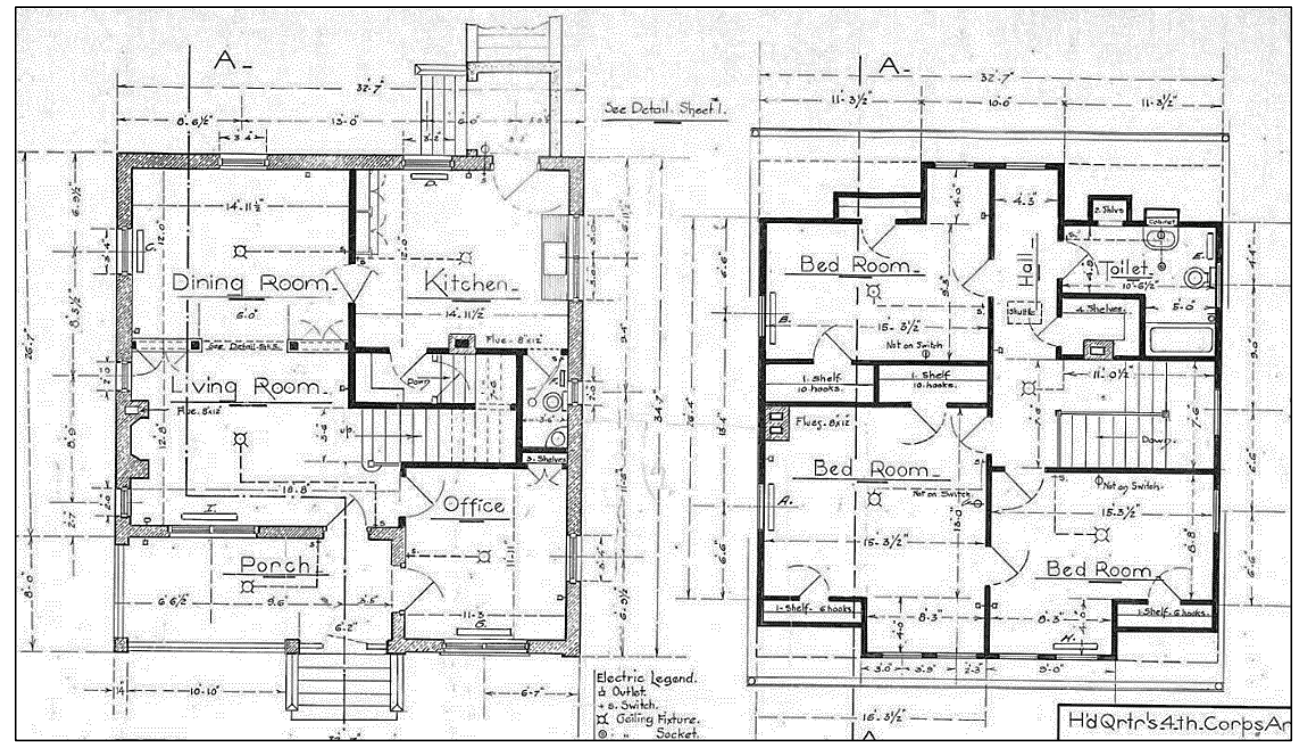

Figure 32. Elevations for the 1933 standard lodge variation constructed at Corinth National Cemetery (Corinth Lodge HSAR, NCA archives, Washington, DC).

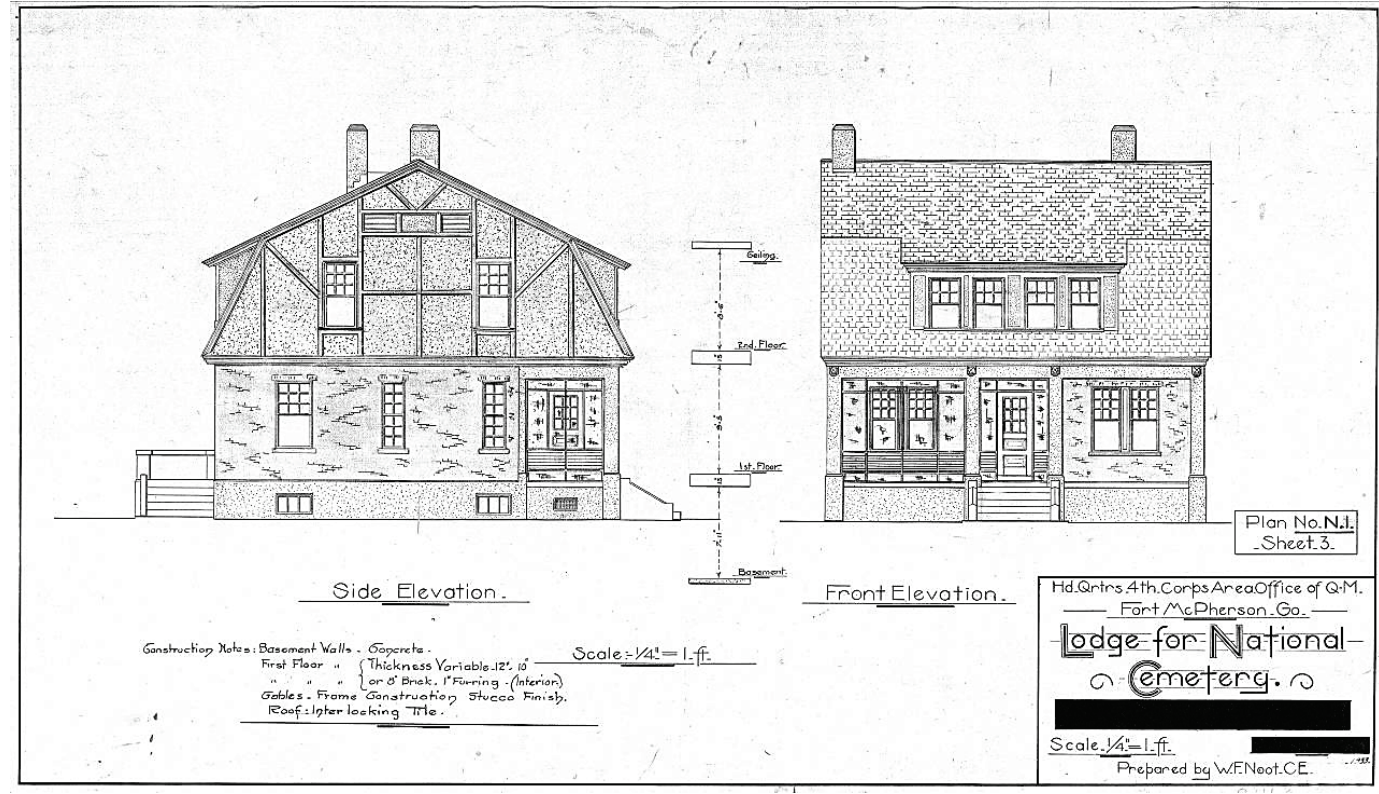


The current superintendent's lodge at Corinth National Cemetery was completed on 19 June 1934 at a cost of $\$ 9,200$, and it was constructed primarily with PWA funds. 95 The building was constructed with a concrete foundation, brick, wood and stucco walls, hardwood floors, and a tile roof. The lodge measured 29'3" x 35'3" with a 27'1" x $33^{\prime} 1$ " basement. Total floor area above the basement was 1,278 square feet contained in seven rooms. ${ }^{96}$ There were three bedrooms. ${ }^{97}$ A sidewalk extended around the front of the lodge to the south and wrapped around the building to the east, in the direction of the former stable area. An early photograph shows shrubs planted against the foundation and along the far perimeter of the sidewalk, with dense vegetation in the background (Figure 33). Copper gutters and downspouts were added in $1948.9^{8}$ Vegetation planted around the lodge varied over time (Figure 34 and Figure 35).

Figure 33. Superintendent's Lodge, ca. 1934 (NCA archives, Washington, DC).

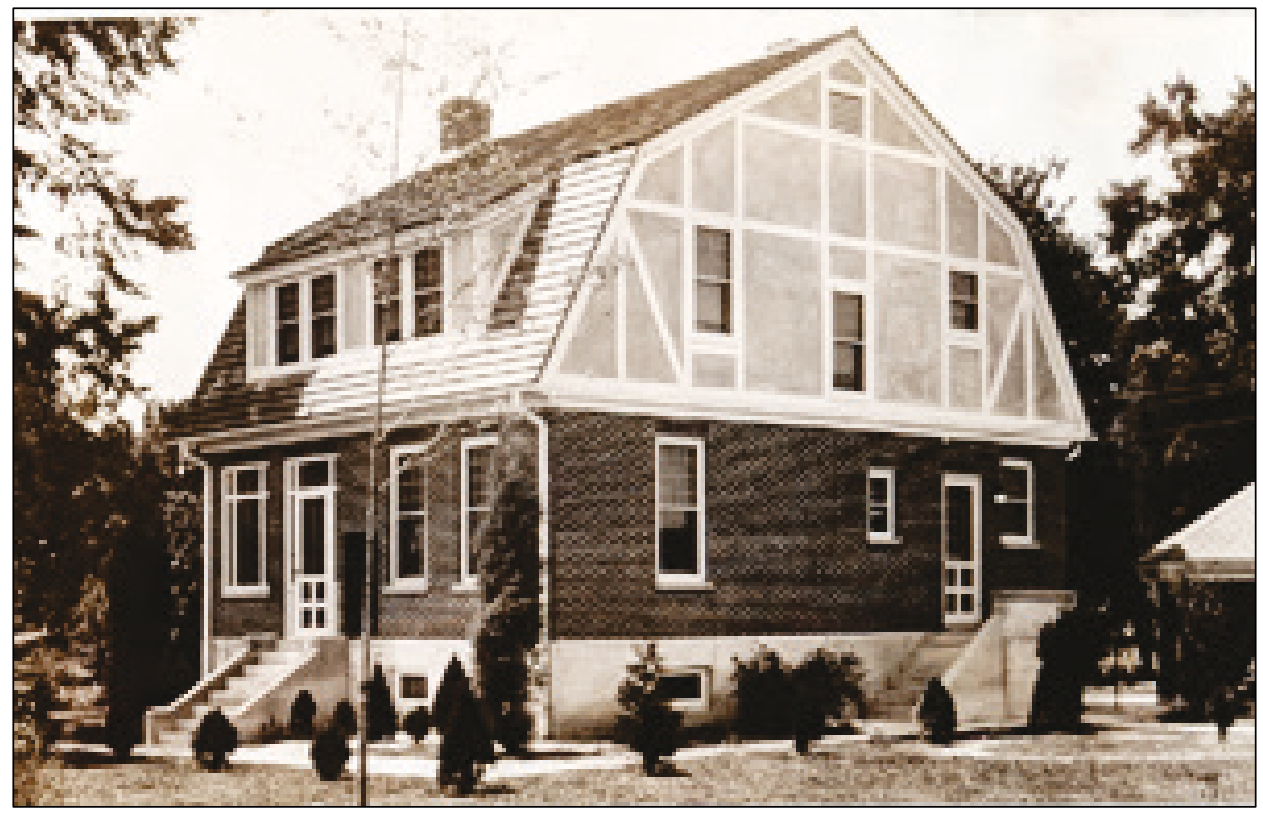

95 “Lodge," U.S. National Cemetery, Corinth, Mississippi, 1941, Real Property form, Corinth National Cemetery records, National Cemetery Administration, U.S. Department of Veterans Affairs, Washington, DC; Historic American Landscapes Survey, “Lodges and Rostrums Data Recorded by HALS," Excel spreadsheet in the collection of the National Cemetery Administration, U.S. Department of Veterans Affairs, Washington, DC.

96 “Lodge," U.S. National Cemetery, Corinth, Mississippi, 1941, Real Property form, Corinth National Cemetery records, National Cemetery Administration, U.S. Department of Veterans Affairs, Washington, DC.

97 “Lodge," U.S. National Cemetery, Corinth, Mississippi, 1952, Real Property form, Corinth National Cemetery records, National Cemetery Administration, U.S. Department of Veterans Affairs, Washington, DC.

98 “Lodge," U.S. National Cemetery, Corinth, Mississippi, 1952, Real Property form. 
Figure 34. Superintendent's Lodge, ca. 1948, with maturing evergreen shrubs (NCA archives, Washington, DC).

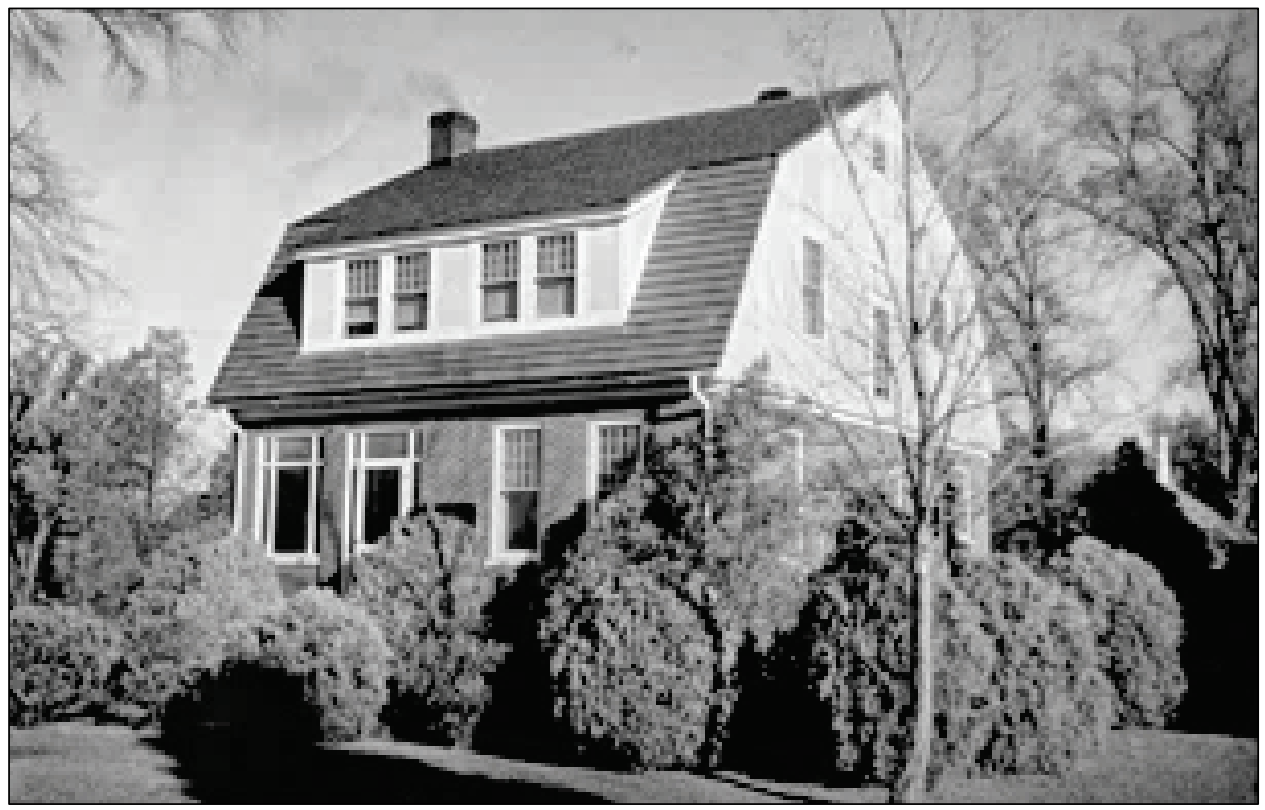

Figure 35. Side view of lodge with family entrance, 1954, showing removal of vegetation around lodge foundation and yard (Corinth Lodge HSAR, NCA archives, Washington, DC).

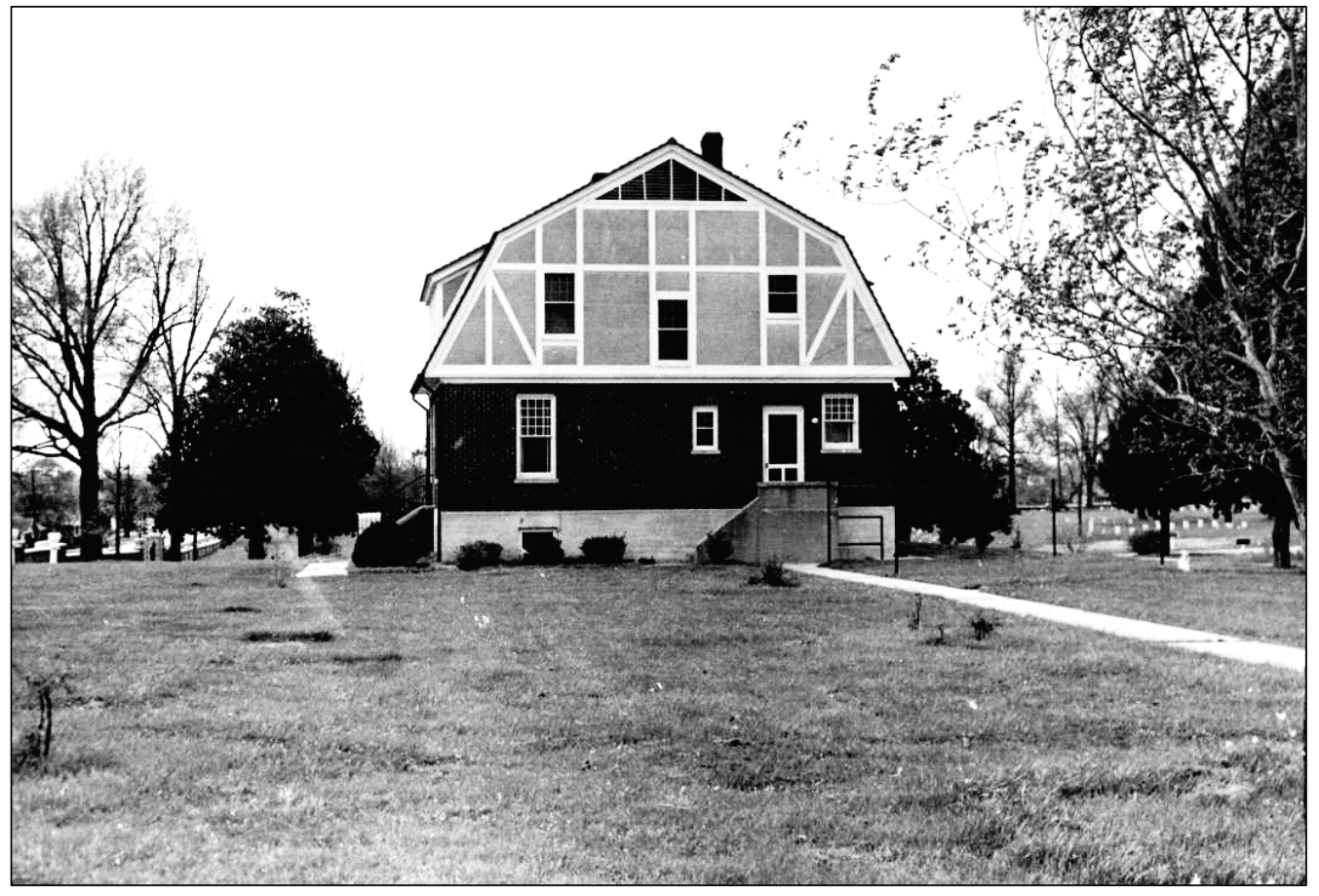

On 15 February 1936, a new brick and concrete utility building was completed using Work Progress Administration (WPA) funds on the site of the 
original stable. Measuring 20' by 31', the 545 square foot building contained a storage room/garage and two public restrooms. It was constructed with a concrete foundation, brick walls, concrete floors, and a roof covered with asbestos shingles (Figure 36). Total cost was $\$ 3,494 \cdot{ }^{99}$ The concrete walk on the north side between the two restroom entrances was landscaped with evergreen shrubs.

A garage addition to the utility building with an overhead door was constructed in 1949 (see Figure 37), and it contained a lawn watering system. The area in front of the building was redone with a 1 " bituminous surface in 1950 (see Figure 37). The wood cornice and metal gutters and downspouts were replaced in 1951 along with a new door on the ladies' restroom. ${ }^{100}$ At some point prior to 1955, the right-hand cargo door on the 1936 section was replaced with an overhead garage door (Figure 38). The lattice work at the restroom entrances had been removed by this point, and vegetation had been cut back.

Figure 36. 1936 Utility Building, ca. 1942 (NARA, Washington, DC).

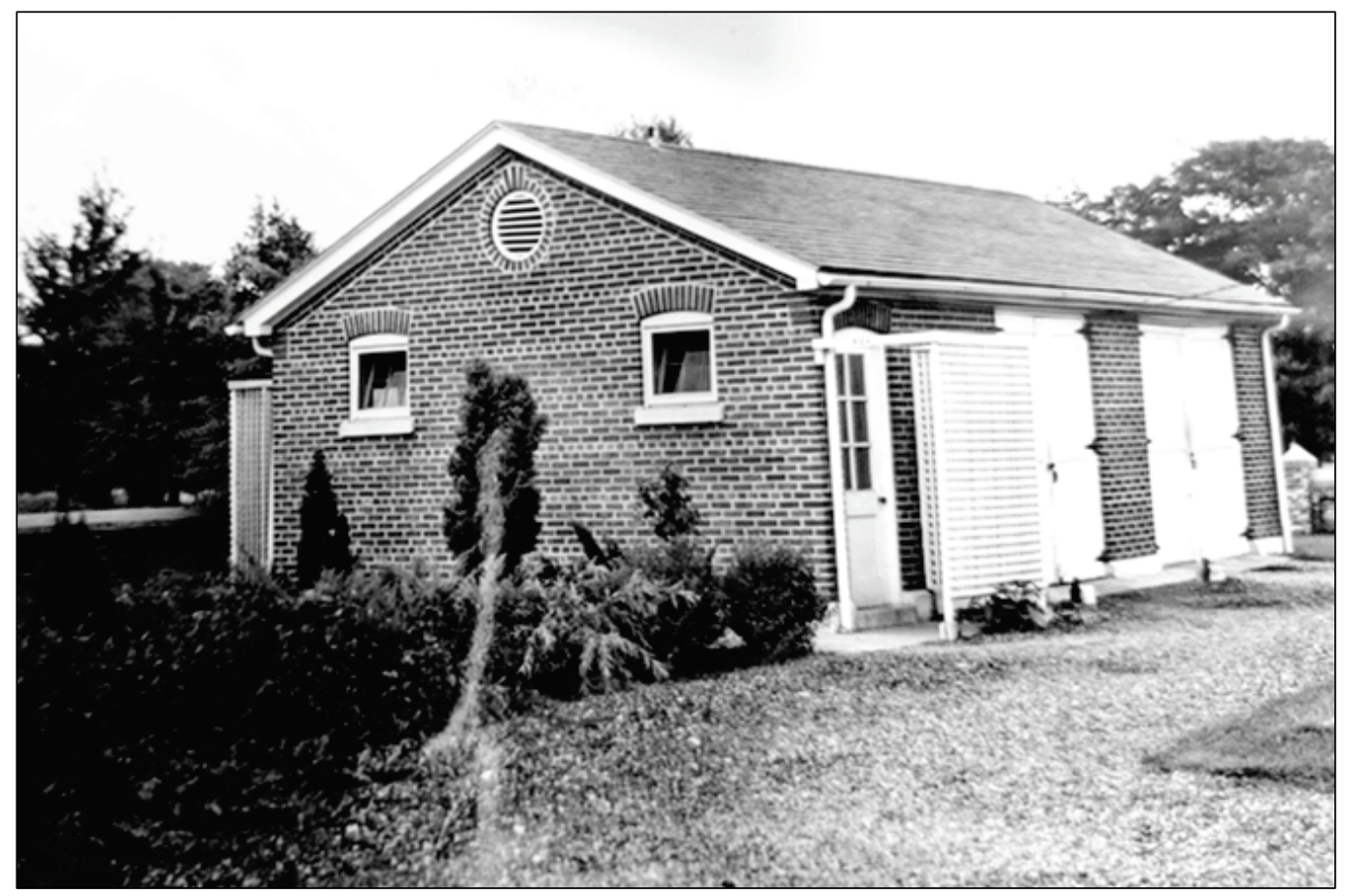

99 “Utility Building," U.S. National Cemetery, Corinth, Mississippi, 1955, Real Property form, Corinth National Cemetery records, National Cemetery Administration, U.S. Department of Veterans Affairs, Washington, DC.

100 “Utility Building," U.S. National Cemetery, Corinth, Mississippi, 1955, Real Property form. 
Figure 37. Addition to right-hand side of Utility Building, as it appeared in 1955

(NARA, Washington, DC).

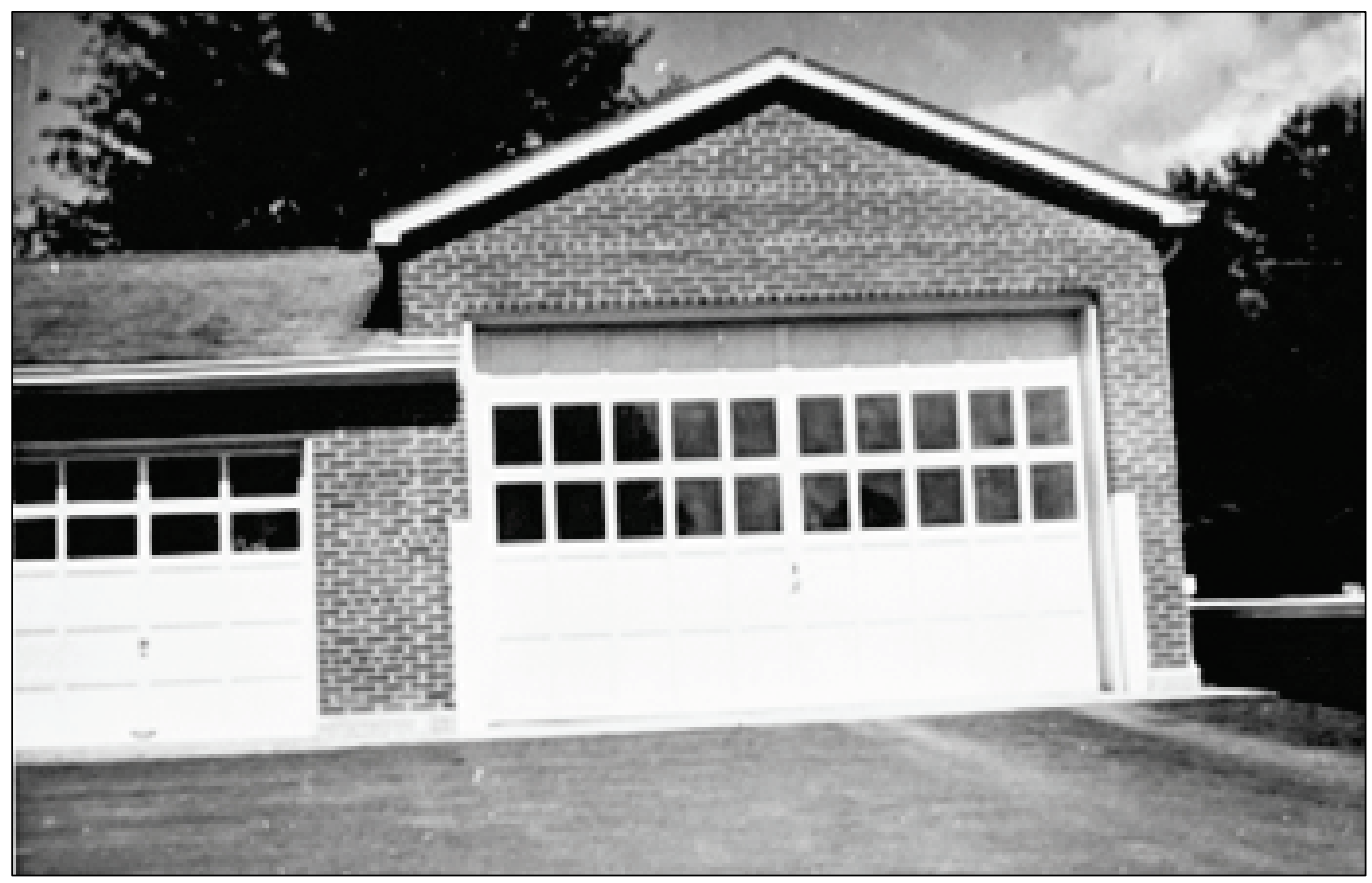

Figure 38. 1936 section of Utility Building with new overhead door (open at left), 1955 (NARA, Washington, DC).

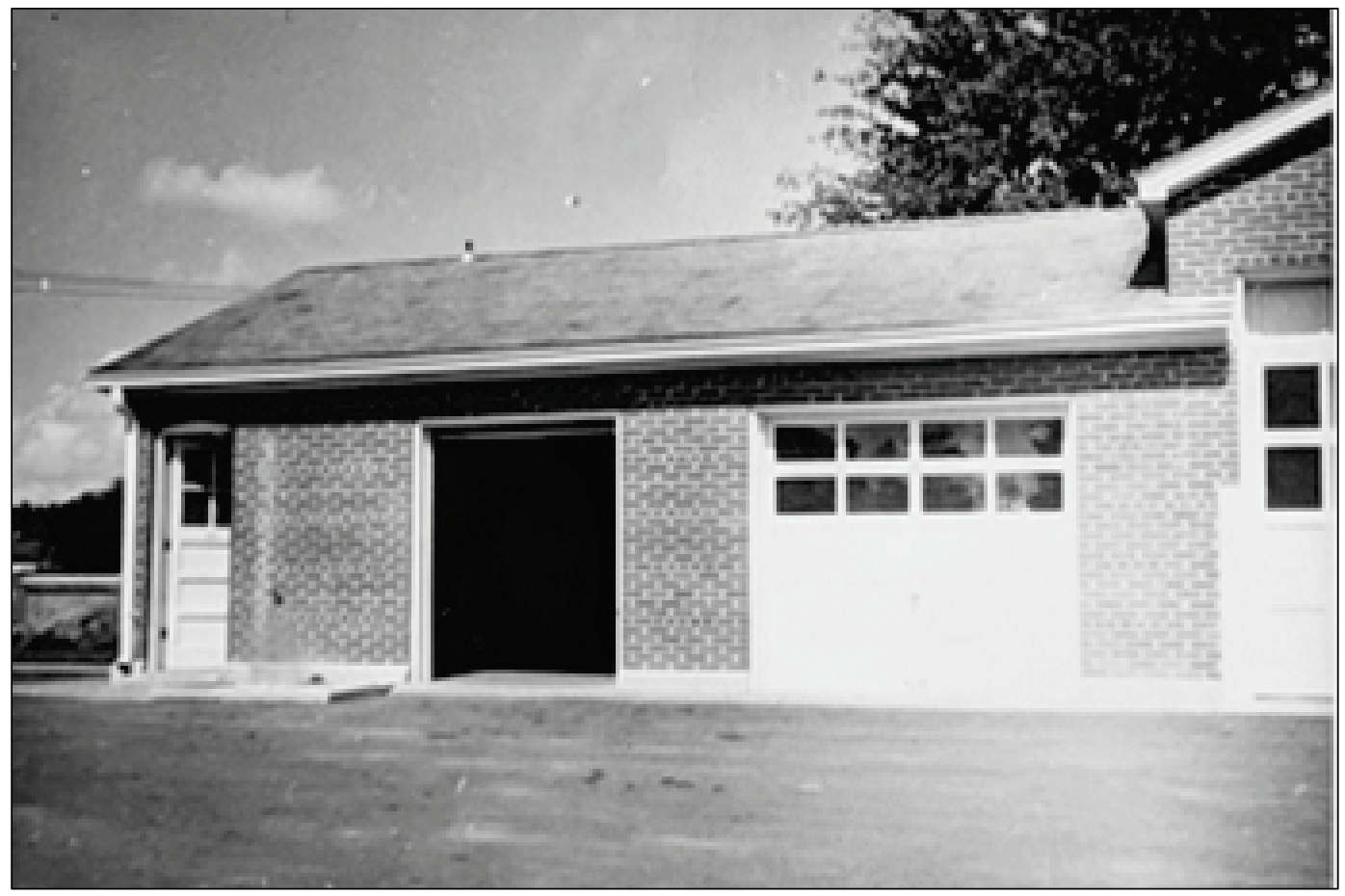


The octagonal iron and brick rostrum from 1889 was removed in 1942 (Figure 39). ${ }^{101}$ The area was seeded over, and no further development took place on the site.

Figure 39. Rostrum prior to 1942 (NARA, Washington, DC).

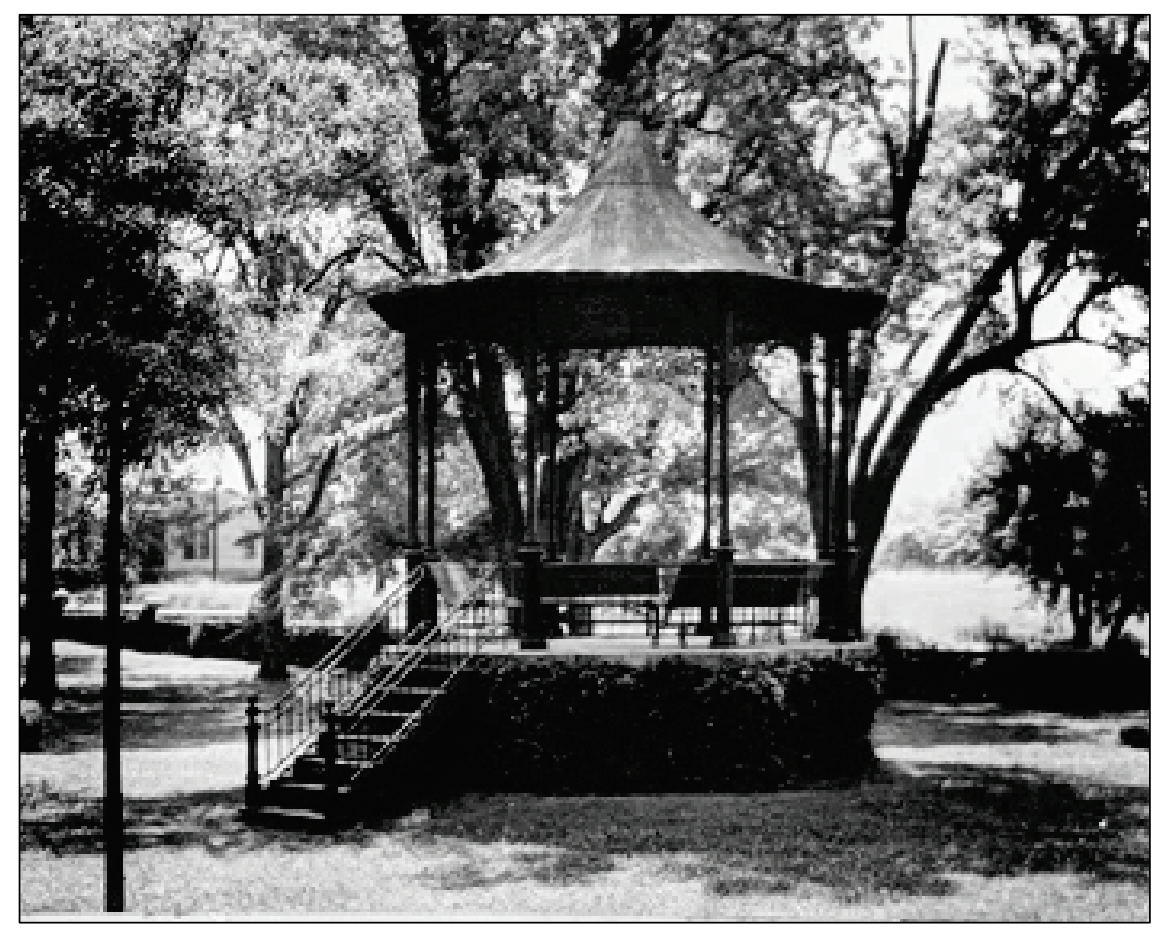

By 1947, the cemetery's buildings and the grounds had access to city water and to city sewer and storm sewer systems. Lawn hydrants had been installed. Gasoline storage was provided in the service area in 1947.102 The 1906 flagpole was replaced on 31 December 1947 with one measuring 75' high (Figure 40). ${ }^{103}$

The main entrance gates were repaired in 1944, but no specific actions were discovered while reviewing subsequent archival documents. ${ }^{104}$ The gates are visible in a 1954 photograph (Figure 41).

\footnotetext{
101 Sammartino, "Corinth National Cemetery," 1996, 6.

102 "National Cemetery Data: Corinth," Real Property form, Corinth National Cemetery records, National Cemetery Administration, U.S. Department of Veterans Affairs, Washington, DC.

103 “Flagpole," U.S. National Cemetery, Corinth, Mississippi, 1958, Real Property form, Corinth National Cemetery records, National Cemetery Administration, U.S. Department of Veterans Affairs, Washington, DC.

104 “Entrance Gates," U.S. National Cemetery, Corinth, Mississippi, 1960, Real Property form, Corinth National Cemetery records, National Cemetery Administration, U.S. Department of Veterans Affairs, Washington, DC.
} 
Figure 40. 1947 flagpole, c. 1953 (NARA, Washington, DC).

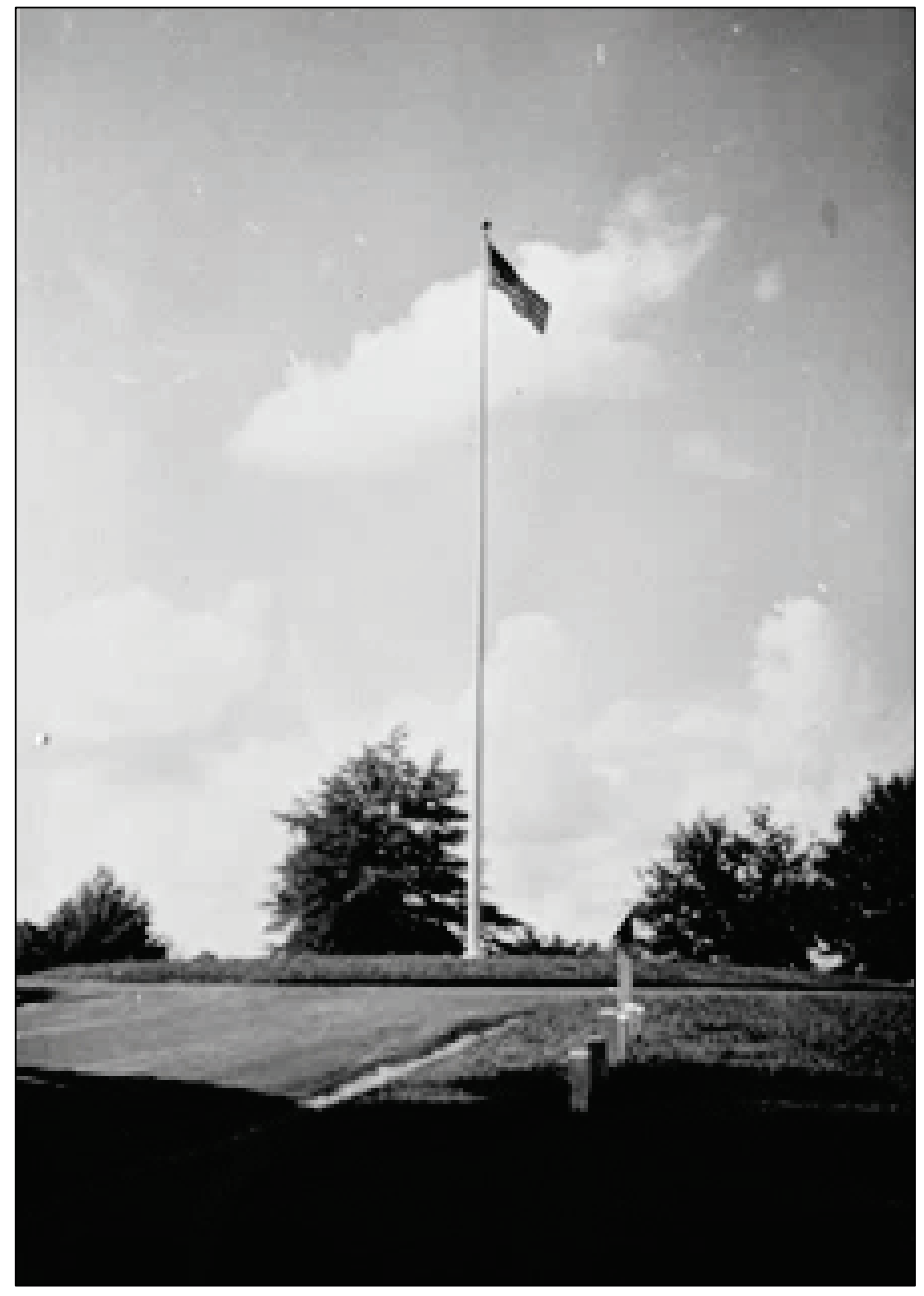

Figure 41. Main entrance gate, 1954 (NARA, Washington, DC).

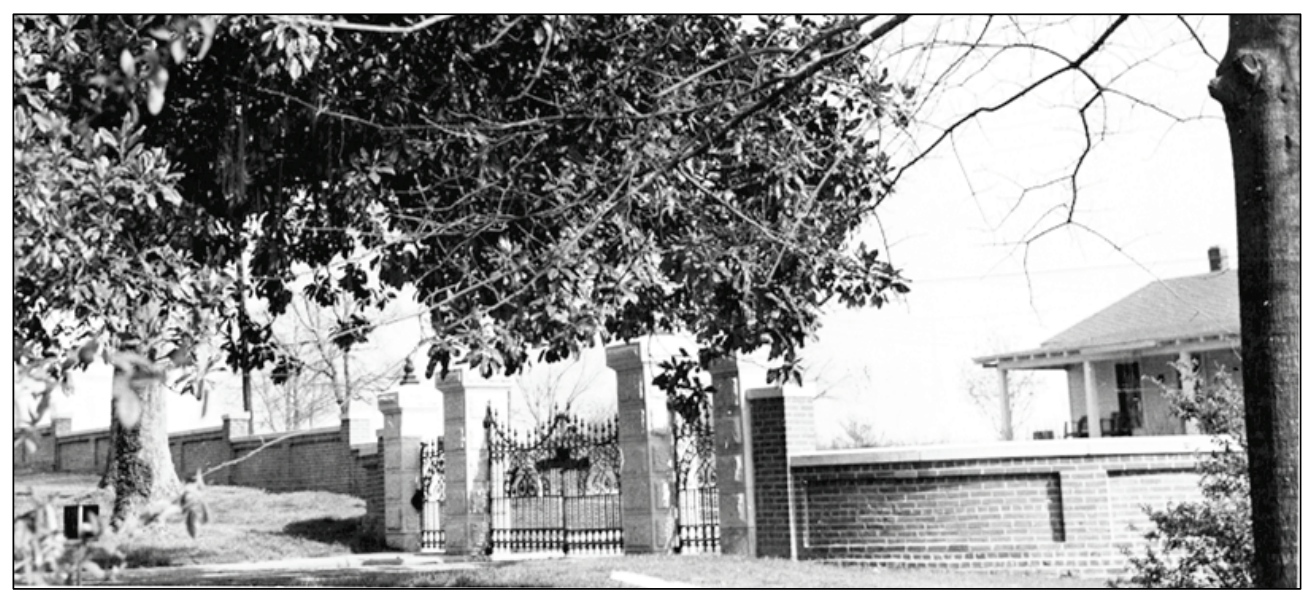

The archival records mention a 1936 WPA project relating to roads and walks at the cemetery, but no details were included. Roads, curbs and gutters were repaired in 1947 and again in 1951. The sidewalk in front of the 
lodge was partially replaced in 1953. Roads and the parking area were resurfaced in 1954, and a large repair project to the cemetery drive took place in $1960 .{ }^{105}$ The main cemetery avenue as it appeared ca. 1947 can be seen in Figure 42.

Figure 42. Central cemetery avenue, ca. 1947 (NARA, Washington, DC).

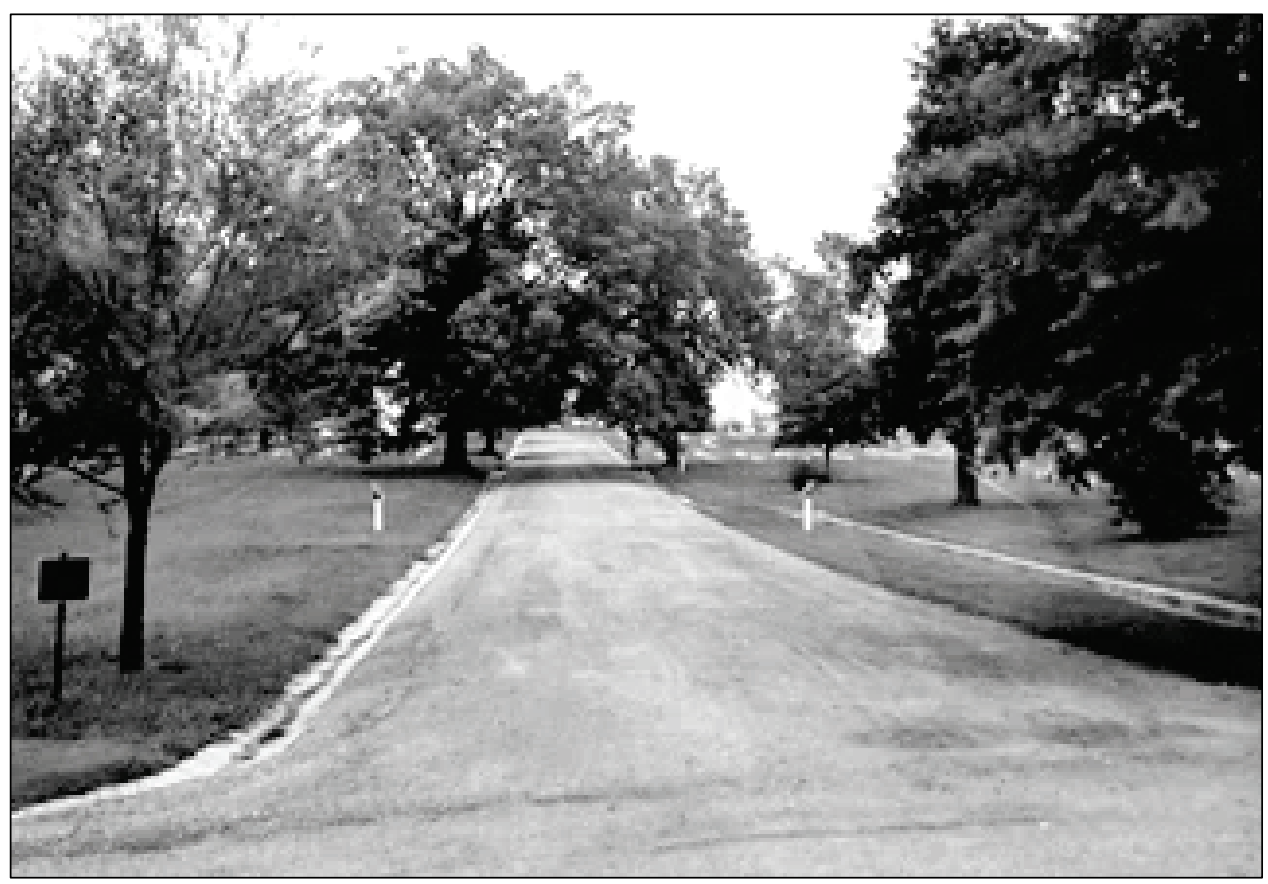

The cemetery's enclosing wall was described in 1945 as being 3,612 feet long and 16 inches wide at the base, with a 12-inch wide wall that had an average height of 4.5 feet. Repairs to the wall were a fairly continuous task throughout the years, with maintenance records listing them in 1945, 1953,1957 , and $1965 .{ }^{106}$ The walls around the main entrance and the pedestrian gate had a sloping, heavy coping prior to a 1953 partial replacement. Walls, particularly next to gate entrances, were rebuilt to be stepped rather than sloped, the walls were straightened up, and a smaller-profile cement coping was applied. Before and after pictures are provided below (Figure 43 through Figure 49).

\footnotetext{
105 “Roads and Walks," U.S. National Cemetery, Corinth, Mississippi, 1960, Real Property form, Corinth National Cemetery records, National Cemetery Administration, U.S. Department of Veterans Affairs, Washington, DC.

106 “Enclosing Wall," U.S. National Cemetery, Corinth, Mississippi, 1965, Real Property form, Corinth National Cemetery records, National Cemetery Administration, U.S. Department of Veterans Affairs, Washington, DC.
} 
Figure 43. Main entrance gate, 1946 (NCA archives, Washington, DC).

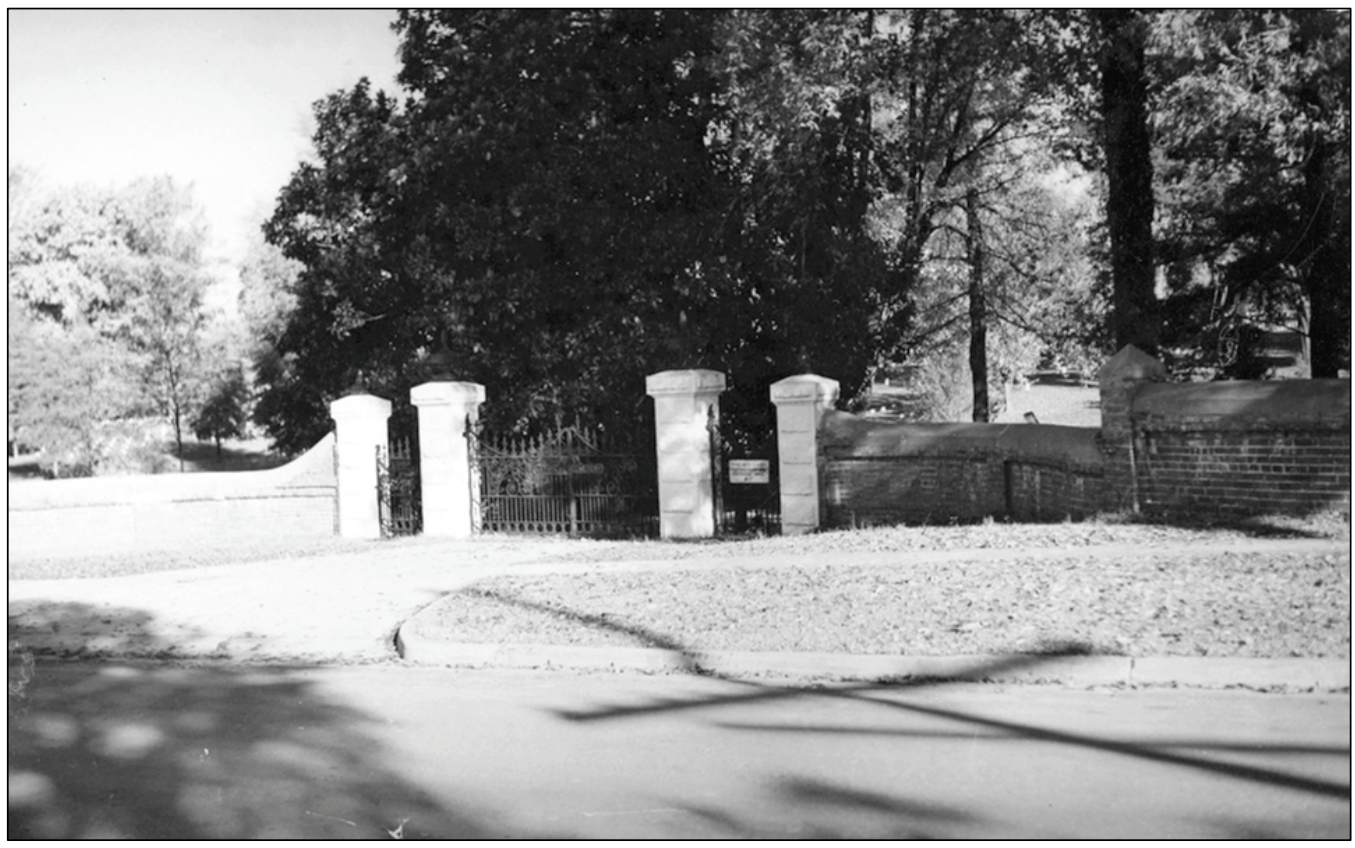

Figure 44. New wall, looking east along Horton Street toward the main entrance, 1953 (NCA archives, Washington, DC).

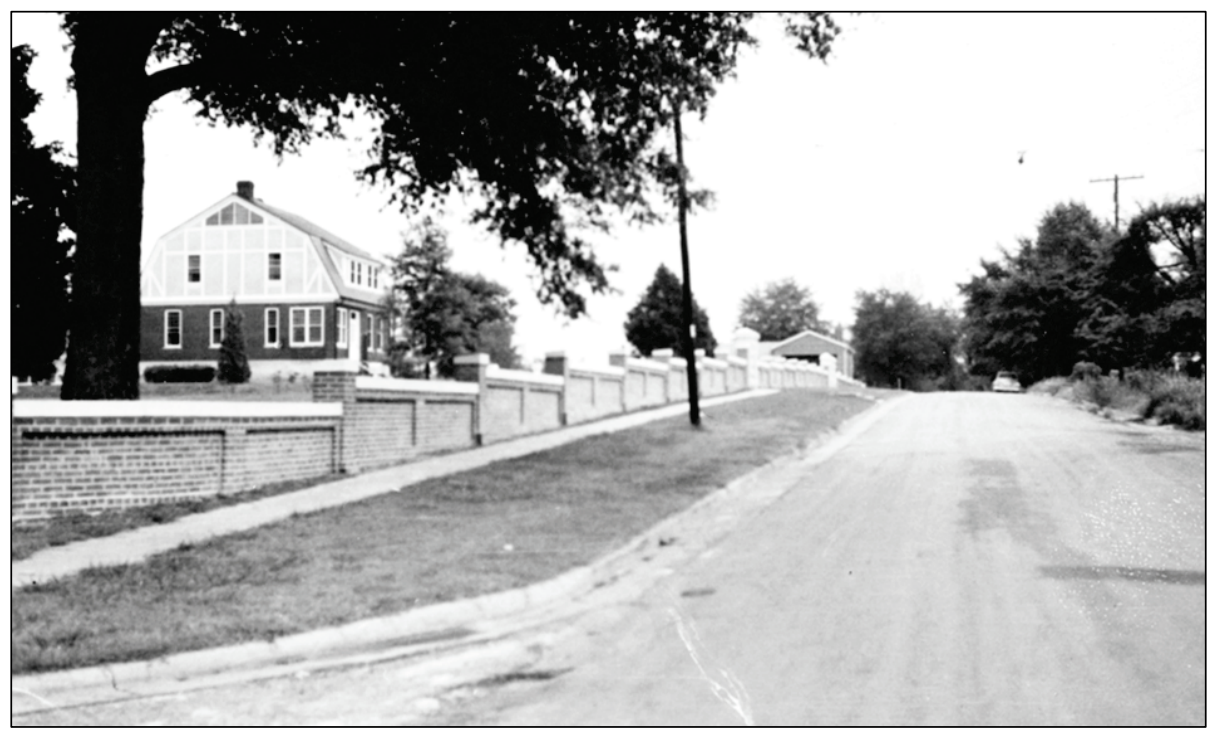


Figure 45. Pedestrian gate in 1946 (NCA archives, Washington, DC).

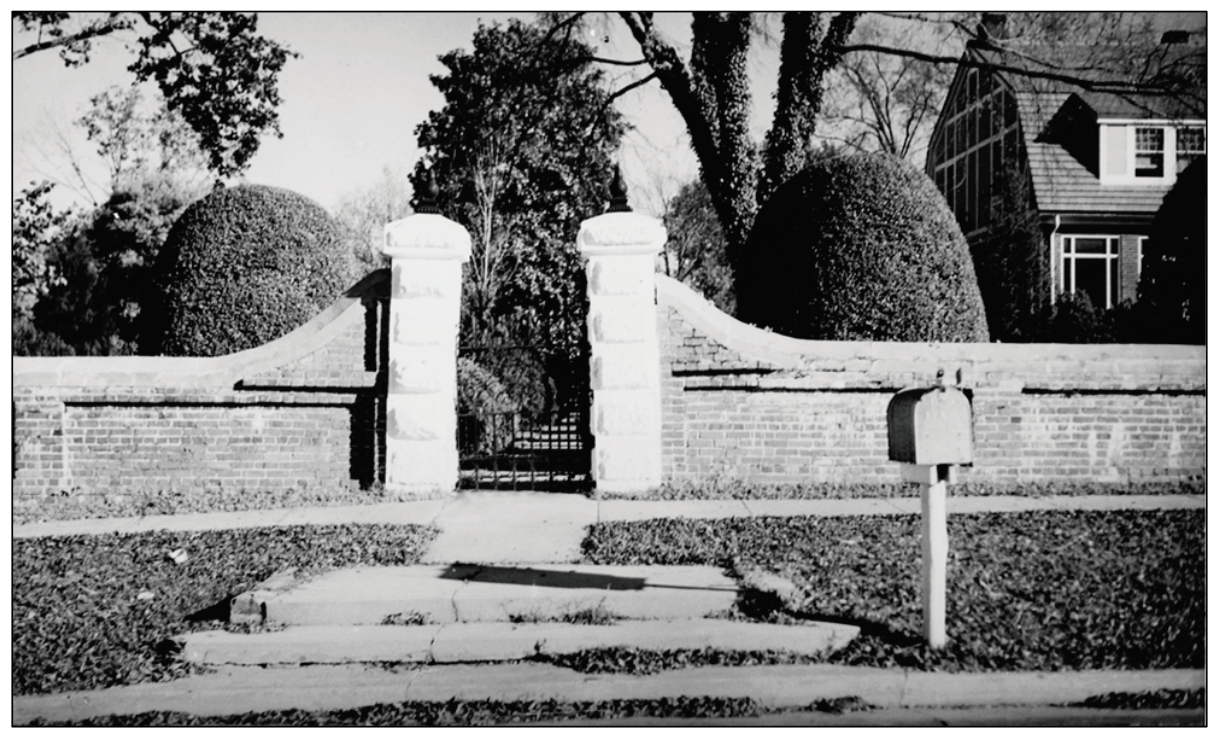

Figure 46. Pedestrian gate and walls in 1953 (NCA archives, Washington, DC).

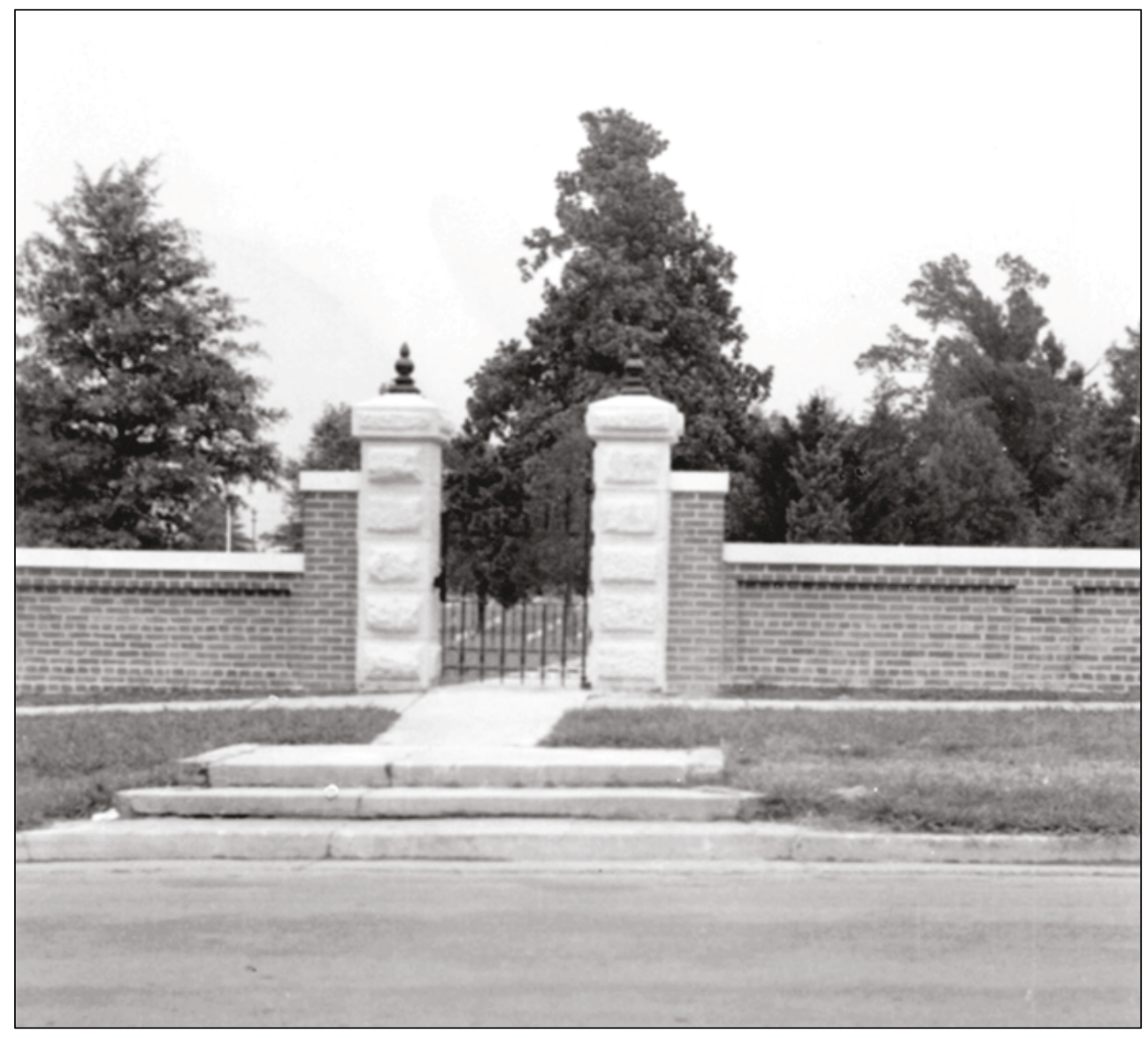


Figure 47. Utility gate in 1946 (NCA archives, Washington, DC).

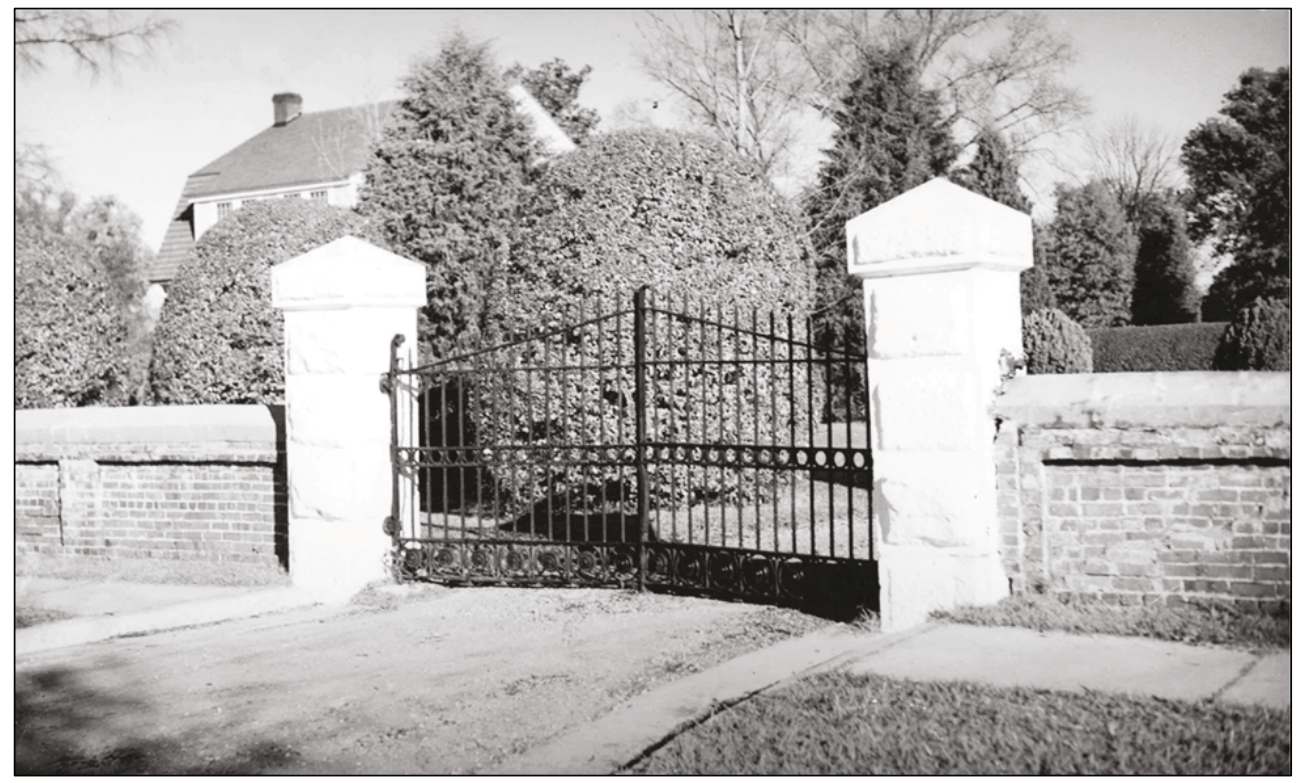

Figure 48. Utility gate in 1953 (NCA archives, Washington, DC).

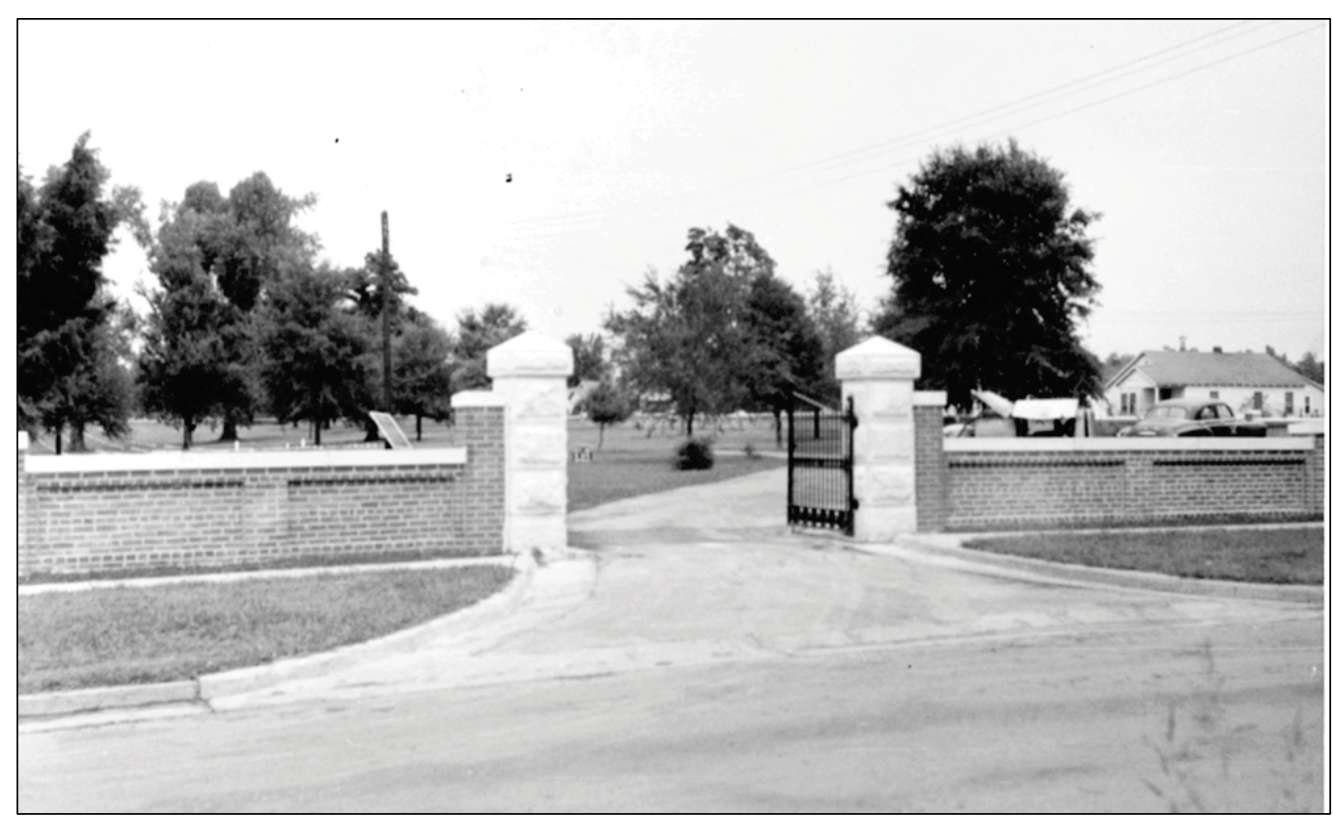


Figure 49. North entrance gate in 1953 (NCA archives, Washington, DC).

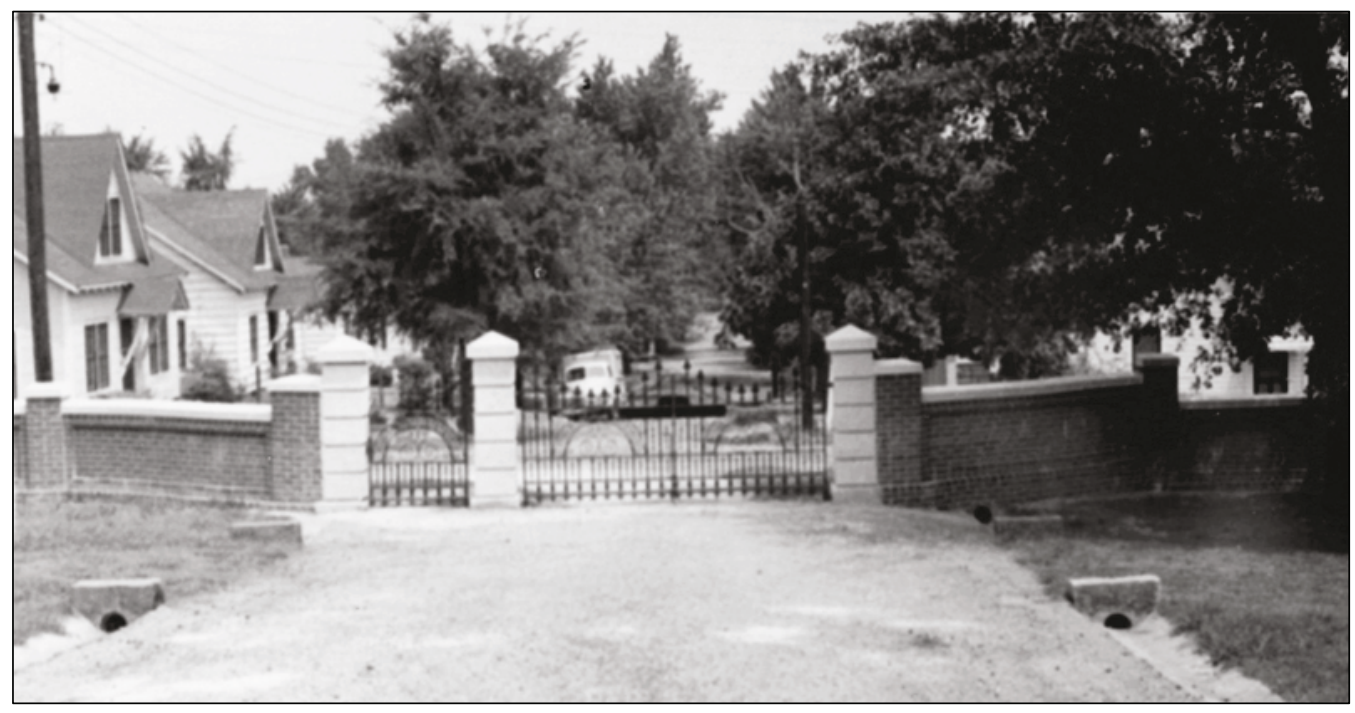

Work on the cemetery grounds was a continuous process. The regular work included interments, setting headstones, cleaning headstones, raising or realigning headstones, replacing headstones when deteriorated, filling sunken gravesites, seeding, fertilizing, and maintaining grass, pruning trees and shrubs, and planting new vegetation when required. A lawn watering system was installed in 1949 at a cost of $\$ 17,428$ (including the cost of the addition to the utility building). That same year, work on the grounds included pruning 117 trees and removing 24 dead trees. ${ }^{107}$

A 1948 aerial photograph provides a snapshot of the cemetery after the last major changes (Figure 50). The encircling road has been covered with trees and shrubs, so it must have been covered over at least 10-15 years prior. A row of trees line the interior of the south wall on the lodge lot, and large shrubs line the concrete walks from the pedestrian gate to the service road. A fence, or thick row of shrubs, make a barrier along the outside of the concrete walk from the lodge to the service area. A mix of evergreen trees and shrubs of varying ages and heights are prominent across the cemetery grounds. A ground view from the same year shows sections of unknown graves covered with spring flowers (Figure 51).

107 “Grounds," U.S. National Cemetery, Corinth, Mississippi, 1952, Real Property form, Corinth National Cemetery records, National Cemetery Administration, U.S. Department of Veterans Affairs, Washington, DC. 
Figure 50. Corinth National Cemetery, 1948 (NCA archives, Washington, DC).

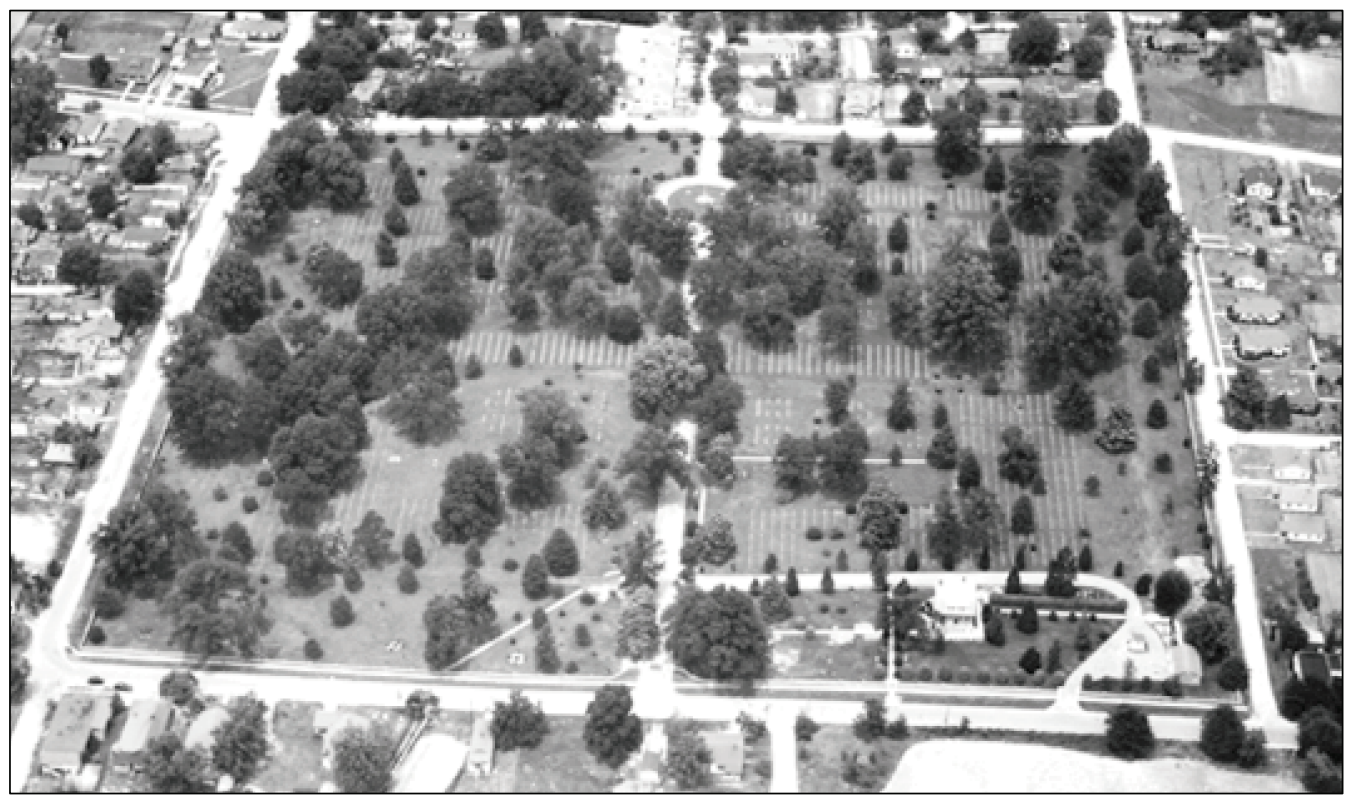

Figure 51. Corinth National Cemetery, spring 1948 (NCA archives, Washington, DC).

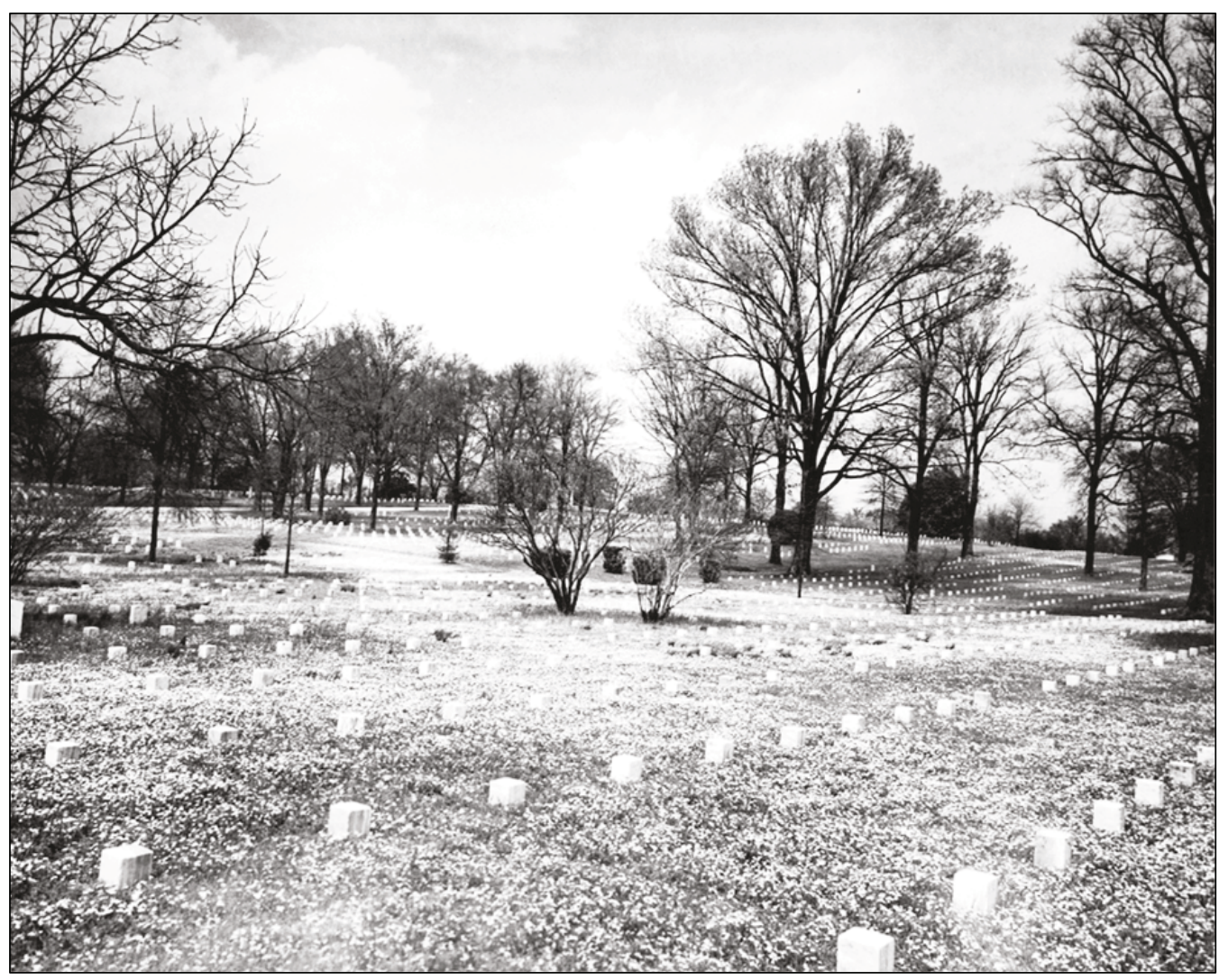




\subsection{Maturity, 1954-2018}

The overall layout of the cemetery in 1954 can be seen in the following series of the cemetery's four sections (Figure 52, Figure 53, Figure 54, and Figure 55). The encircling road is gone, replaced with plans for future grave sites (these areas remain empty of burials today). The original grass drives are no longer used, but they still exist as open space. The grassy open spaces along the main avenue have been filled in with grave sites, and a memorial area has been created on the northeast exterior of the circular drive. The open space to the west of the service area is shown as planned for grave sites, but this did not occur to date in 2018. The residential and service areas are shown with several large groupings of vegetation at the southwest and northwest corners of the lodge, shrubs around the southeast corner, and grassy lawn covering the area on the lodge lot and northwest/west of the service area pavement. A massing of vegetation lines the western edge of the pavement.

Figure 52. Plan of Sections A, E F, I, U, \& V, 1954 (NCA archives, Washington, DC).

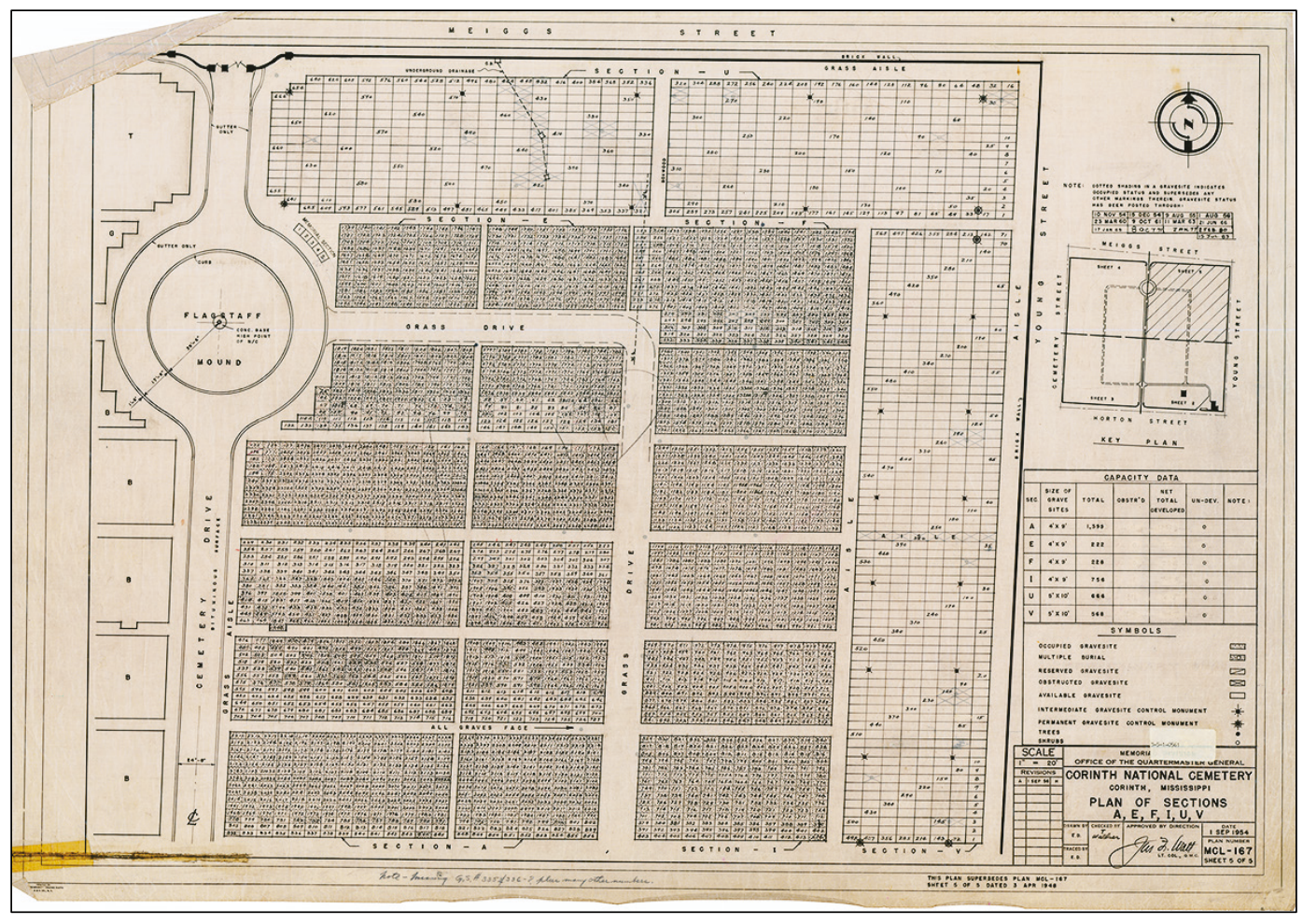


Figure 53. Plan of Sections C, L, P \& W, 1954 (NCA archives, Washington, DC).

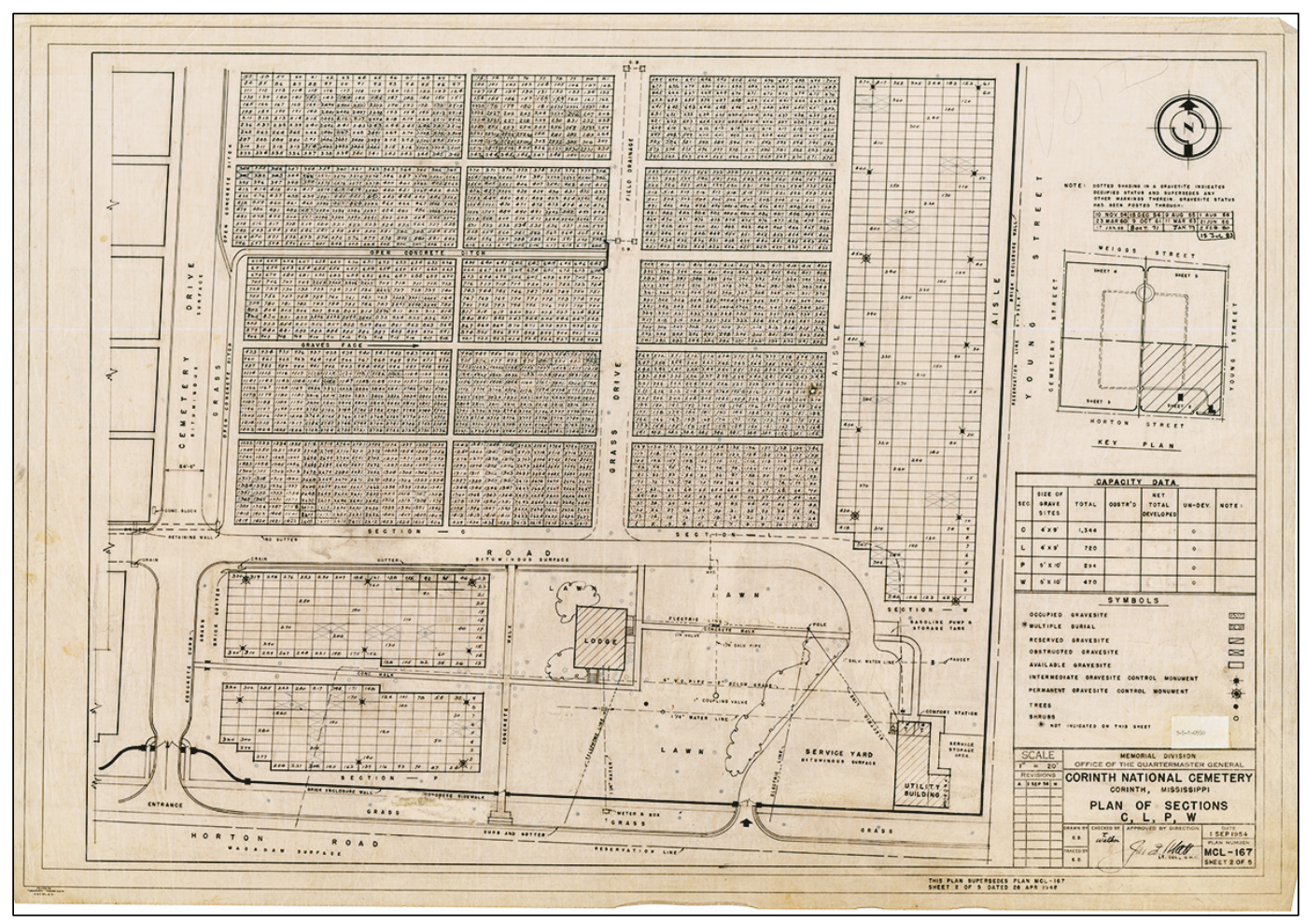

Figure 54. Plan of Sections D, M, N, O \& R, 1954 (NCA archives, Washington, DC).

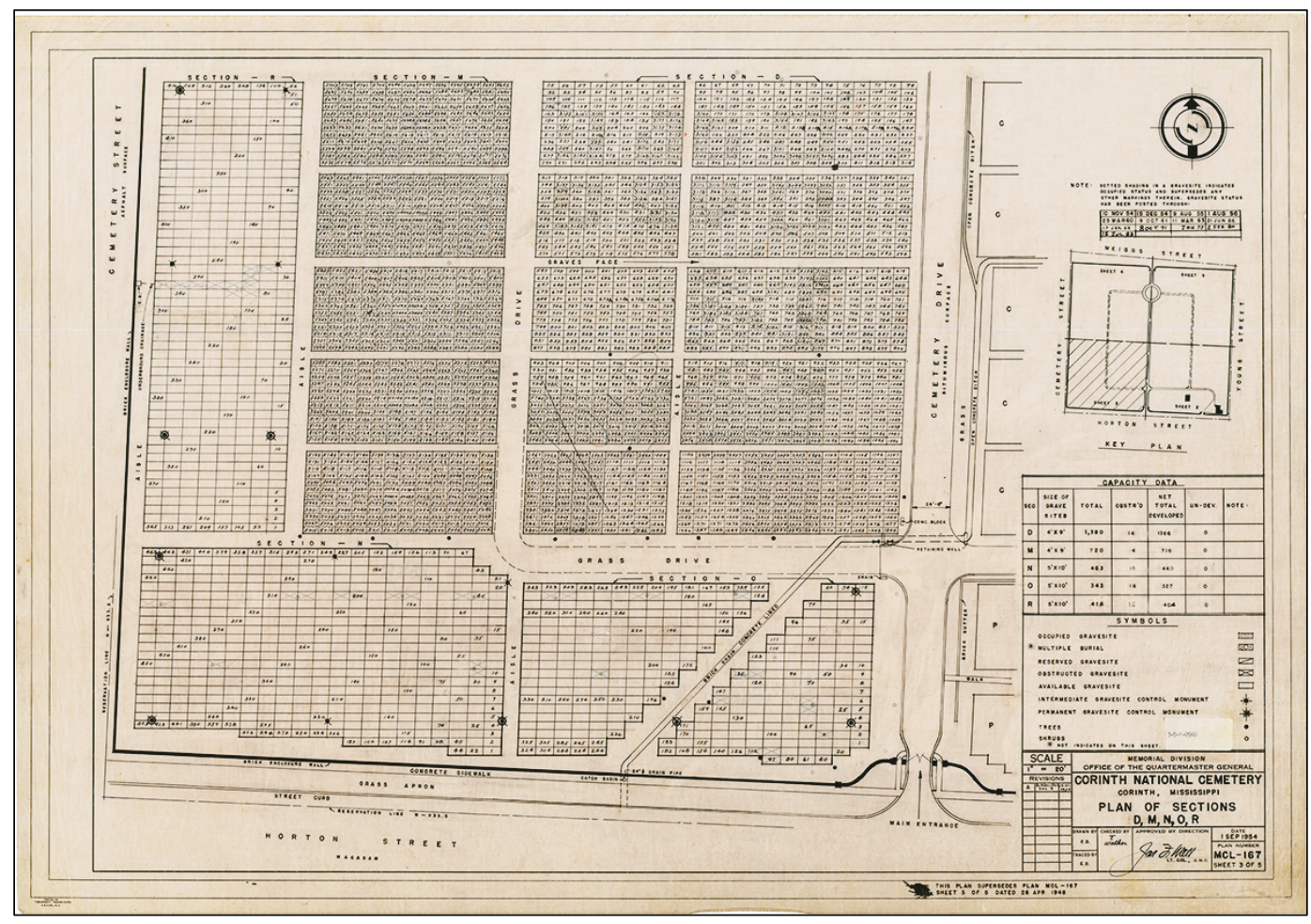


Figure 55. Plan of Sections B, G, H, K, S \& T, 1954 (NCA archives, Washington, DC).

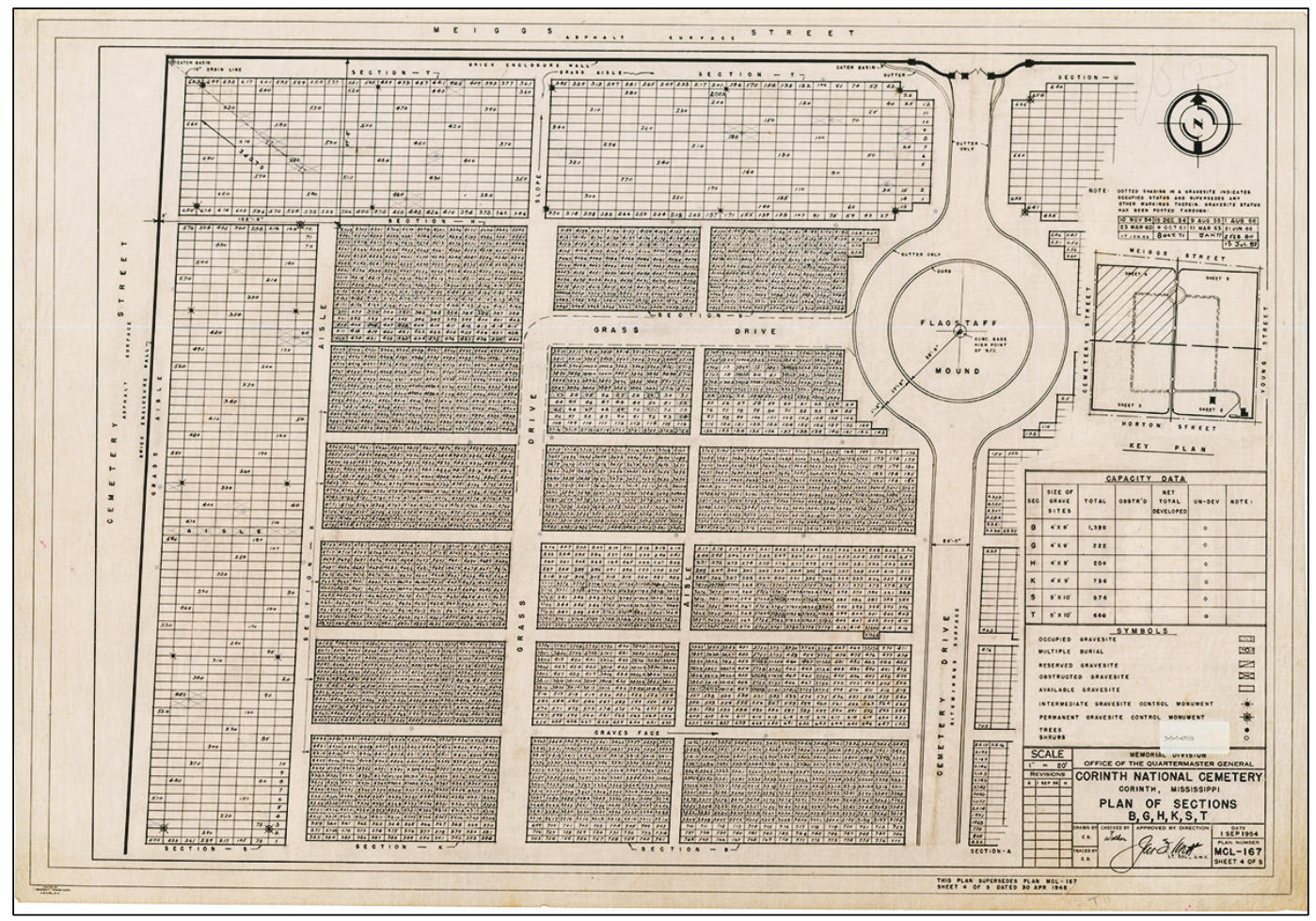

In 1953, the grass drive between Sections L and C was filled in and graded. Existing catch basins were raised to the new grade level. There were extensive repairs to the drainage ditch in 1954, including new headwalls for culverts (Figure 56). The next year, Sections N, O, P, R, S, U, V, W, and the lodge area were graded. Trees and shrubs were planted around the lodge, and 16 willow oaks were planted outside the south wall. A copper water line was extended from the city main to the lodge in 1958, and more plantings were placed near the lodge. ${ }^{108}$ The 10 "Bivouac of the Dead" plaques listed in the 1909 inspection report were still in place in 1959, along with plaques containing text from the 1867 Act to Establish and to Protect National Cemeteries (4), The Gettysburg Address (1), and General Order No. 80 (1). ${ }^{109}$

\footnotetext{
108 "Grounds," U.S. National Cemetery, Corinth, Mississippi, 1960, Real Property form, Corinth National Cemetery records, National Cemetery Administration, U.S. Department of Veterans Affairs, Washington, DC.

109 "Corinth National" Inspection report 25 July 1959, in Corinth Vertical File, National Cemetery Administration, U.S. Department of Veterans Affairs, Washington, DC.
} 
Figure 56. Drainage system construction in 1954 (NCA archives, Washington, DC).

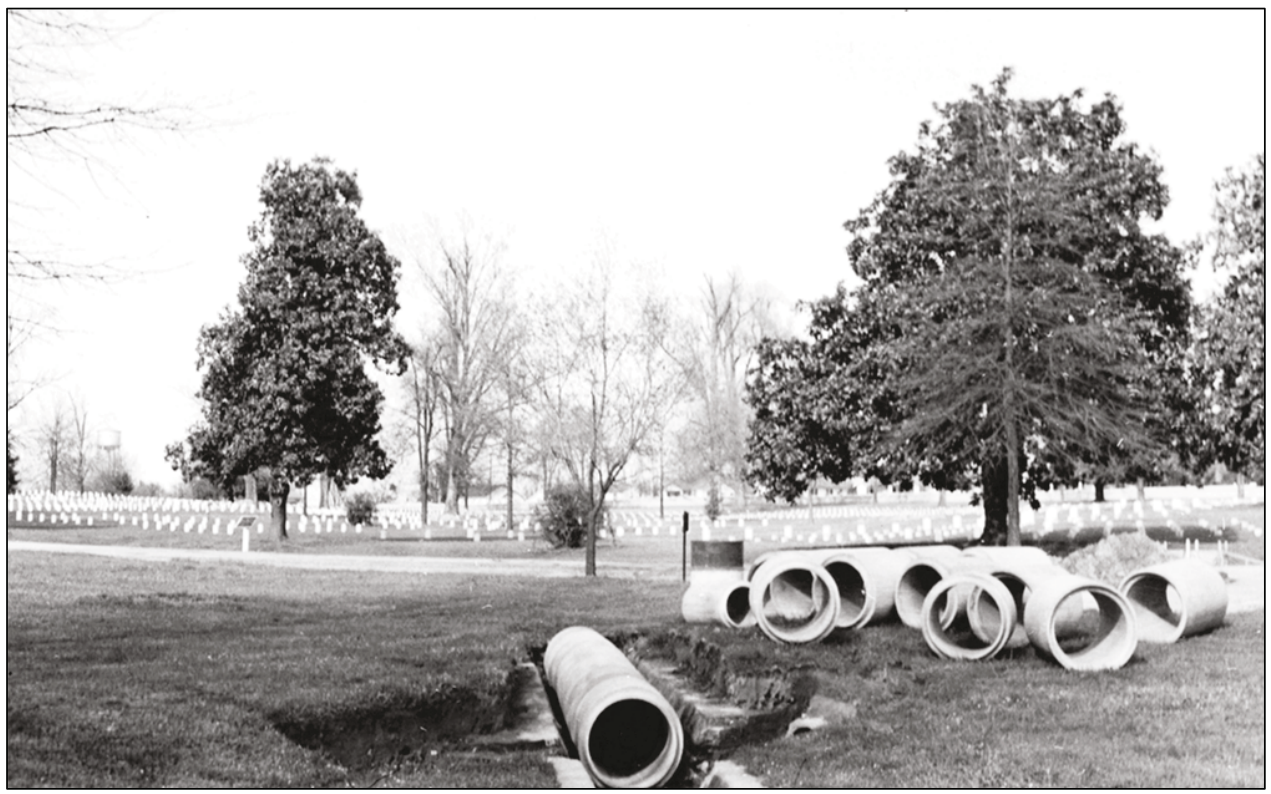

The front porch of the lodge was enclosed in 1952.110 Lights were installed over the front steps and on the utility pole in 1956, and a railing was added along the back porch and steps. Storm doors to the lodge and office were installed in 1961, along with storm windows on all lodge and office windows. ${ }^{111}$ By 1954, the utility building had a garage and workshops, and exterior lights were installed on the building in $1956 .{ }^{112}$

New bronze entrance plaques were placed on the main entrance gate piers in August 1960. The plaques were installed by Boatman Monument Works at a cost of $\$ 55.00$ (Figure 57). ${ }^{113}$

\footnotetext{
110 Sammartino, “Corinth National Cemetery," 1996, 5.

111 “Lodge," U.S. National Cemetery, Corinth, Mississippi, 1964, Real Property form, Corinth National Cemetery records, National Cemetery Administration, U.S. Department of Veterans Affairs, Washington, DC.

112 "Corinth National Cemetery," typed manuscript, 1954; “Lodge," U.S. National Cemetery, Corinth, Mississippi, 1968, Real Property form, Corinth National Cemetery records, National Cemetery Administration, U.S. Department of Veterans Affairs, Washington, DC.

113 “Entrance Gates," U.S. National Cemetery, Corinth, Mississippi, 1960, Real Property form.
} 
Figure 57. New bronze plaques on pillars of main entrance gates, 1960 (NARA, Washington, DC).

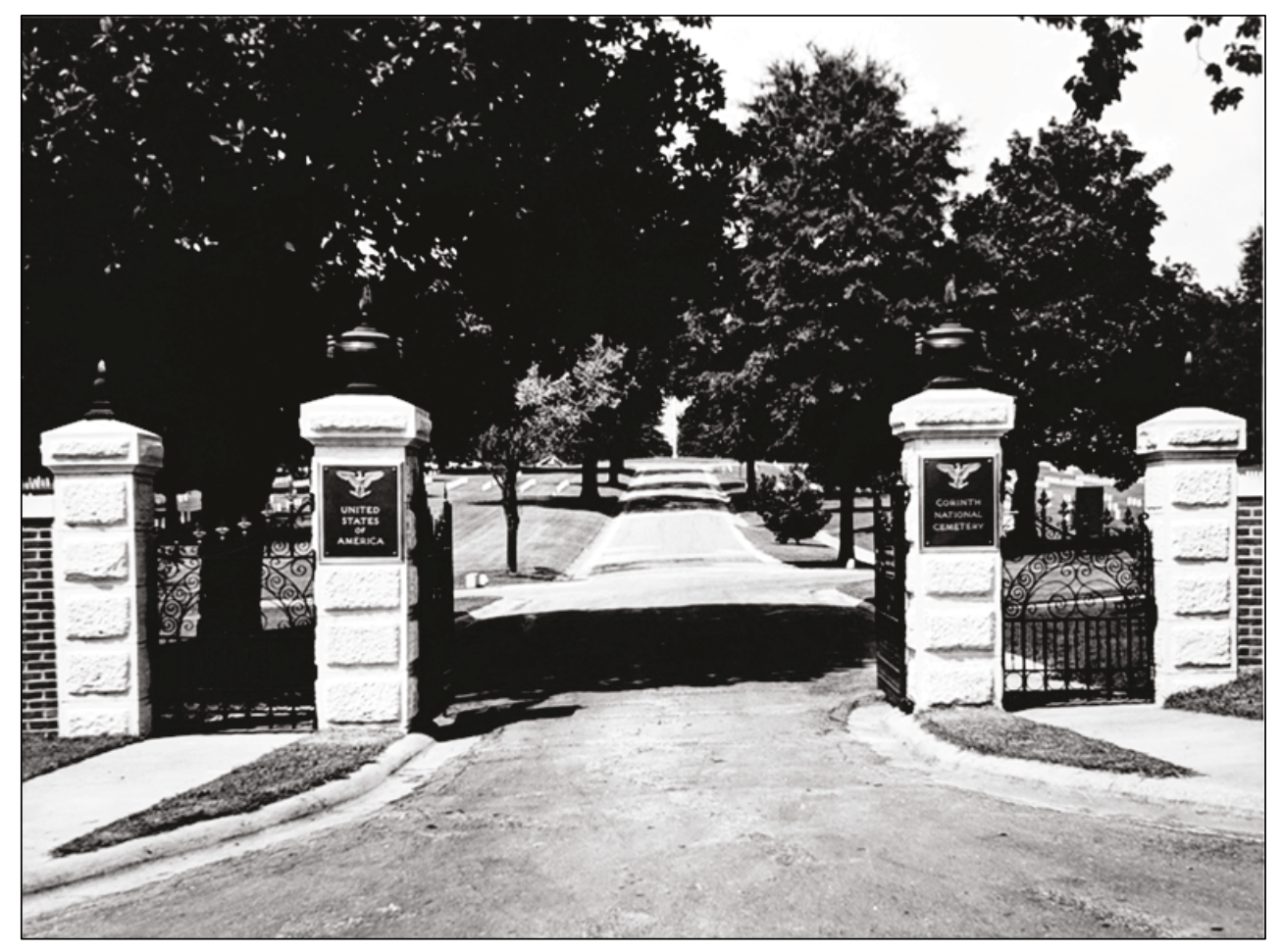

By the time the aerial photographs below were taken in 1963 and 1968, Corinth National Cemetery had assumed its current configuration with the rostrum and summer house removed, the service area behind the lodge with existing buildings, the interior circular drive removed, and the drainage systems in place (Figure 58, Figure 59, and Figure 60). 
Figure 58. Corinth National Cemetery, May 1963 (NARA, Washington, DC).

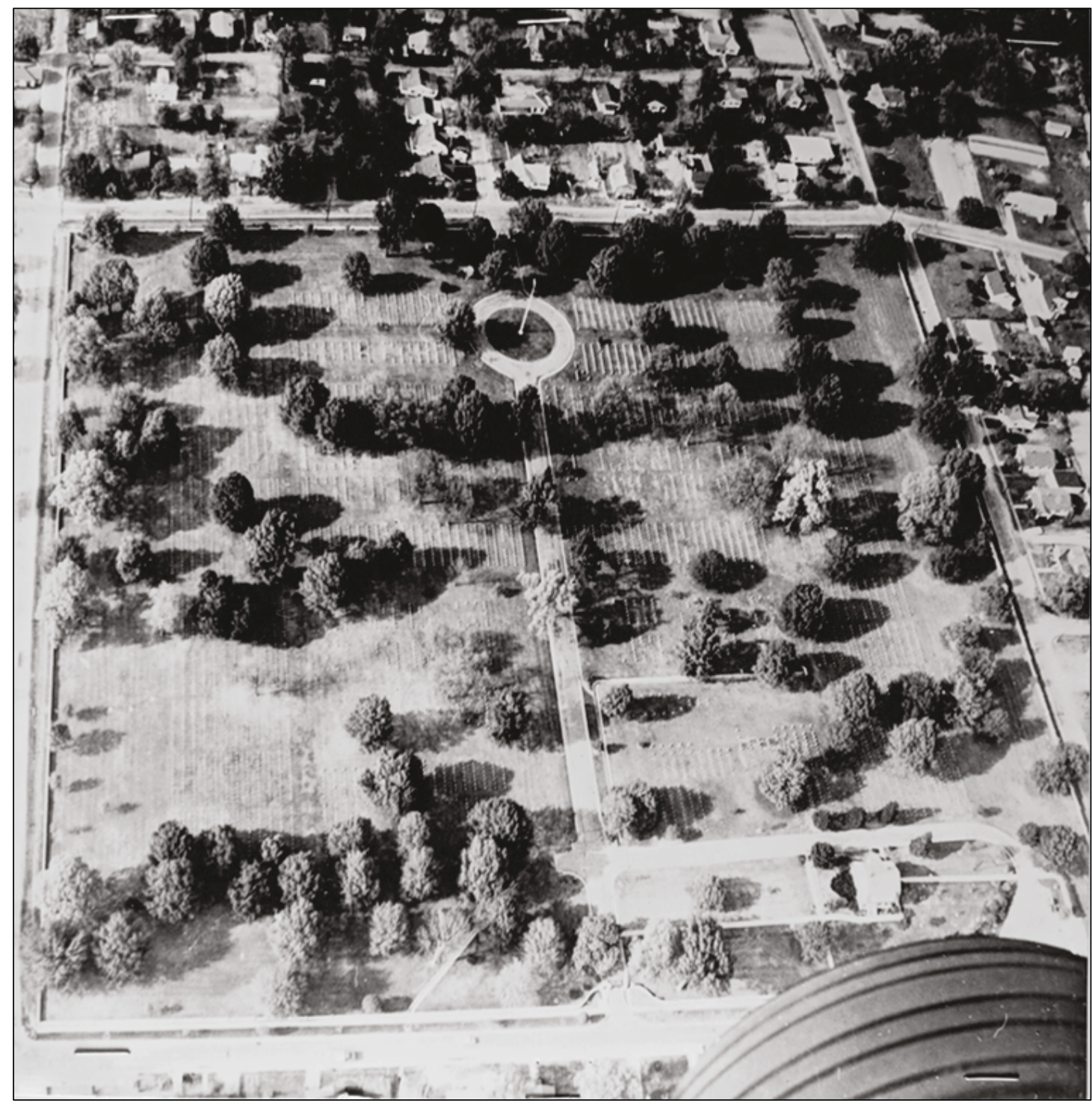


Figure 59. Aerial photograph of Corinth National Cemetery, 1963 (Library of Congress, HALS MS-3).

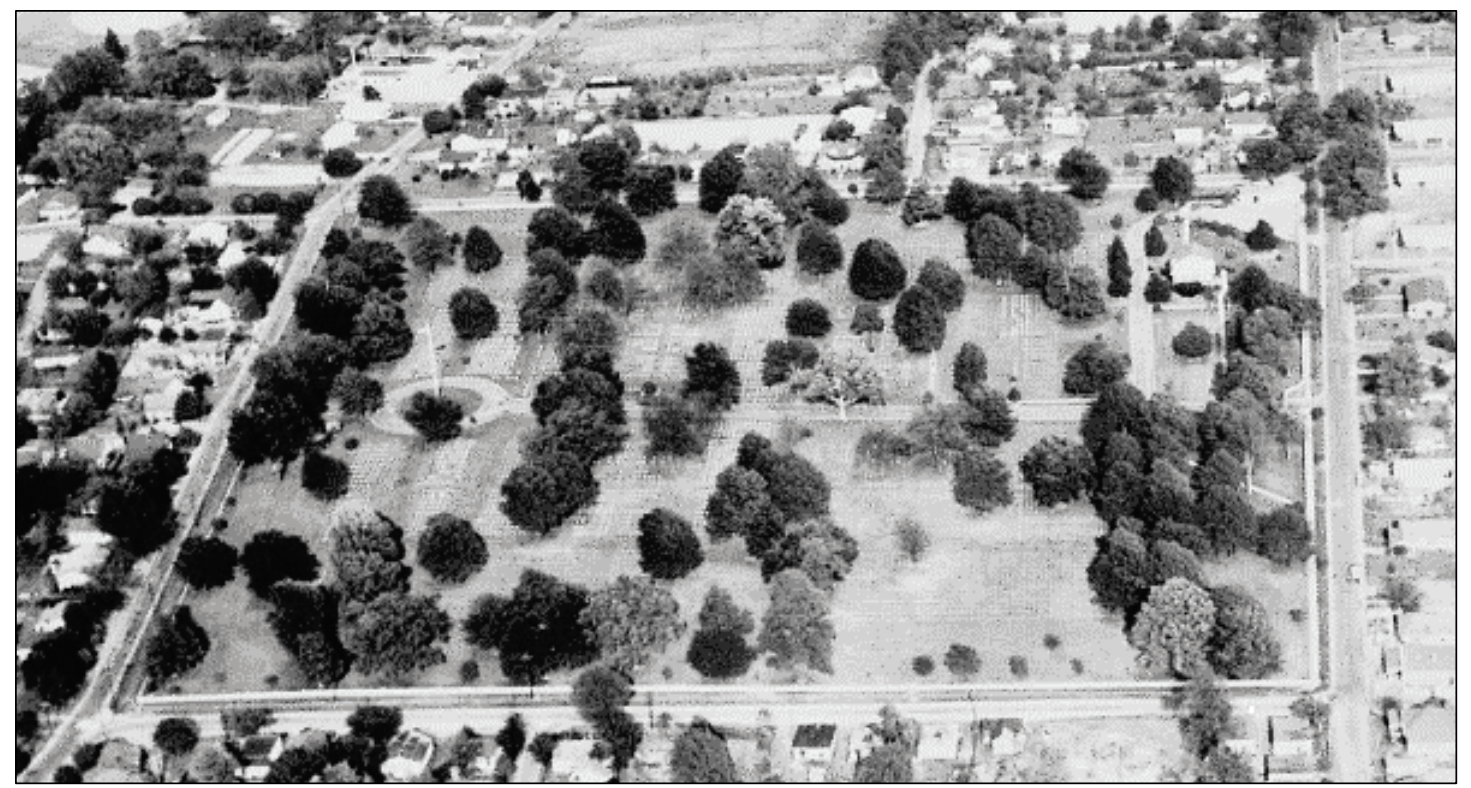

Figure 60. Aerial photograph of Corinth National Cemetery, 1968 (Library of Congress, HALS MS-3).

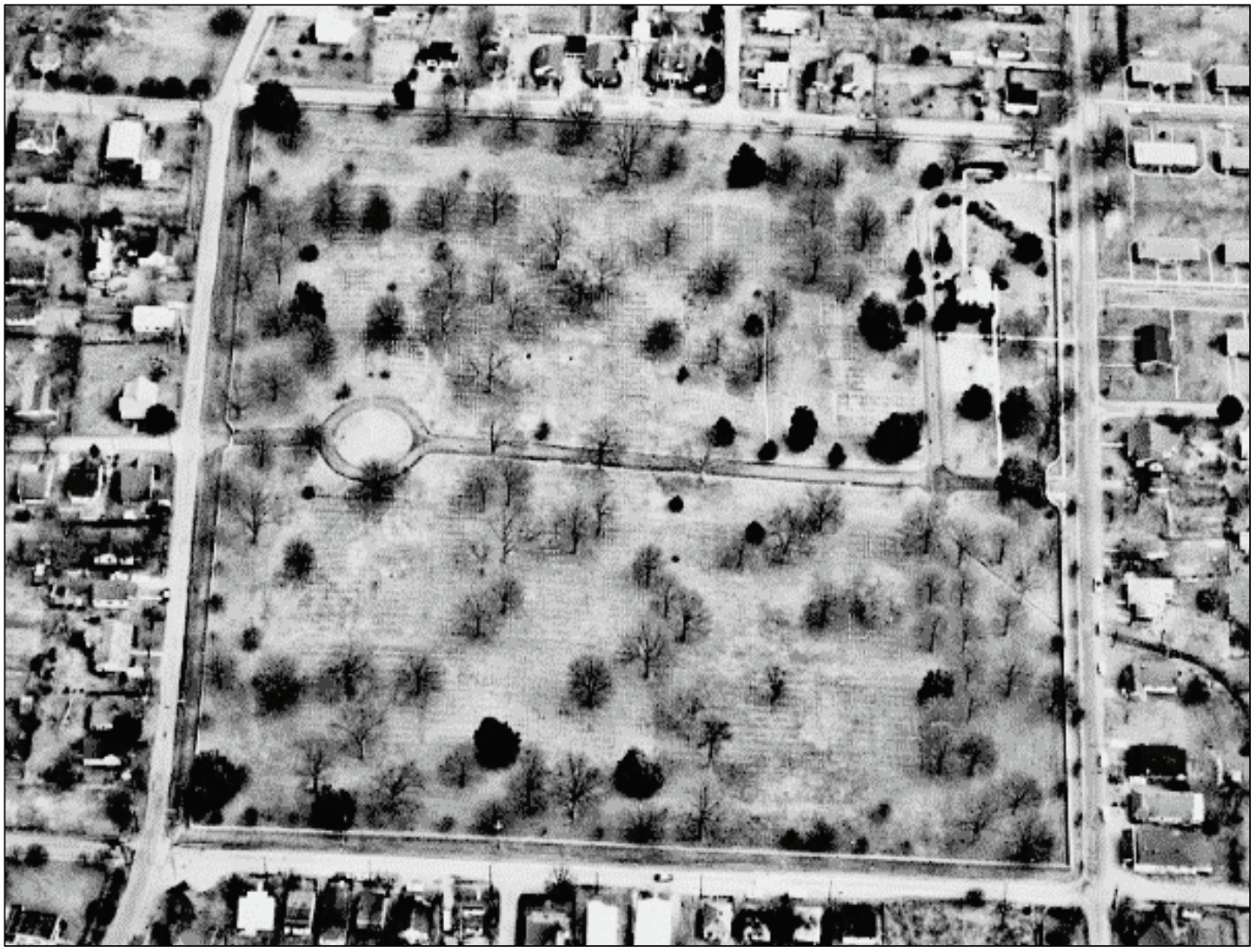


The administration of the cemetery changed on 1 September 1973, when 82 of the 84 National Cemeteries under the jurisdiction of the Secretary of the Army were transferred to the Veterans Administration, including Corinth National Cemetery. ${ }^{114}$ When the Veterans Administration took over Corinth National Cemetery, a transfer of real property form was produced, listing the cemetery assets at that time (Table 1).

Table 1. Facilities transferred to the Veterans Administration in 1973 (NCA archives, Washington, DC).

\begin{tabular}{|l|l|l|l|}
\hline Facility & $\begin{array}{l}\text { Unit of } \\
\text { Measure }\end{array}$ & Total Quantity & Cost (\$) \\
\hline FE Maintenance Shop & SF & 1219 & 14,000 \\
\hline Flagpole & & 1 & 1,900 \\
\hline Family Housing & SF & 2064 & 20,100 \\
\hline Electrical Distribution System & LF & 400 & 500 \\
\hline Sanitary Sewer & LF & 370 & 1,000 \\
\hline Water Pipe Line Potable & LF & 669 & 900 \\
\hline Roads Paved & SY & 4479 & 10,200 \\
\hline Vehicle parking Area & SY & 2132 & 3,000 \\
\hline Sidewalk & SY & 732 & 700 \\
\hline Storm Sewer & LF & 190 & 1,400 \\
\hline Irrigation Facility & LF & 6065 & 12,000 \\
\hline Gutters & LF & 514 & 600 \\
\hline Fence or Walls & LF & 3538 & 34,400 \\
\hline Gates & LF & 52 & 700 \\
\hline Land Purchase & AC & 20 & 3,500 \\
\hline SF = square feet; LF = linear feet, SY = square yards, and AC = acres \\
\hline
\end{tabular}

A preliminary NRHP form from 1974 describes the property's appearance as: "grassy, landscaped grounds [that] are complemented by a fine stand of hardwood and magnolia trees which add to the park-like nature of the cemetery." 115 The wall was described as "four feet in height with concrete

\footnotetext{
114 National Cemetery Association, "History of Government Furnished Headstones and Markers," 2015. 115 Webb, "Corinth National Cemetery National Register of Historic Places Inventory - Nomination Form," 1974, 7.
} 
coping," and the gates as being "ornamental wrought iron."116 Lighting for the flagpole was installed in the fall of $1974 .{ }^{117}$ It is not clear if there was a lighting system previously. The open spaces depicted in the nineteenthcentury plans began to be filled in with burials during the $1970 \mathrm{~s}$ and 1980s. By 31 March 1978, the cemetery contained 6,206 interments, with 3,996 of them unknown. ${ }^{118}$

The exterior of the lodge had not been altered much since its construction. By the mid-1970s, the windows and doors were covered by awnings, and the tile roof had been replaced with one of asphalt shingles. The 1950 os shrubs around the lodge had matured, and there were mature evergreen trees near the west side of the lodge. A wooden privacy fence with a wooden gate was erected at some point. It is not clear how long the fence existed (Figure 61 and Figure 62).

116 Webb, "Corinth National Cemetery National Register of Historic Places Inventory - Nomination Form," $1974,7$.

117 John W. Clemons, Superintendent, “Memorandum: Lighting of Flagpole," 30 September 1974 in Corinth Vertical File, National Cemetery Administration, U.S. Department of Veterans Affairs, Washington, DC.

118 “Corinth National Cemetery," typed manuscript, no date, 2. 
Figure 61. Lodge at southwest corner, with asphalt shingles, awnings, and mature shrubs, ca. 1970s (Corinth Lodge HSAR, NCA archives, Washington, DC).

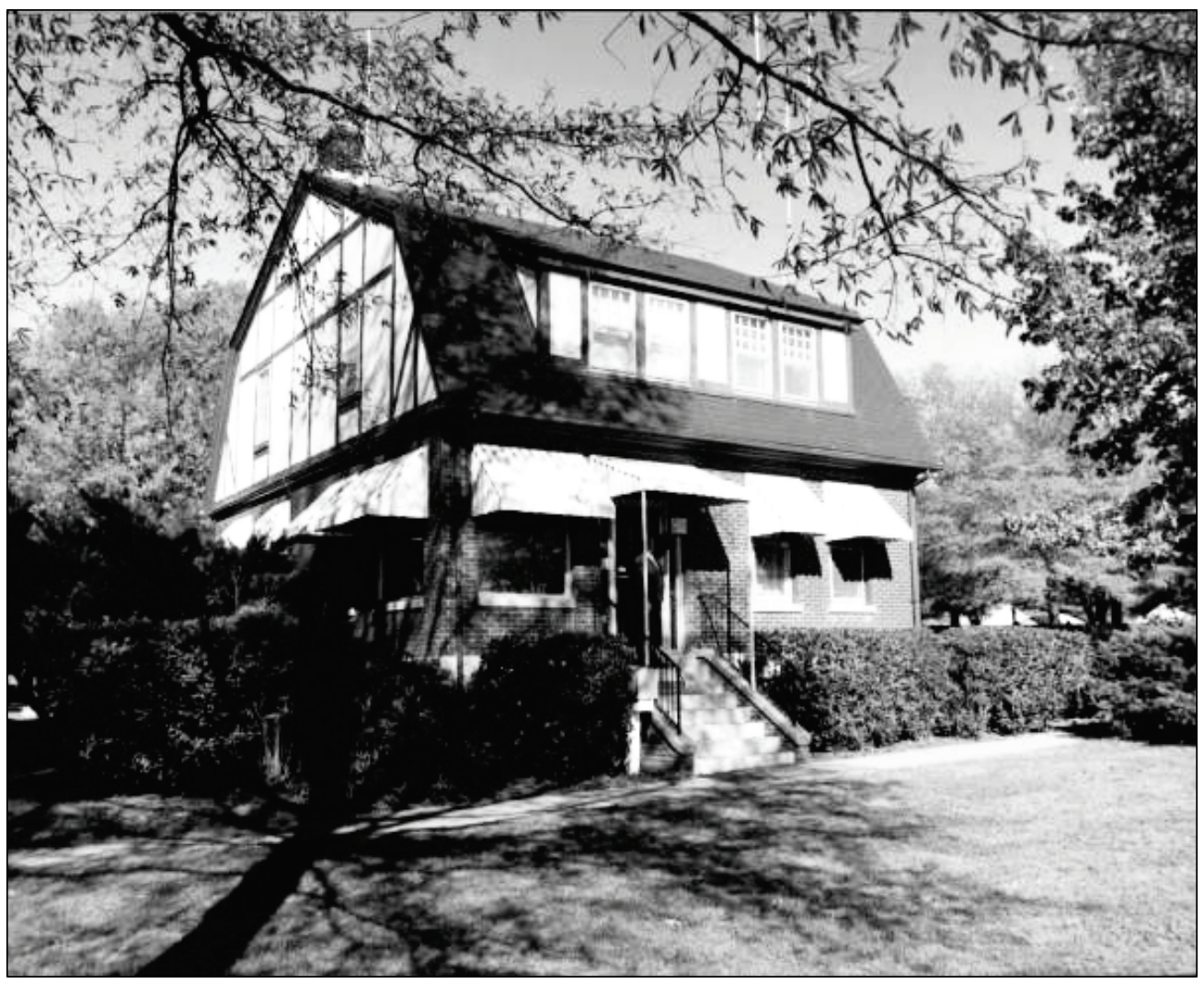

Figure 62. East elevation of lodge with awnings, evergreen trees, mature shrubs, and privacy fence, ca. 1970s (Corinth Lodge HSAR, NCA archives, Washington, DC).

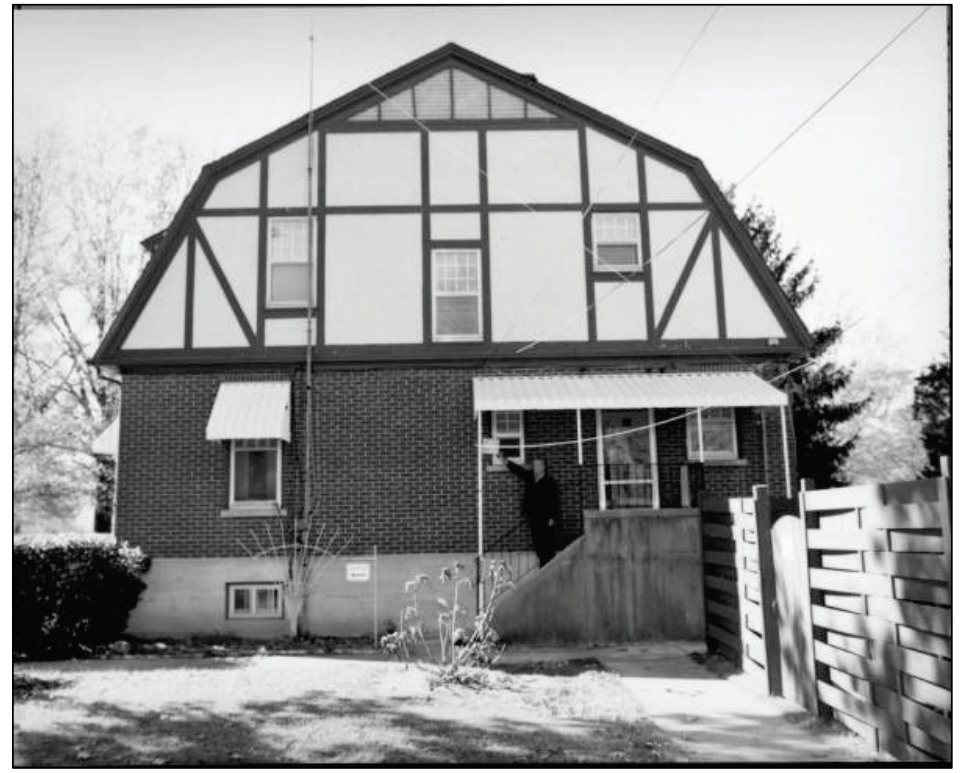


The main avenue, the road to the service area, and the parking area were repaired in 1985. Repairs included resurfacing as well as removing and replacing concrete valley gutters along most of the avenue and service road. ${ }^{119}$

Small-scale changes during this period included inscriptions on the headstones. On 31 October 1983, the VA authorized "Lebanon" or "Grenada" to be labeled as the war service for those killed during those conflicts. In December 1988, the Director of Monument Services, Veterans Administration, authorized designations of "MIA" and "POW" to be inscribed on headstones at the government's expense for those soldiers listed as missing in action (MIA) or prisoner of war (POW). And then a year later in December 1989, the Director of the National Cemetery System, Veterans Administration, authorized "Panama" and "Persian Gulf" as an inscription for personnel killed during those military actions. ${ }^{120}$ In the early 1990 , headstone modifications included authorization of "Persian Gulf" and "Somalia" to be inscribed on headstones for the soldiers killed during those military conflicts. ${ }^{121}$

As of 1991, the lodge was no longer used for the cemetery director's residence. The building continued to function as an administrative office. ${ }^{122} \mathrm{~A}$ 1996 view of the building shows little change, with the exception of the vegetation around the lodge having been mostly cleared (Figure 63).

\footnotetext{
119 “Road Repairs G.O.E. Maintenance \& Repairs - 1985," Veterans Administration plan, in collection of the National Cemetery Administration, U.S. Department of Veterans Affairs, Washington, DC.

120 National Cemetery Association, "History of Government Furnished Headstones and Markers," 2015.

121 National Cemetery Association, "History of Government Furnished Headstones and Markers," 2015.

122 Sammartino, “Corinth National Cemetery,” 1996, 7-1.
} 
Figure 63. South elevation of lodge, 1996 (Corinth Lodge HSAR, NCA archives, Washington, DC).

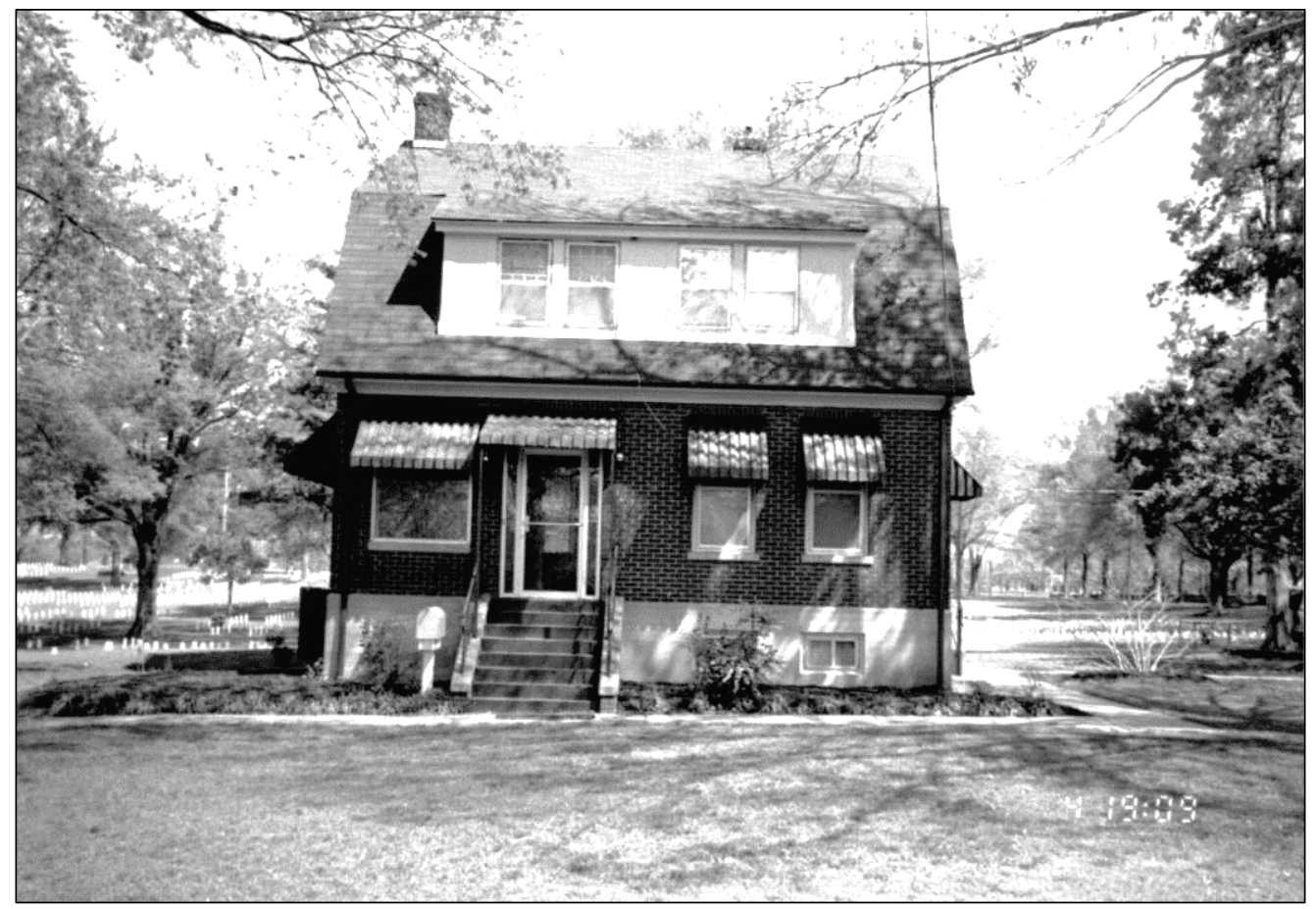

The service area was enclosed by a wooden picket fence by 1996 . At some later point, the wooden fence was replaced with a metal chain link one, which remains today. ${ }^{123}$ The status of the cemetery as to space for new burials was explained in the 1996 NRHP nomination: ${ }^{124}$

As of May 31, 1996, there were 6,615 graves used for the interment of 6,714 casketed remains and 7 sites used for the interment of 10 cremated remains. Interments of casketed remains in occupied graves and reserved graves, as well as interments of cremated remains, continue. As of May 31,1996 , there were 6,842 gravesites available for the interment of casketed remains, plus 13 reserved gravesites, and 38 sites available for the interment of cremated remains. It is estimated that the cemetery will have gravesites available until beyond the year 2030.

The most problematic maintenance issue over the years has been keeping the wall intact and in good repair. The wall has undergone extensive repairs, and it has been largely replaced several times. The most damage comes from motorists hitting the wall with their vehicles. In the late 1990s,

\footnotetext{
123 Sammartino, "Corinth National Cemetery," 1996, 6.

124 Sammartino, “Corinth National Cemetery,” 1996, 7-1.
} 
the wall was hit half dozen times. ${ }^{125}$ The wall's condition had become so bad by 2000 that a partial rebuilding and repair project was funded. The toppled walls were restored using as much original brick as possible during the summer of 2001, at a cost of $\$ 300,000$. The work was contracted to Global Construction of North Carolina. Additional work included tuckpointing the brick, repairing the coping, fortifying the west wall, placing root barriers, and painting all the wrought iron gates. ${ }^{126}$

In 2009, the VA NCA initiated a project to fabricate and install replica Gettysburg Address tablets to replace the ones that in 1909 had originally commemorated the centennial of President Lincoln's birth at all National Cemeteries. Because some of the original tablets had been removed from cemeteries and omitted from the creation of new cemeteries, not all National Cemeteries still featured the tablets. This lack of uniformity justified the re-creation and installation of the replicas. ${ }^{127}$ At Corinth National Cemetery, the original tablet was installed outside the cemetery office in the lodge. The replica tablet is located in the southeast quadrant, northeast of the main avenue and the drive to the service area (Figure 64).

\footnotetext{
125 Jebb Johnston, “Toppled tribute," Daily Corinthian, 23 June 2000, 1A-2A, in Corinth Vertical File, National Cemetery Administration, U.S. Department of Veterans Affairs, Washington, DC.

126 Jeb Johnston, “Work on walls surrounding Corinth National Cemetery is completed," Daily Corinthian, 14 December 2001, 1A-2A, in Corinth Vertical File, National Cemetery Administration, U.S. Department of Veterans Affairs, Washington, DC.

127 National Cemetery Division, “150th Anniversary,” 2011; “New Gettysburg Address Tablets for National Cemeteries To Honor Abraham Lincoln Bicentennial," (Washington, DC: National Cemetery Administration, U.S. Department of Veterans Affairs, last updated 2015), https://www.cem.va.gov/history/LincBic.asp.
} 
Figure 64. Replica Gettysburg Address tablet, 2018 (ERDC-CERL).

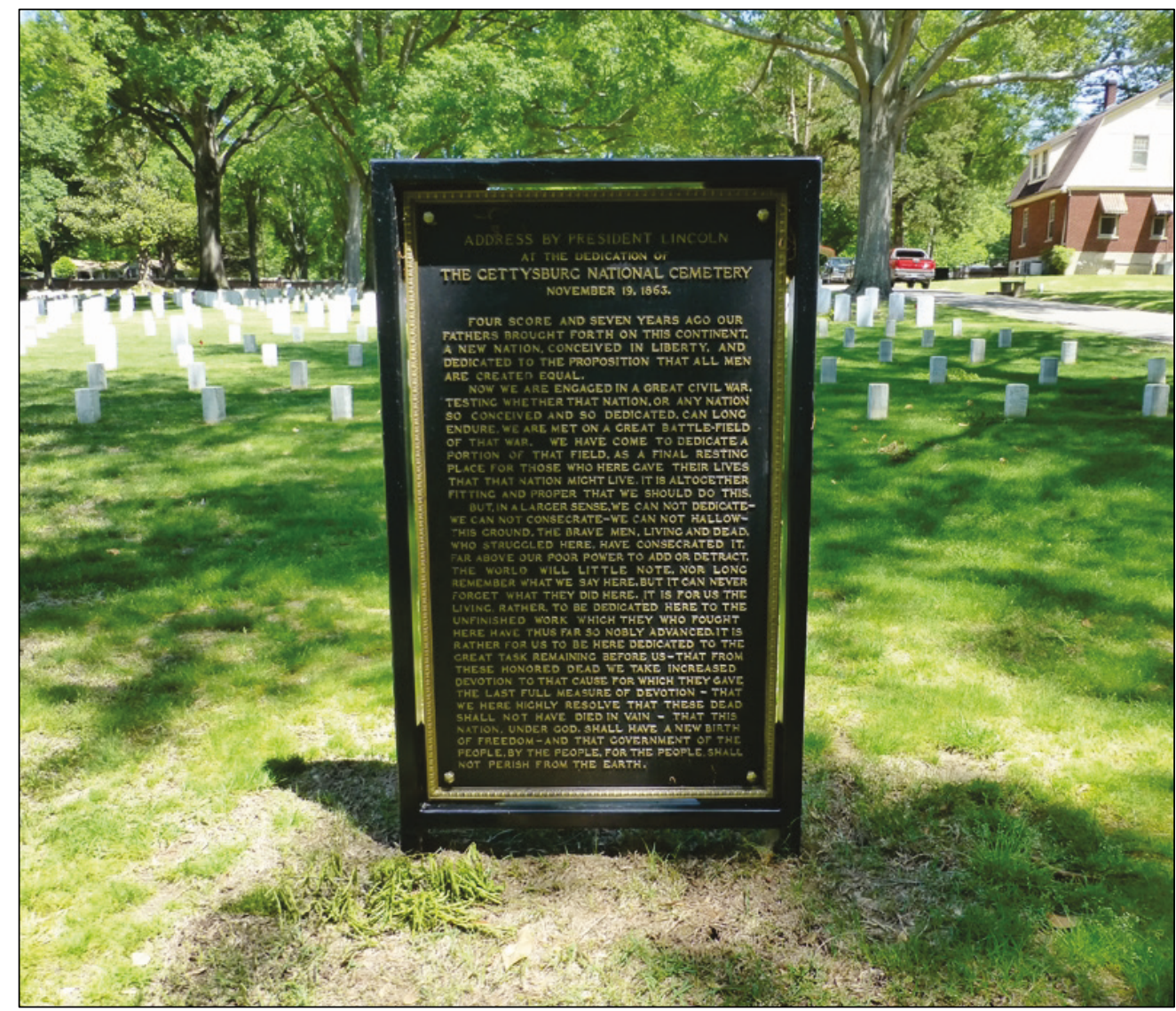

There was an extensive project to repair, reconstruct, and restore the cemetery's brick enclosing wall in 2012. The project was undertaken by SmithGroup JJR LLC of Ann Arbor, Michigan, and completed in 2015. ${ }^{128}$ In 2016, one of the main entrance gate posts was repaired after being hit by a garbage truck, which knocked off the urn on top of one post. In 2017, the Navy Seabee Veterans of America donated a granite monument to the cemetery as part of their "Seabee Monument in every National Cemetery Project.” The Seabee monument is located near the cemetery's main entrance (Figure 65). ${ }^{129}$

\footnotetext{
128 Department of Veterans Affairs, "Corinth National Cemetery: Historic Wall Repair, Reconstruction, and Restoration, Bid Documents," 12 March 2012, in collection of the National Cemetery Administration, U.S. Department of Veterans Affairs, Washington, DC.

129 "Corinth National Cemetery," https://www.cem.va.gov/cems/nchp/corinth.asp; Navy Seabee Veterans of America, "Can Do," Volume 28, Number 3, September 2018, 10, https://www.nsva.org/pdf/CAN-DO.pdf
} 
As of September 2018, there are 7,892 burials at Corinth National Cemetery. 130

Figure 65. Seabee monument, 2018 (ERDC-CERL).

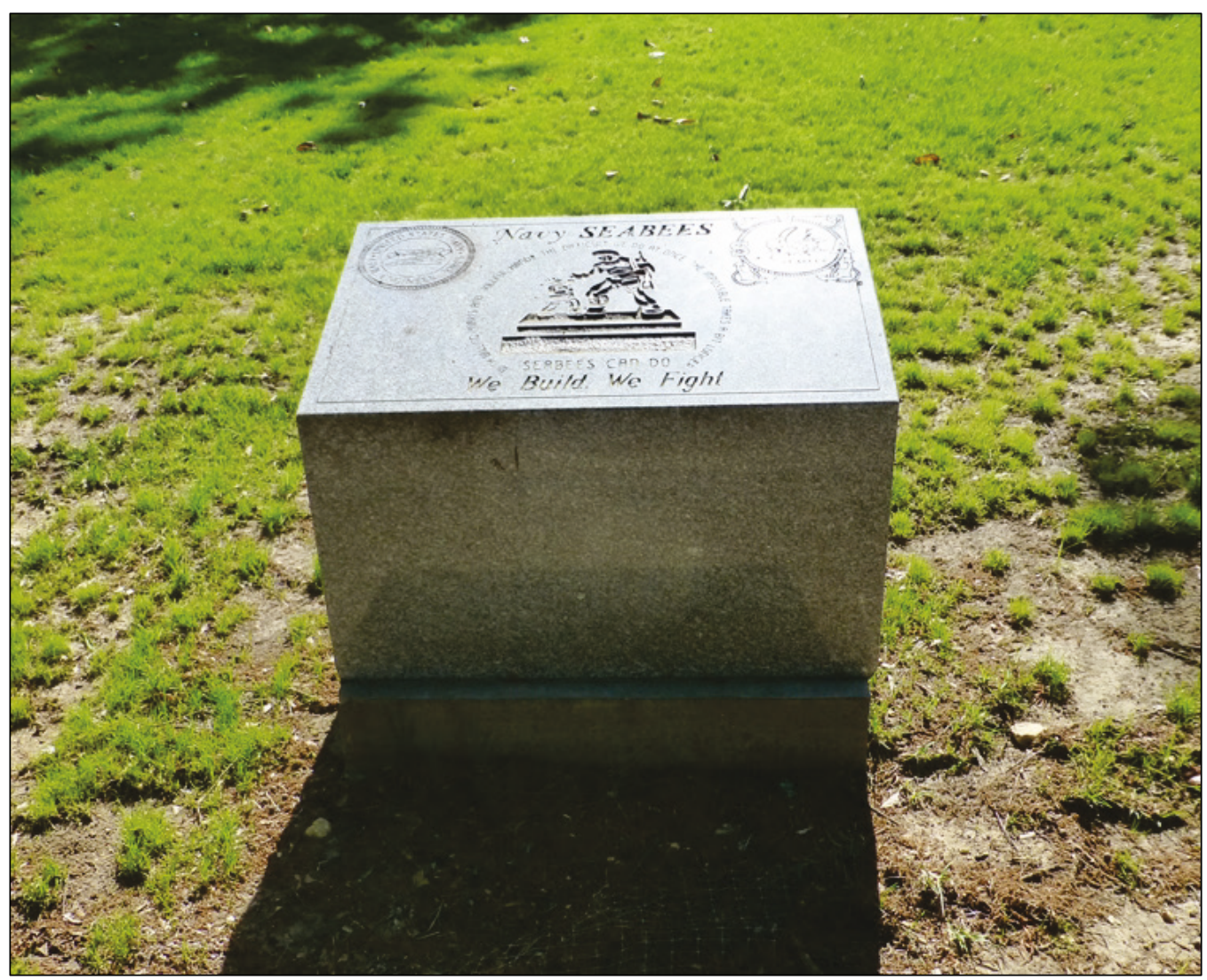

130 Amanda Rhodes-Wharton, Cemetery Administrator/Director, Memphis National Cemetery and Corinth National Cemetery, e-mail to William E. Hooker III, Historic Architect/Cultural Resources Manager, U.S. Department of Veterans Affairs, National Cemetery Administration, 20 September 2018. 


\section{National Register Evaluation}

\subsection{4 nomination}

An NRHP nomination was written in 1974 and certified by the State Liaison Officer. No period of significance is mentioned in the 1974 nomination, and a list of contributing and noncontributing features is not provided. Figure 66 reproduces the cemetery's 4-page NRHP nomination form from 1974 and the letter of submittal.

Figure 66. Reproduction of pages with NRHP nomination of the Corinth National Cemetery, 1974 (NCA, Washington, DC).

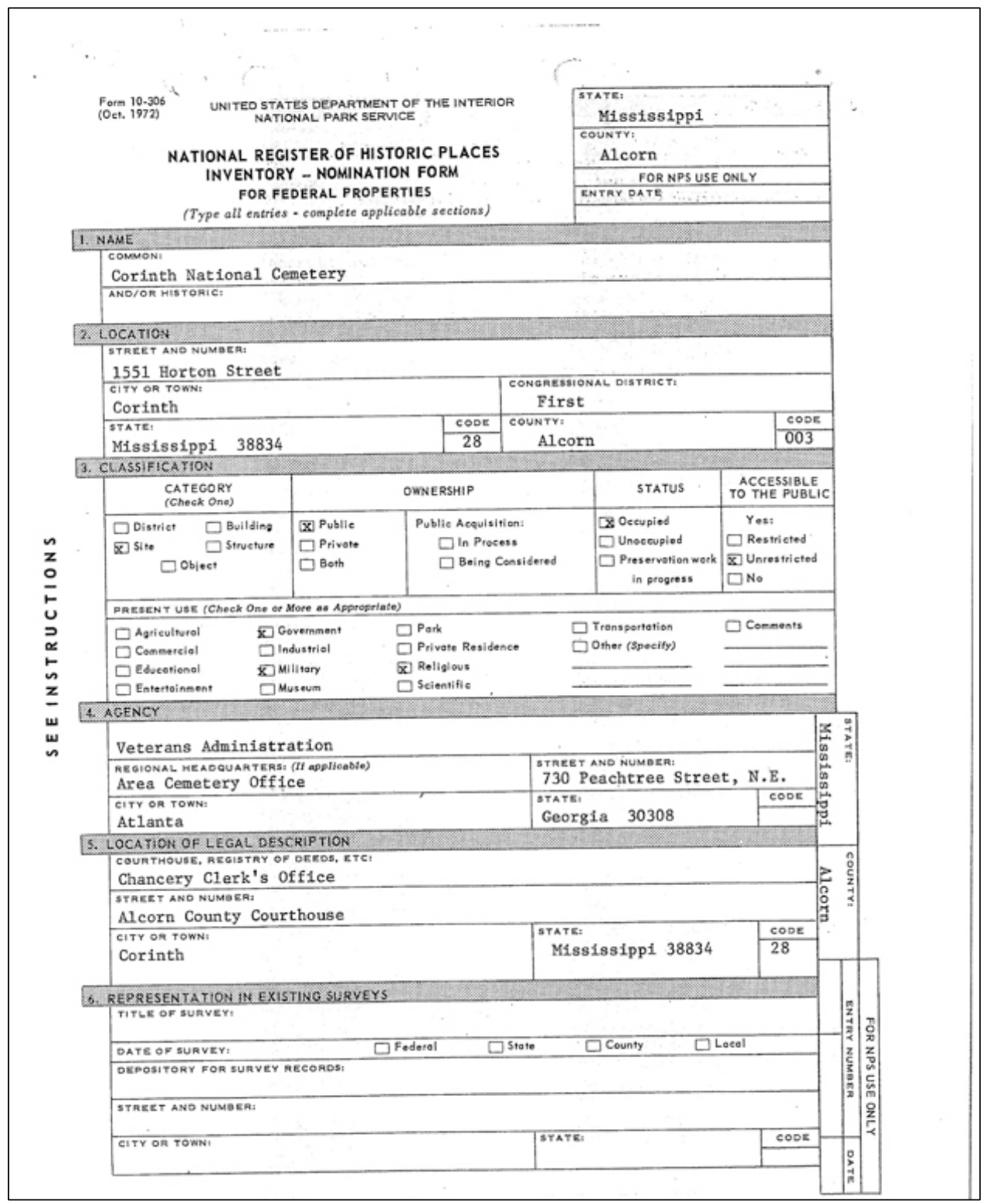




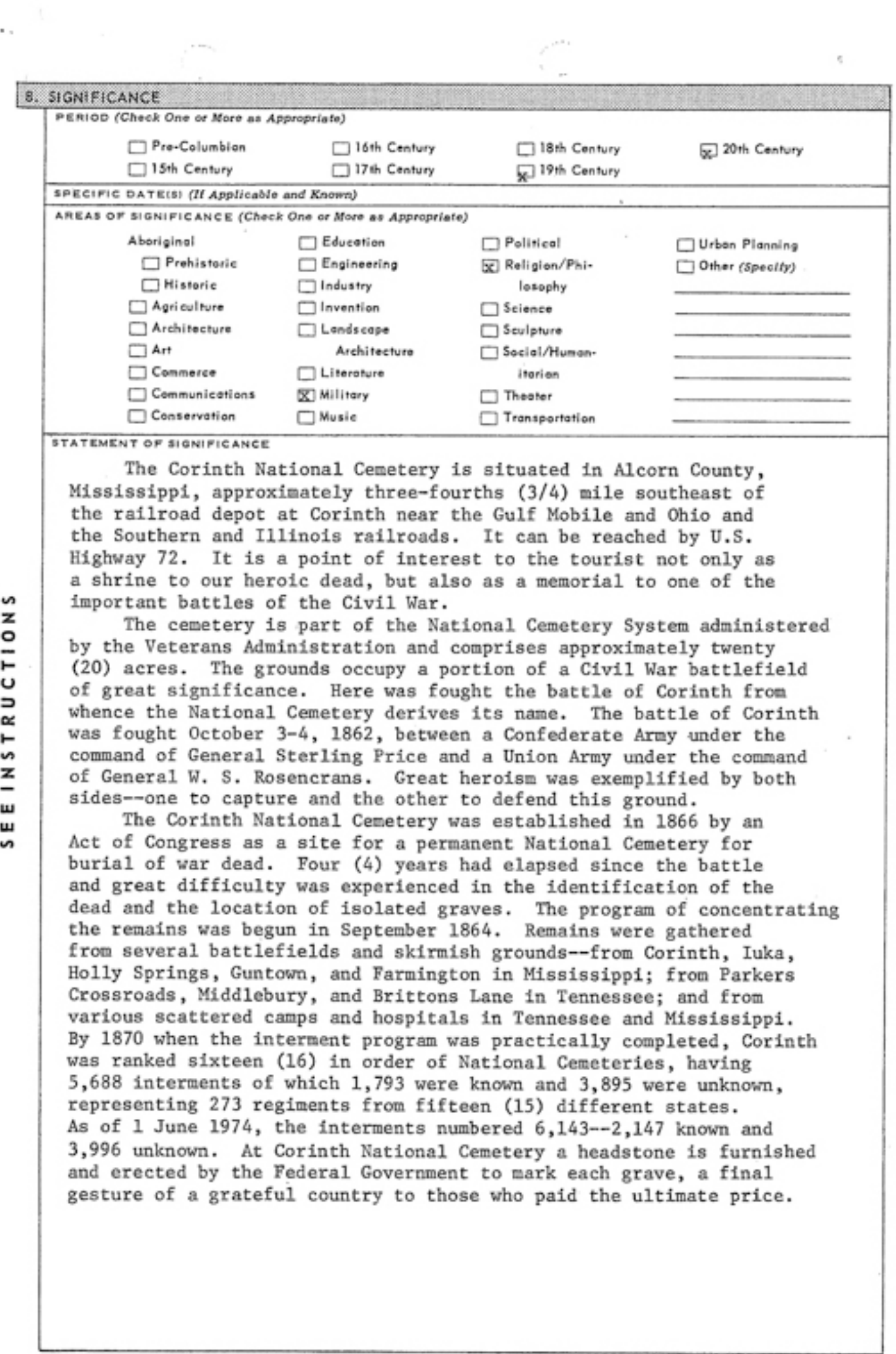




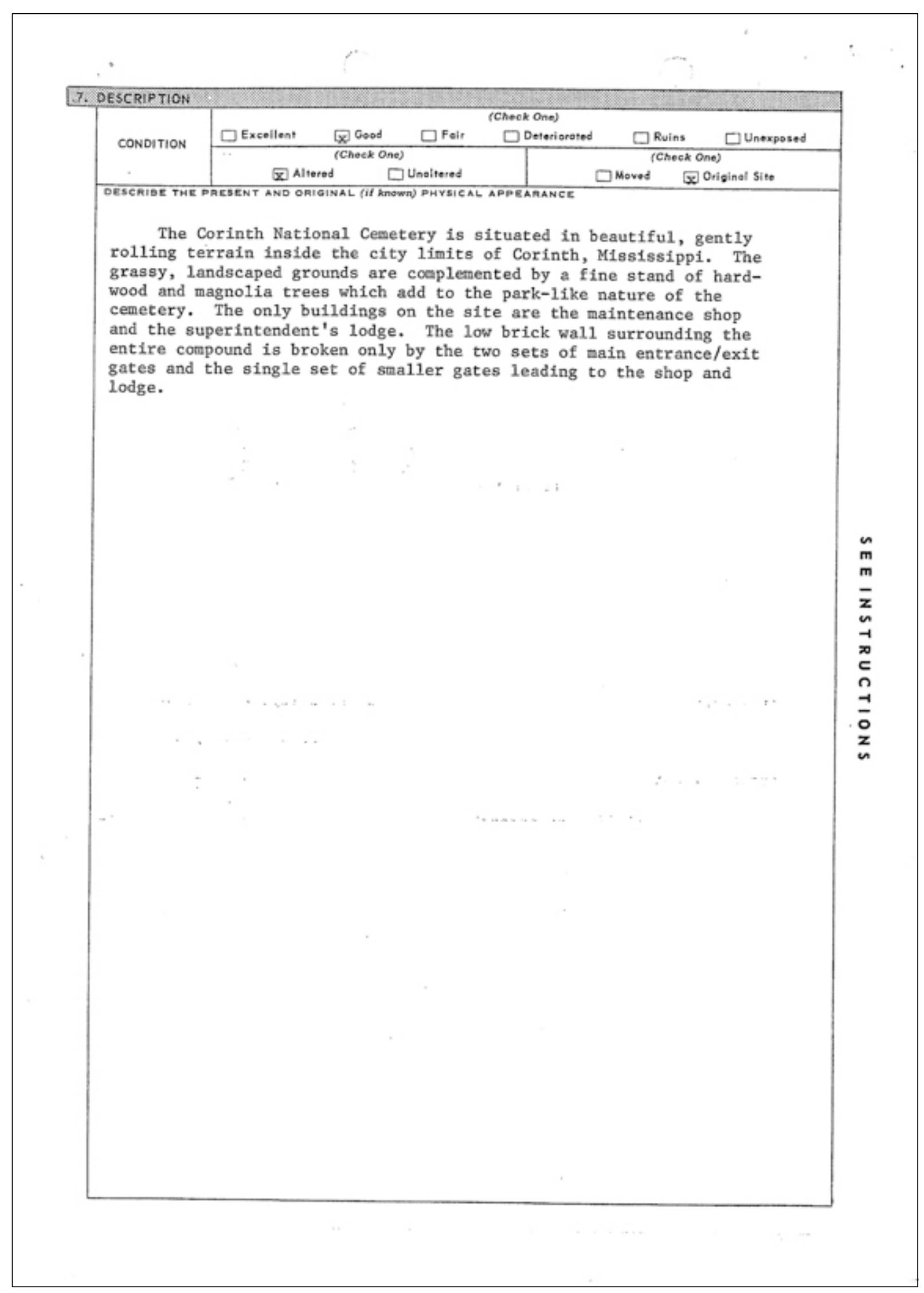



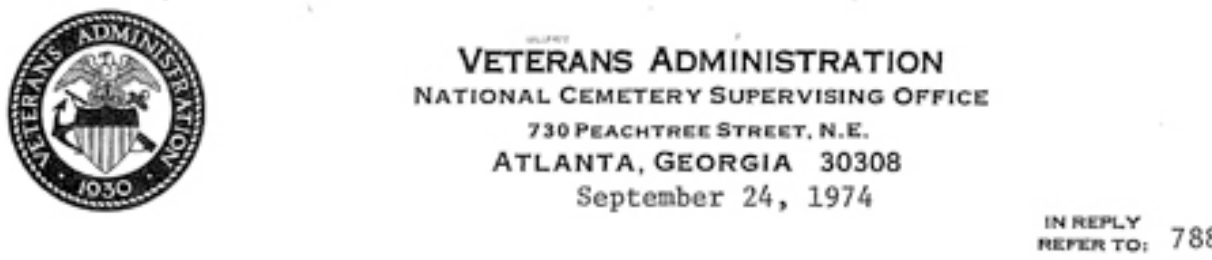

Director, National Cemetery System (40)

Veterans Administration

Attn: Historic Preservation officer

810 Vermont Avenue

Washington, D. C. 20420

Subject: National Register of Historic Places

Enclosed are documents, with affirmative recommendation, nominating the Corinth National Cemetery to the National Register of Historic Places.

Enclosure

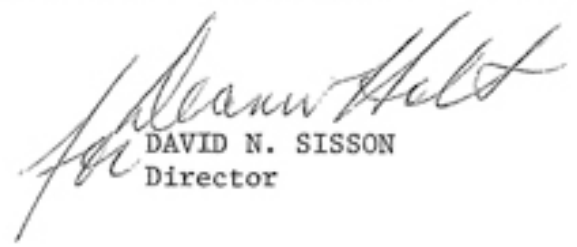




\subsection{0 nomination}

An NRHP nomination for "determination of eligibility" was written in 1980. No period of significance is mentioned in the 1980 nomination, and the Superintendent's Lodge and Service Complex were determined not to be contributing features. Figure 67 reproduces the cemetery's 5-page NRHP nomination form from 1980 and letter of submittal to the Keeper of the National Register in 1983.

Figure 67. Reproduction of pages with NRHP nomination of the Corinth National Cemetery, 1980 (NCA archives, Washington, DC).

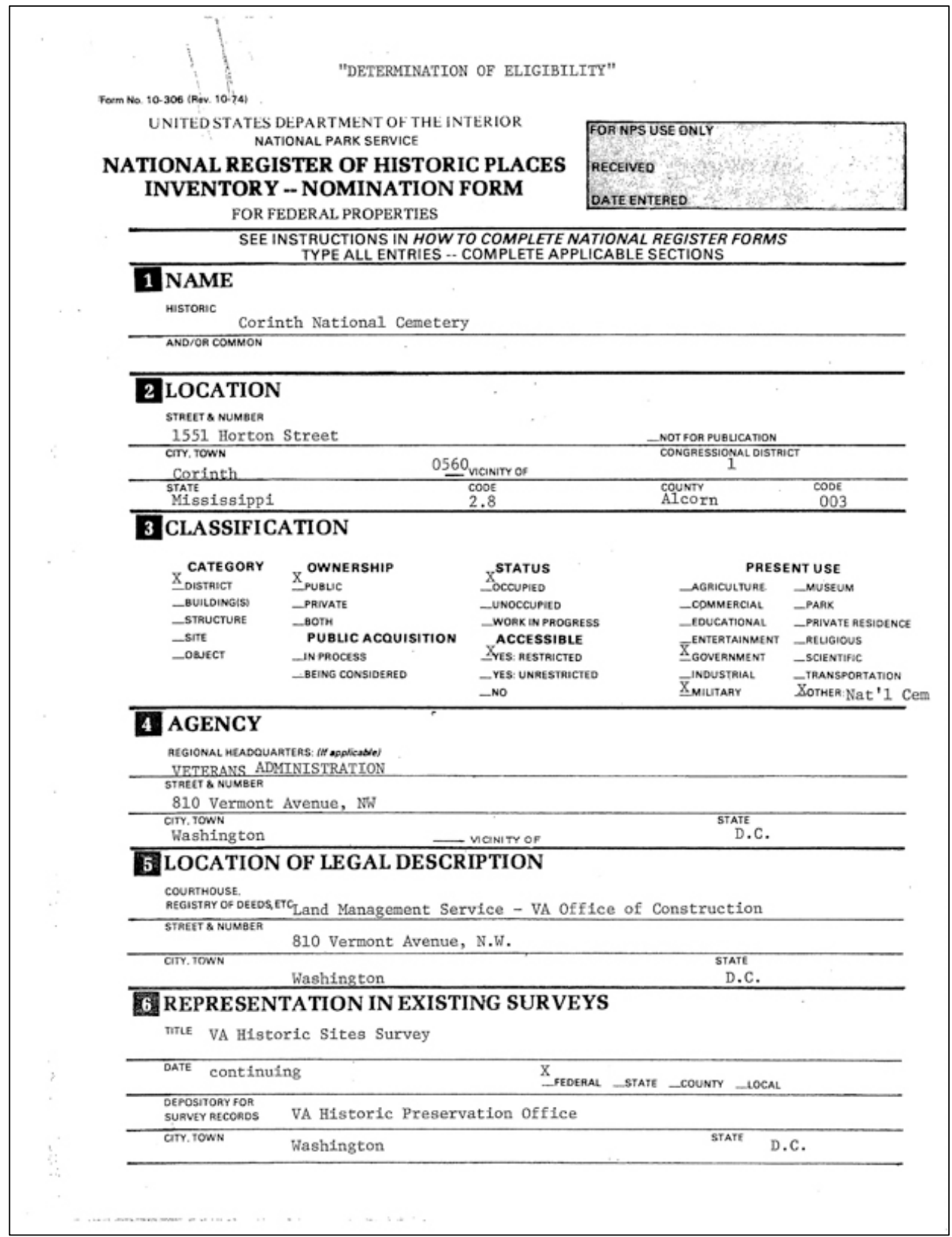




\section{DESCRIPTION}

\begin{tabular}{|c|c|c|c|c|}
\hline \multicolumn{2}{|c|}{ CONDITION } & CHECK ONE & \multicolumn{2}{|c|}{ CHECK ONE } \\
\hline _EXCELLENT & -DETERIOAATED & -UNALTEAED & X_OAIGINA & \\
\hline$x_{6000}$ & -RUIN5 & X-ALTERED & MOVED & DATE_ \\
\hline -FAIR & -UNEXPOSED & & & \\
\hline
\end{tabular}

DESCRIBE THE PRESENT AND ORIGINAL (IF KNOWN) PHYSICAL APPEARANCE

The Corinth National Cemetery is situated in beautiful, gently rolling terrain inside the city limits of Corinth in Aicorn County. The grassy, landscaped grounds are complemented by a fine stand of hardwood and magnolia trees which add to the park-like nature of the cemetery. The only permanent buildings on the site are the director's lodge and service complex.

The cemetery contains approximately 20 acres of land and was sold to the United States on February 17, 1868, for the sum of $\$ 3,500$. The cemetery is nearly square, laid of in 24 unequal burial sections. It is surrounded by a brick wall four feet in height with concrete coping. The main entrance is located at the center with concre north wall with entry gates of ornamental wrought iron. A driveway leads from the gates and is a continuation of the road which extends through the cemetery to the south wall where there is another entrance originally for carriages. Two smaller gateways of ornamental wrought iron admit pedesterians.

The $11 / 2$ story lodge was constructed in 1934 and is a typical example of a standard, modest cost cottage of the period. The design was the standard for national cemeteries between 1928 and 1934. All details and materials are "off the shelf". The only significant feature is the flat clay tile gambrel roof. The fist story is brick resting on a high, exposed concrete foundation wall. The dormered second story has stucco gabels with exposed wood loosely imitating half-timber English tudor. The 1900 square foot plan is approximately square with a cut out on the fist floor under the roof for an entry porch. The design has an unexpected degree of character resulting from the overscaled roof which gives a sheltered, protective quality counteracting the negative aspects of the elevated first floor.

A stable was originally on the site of the service complex. The date of construction is not known. It was of brick with arched door openings approximately 20 by 40 feet. The building was demolished in 1934.

A service complex was constructed in 1935 consisting of a combination garage, outbuilding for employees and restroom facility. This was a Works Progress Administration(WPA) project and the total cost of construction was $\$ 3,500$. The structure is of brick with double hung six over six windows. It has a composition asphalt shingle hip roof.

These buildings do not contribute to the historical significance of this national cemetery. 


\section{SIGNIFICANCE}

\begin{tabular}{|c|c|c|c|c|}
\hline PERIOD & & IGNIFICANCE $\ldots \mathrm{CH}$ & ECK AND JUSTIFY BELOW & \\
\hline PAEHISTORIC & -A.ACHEOLOGY.PREHISTOAIC & -COMMUNITY PLANNING & - LANDSCAPE ARCHITECTUAE & -REUGION \\
\hline$-1400 \cdot 1499$ & ARCHEOLOGYHISTOAIC & -CONSERVATION & -UaW & -SCENCE \\
\hline$-1500 \cdot 1599$ & AGRICULTUAE & -ECONOMICS & $\bar{X}_{\text {UTERATURE }}$ & -SCULPTURE \\
\hline$-1600 \cdot 1699$ & AACHITECTURE & -EDUCATION & XMIUTARY & - SOCIALHUMANITARIAN \\
\hline $\mathrm{X}^{1700.1799}$ & -ART & -ENGINEERING & -Music & - THEATER \\
\hline $\begin{array}{l}-1800 \cdot 1899 \\
-1900\end{array}$ & $\begin{array}{l}\text {-COMMERCE } \\
\text {-COMMUNICATIONS }\end{array}$ & $\begin{array}{l}\text {-EXPLOAATION/SETTLEMENT } \\
\text {-INDUSTRY } \\
\text {-INVENTION }\end{array}$ & $\begin{array}{l}\text {-PHELOSOPHY } \\
\text {-POUTICS/GOVERNMENT }\end{array}$ & $\begin{array}{l}\text { XOTHER ISPECIEV Nat ' } 1 \\
\text { TRANSPOATATION }\end{array}$ \\
\hline
\end{tabular}

SPECIFIC DATES

BUILDER/ARCHITECT

STATEMENT OF SIGNIFICANCE

National Cemeteries administered by the Veterans Administration are eligible for listing on the National Register of Historic Places because they have been designated by Congress as primary memorials to the military history of the United States. These cemeteries were created in response to a national sense of obligation to care for those who served their country, and are physical manifestations of our social conscience. It is important that these sites be preserved and maintained as a statement of these sentiments for future generations.

Corinth National Cemetery was established in 1866 for the reinterment of remains of Union soldiers. The cemetery derives its name from the Battle of Corinth which was fought October 3-4, 1862 .

The battle started early on October 3 and lasted two days. Major General William S. Rosecraps led the Union forces and Major Generals Earl Van Dorn and Sterling Price led the Confederates.

Van Dorn's first attack hit two Federal divisions outside the inner defenses. The bluecoats fought stubbornly but had to fall back behind the fortifications. Price then sent his divisions against the Union center line about 1 p.m.

The Federals waited until the Confederates broke out of a woods and advanced over an open field. When they reached point blank range the Federals poured in a deadly fire, including artillery from entrenched positions on the left.

Prices's men retreated, reformed and tried again but were repulsed. The third charge sent some Federals running but the line held until fighting died out at nightfall.

Van Dorn felt he had the battle won and that another thrust would bring victory. It was $9 \mathrm{a} . \mathrm{m}$. before the Confederates attacked on October 4. They hit first on the Federal right. Again Price's troops led the attack, broke through and penetrated into the town of Corinth, fighting along streets and around houses. 


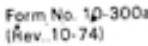

UNITED STATES DEPARTMENT OF THE INTERIOR

NATIONAL PARK SERVICE

\section{NATIONAL REGISTER OF HISTORIC PLACES INVENTORY -- NOMINATION FORM}

FOR NPS USE ONLY
RECEIVED
DATE ENTERED

Rosecrans saw the break and rode among his panicked troops. His hat was shot away, and his hair streamed in the wind. He "fought" like a private soldier, delt sturdy blows with the flat of his sword and fairly drove them to stand," Whitelaw Reid, a war correspondent wrote.

At the same time the Confederates also hit the Federal left. They stormed Battery Robinett, an entrenched artillery positions, and some of the foremost ranks spilled over the top of the works but were driven out by a bayonet charge.

Back in the woods they reformed and, led by Col. W. P. Rogers of the Second Texas, swarmed over the works despite heavy losses. Colonel Rogers carried a flag to the rampart. A Union drummer boy picked him off with a single revolver shot. His men raced on, about 100 reaching the Corinth public square. But then they were beaten back into the woods. That was enough for Van Dorn. Soon after $7 \mathrm{p} . \mathrm{m}$. he ordered a retreat. Union casualties were: 355 killed; 1,841 wounded, 324 missing. The Confederate losses were 473 killed, 1,997 wounded and 1,763 missing.

Four years had elapsed since the battle and great difficulty was experienced in the identification of the dead and the location of isolated graves. The program of reinterements of the dead began in September 1864. Remains were gathered from Corinth, Iuka, Holly Springs, Guntown, and Farmington in Mississippi; from Parkers Crossroads, Middlebury and Brittons Lane in Tennessee; and from various scattered camps and hospitals in Tennessee and Mississippi. As far as possible interments were by states and by 1870 when the program was practically completed, Corinth was ranked sixteenth in order of National Cemeteries having approximately 5,670 interred of these 3,760 were unknowns. They represented 273 regiments from 15 states including the dead of the 63 rd Regiments of Ohio Volunteers, 4th Regiment of Illinois Volunteers and Michigan Volunteers. 
MAJOK GIBLIOGRAPHICAL REFERENCES

10 GeOgRaPhical DATA

ACREAGE OS NOMINATED PAOPERTY 20.0

UTM AETERENCES

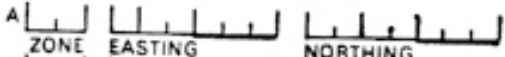

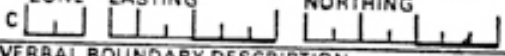

VERBAL BOUNDARY DESCAIPTION

At the intersection of Johns and Horton Streets.

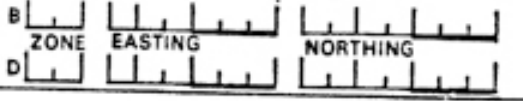

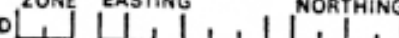

..........

LIST ALL STATES AND COUNTIES FOR PROPERTIES OVERLAPPING STATE OR COUNTY BOUNDARIES
\begin{tabular}{cccc} 
CTATE & COUNTY & CODE \\
\hline STATI & CODE & COUNTY & COOt
\end{tabular}

\section{FORM PREPARED BY}

NAME - TYTLE

\begin{tabular}{|c|c|c|}
\hline 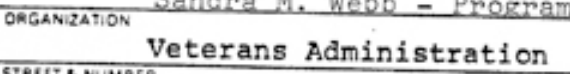 & DATE & \\
\hline $\begin{array}{l}\text { STRLIT S NUMBER } \\
810 \text { Vermont Avenue }\end{array}$ & $\begin{array}{r}\text { TELEPHONE } \\
(202)\end{array}$ & $389-3447$ \\
\hline $\begin{array}{l}\text { CITY OR TOW } \\
\text { Washinaton, }\end{array}$ & STATE D.C. & \\
\hline
\end{tabular}

12 CERTIFICATION OF NOMINATION

STATE HISTORIC PRESERVATION OFFICER RECOMMENDATION

YES N NO_ NONE.

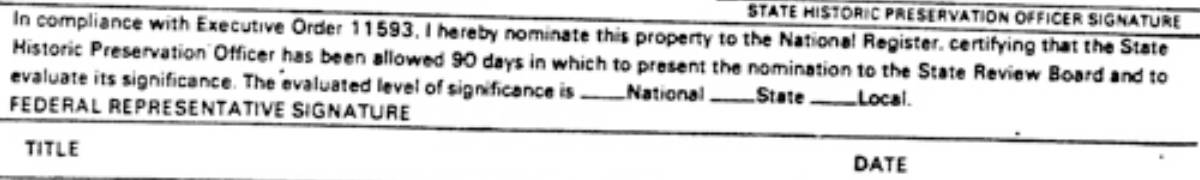

FOA NPS USE ONLY

I HEREBY CERTIFY THAT THIS PROPERTY IS INCLUDED IN THE NATIONAL REGISTER

DIAECTOR. OFFICE OF ARCHEOLOGY AND HISTORIC PRESERVATION DATE
ATTEST:

KEEPER OF THE NATIONAL REGISTER

DATE 
VETERANS ADMINISTRATION

OPFICE OF CONSTRUCTIOH

WASHINGTOR, D. C. 20420

\section{MAR 151983}

Virs. Carol D. Shuil

Hational Register of Historie Places

Hational Parik Servioe

Departwent of Interior

440 G Street, WI

Hashington, D.C. 20243

Dear Mrs. Shu12:

It is the opinion of the Veterans Administration that the Corinth lletional Cemetory, Aloom County, Corinth, Hisaissipp1, appears to meet the oriteria for listing on the fistional Register or Historio Places.

The Vississippi State Historic Preservation Oripioe has suvisod us (copy onclosed) that the office concurs in our opiaion and our intention to notinate this property to the Wational Register.

Enclosed plesse find a supporting docutentation covering the algaisficanoe of the Corinth National Cesotery for your consideration under 36 CFn 63.3 . A atruoture-my-structure iisting indicating which contribute to the historio

significance of the district and wich constitute intrusions ia included as is a set of photographs. The photogrspha should be retafiod as pertanent gile coples.

ife wowld efpreciate your determination regerding the oligibility of this property for the Mational Register of fidstoric Places.

sincereiy,

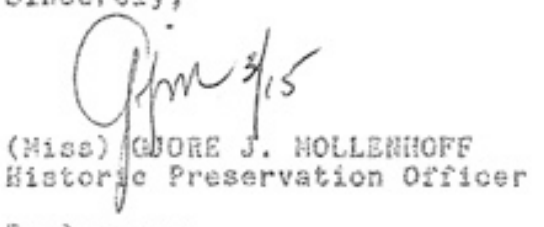

Enclosures

cc: $08 \mathrm{~A}$

08A1

40

41 


\subsection{Siege and Battle of Corinth Sites, National Historic Landmark nomination}

A National Historic Landmark (NHL) nomination was accepted in 1991 for the Siege and Battle of Corinth including the Corinth National Cemetery. The period of significance in the 1991 NHL nomination is from April 1862 through October 1862, with significant dates of April 28-May 30, 1862 (siege), and October 3-October 4, 1862 (battle). The Siege and Battle of Corinth was nominated under Criteria A and B. The Superintendent's Lodge was not considered a contributing feature of the NHL nor was the utility building, since they were constructed in 1934. Figure 69 reproduces three pages from the 1991 NHL nomination that are specifically relevant for Corinth National Cemetery.

Figure 68. Reproduction of pages concerning the Corinth National Cemetery in the NHL registration form for the Siege and Battle of Corinth Sites, 1991 (NCA).

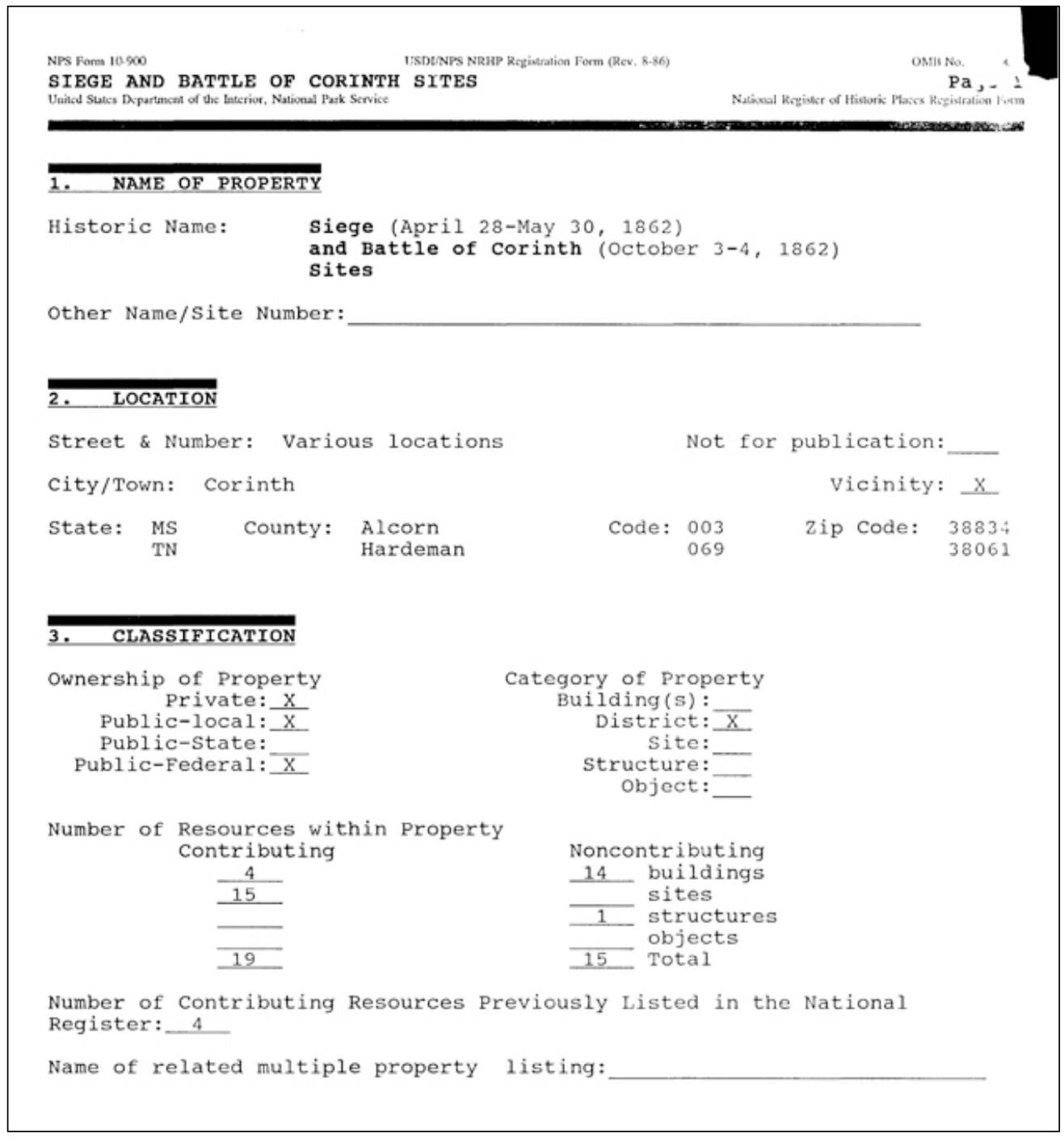


magazine. The mound is three to five feet high and 25 feet deep by 25 feet wide. The mound is depressed in the center and on the northeast side, having collapsed when the timber linings rotted.

Five hundred feet southwest of this emplacement and bombproof is another emplacement and bombproof in the same configuration as the previous set. The emplacement is two to four feet high, eight to ten feet wide, and 250 feet long. A bombproof is located at the end of the battery. (The second emplacement and bombproof resemble the configuration of the first emplacement and bombproof.) The bombproof is three to five feet high and 25 feet deep by 25 feet wide. The center is depressed in the same configuration as the first, with the northeast side depressed more than the other sides.

\section{UNION SIEgE LINE: Army of the Mississippi (Brig. Gen. E.A. Paine's Division)}

There are two lines of rifle-pits along the ridge line. The line lower on the ridge is 168 feet long, one to two feet high, and approximately two feet wide. The second earthwork is about 50 feet above the lower and is 200 feet long, one to two feet high, and approximately two feet wide. The earthworks at the north end have been badly eroded. The area is kept as a grassy mowed field. A few hardwood trees shade the area.

\section{CONFEDERATE RIFLE-PIT}

The rifle-pit is crescent-shaped in plan and is oriented to face northeast. It consists of a low earthwork behind which was a shallow trench. The front trench has been infilled by slope wash from the embankment. The earthwork is devoid of sod and is subject to erosion. The earthwork is approximately three feet high, ten to twelve feet wide, and fifty feet long.

\section{CORINTH NATIONAL CEMETERY}

The Corinth National Cemetery is situated approximately three quarters of a mile southeast from the railroad depot in Corinth. Established in 1866 by an Act of Congress, it is part of the National Cemetery System administered by the Department of Veteran Affairs and comprises approximately 16 acres. Fighting during the Battle of Corinth (on the morning of October 4, 1862) took place on the grounds.

The interment of the remains of Civil War soldiers at this cemetery began in September 1864. The remains were gathered from approximately 20 battlefields. By 1870 , when the interment program was nearly completed, Corinth was the sixteenth largest National Cemetery. There were 5,688 interments, of which 1,793 were known and 3,895 were unknown. The interred represent 273 regiments from fifteen states. Today, there are 6,500 interments. Headstones mark the site of each grave. 
There are two noncontributing buildings within the National Cemetery boundary. The superintendent's house is a two-story, Tudor style house built in 1934. The maintenance building is an architecturally non-descript $\mathrm{T}$-shaped structure with a tile roof. It was also built in 1934 .

\section{RAILROAD CROSSOVER}

The crossover of the Memphis and Charleston and Mobile and Ohio Railroads was the catalyst for Corinth's existence and military significance. The crossover is represented today by the crossing of the Illinois Central Gulf and the Southern Railroads. There is a depot, which is the third depot to stand at this site, built in 1917 .

\section{DAVIS BRIDGE: Battle of the Hatchie (October 5, 1862)}

Davis Bridge is the site of the savage fight on October 5, 1862, between Confederate Maj. Gen. Earl Van Dorn's Army of the West retreating from Corinth and a Union force under Maj. Gen. E.O.C. ord. The bridge spanned the Hatchie River two miles south of Pocahontas, Tennessee, the latter three miles north of the Mississippi border.

The site of the battle is forested with hardwood and pine and heavy undergrowth. An unimproved trail/road, on the historic roadway, serves as access to the site. There are several stone monuments commemorating the battle and those who fell there. The bridge has long since washed away and the river banks may have eroded slightly, but the site maintains a high degree of integrity.

\section{DUNCAN HOUSE}

The Duncan House--at the northeast corner of Bunch and Polk streets--was the headquarters of Confederate Maj. Gen. John C. Breckenridge in April and May 1862. The house has undergone many changes since it was constructed. The most obvious is that the house was moved, from around the corner on Bunch street, during the early twentieth century. The exterior of the Duncan house was covered with asbestos shingles; a full-width porch was constructed on the front facade; the rear facade was altered; and many interior features, including partitions and trim, were removed. The front fenestration--a central door with transoms and sidelights, flanked by two windows on each side--appears to be original. The windows are two over two replacements.

The bracketed cornice in the front is intersected by a central gabled roof, presumably the remnants of the original portico depicted on a civil War-era sketch of the house. Presently, a full length front porch, roofed below the cornice and supported by paired square wood columns, is a replacement that was added, likely when the house was moved to the present site. Little of the original interior remains. The central hall wall has been removed to make a large living room. The existing wood trim 


\subsection{6 nomination}

The 1996 nomination is part of a multiple property theme of Civil War Era National Cemeteries. The VA nominated 14 national cemeteries to the NRHP, including Corinth. Corinth National Cemetery was significant for its association with the Civil War and ongoing association with veterans from multiple wars. The nomination was accepted 19 October 1996.

The period of significance in the 1996 nomination is from 1866 to 1934, and the only significant date is 1866 . The cemetery is nominated under Criterion A. The contributing resources include one building (Superintendent's Lodge), the site, five structures (south entrance gate, south pedestrian gate, north entrance gate, north pedestrian gate, and perimeter wall), and one object (flagpole). There is only one noncontributing resource, the utility building. The headstones, wisteria arbor, and the comfort station are not included on either list. Figure 69 reproduces the cemetery's 19page NRHP nomination form from 1996. 
Figure 69. Reproduction of registration form for Corinth National Cemetery nomination to NRHP, 1996 (NCA).

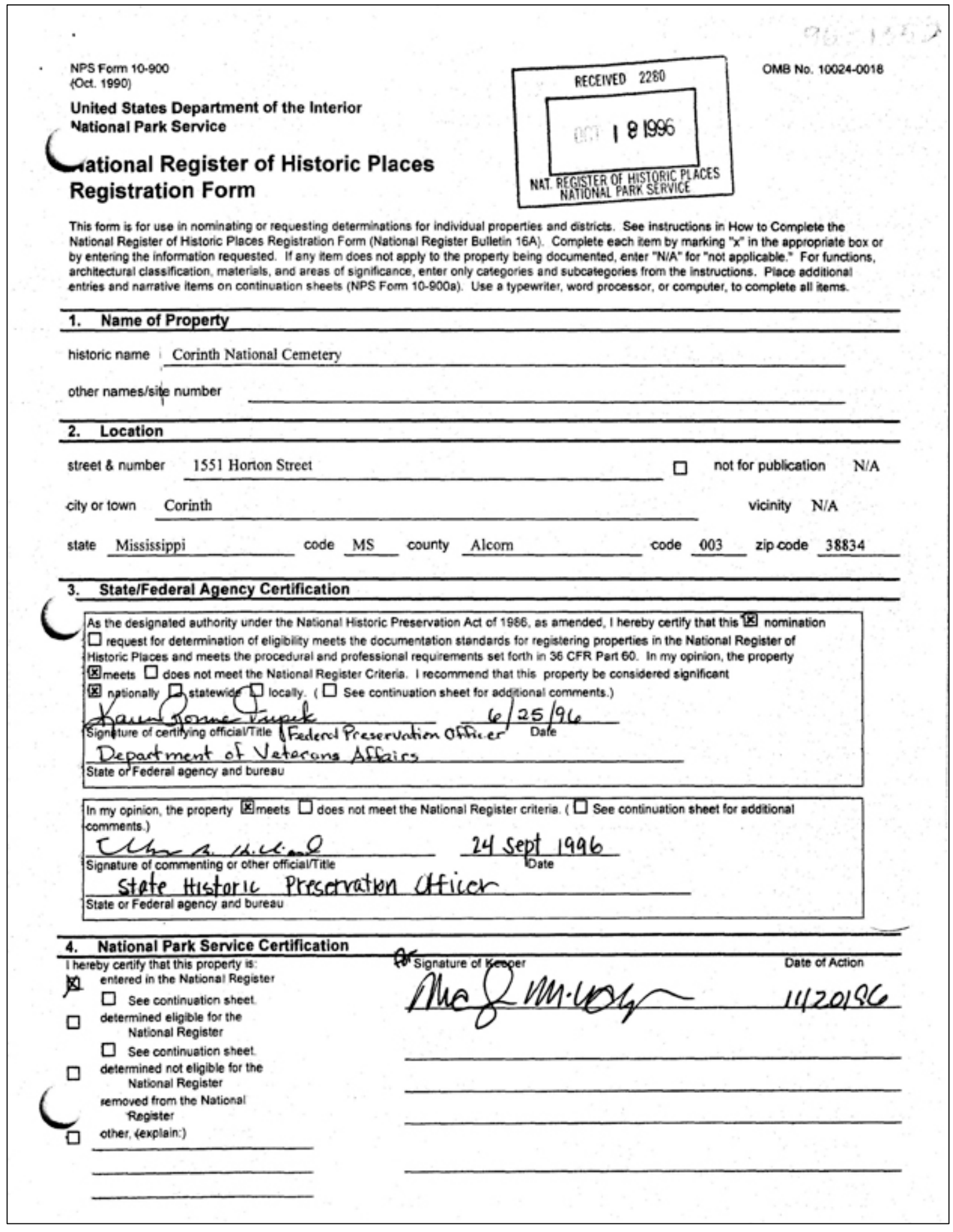




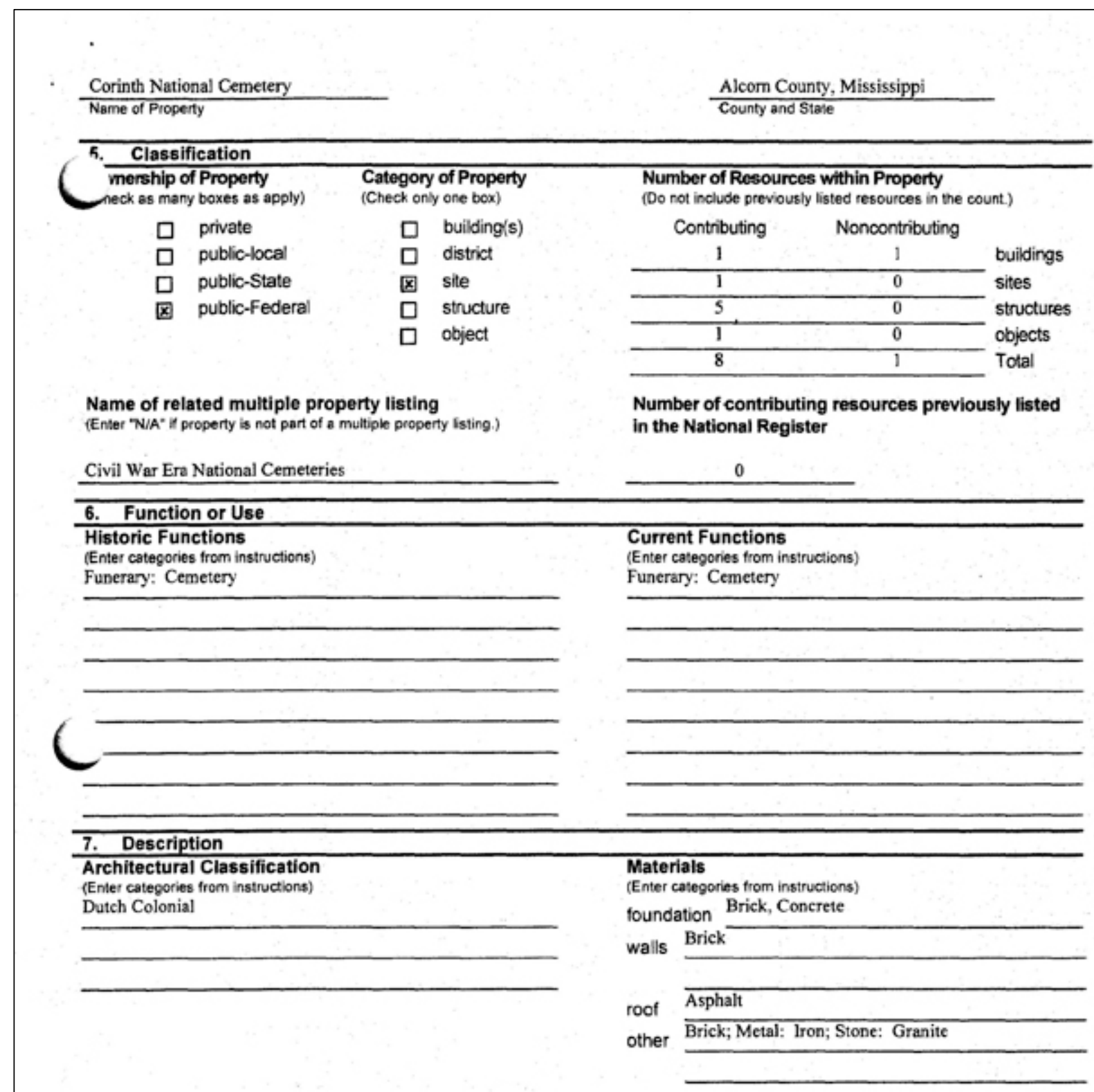

Narrative Description

(Describe the historic and current condition of the property on one or more continuation sheets.) 


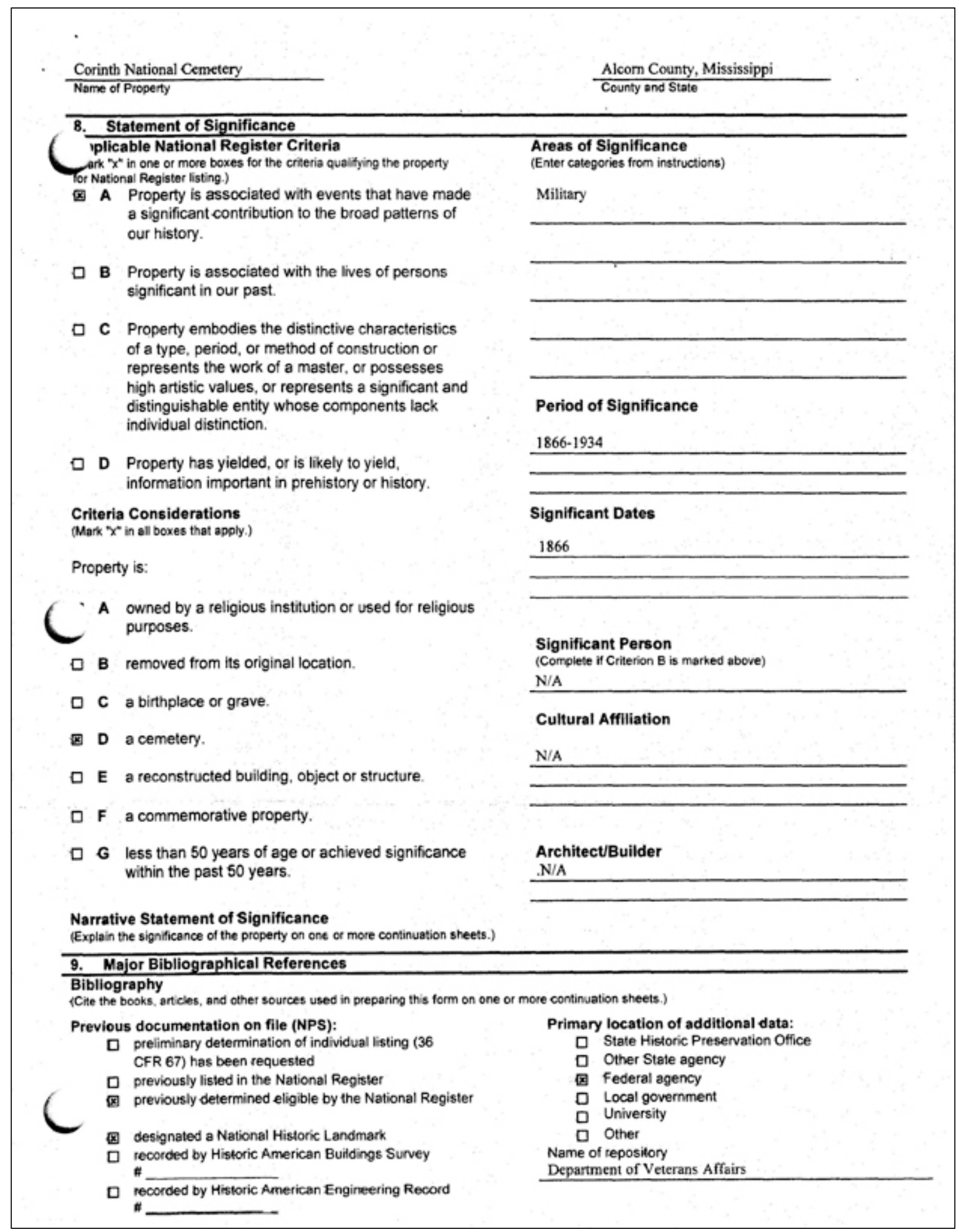


.

Corinth National Cemetery Name of Property

10. Geographical Data

reage of Property 20.0

UTM References

(Place addational UTM references on a continuation sheet)

\begin{tabular}{|c|c|c|}
\hline 16 & 362220 & 3865860 \\
\hline $\begin{array}{l}\text { Zone } \\
116\end{array}$ & $\begin{array}{l}\text { Easting } \\
362210\end{array}$ & $\begin{array}{l}\text { Northing } \\
3865580\end{array}$ \\
\hline
\end{tabular}

Verbal Boundary Description

(Describe the boundaries of the property on a continuation sheet.)

Boundary Justification

(Explain why the poundaries were selected on a continuation sheet.)

11. Form Prepared By

name/title Therese T. Sammartino, Staff Assistant, National Cemetery System

organization Department of Veterans Affairs date

October 7, 1996

street 8 number 810 Vermont Avenue, N.W. telephone (202) 565-4895

city or town Washington, D.C.

state

zip code 20420

ditional Documentation

mit the following items with the completed form:

\section{Continuation Sheets}

Maps

A USGS map ( 7.5 or 15 minute series) indicating the property's location.

A sketch map for historic districts and properties having large acreage or numerous resources.

\section{Photographs}

Representative black and white photographs of the property.

Additional items

(Check with the SHPO or FPO for any additional trems)

\section{Property Owner}

(Complete this hiem at the request of the SHPO of FPO.)

name

Department of Veterans Affairs

street 8 number 810 Vermont Avenue, N.W. telephone

city or town Washington, D.C. state zip code 20420

xerwork Reduction Act Statement: This information is being cellected for applications to the National Register of Historic Places to nominate serties for listing or determine eligibility for listing, to ist properties, and to amend existing istings. Response to this request is required to obtain denefts in accordance with the National Histcric Preservation Act, as amended (16 U.S.C. 470 et seq.)

Estimated Burden Statement: Public report ing burden for this form is estimated to average 18.1 hours per response including the time for reviewing instructions, gathering and maintaining-data, and completing and reviewing the form. Direct comments regarding this burden estimate or any aspect of this form to the Chief, Administrative Services Division, National Park Service, P O. Box 37127. Washington, OC 20013.7127; and the Office of Management and Budget, Paperwork Reductions Project (1024-0018), Washington, DC 20503. 
NPS F crm 10-900-8

(8-86)

United States Department of the Interior

National Park Service

\section{National Register of Historic Places Continuation Sheet}

Section number
Page
OME No. 1C024-0018

Civil War Era National Cemeteries

Corinth National Cemetery

Alcorn County, Mississippi

\section{NARRATIVE DESCRIPTION}

The Corinth National Cemetery is located at 1551 Horton Street, approximately $3 / 4$ mile southeast of the court house within the city limits of Corinth, Mississippi, in Alcom County. The site is nearly square in shape and was originally enclosed by a wooden picket fence which was replaced in 1872 with a brick wall, four feet in height with concrete coping. The main entrance is situated at the center of the north side and is protected by a double ornamental wrought-iron gate supported by granite piers with a pedestrian gate on each side. There are three other entrances to the cemetery. On the south side, there are two entrances, one for pedestrians and one for carriages, both protected by wrought-iron gates; on the north side is an entrance, also protected by a wrought-iron gate, with a pedestrian gate on one side. From the main entrance, a road leads north to a circle, where the flagpole is located. The lodge is located northeast of the main entrance, and the utility building is situated in the southeast corner of the cemetery.

The cemetery was established in 1866. The first superintendent was Mr. Joseph Berrigan, a discharged private of Company B, 43rd Regiment of Infantry, who was appointed on November 26, 1867. Graves were originally marked with stakes, properly numbered, that were later replaced with upright marble headstones.

As of May 31, 1996, there were 6,615 graves used for the interment of 6,714 casketed remains and 7 sites used for the interment of 10 cremated remains. Interments of casketed remains in occupied graves and reserved graves, as well as interments of cremated remains, continue. As May 31, 1996, there were 6,842 gravesites available for the interment of casketed remains, plus 13 reserved gravesites, and 38 sites available for the interment of cremated remains. It is estimated that the cemetery will have gravesites available until beyond the year 2030 .

The original superintendent's lodge, constructed some time prior to 1869 , was a wooden cottage containing six rooms with a small cellar under the kitchen and was located east of the south entrance. By 1872, it had been replaced with one of brick, one and one-half stories high, with a French roof. In 1934 , a new lodge was constructed. The first story is brick and the dormered second story frame and stucco, with a concrete foundation and an asphalt shingle gambrel roof. The second story has stucco gables with exposed wood loosely imitating half-timber English tudor. The lodge contains six rooms, an office, a basement, and a front porch which was enclosed in 1952. No director has resided in the lodge since January 1991, and the building is now used as an administrative office. 


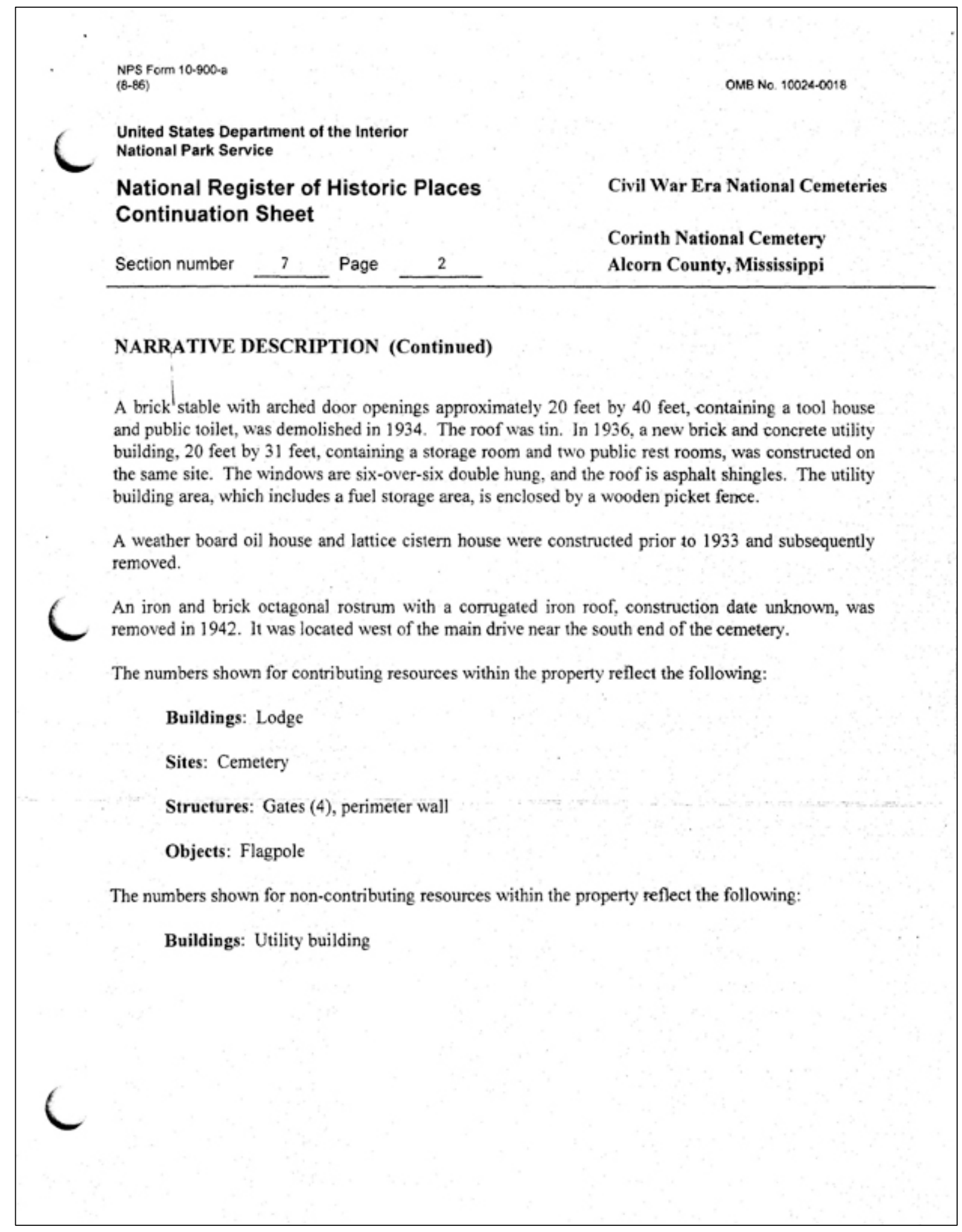


NPS Form 10-900-a

(18-86)

OMB No. $10024-0018$

United States Department of the Interior

National Park Service

\section{National Register of Historic Places Continuation Sheet}

Civil War Era National Cemeteries

Corinth National Cemetery

Alcorn County, Mississippi

\section{NARRATIVE STATEMENT OF SIGNIFICANCE}

The Corinth National Cemetery is significant under Criterion A, and is an important component of the multiple property submission of Civil War Era National Cemeteries. It is significant under Criterion A because of its association with the Civil War.

The "Siege and Battle of Corinth Sites" received the designation of a National Historic Landmark on May 6, 1991. The Corinth National Cemetery is a contributing resource within this historic landmark designation, which is on file at the National Park Service, Washington, D. C.

The city of Corinth was strategically located, and its capture was a prime objective of Union forces in the area. It was regarded as the symbol of the south throughout the conflict. It was where the vital railway line which led east from Memphis, connecting the western part of the Confederacy from Virginia, crossed the north-south line of the Mobile and Ohio. The Confederates kept the city heavily fortified, but early in the spring of 1862 , they were forced to evacuate. Union troops soon occupied the city and continued to do so for five months.

In mid-March 1862, the troops of General Albert Sidney Johnston, Commander of the Western Department of the Confederate Armies, began arriving in Corinth from Murfreesboro, Tennessee, and all had arrived by March 24. General Johnston had charged General P. G. T. Beauregard, his second in command, with the responsibility of assembling troops at Corinth. Later, the Confederate Army of Kentucky and that of Mississippi were consolidated under General Johnston's command. He decided that he would attack the Federals at Pittsburg Landing, Tennessee, and drive them into the river. The troops were to move early on April 3, but one delay caused another. More delays occurred on April 4 and Johnston did not get his troops aligned until late in the day on April 5 and decided to wait until the following day. Then, on April 6, he sent them into the unsuspecting Union lines around Shiloh Church. Most Union troops did not react and were unprepared for the charge. General Ulysses S. Grant was alerted and immediately went to Pittsburg Landing. Sometime around 3 p.m. that day, General Johnston was wounded in the leg. He continued to direct the battle but slowly bled to death. Command of the troops passed to General P. T. Pierre Beauregard, who collected his battered units and organized a defense at Corinth. His army recovered at Corinth. Major General Henry W. Halleck arrived at Pittsburg Landing to assume direct command of the Union troops. By April 29, Halleck, with over 100,000 men, prepared to attack Beauregard's nearly 65,000 . Halleck would march from Pittsburg Landing to Corinth. From early May to about May 29, skirmishing took place between Halleck's and Beauregard's forces. After all the waiting and watching, nothing happened. On May 29. Beauregard decided to quit and ordered a pullout. To cover the withdrawal, he had the front-line troops make loud noises to keep the Federals occupied. Although Halleck called it a victory, some wondered. 
NPS Form 10-900-a

(8-86)

OMB No. $10024-0018$

United States Department of the Interior

National Park Service National Register of Historic Places
Continuation Sheet

Section number $\quad 8 \quad$ Page $\quad 4$
Civil War Era National Cemeteries

Corinth National Cemetery

Alcorn County, Mississippi

\section{NARRATIVE STATEMENT OF SIGNIFICANCE (Continued)}

The next morning, May 30, Halleck's Union forces cautjously entered Corinth only to find the village deserted. General Halleck ordered Generals W. S. Rosecrans and John Pope to pursue the Confederates. A Union cavalry column caught up with the Confederate rear guard in Tuscumbia bottom late in the afternoon and met strong resistance. The Confederates crossed the river and burned the bridge, leaving sufficient force to prevent reconstruction of the bridge. The next morning, the Federals went up-stream to a narrow place in the river, felled trees, and crossed. While the artillery engaged the Confederates at the bridge, the infantry began a flanking movement. Seeing they were about to be trapped, the Confederates withdrew toward the south with the Federals continuing to press their rear. The Federals halted their pursuit at Twenty Mile Creek near Baldwyn. They remained there for eight days before returning to Corinth. When the pursuit ended, General Halleck began to break up his army into smaller commands. He sent Major General Don Carlos Buell off toward Chattanooga and detaching another 20,000 men to guard railroad communications. He reduced his grand army to less than 40,000 , and the initiative passed to General Braxton Bragg, who had superseded General Gaston T. Beauregard. Bragg hurried off to Chattanooga, leaving Major Generals Earl Van Dorn and Sterling Price with about 40,000 men. President Abraham Lincoln then appointed Halleck as general-in-chief of the United States land forces. General Ulysses S. Grant was named to succeed Halleck. He was supervising the new line of defense begun by General Halleck. When completed, the Halleck line and the Beauregard line would encircle the city. Grant, however, was expected to protect the whole of westem Tennessee; he had 7,000 men at Memphis, 12,000 at Bolivar, 6,000 at Jackson, and 23,000 at Corinth under Major General William S. Rosecrans. General Beauregard was able to complete all duties assigned to him, although he had not been feeling well. General Braxton Bragg later relieved Beauregard. At Tupelo, he reorganized the Army of Tennessee. During the last week in July, Bragg began transferring his forces to Chattanooga. Price was left in Tupelo to keep an eye on Grant in Corinth.

After a battle at luka, Mississippi, on September 19, Rosecrans moved his command northwest to Corinth where he strengthened the fortifications in Corinth. Van Dorn and Price moved in on Corinth late in September with 22,000 men. Rosecrans opposed them with about 21,000 troops. The battle of Corinth began on October 3. Van Dorn's first attack hit two Federal divisions outside the inner defenses. The blue-coats fought stubbornly but had to fall back behind the fortifications. Price then sent his divisions against the Union center. The Federals waited until the Confederates broke out of the woods and advanced over an open field. When they reached point blank range, the Federals poured in a deadly fire, including artillery from entrenched positions on the left. Price's men retreated, reformed, and tried again, but were repulsed. The third charge sent some Federals running but the line held until fighting died out at nightfall. Van Dorn felt he had the battle won and that another thrust would bring victory. 
NPS Form 10-900-8

(8-86)

OMB No. 10024.0018

United States Department of the Interior

National Park Service

National Register of Historic Places Continuation Sheet

$\begin{array}{llll}\text { Section number } & 8 & \text { Page } & \\ & 5 & \text { Corinth National Cemetery } \\ \text { Alcorn County, Mississippi }\end{array}$

\section{NARRATIVE STATEMENT OF SIGNIFICANCE (Continued)}

It was 9 a.m. before the Confederates attacked on October 4 . They hit first on the Federal right. Again, Price's troops led the attack, broke through and penetrated into the town of Corinth, fighting along streets and around houses. Rosecrans saw the break and rode among his panicked troops. His hat was shot away. His hair streamed in the wind. He "fought like a private soldier, dealt sturdy blows with the flat of his sword and fairly drove them to stand," Whitelaw Reid, a war correspondent wrote. "Then came a quick rally which his magnificent bearing inspired. . and the charging column was speedily swept back outside the entrenchments."

At the same time the Confederates also hit the Federal left. They stormed Battery Robinett, an entrenched artillery position, and some of the foremost ranks spilled over the top of the works but were driven out by a bayonet charge. Back in the woods they reformed and, led by Colonel W.P. Rogers of the Second Texas, they swarmed over the works despite heavy losses. Colonel Rogers carried a flag to the top of the rampart. A Union drummer boy picked him off with a single revolver shot. His men raced on, about 100 reaching the Corinth public square, but then they were beaten back into the woods. That was enough for Van Dorn. Soon after 7 p.m., he ordered a retreat. Union casualties were: 355 killed, 1,841 wounded, 324 missing; Confederate losses were 473 killed, 1,997 wounded, and 1,763 missing.

During the next fifteen months, Corinth continued to be a base for Union reconnaissance and raids throughout the northeastern counties of Mississippi, the northwestern ones in Alabama, and the adjacent counties in southern Tennessee. Many skirmishes occurred, mainly between cavalry units of the two armies.

The casualties of this battle and other clashes between the two armies were so numerous that in 1866 the cemetery was established on a portion of the battlefield. Original interments were remains gathered from some 10-15 battlefields or skirmish sites. In addition to Corinth, Iuka, and Holly Springs, remains were brought from Grenada, Guntown, and Farmington, Mississippi; from Parker's Crossroads, Middlebury, and Brittans Lane, Tennessee; from Florence, Tuscambia, Decatur, and Cullman, Alabama; and from various scattered camps in Tennessee and Mississippi. Original interments represented regiments from 15 different states, including the dead of the 63rd regiment of Ohio volunteers, 4 th regiment of Illinois volunteers, and Michigan volunteers. As far as possible, the interments were made by states. There are three Confederates interred in the cemetery, two known and one unknown. 
NPS Form 10-900-0

(8-86)

OMB No. $10024-0018$

United States Department of the Interior

National Park Service

National Register of Historic Places

Continuation Sheet

Section number $8,9,10$ Page 6

Corinth National Cemetery

Alcorn County, Mississippi

\section{NARRATIVE STATEMENT OF SIGNIFICANCE (Continued)}

The cemetery contains 20 acres. It was formerly owned by Calvin F. Vance and Margaret, his wife; Francis M. White and Catherine S., his wife; and James H. Walker, who on February 1, 1868, by deed in fee simple, conveyed the same to the United States for the sum of $\$ 3,500$.

\section{MAJOR BIBLIOGRAPHICAL REFERENCES}

National Cemetery System Microfilm Records

Report of the Inspector of the National Cemeteries of the United States for 1869

Report of the Inspector of the National Cemeteries of the United States for '1870-1871

Commager, Henry Steele. The Blue and the Gray. Wings Books, New York, 1991.

Holt, Dean W. American Military Cemeteries. McFarland \& Company, lnc., 1992.

Denney, Robert E. The Civil War Years. Sterling Publishing Company, Inc., New York, 1992.

Rogers, Margaret Greene: Civil War Corintb 1861-1865. The Rankin Printery, Corinth, MS, 1989.

\section{GEOGRAPHICAL DATA - VERBAL BOUNDARY DESCRIPTION}

The boundaries are shown on the accompanying base map.

\section{BOUNDARY JUSTIFICATION}

The National Cemetery System has used the existing boundaries of the cemetery. 


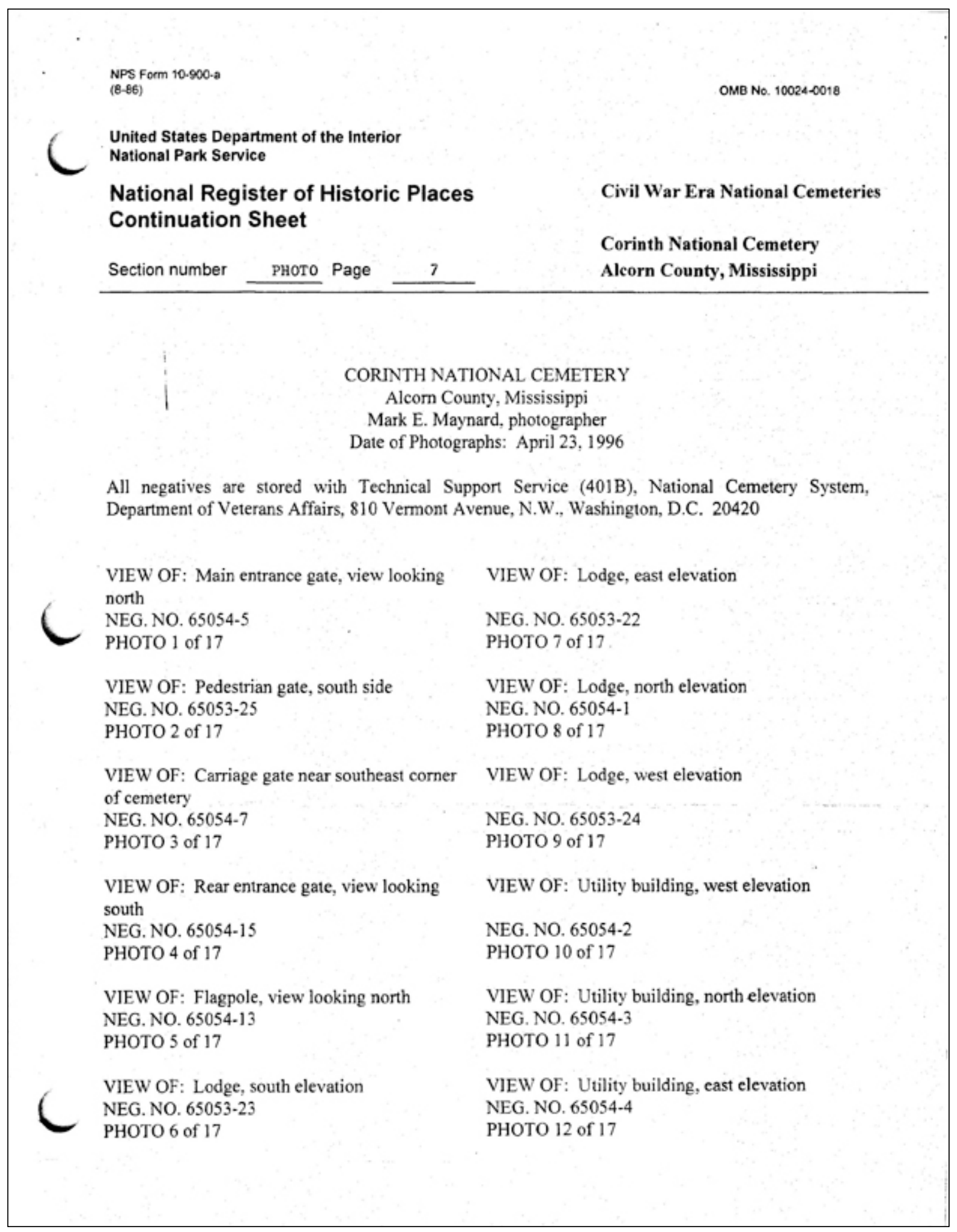




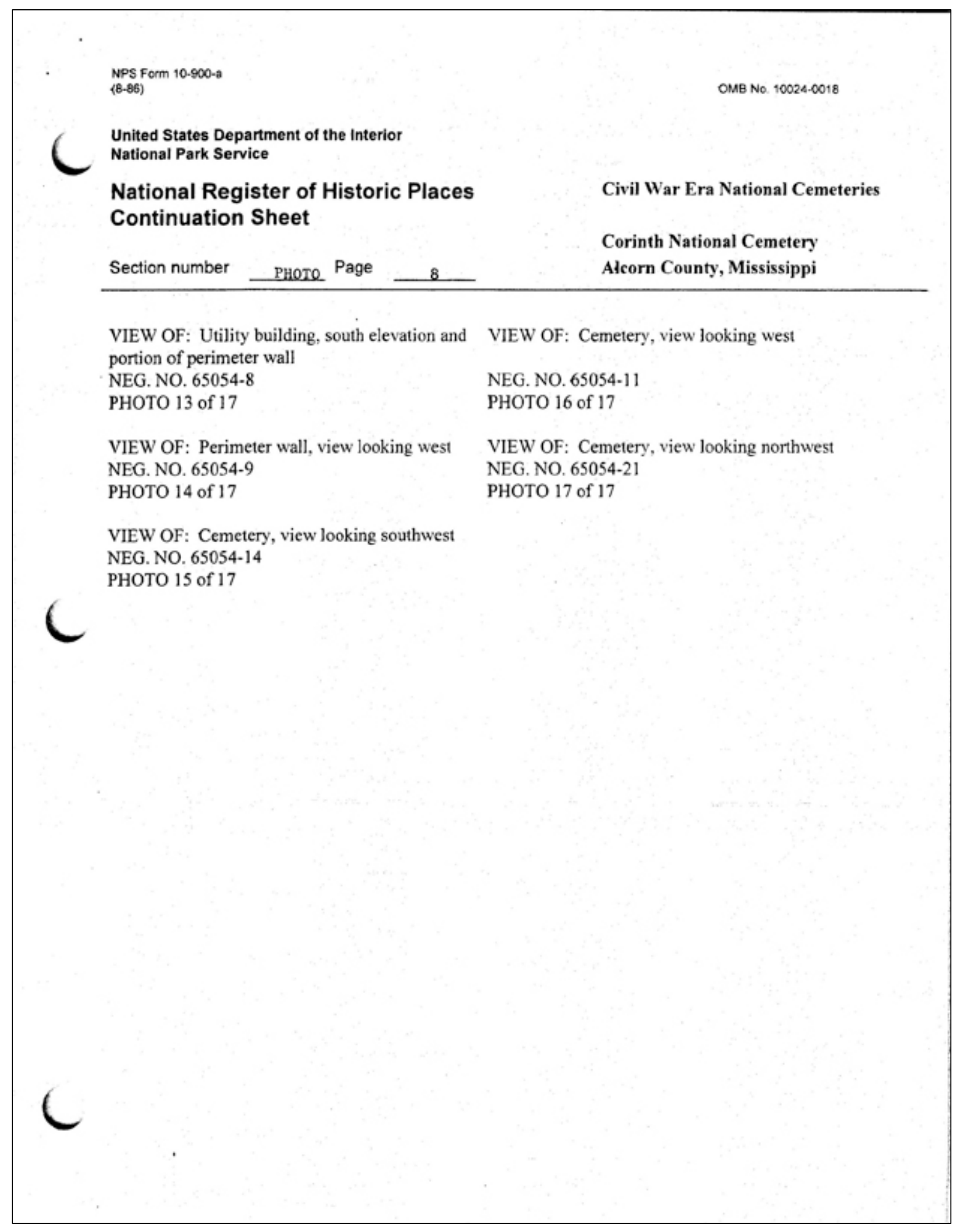




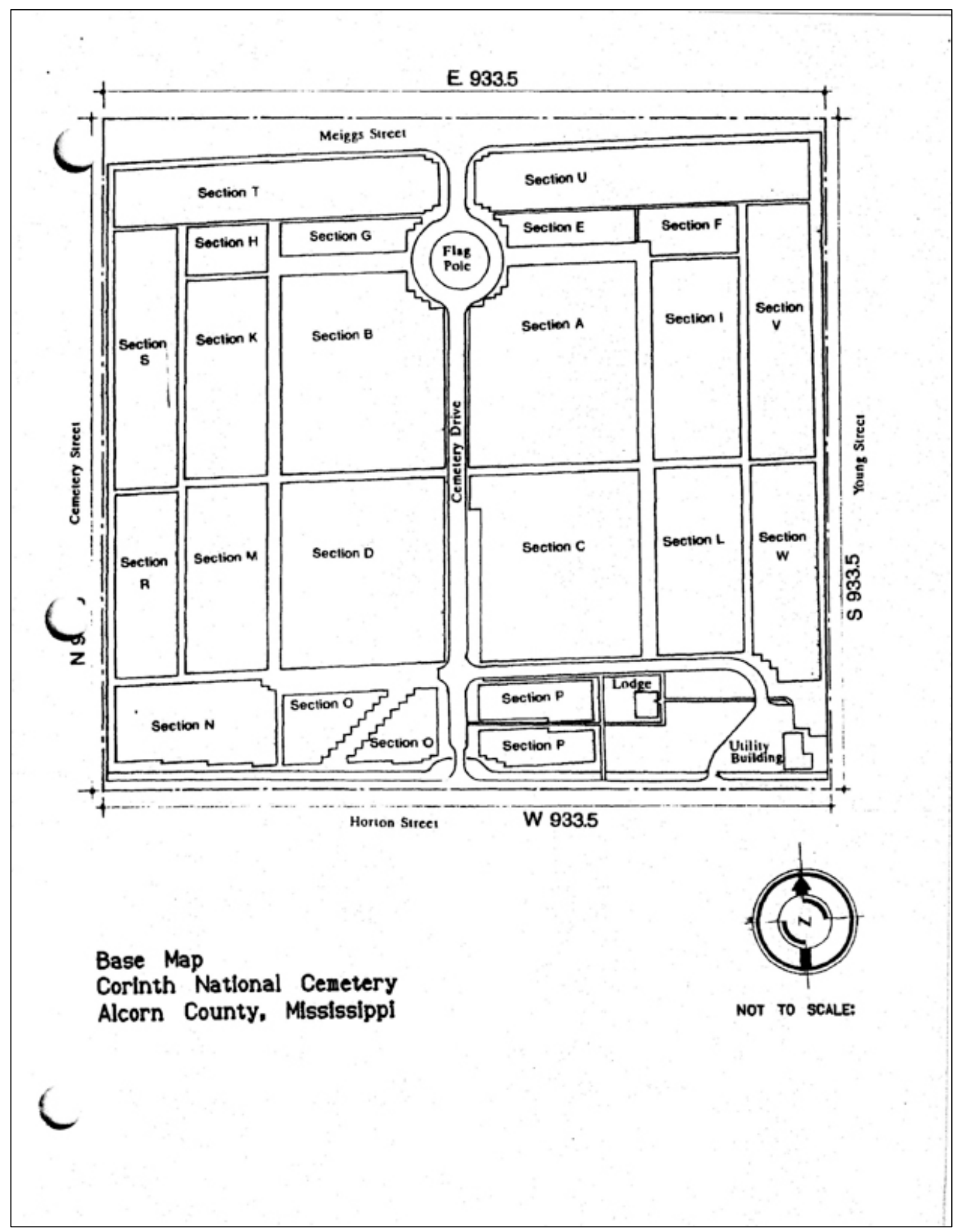




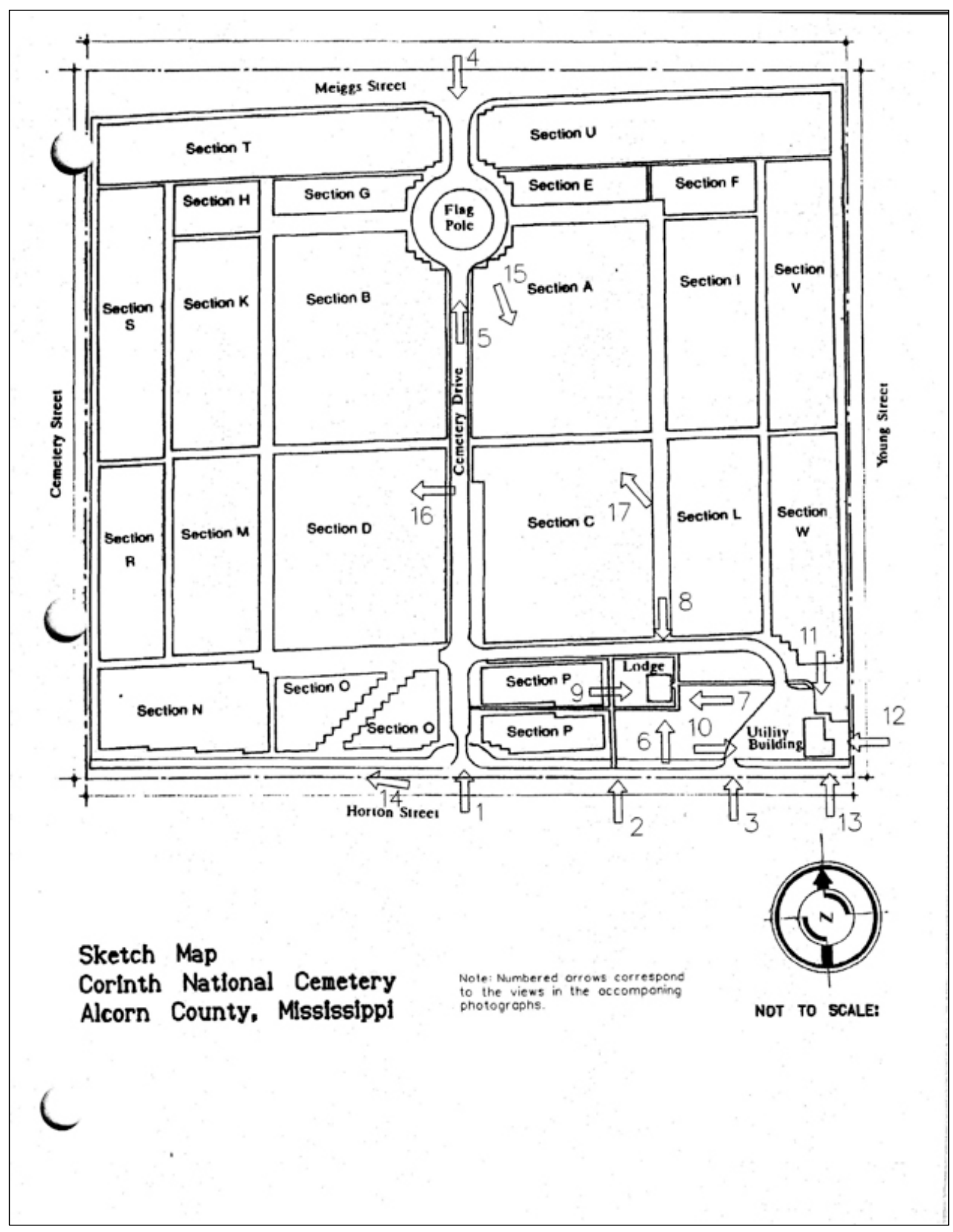




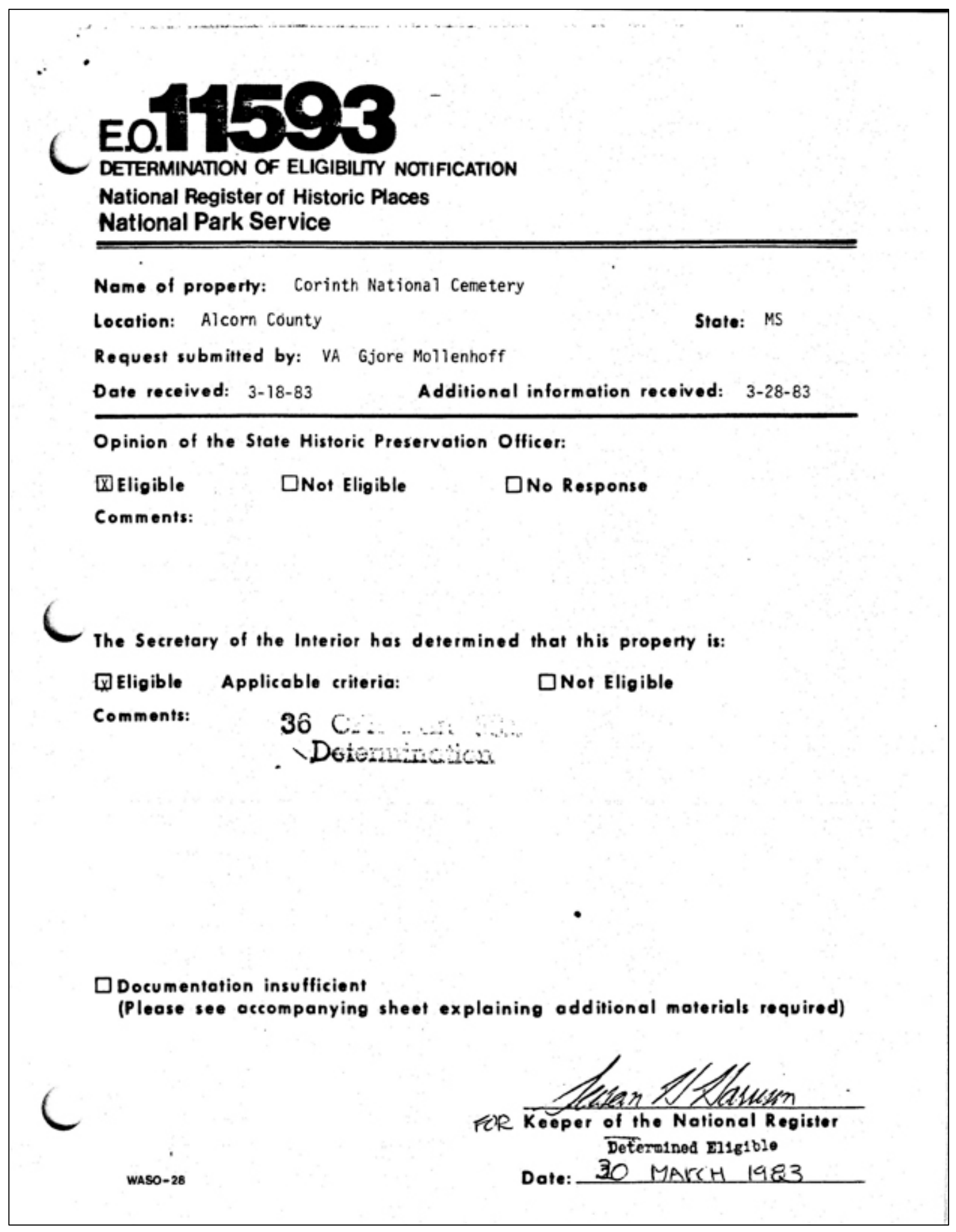




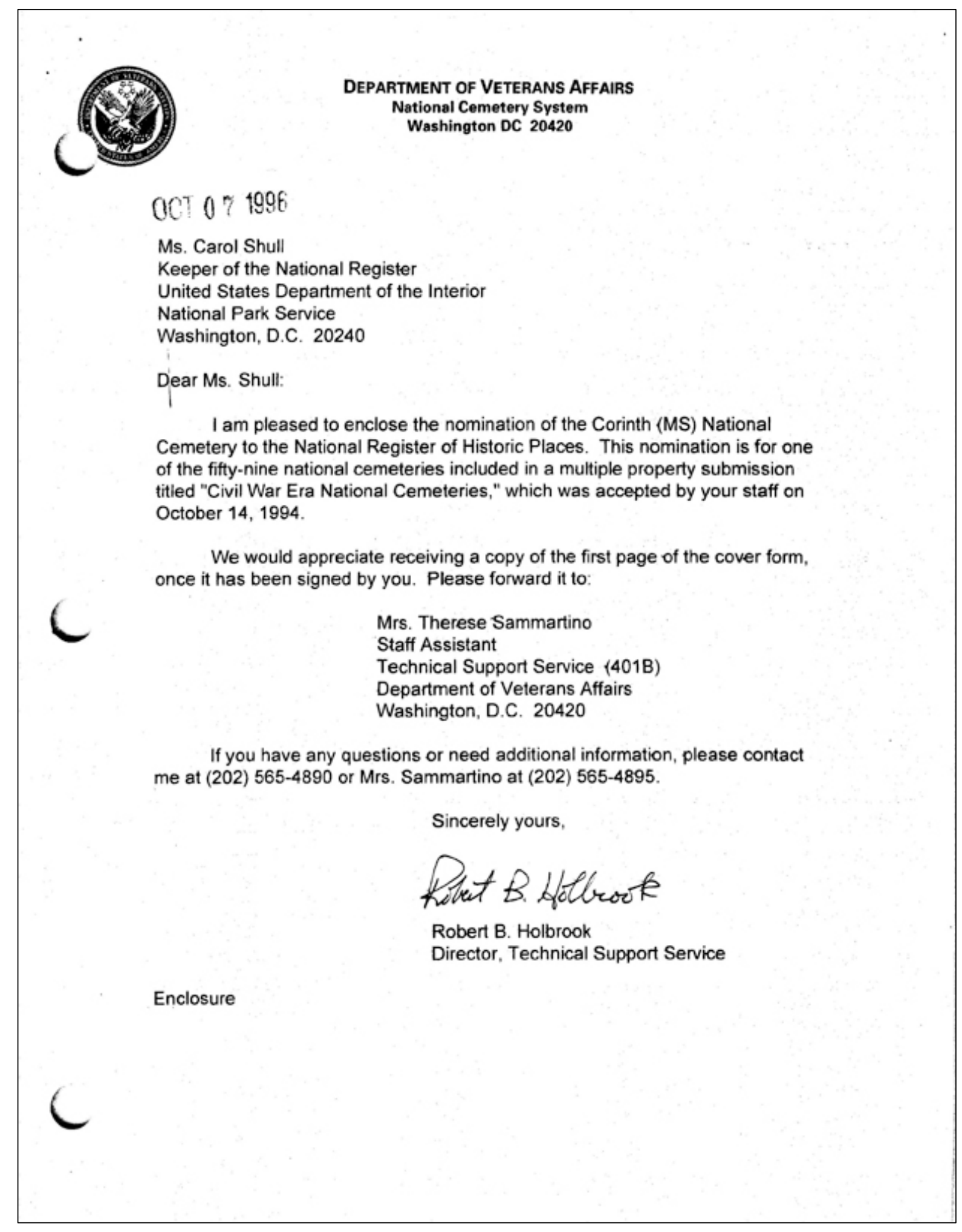




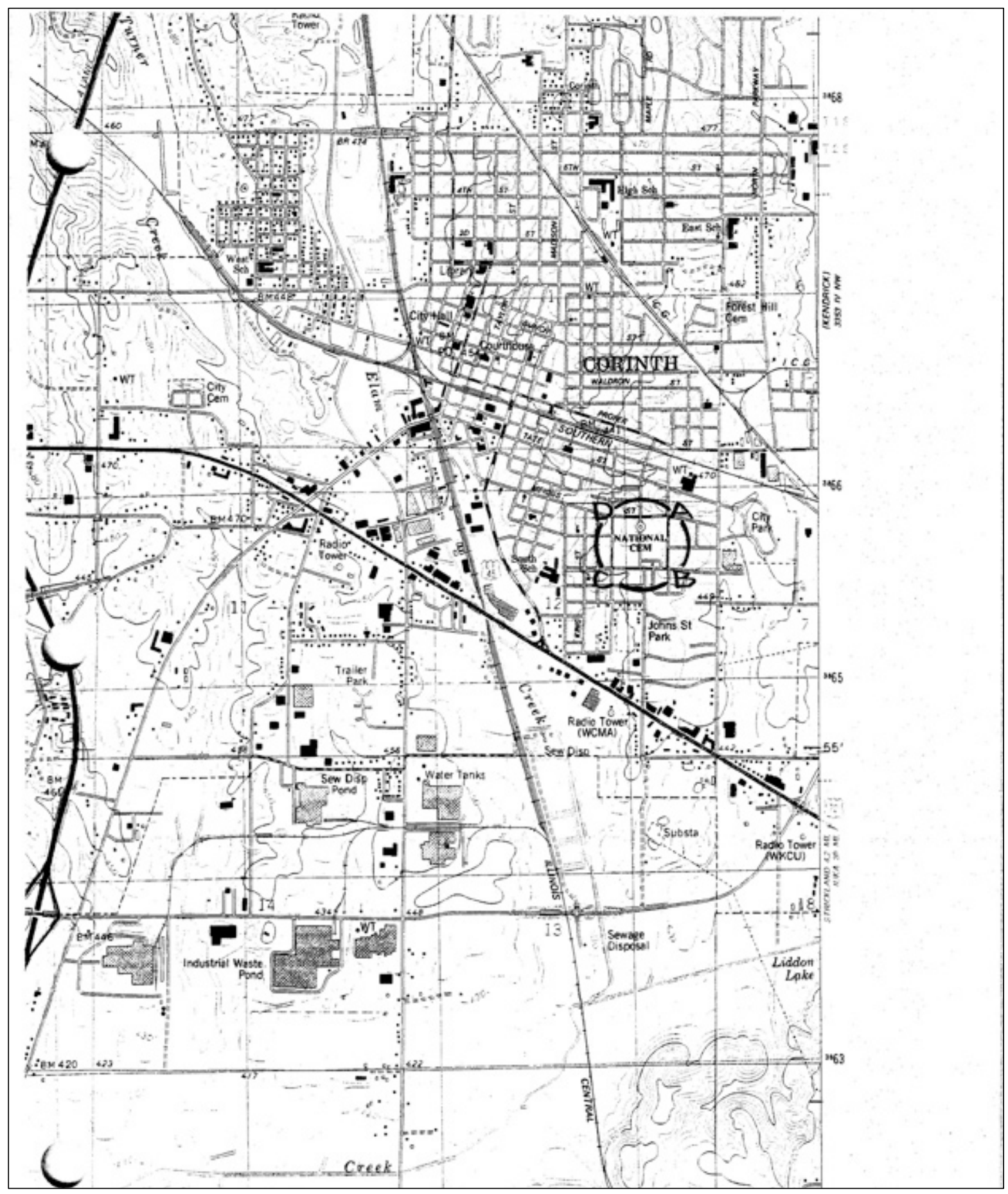




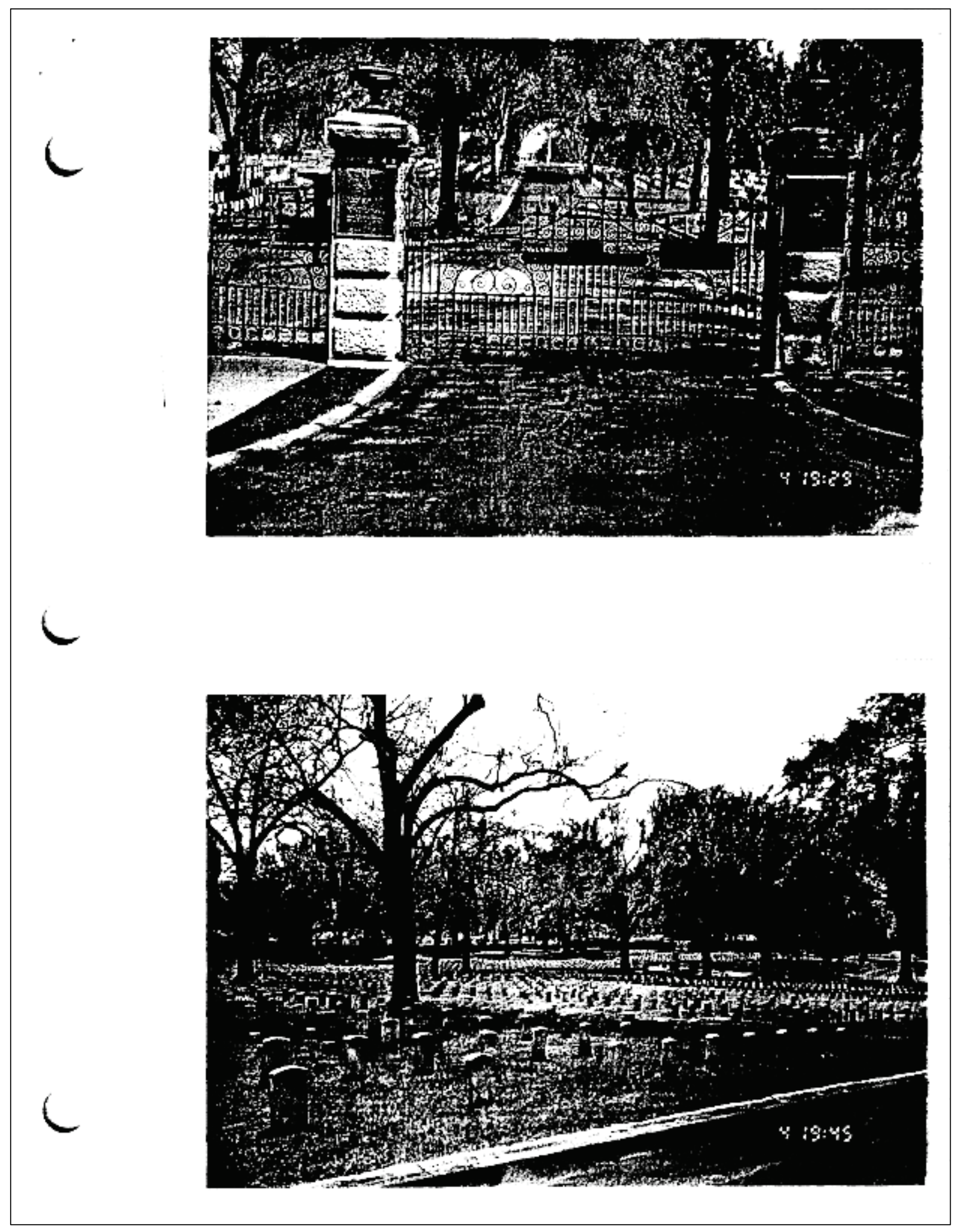



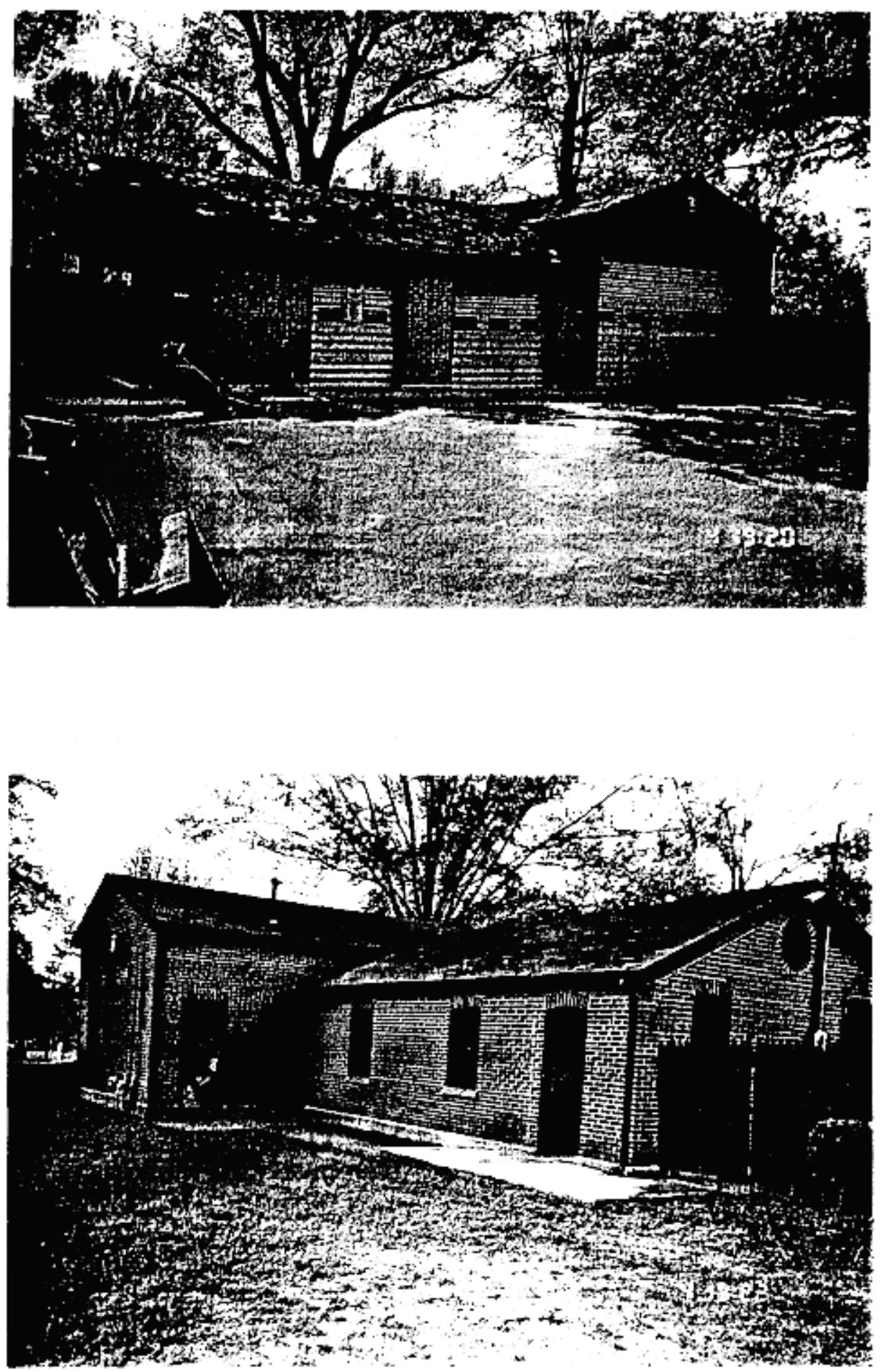


\subsection{National Register Eligibility of National Cemeteries - a Clarification Policy (9/8/2011)}

In 2011, the NRHP staff clarified certain aspects of nominating National Cemeteries to the NRHP and their component parts and character-defining features. The key parts of this clarification policy ${ }^{131}$ are that "The period of significance for a national cemetery is the period of time beginning with the date of the earliest burials and extending to the present." It also clarified that "...component resources contribute to the cemetery's significance regardless of their age, function, or administrative role." In addition, "Certain smaller-scale features, such as grave markers, street signs, water fountains, curbs and culverts, and plantings are considered integral to the overall contributing site and its identity as a national cemetery; these should be described collectively as significant or character-defining features of the site in Section 7 of the National Register form but do not need to be classified and counted separately." Figure 70 reproduces the NRHP's four-page clarification policy.

\footnotetext{
131 National Park Service, National Register of Historic Places, "National Register Eligibility of National Cemeteries-a Clarification of Policy," (Washington, DC: NRHP, 08 September 2011). Accessed online: https://www.cem.va.gov/CEM/pdf/Final Eligibility of VA cemeteries A Clarification of Policy rev.pdf
} 
Figure 70. Reproduction of “A Clarification of Policy" for National Register eligibility of national cemeteries, 2011 (NPS).

National Register Eligibility of National Cemeteries - A
Clarification of Policy - A Clarification of Policy ( $9 / 8 / 2011)$

$\underline{\text { Summary }}$

All national cemeteries are considered exceptionally significant as a result of their Congressional designation as nationally significant places of burial and commemoration. This means they meet the special requirements set forth in the National Register Criterion Considerations for cemeteries, graves, commemorative properties, and resources less-than-50 years of age. It also means that for the purpose of documenting a national cemetery as a National Register district, facilities and sections developed within the past fifty years are considered significant and are eligible for National Register listing as contributing resources. While most national cemeteries fall under the jurisdiction of the U.S. Department of Veterans Affairs, several others are managed by either the National Park Service or the U.S. Department of Defense.

\section{Background}

National cemeteries continue to expand, and many include land held for future development. For this reason, questions typically arise about the selection of boundaries and the contributing/noncontributing status of parcels of land within a cemetery's boundaries. Based on prior agency to agency consultations, the Keeper of the National Register in June 1981 sent a letter to the Federal Preservation Officer of the Veterans Administration (after 1989 known as the Department of Veterans Affairs) clarifying a policy that applied to the National Register eligibility and the unique set of issues associated with the eligibility of national cemeteries-properties considered ever-changing and recognized for their continuing exceptional importance.

The following statement of policy was consequently set forth on page 36 of the National Register Bulletin, How to Apply the National Register Criteria for Evaluation:

National Cemeteries administered by the Veterans Administration are eligible because they have been designated by Congress as primary memorials to the military history of the United States. Those areas within a designated national cemetery that have been used or prepared for the reception of the remains of veterans and their dependents, as well as any landscaped areas that immediately surround the graves may qualify. Because these cemeteries draw their significance from the presence of the remains of military personnel who have served the country throughout its history, the age of the cemetery is not 
a factor in judging eligibility, although integrity must be present. A national cemetery or portion of a national cemetery that has only been set aside for use in the future is not eligible.

This statement clarified that, for evaluating National Register eligibility, the age of a national cemetery was not a determining factor and that sections of the cemetery prepared for use or already in use were differentiated from unimproved land that was not ready to receive burials. Recent efforts to nominate national cemeteries have raised additional questions and are addressed in this clarification of policy.

\section{Classification}

Because they contain a combination of resource types and cover substantial acreage, national cemeteries are considered historic districts for the purposes of National Register listings and determinations of eligibility. Generally national cemeteries are significant under criterion A for their association with significant events related to the nation's military history and the role of the Department of Veterans Affairs. Those having artistic or architectural significance as designed landscapes or for the design of memorials, monuments, or historic buildings, may also be documented under Criterion $\mathrm{C}$.

Regardless of the date of acquisition or construction, the overall acreage within the boundaries of the cemetery that has been developed for cemetery purposes is considered one contributing site for National Register purposes. This site includes commemorative sections of the cemetery containing existing graves and memorials, sections having the infrastructure necessary to receive new interments and memorials (for example, streets, utilities, pre-placed crypts, columbaria, and memorial walkways), and areas of the cemetery developed for administrative and maintenance purposes (offices, restrooms, garages, and maintenance yards). Unimproved acreage within the cemetery boundaries that is being held for future use is considered noncontributing; although it does not need to be counted as a separate noncontributing site, its location and approximate size should be described in Section 7 of the National Register. nomination and indicated on the sketch map for the district. As additional sections are developed in the future, the National Register documentation can be updated with continuation sheets describing the newly developed section and revising the description of the acreage considered contributing. In cases where new land is acquired after National Register listing, the more involved process for expanding boundaries set forth in 36 CFR Part 60.14(a) will need to be followed to update the nomination. 
Buildings, structures, or objects that are substantial in size or scale or have special importance are to be classified according to the definitions provided on page 15 of the National Register Bulletin, How to Complete the National Register Registration Form. Certain smaller-scale features, such as grave markers, street signs, water fountains, curbs and culverts, and plantings are considered integral to the overall contributing site and its identity as a national cemetery; these should be described collectively as significant or character-defining features of the site in Section 7 of the National Register form but do not need to be classified and counted separately.

\section{Period of Significance}

The period of significance for a national cemetery is the period of time beginning with the date of the earliest burials and extending to the present. A closing date of "present" allows the recognition of the highly significant values these places have had in the recent past (for example, honoring those killed in recent wars). This policy means that recently developed areas are to be included within the boundaries of the historic district and recently constructed resources are to be recognized as contributing resources. Land acquired for future development but not yet developed can be included in the National Register boundaries but will not be considered contributing.

The period of significance for a national cemetery may include development that occurred before its designation as a national cemetery, and resources in place at the time of nomination may be considered contributing. It is anticipated that most cemeteries will represent multiple layers of expansion with new sections being acquired and developed for use periodically as available grave sites are depleted.

Several other possible closing dates were considered. It was suggested that "1973," the date when the majority of military cemeteries was transferred from the U.S. Army to what is now the National Cemetery Administration, be used as an end date for all national cemeteries. While "1973" is a date of great importance in the administration of the nation's programs to provide burial benefits to veterans and their families, it is not a date that applies to the continuing evolution of these places as national cemeteries or to the ongoing program of cemetery administration. That year may mark the beginning of a new stage in the history of national cemetery management, but it doesn't qualify as the endpoint of historically significant activities.

The suitability of using the date fifty years before the present as the closing date was also considered. While this approach is often taken in National Register nominations, it often results in an arbitrary end date and, in the case of properties having continuing significance, warrants frequent revision. For 
national cemeteries, which by their designation are deemed in perpetuity exceptionally important, such a date has little meaning and precludes recognition of the highly significant values these places engender as they receive more burials and continue to honor those who have served the nation. A question was also raised about inactive cemeteries and the suitability of ending the period of significance for such a cemetery with the date it was officially closed to new burials. While such a date may be meaningful from a historical perspective, it does not take into consideration the ongoing role and exceptional importance of national cemeteries as public places of commemoration and honor even if new burials can no longer be accommodated. After closely examining this issue, the National Register has determined that the "present" is the end date most consistent with the Congressional intent of the federal laws establishing the national cemeteries and with the National Register policies for evaluating properties of continuing exceptional importance.

\section{Boundaries}

The boundaries of an eligible historic district for a national cemetery can be based on the current land holdings of the federal agency responsible for managing the cemetery. National Register boundaries should encompass all portions of the land that are used for burial, commemorative, and administrative purposes, including recently improved areas and new construction. To avoid having to expand the boundaries at a later date, the district can also include any noncontributing acreage currently being held for the future expansion of the cemetery.

Contributing and Noncontributing Resources

National Register documentation standards require that resources that are substantial in size or scale or importance be classified as contributing or noncontributing. The National Register program recognizes that the contributing resources for a given cemetery may differ in age, function, design qualities, and the way each relates to the mission of the national cemetery program or the operation of the national cemetery. Differences may also exist between those resources that are integral to the nationally significant values and commemorative functions of the national cemetery-including memorials, areas prepared for burials, designed landscape features, and administration buildings-and those that relate to the day-to-day operations of the cemeteryincluding comfort stations, maintenance facilities, and service roads. For National Register purposes, component resources contribute to the cemetery's significance regardless of their age, function, or administrative role. In addition, some resources may reflect additional historical values important at the local, state, or national levels of significance due to their age or history prior to a cemetery's designation. 


\section{Current Condition}

The existing conditions of the Corinth National Cemetery were surveyed in May 2018 by Adam Smith, an architectural historian, and by Ellen Hartman, a landscape architect.

\subsection{Ownership and oversight}

The cemetery is a federal property that is owned and maintained by the U.S. Department of Veterans Affairs National Cemetery Administration. The cemetery is managed as a satellite of the Memphis National Cemetery located in Memphis, Tennessee. The Continental District of the National Cemetery Administration, with its office located at Lakewood, Colorado, is responsible for projects undertaken at Corinth National Cemetery, since Mississippi is one of the states within that district.

\subsection{Physical site}

Corinth National Cemetery is located in Alcorn County in Corinth, Mississippi. Corinth is a town of about 15,000 people in northeast Mississippi and near the Tennessee border. It is the county seat of Alcorn County. The town was founded in 1853 and developed around the intersection of two rail lines through the south. After the Civil War battles Siege of Corinth and the Second Battle of Corinth in 1862, the Corinth National Cemetery was established in 1866. At the time, the location of the cemetery southeast of downtown was on the outskirts of town but as the town grew, residential neighborhoods surrounded the 20-acre cemetery. By the 1950s, the area around the cemetery was well established with housing that included a well-defined north-south street grid, sidewalks, curbs, and other urban infrastructure. The cemetery is bounded by Meigg Street to the north, Young Street to the east, Horton Street to the south, and Cemetery Street on the west.

Corinth, Mississippi, is in the Southeastern Plains ecoregion of Mississippi, and that ecoregion is composed of a mix of "cropland, pasture, woodland, and forest." ${ }^{132}$ Climatologically, the area is subtropical and has hot, humid summers and mild winters. In general, the area receives regular rain events, with peak rainfall in early spring to midsummer. However,

\footnotetext{
132 Level III and IV Ecoregions of Mississippi. Accessed online: https://efotg.sc.egov.usda.gov/references/public/MS/MS_ecoregions.doc.
} 
droughts can occur, and they can impact vegetation. ${ }^{133}$ The region has a mix of soils ranging from sands, silts, and clays. More specifically in the Blackland Prairie subregion where Corinth is located, the clay soils swell when wet and crack when dry. ${ }^{134}$ Stormwater in the cemetery is managed on site with concrete channels that direct flow into the municipal stormwater system.

\subsubsection{Topography}

The region's general surface land form is undulating hills with an overall gentle slope south toward the Gulf of Mexico. ${ }^{135}$ The site of Corinth National Cemetery is on a low hill, with the highest point occurring on the northern quarter of the property at the flagstaff mound (Figure 71). Overall, the site slopes downward from east to west. The cemetery's lowest points are in the northwest corner and along the west and south sides, with the south side including the main entrance.

\footnotetext{
133 U.S. Forest Service, “231 Southern Mixed Forest Province.” https://www.fs.fed.us/land/ecosysmgmt/colorimagemap/images/231.html.

134 U.S. Department of Agriculture, "Level III and IV Ecoregions of Mississippi." Accessed online: https://efotg.sc.egov.usda.gov/references/public/MS/MS_ecoregions.doc .

135 https://www.fs.fed.us/land/ecosysmgmt/colorimagemap/images/231.html.
} 
Figure 71. Exaggerated topographic section of Corinth National Cemetery, 2018 (ERDC-CERL).

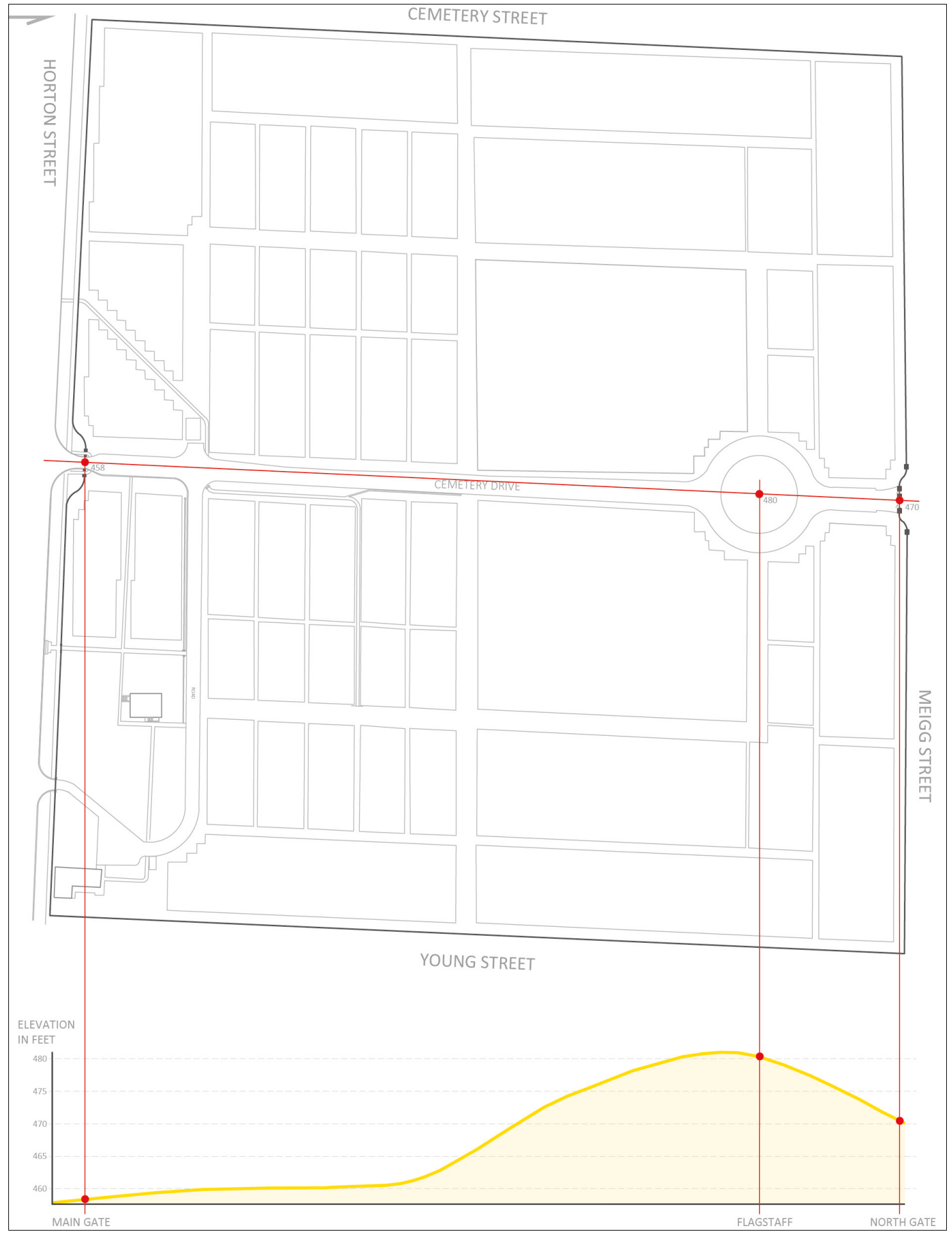




\subsubsection{Spatial organization}

Corinth National Cemetery adheres to a standard, shared, spatial organization that reflects military culture. The military has a unique culture with its own system of beliefs, practices, and cultural values associated with hierarchy, uniformity, order, utility, discipline, and patriotism. Those values are symbolized within a military landscape such as a national cemetery. ${ }^{136}$ The National Cemeteries that were designed and constructed to inter the Civil War dead used spatial organization and physical object placements to visually emphasize the values upheld in military culture. Corinth National Cemetery was designed with those principles, and it features a distinct hierarchy of functional spaces, ordered and uniformly constructed objects, and manicured vegetation.

Currently, the cemetery is bounded by a brick wall that varies in height because of changes in topography, but is around four feet tall. The cemetery is organized along a north-south axial road, Cemetery Drive, with the main entrance on the south side. Looking north, the road progresses to the high point on the site on which the flagstaff is located. The road encircles the flagstaff mound and then exits at a secondary entrance on the north side of the cemetery. Grassed lanes divide the gravesites into distinct burial sections. There are 21 burial sections. Over time, additional gravesites have been placed in the original grassed lanes that divided the sections. Not all of the original sections have burials in them.

In the late 1870 , the defining visual expression of the National Cemeterydesigned landscape was the regularly spaced and uniform headstones. At Corinth, the uniform headstones are arrayed in distinct geometric patterns that delineate burial sections. Throughout the cemetery, the regular spacing and uniform design of the headstones emphasizes the topographic contours of the site.

The military value of hierarchy is expressed by locating the flagstaff at the highest and most prominent point of the site. At Corinth, the flagstaff remains in its original location on a mound in the north section of the site.

\footnotetext{
136 Suzanne Keith Loechl, Susan I. Enscore, Megan Weaver Tooker, and Samuel A. Batzli, Guidelines for Identifying and Evaluating Historic Military Landscapes, ERDC/CERL TR-09-6 (Champaign, IL: ERDC/CERL, 2009), 3.
} 
Throughout the site, tall shade trees are arrayed throughout the burial sections and create sequences of open and enclosed spaces that reinforce the feelings of solemnity and contemplation within the cemetery.

The support buildings are clustered together in the southeast quarter of the site, away from the majority of burials. The grouping includes the superintendent's lodge and a maintenance building, which has a restroom for visitor use. The maintenance area is surrounded by an eight-foot tall chain-link fence topped with barbed wire that has brown plastic woven through it to obscure views into the area.

\subsubsection{Vegetation}

The vegetation within the cemetery includes tall deciduous and evergreen trees, a few small ornamental trees, and very few shrubs. The tree species are typical of the climate zone and include oaks, magnolias, hickories, and junipers. Deciduous and evergreen trees are intermixed throughout the site, but they are more densely clustered on the south side of the site (Figure 72). Throughout the cemetery, trees have been removed, which has altered the original planting plan. However, a single row of evenly spaced large oaks surrounds the cemetery along the inside of the perimeter wall. In a few areas, trees remain from the second row of trees that originally lined the perimeter. Seven crape myrtles line the sidewalk that leads from the main road to the front of the lodge (Figure 73). 
Figure 72. Diagram of tree cover in Corinth National Cemetery, 2018 (ERDC-CERL).

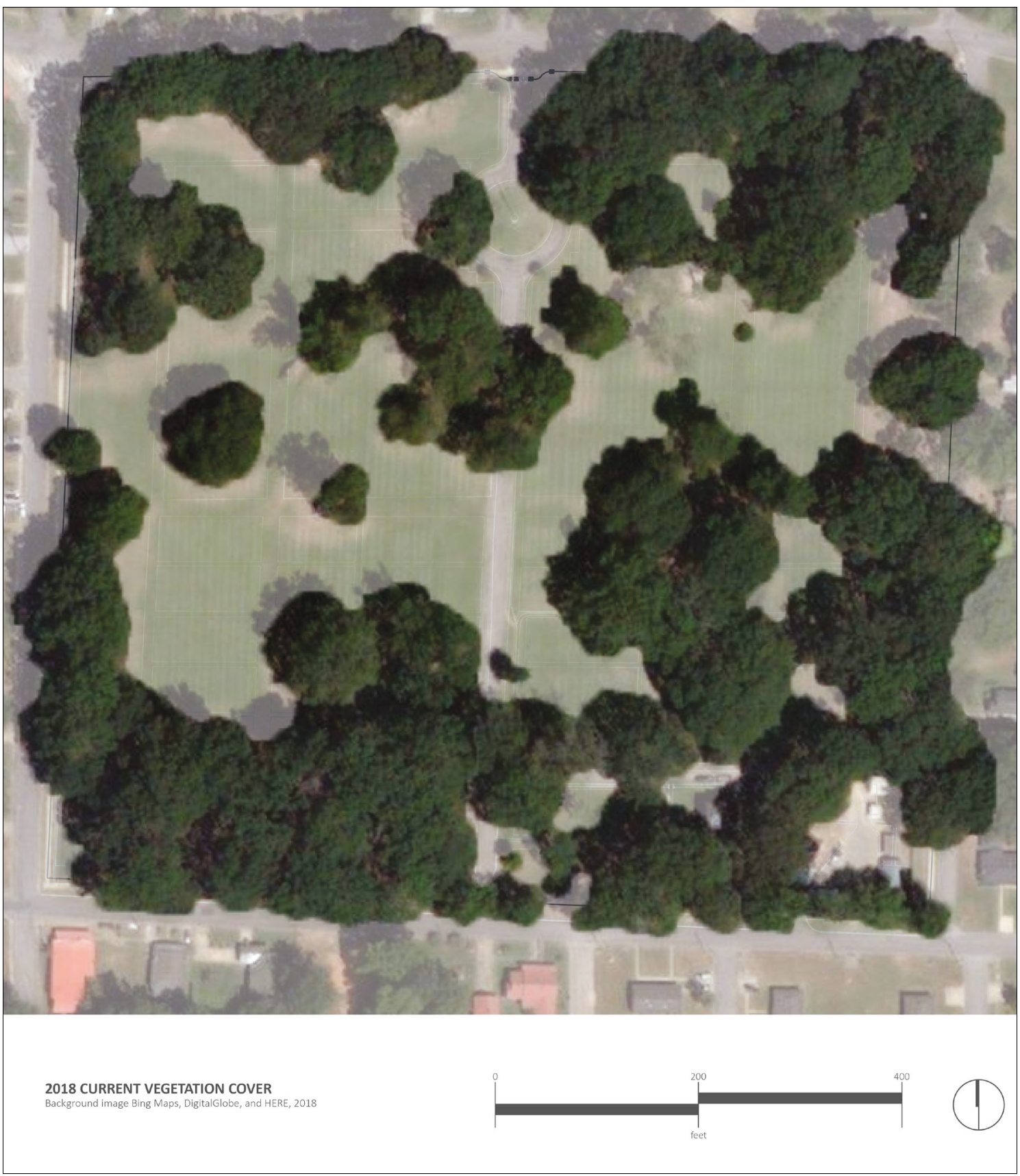


Figure 73. Crape myrtles line the sidewalk from the main road to the Superintendent's Lodge, 2018 (ERDC-CERL).

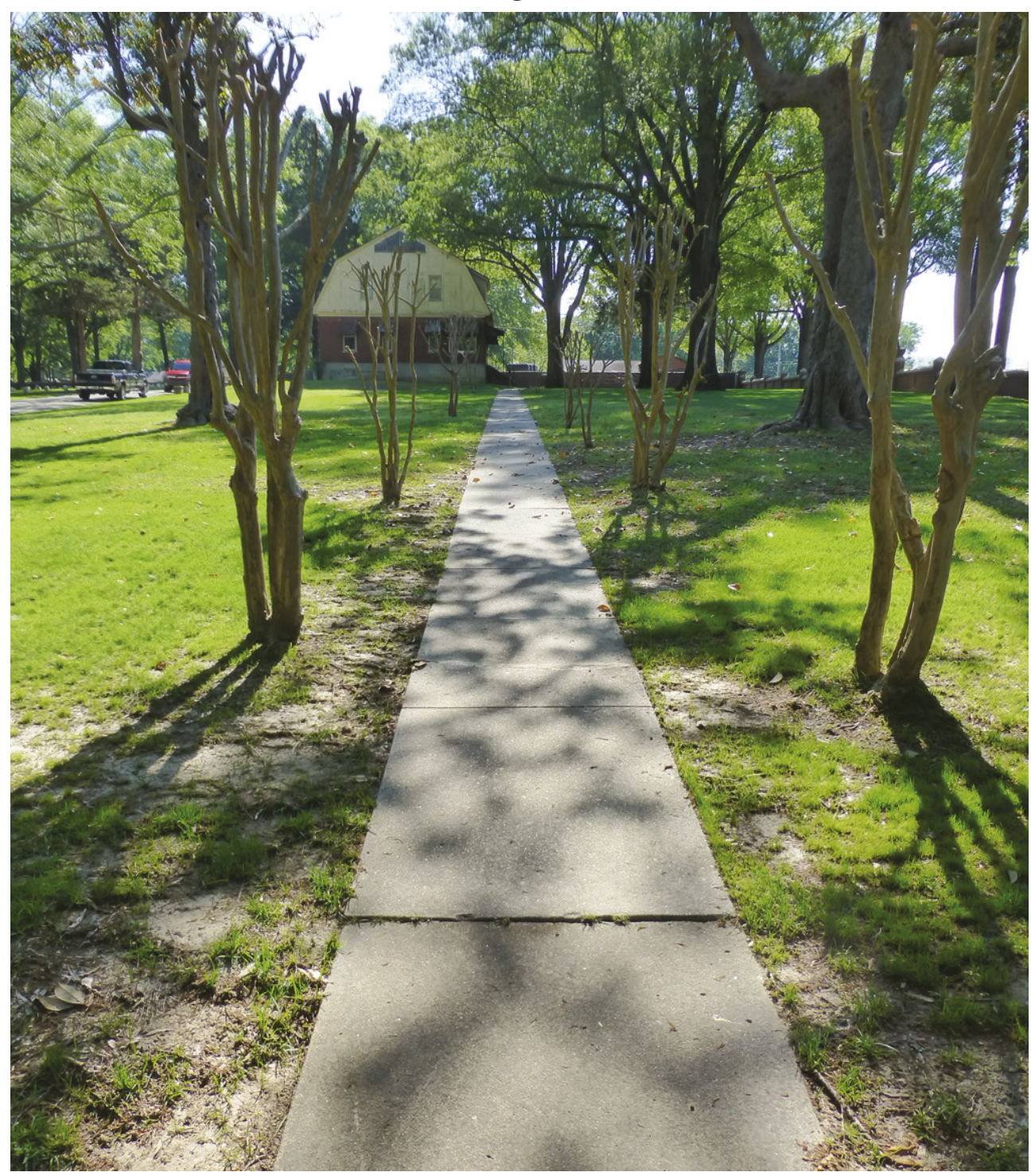

In the center of the east side of the cemetery, there is a concrete stormwater outlet that has five small boxwoods and two larger privets planted around a seating area (Figure 74 and Figure 75). The area is rectangular and bounded by landscape timbers and concrete retaining wall blocks. Over the water outlet is a concrete pad with a concrete bench and trash bin. The area around the concrete pad is white landscape rock.

Lists of trees and shrubs within Corinth National Cemetery in May 2018 are given in Table 2 and Table 3. 
Figure 74. Seating area with shrubs and white rocks, 2018 (ERDC-CERL).

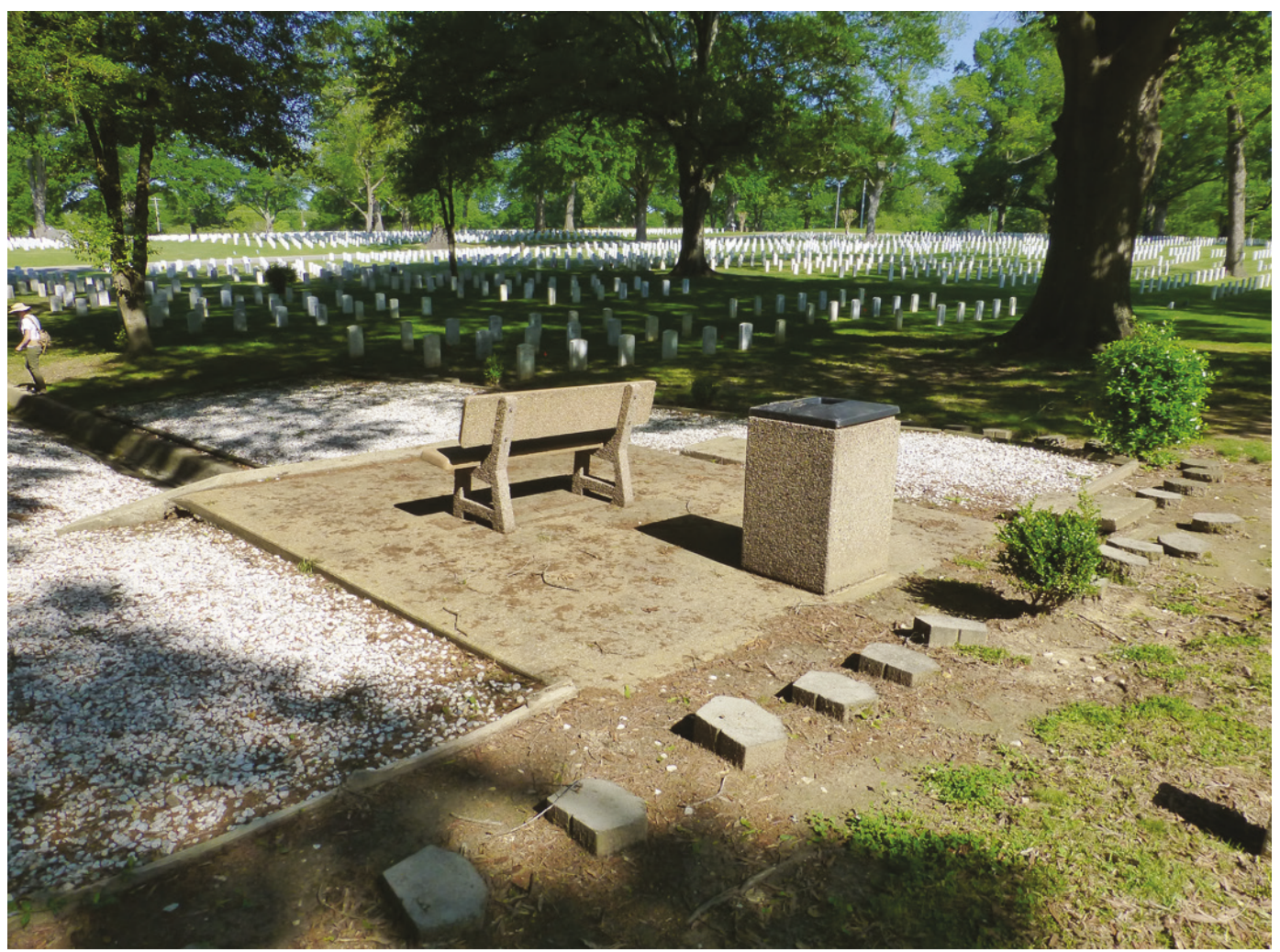

Figure 75. Seating area, view from the north, 2018 (ERDC-CERL).

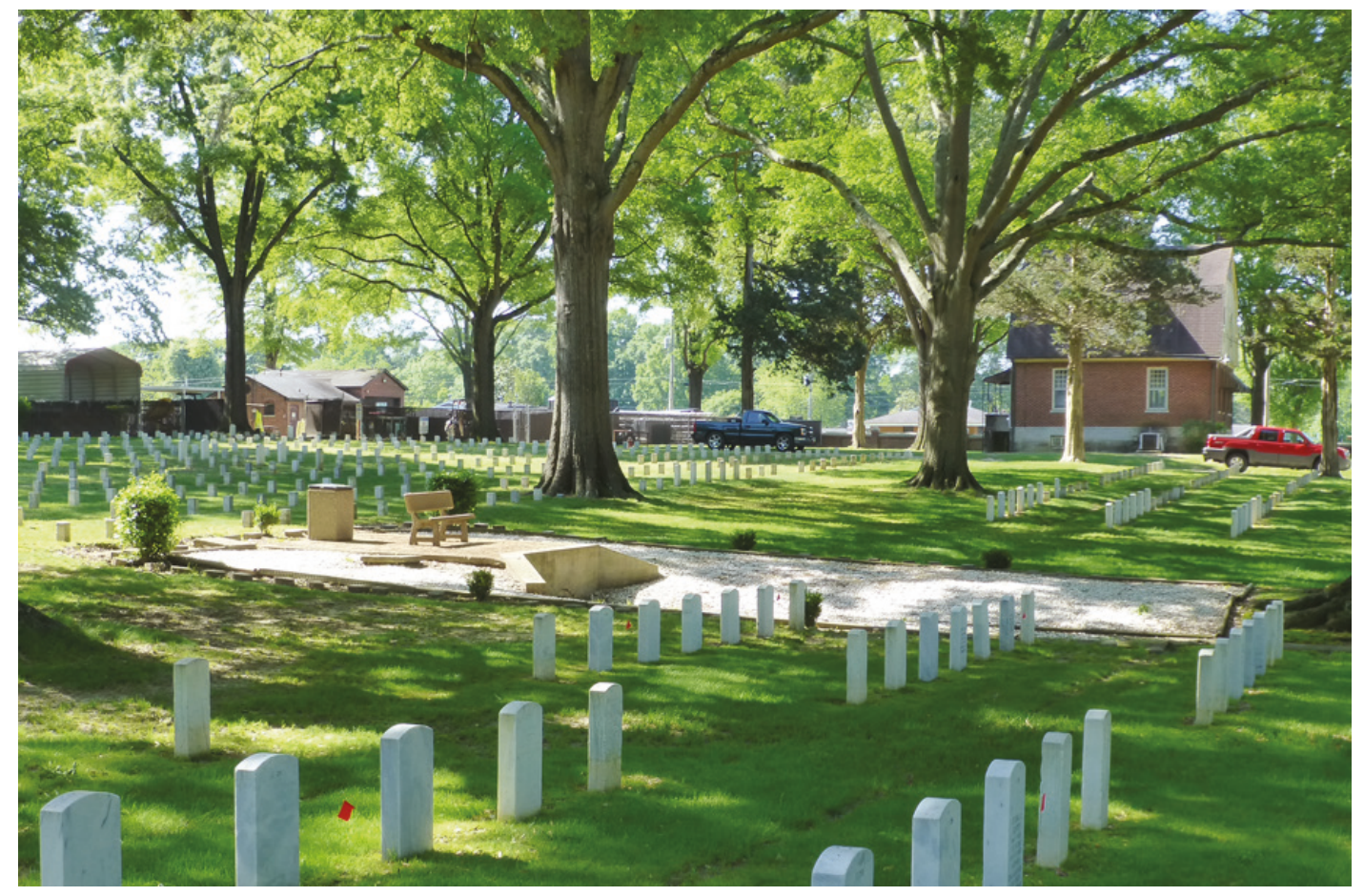


Table 2. List of trees at Corinth National Cemetery in May 2018 (ERDC-CERL).

\begin{tabular}{|l|l|}
\hline Common Name & Scientific Name \\
\hline Southern Sugar Maple & Acer floridanum \\
\hline Pecan & Carya illinoensis \\
\hline Flowering Dogwood & Cornus florida \\
\hline Red Flowering Dogwood & Cornus florida rubra \\
\hline White Ash & Fraxinus americana \\
\hline American Holly & Ilex opaca \\
\hline Eastern Redcedar & Juniperus virginiana \\
\hline Southern Magnolia & Magnolia grandiflora \\
\hline Saucer Magnolia & Magnolia soulangeana \\
\hline Southern Red Oak & Quercus falcata \\
\hline Water Oak & Quercus nigra \\
\hline Willow Oak & Quercus phellos \\
\hline Winged Elm & Ulmus alata \\
\hline American Elm & Ulmus americana \\
\hline September Elm & Ulmus serotina \\
\hline
\end{tabular}

Table 3. List of shrubs at Corinth National Cemetery in May 2018 (ERDC-CERL).

\begin{tabular}{|l|l|}
\hline Common Name & Scientific Name \\
\hline Common Box & Buxus sempervirens \\
\hline Greenstem Forsythia & Forsythia viridissima \\
\hline Common Crape Myrtle & Lagerstroemia indica \\
\hline Glossy Privet & Ligustrum lucidum \\
\hline
\end{tabular}

\subsubsection{Circulation}

The main road and secondary road to the maintenance area are paved, and curbs discourage visitors from driving or parking on the original grass drives. There is no designated parking area, so vehicles park on the sides of the main road. Pedestrians use the grass drives to navigate through the cemetery (Figure 76). 
Figure 76. Circulation diagram showing the paved roads in dark yellow, the main grassed drives in green, and the sidewalks in yellow, 2018 (ERDC-CERL).

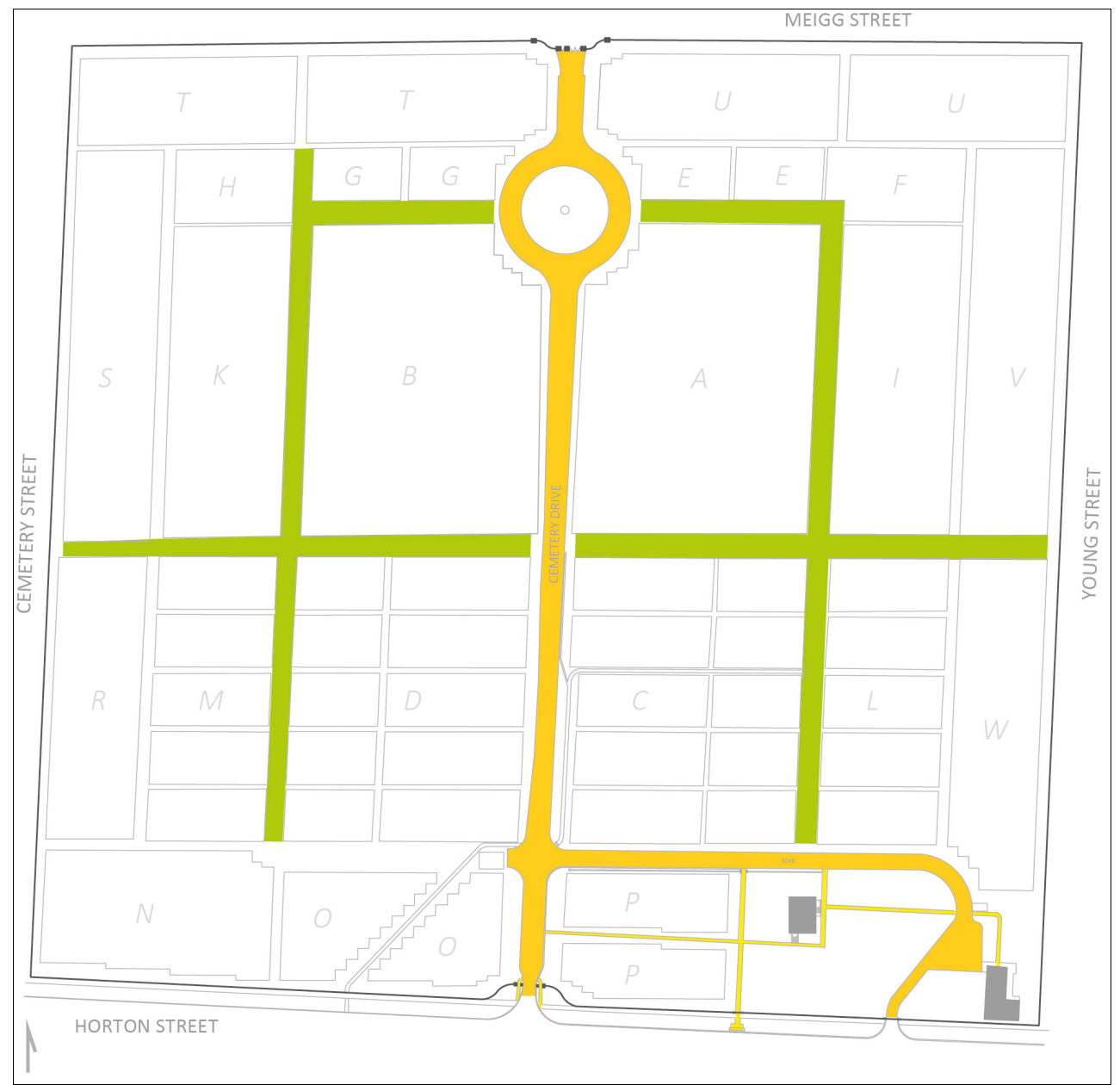

\subsubsection{Road paving materials}

The main road through the cemetery is paved with asphalt and has concrete water gutters running on both sides. The access road that leads to the service buildings is also asphalt with concrete gutters (Figure 77). The cemetery is further divided into quadrants and subsections by grassed lanes (Figure 78). 
Figure 77. Asphalt paving in 2018 (ERDC-CERL).

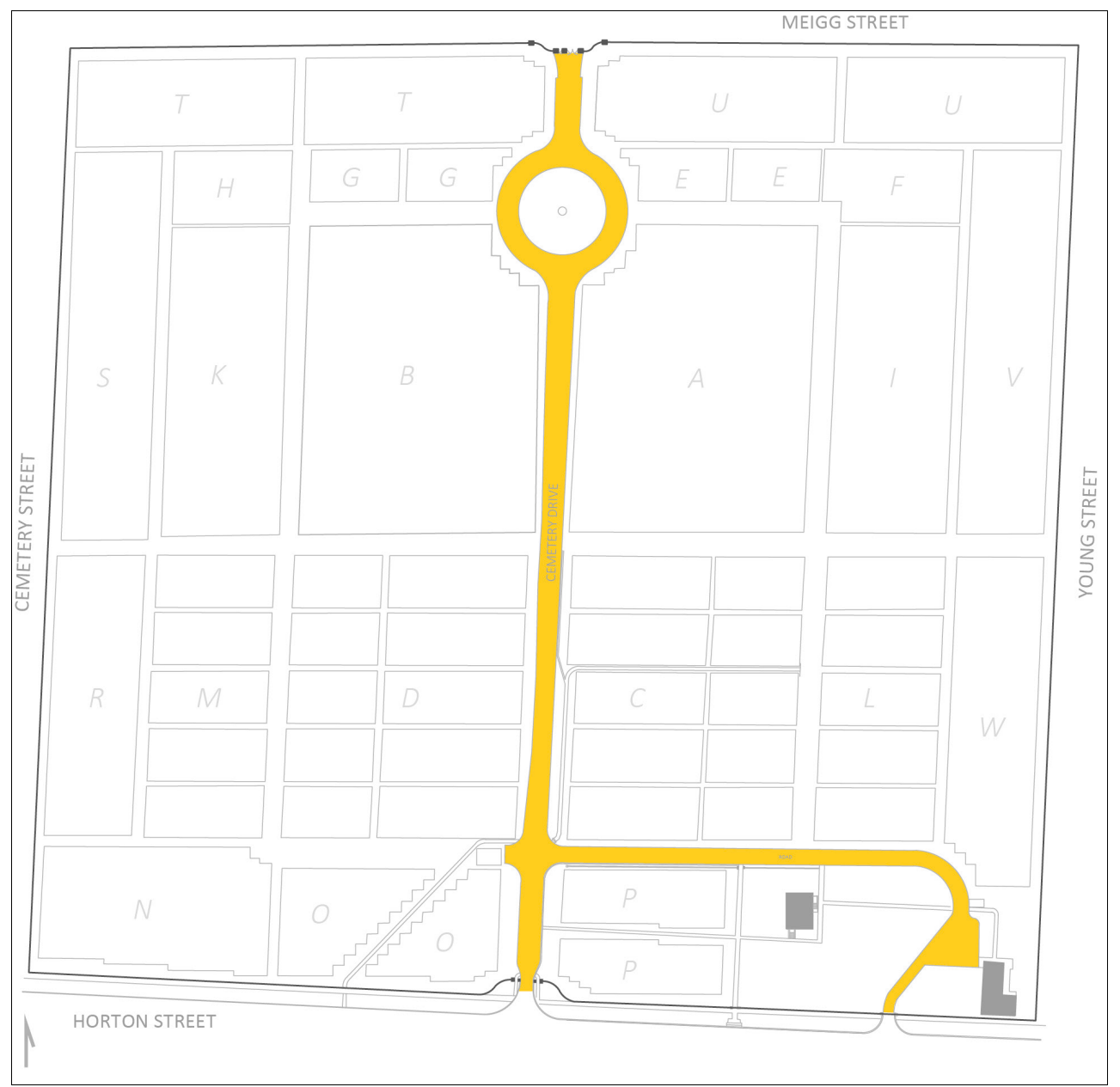


Figure 78. Grass drives and aisles in 2018 (ERDC-CERL).

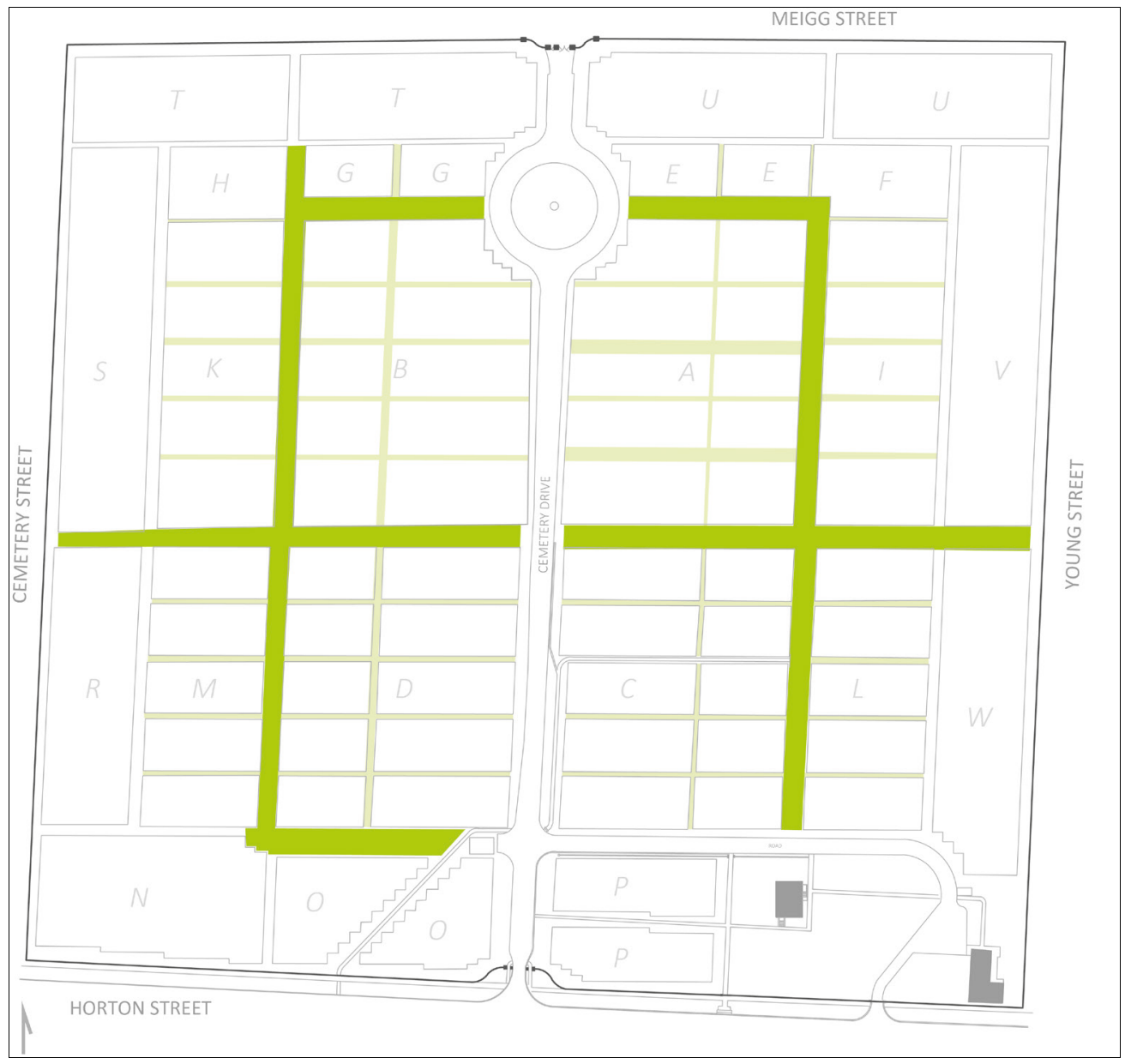

\subsubsection{Sidewalk paving materials}

There are three sections of concrete sidewalks in the cemetery (Figure 79). They are all in the southeast quadrant and are associated with the lodge. The longest sidewalk runs east-west from the main road around to the east side of the lodge. The second is oriented north-south and connects a pedestrian gate with the service road. The third runs from the east side of the lodge to the maintenance area. Two of the sidewalks intersect west of the lodge. Primarily, pedestrians use the main road and grassed lanes to navigate through the cemetery. 
Figure 79. Concrete sidewalks (shaded in yellow) in 2018 (ERDC-CERL).

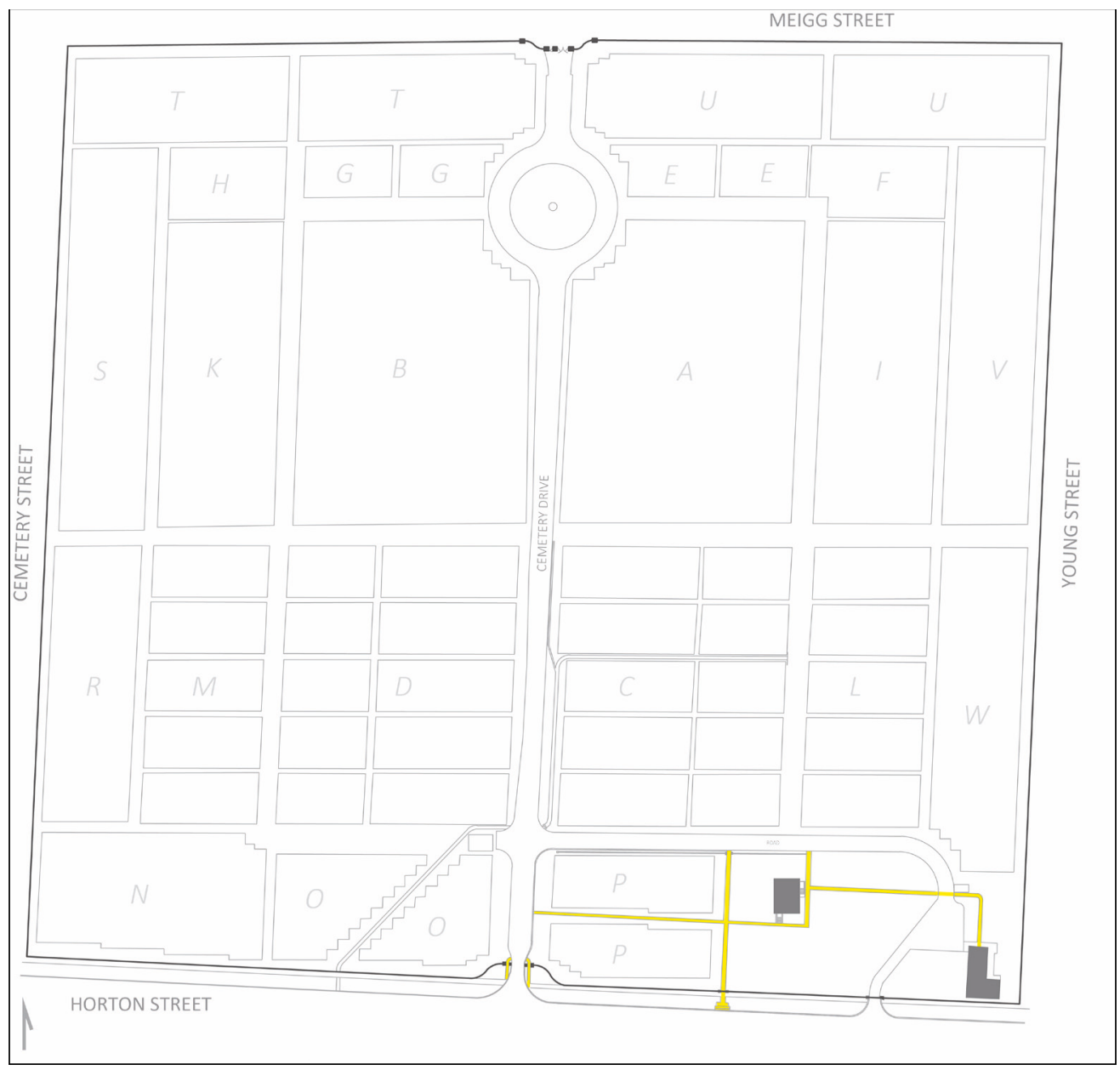

\subsubsection{Buildings}

According to National Register Bulletin \#15, buildings are structures created to "shelter any form of human activity." 137 At Corinth National Cemetery, the buildings are the superintendent's lodge and a maintenance building. They are clustered near each other in the southeast corner of the site.

\subsubsection{Superintendent's lodge}

The current superintendent's lodge was built in 1934. It is a two-story building clad in brick on the first floor, and frame and stucco on the second. The building has a gambrel roof. The second story loosely imitates a half-timber English Tudor style. The porch was enclosed in 1952. The first-

137 NPS (National Park Service), National Register Bulletin \#15: How to Apply the National Register Criteria for Evaluation (Washington, DC: U.S. Department of the Interior, National Park Service, 1997), 4. 
floor windows and doors have metal awnings over them, except for the windows on the north side. The front door is a single swing storefront with two side lights (Figure 80-Figure 83).

Figure 80. Front facade of the superintendent's lodge-the house faces south, 2018 (ERDC-CERL).

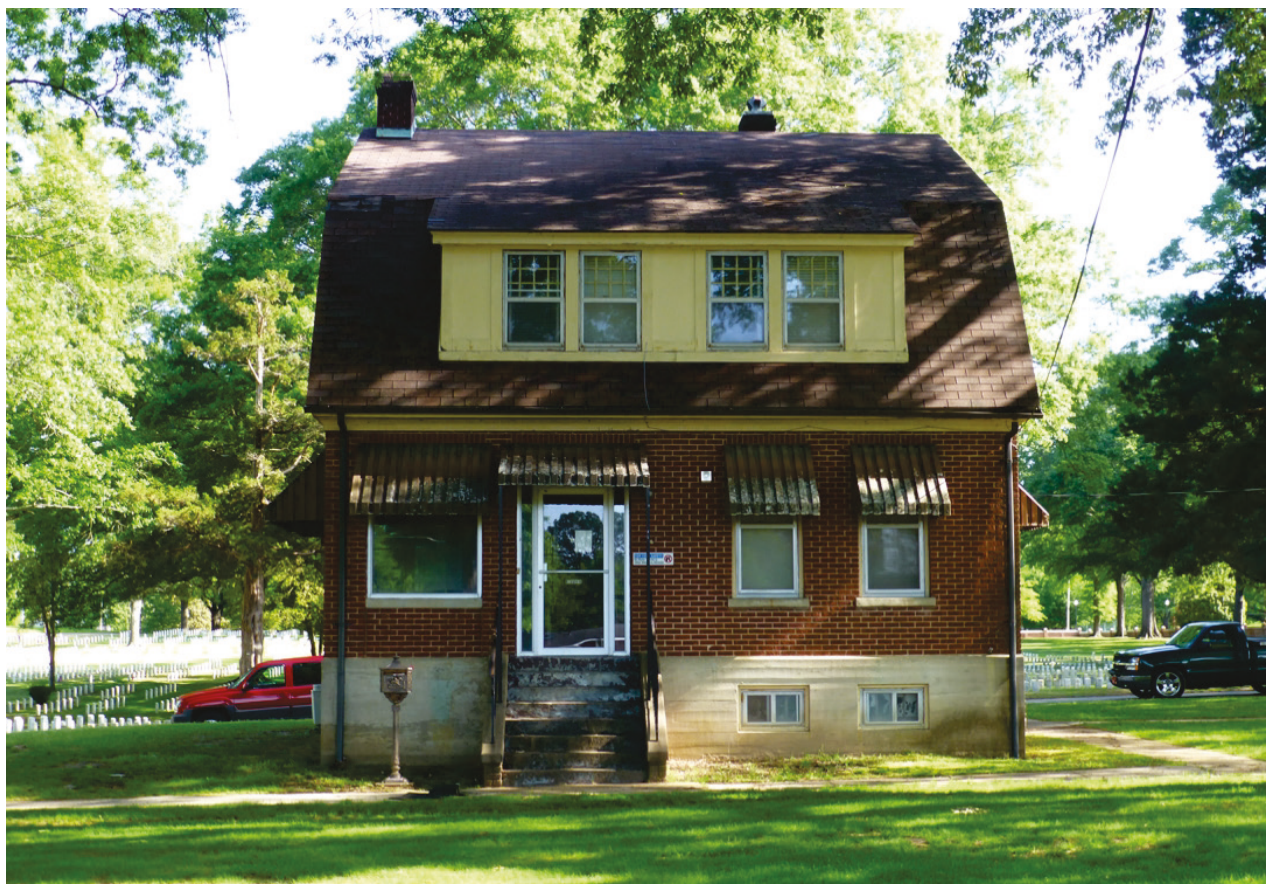

Figure 81. Oblique view of the southeast corner of the superintendent's lodge, 2018 (ERDC-CERL).

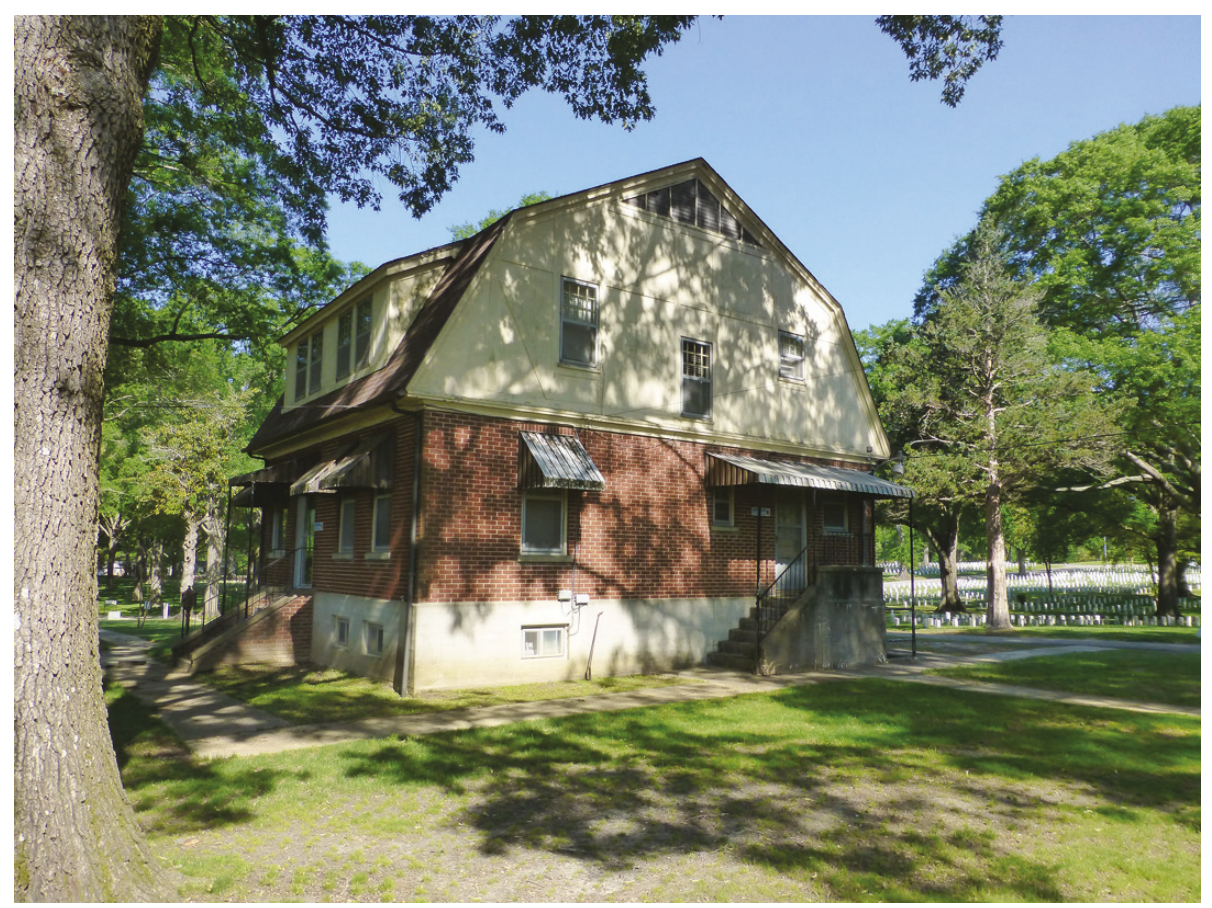


Figure 82. North (rear) side of the Superintendent's Lodge, 2018 (ERDC-CERL).

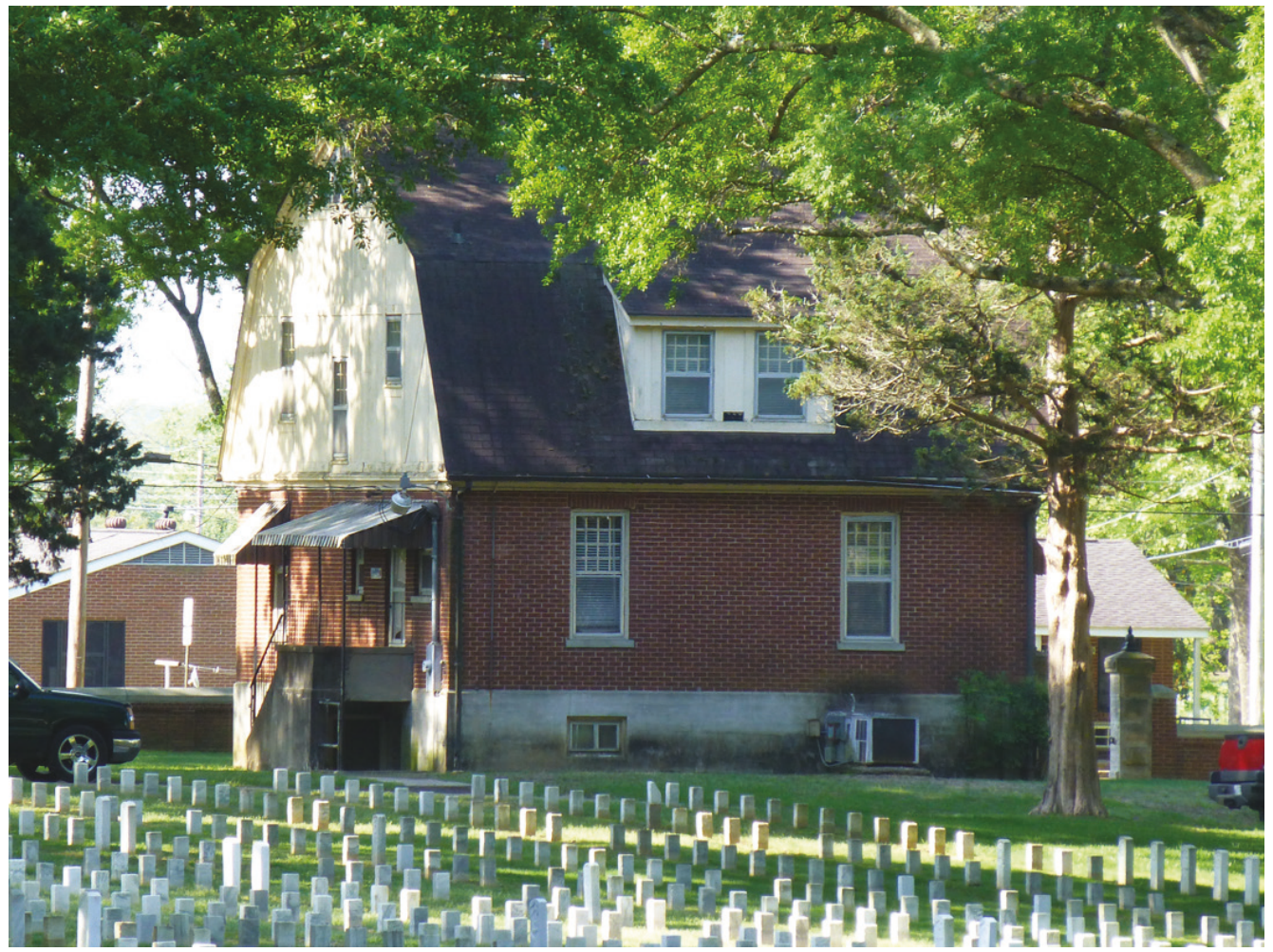

Figure 83. West side of the Superintendent's lodge, 2018 (ERDC-CERL).

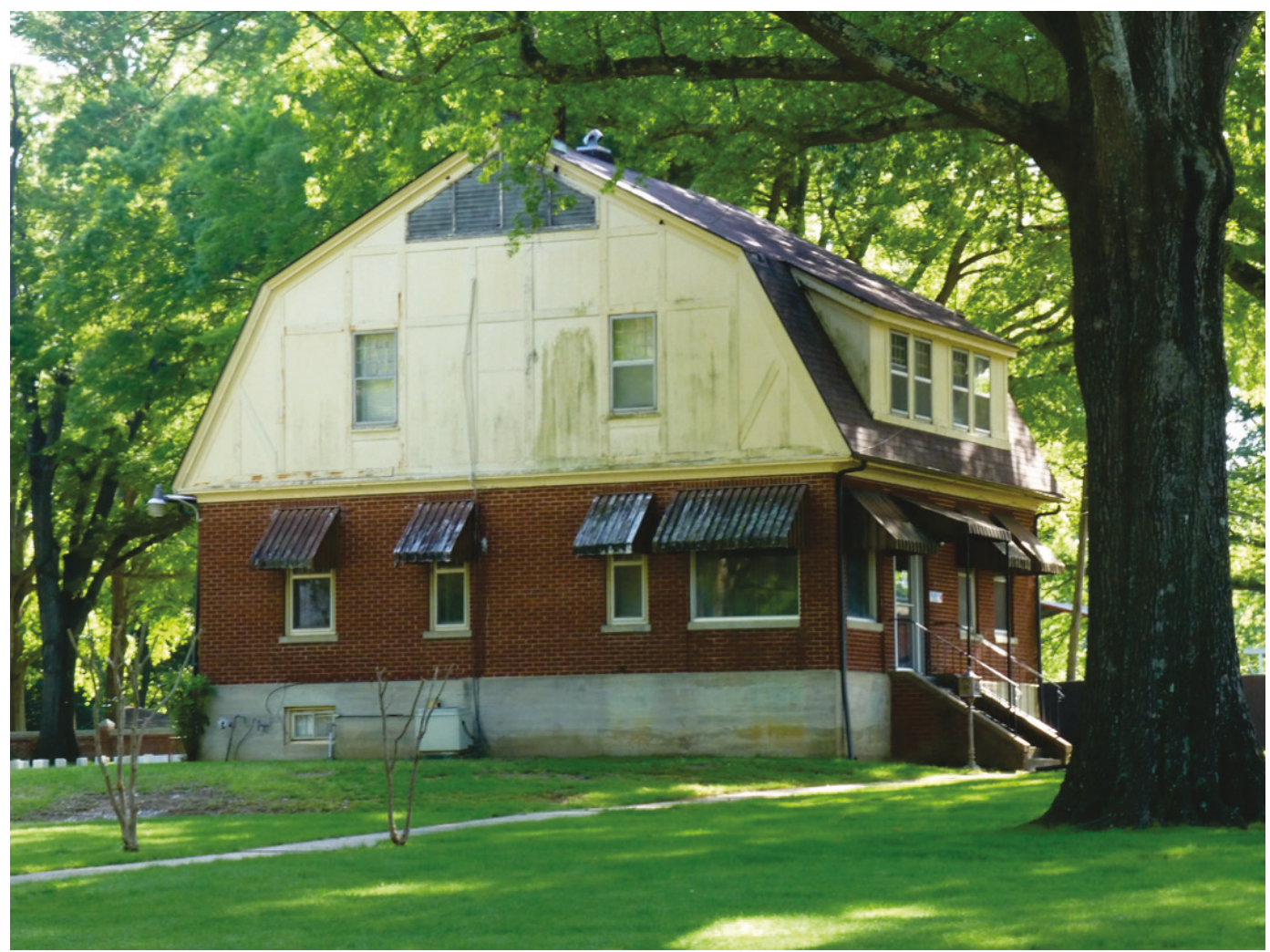




\subsubsection{Utility building}

The utility building is clad in red brick and was constructed in 1936. The building plan is L-shaped with gable roofs. The building has three garage bays and restrooms for visitors (Figure 84).

Figure 84. Utility building in the maintenance area. The single door is the visitor comfort station, 2018 (ERDC-CERL).

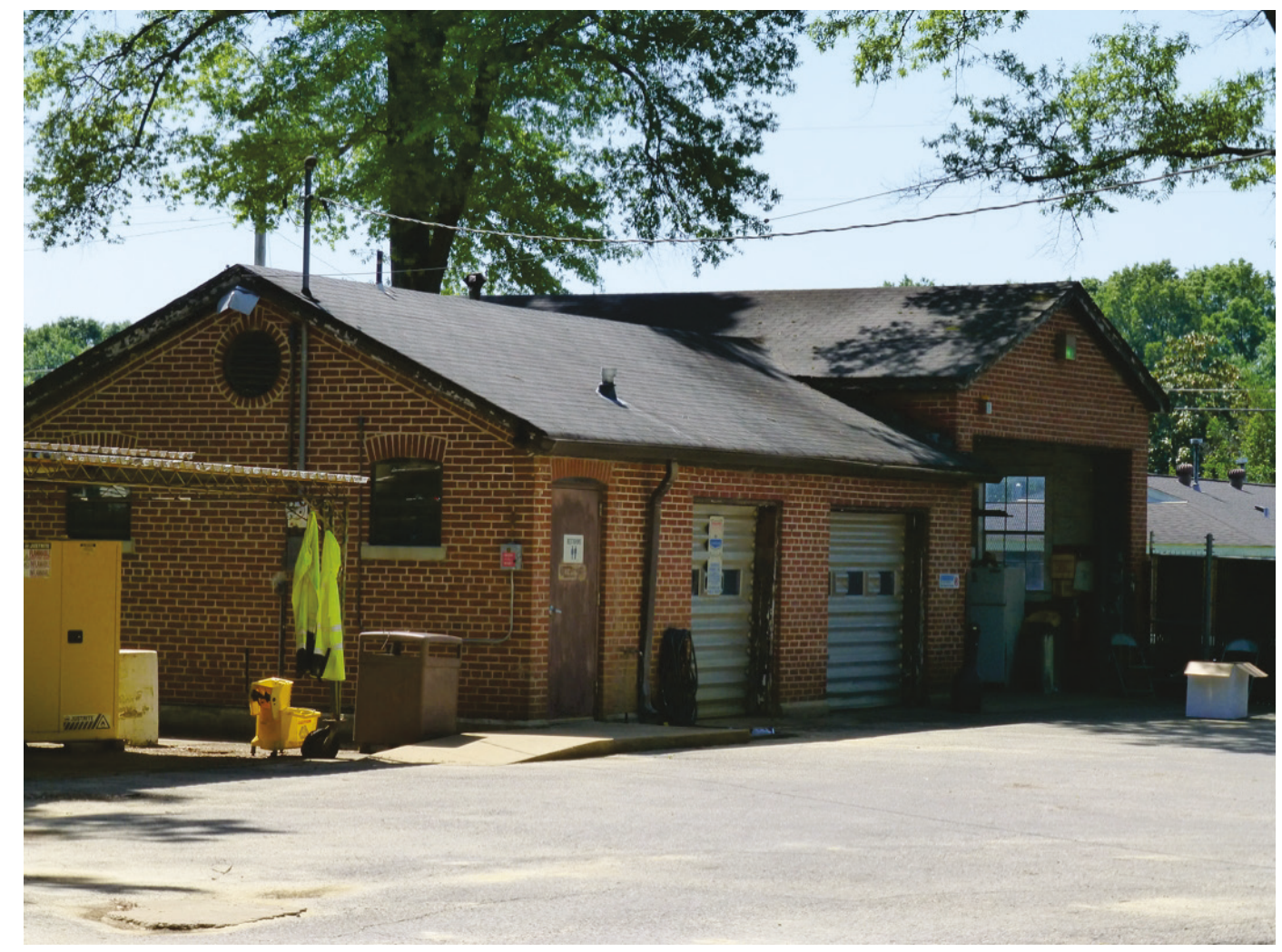

\subsubsection{Structures}

According to National Register Bulletin \#15, structures are used "for purposes other than to create human shelter." 138 There are two significant structures at the Corinth National Cemetery-the perimeter wall and the committal shelter-as well as three open-air storage shelters in the maintenance area (Figure 85). 
Figure 85. The location of structures at Corinth National Cemetery, 2018 (ERDCCERL).

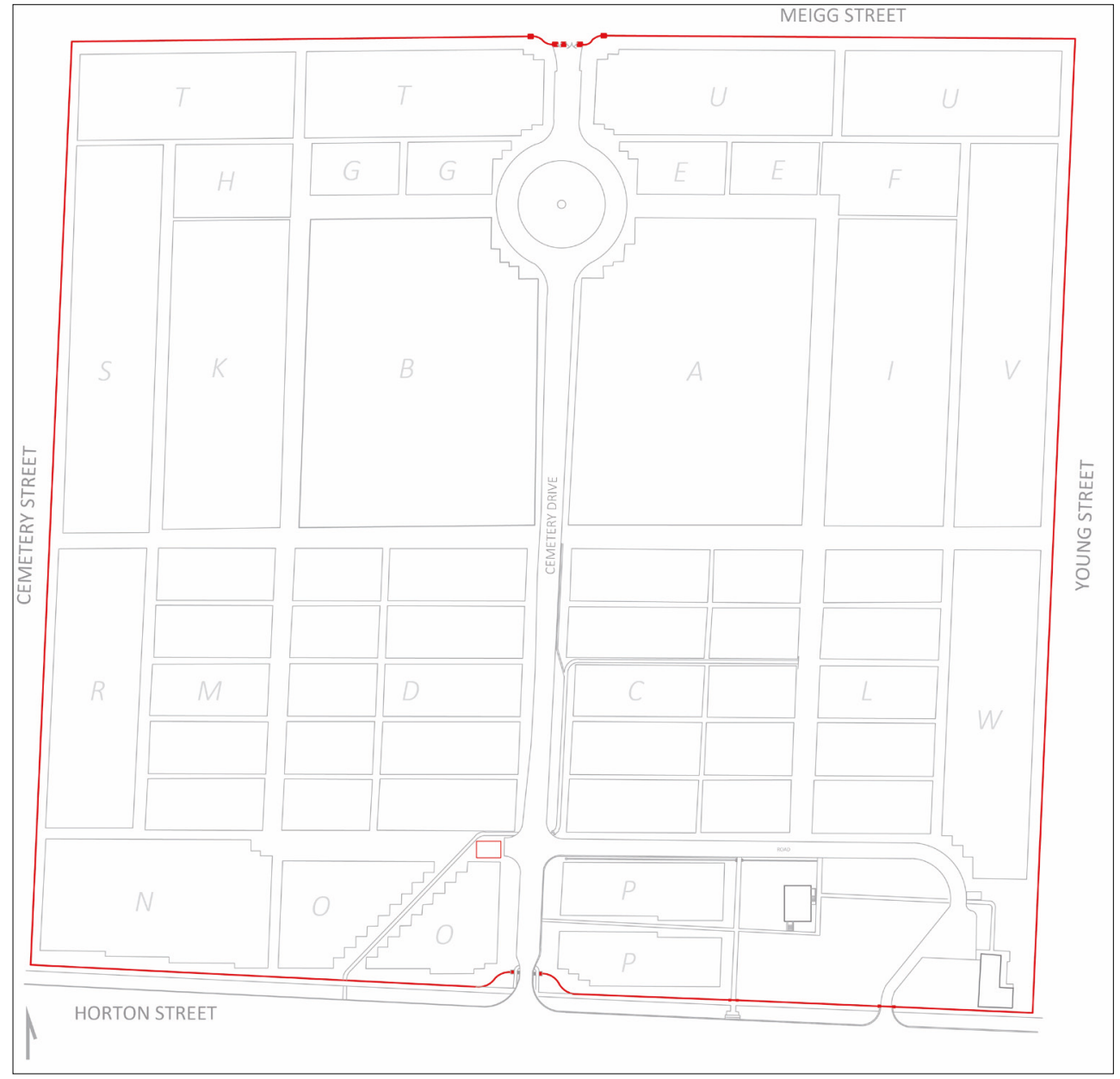

\subsubsection{Perimeter wall}

The perimeter wall is red brick with peaked concrete coping along the wall segments and pillars. The wall varies in height according to the topography. The segments of wall between the pillars have rectangular insets of brickwork (Figure 86). In two of the brick courses, the bricks are oriented width-wise instead of the predominant length-wise. There have been repairs made to the brickwork (Figure 87). 
Figure 86. View of the varying heights of the perimeter wall, 2018 (ERDC-CERL).

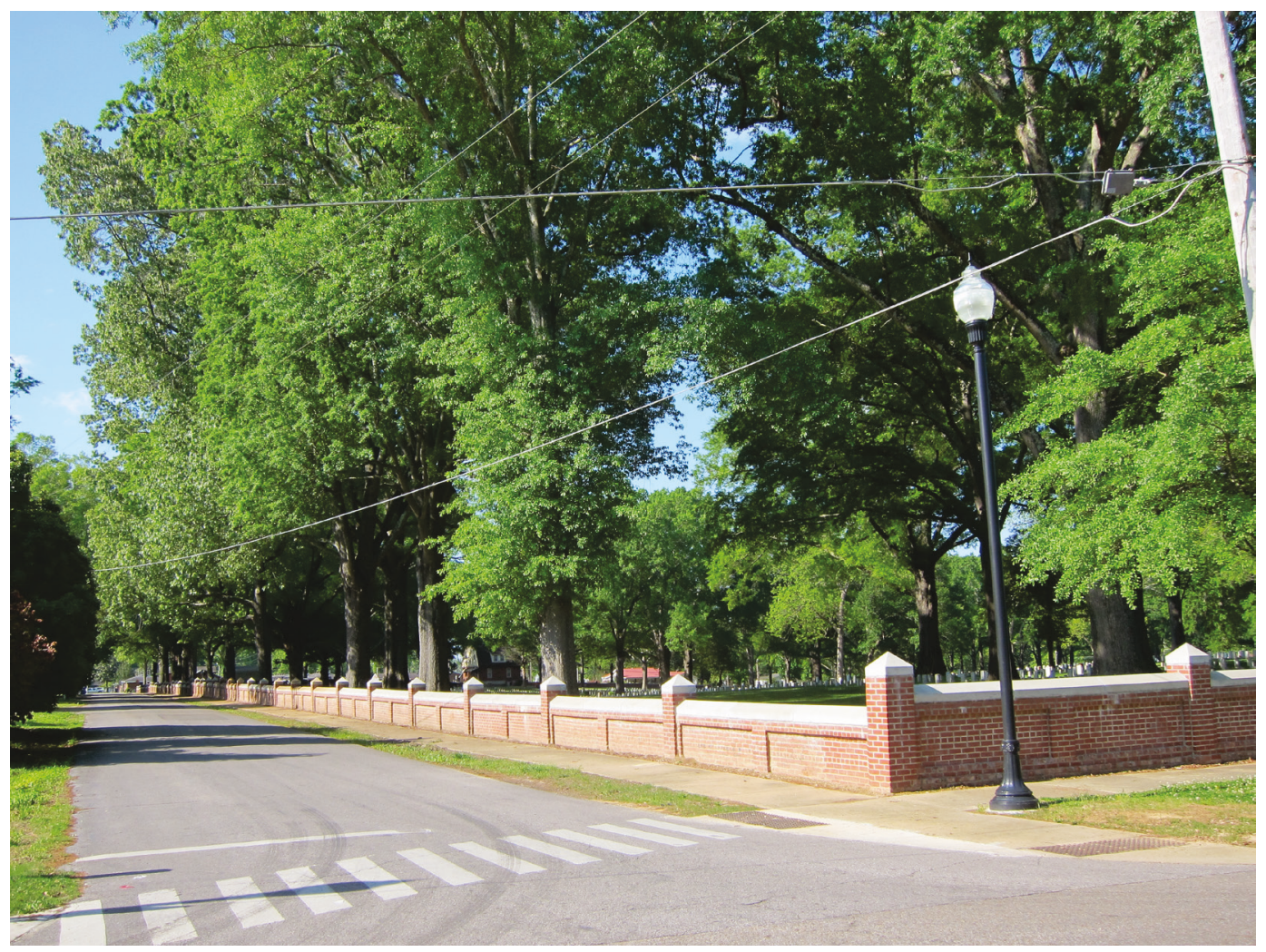

Figure 87. Detail of a recent repair to the perimeter wall, 2018 (ERDC-CERL).

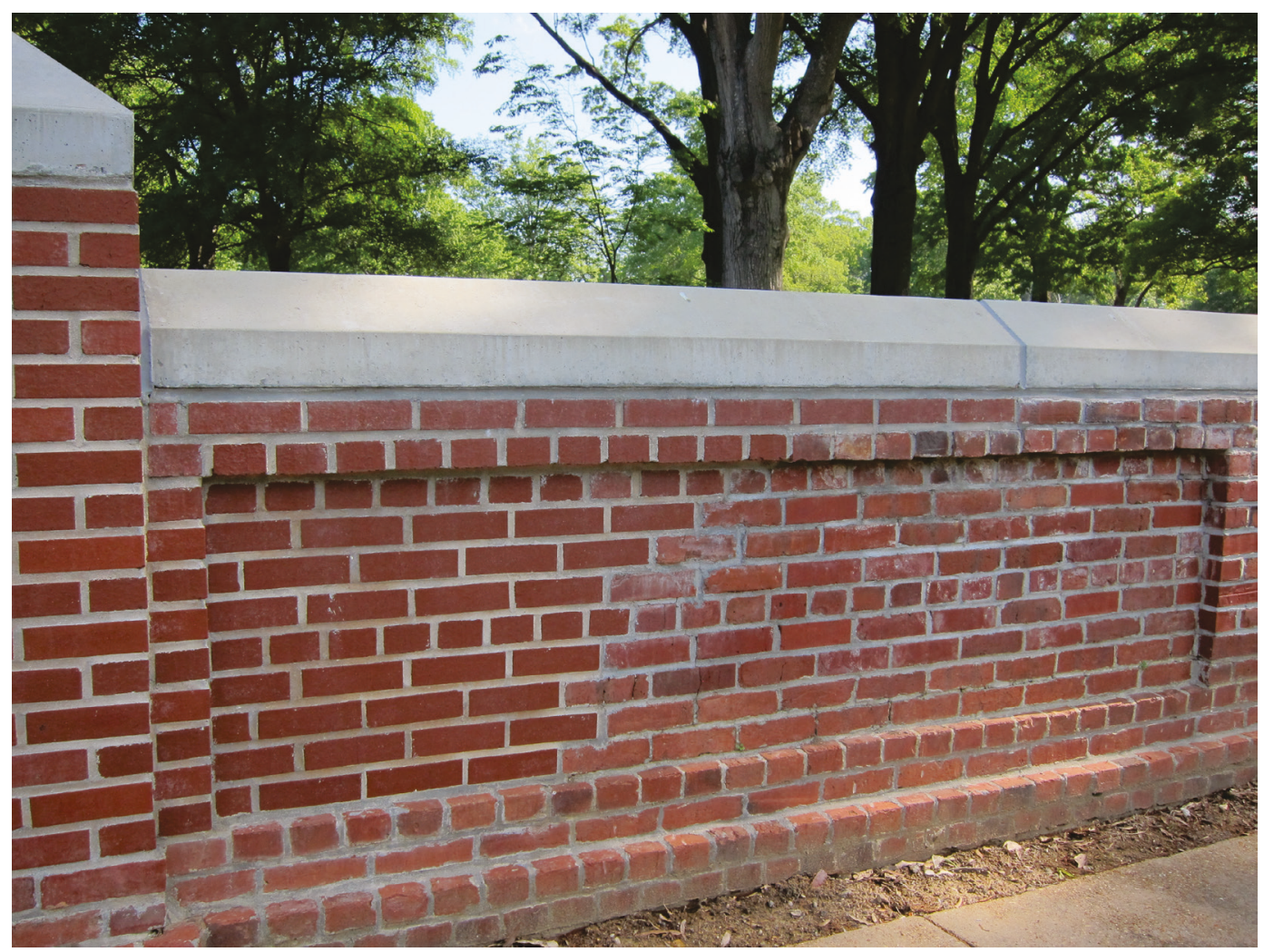




\subsubsection{Entrance gates}

The main entrance gate is on the south side of the property. It is composed of a wide vehicular gate flanked by two narrower pedestrian gates. The gateways are defined by four granite piers that support ornamented wrought-iron gates. The stones of the piers are roughhewn (Figure 88Figure 91). The piers that support the vehicular gates are taller than the other two piers and have ornamental iron urns on their peaked caps (Figure 92). The center piers also have bronze plaques on their south faces (Figure 93).

Figure 88. The main gate at Corinth National Cemetery, 2018 (ERDC-CERL).

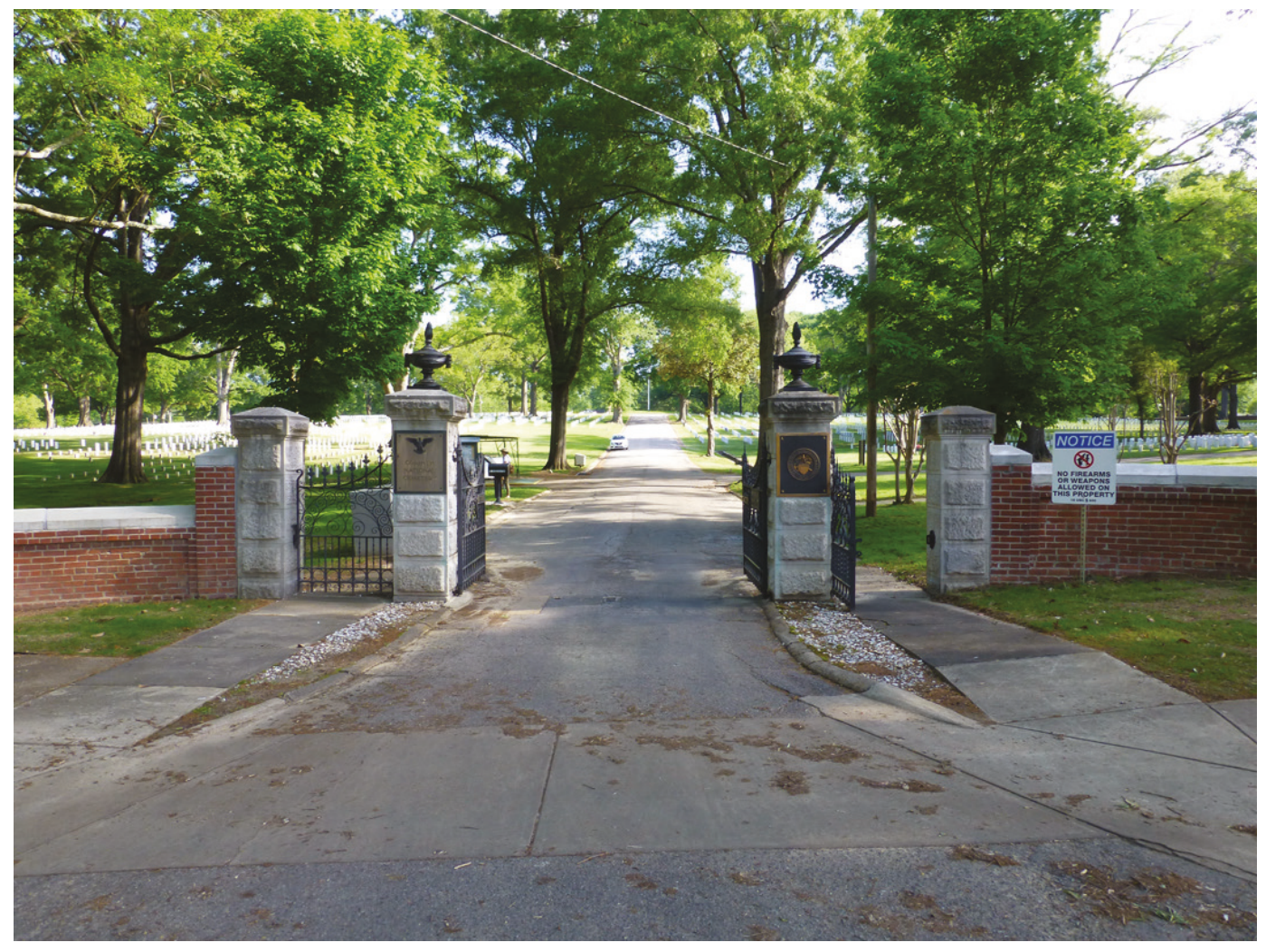


Figure 89. Showing one of two wrought-iron pedestrian gates that are part of the main gate, 2018 (ERDC-CERL).

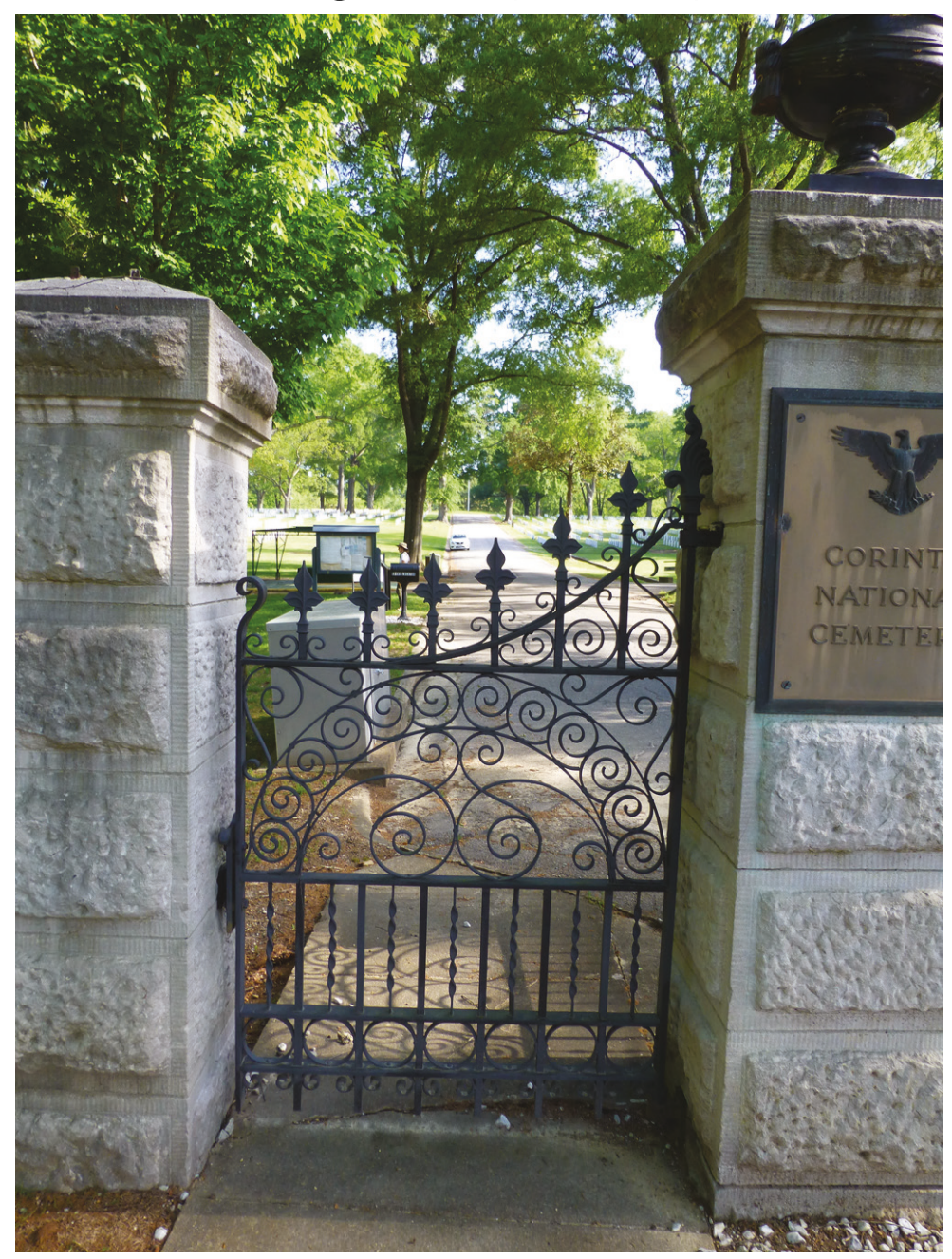


Figure 90. East side of the wrought-iron road gate, 2018 (ERDC-CERL).

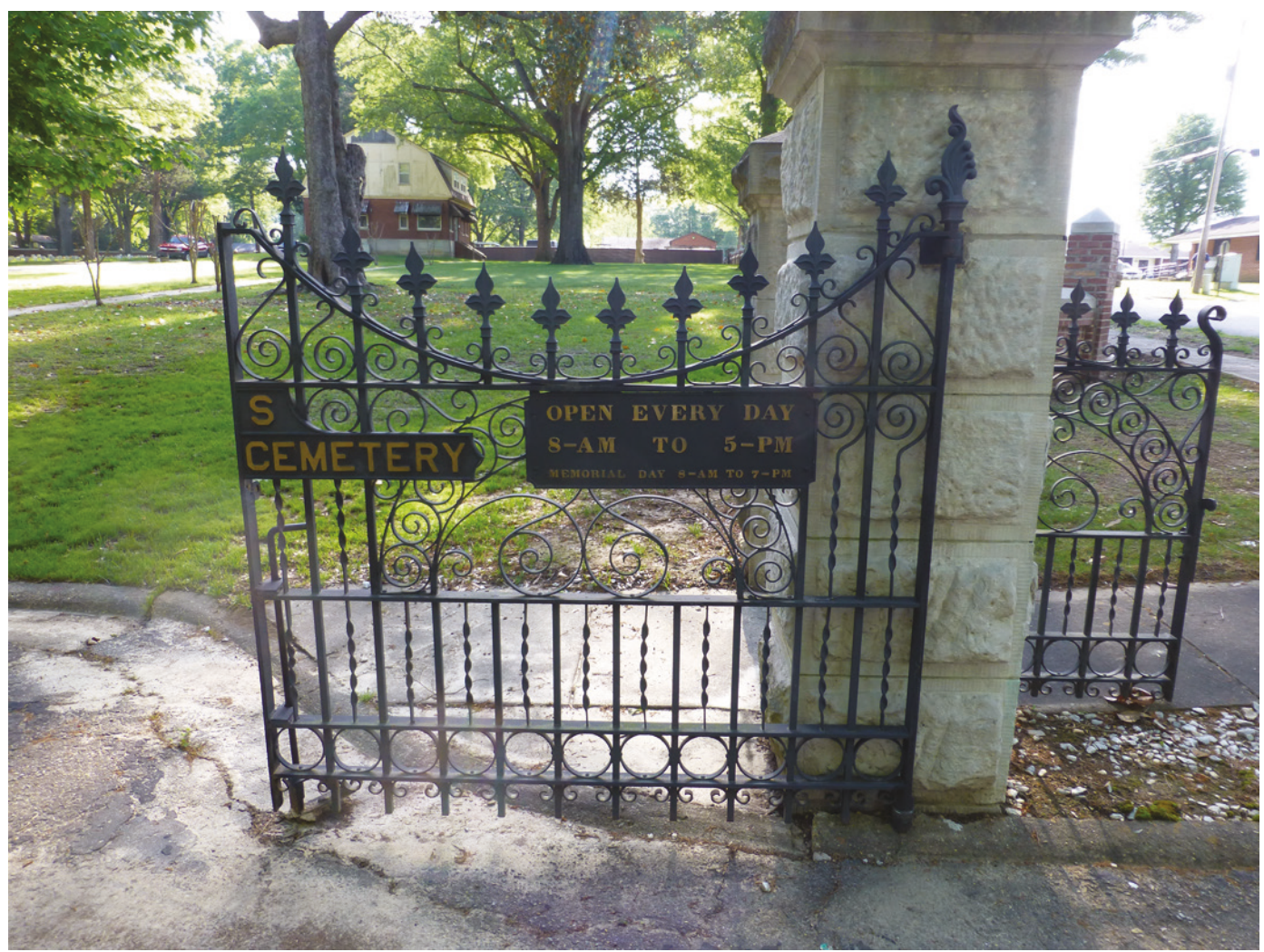

Figure 91. West side of the wrought-iron road gate, 2018 (ERDC-CERL).

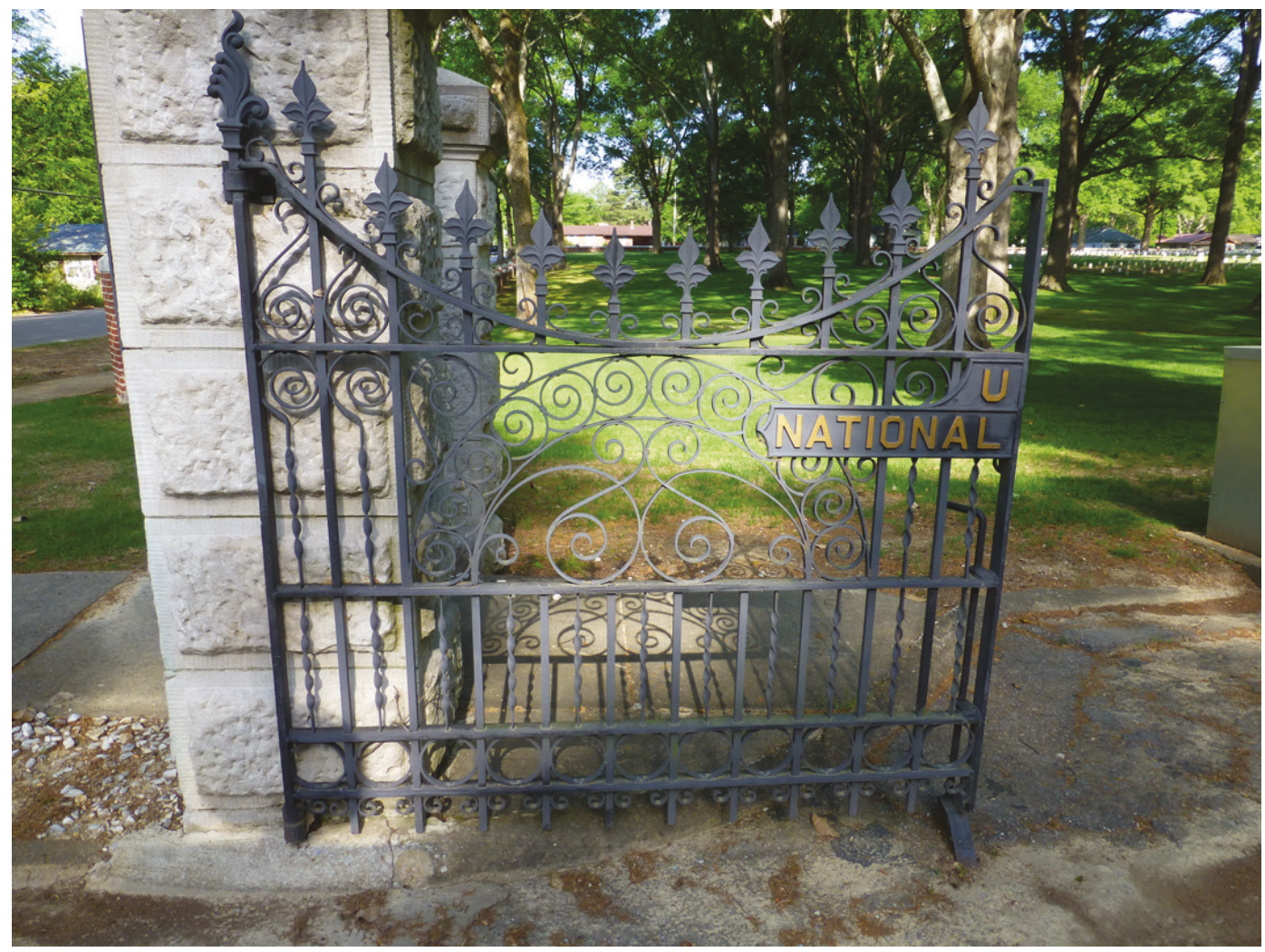


Figure 92. Example of the decorative urns on the central piers of the main gate, 2018 (ERDC-CERL).

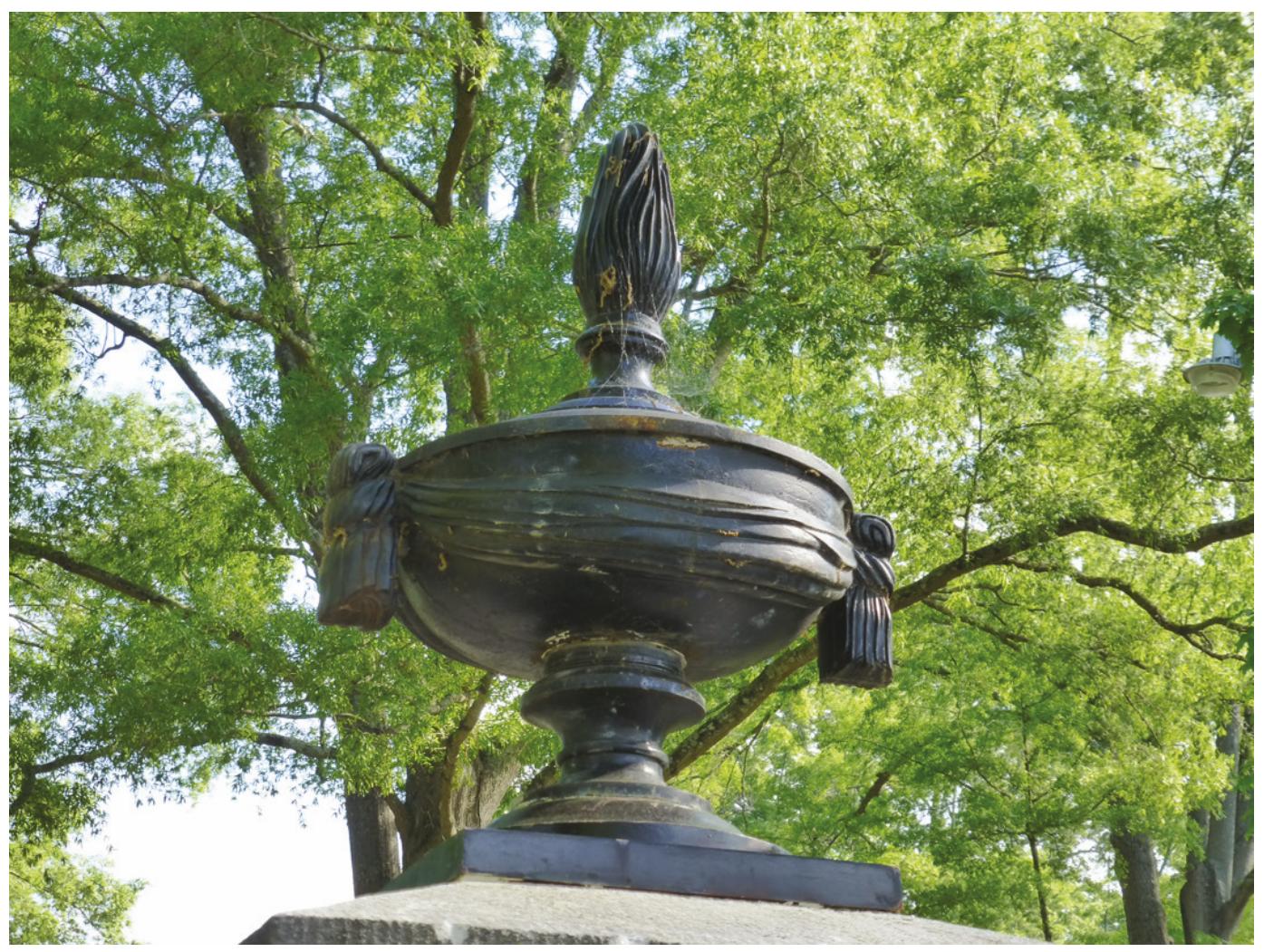

Figure 93. Looking north at bronze plaques on south side of the main gate piers, 2018 (ERDC-CERL).

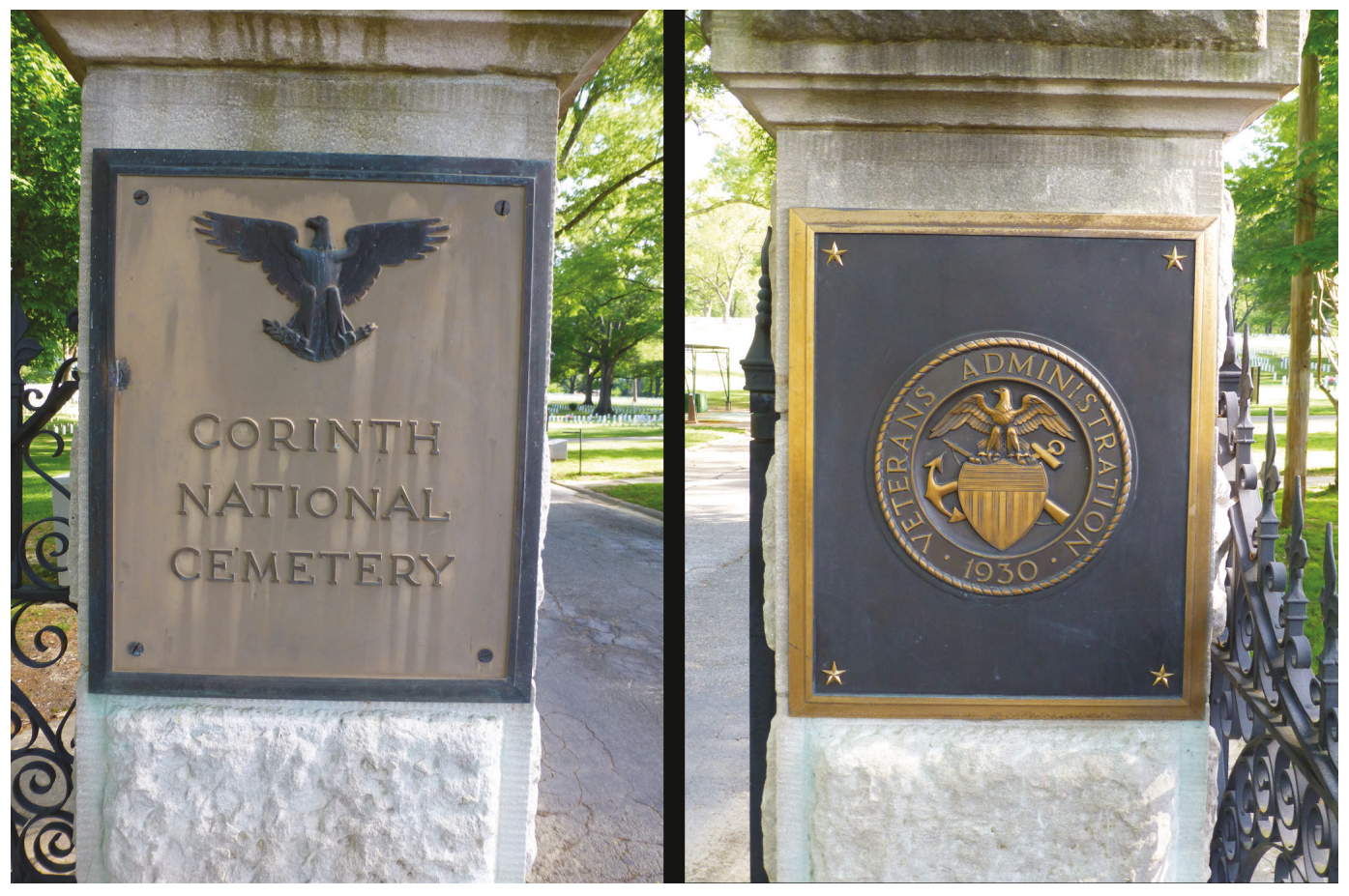


The entrance gate on the north side of the property is similar to the main gate, but with less ornamentation. It has three granite piers that support ornamented wrought-iron gates for one vehicle entrance and one pedestrian entrance. The stone used for these piers is smooth hewn, unlike the main entrance stonework. All these piers have peaked caps. Unlike the pedestrian entrances next to the south main gate, there is no sidewalk leading through this pedestrian gate (Figure 94).

Figure 94. North gates for vehicles and pedestrian at Corinth National Cemetery, 2018 (ERDC-CERL).

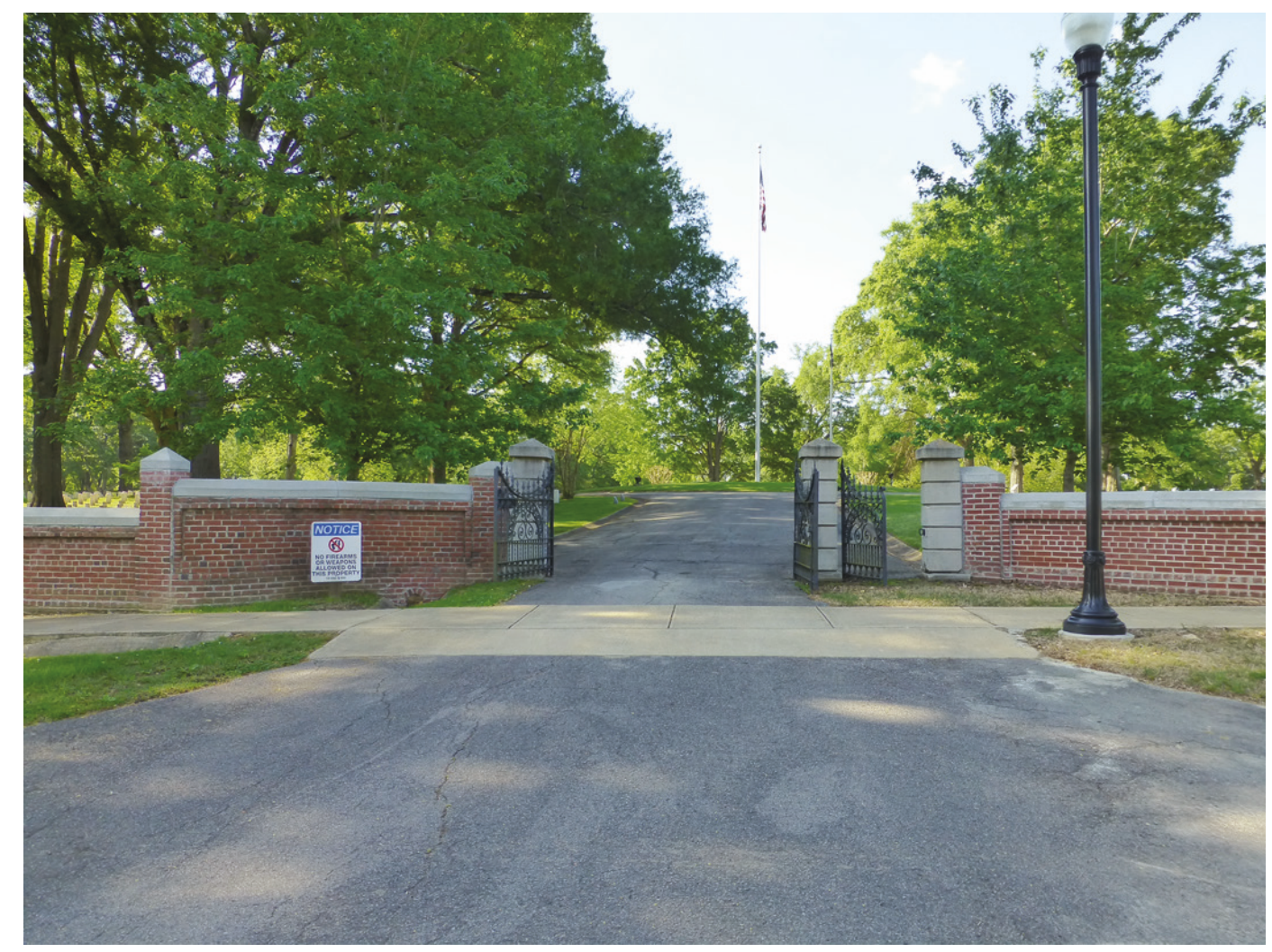

\subsubsection{Pedestrian-only gate}

An additional pedestrian gate is located in the south perimeter wall approximately 190 feet east of the main gate and near the Lodge and maintenance area. It is similar in style to the main gate's pedestrian entrances except that it features tall, roughhewn granite piers with wrought-iron finials on the tops. The gate is ornamental wrought iron and is not co-located with a vehicle entrance. Concrete steps lead up to the gate from the street and connect to one of the interior sidewalks in the cemetery (Figure 95Figure 96). 
Figure 95. An additional pedestrian gate on the south wall of the cemetery, is located near the Lodge, not adjacent to the main gate entrance as the other two pedestrian gates on the south wall are. The wrought-iron gate is propped open in this 2018 photo (ERDC-CERL).

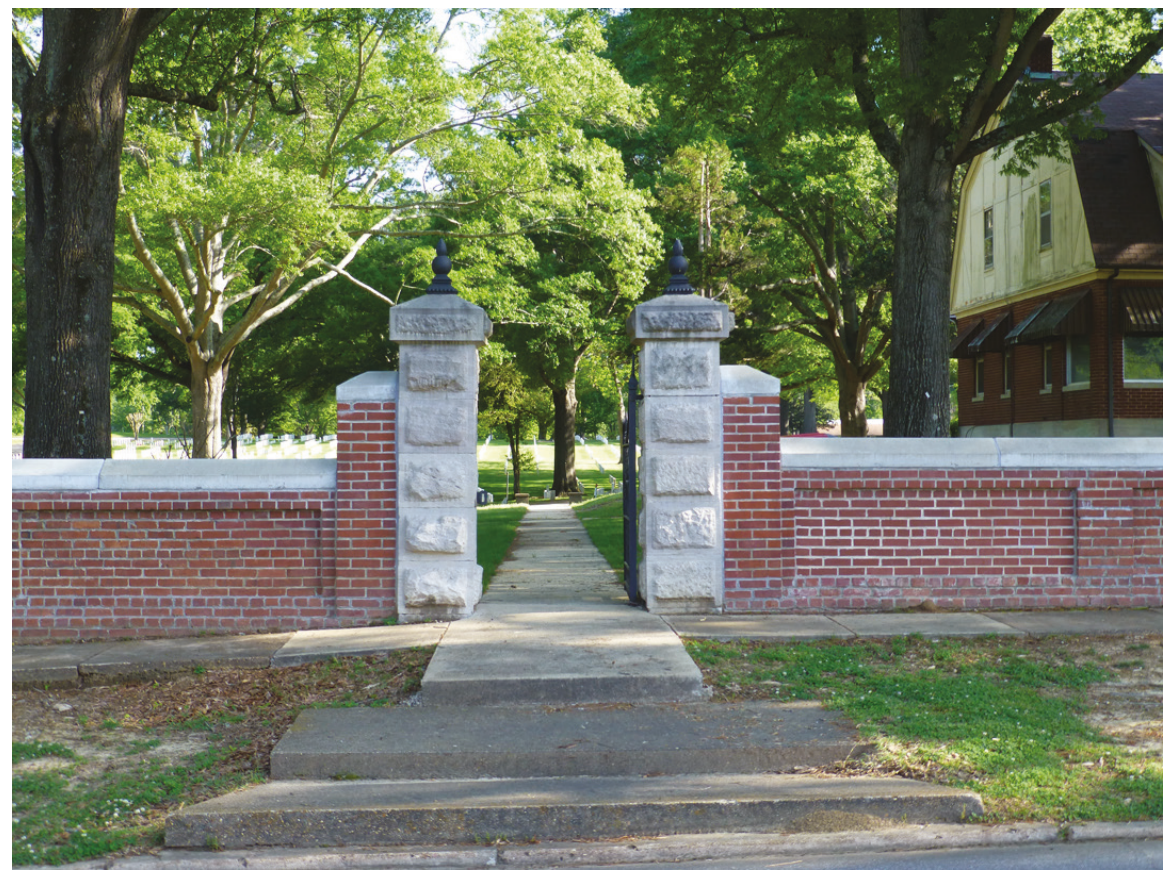

Figure 96. Gate and post detail on the additional south side's pedestrian-only gate, 2018 (ERDC-CERL).

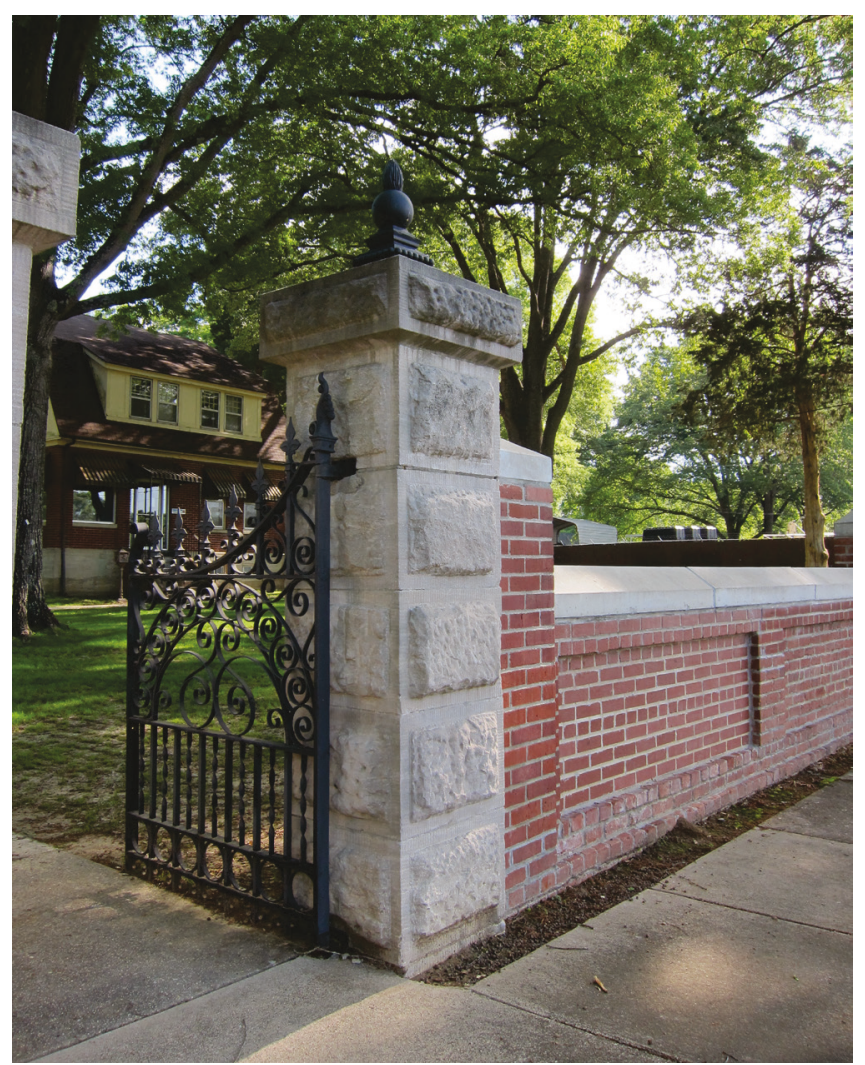




\subsubsection{Service gate}

The service gate for vehicles is also located on the south perimeter wall, and it is approximately 330 feet east of the main gate. It is similar in style to the main gate with roughhewn granite piers with peaked caps. It has two ornamental wrought iron gates. The maintenance area chain link gate is located directly behind the service gate. There is a newer concrete drive and sidewalk that connects the street through this gate (Figure 97).

Figure 97. The service gate on the south wall, 2018 (ERDC-CERL).

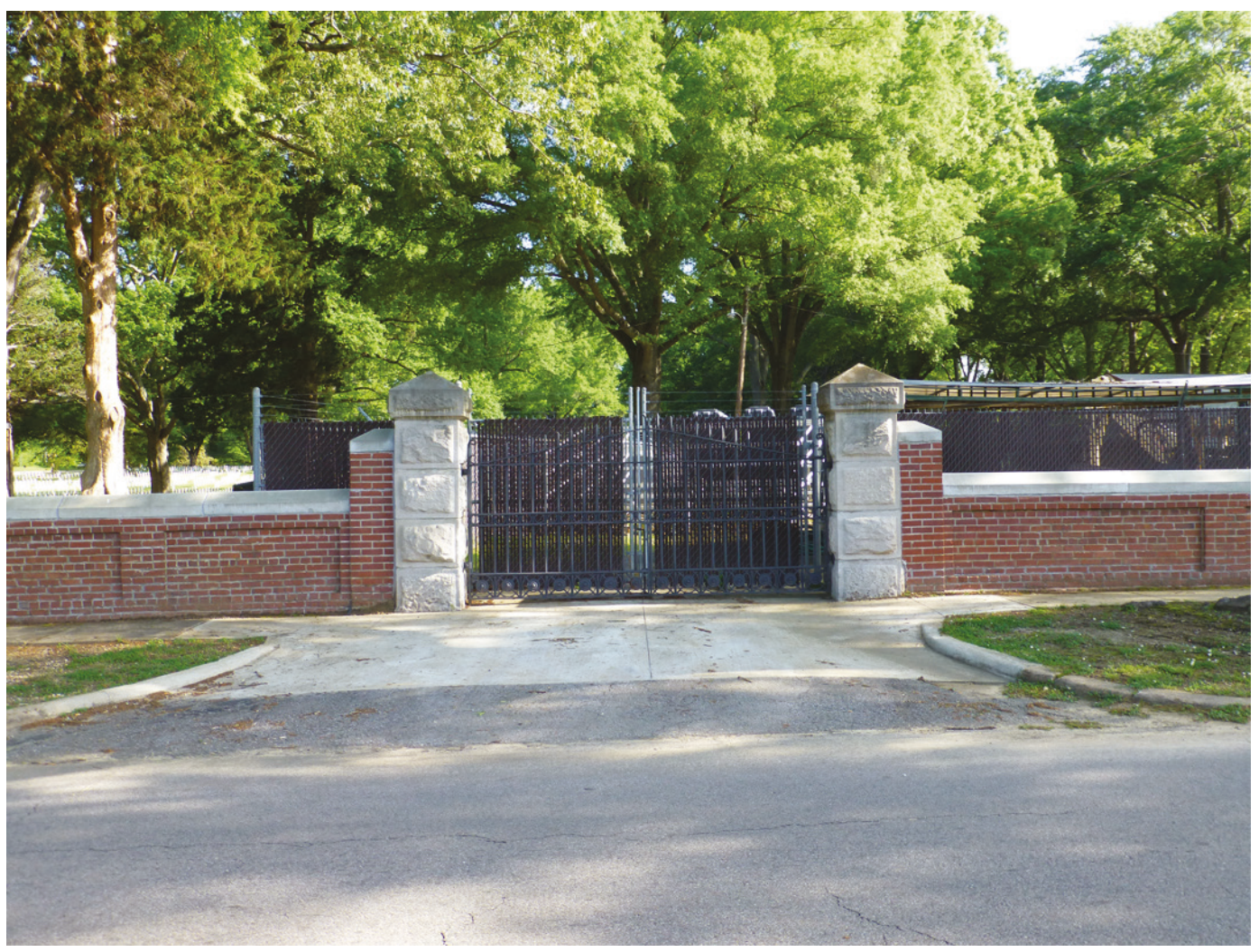

\subsubsection{Committal shelter}

The committal shelter is located on the west side of the main road through the cemetery. It is north of the main entrance by about 120 feet. The rectangular committal shelter is constructed of triangular metal supports at the four corners. It has a standing seam metal roof. The structure covers a painted green concrete pad that has a casket stand. The area is surrounded by white river rock and landscape timbers (Figure 98). 
Figure 98. Looking south at the committal shelter near the south main gate, 2018 (ERDC-CERL).

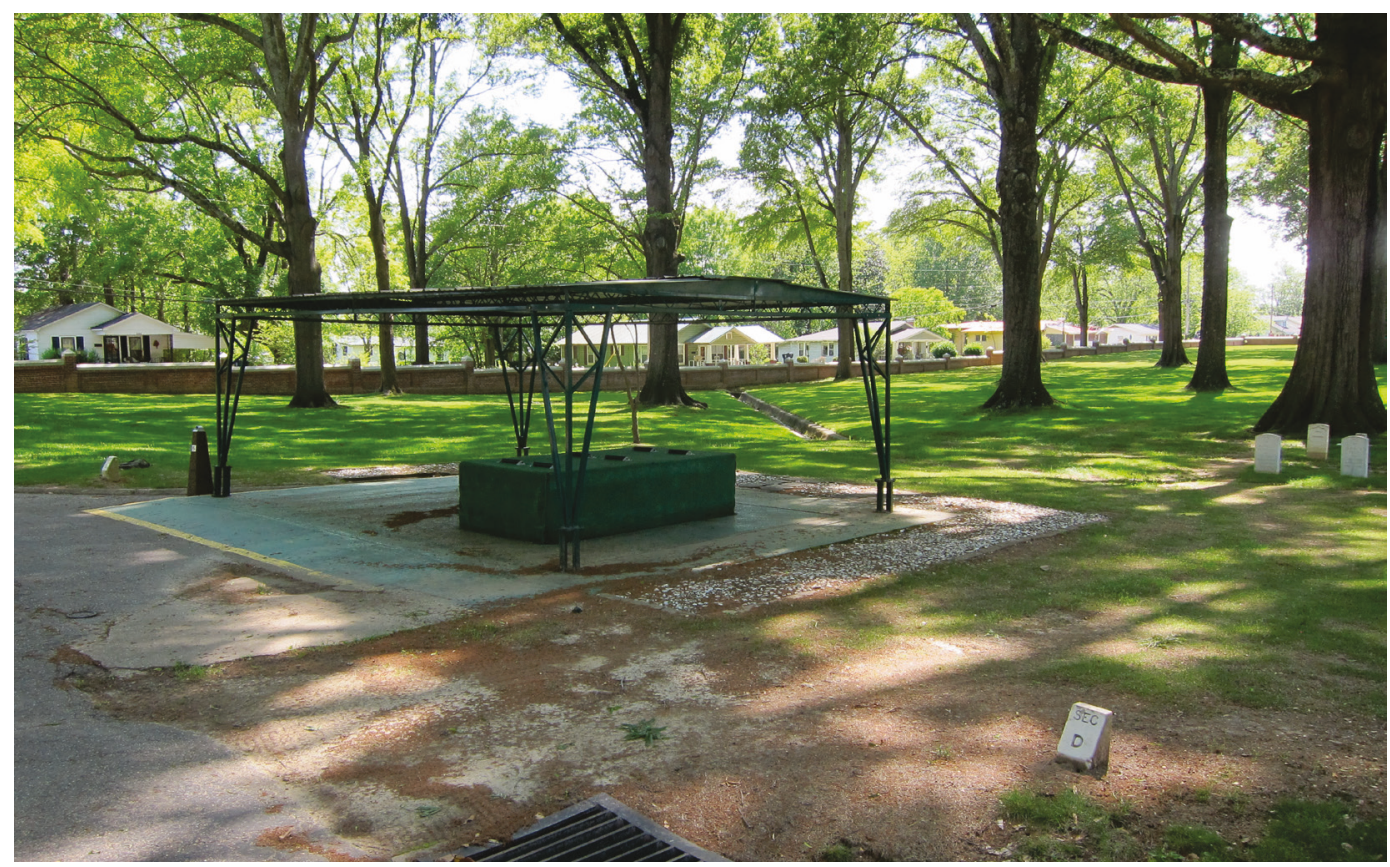

\subsubsection{Maintenance structures}

There are three storage structures in the maintenance area. All have roofs with open sides (Figure 99-Figure 101).

Figure 99. Storage shed in the maintenance area, 2018 (ERDC-CERL).

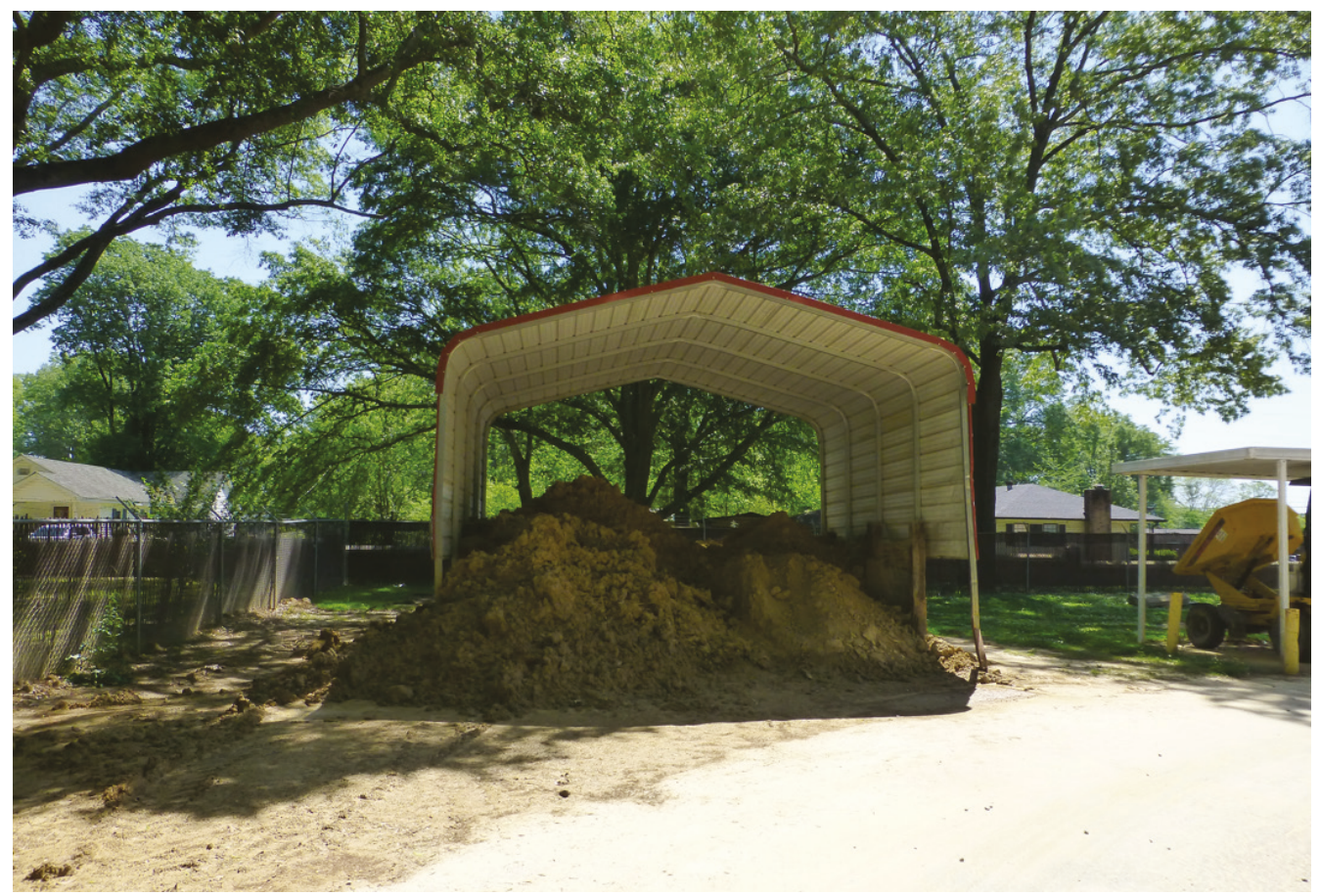


Figure 100. In the maintenance area is an open-air storage shelter for machinery, 2018 (ERDC-CERL).

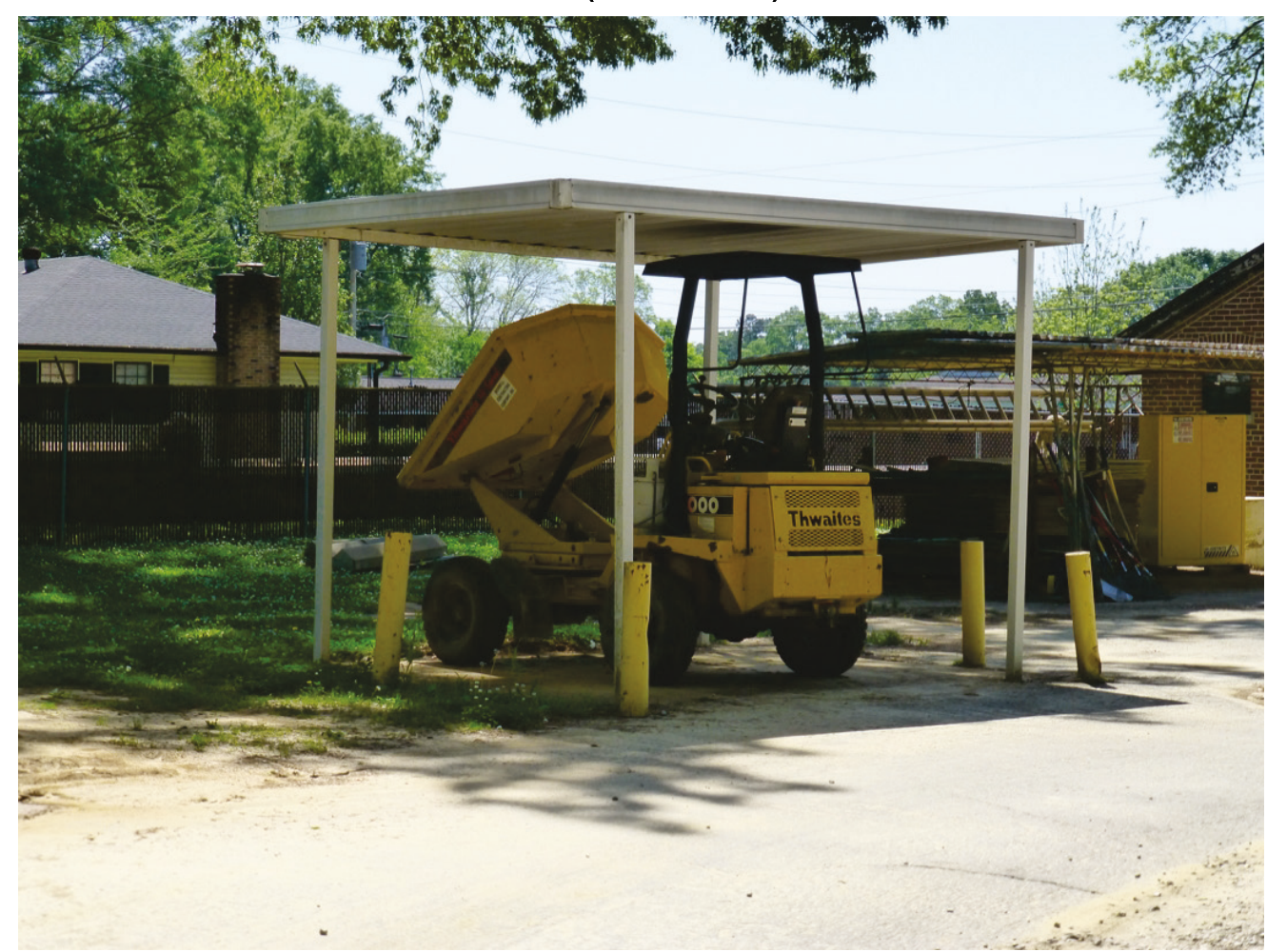

Figure 101. To the left of the maintenance building is another open-air storage shelter, 2018 (ERDC-CERL).

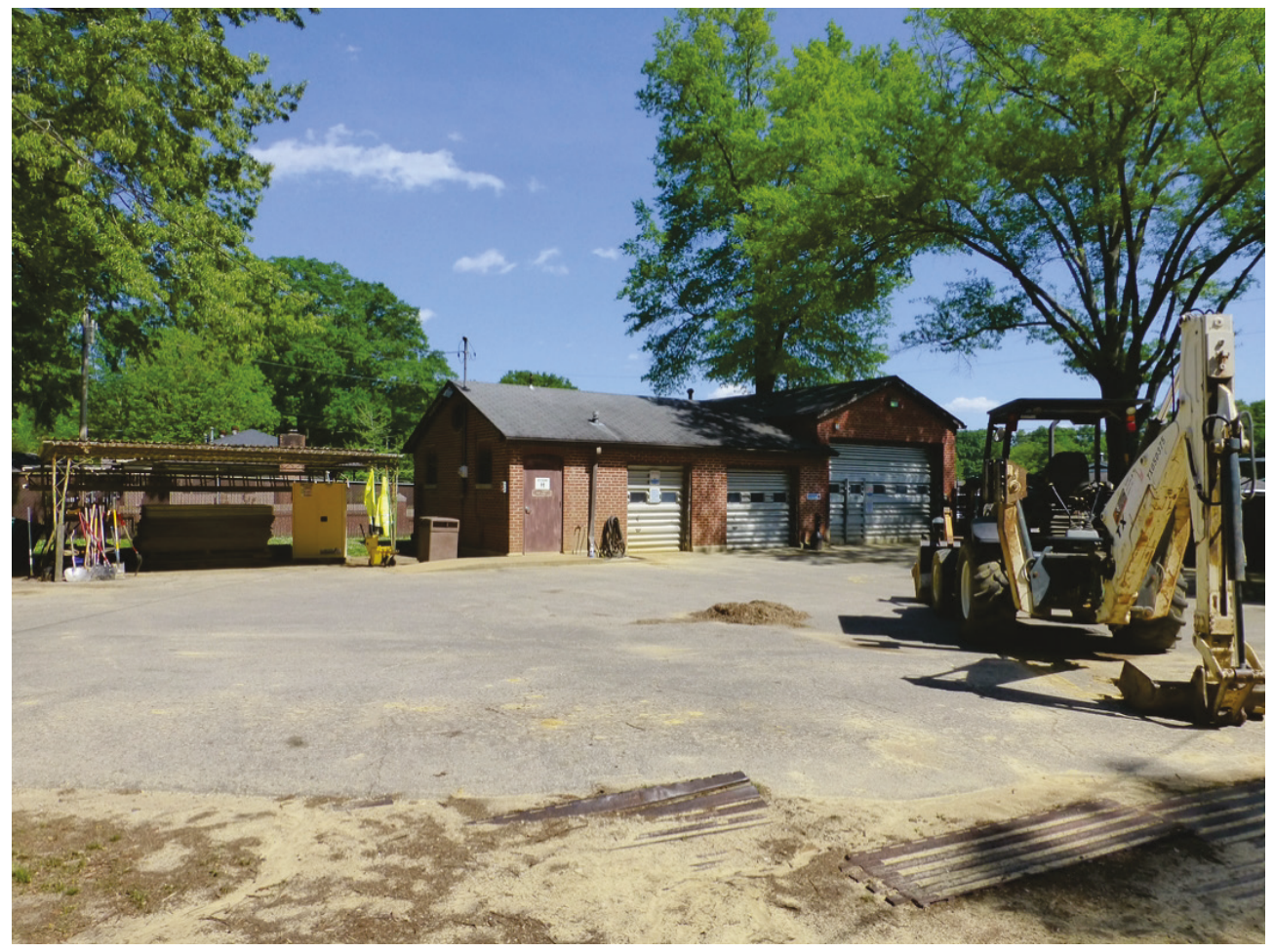




\subsubsection{Objects}

The National Register defines an "object" as an element distinct from buildings and structures and "those constructions that are primarily artistic in nature or are relatively small in scale and simply constructed." 139 There are three predominate objects at Corinth National Cemetery-the headstones, the flagstaff, and the monuments that are placed throughout the cemetery.

\subsubsection{Headstones}

The headstones at Corinth National Cemetery are grouped into $21 \mathrm{sec}-$ tions. In all sections, the headstones now face east. ${ }^{140}$ The original configuration of headstones had seven sections that featured the headstones arrayed in specific geometric patterns. Currently, all but one of those patterns are no longer distinct because they have been filled in with new burials.

The War Department adopted the Civil War-type headstone in 1873. The headstone consisted of white marble slab that measured 12" high, 10" wide, and 4 " thick, with a rounded top. A shield was cut into the face, and it contained the grave number, soldier rank, soldier name, and home state's name in bas relief (Figure 102, center and right). This type of headstone was used to mark the graves of soldiers killed during all conflicts through the Spanish-American War. In 1903, the headstone's size was increased to 39" high and 12" wide, but still 4 " thick (Figure 102, left). At Corinth National Cemetery, headstones that have been displaced by tree growth have been re-laid to be flat to the ground (Figure 103). In the memorial section of the cemetery that is northeast of the flagstaff mound, there are six Confederate grave markers. These markers have a peaked top that delineates them from the Union grave markers (Figure 104).

\footnotetext{
139 NPS, National Register Bulletin \#15, 1997, 5. Accessed online: https://www.nps.gov/nr/publications/bulletins/nrb15/nrb15_4.htm\#site.

140 Sometime between 1892 and 1953, the headstones were reversed from facing west to facing east. The date for this change could not be determined due to the lack of archival material from this period.
} 
Figure 102. Rows of Civil War headstones featuring the original dimensions and layout of the markers in the center and right of the photo. Markers on the left show the wider and taller dimensions, 2018 (ERDC-CERL).

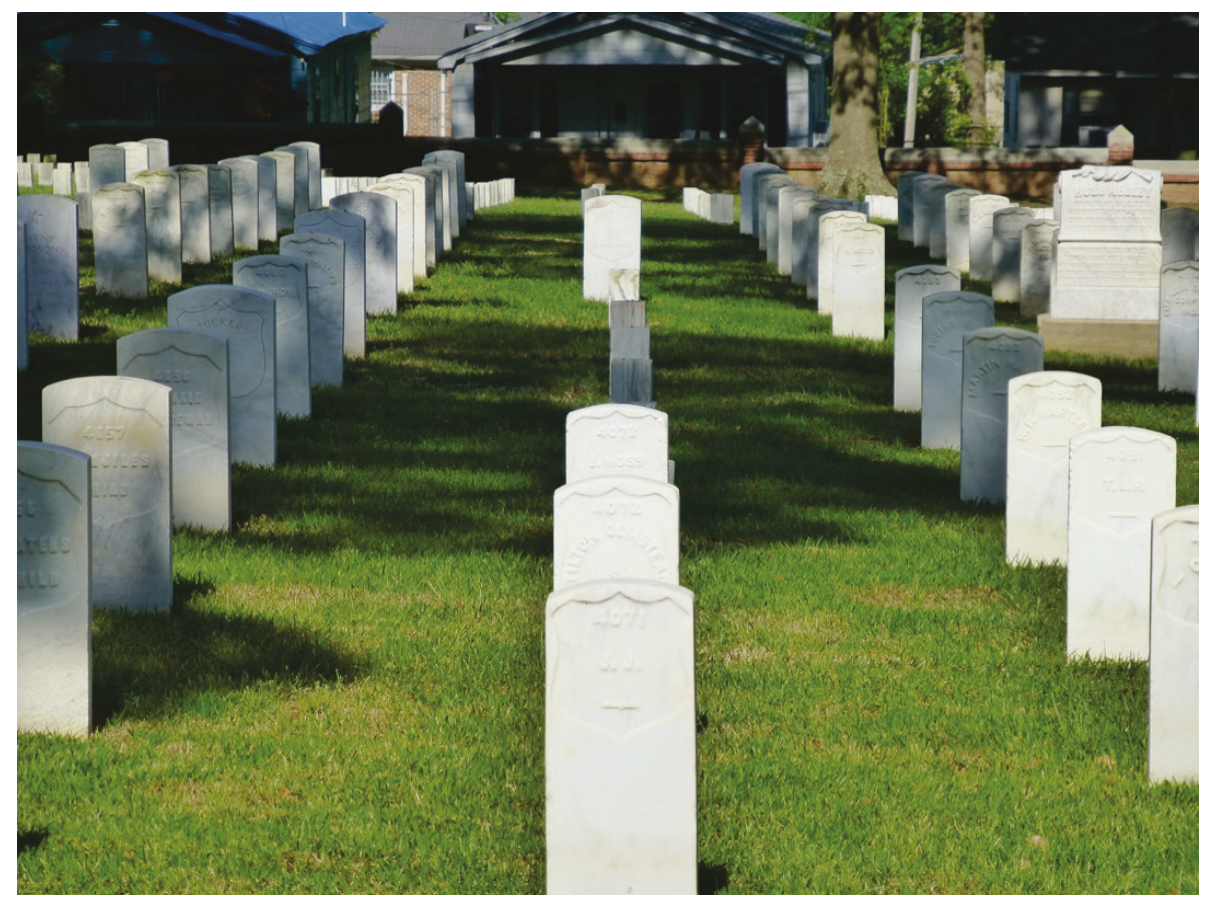

Figure 103. Grave markers displaced by tree growth were laid flat to the ground near their original locations, 2018 (ERDC-CERL).

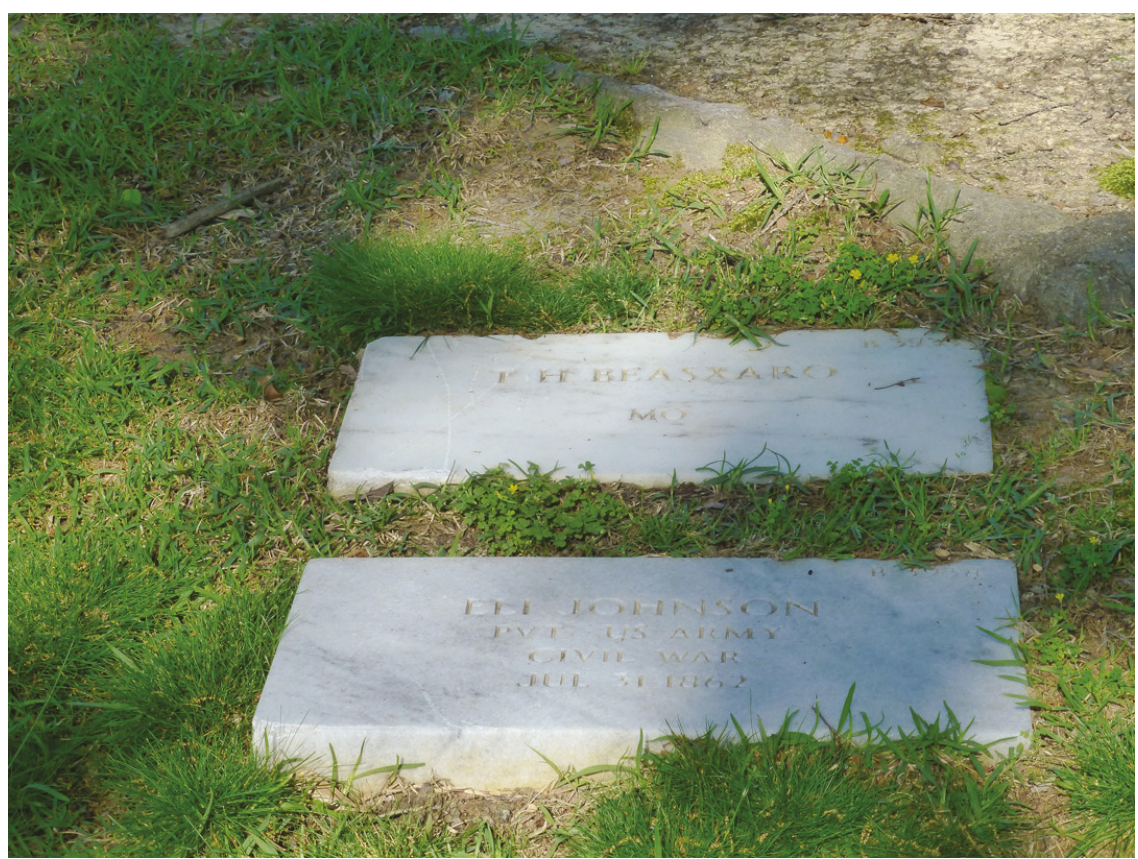


Figure 104. Example of one of the Confederate grave markers in Corinth National Cemetery, 2018 (ERDC/CERL).

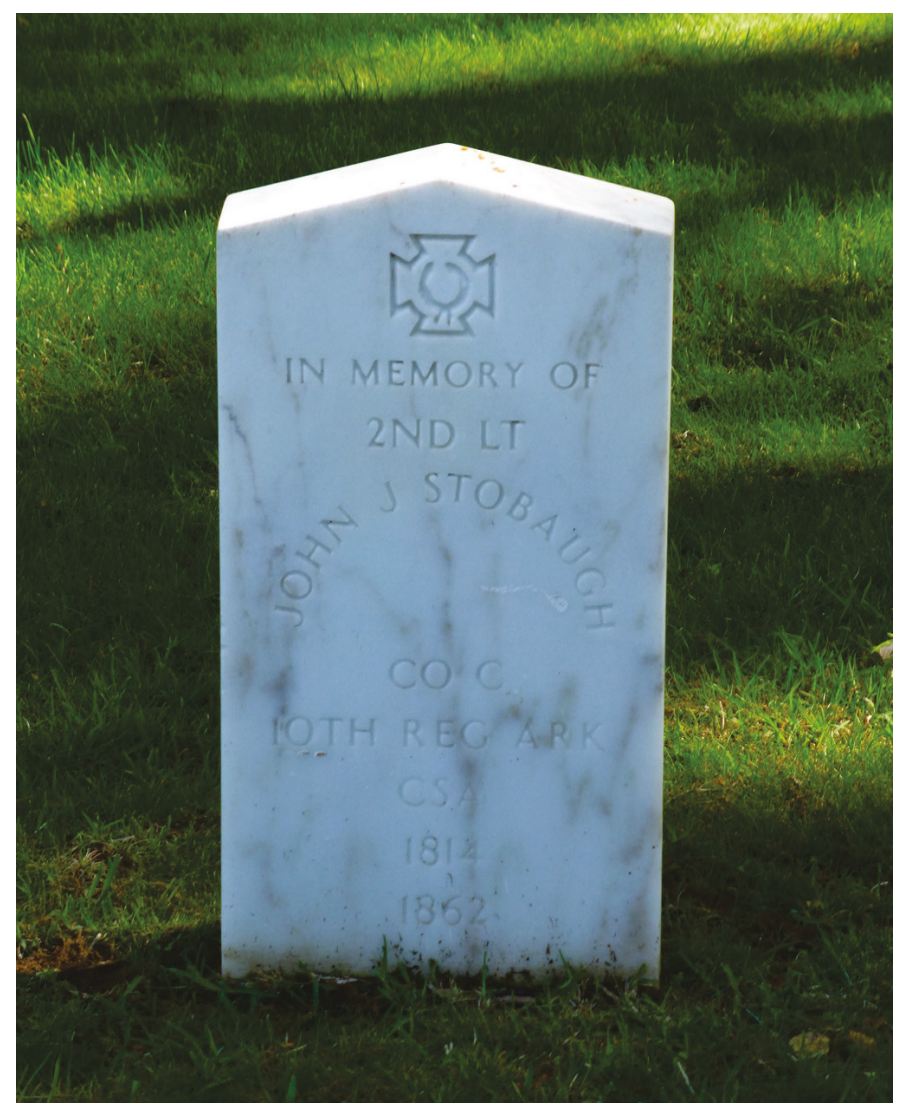

For the Union Civil War unknown dead, headstone design is a marble block six inches square and 30 inches high (Figure 105). The top and upper four inches were dressed, and the grave number was inscribed into the block's top (Figure 106). The unknown headstones at Corinth have been raised (Figure 107). The War Department discontinued use of the unknown type of headstone in 1903. 
Figure 105. Section of Civil War unknown dead, 2018 (ERDC-CERL).

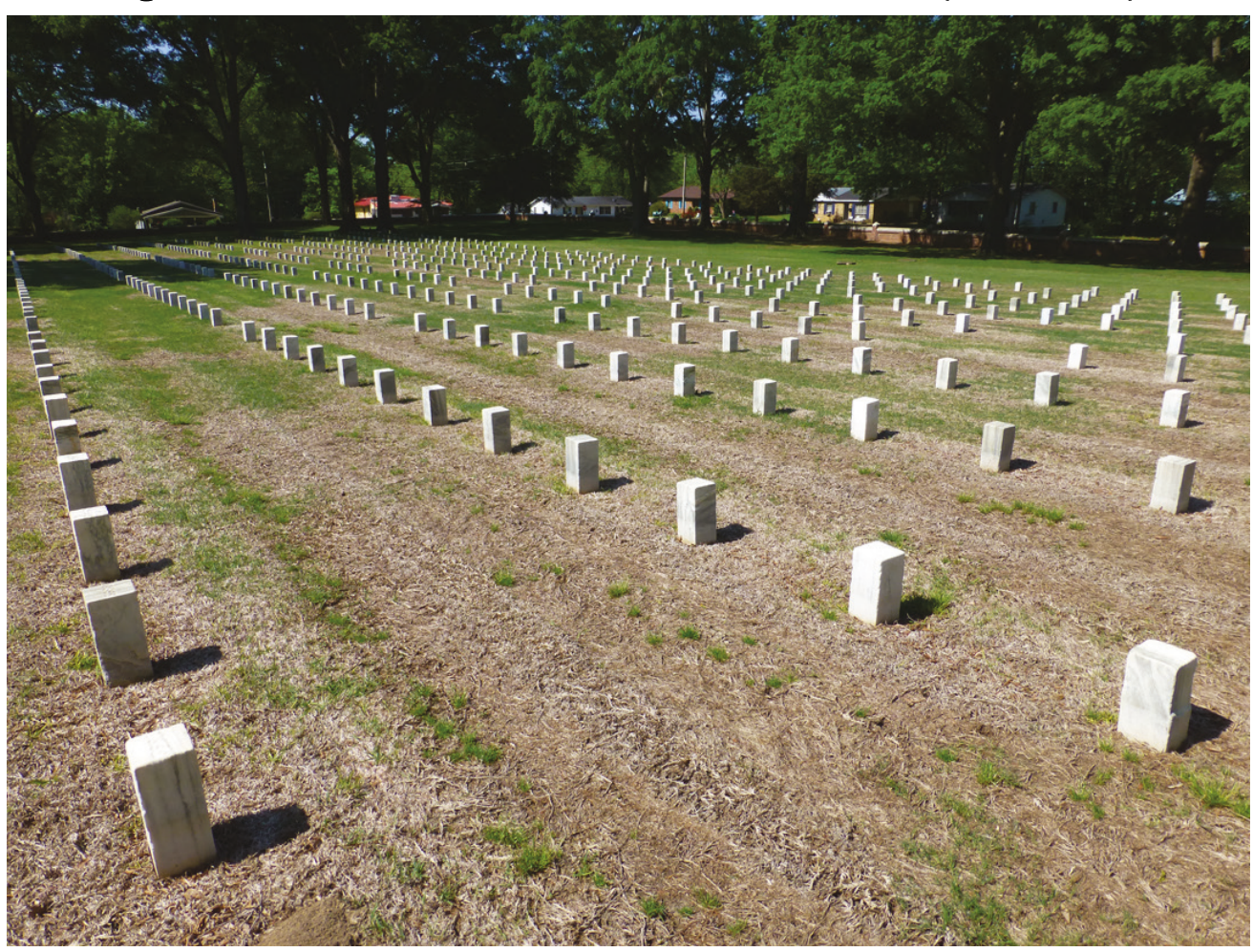

Figure 106. Civil War unknown dead marker, with grave number inscribed on the top face, 2018 (ERDC-CERL).

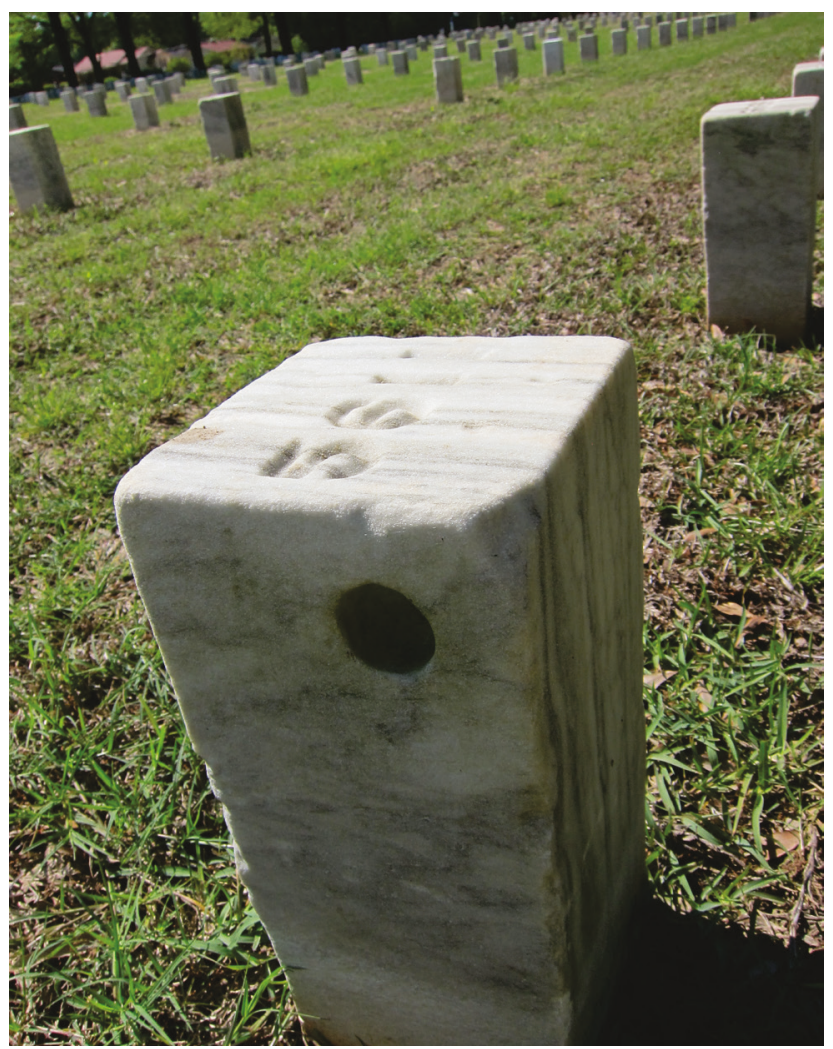


Figure 107. The Civil War unknown dead grave markers have been raised, 2018 (ERDC-CERL).

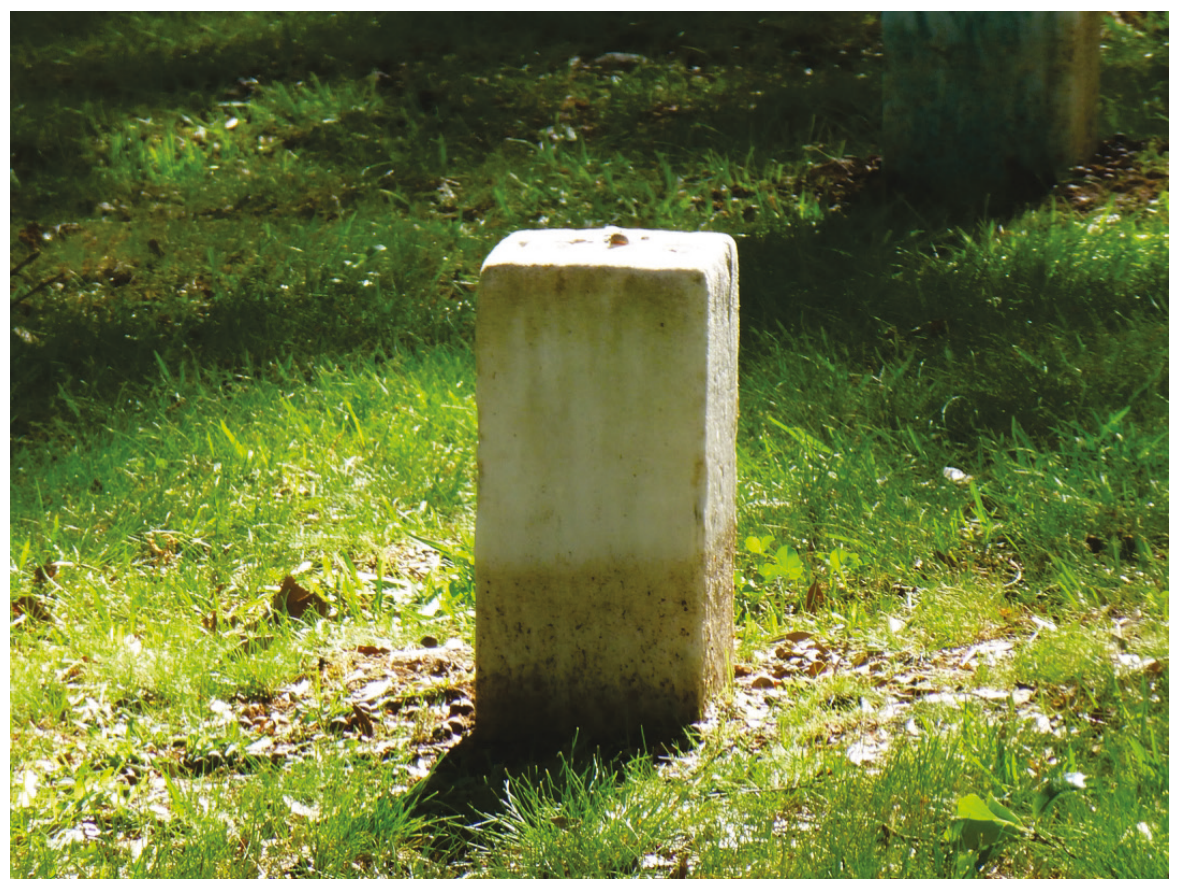

The War Department started using the general type of headstone after World War I. The headstone consisted of white marble that was 42" high, 13 " wide, and 4" thick, and it had a rounded top (Figure 108). The general type is now used for all headstones at Corinth National Cemetery. New stones are intermingled with old stones. 
Figure 108. The original design of gravestones mixed with the new style of markers, 2018 (ERDC-CERL).

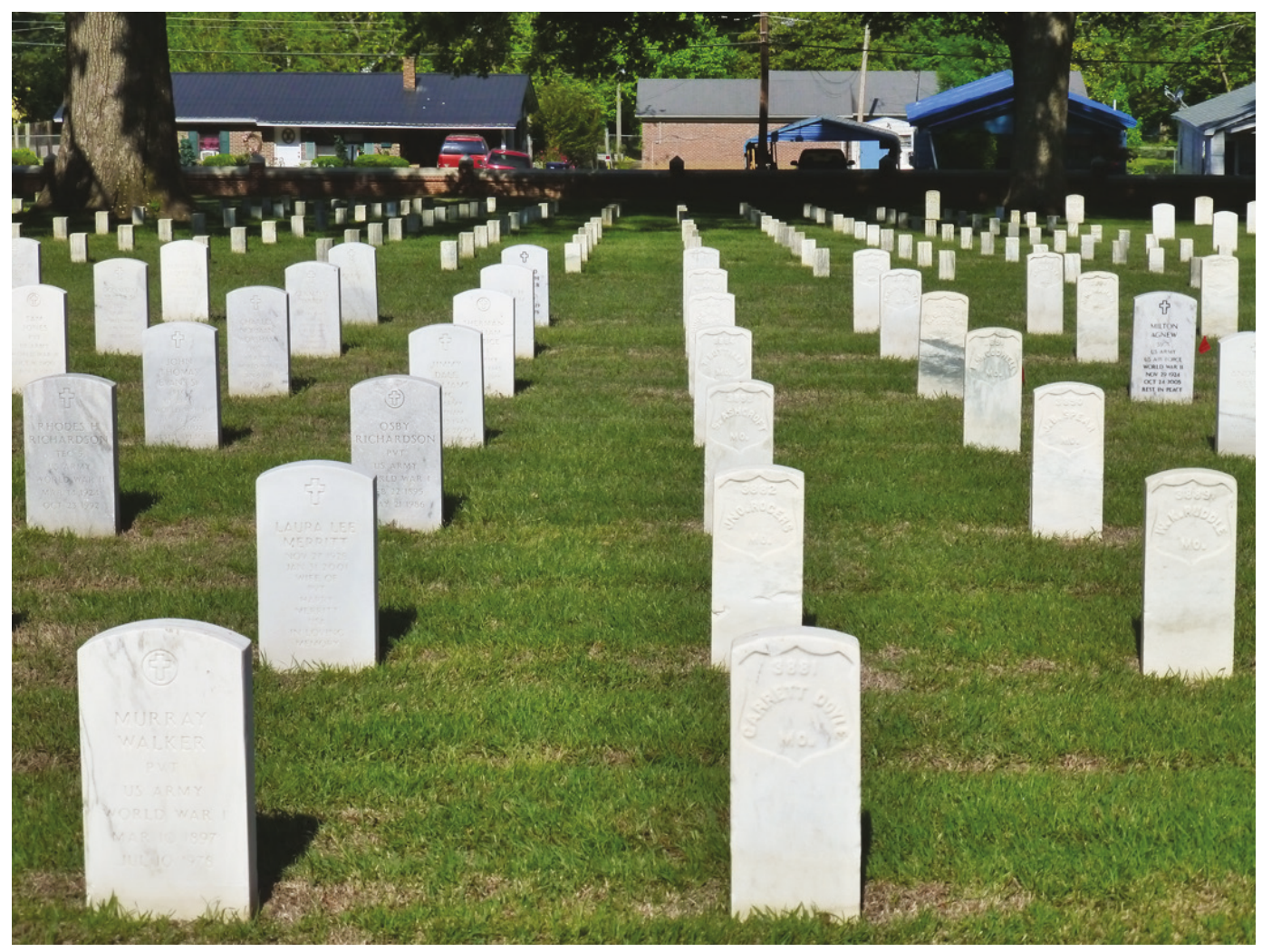

There are a few nongovernment-furnished headstones in the cemetery. The stones honor a Civil War private who died in a hospital near Corinth (Figure 109), a former superintendent (Figure 110 and Figure 111), and someone who died in 1884 (Figure 112). 
Figure 109. Nonstandard grave marker for Ross Negley, who died in 1862, 2018 (ERDC-CERL).

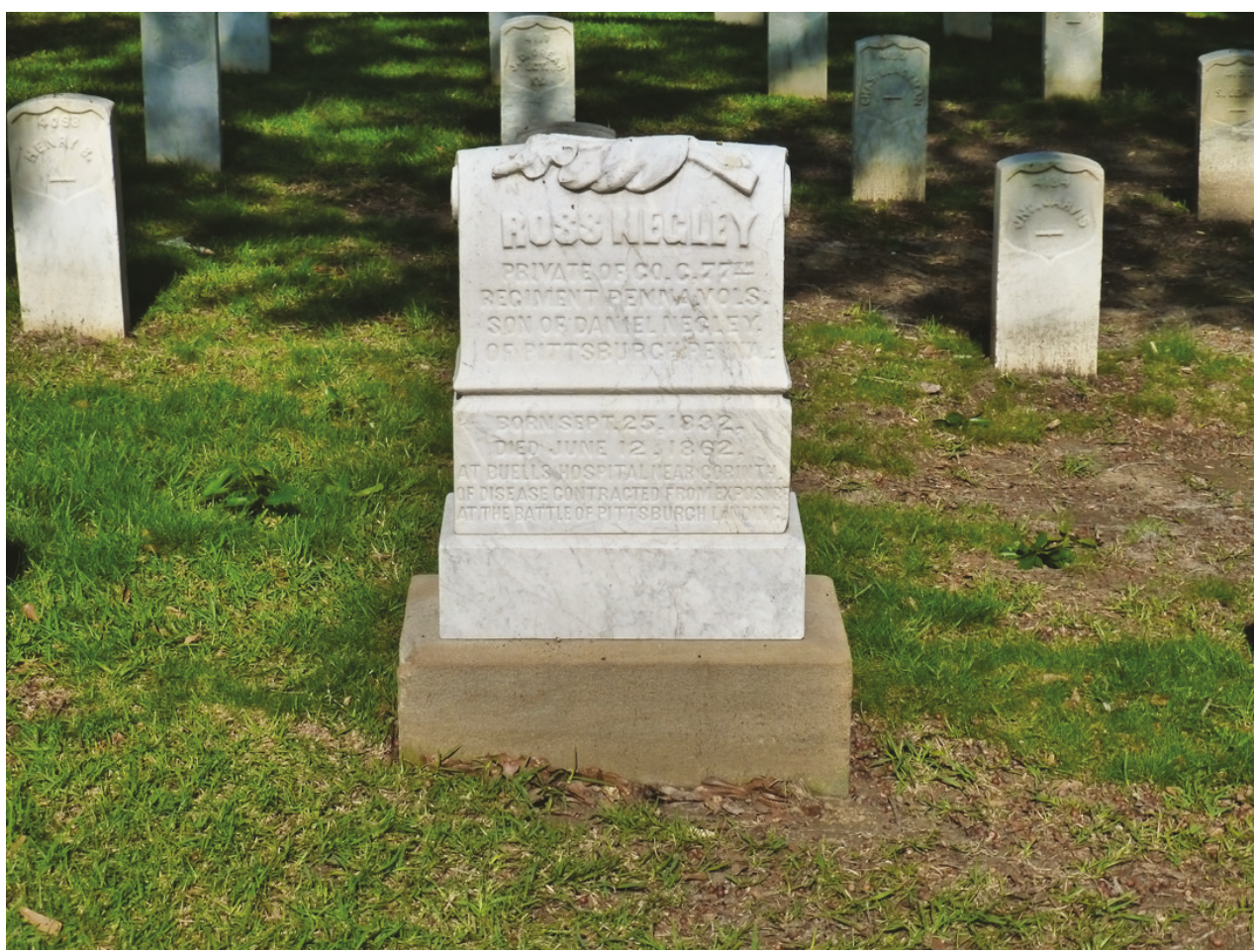

Figure 110. Grave marker for Rufus Taylor, superintendent of Corinth National Cemetery, who died in 1929, 2018 (ERDC-CERL).

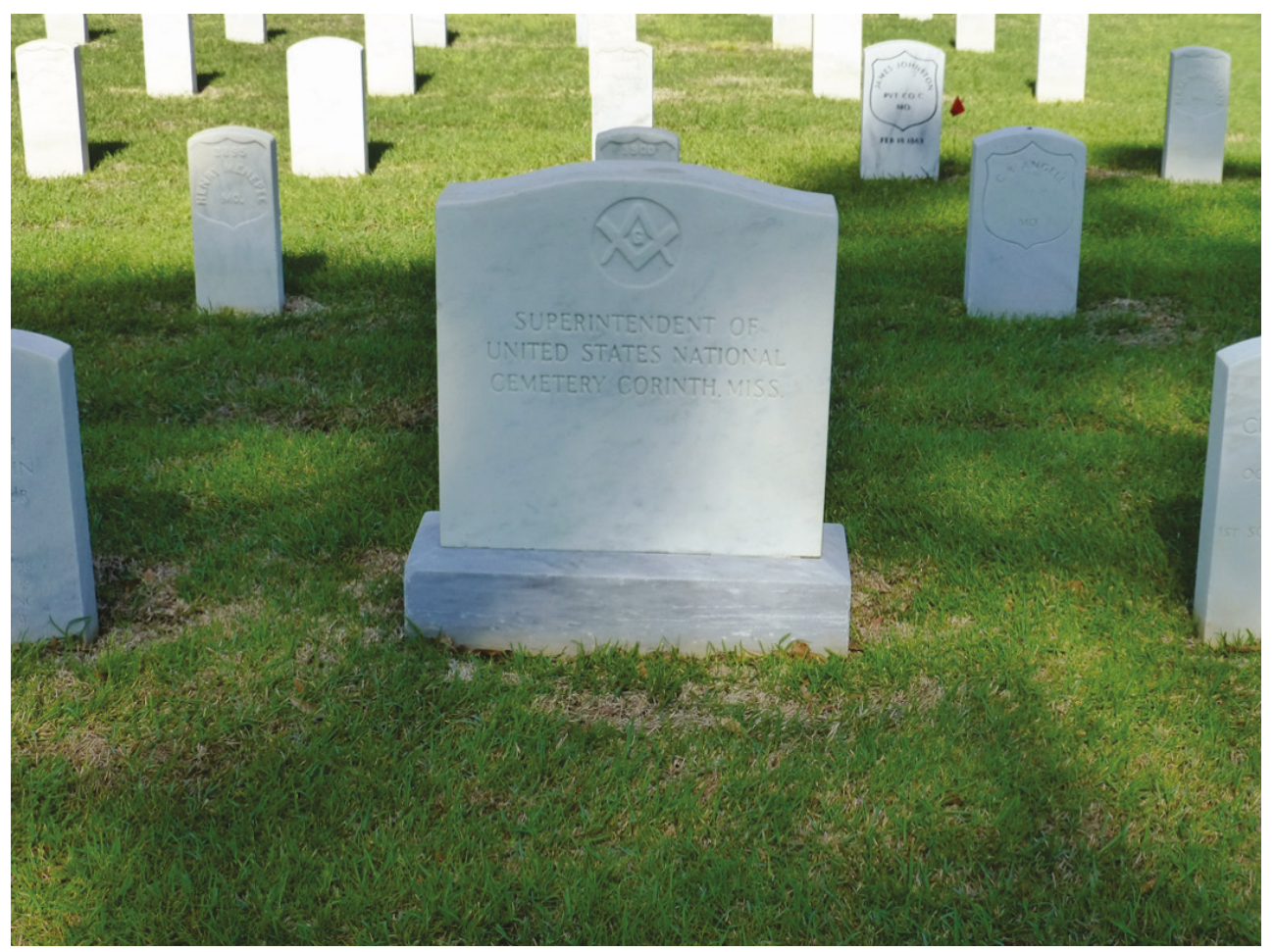


Figure 111. Non-standard grave maker design for Superintendent Rufus Taylor, 2018 (ERDC-CERL).

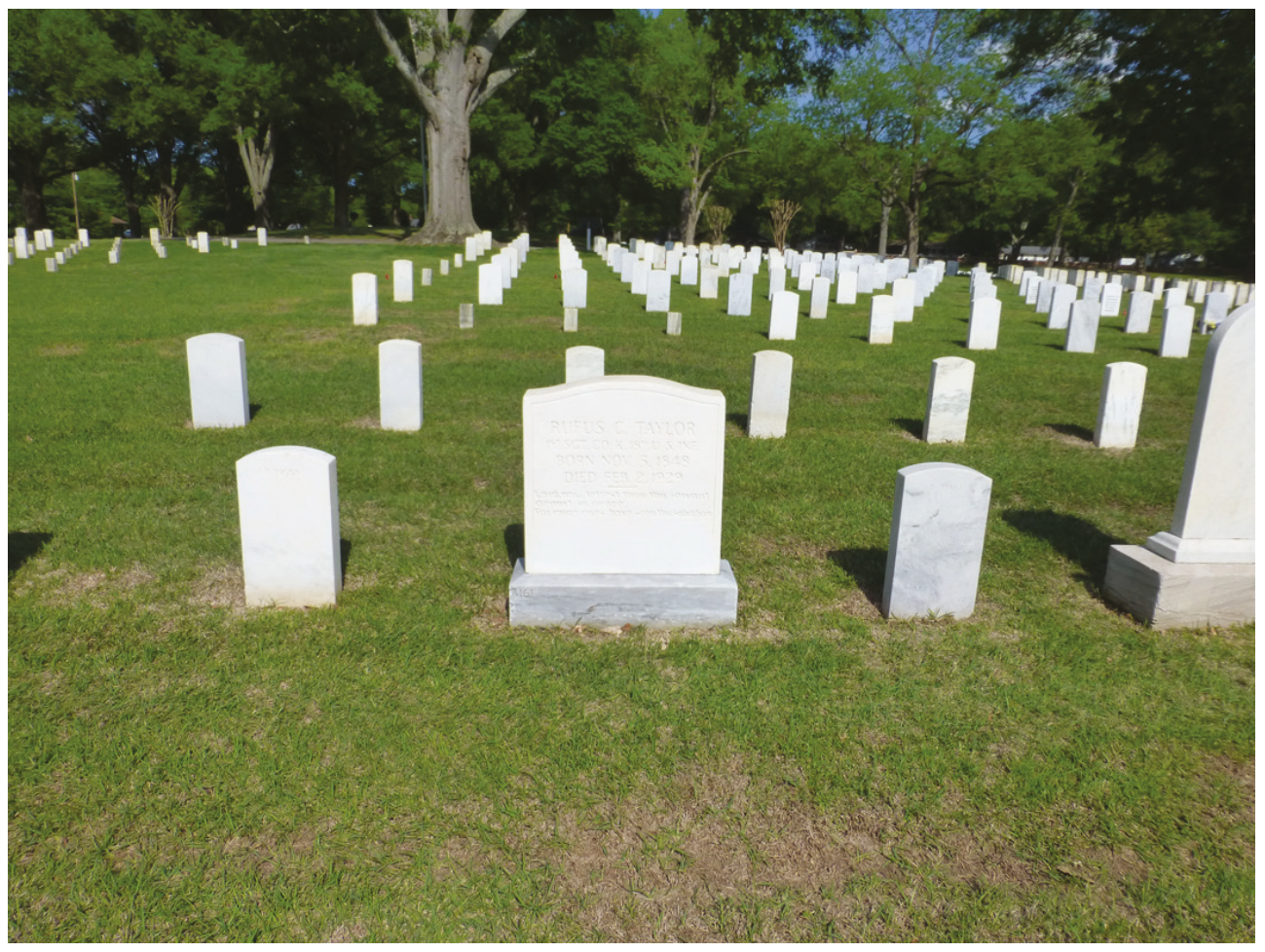

Figure 112. Non-standard grave marker, 2018 (ERDC-CERL).

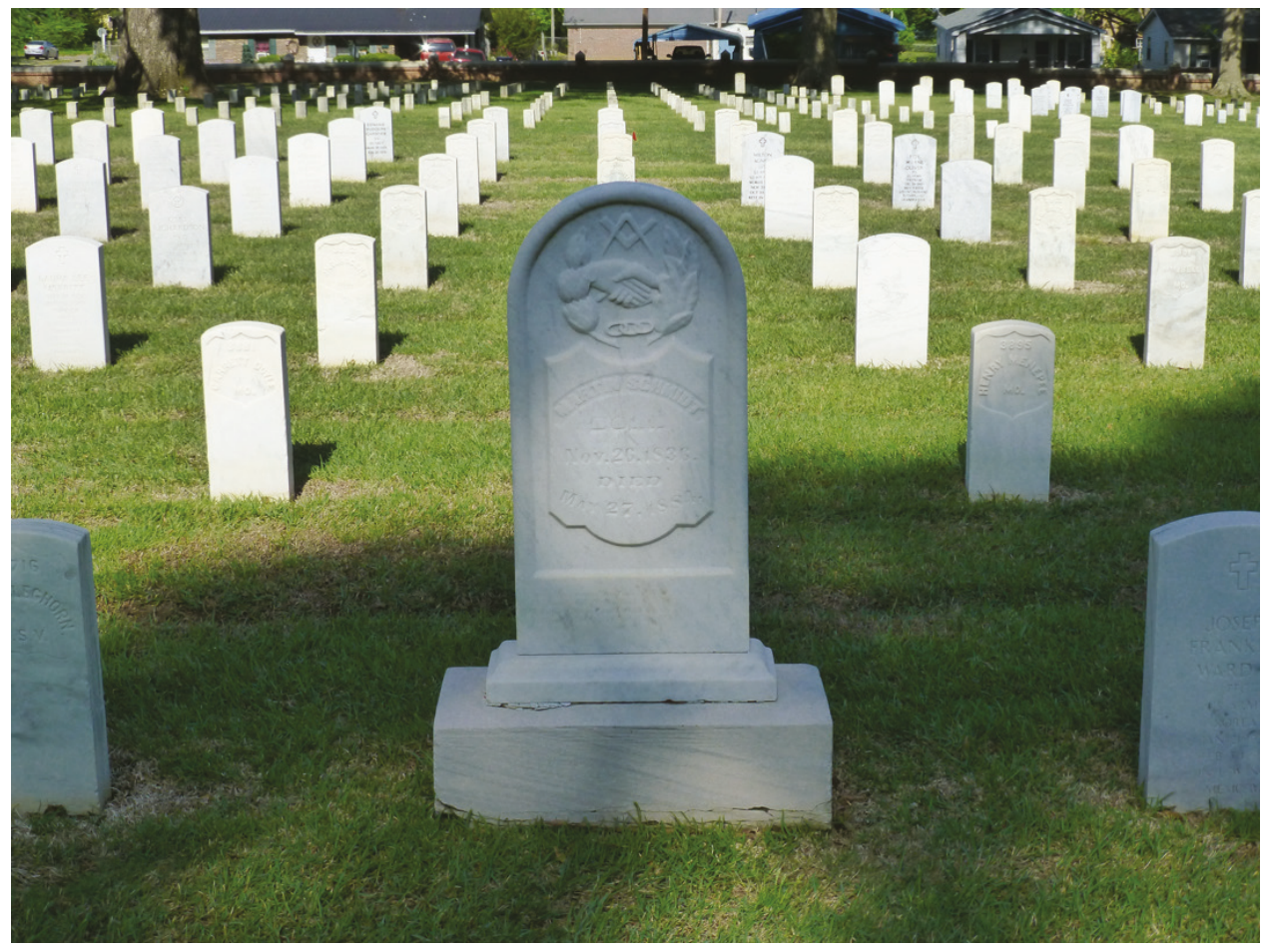




\subsubsection{Flagstaffs}

There are two flagstaffs in the Corinth National Cemetery. They are located on a mound in the northern section of the cemetery. The main road encircles the mound. The tallest flagstaff, that flies the American flag, is located at the center of the mound. The second flagstaff is located about 15 feet west of the main flagstaff (Figure 113).

Figure 113. View looking south at the flagstaff mound, 2018 (ERDC-CERL).

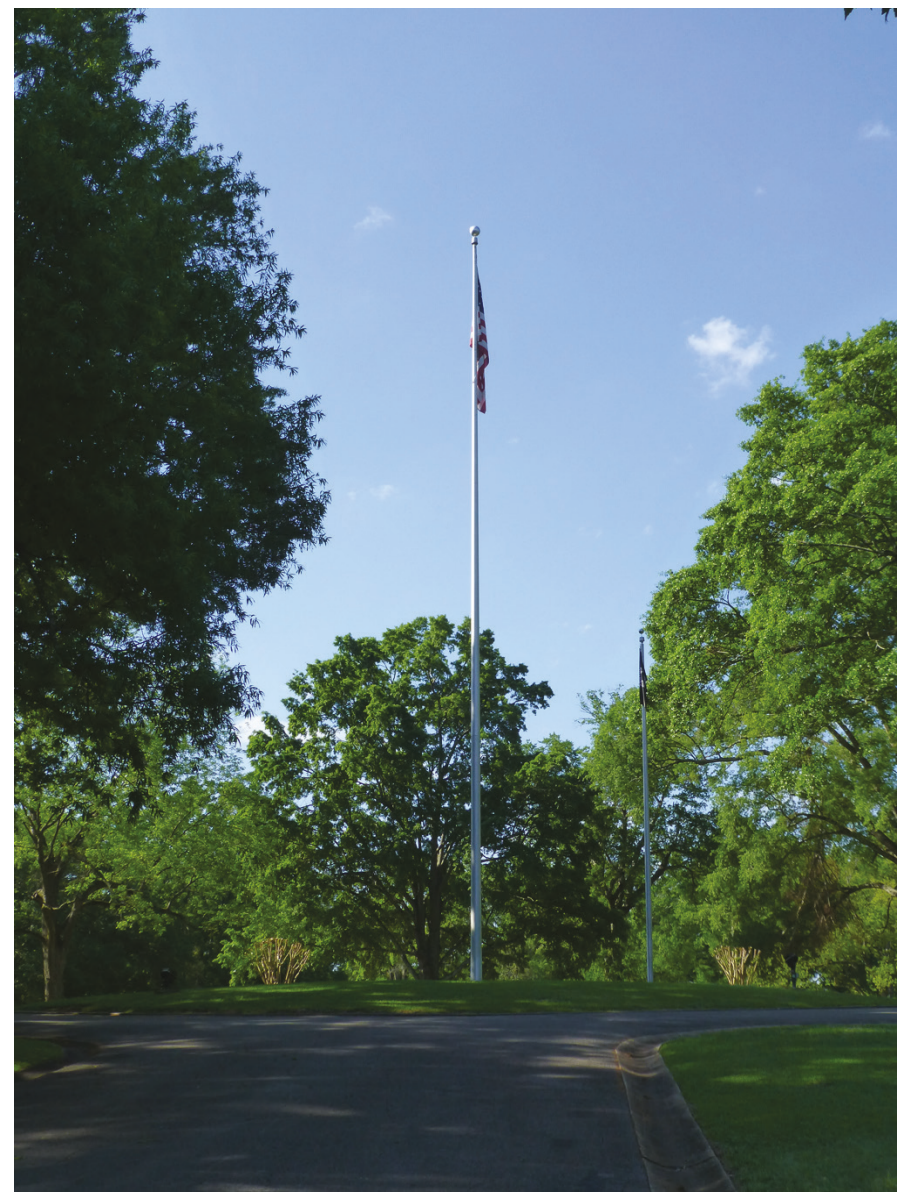

\subsubsection{Monuments}

There are several monuments in the cemetery. There is a grouping of headstones northeast of the flagstaff mound that honors Union and Confederate veterans whose remains could not be recovered or those whose remains could not be identified (Figure 114). In that section there are 16 headstones and one granite explanatory marker with a bronze plaque (Figure 115). 
Figure 114. Grouping of memorial headstones north of the Corinth flagstaff mound, 2018 (ERDC-CERL).

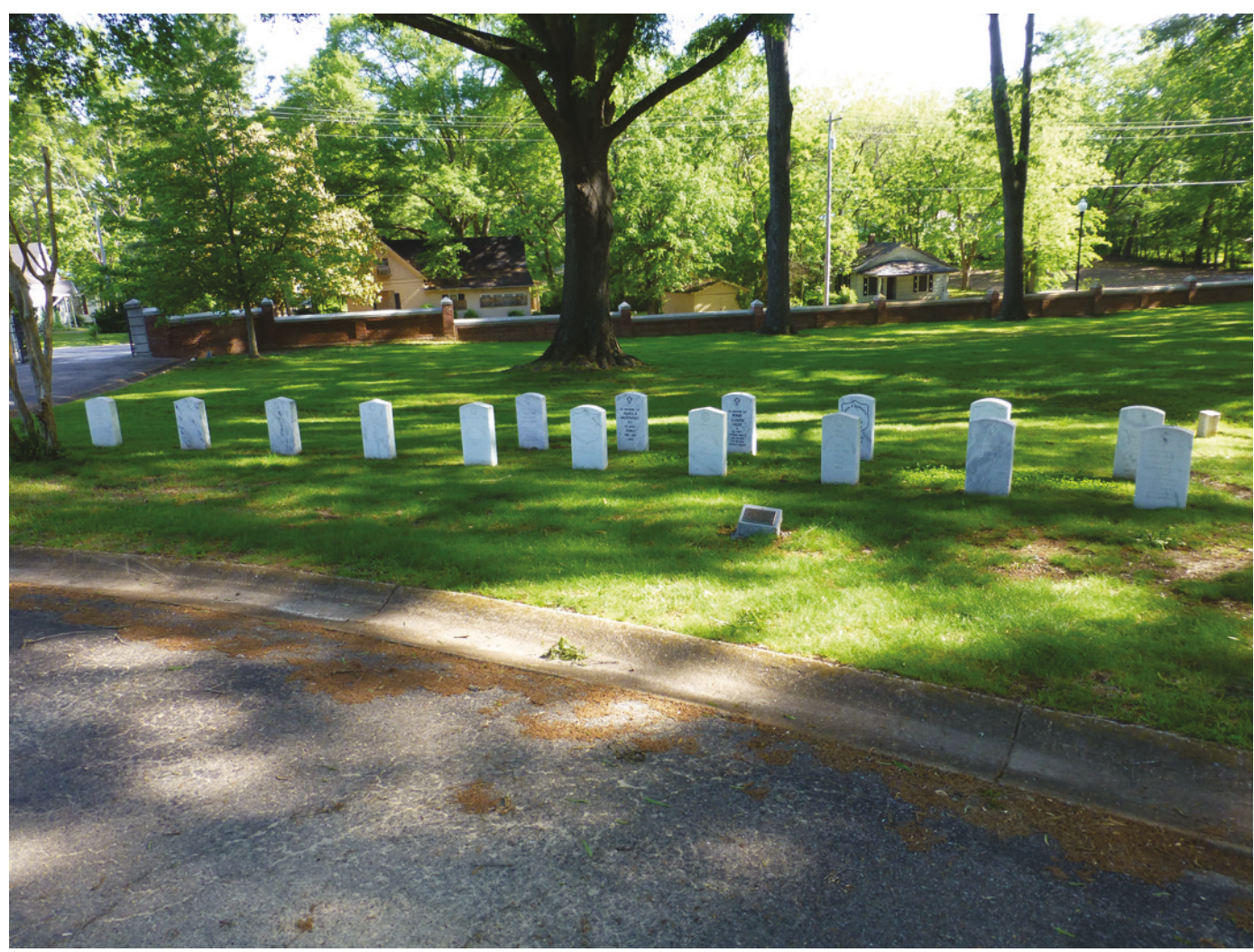

Figure 115. Granite marker with explanatory text for the memorial area in Corinth National Cemetery, 2018 (ERDC-CERL).

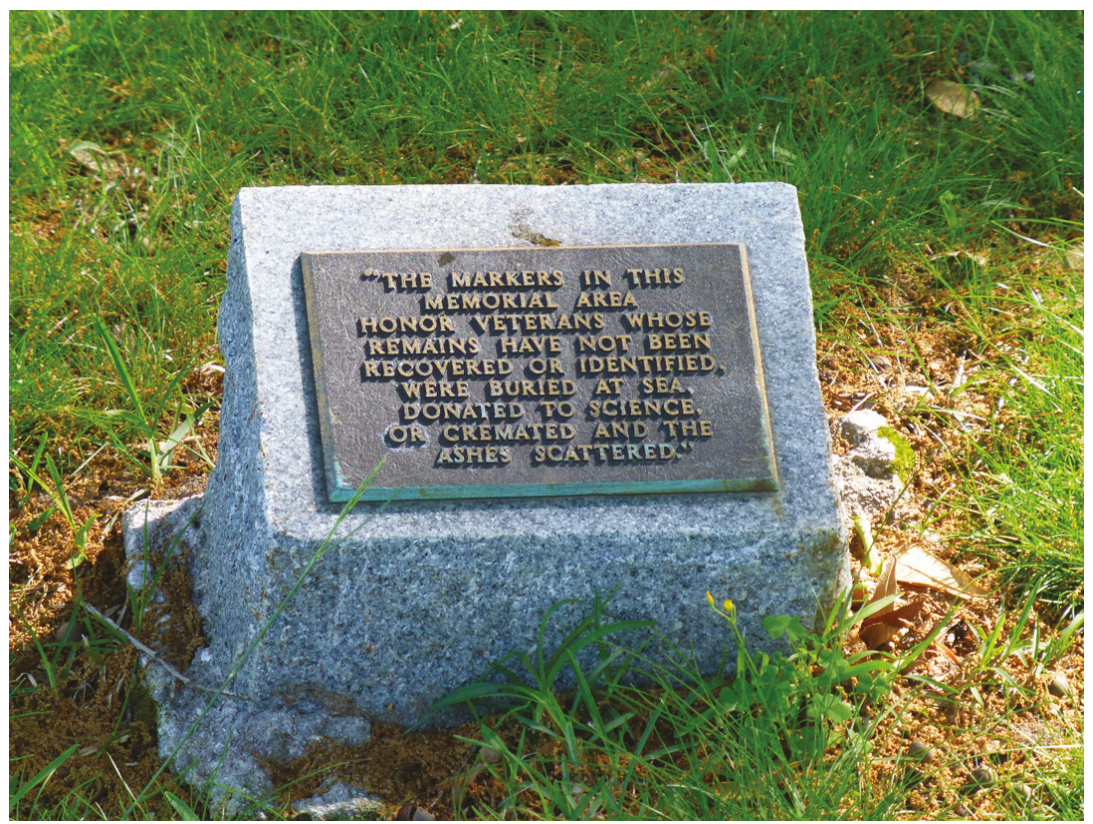


There is a monument to the Navy Seabees northeast of the main entrance. The monument was donated by the Navy Seabees of America. It is a granite cube with text engraved in the top surface (Figure 116). The monument was placed in 2016. ${ }^{141}$

Figure 116. Navy Seabee memorial, 2018 (ERDC-CERL).

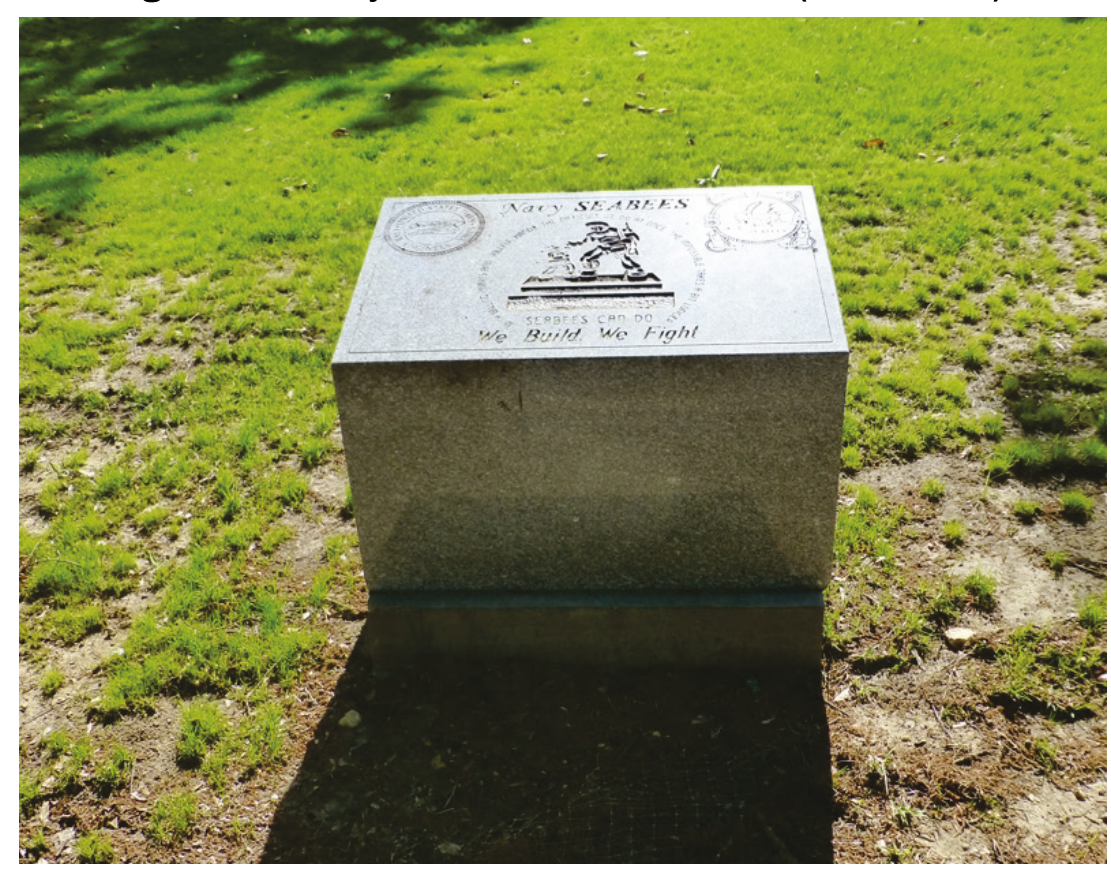

\subsubsection{Small-scale features}

Small-scale features are elements in the landscape that are intentionally placed and serve a prosaic purpose. Small-scale features are integral to how people use and navigate a site.

\subsubsection{Benches}

There is one concrete bench located on the east side of the cemetery. It is placed in the landscaped area that surrounds the stormwater channel outlet (Figure 117).

\footnotetext{
141 National Cemetery Administration. "Corinth National Cemetery," Accessed online: https://www.cem.va.gov/cems/nchp/corinth.asp.
} 
Figure 117. Concrete bench, 2018 (ERDC-CERL).

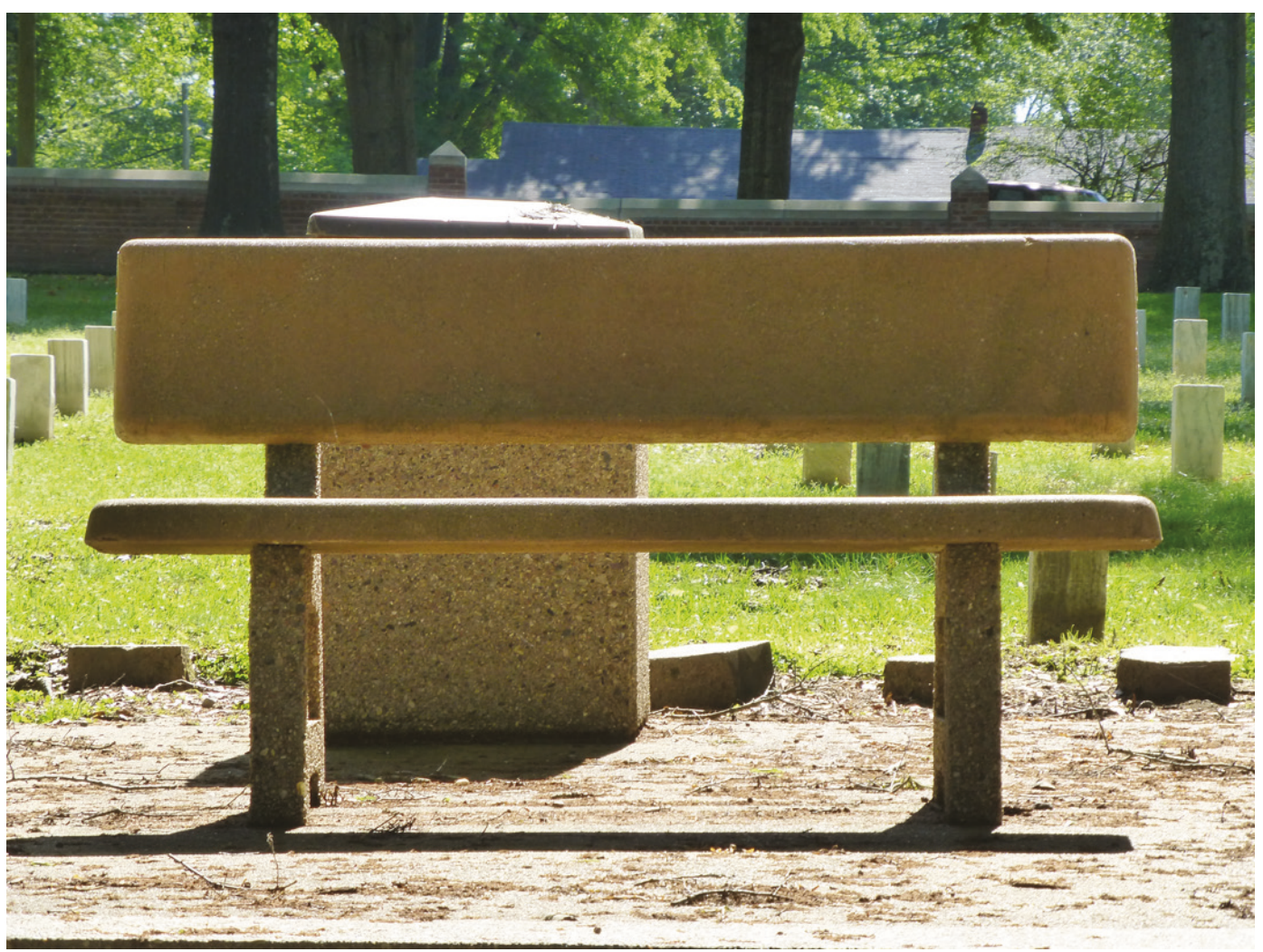

\subsubsection{Signage}

There are several signs and plaques throughout the cemetery. In general, they are arrayed near the entrance, along the main road, and around the flagstaff mound. The signs are constructed in a variety of styles in both wood and metal. Figure 118-Figure 126 show the different types of signs in Corinth National Cemetery. 
Figure 118. Near the main entrance there are several signs in a variety of designs and materials, 2018 (ERDC-CERL).

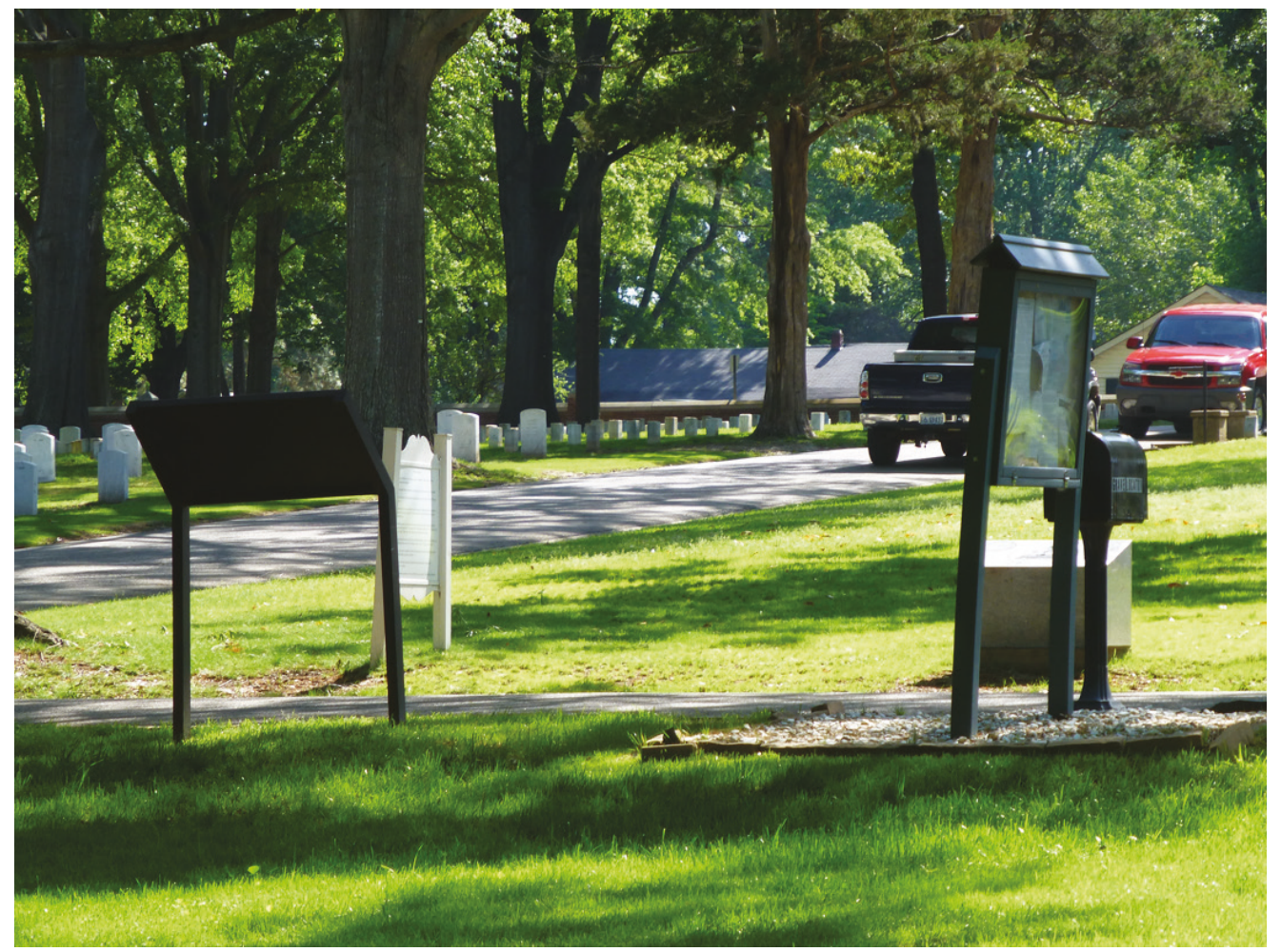

Figure 119. Signboard west of the main road with posted informational flyers on both sides, 2018 (ERDC-CERL).

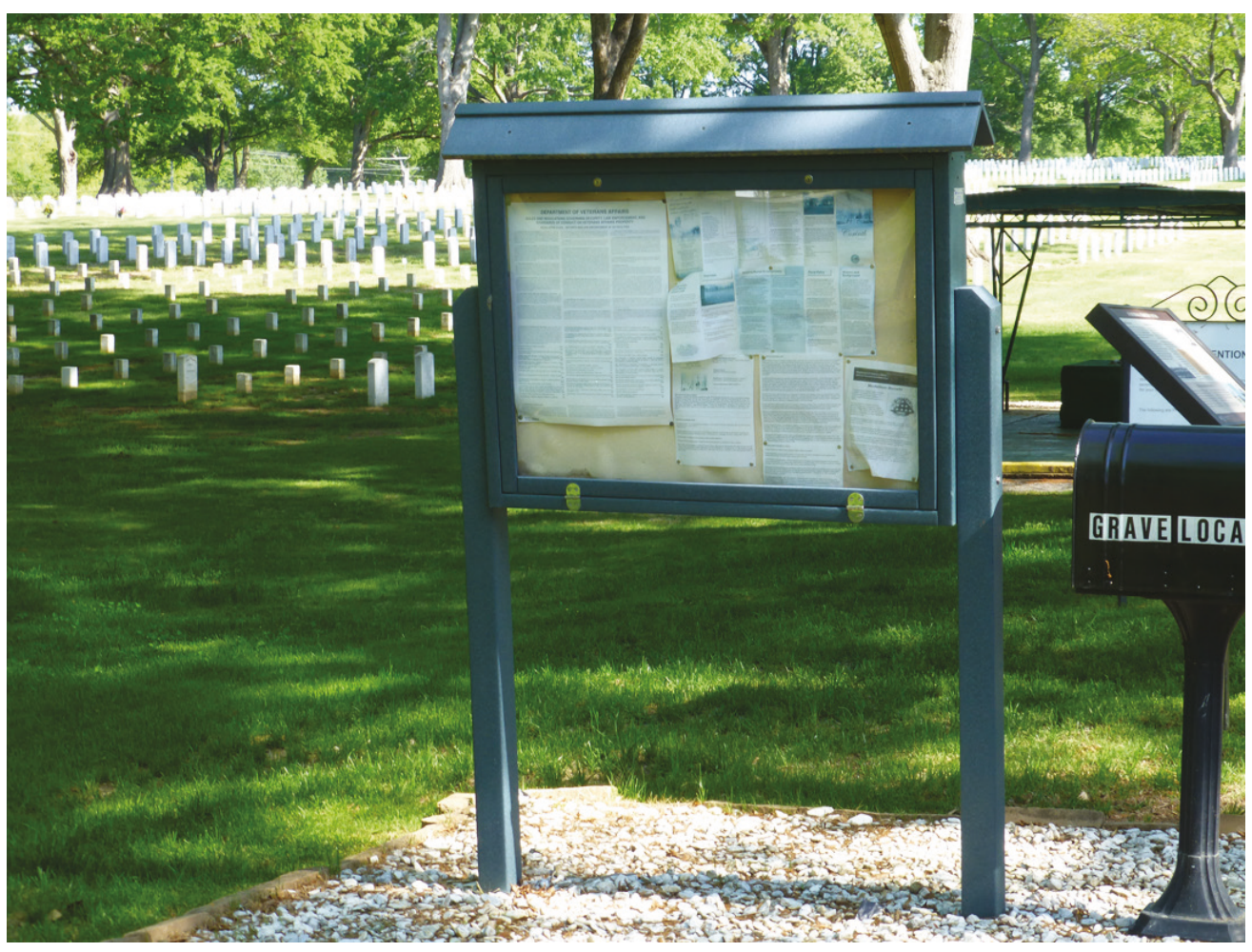


Figure 120. Sign and mailbox with the grave locator, 2018 (ERDC-CERL).

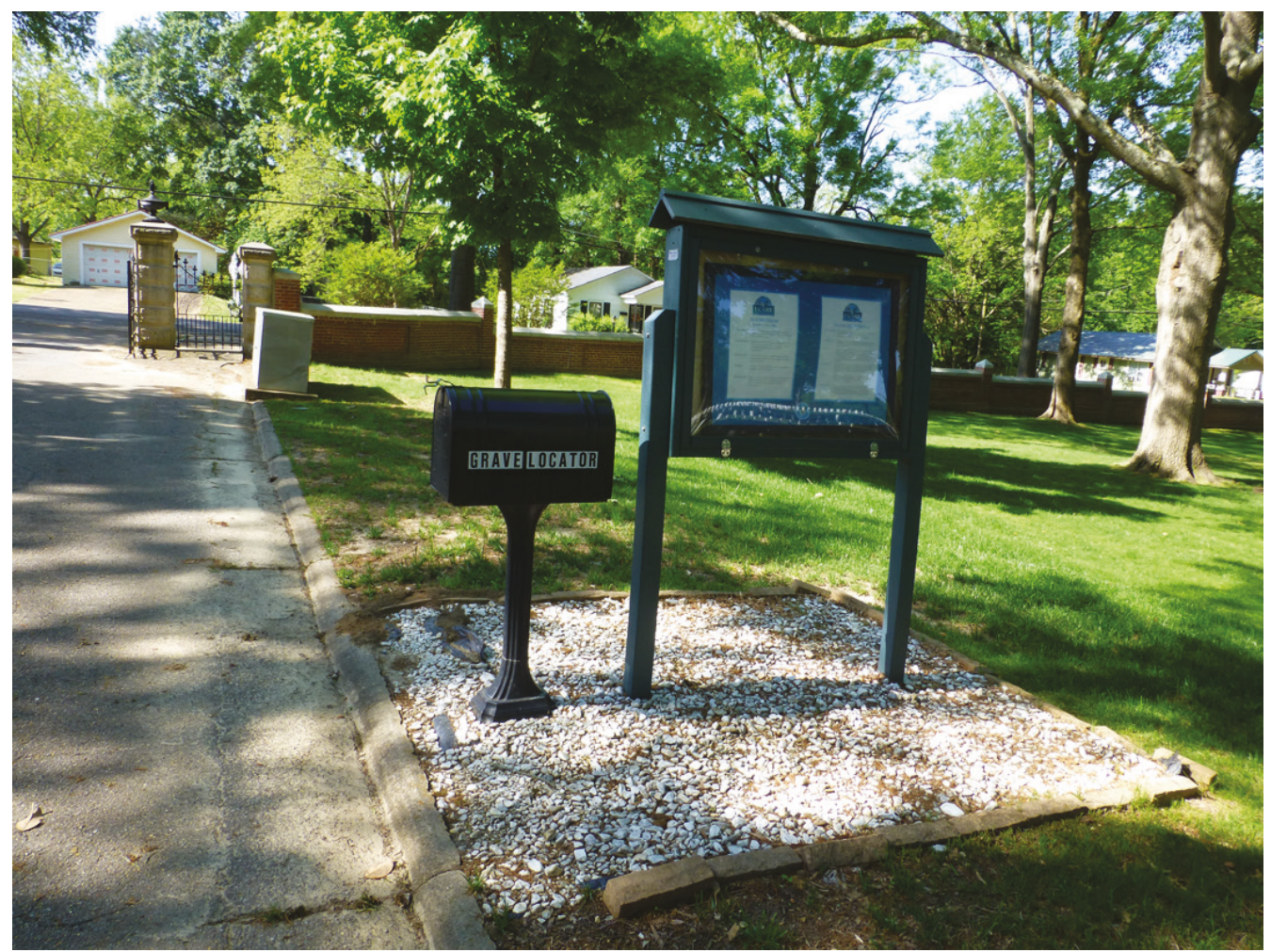

Figure 121. Sign that displays the history behind the formation of the national cemetery system, 2018 (ERDC-CERL).

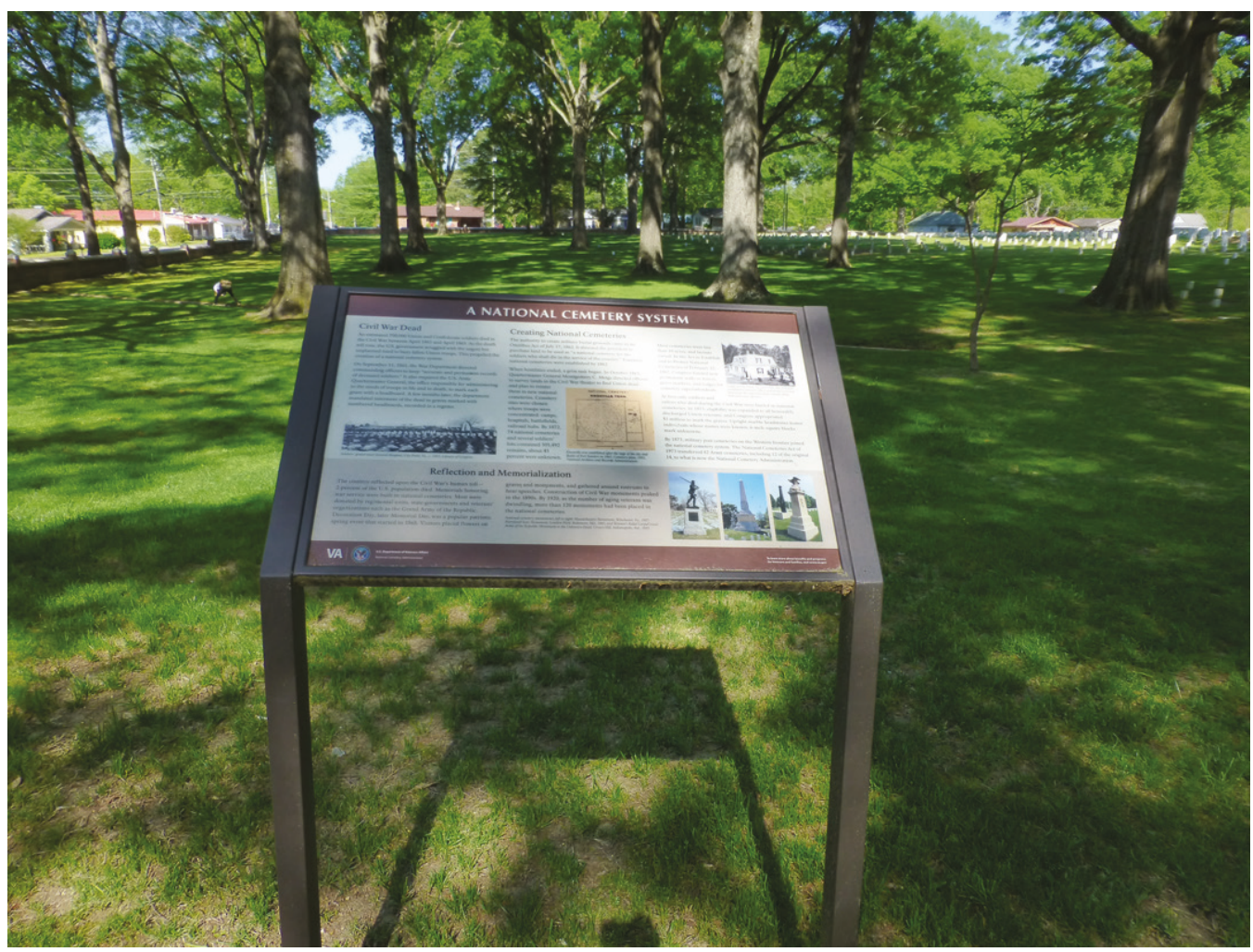


Figure 122. Sign outlining rules of conduct in the cemetery, 2018 (ERDC-CERL).

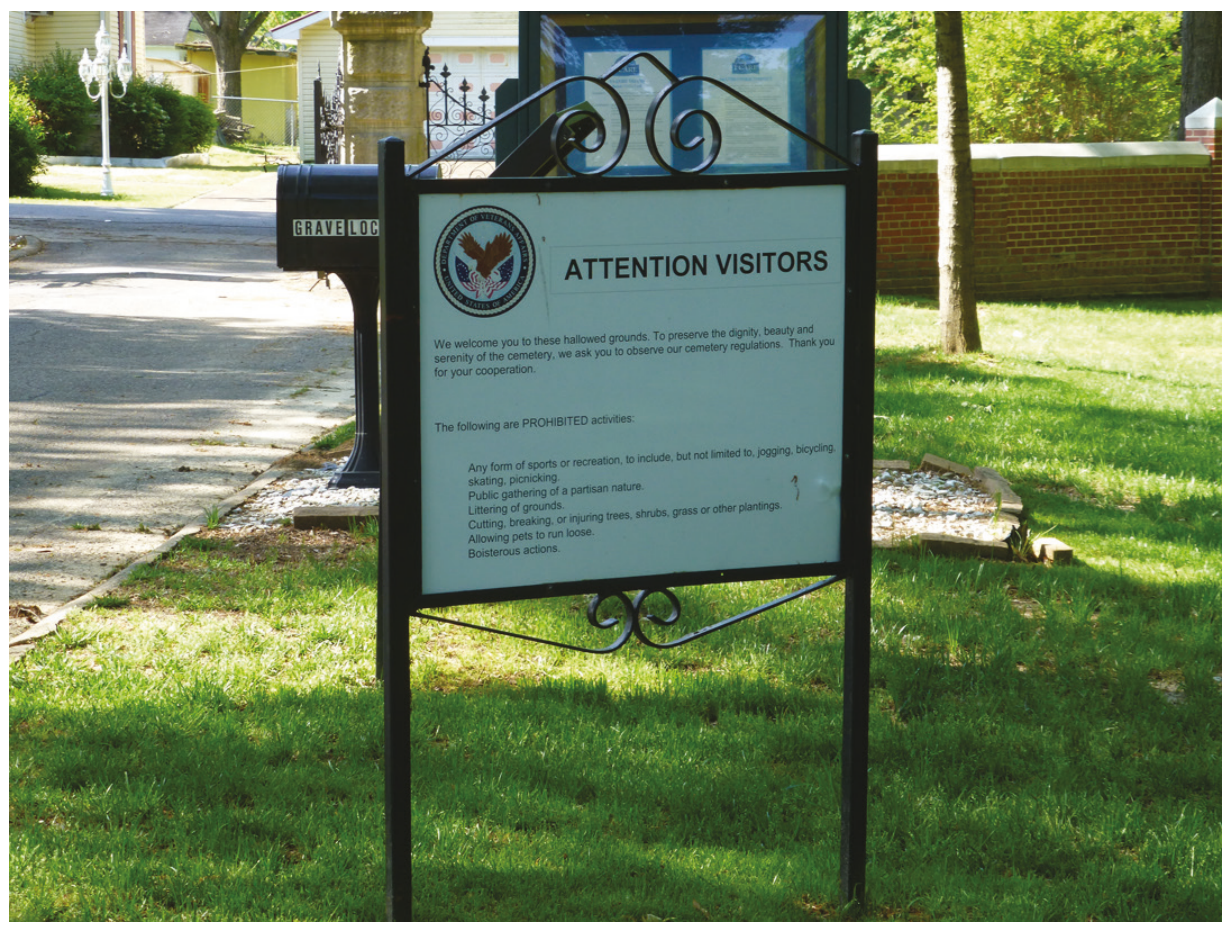

Figure 123. Small sign that directs visitors toward the restrooms, 2018 (ERDC-CERL).

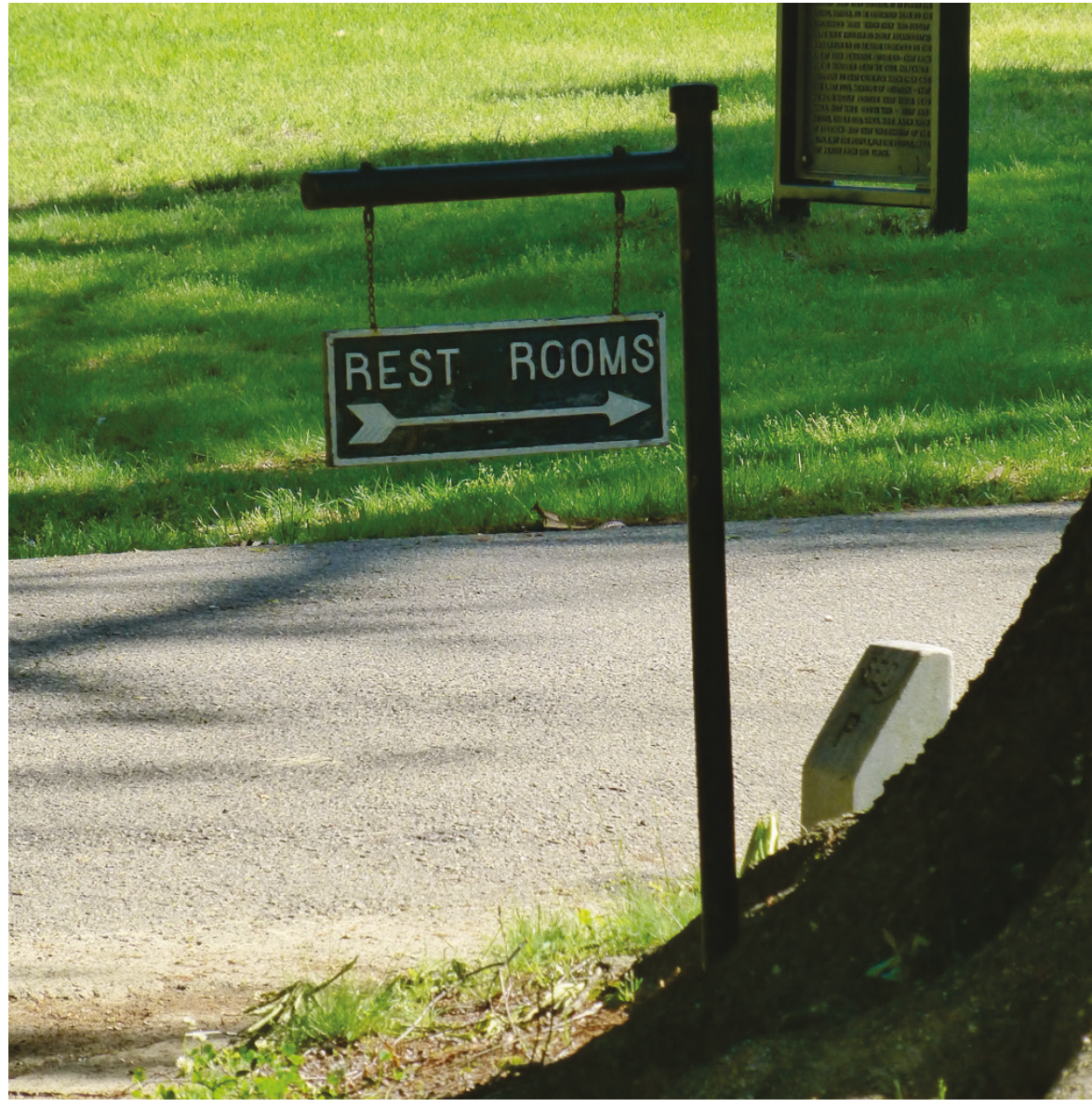


Figure 124. One of several signs outside the perimeter wall prohibiting weapons in the cemetery, 2018 (ERDC-CERL).

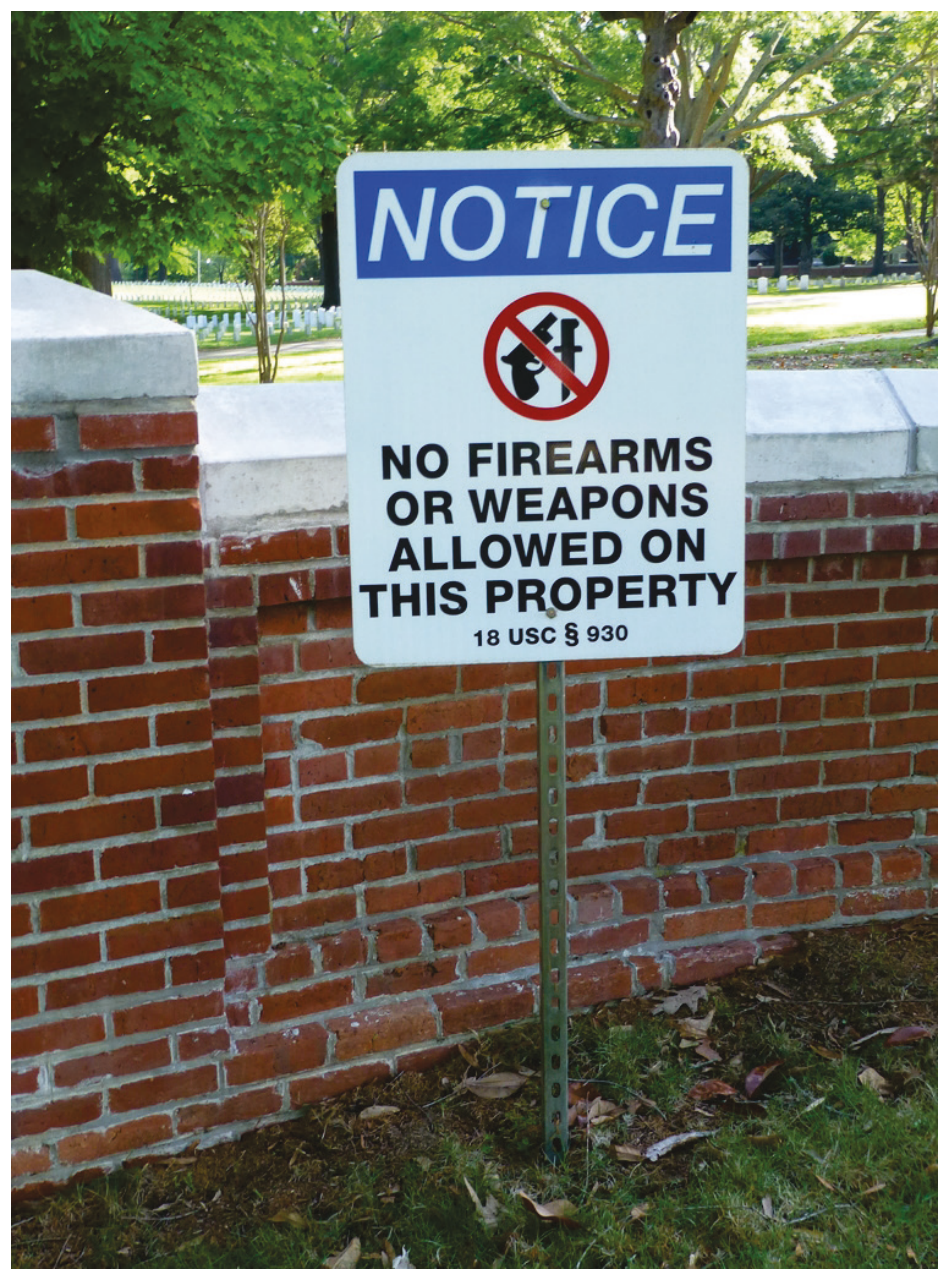


Figure 125. US Government property, no trespassing sign near the maintenance area, 2018 (ERDC-CERL).

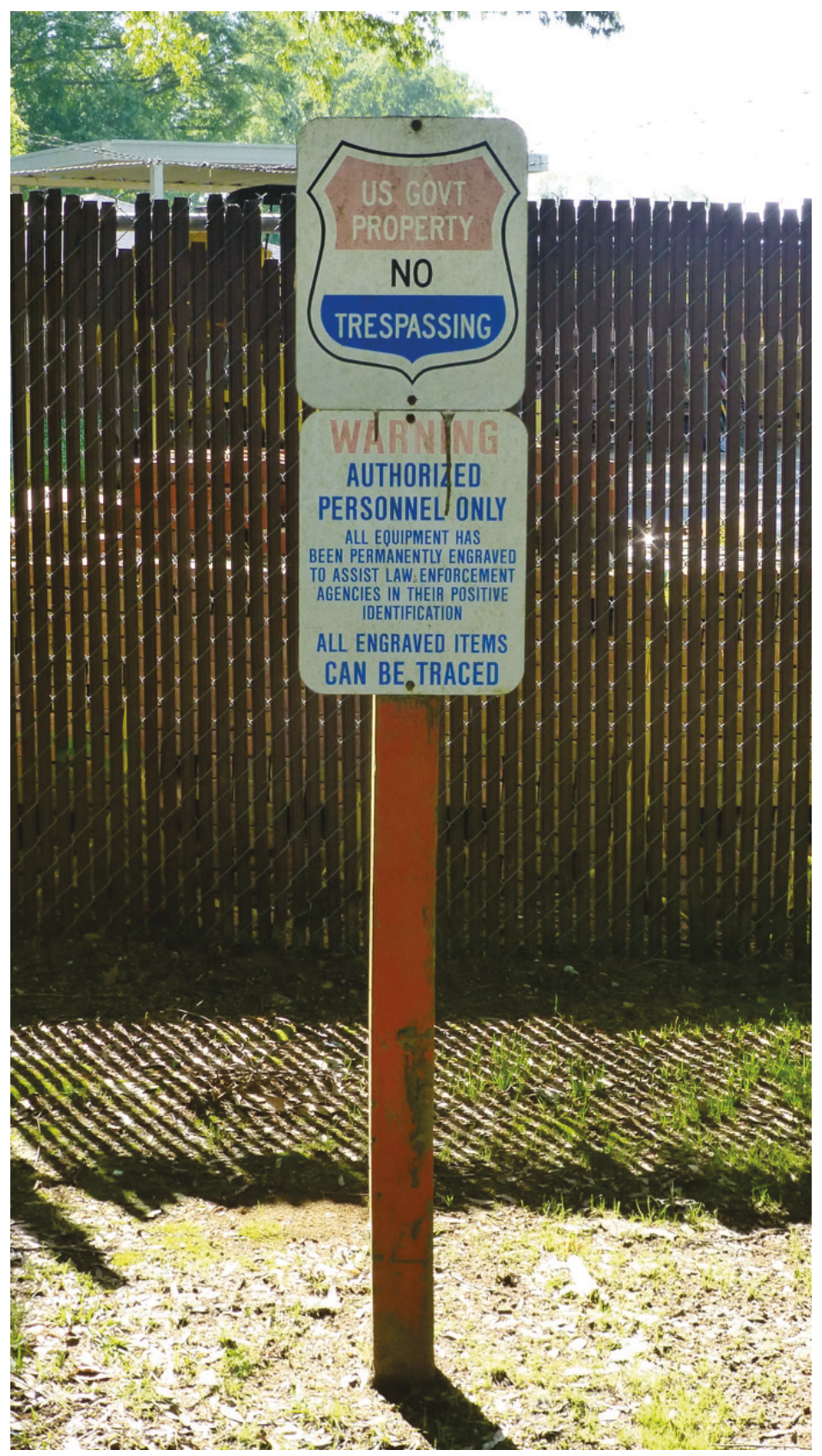


Figure 126. Speed limit sign along the main road, 2018 (ERDC-CERL).

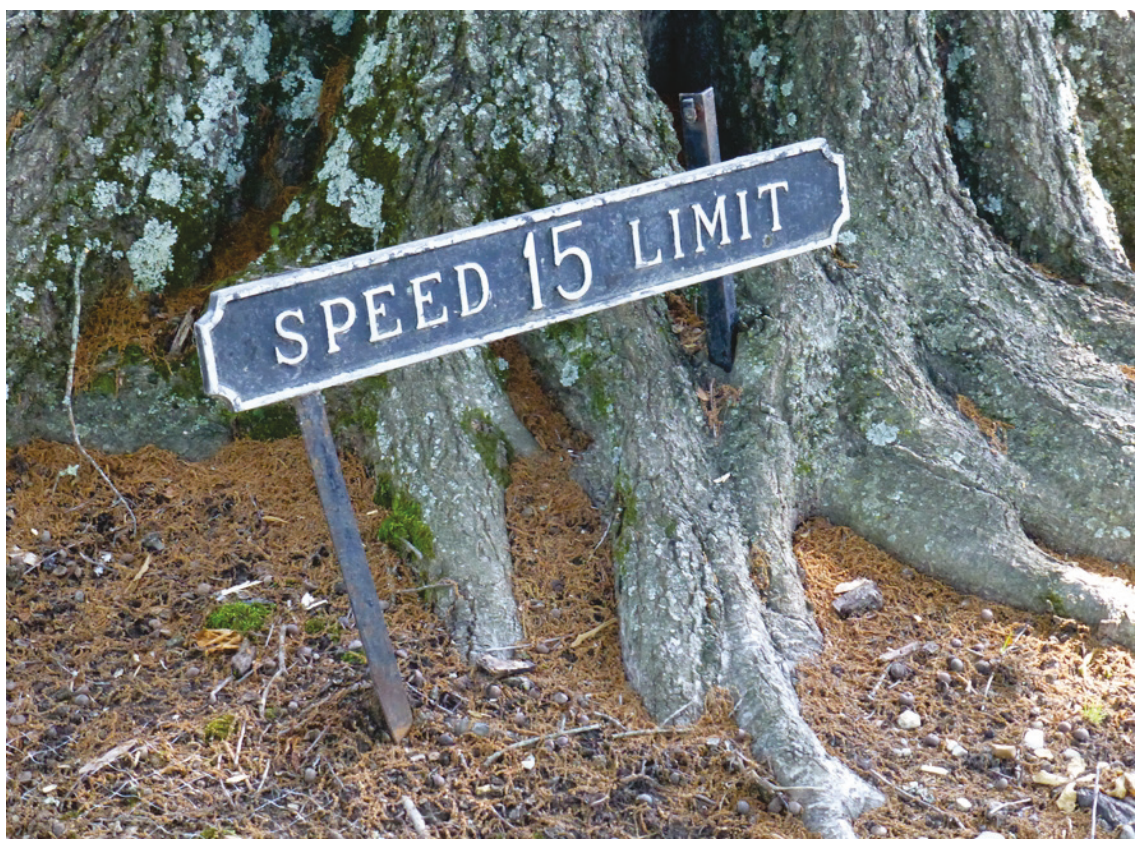

There are several plaques in Corinth National Cemetery. Two are located southwest of the flagstaff mound and another is located near the main entrance east of the main road.

The two plaques near the flagstaff mound are mounted on posts. The larger of the two presents the text from Section 3 of the 1867 Act that established and protects national cemeteries (Figure 127). The smaller plaque is inscribed with a passage from the poem by Theodore O'Hara, The Bivouac of the Dead (Figure 128). 
Figure 127. Plaque near the flagstaff mound inscribed with the text from Section 3 of the act that formed the national cemetery system, 2018 (ERDC-CERL).

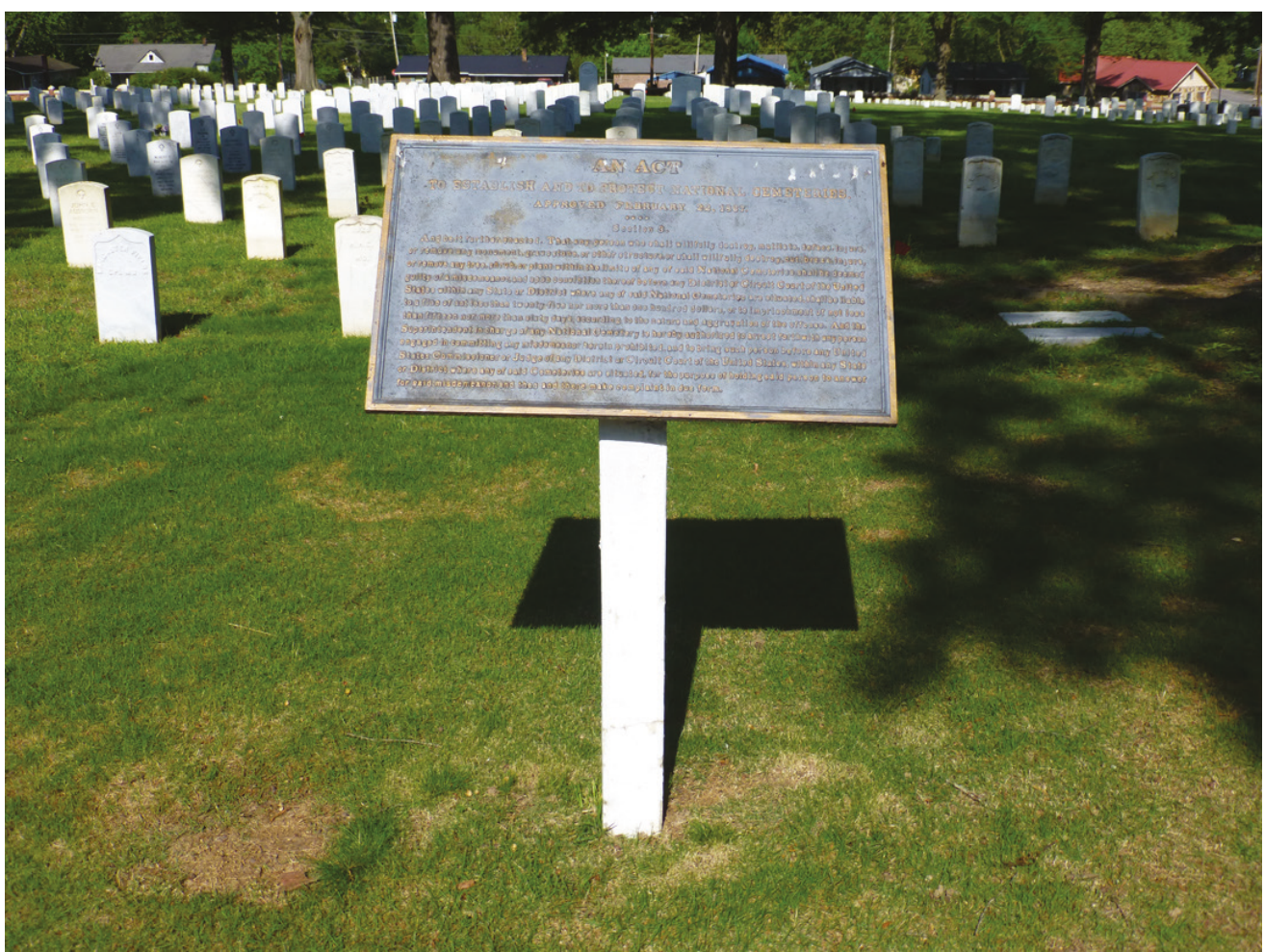

Figure 128. Plaque near the flagstaff mound with a passage from the poem, The Bivouac of the Dead, 2018 (ERDC-CERL).

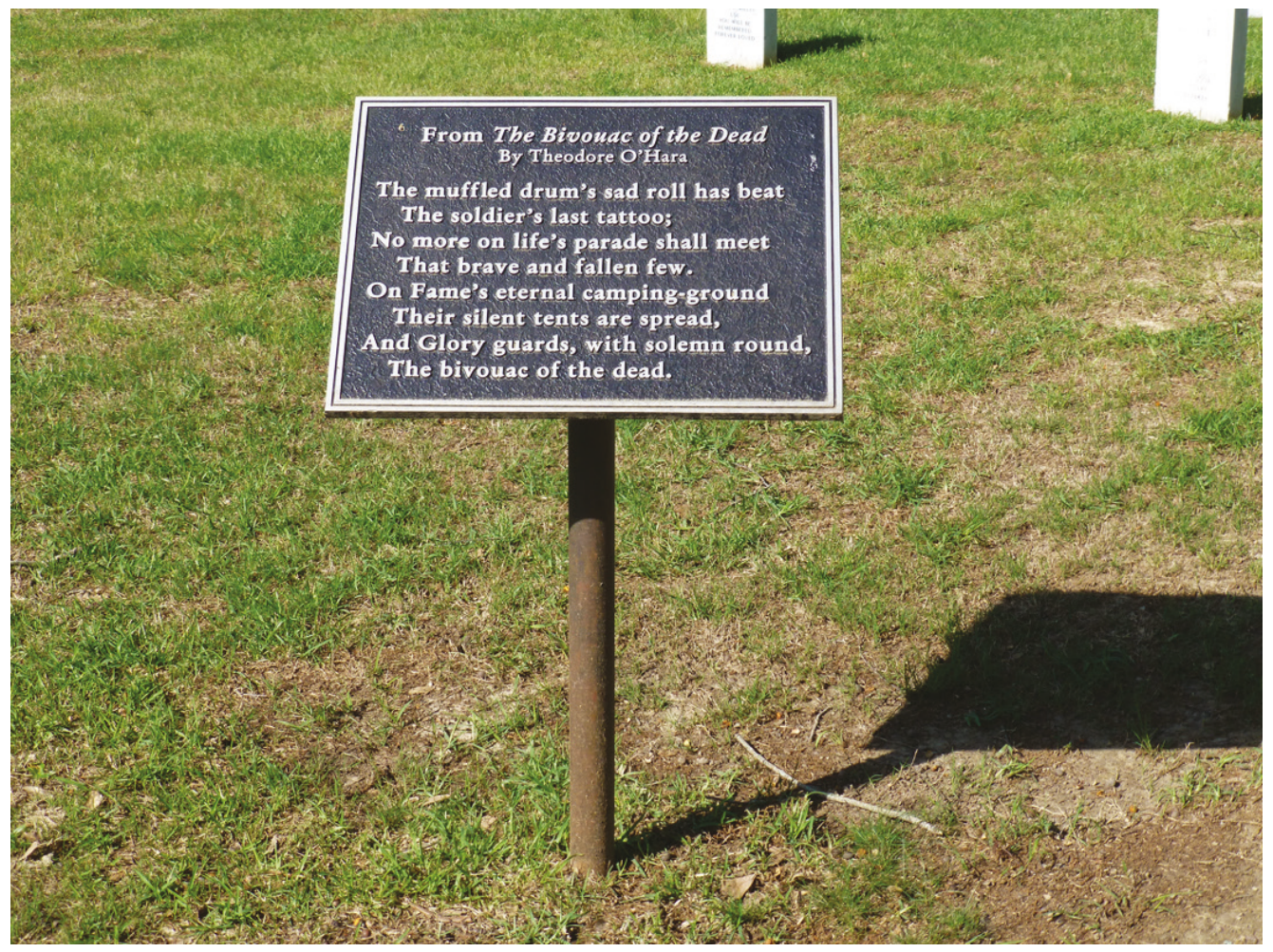


The plaque near the main entrance is a Gettysburg Address Tablet commemorating the bicentennial of President Abraham Lincoln's birth and the impact Lincoln had on establishing the cemetery system. ${ }^{142}$ The tablet measures five feet tall and three feet wide and has the Gettysburg address inscribed on it. It is held in a black metal frame (Figure 129).

Figure 129. The Gettysburg tablet near the main entrance, 2018 (ERDC-CERL).

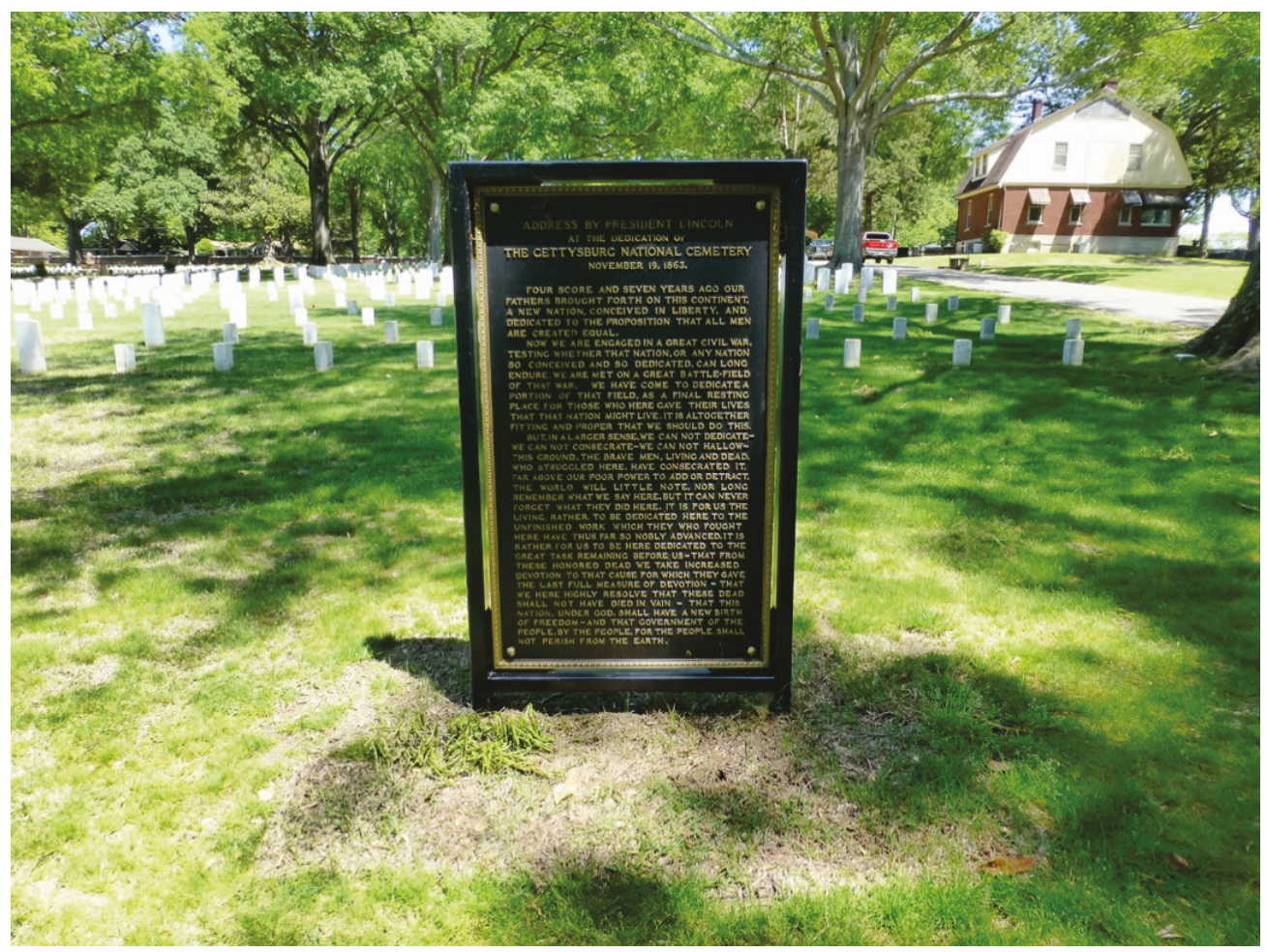

\subsubsection{Section markers}

The section markers are granite cubes with an angled face where the section label is engraved into the stone (Figure 130).

\footnotetext{
142 National Cemetery Administration. New Gettysburg Address Tablets for National Cemeteries To Honor Abraham Lincoln Bicentennial. Accessed online: https://www.cem.va.gov/history/LincBic.asp.
} 
Figure 130. Granite section markers for Sections R, S, M, and K, 2018 (ERDC-CERL).

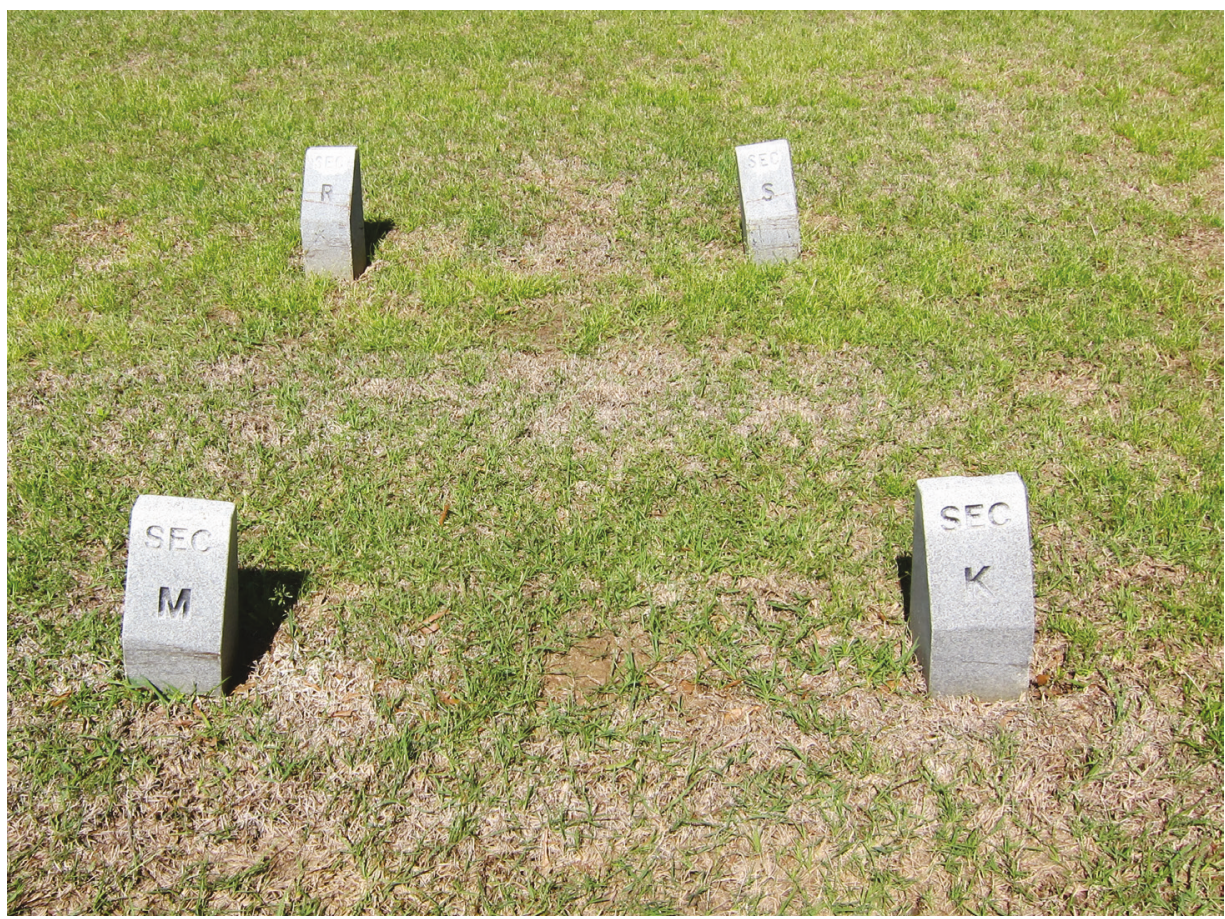

\subsubsection{Water related infrastructure-irrigation and drainage}

A prominent feature in the Corinth National Cemetery is an open concrete water channel that runs from the southeast quadrant under the main road and then diagonally through the southwest portion of the cemetery (Figure 131 and Figure 132). In places, the concrete is cracked enough to reveal bricks underneath (Figure 133). Water in the channel flows from east to west. The upper outlet of the channel is a concrete abutment over a brick arch. The open channel runs through a concrete pipe under the main road but is uncovered again until it meets the perimeter wall where it goes back underground (Figure 134). 
Figure 131. Concrete water channel running through the eastern section of the cemetery, 2018 (ERDC-CERL).

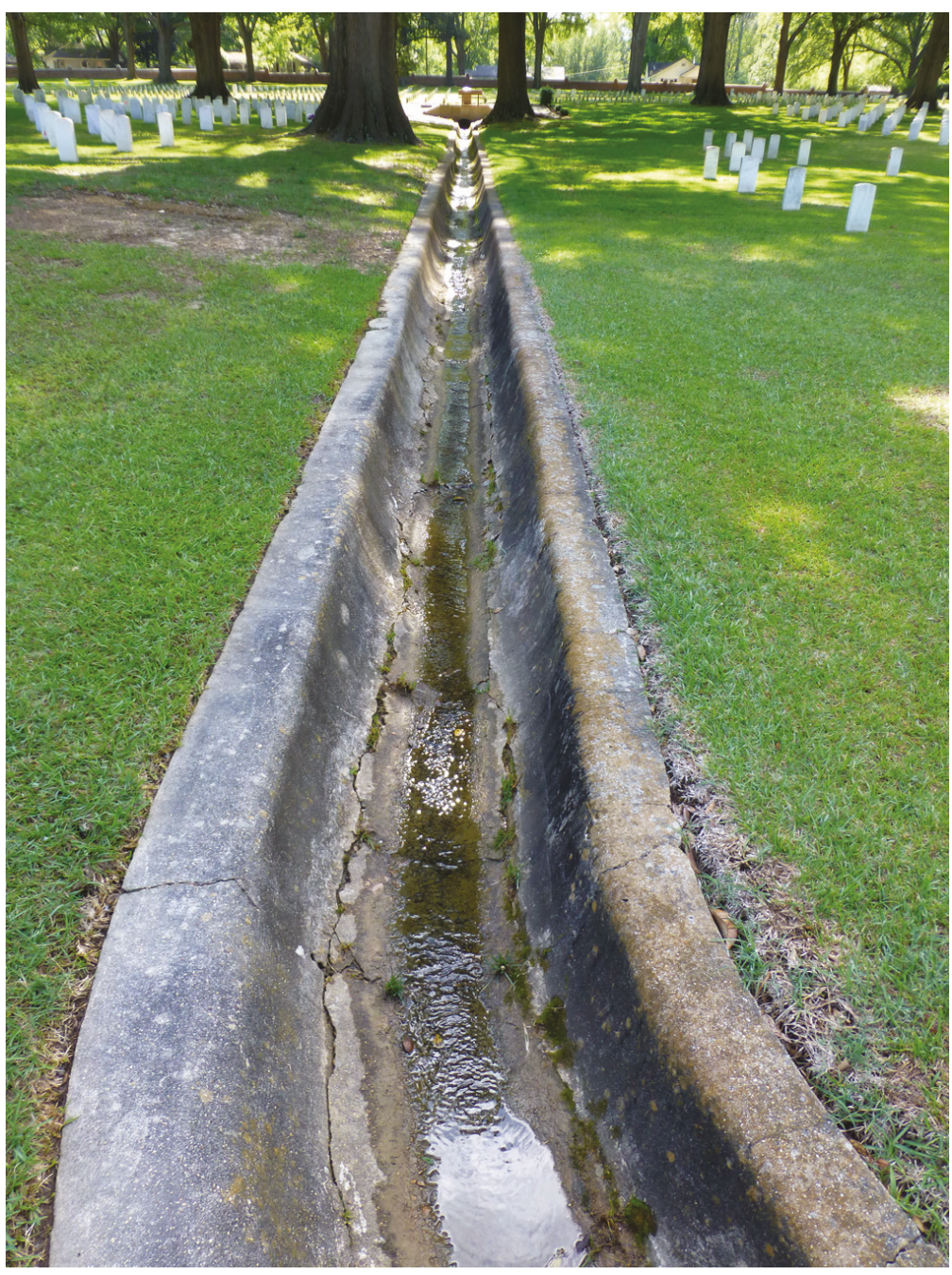


Figure 132. Concrete channel and gutter on the east side of the cemetery, 2018 (ERDC-CERL).

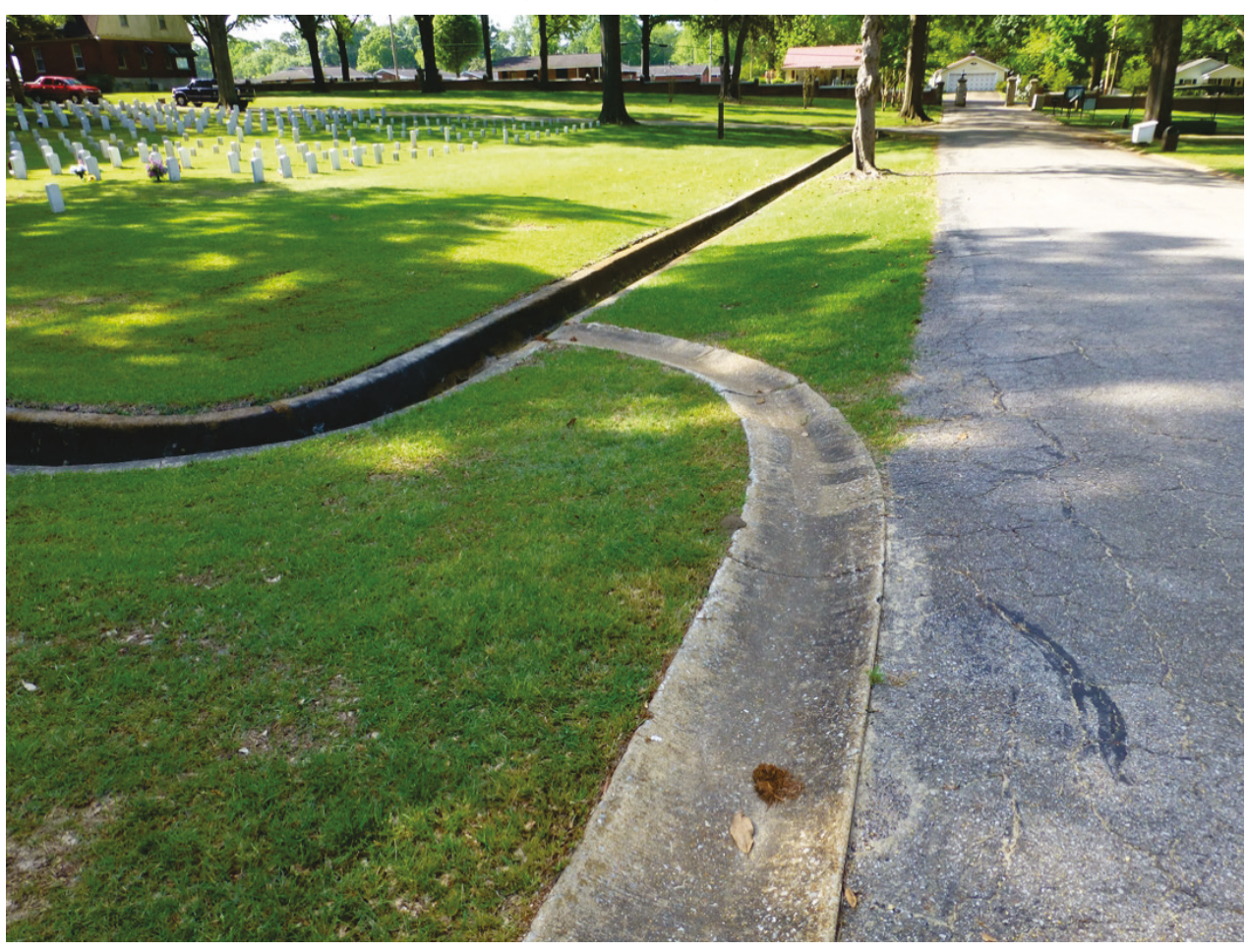

Figure 133. Concrete water channel damage revealing the brick underneath, 2018 (ERDC-CERL).

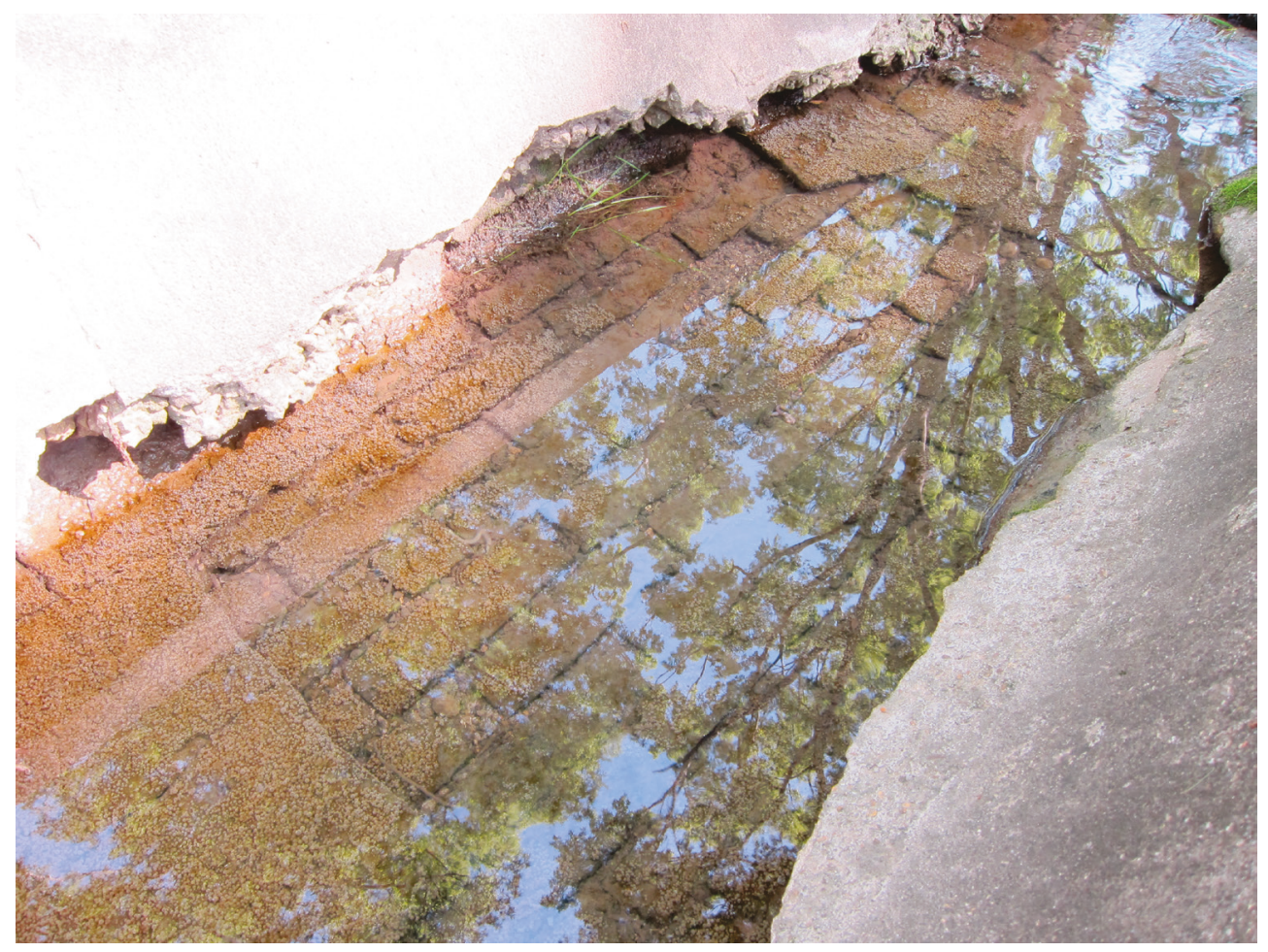


Figure 134. Continuation of the concrete channel west of the main road, 2018 (ERDC-CERL).

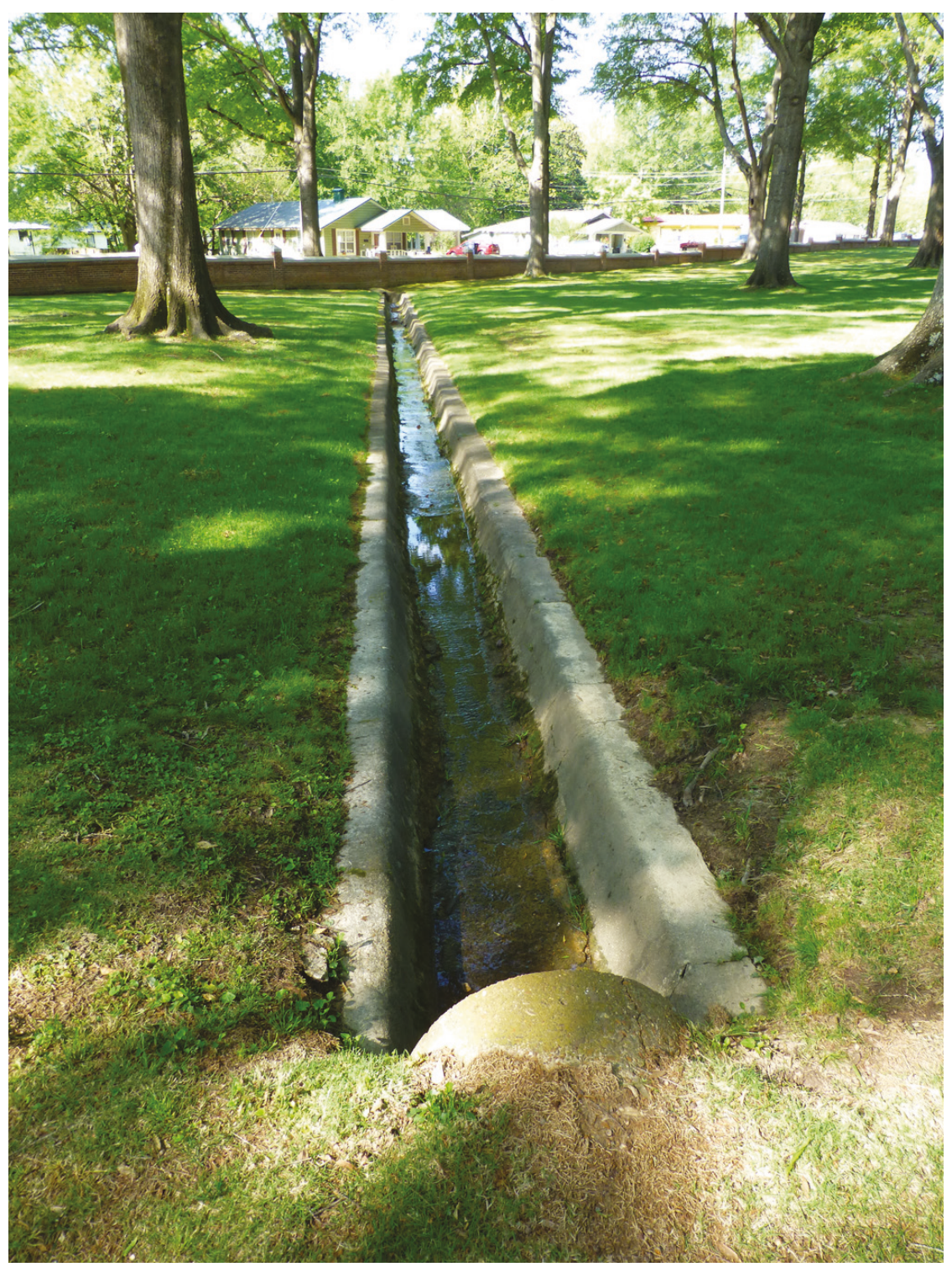

Part of the stormwater infrastructure are square concrete panels resting on bricks covering water inlets (Figure 135). There is a series of these on the east side, three near the stormwater outlet and then three more near the north perimeter wall. On the west side there are three in the northwest corner near the perimeter wall and then another three in the southwest quadrant of the cemetery. 
Figure 135. Concrete panels over stormwater inlets in the northwest corner of the cemetery, 2018 (ERDC-CERL).

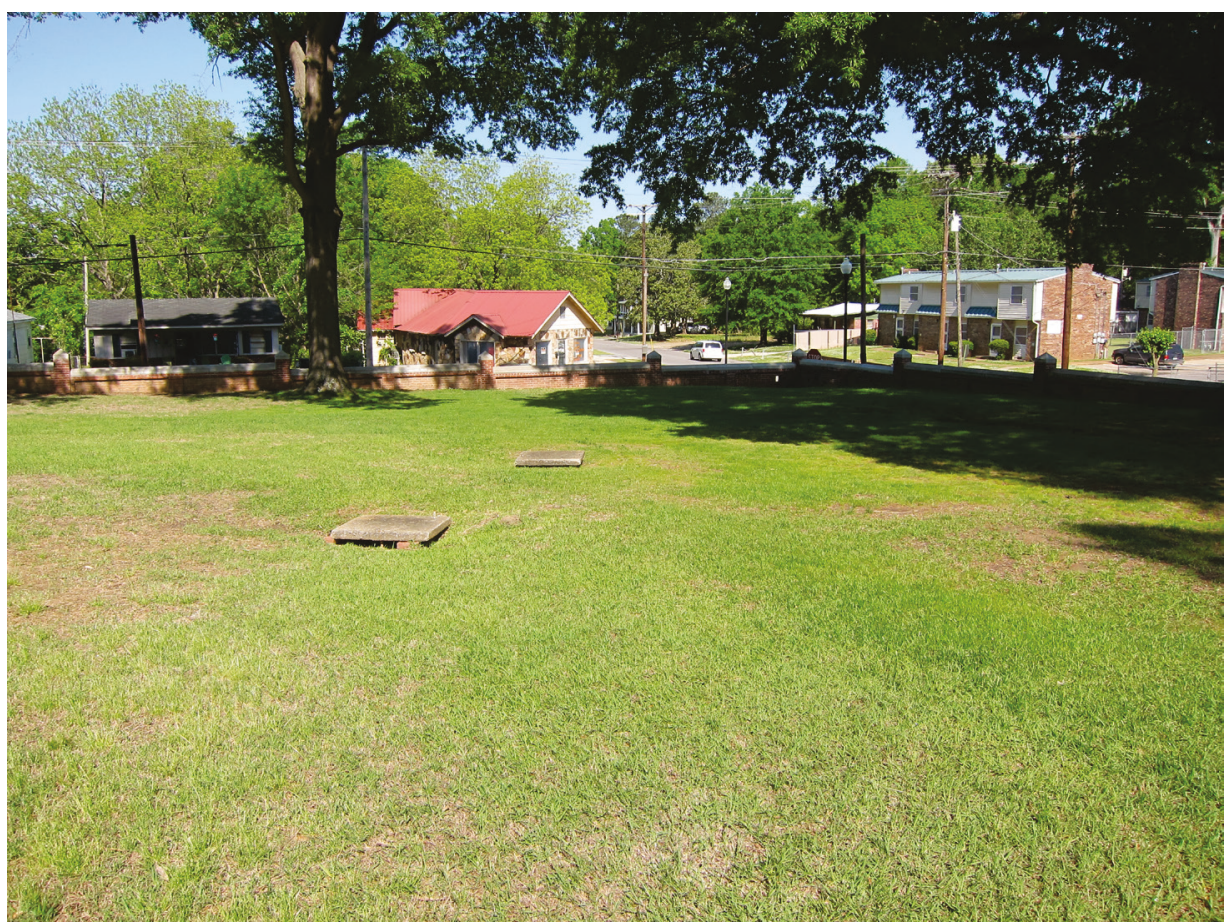

Near the main entrance, steel grates cover the stormwater inlets (Figure 136).

Figure 136. Example of the type of steel grate used near the main entrance, 2018 (ERDC-CERL).

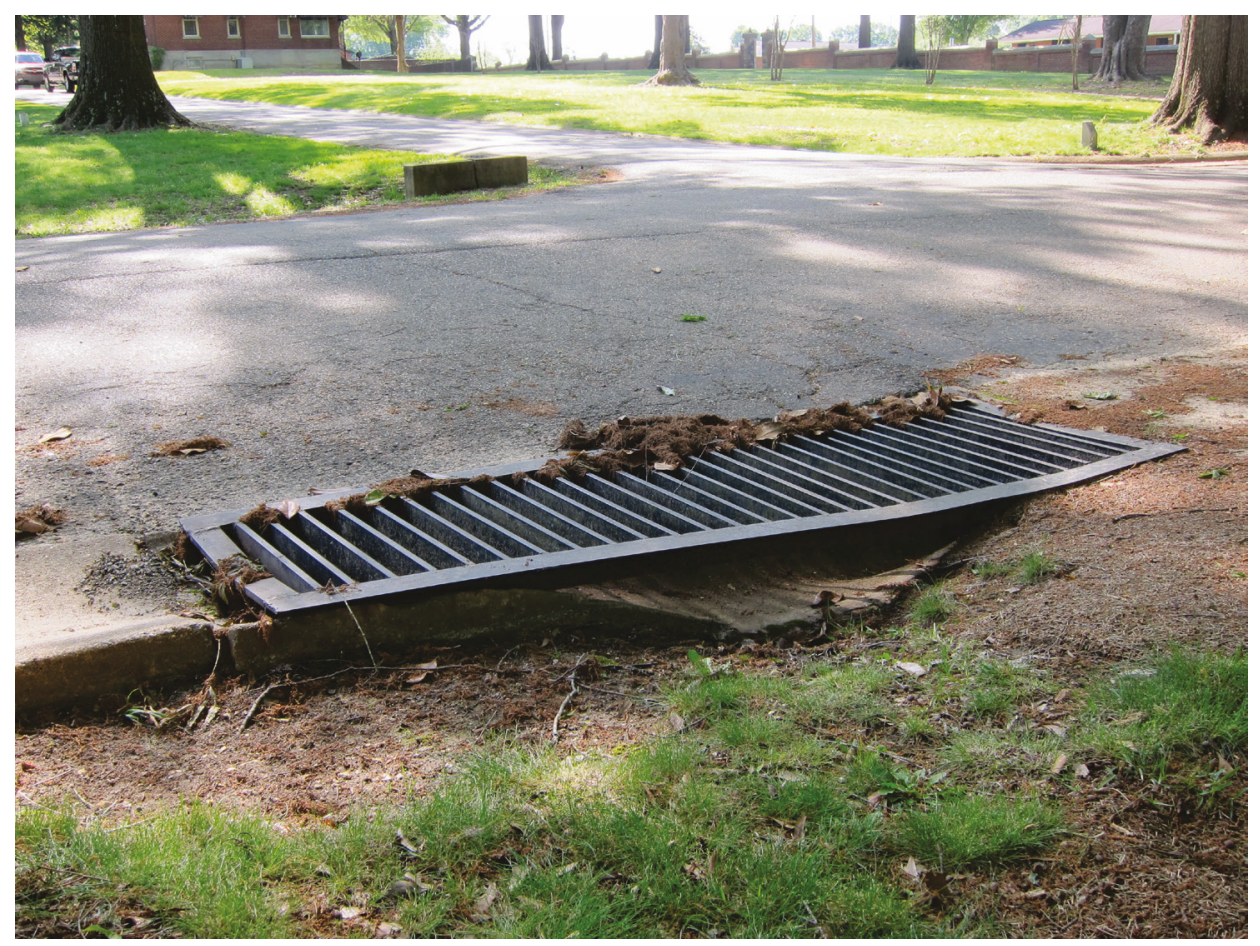


Other water-related infrastructure in the cemetery includes a fire hydrant (Figure 137) and water spigot (Figure 138) near the lodge and the irrigation system control box (Figure 139) and valves throughout the site (Figure 140).

Figure 137. Fire hydrant, 2018 (ERDC-CERL).

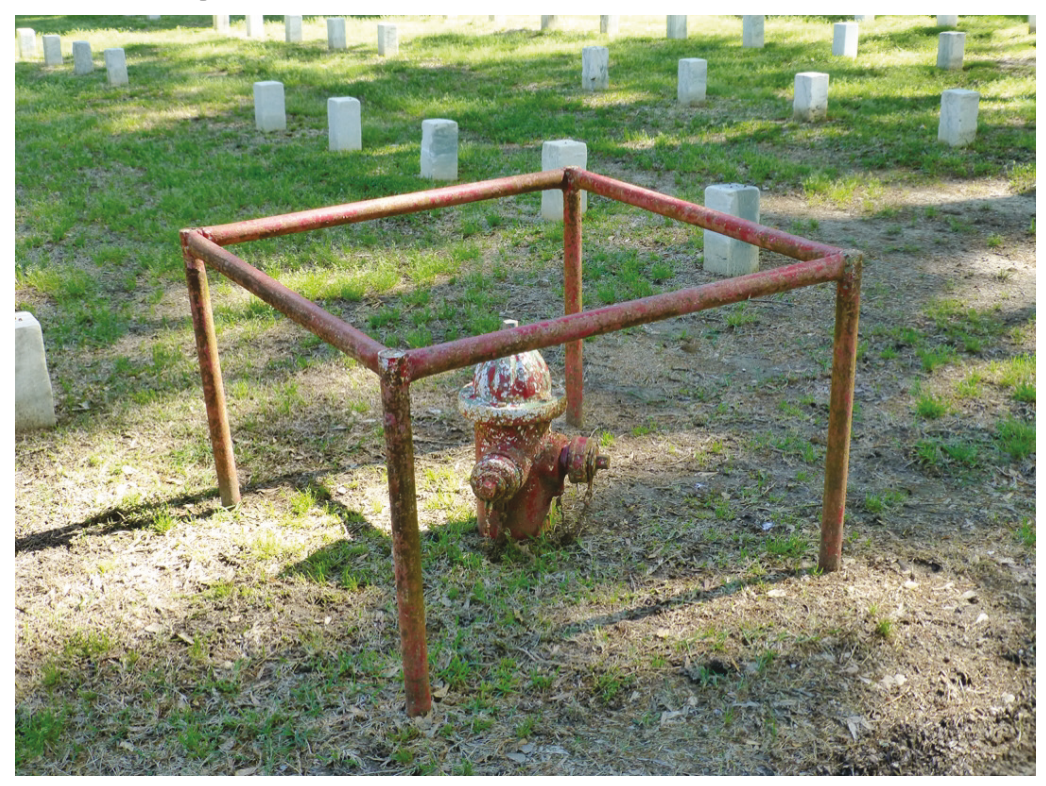

Figure 138. Water spigot south of the maintenance road, 2018 (ERDC-CERL).

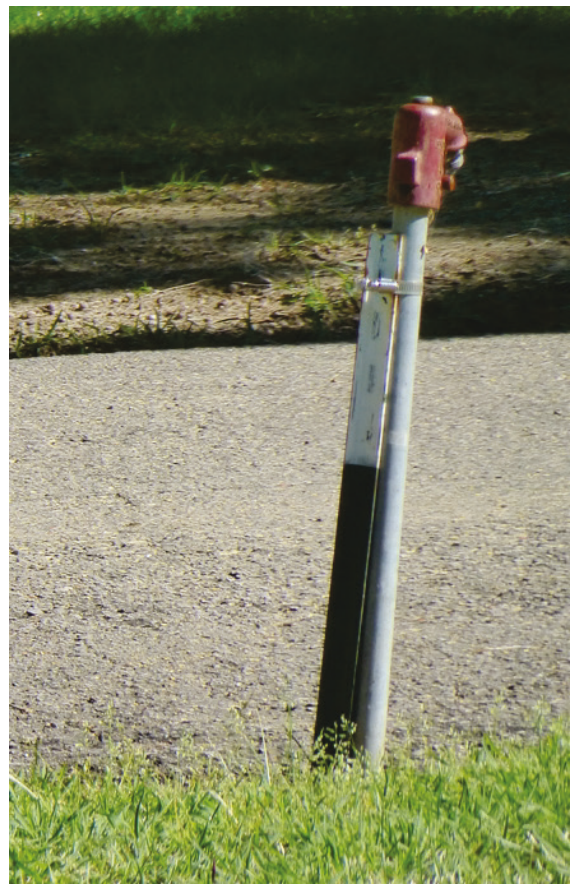


Figure 139. Irrigation control box near the main entrance, 2018 (ERDC-CERL).

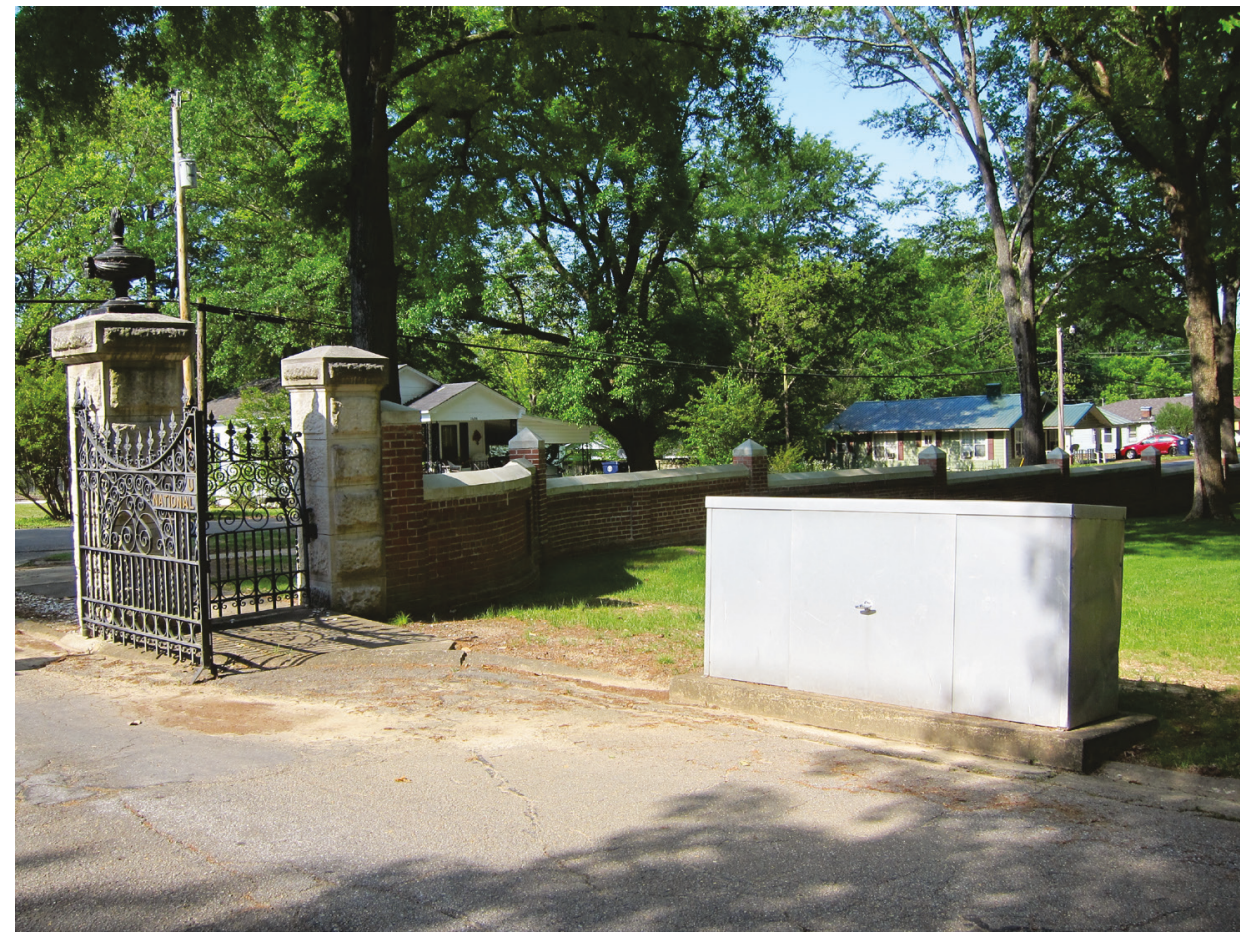

Figure 140. Example of the irrigation system control valve found throughout the site, 2018 (ERDC-CERL).

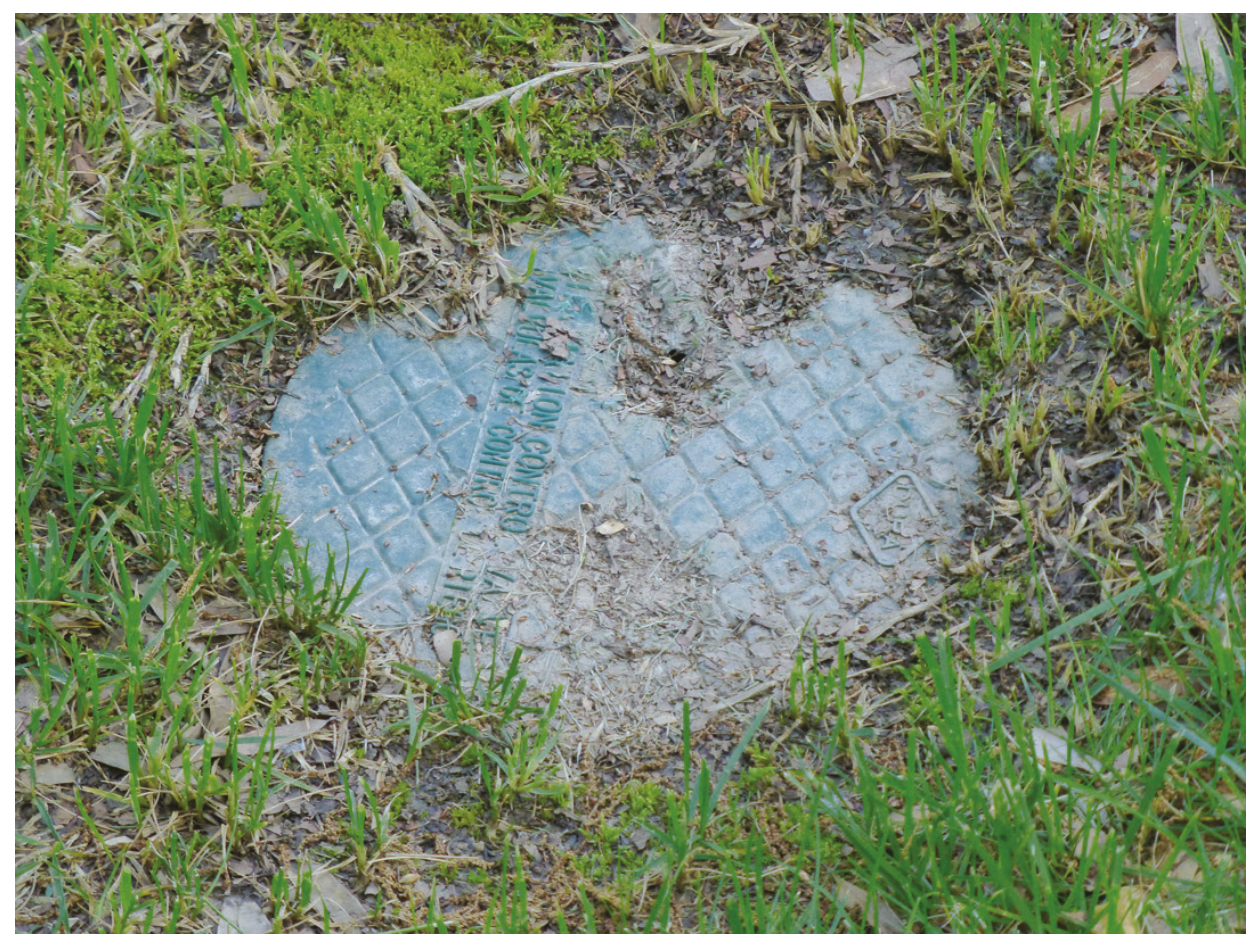




\subsubsection{Trash receptacles}

There are three trash receptacles in the cemetery. One is located near the main entrance, one is near the flagstaff mound, and one is located in the landscaped area over the stormwater drainage channel. The trash receptacle near the entrance and the one near the flagstaff are similar types, square and constructed out of metal painted brown with exposed aggregate paneled sides (Figure 141). The trash receptacle in the landscaped area is a cube with large aggregate concrete sides and a black plastic top (Figure 142).

Figure 141. Example of trash receptacle located near the main entrance and flagstaff mound, 2018 (ERDC-CERL).

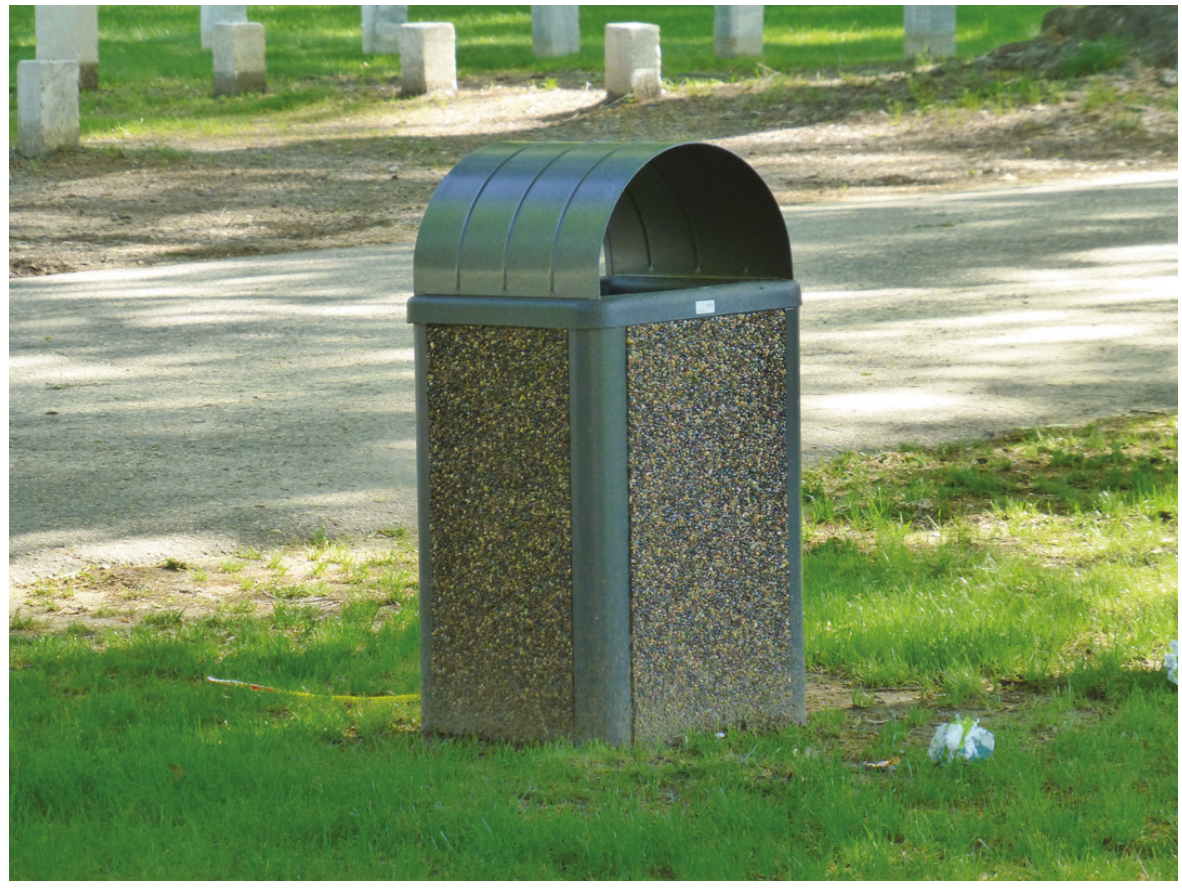


Figure 142. Second type of trash receptacle located in the landscaped area east of the main road, 2018 (ERDC-CERL).

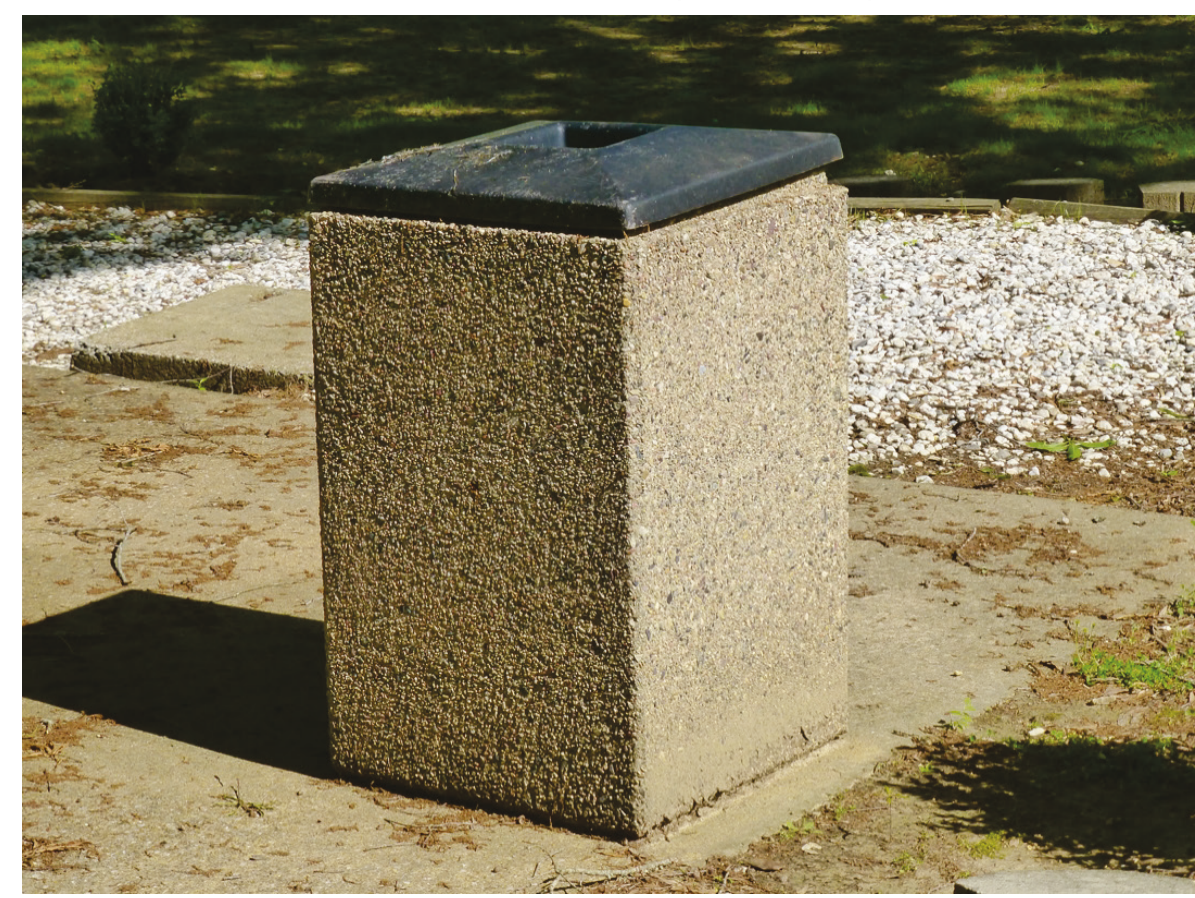

\subsubsection{Lighting}

There are two types of lights in the Corinth National Cemetery. Newer LED floodlights that illuminate the flagstaffs (Figure 143 and Figure 144) and a security light near the main entrance (Figure 145).

Figure 143. LED floodlight on the flagstaff mound, 2018 (ERDC-CERL).

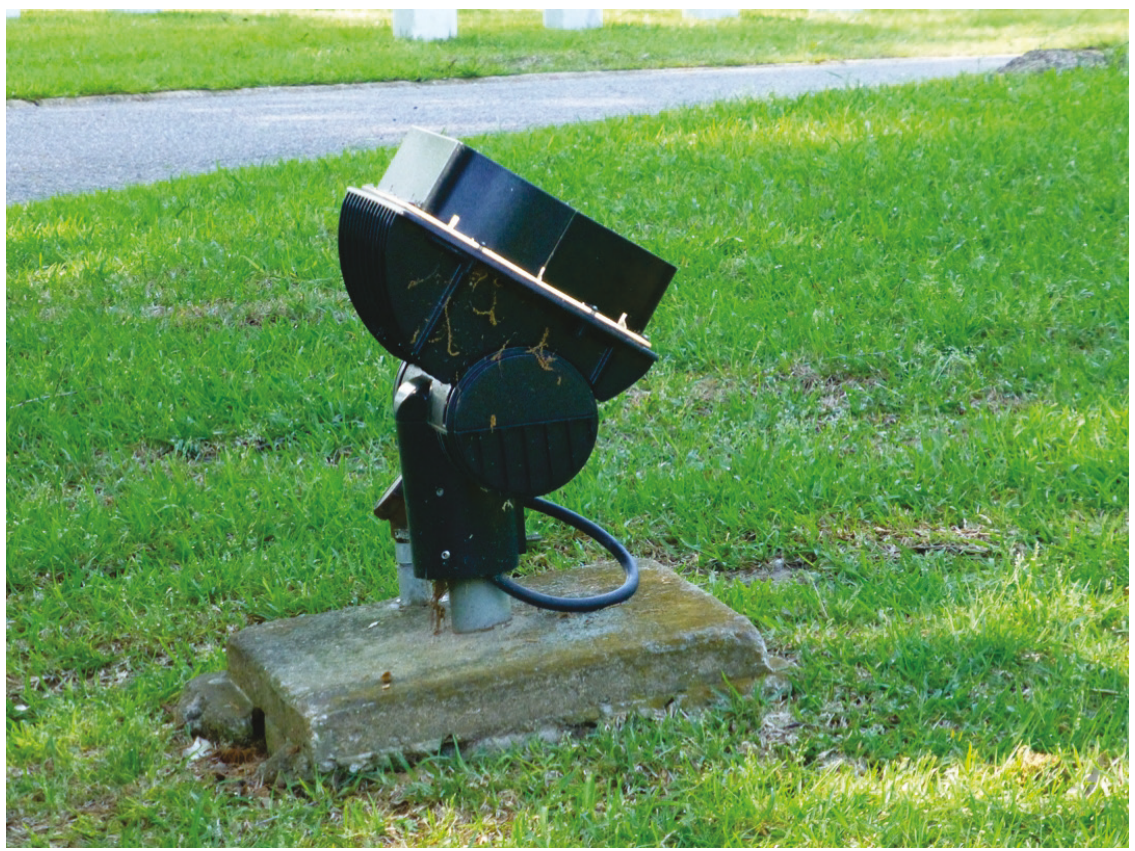


Figure 144. LED floodlight on the flagstaff mound, 2018 (ERDC-CERL).

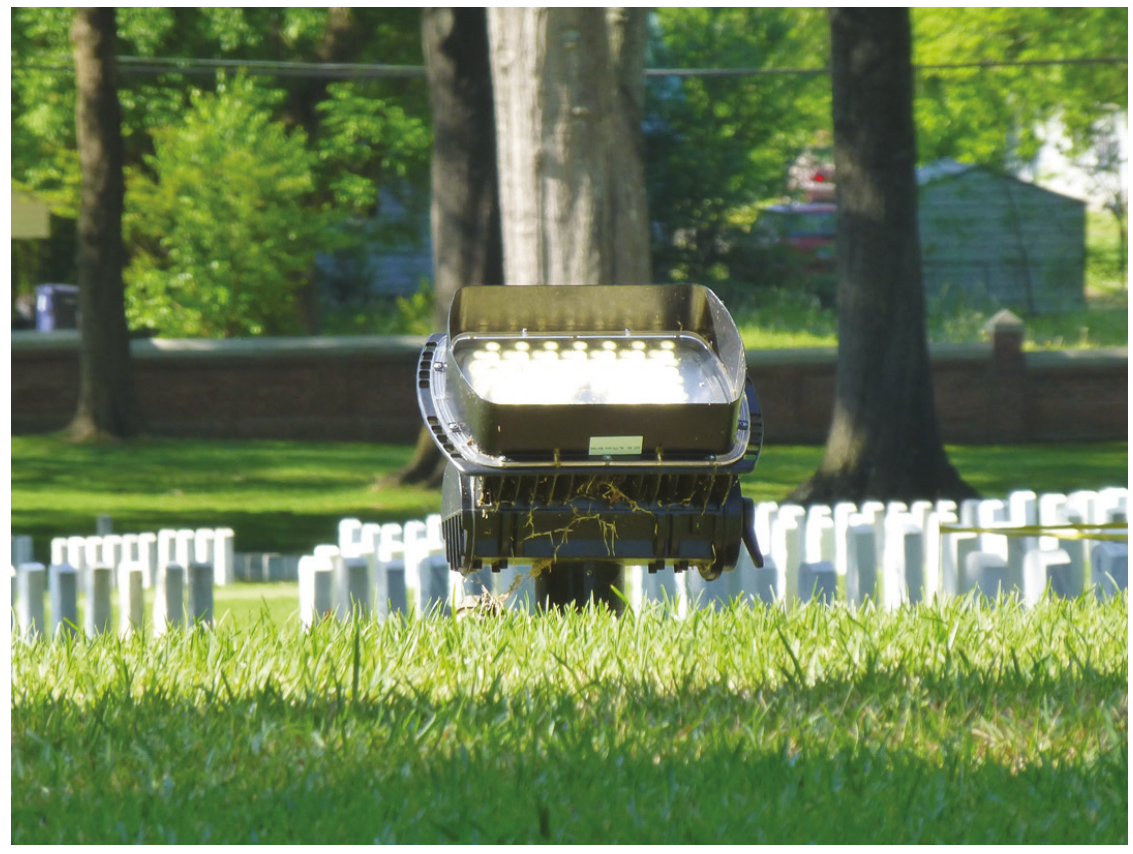

Figure 145. Security light near the main entrance, 2018 (ERDC-CERL).

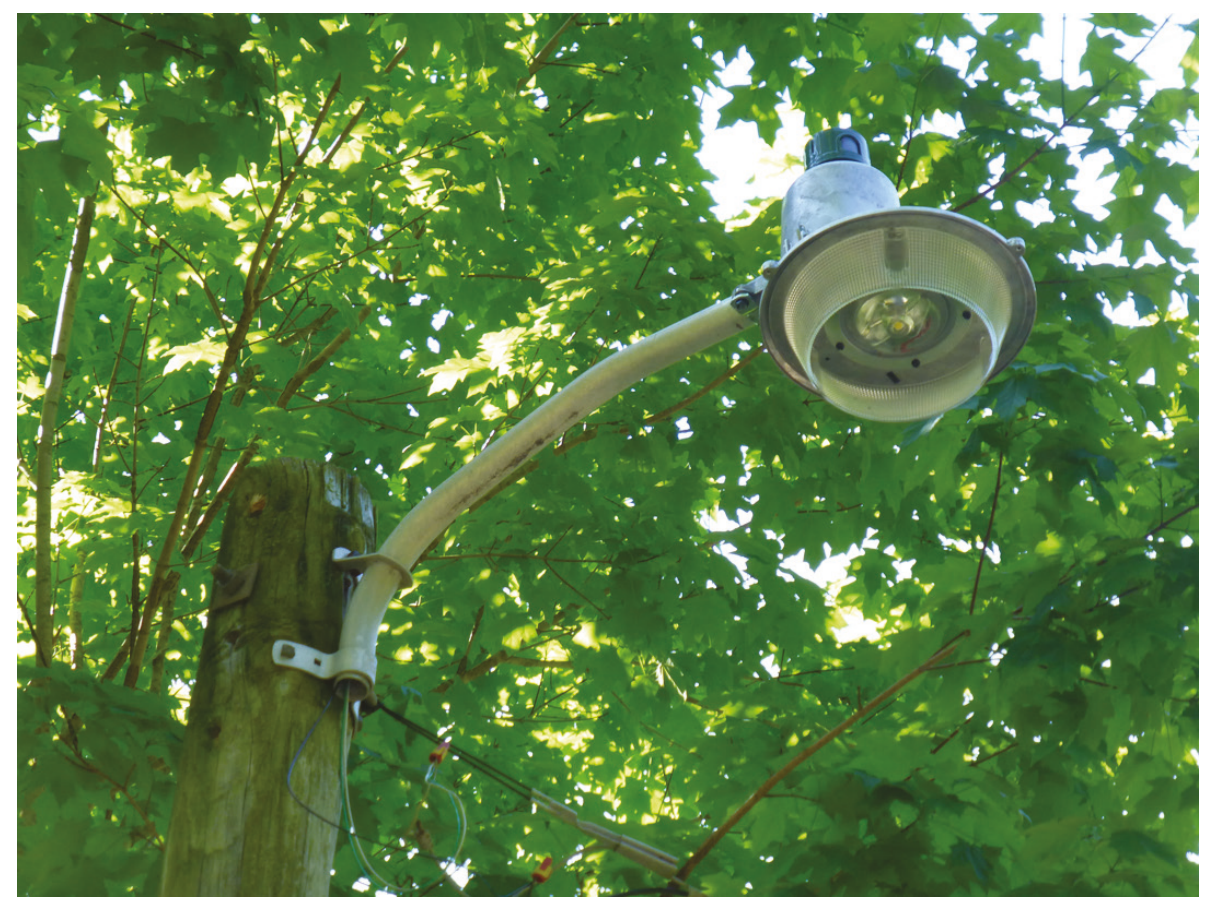

\subsubsection{Miscellaneous}

There are several miscellaneous small-scale landscape objects in the Corinth National Cemetery including a mailbox (Figure 146), storage receptacle for flower stands (Figure 147), an ashtray near the committal shelter 
(Figure 148), and a survey marker (Figure 149). The locations of these objects are concentrated near the lodge and the main entrance.

Figure 146. Mailbox near the superintendent's lodge, 2018 (ERDC-CERL).

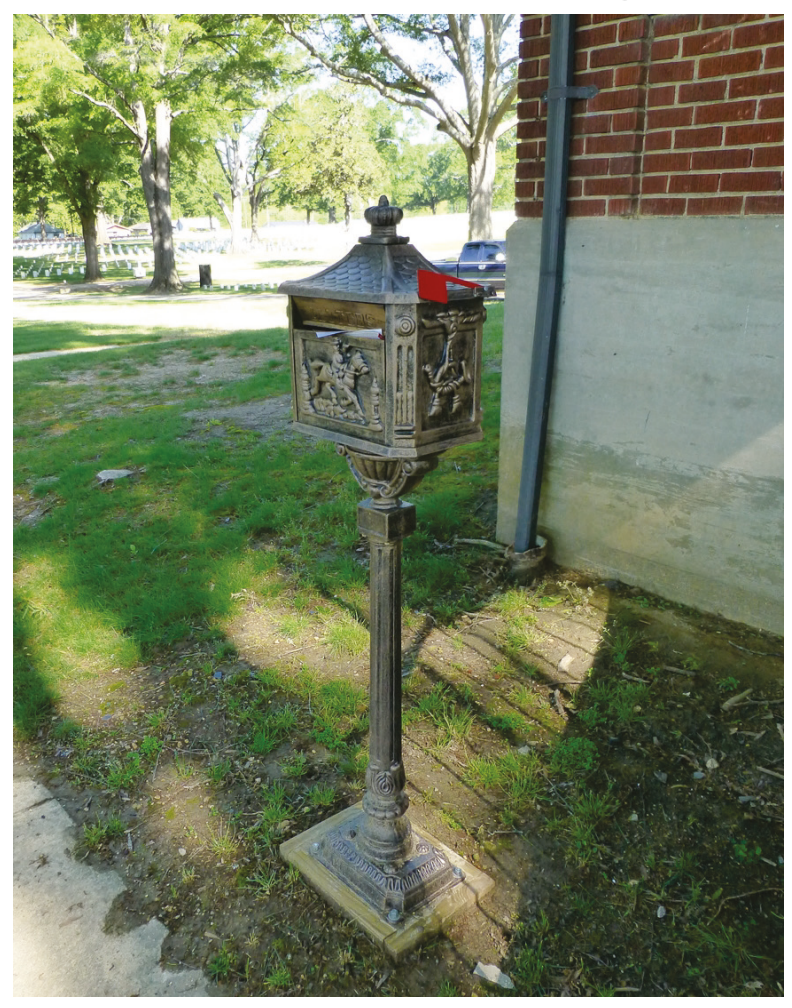

Figure 147. Receptacle for storing reusable flower stands located along the main road north of the main entrance, 2018 (ERDC-CERL).

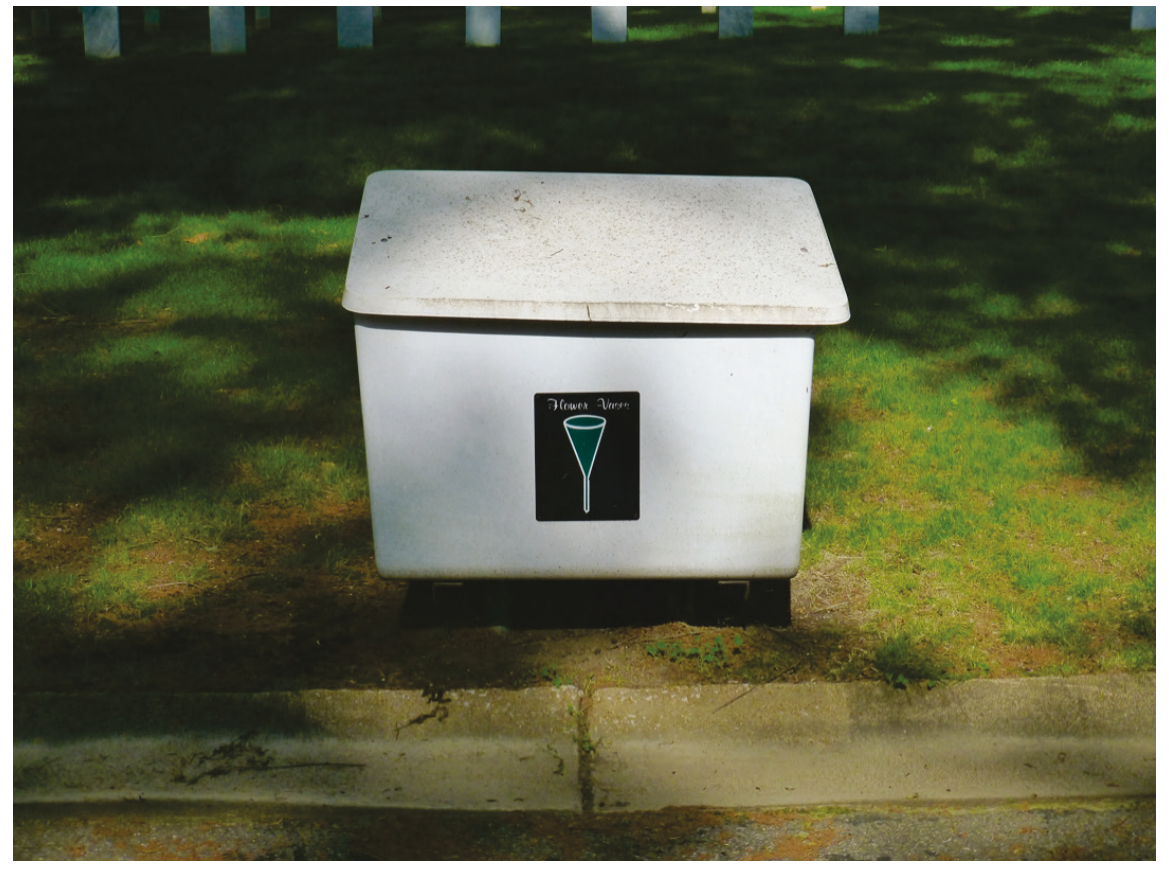


Figure 148. Outdoor ashtray made out of brown aggregate. Located near the committal shelter, 2018 (ERDC-CERL).

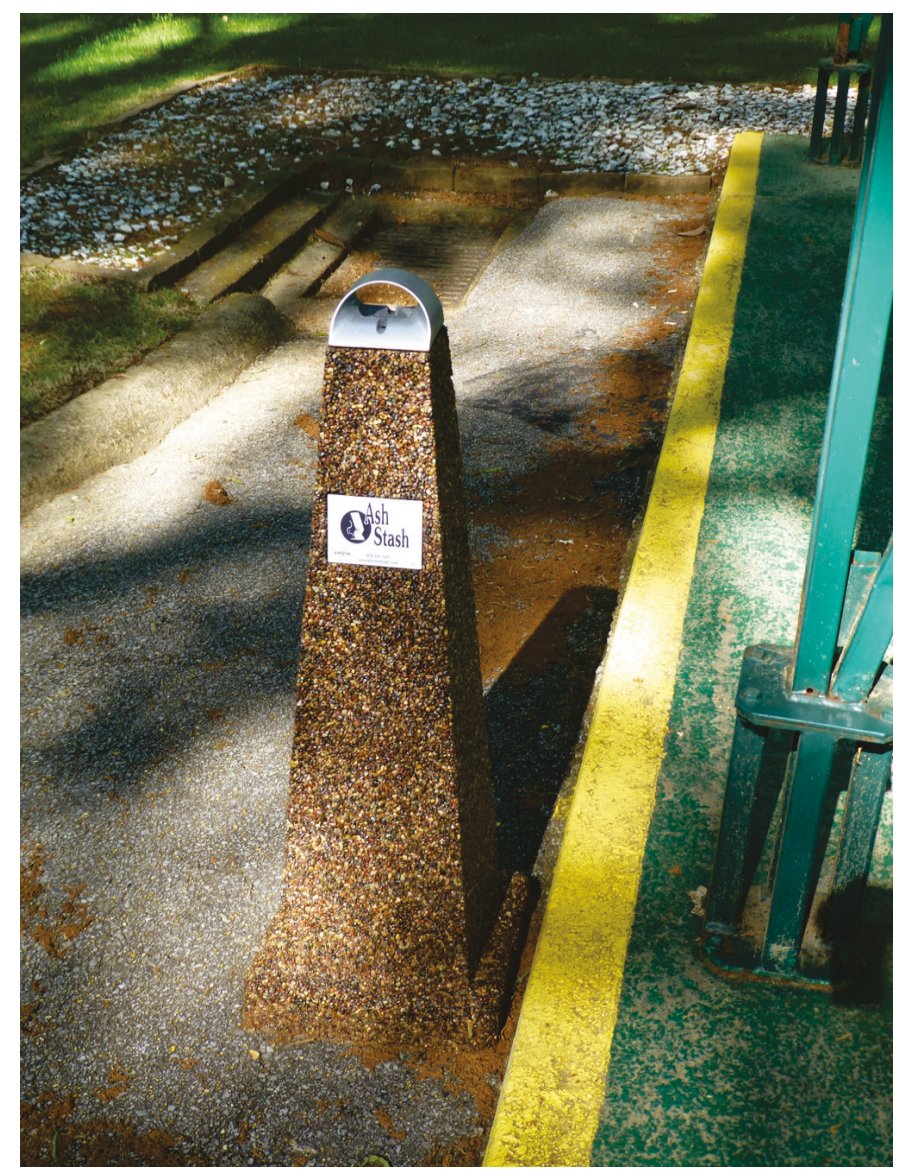

Figure 149. Survey marker set in concrete, 2018 (ERDC-CERL).

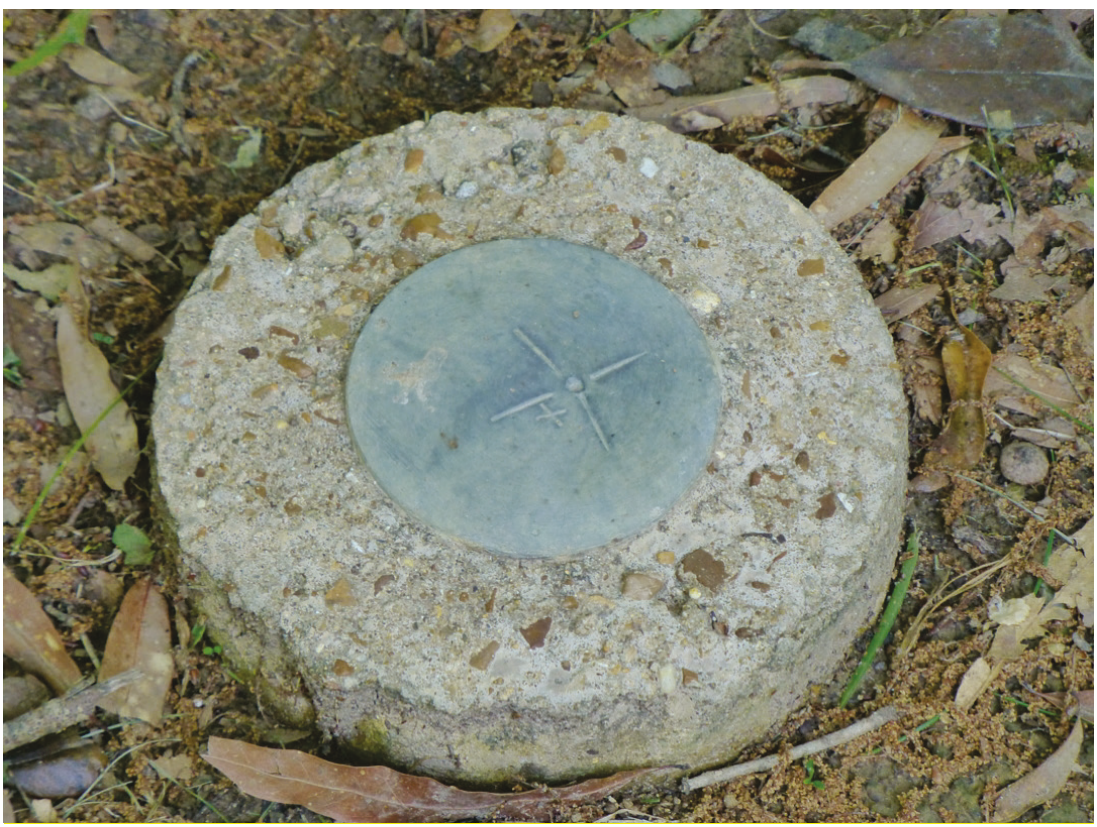




\subsubsection{Views and vistas}

Because Corinth National Cemetery encompasses a small site, most of the cemetery can be seen from any one point. The cemetery edges are lined with tall shade trees that provide a background for the views. However, there are two significant viewpoints-one from the flagstaff mound looking south (Figure 150) and the other from the main entrance looking north (Figure 152). Those two locations take into account the topography of the site and provide the most dramatic views of where the defining features of the landscape can be viewed (Figure 151 and Figure 153).

Figure 150. Viewshed from the flagstaff mound looking south toward the main entrance, 2018 (ERDC-CERL).

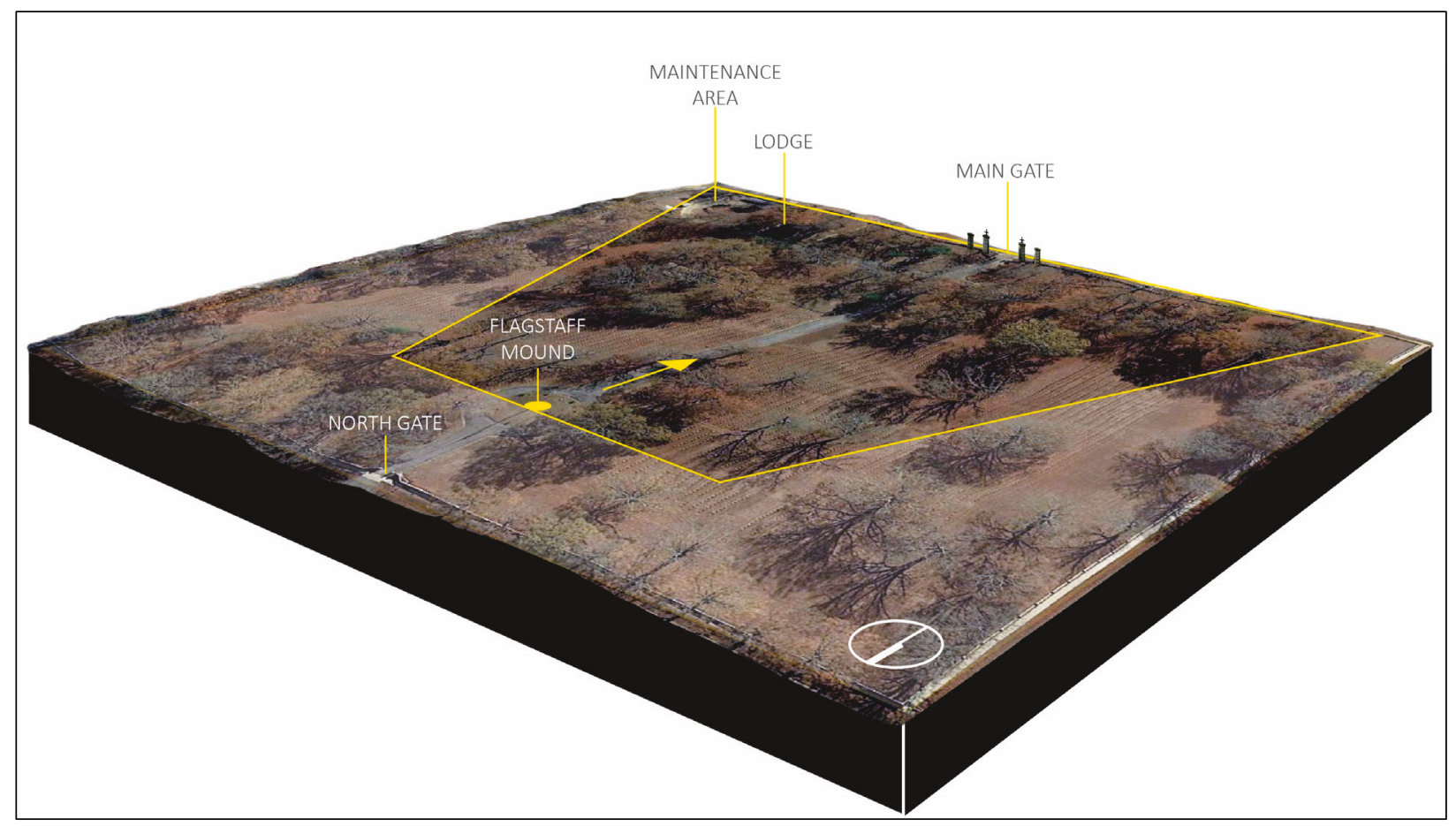


Figure 151. View from the flagstaff south to the main gate, 2018 (ERDC-CERL).

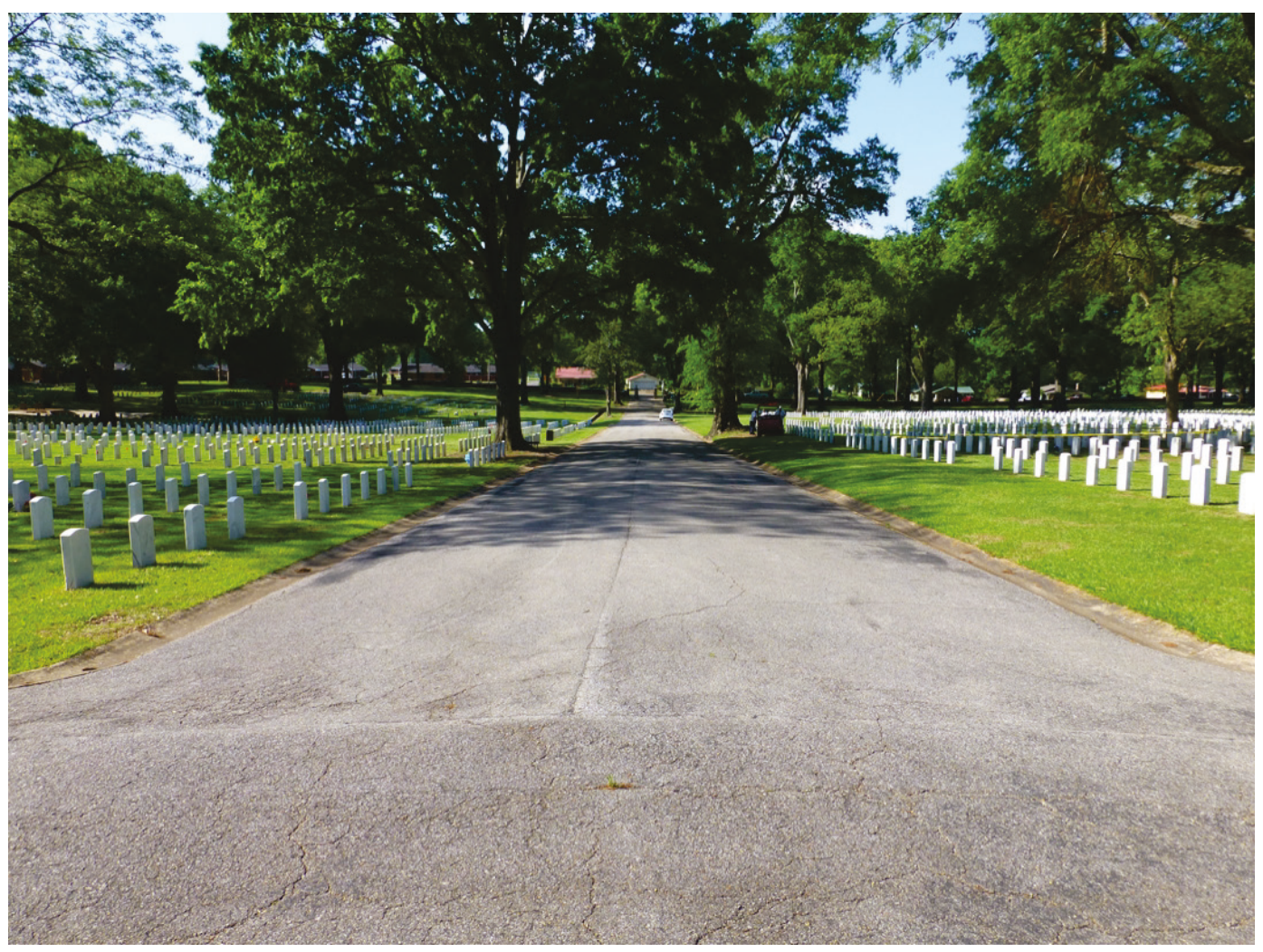

Figure 152. Viewshed from the main gate toward the flagstaff mound, 2018 (ERDCCERL).

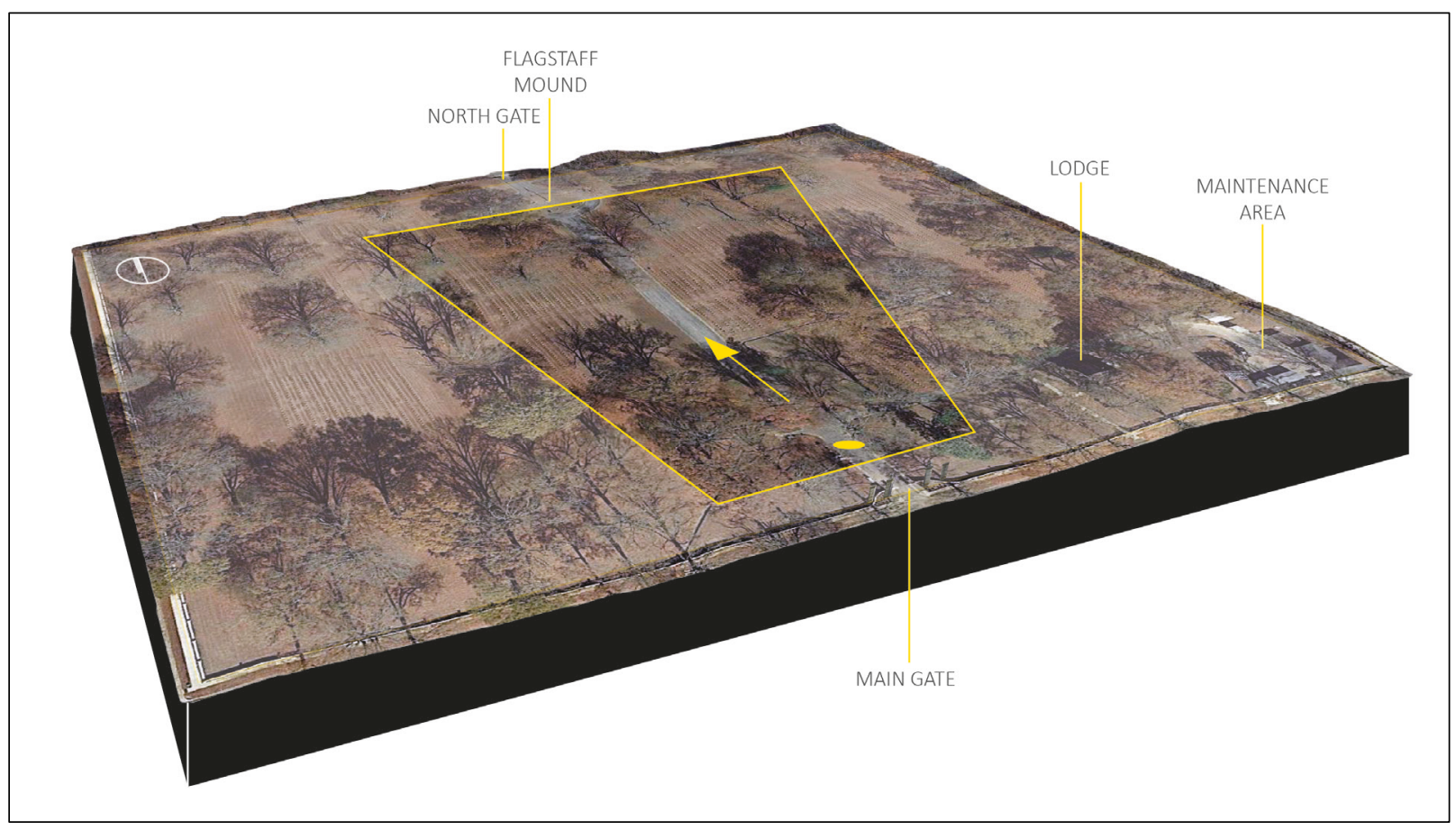


Figure 153. View from the main gate looking north toward the flagstaff mound, 2018 (ERDC-CERL).

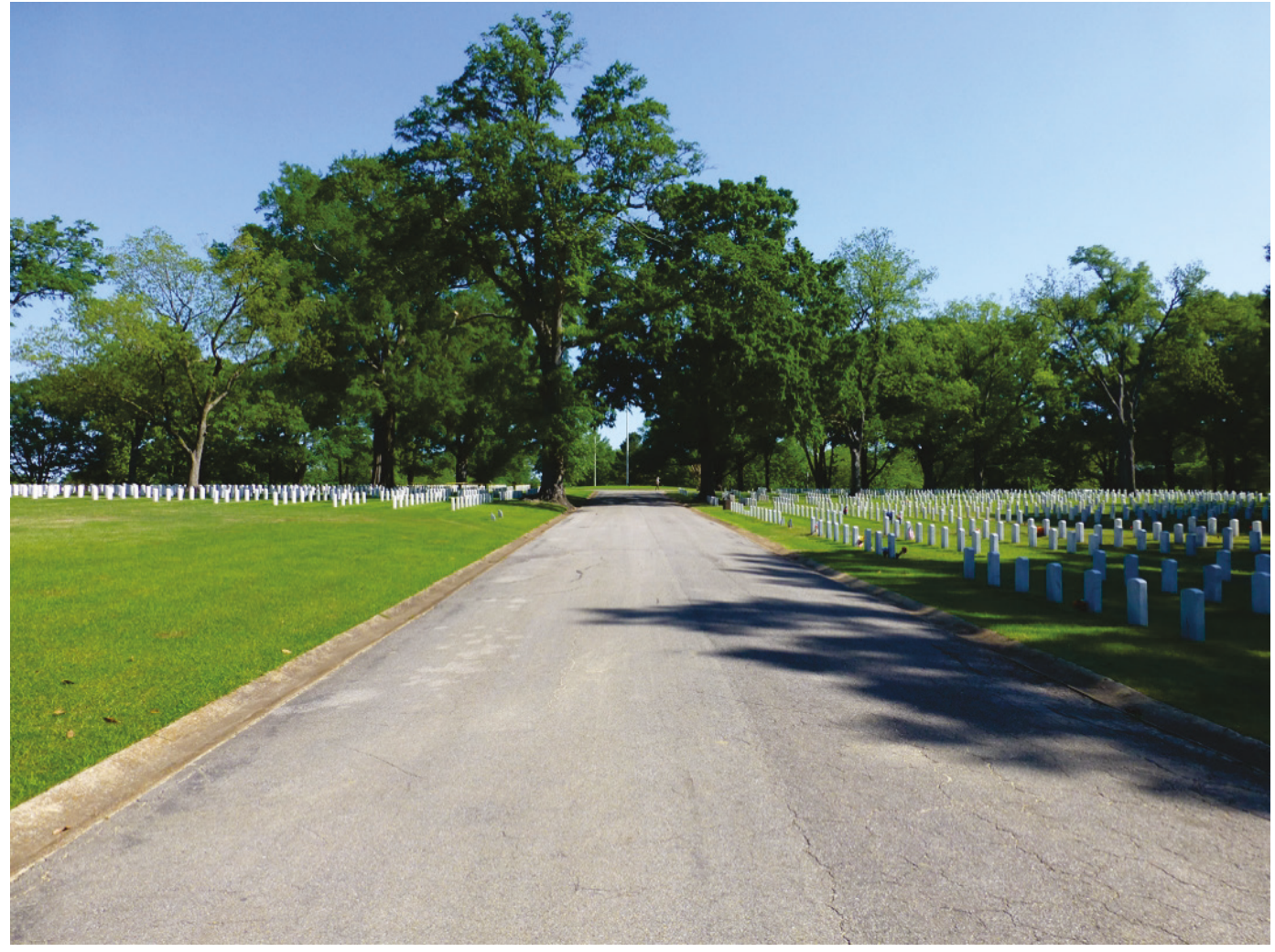

Secondary viewsheds exist looking east from the location of the old rostrum towards the lodge, and north-south along the former allèe of trees along the western side of the cemetery (Figure 154). These viewsheds were identified through the landscape development history research, and sufficient remnants remain today to locate these viewsheds in the current landscape. 
Figure 154. Secondary viewsheds along allée and towards lodge, 2018 (ERDC-CERL).

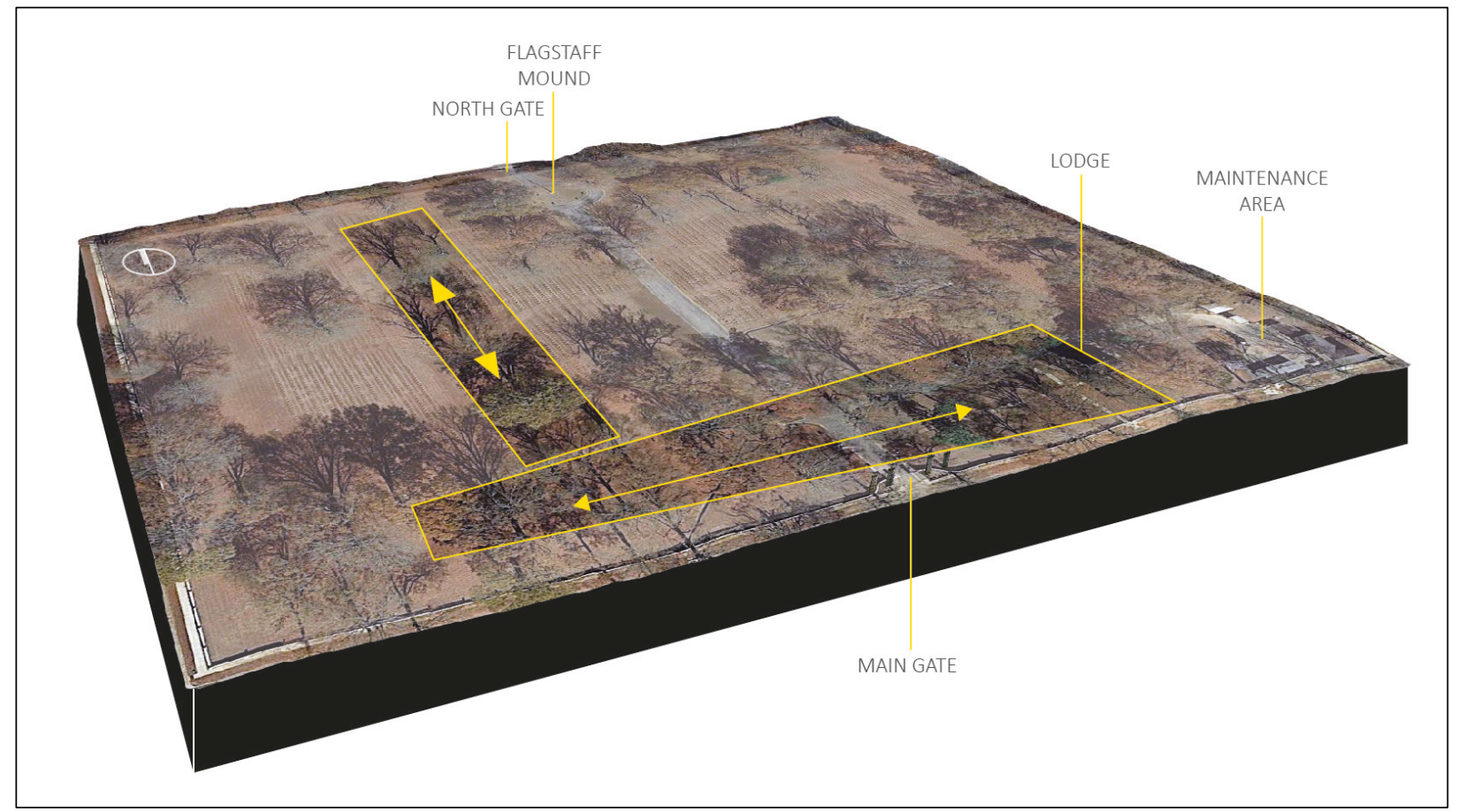




\section{Landscape Features Analyses}

As stated in the 2011 clarification policy from NRHP, all features within the boundary of a national cemetery are considered to be contributing resources to the history of the site. ${ }^{143}$ That type of all-encompassing consideration is different from most NRHP-eligible properties. For most properties, there are almost always some resources that do not contribute to the significance of the property, whether that property is a site, building, structure, or district.

The inventory and analysis for this work documents the physical changes to Corinth National Cemetery over time-from its inception through 2018. The resources used for the analysis are historic plans of the cemetery (1892, 1954, 1964, 1983, and 2009), historic photographs, and the field survey the authors conducted during May 2018. As of spring 2018, there were 7,892 burials recorded at Corinth National Cemetery.

For purposes of analyzing the landscape of Corinth National Cemetery, the site has been divided into four quadrants-northeast, southeast, southwest, and northwest. The site is divided into those quadrants naturally by the main road and the original east-west grass drive, and each quadrant encompasses multiple burial sections (Figure 155). Each quadrant's analysis is given below in sections 5.1.2-5.1.5. The site's perimeter fence is discussed in section 5.1.1, and the flagstaff mound is discussed individually in section 5.1.6.

143 NPS, National Register of Historic Places, “National Register Eligibility of National Cemeteries-a Clarification of Policy," 
Figure 155. Corinth National Cemetery divided into quadrants for landscape feature analysis. Gray shading indicates those sections that have burials, 2018 (ERDC/CERL).

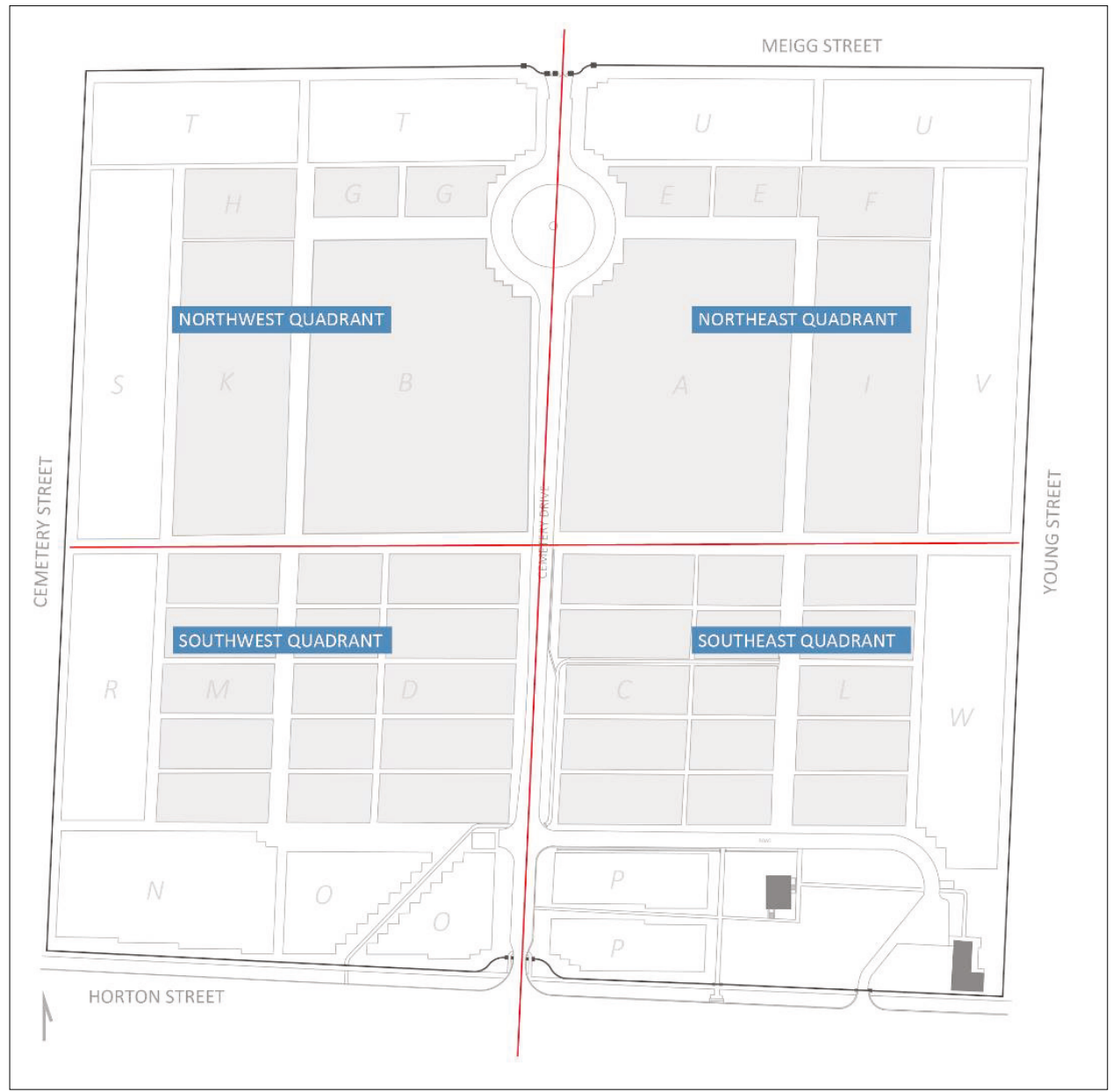

\subsection{Features analyses}

\subsubsection{Perimeter fence}

According to the original Act of Congress establishing the National Cemeteries, Corinth National Cemetery was bounded by a perimeter fence. The original fence was built from wooden pickets, but it was soon replaced with a brick wall. Since the construction of the original brick wall, the wall has been repaired and/or replaced several times $(1871,1874,1876,1888$, 1953, and 2015). The placement of the current wall reflects the location of the original wall, the placement of the north and south entrance gates, and the pedestrian and maintenance area gates within that wall. The brick wall that stands today was built in 1953 and was repaired most recently in 2015. Repairs to the current wall have left older bricks along the bottom 
courses and placed newer bricks at the top. The current concrete coping was added in 2015 .

\subsubsection{Northeast quadrant}

The northeast quadrant encompasses Sections A, E, F, I, U, and V as well as a small memorial section in the northwest corner of the quadrant. By 1954, Sections U and V were incorporated into the plan, but as of 2018 neither contains any burials. Sections U and V were located near the property's edge, where there was originally an undulating grass drive that encircled the property's perimeter.

\subsubsection{Preliminary plan (undated)}

An undated preliminary design for the cemetery illustrated the sections with more elaborate geometries than what was later constructed (Figure 156). Section A is the most changed from those early designs. The early layout featured the burial sections divided by a circular path that created smaller, rectangular and wedge-shaped burial sections. That central area in Section A was labeled Illinois, presumably to denote a section for burial of Illinois soldiers. In Section A, the northernmost burial area was marked Indiana. In this preliminary design, Section $\mathrm{E}$ was marked for Miscellaneous, Section F was marked Unknown, and Section I was marked Unknown Colored. Along the main drive was a strip designated as reserved vacant space. In the middle of the north wall was an entrance labeled "gateway" (as labeled at far upper left in Figure 156). 
Figure 156. The northeast quadrant of an undated preliminary design for the Corinth National Cemetery. Several of the design features were carried through into what was constructed (NARA, College Park, MD).

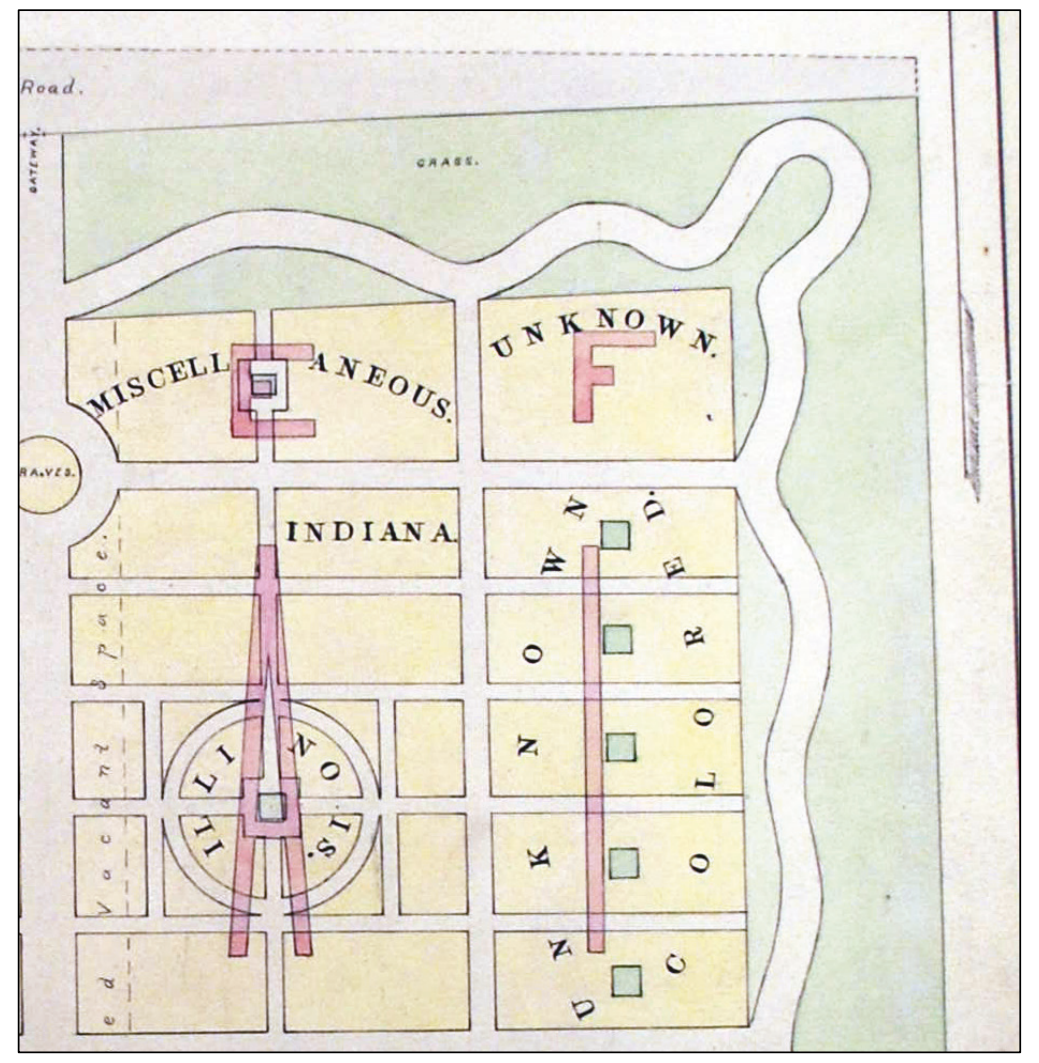

\subsubsection{1892 plan}

The 1892 plan shows many deciduous and coniferous trees as well as shrubs had been planted in the northeast quadrant. Running north-south through the center of the quadrant was a wide, grassed drive. That drive connected to the curvilinear perimeter grass drive to the north and the central east-west grass drive at the quadrant's south side. East of the flagstaff mound was another grass drive. The grass drives were wider than the aisles between burial sections. In this quadrant, Section A extends over the largest area. Within the section are four distinct burial groupings-two that are rectangular and filled with regularly spaced graves. Between those two groupings are burials arrayed in geometric patterns with a lot of open area around the groups. In the north portion of Section A is a gun monument (Figure 157). 
Figure 157. Photograph of the gun monuments in Corinth National Cemetery, Sections A and B, undated (NCA archives, Washington, DC).

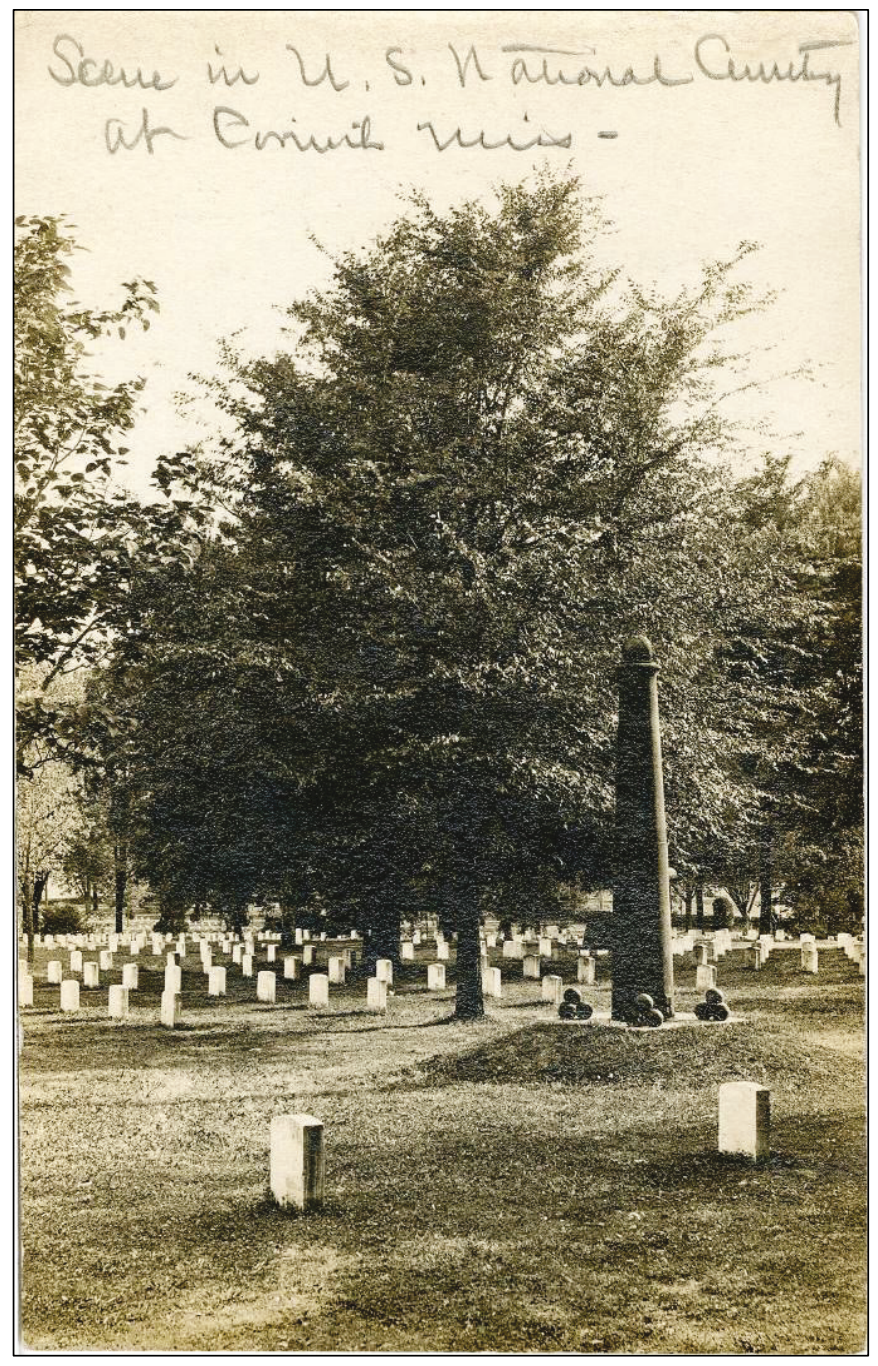

On this 1892 plan, section markers were represented as small squares. Photographs from around this time show the section markers to be tall, white, square pillars with a sphere on top (Figure 158). 
Figure 158. A tall, sphere-topped section marker is shown to the right of the image here, which has been cropped from an undated postcard of Corinth National Cemetery (NCA archives, Washington, DC).

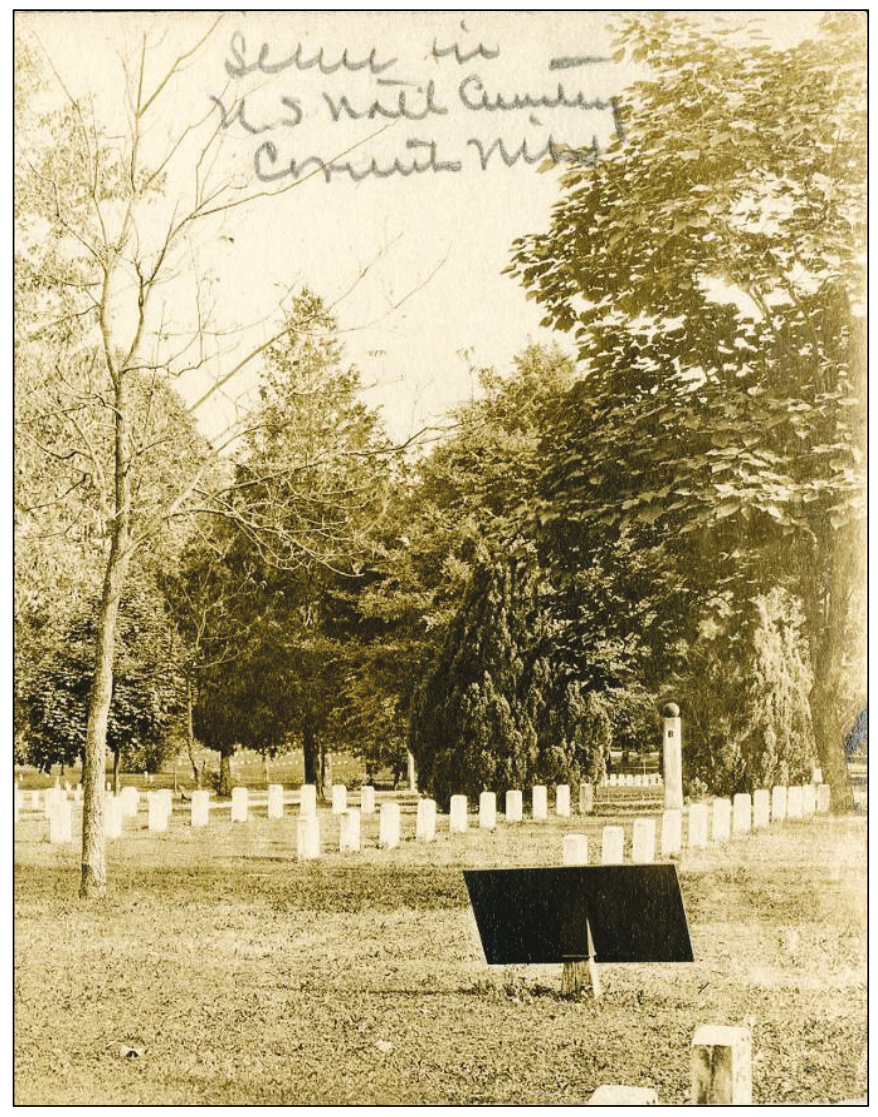

The 1892 plan documents rectangular burial groups for Sections E, F and I in the northeast quadrant. The headstones were evenly arrayed into rows, with the gravesites oriented east-west. Sections E and F are shown completely filled, with section markers located at their midpoints and slightly north of the sections. Section I is also shown as filled with graves. All of the sections have trees interspersed among the graves, obstructing some of the sites.

Figure 159 is the 1892 plan for the northeast quadrant, showing the layout of gravestones in the sections as well as the arrangement of vegetation throughout the area. 
Figure 159. Plan of the northeast quadrant of Corinth National Cemetery, drawn in 1892 (NCA archives, Washington, DC).

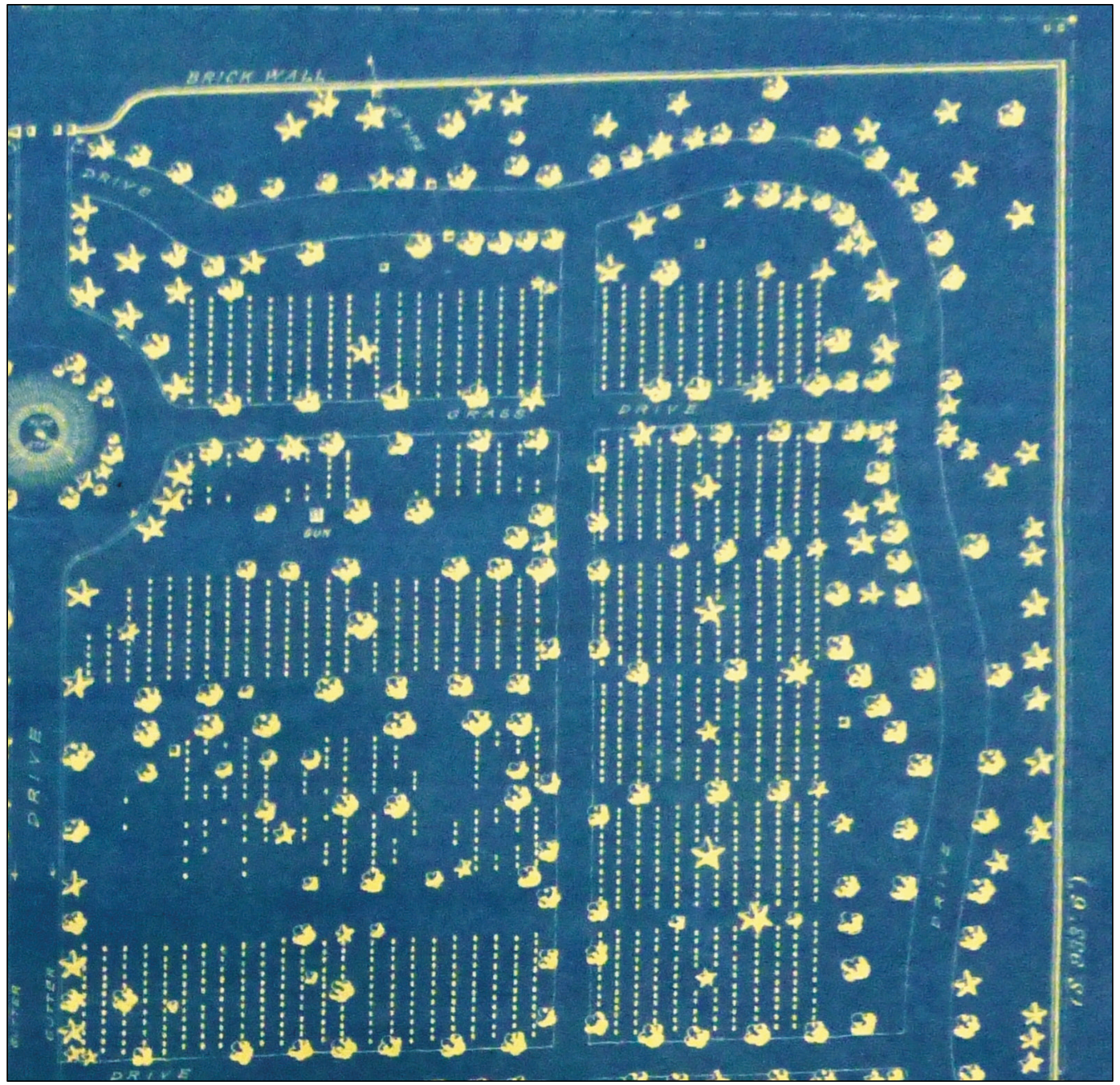

Figure 160 shows the cemetery in the spring of 1948. In the view there are many large deciduous trees, evergreen trees and shrubs, and other shrubs. The site is framed by vegetation. 
Figure 160. Spring 1948, looking across a section of graves for Unknown Soldiers at Corinth National Cemetery. There are many trees and shrubs arrayed across the site (NCA archives, Washington, DC).

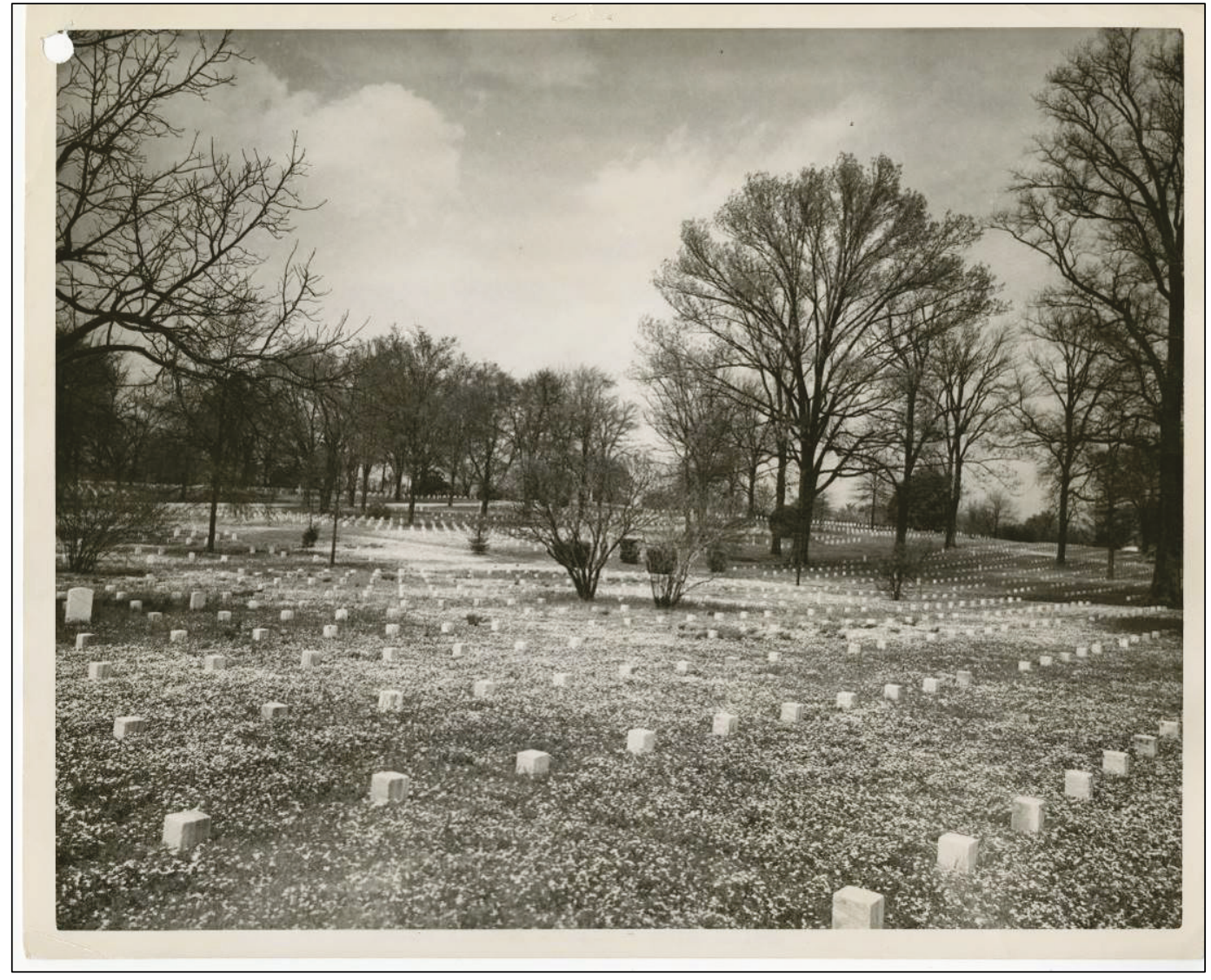

\subsubsection{1954 plan}

The records for Corinth National Cemetery have a gap in information between the late 1800 s and the mid-twentieth century. A 1954 plan of the northeast quadrant shows that significant changes had altered the layout shown in the 1892 plan. The most significant change was in Section A, where the geometric headstone patterns and open spaces were being erased by the incorporation of newer burials in the open spaces. In Section A, there is a gravesite that intrudes into the grass aisle. Between 1892 and 1953, the headstones were reversed from facing west to facing east. The date for this could not be determined due to the lack of archival material from this period. By 1954, the undulating perimeter grass drive had also been removed to make two new burial sections-U and V (Figure 161). It is unclear when the vegetation that lined the perimeter grass drive was removed. Between 1892 and 1953, the headstones were reversed from facing west to facing east (an 1892 photo shows the headstones facing west while 
the 1954 plan shows them facing east). The date for this could not be determined due to the lack of archival material from this period (1909 is the most likely date due to the destructive impact of a storm that year). ${ }^{144}$

Another addition to the September 1954 plan shows a memorial section located west of Section $\mathrm{E}$ and curved to align with the roundabout junction at the flagstaff mound (Figure 161). The five grave sites in the memorial section were documented as being empty at that time. In 1981, however, a plan for the memorial section shows five grave sites, with graves 1 and 2 filled. In Grave 2, a Confederate States of America soldier is buried.

Figure 161. The 1954 plan of the northeast quadrant of Corinth National Cemetery (NCA archives, Washington, DC).

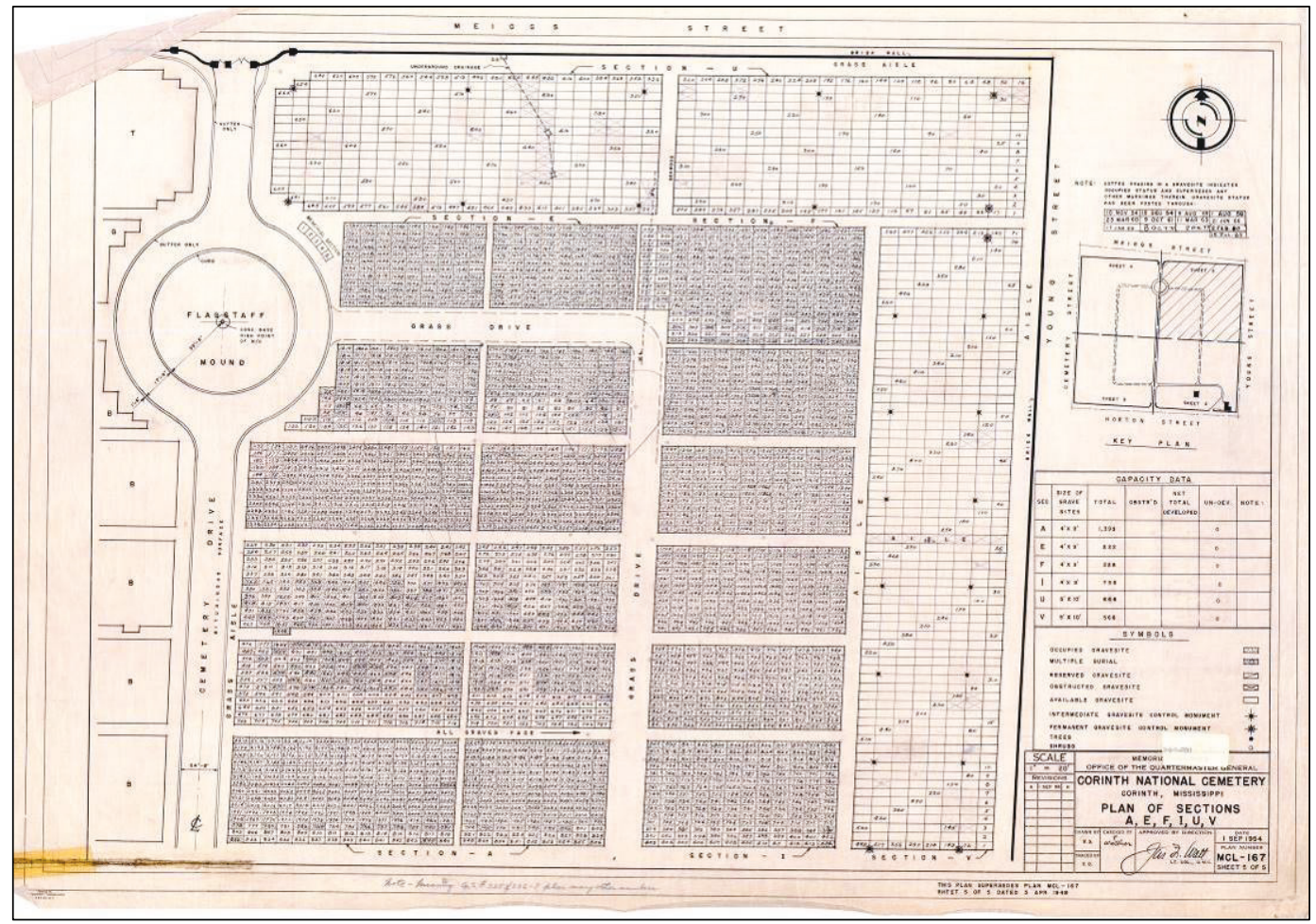

In a departure from the photographs from the 1940s, photographs from the 1950 s show a significant decrease in mature vegetation throughout the cemetery. Figure 162-Figure 164 show photographs taken of the northeast quadrant in the early 1950s, illustrating the changes in vegetation.

\footnotetext{
144 The change in the direction that grave markers faced was noticed by ERDC-CERL researchers when studying historical photos onsite at Corinth National Cemetery, but no archival documentation was ever located regarding this change.
} 
Figure 162. View toward the northeast corner of Corinth National Cemetery in April 1954 (NCA archives, Washington, DC).

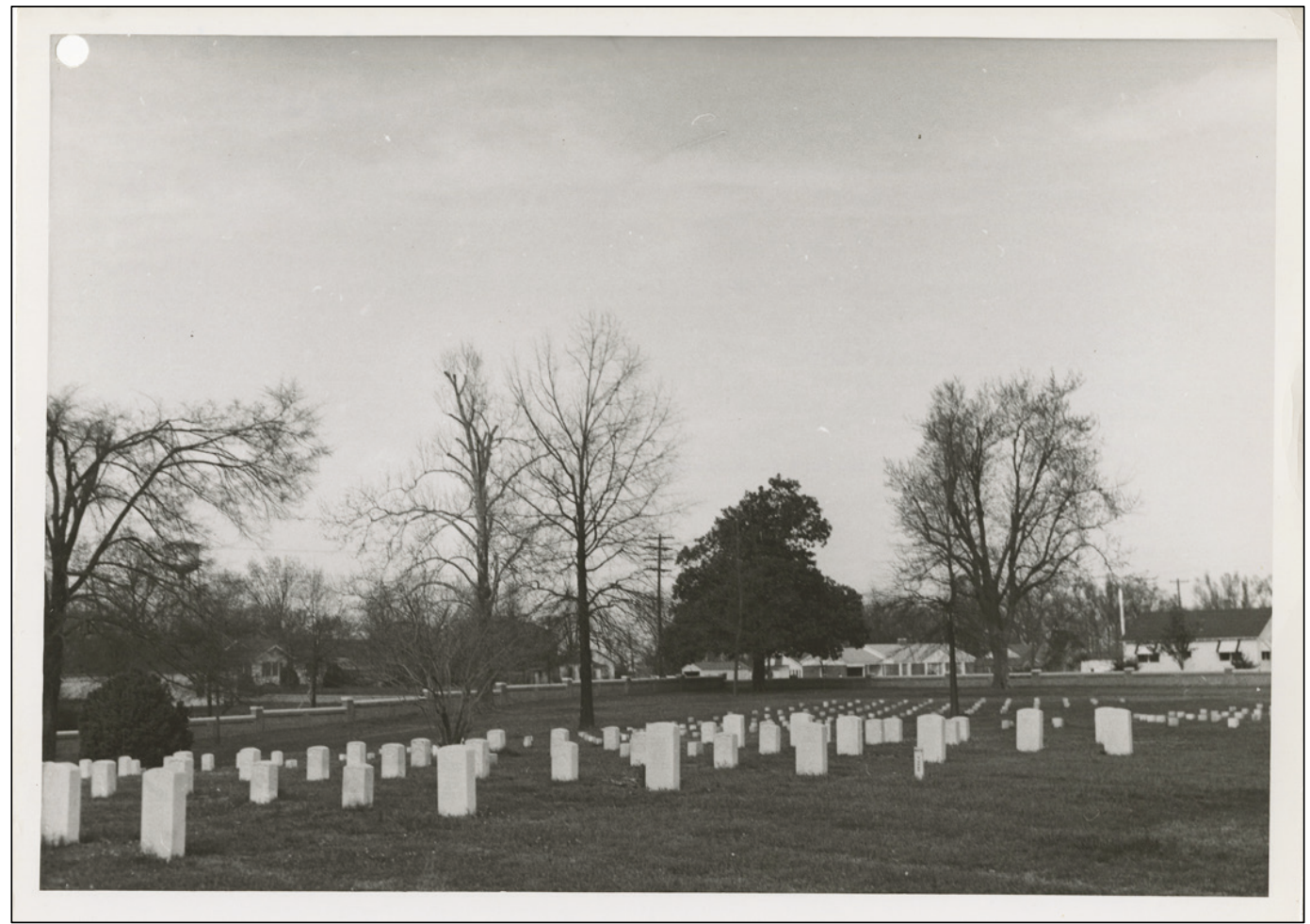

Figure 163. View looking east along the north perimeter wall of Corinth National Cemetery in April 1954. Note the size of the deciduous trees along the wall (NCA archives, Washington, DC).

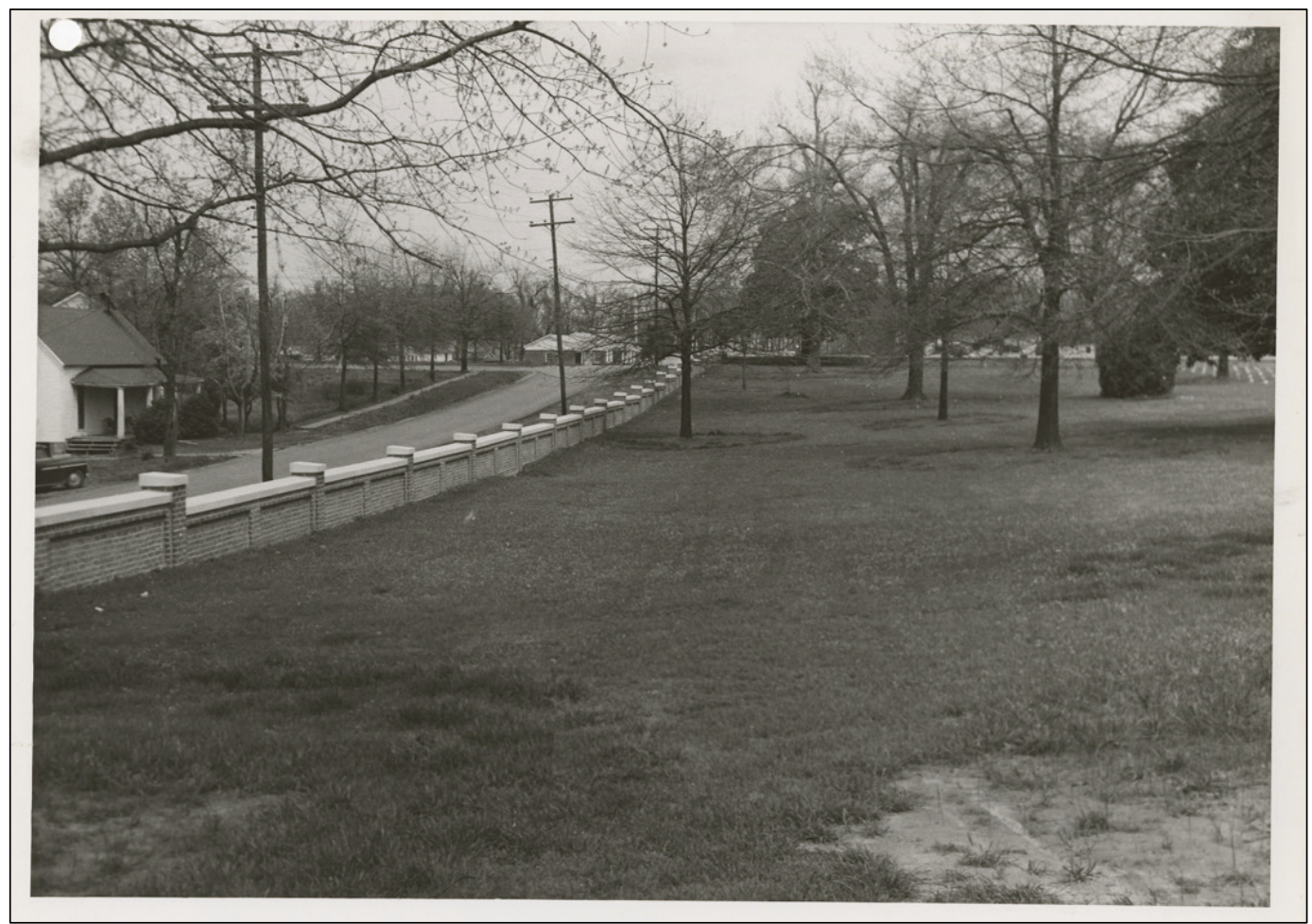


Figure 164. View looking east from flagstaff mound in April 1954. Note the decrease in vegetation across the quadrant (NCA archives, Washington, DC).

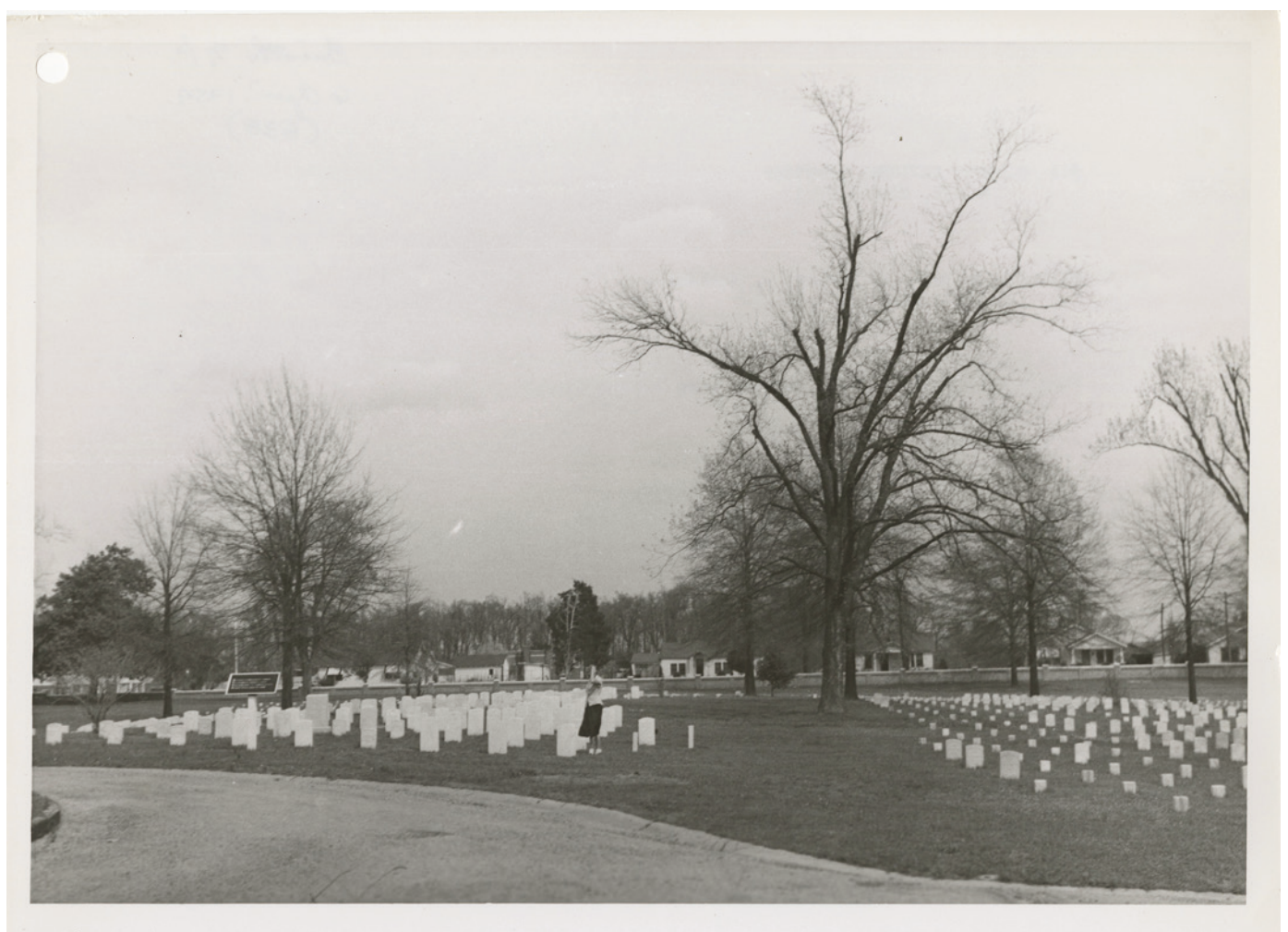

\subsubsection{1964 planting plan}

The 1964 planting plan shows that the outlines of the northeast quadrant section were interspersed with large deciduous and evergreen trees, smaller ornamental trees, and shrubs (Figure 165). In this quadrant, the main road was lined with Flowering Dogwoods. Near the flagstaff mound were crape myrtles. Along the inside of the perimeter wall were oak treesSouthern Red Oak, Water Oak, and Willow Oak. The following types of trees were scattered throughout the quadrant: Pecan, White Ash, American Holly, Tuliptree, Magnolia, and Winged Elm.

In 1964, Section A was planted with the following trees and shrubs: five Pecan (Carya illinoensis), six Flowering Dogwood (Cornus florida), two Peegee Hydrangea (Hydrangea paniculata grandiflora), one Common Crape Myrtle (Lagerstroemia indica), one Saucer Magnolia (Magnolia soulangeana), one Water Oak (Quercus nigra), and three Willow Oak (Quercus phellos).

In 1964, Section E was planted with one Willow Oak (Quercus phellos). 
In 1964, Section F was planted with one Willow Oak (Quercus phellos).

In 1964, Section I was planted with the following trees and shrubs: one American Holly (Ilex opaca), one Saucer Magnolia (Magnolia soulangeana), one Water Oak (Quercus Nigra), and two Willow Oak (Quercus phellos).

In 1964, Section U was planted with the following trees and shrubs: one Common Box (Buxus sempervirens), one Flowering Dogwood (Cornus florida), two American Holly (Ilex opaca), three Southern Magnolia (Magnolia grandiflora), five Water Oak (Quercus nigra), six Willow Oak (Quercus phellos), one Winged Elm (Ulmus alata), one Common Crape Myrtle (Lagerstroemia indica), and one Southern Red Oak (Quercus falcata).

In 1964, Section V was planted with the following: two Southern Red Oak (Quercus falcata), two Water Oak (Quercus nigra), and six Willow Oak (Quercus phellos).

Figure 165 shows the plan of trees and shrubs in the northeast quadrant in 1964. Figure 166 is a view through the northeast quadrant, showing maturing vegetation and an overall increase in density from the $1950 \mathrm{Os}$. 
Figure 165. 1964 planting plan of the northeast quadrant of Corinth National Cemetery (NCA archives, Washington, DC).

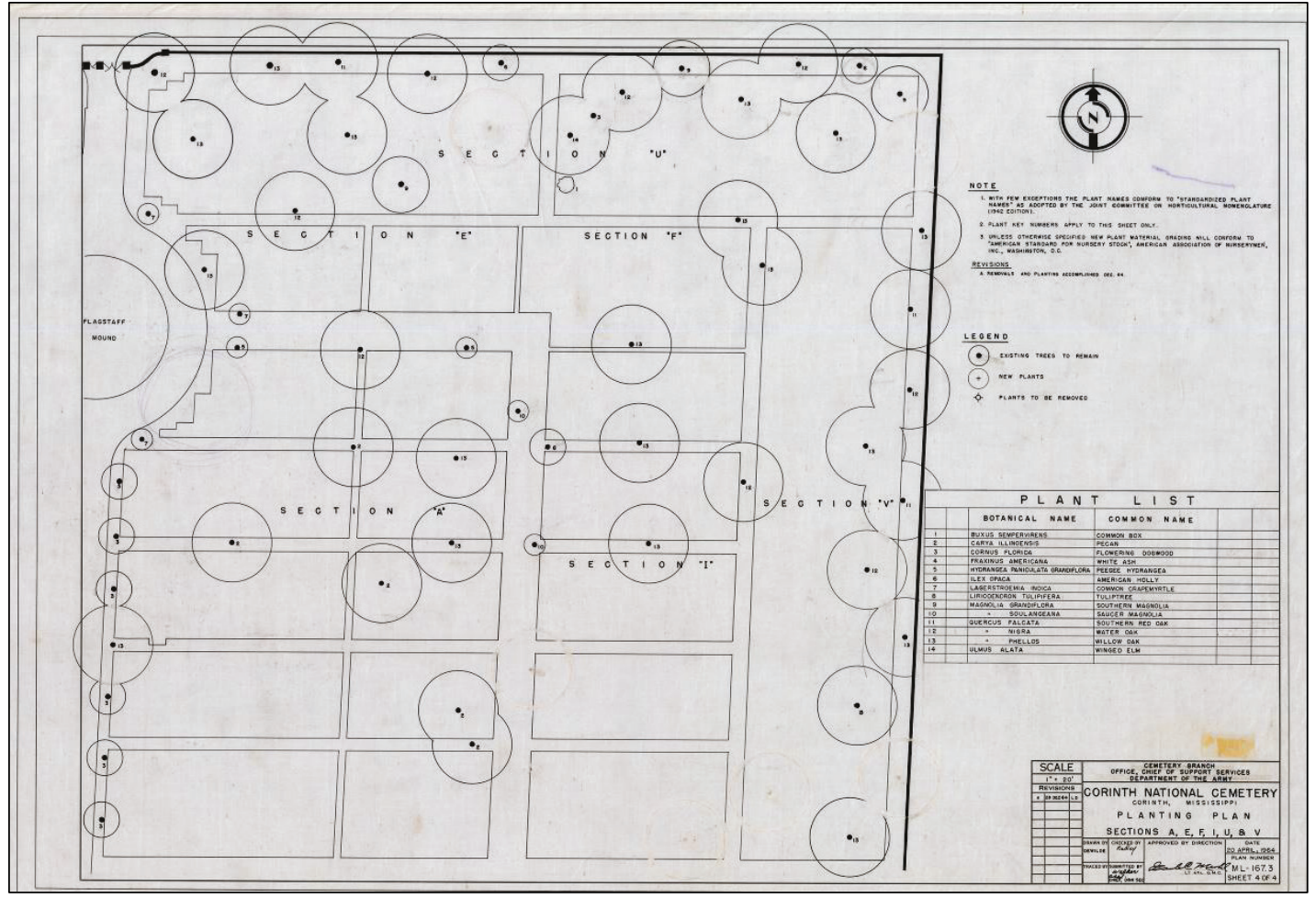

Figure 166. View west through the northeast quadrant of Corinth National Cemetery, toward the flagpole in September 1974 (NCA archives, Washington, DC).

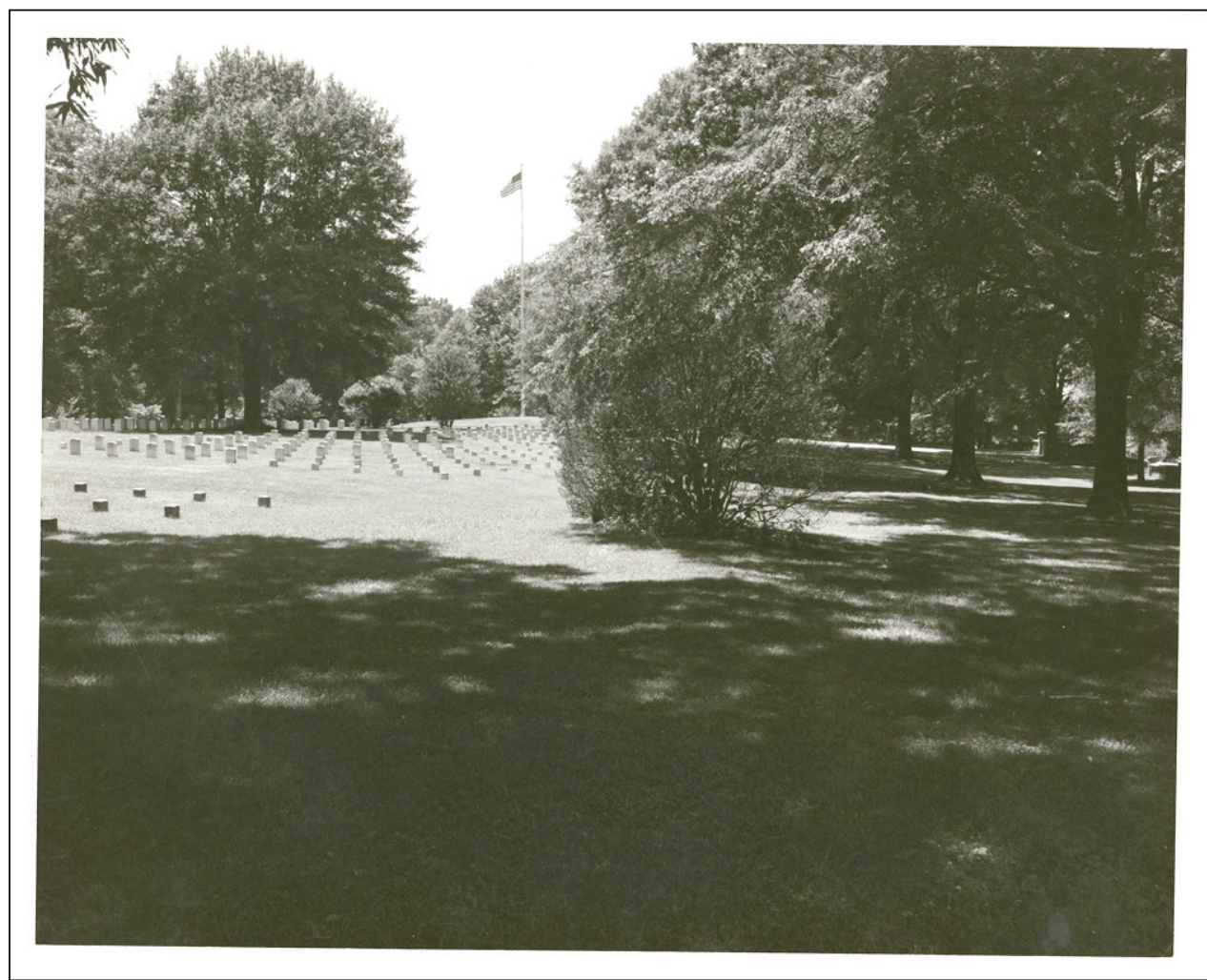




\subsubsection{1983 plan}

Figure 167 shows the 1983 burial plan of the northeast quadrant. The layout of the quadrant remains similar to the 1954 plan except for new graves being added in Section A, filling in around the distinct geometric burial patterns. Figure 168 illustrates that there was not much decrease in the vegetation in the northeast quadrant between 1964 and 1983 .

Figure 167. 1983 plan of the northeast quadrant of Corinth National Cemetery (NCA archives, Washington, DC).

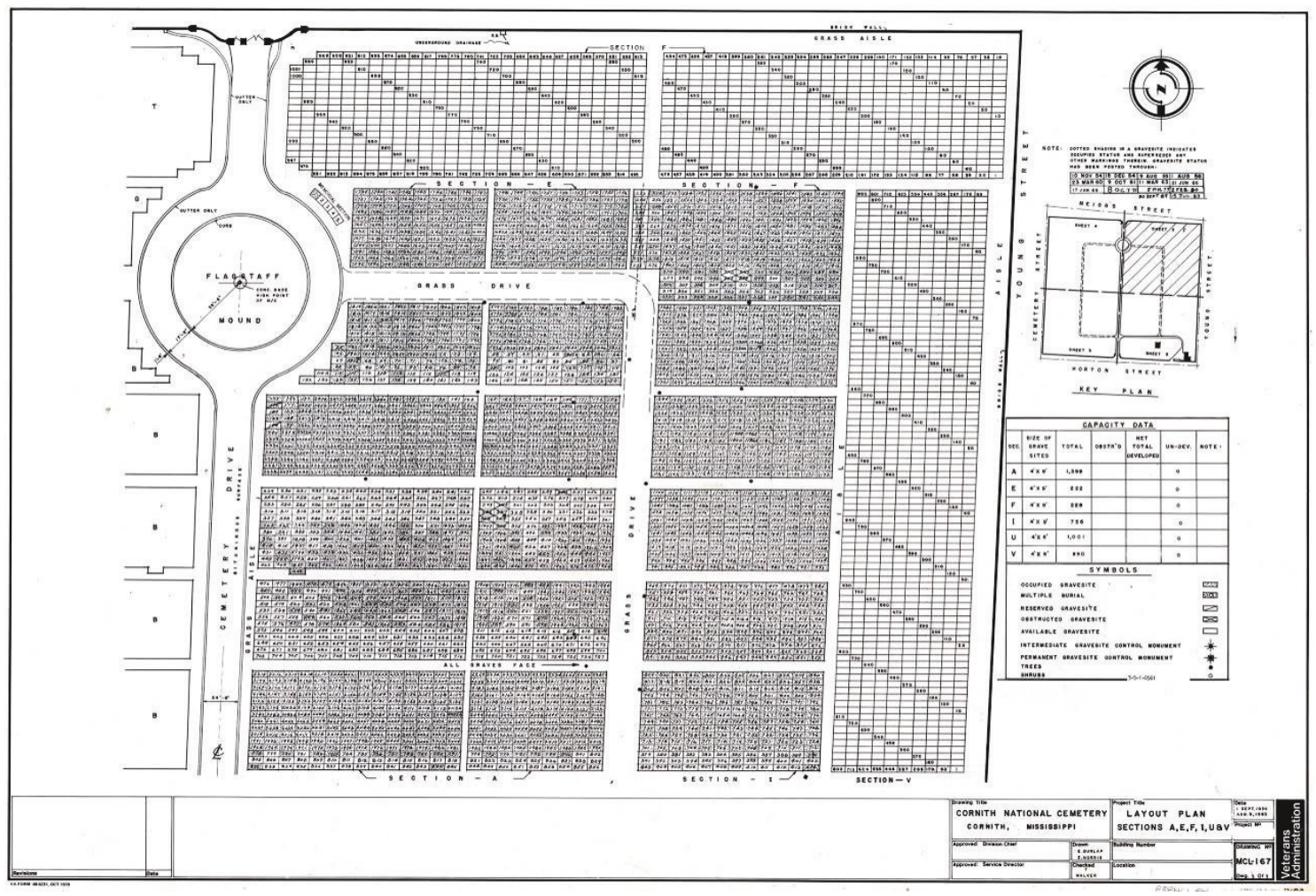


Figure 168. 1983 planting maintenance plan for the northeast quadrant of Corinth National Cemetery (NCA archives, Washington, DC).

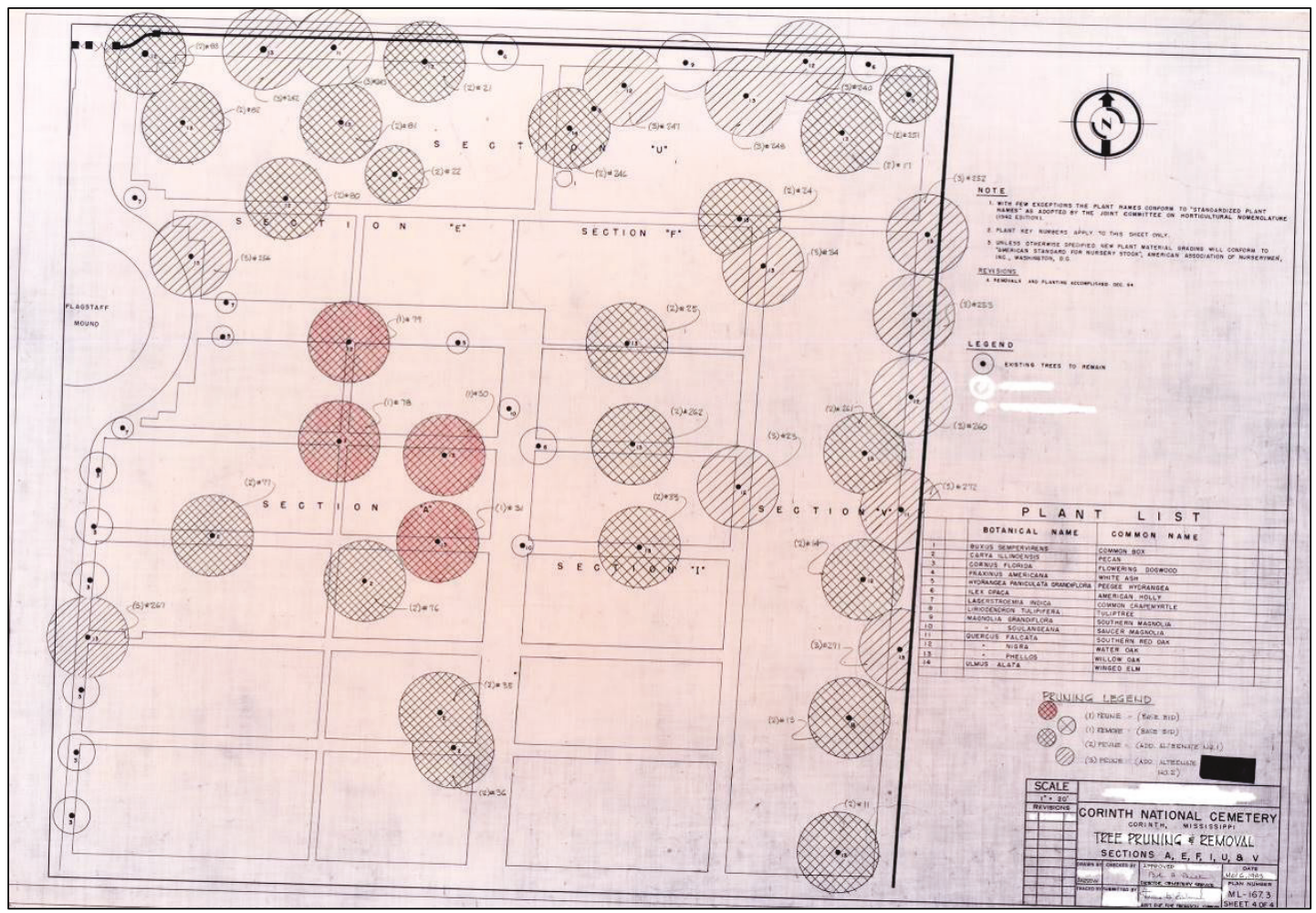

\subsubsection{2000s}

Figure 169 is a burial plan of the northeast quadrant in 2009. Between the 1980s and 2018, the memorial area was expanded to add a second row of graves, and the open spaces in Section A continue to be filled with new graves. The newer Sections of U and V remain empty of burials. 
Figure 169. Plan of the northeast quadrant of Corinth National Cemetery in 2009 (Veteran's Administration).

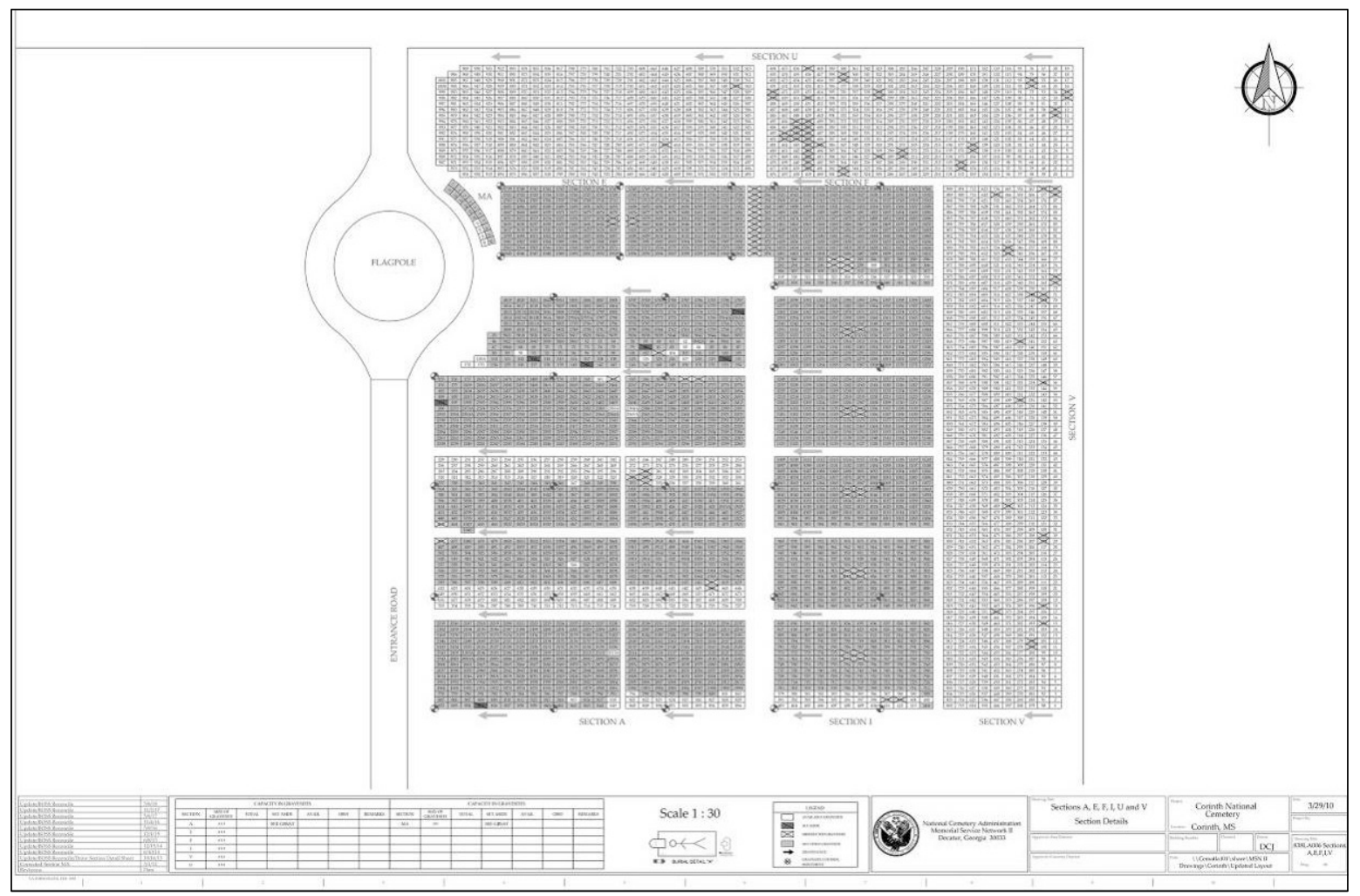

\subsubsection{Burial register summary}

According to records from spring 2018, Section A has 1,232 burials. Of those, 115 are Unknown Soldier burials, 539 of the burials are from deaths in the $1860 \mathrm{~s}$, and 2 burials are from deaths in the 1880s. The remaining burials in Section A are from the twentieth and twenty-first centuries, with the most recent in 2017. The open spaces that defined the geometric burial groupings in Section A have been filled with newer graves, and these are marked with the newer style of headstone.

In Section E, there are a total of 213 burials and of those, 109 are for Unknown Soldiers. Twenty-one of the known soldiers died in the 1860s. The remaining graves are known soldiers, but the grave markers lack dates of death or interment.

Section F has 215 burials. Of those, 144 are graves for Unknown Soldiers. There were 39 people buried in Section F in the 1970s, 4 people were buried in the 1980s, 5 people in the 1990s, 17 in the early 2000s, and 3 in the 2010s. 
There are 705 burials in Section I; 691 are Unknown Soldiers. The remaining 14 burials are 7 known soldiers who died in the 1860s, 4 people who were buried in the twentieth century, 1 person who was buried in 2014, and 2 graves that do not list dates of death or interment.

\subsubsection{Southeast quadrant}

\subsubsection{Preliminary plan (undated)}

On the undated preliminary design plan for Corinth National Cemetery, the southeast quadrant had two burial sections, Section C and Section L (Figure 170). Section C was designed like Section A in the northeast quadrant; it was a grid of burial groups divided by paths with a square and a circular path making a distinct shape in the center of the section. On this plan, the burial area defined by the circular path is labeled "Michigan." Written through the southern burial groupings in Section C is the label "Dead from Guntown" (a battled during the Siege of Corinth). Water drainage is illustrated to run between Sections $\mathrm{C}$ and $\mathrm{L}$ and then west through Section C. Section L is laid out like Section I in the northeast quadrant with regular rectangular burial groups with centralized square of open space. Section L is labeled "Unknown Colored." The undulating perimeter drive starts where the southwest corner of Section $\mathrm{C}$ meets the main road. The perimeter drive then runs straight past both sections and begins to curve when it reaches the east side of Section L. On this plan, the areas outside the burial sections are open. The main entrance is located in the middle of the cemetery's south side (visible in lower left corner of Figure 170). 
Figure 170. Undated design scheme for Corinth National Cemetery southeast quadrant (NCA archives, Washington, DC).

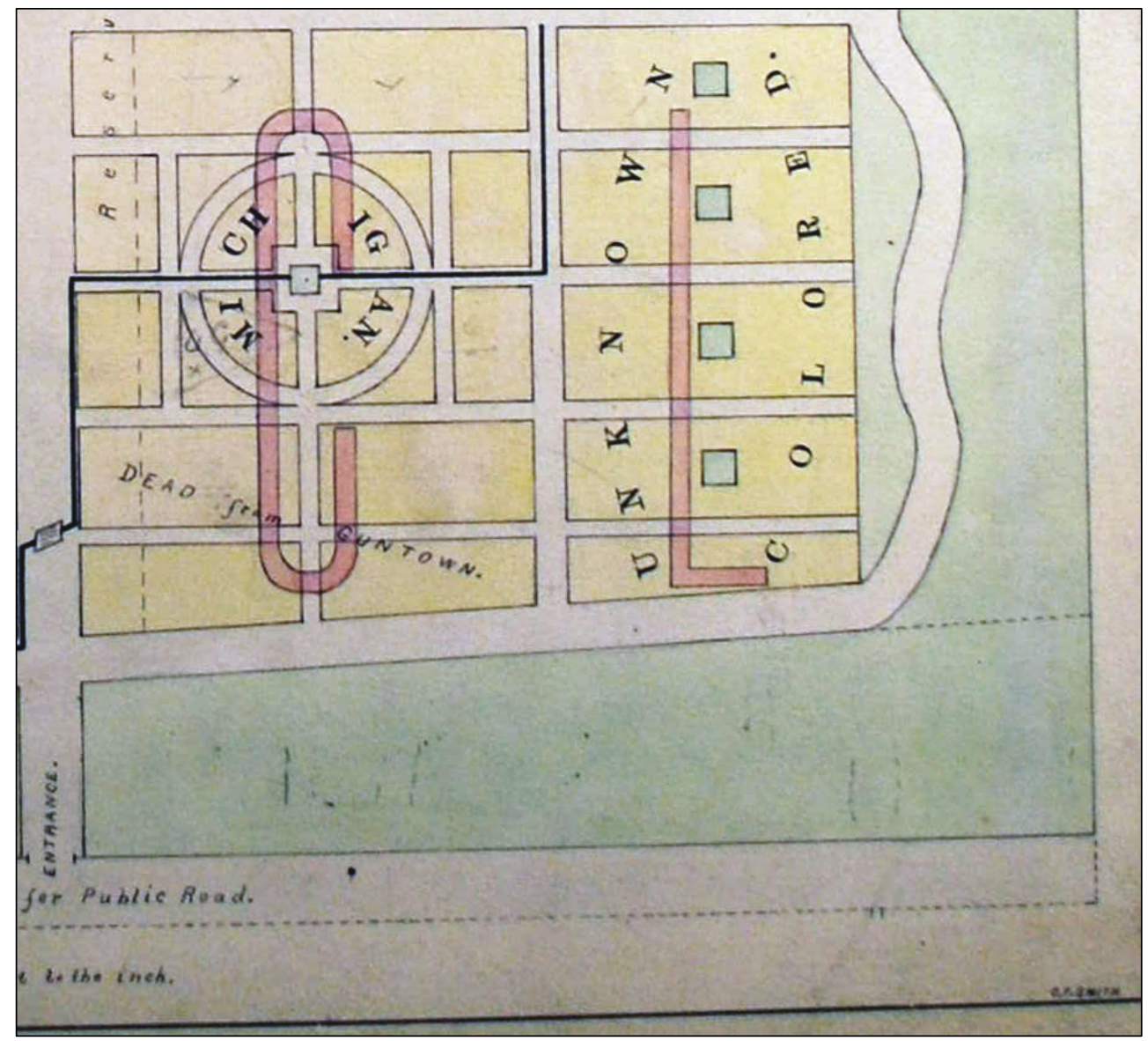

\subsubsection{1892 plan}

The southeast quadrant in the 1892 plan shows some significant changes from the preliminary design. Figure 171 illustrates the spatial organization of the southeast quadrant. Sections C and L occupied similar areas, but the burial groupings within those were organized differently. Section $\mathrm{C}$ featured two areas of distinct geometric burial patterns-where the placement of the headstones created square, circular, and wishbone patterns. These burial groupings were also differentiated because they were situated with a significant amount of open space around and in them. The open spaces in Section $\mathrm{C}$ were lined with vegetation, both deciduous and coniferous trees as well as smaller vegetation. The open space in the southern burial grouping was planted with trees. Section $L$ had five uniform rectangular burial groupings. There were trees planted in the middle of three of the groupings, and open spaces in the middle of two. Trees surrounded the perimeter of Section L, with a few trees scattered among the graves. East of Section L, the curvilinear grass drive was lined with trees. 
Figure 171. 1892 plan of Corinth National Cemetery southeast quadrant (NCA archives, Washington, DC).

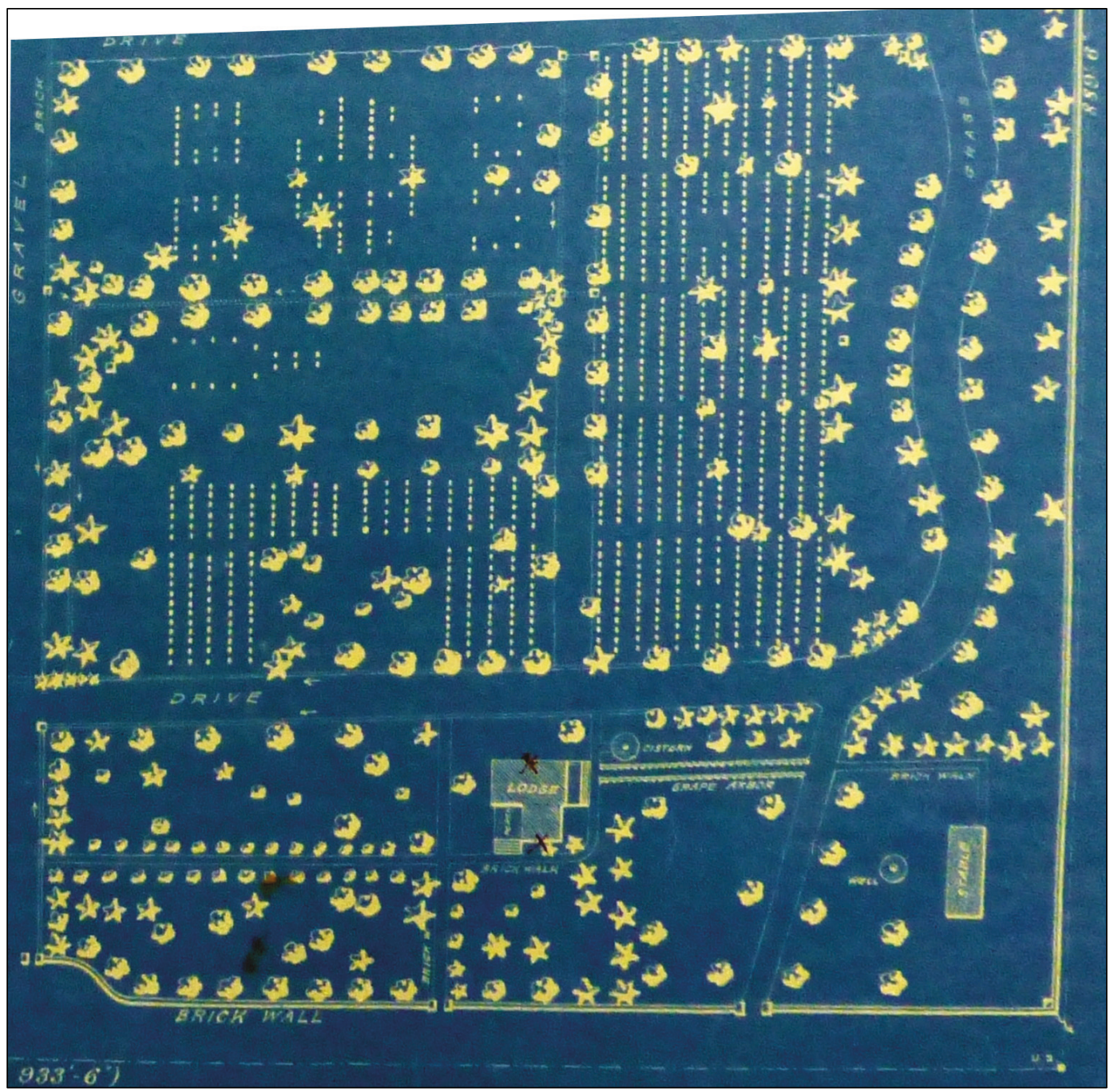

The 1892 plan shows the configuration of the Superintendent's Lodge and stable areas. The lodge was located east of the cemetery's main road. A brick walk ran east from the main gravel drive to the south side of the lodge. The walk curved around the east side of the lodge and ran north until it intersected the grass drive. There was another brick walk that ran north-south, and it was located west of the lodge that connected a pedestrian gate to the grass drive. This path crossed the other walk near the lodge. The area west of the lodge to the main drive was represented as open, with an array of trees and shrubs across the space. The brick walk through this area was lined with shrubs. The area between south of the lodge to the perimeter wall featured a variety of vegetation. East of the lodge was the cistern. Between the lodge and the stable area was a grape arbor that connected the brick walk east of the lodge to the service drive. 
There was a brick walk from the service drive to the stable. West of the stable was the well. The southern perimeter wall had a service gate and a pedestrian gate. The grass drive ran north of the lodge.

Figure 172 shows the layout of the maintenance area in 1892. Figure 173 and Figure 174 show the arrangement of buildings and structures as well as the vegetation around the lodge and maintenance area in 1904.

Figure 172. View of the lodge and stable area at Corinth National Cemetery in 1892. There is a hedge that defines the maintenance area. The well has yet to be covered with a structure. Vegetation in various stages of growth frames the background, 1892 (NARA, College Park, MD).

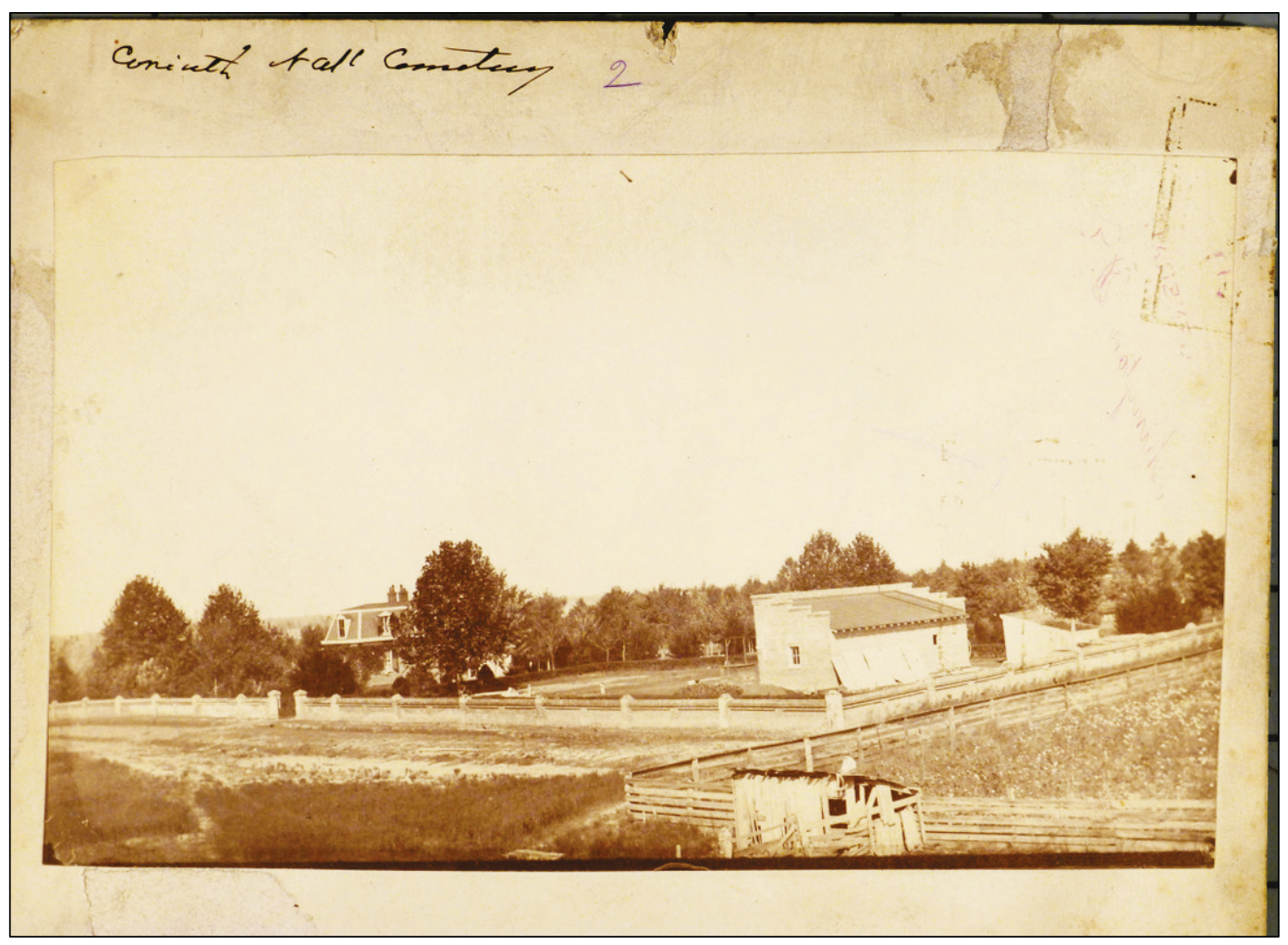


Figure 173. View of the pedestrian gate, wall, and lodge as well as vegetation in 1904 (NARA, College Park, MD).

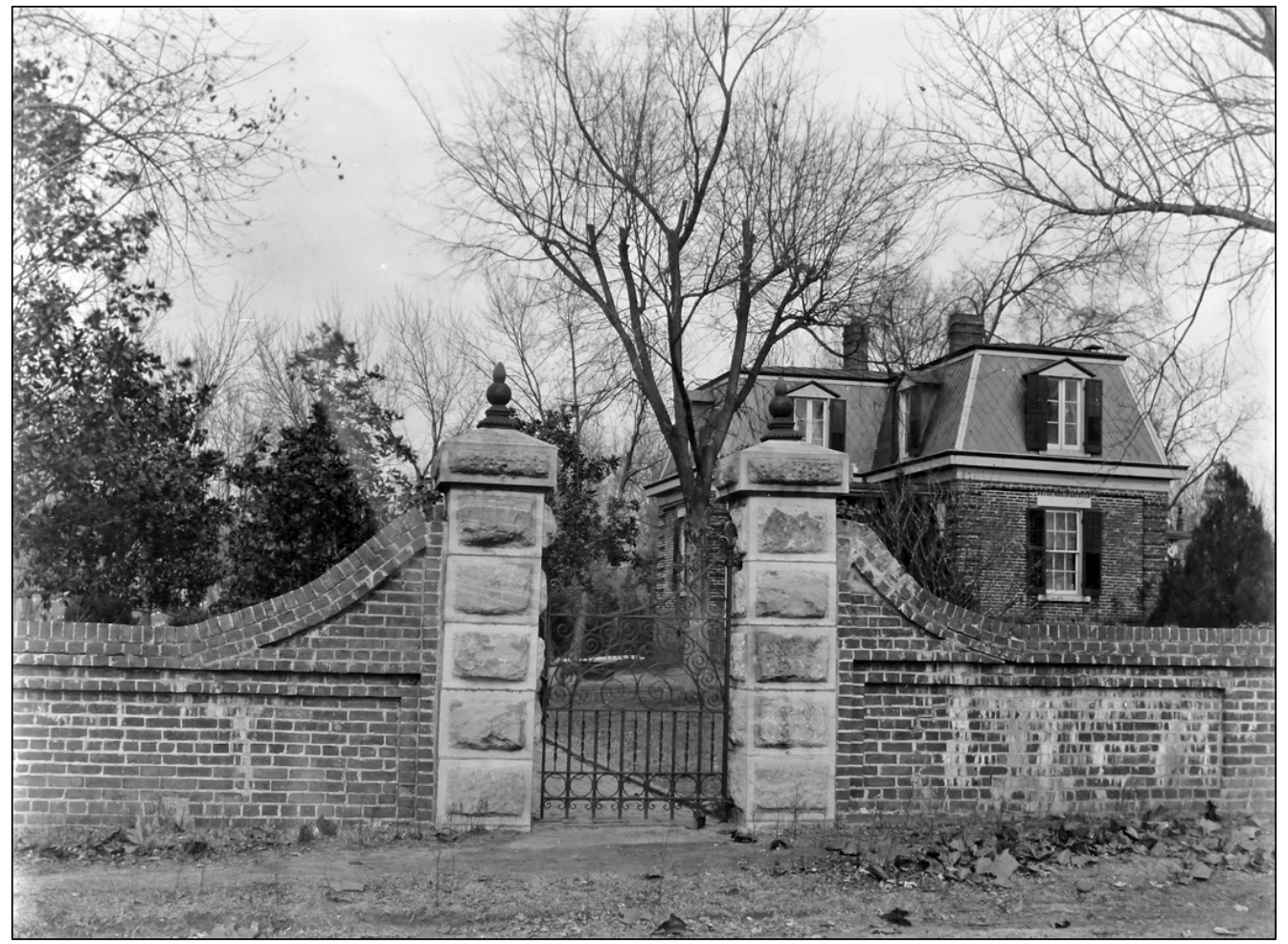

Figure 174. Maintenance area showing the gate, well, and stable at Corinth National Cemetery. The background on the left is the grape arbor, 1904 (NARA, College Park, $\mathrm{MD})$.

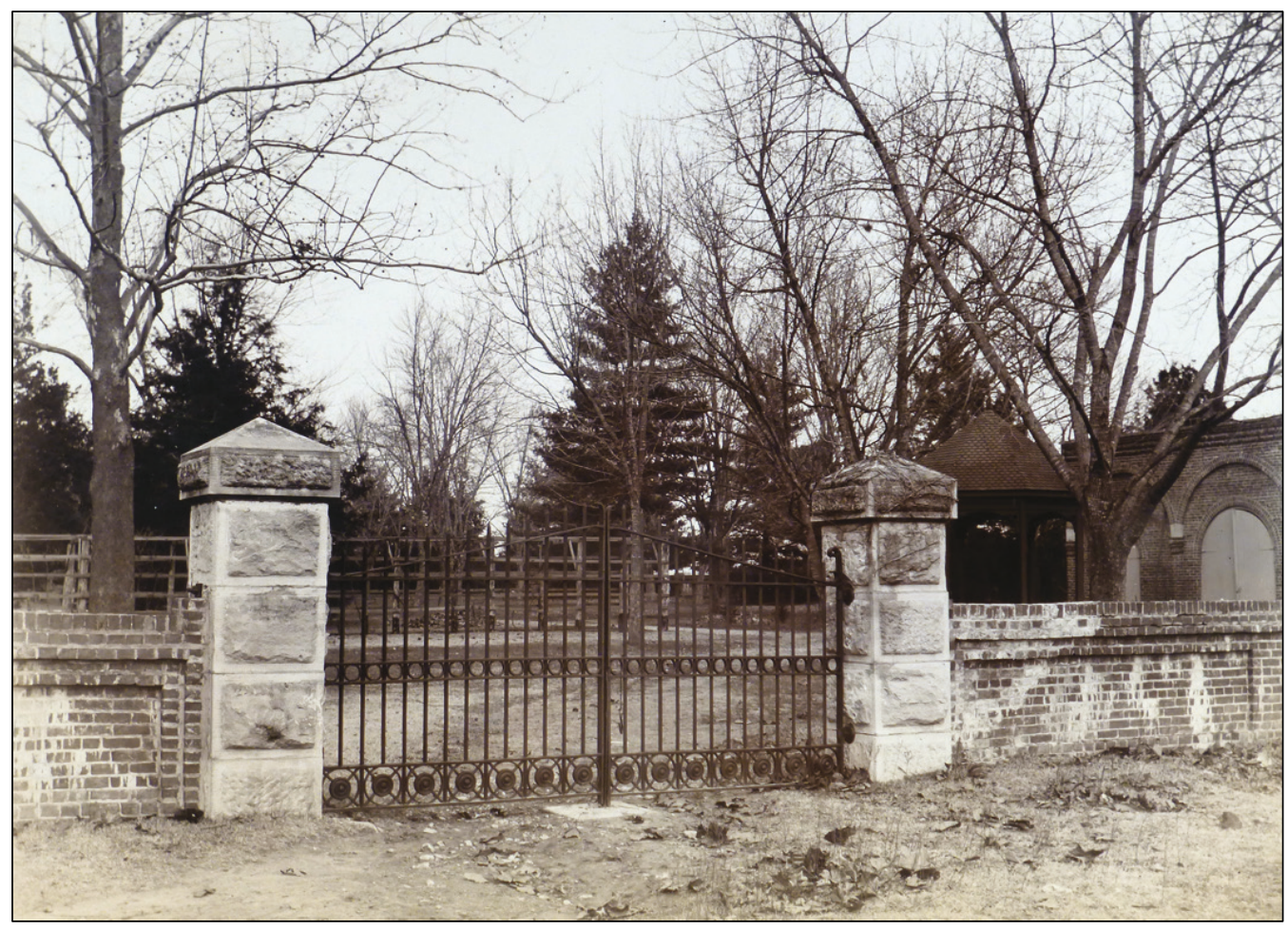




\subsubsection{1946}

Figure 175 and Figure 176 show the pedestrian and maintenance gates in October 1946. The images showed the perimeter wall with large pruned shrubs behind it. Lining the walk into the cemetery from the pedestrian gate were smaller shrubs pruned into globes. In the background, the area to the west of the lodge was a mix of large deciduous and evergreen trees.

Figure 177-Figure 179 show the maintenance building and surrounding area in October 1946. The building was rectangular, with double doors on the west side and visitor bathrooms to the north that were entered from the east and west sides. The maintenance area is surrounded by mature vegetation. The north side of the building is carefully landscaped because of the visitor restrooms.

Figure 175. A pedestrian gate at Corinth National Cemetery, 1946. View is from the city street toward lodge at right (NCA archives, Washington, DC).

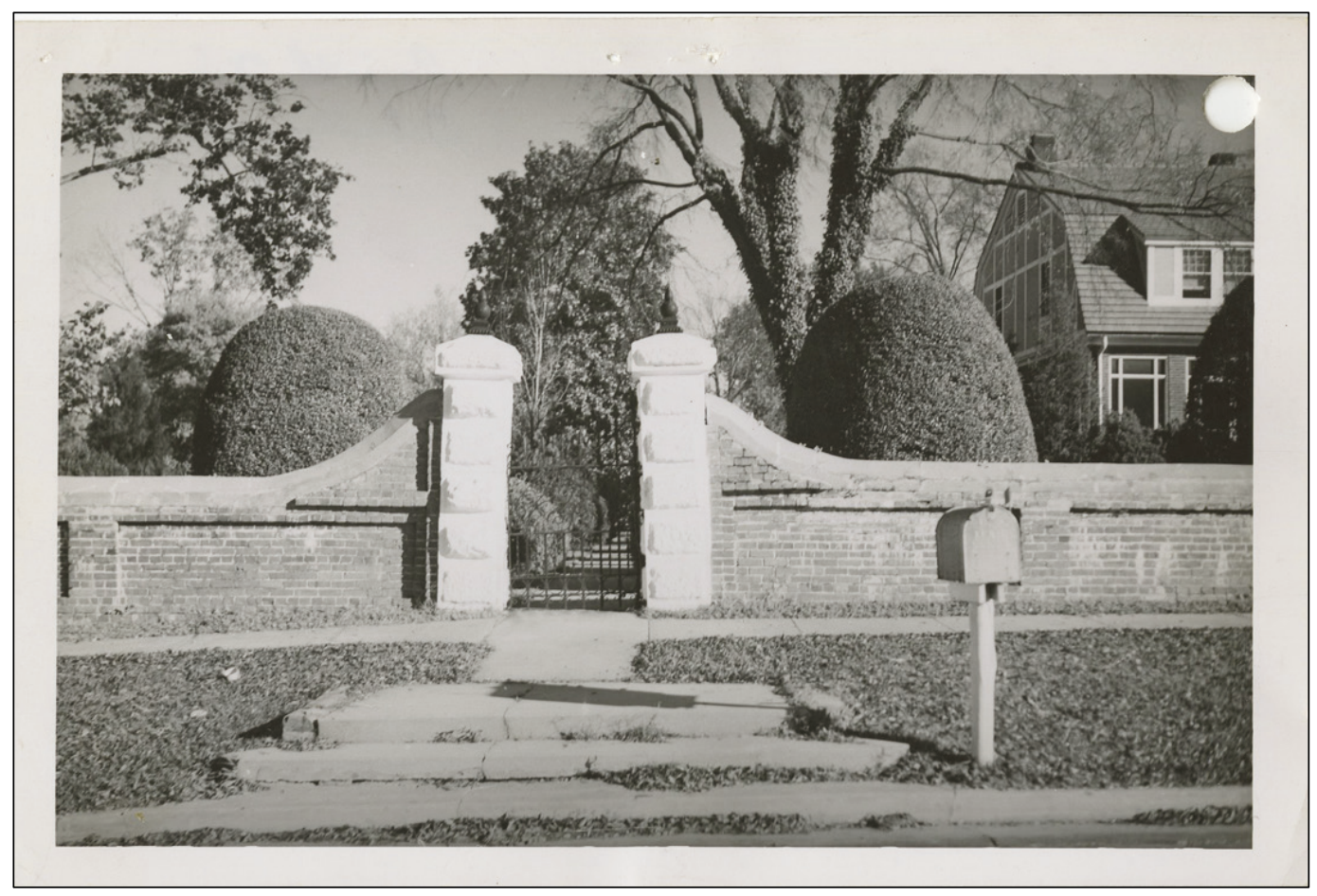


Figure 176. View of the maintenance gate at Corinth National Cemetery in 1946. In the background are highly manicured shrubs and hedges. Evergreens fill the space between the maintenance area and the lodge (NCA archives, Washington, DC).

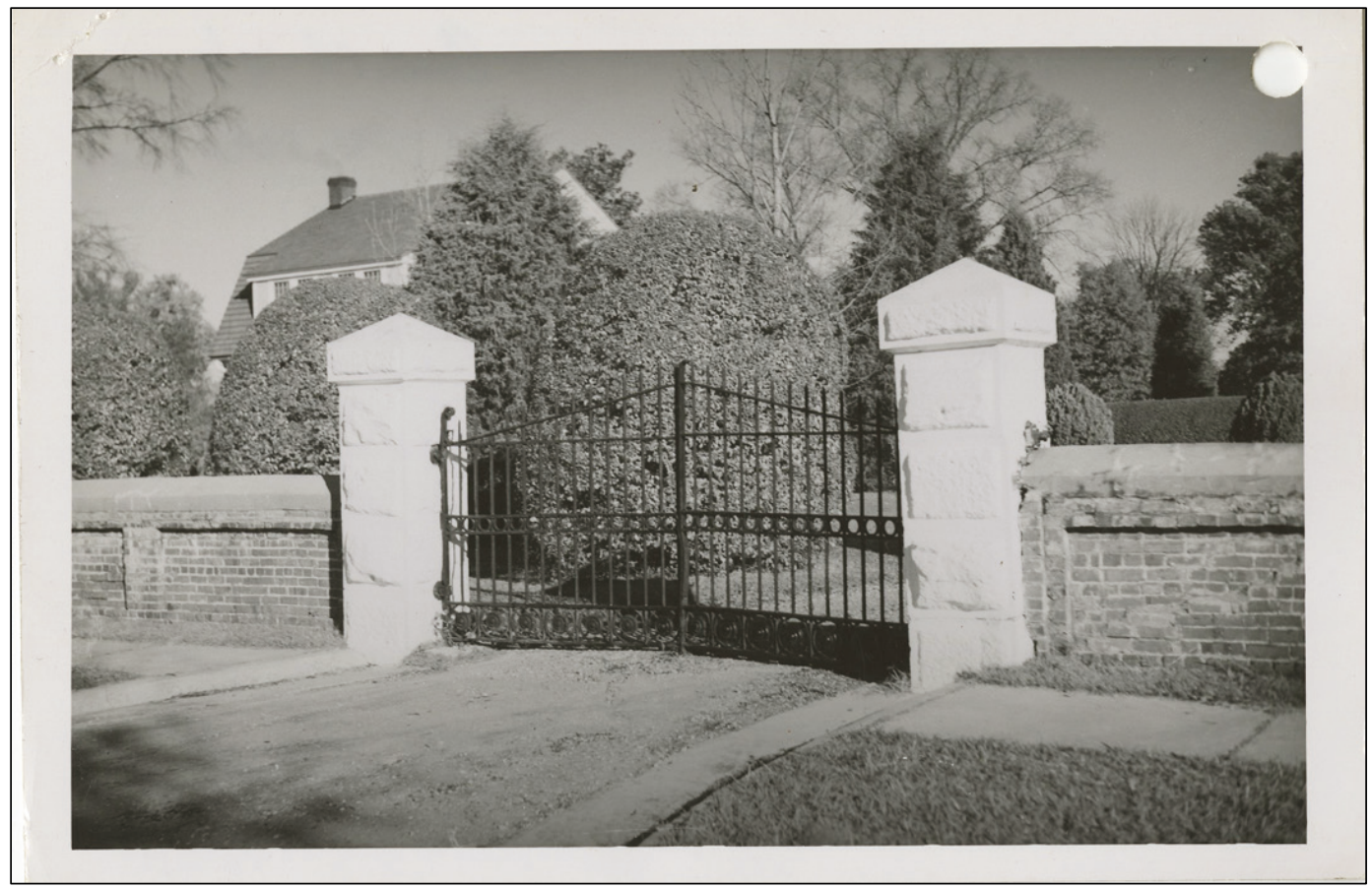

Figure 177 . Utility building west facade 1946 . The building is framed by vegetation, including a willow to the northeast (NCA archives, Washington, DC).

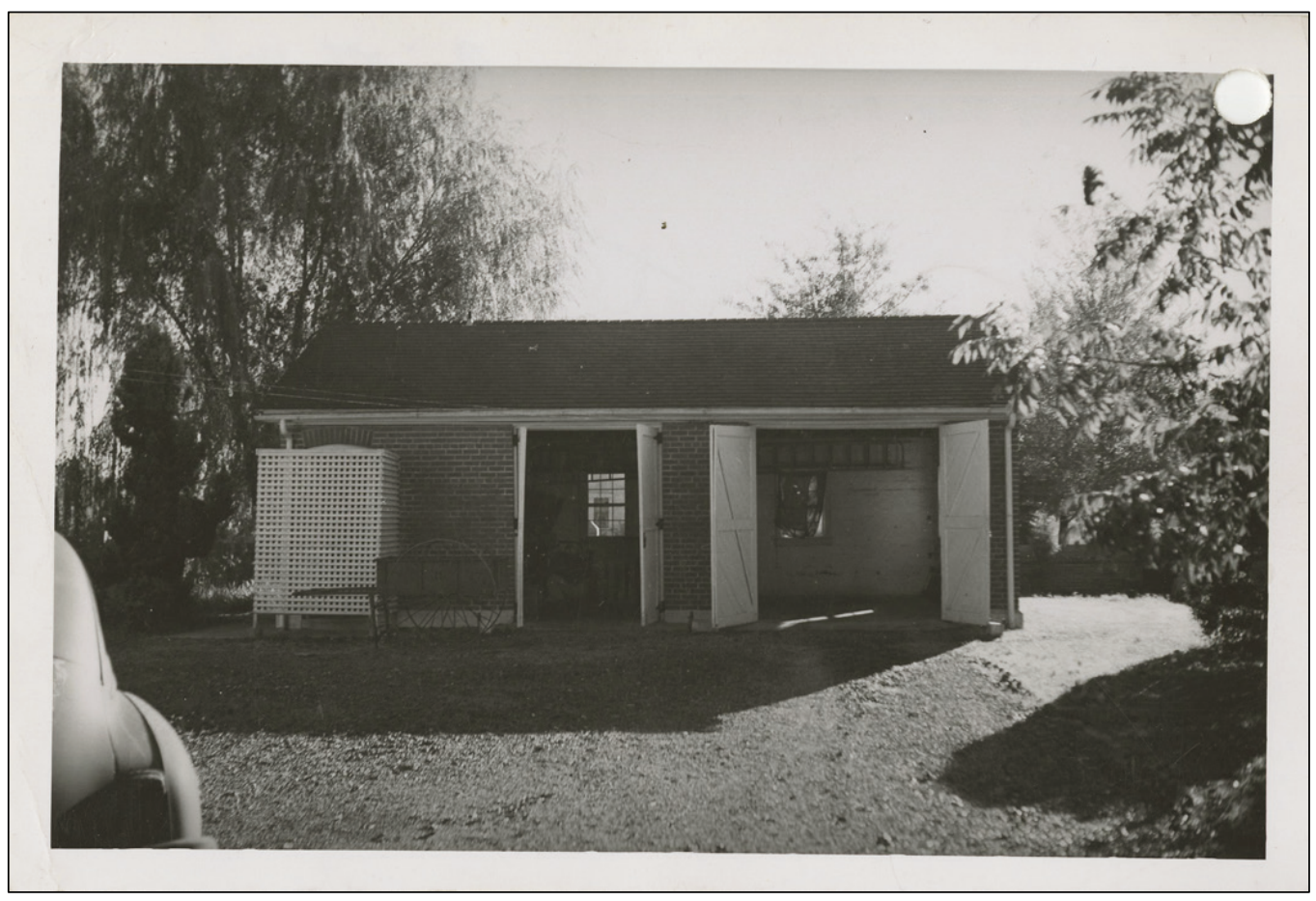


Figure 178. View at southeast corner of the Corinth National Cemetery, showing the maintenance building surrounded by mature vegetation, August 1947

(NCA archives, Washington, DC).

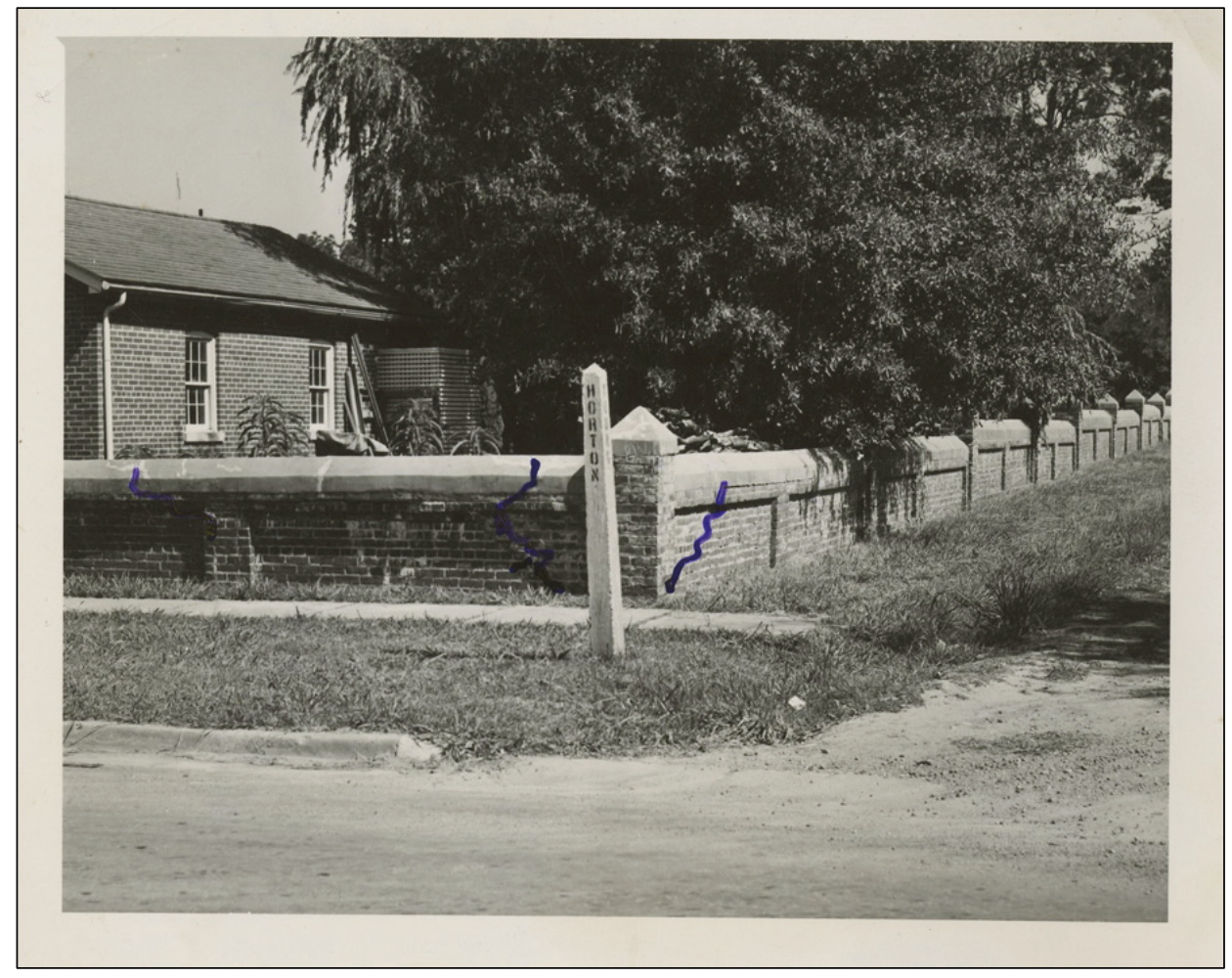

Figure 179. View of the north façade of the maintenance building at Corinth National Cemetery in 1946. The walk to the visitor restrooms is lined with vegetation (NCA archives, Washington, DC).

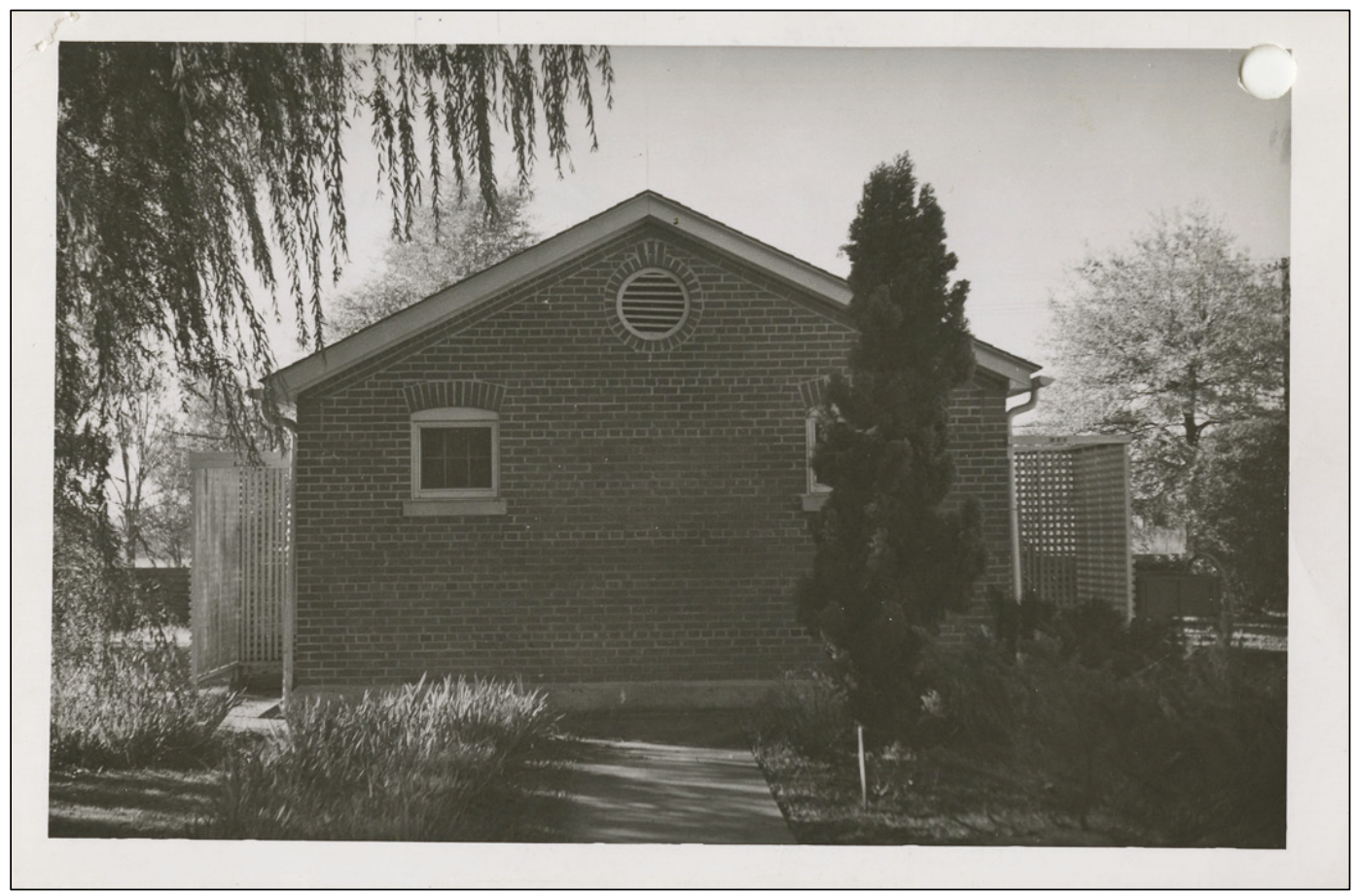


Figure 180 shows the lodge and surrounding area in 1946. The lodge has mature evergreen shrubs as foundation plantings, and the image is framed with surrounding evergreen trees.

Figure 180. View of the north and west sides of the lodge at Corinth National Cemetery in October 1946 (NCA archives, Washington, DC).

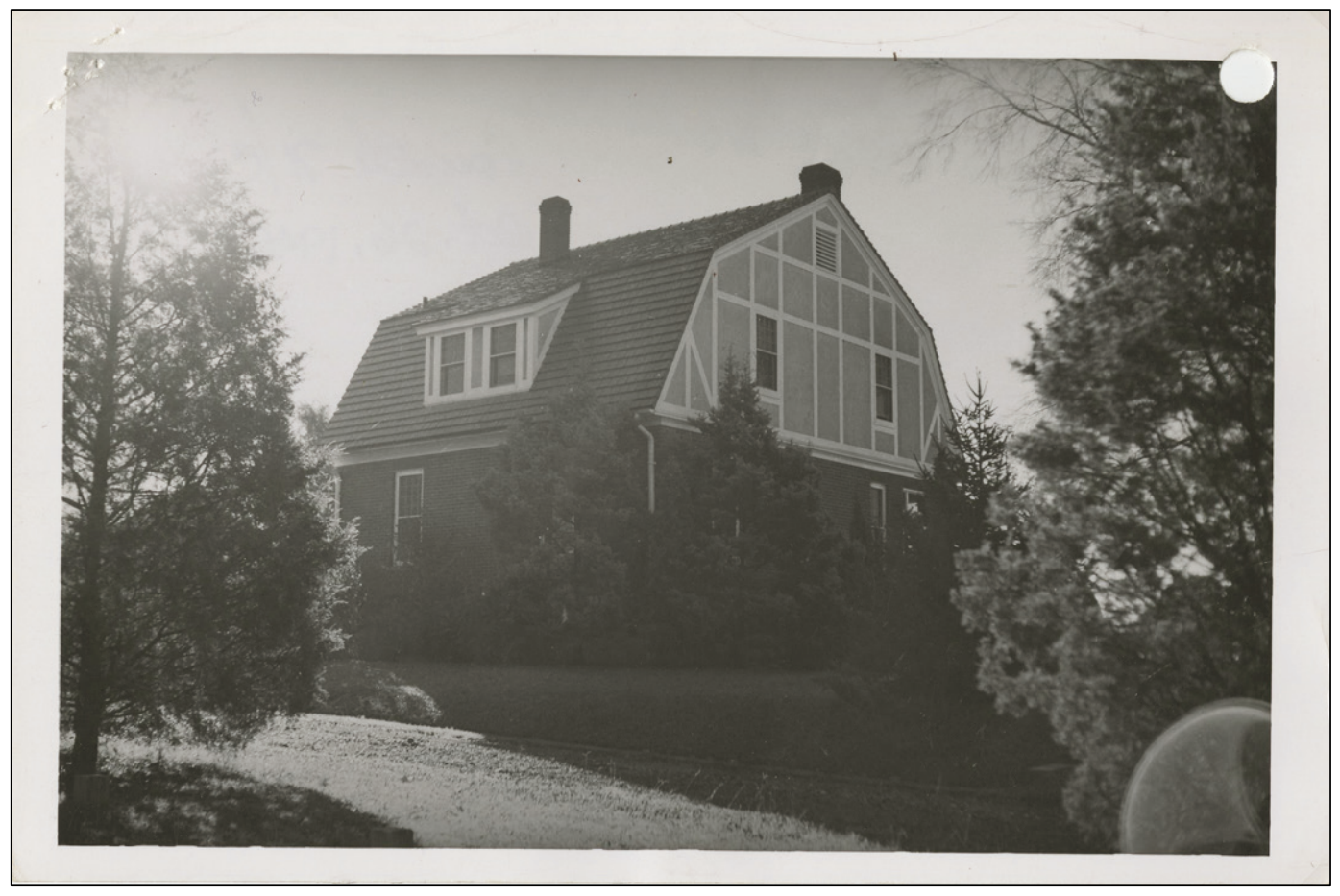

\subsubsection{1954 plan}

There is a chronological gap in the Corinth National Cemetery records in which plans or maps of the built conditions are missing for the years between the late 1800 s and the mid-twentieth century. Plans for the cemetery in 1954 are the next records available.

By 1954, the southeast quadrant had significant changes made to it. Two burial sections were added-Section P, west of the lodge and Section W, east of Section L where the perimeter drive was in the 1892 plan. In Section $\mathrm{C}$, much of the open space that previously defined the geometric headstone patterns had been filled with new graves. The main road had been widened and paved. The road connecting the maintenance area to the main drive was paved with a bituminous surface. The brick walks around the lodge had become paved with concrete. The vegetation previously shown to be south of the lodge was removed in the 1954 plan, but with more vegetation shown around the perimeter of the lodge. South and east 
of the lodge is lawn, but the service yard is screened from view with vegetation groupings. In 1954, the service yard was paved and had a utility building with the cemetery's comfort station. There was a gasoline pump and storage tank north of the utility building. In this quadrant, the pedestrian gate and maintenance gate remained at the same locations within the perimeter wall as in the 1892 plan. Outside the cemetery wall was a concrete sidewalk, grass verge, curb, and gutter (Figure 181).

Figure 181. 1954 plan of the southeast quadrant of Corinth National Cemetery (NCA archives, Washington, DC).

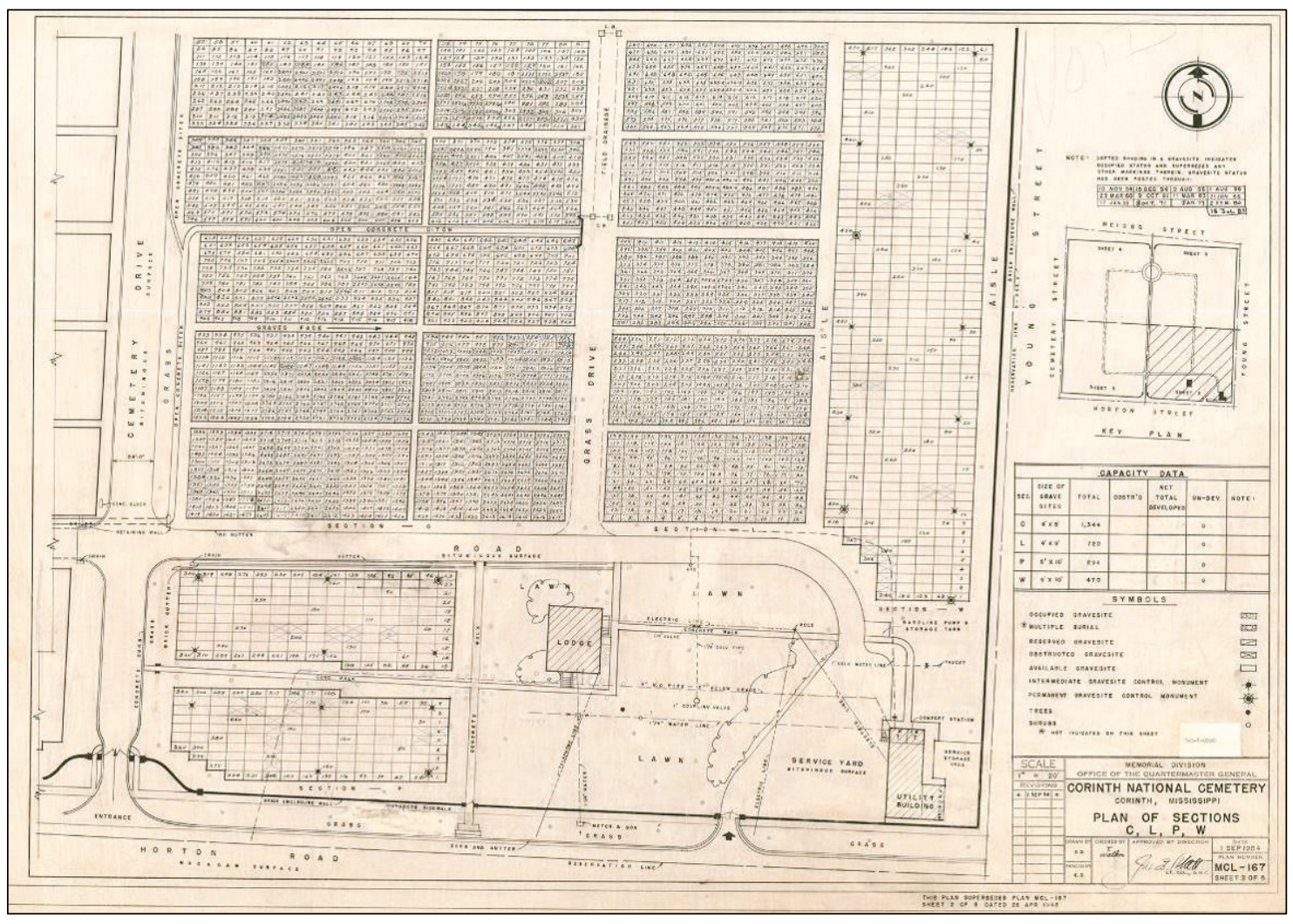

Photographs from the 1950 s showed the cemetery with a mix of mature and young vegetation. The mature vegetation around the lodge and maintenance area shown in the photographs from the 1940 s had been removed by the early 1950 s. The perimeter wall was replaced in the early 1950 s.

Figure 182-Figure 184 show the perimeter wall and the pedestrian and maintenance gates. The backgrounds of these images show the changes in vegetation-only a few large deciduous and evergreen trees remain, and most of the shrubs have been removed. 
Figure 182. View of the perimeter wall at Corinth National Cemetery. looking east along Horton Street in 1953. There are no street trees in the verge between the street and the wall (NCA archives, Washington, DC).

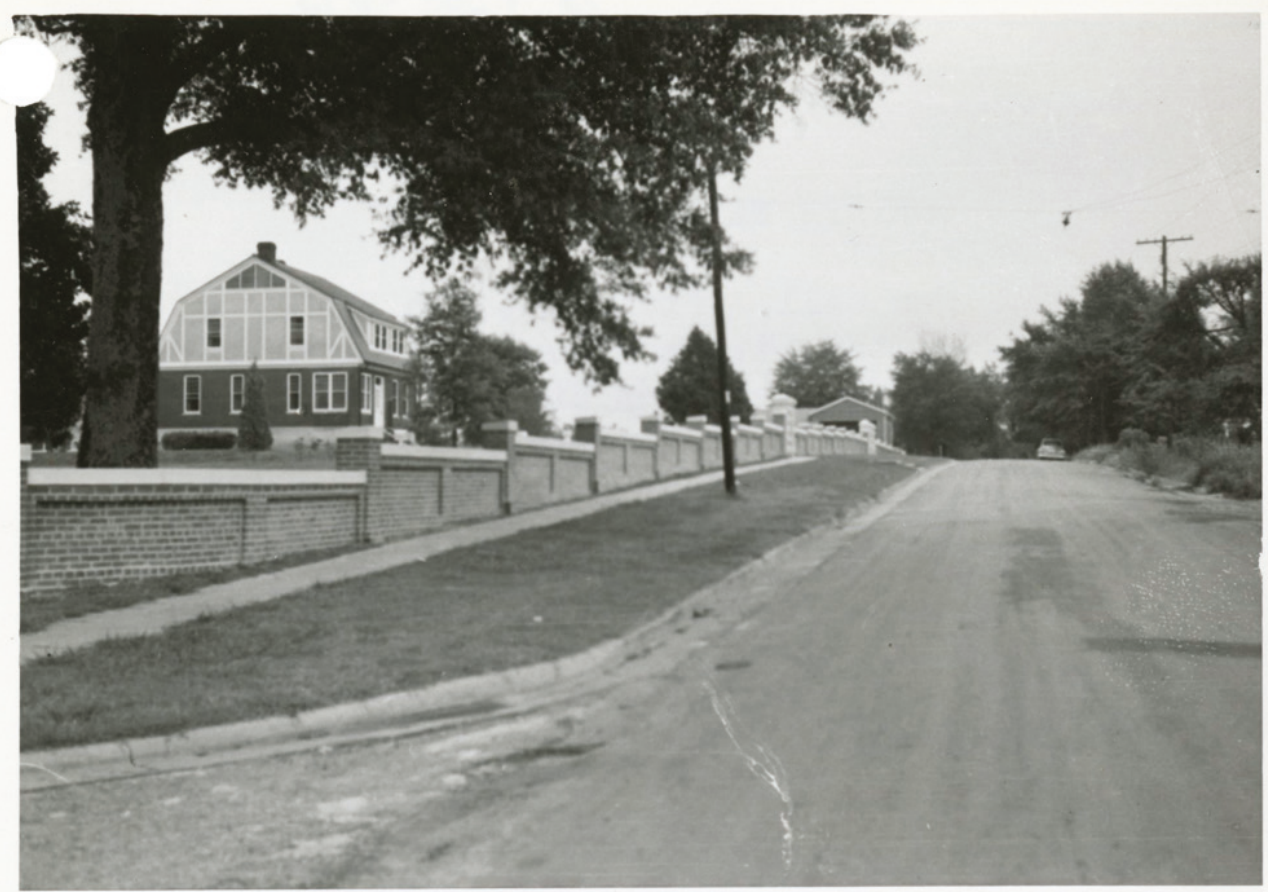

Figure 183. Single pedestrian gate in in southeast quadrant of Corinth National Cemetery, July 1953. Note the standing plaque inside the gate (NCA archives, Washington, DC).

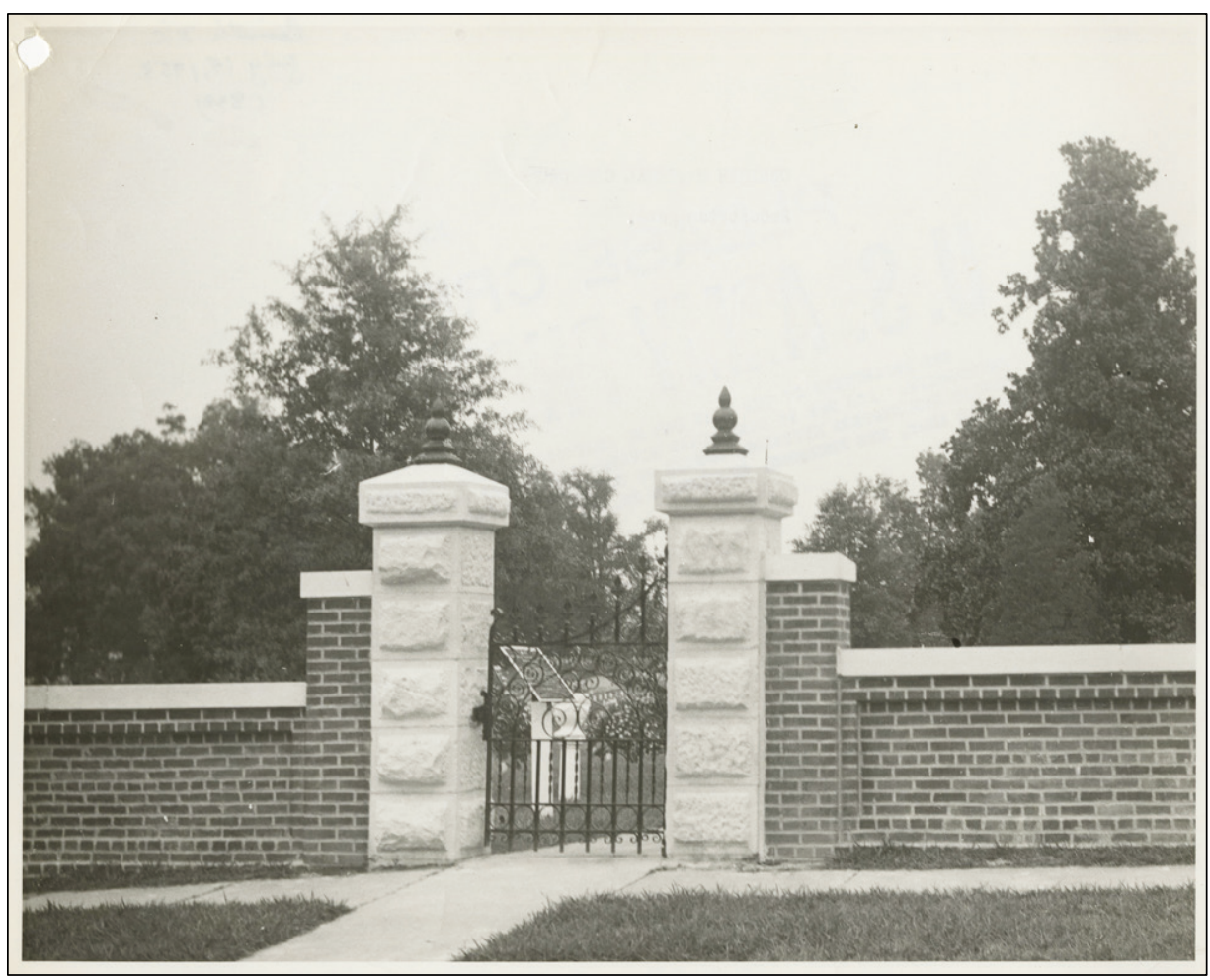


Figure 184. Maintenance gate in 1953 at Corinth National Cemetery. Note the plaque inside the gate (NCA archives, Washington, DC).

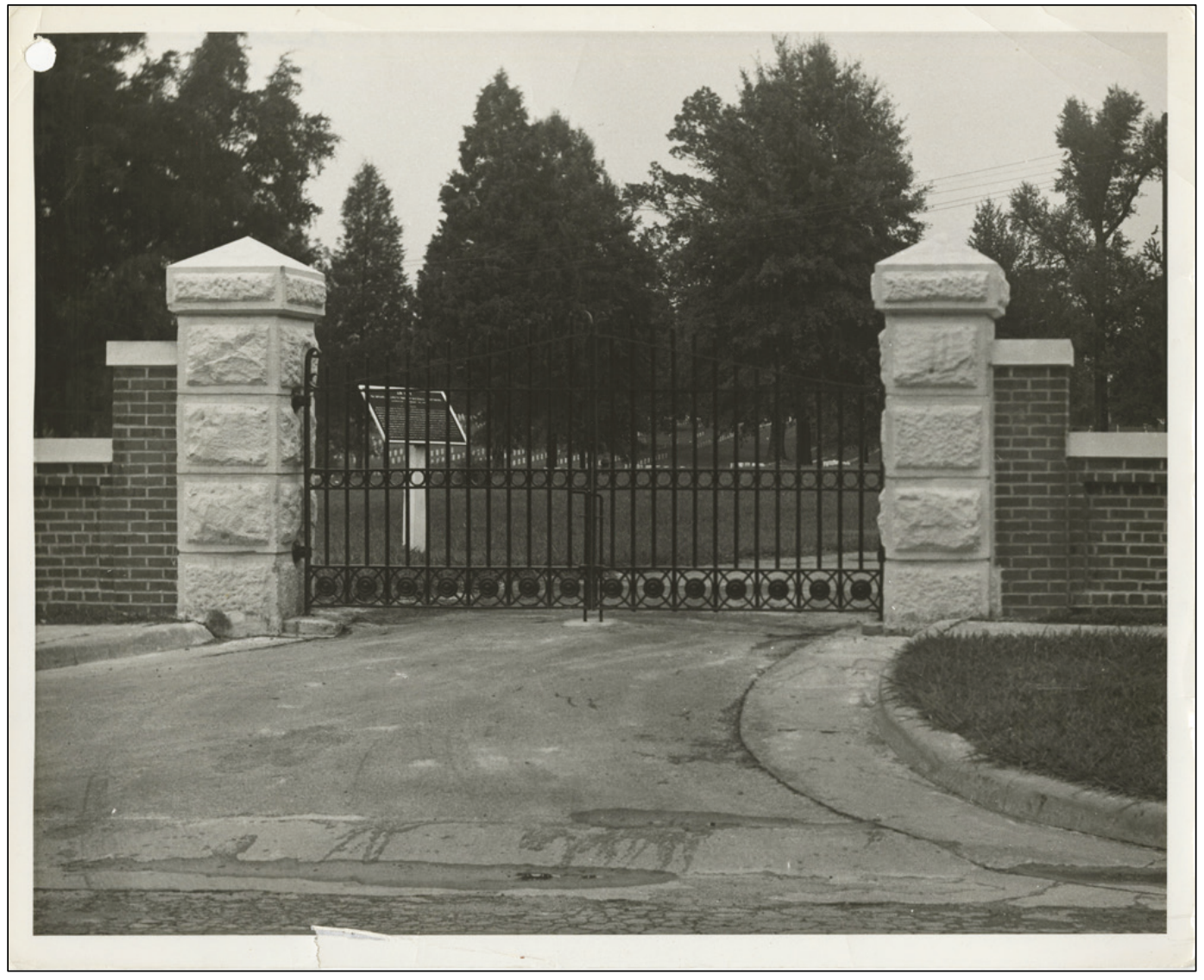

Figure 185-Figure 187 show views of the southeast quadrant from the lodge and maintenance area. In particular, Figure 185 shows young trees in the foreground and the distinct geometric headstone patterns in Section C. 
Figure 185. View north toward the flagpole from the pedestrian entrance at Corinth National Cemetery, April 1954 (NCA archives, Washington, DC).

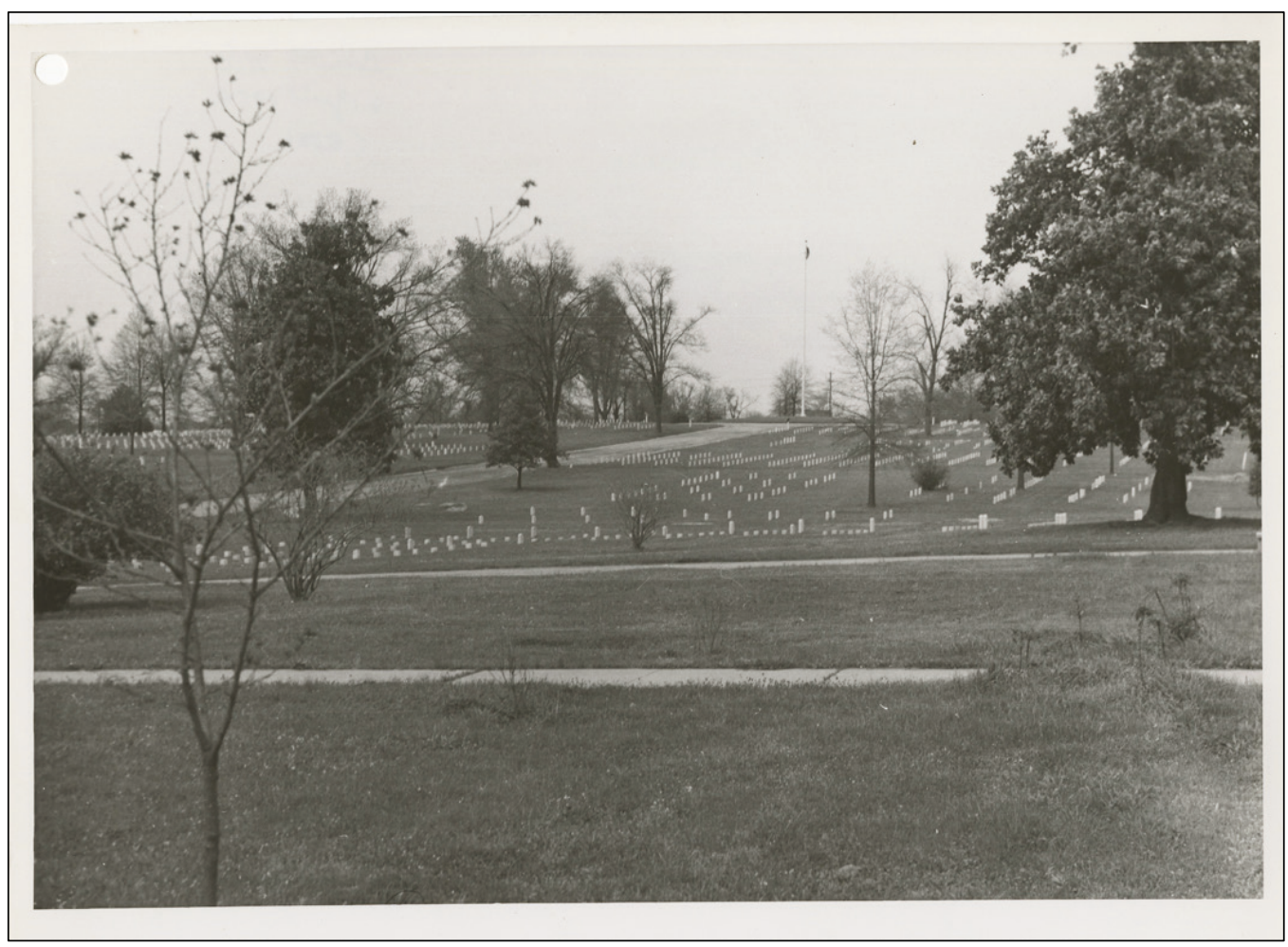

Figure 186. View northeast across Section $L$ from the north side of the lodge at Corinth National Cemetery, July 1953 (NCA archives, Washington, DC).

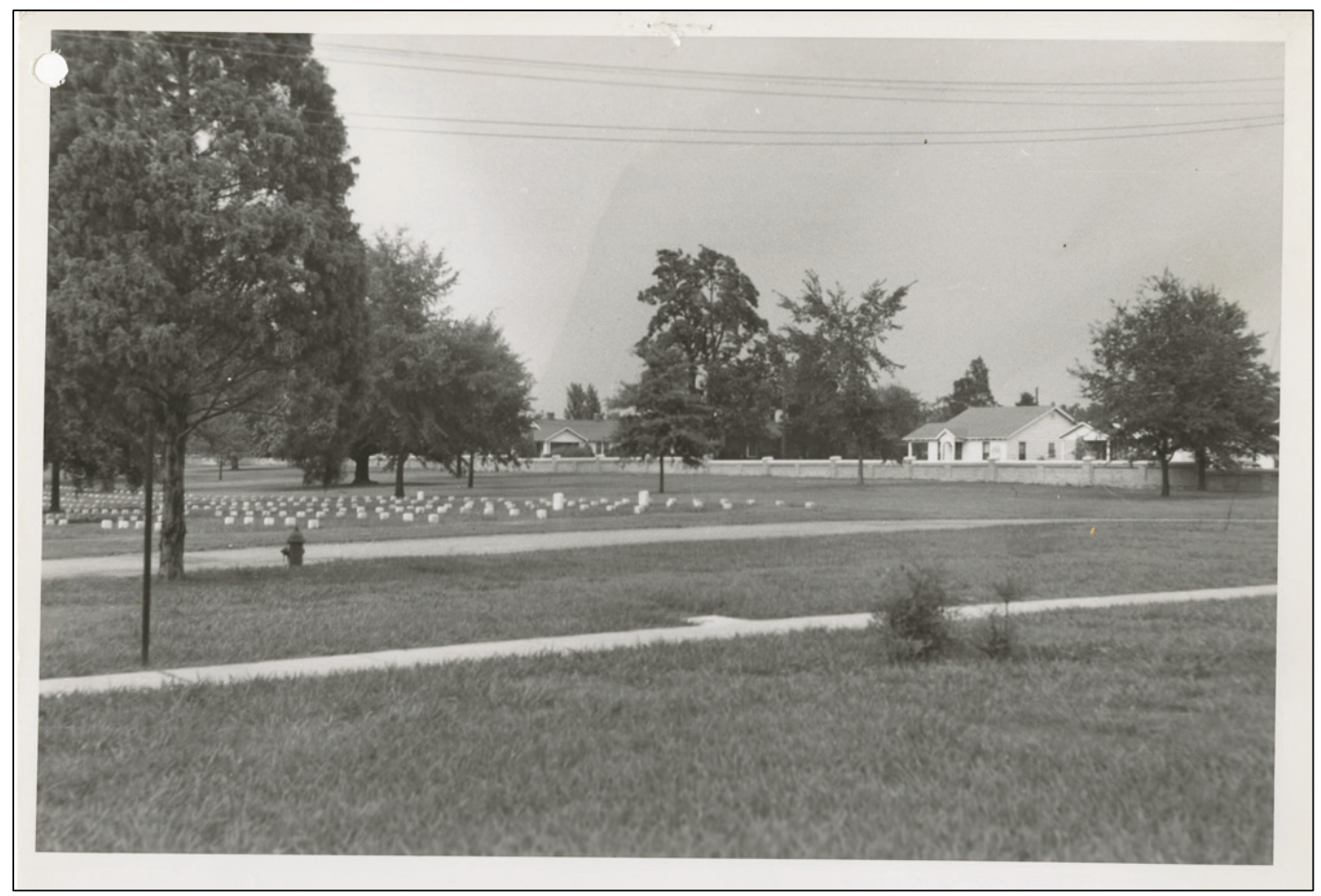


Figure 187. View north along east wall at Corinth National Cemetery in April 1954 (NCA archives, Washington, DC).

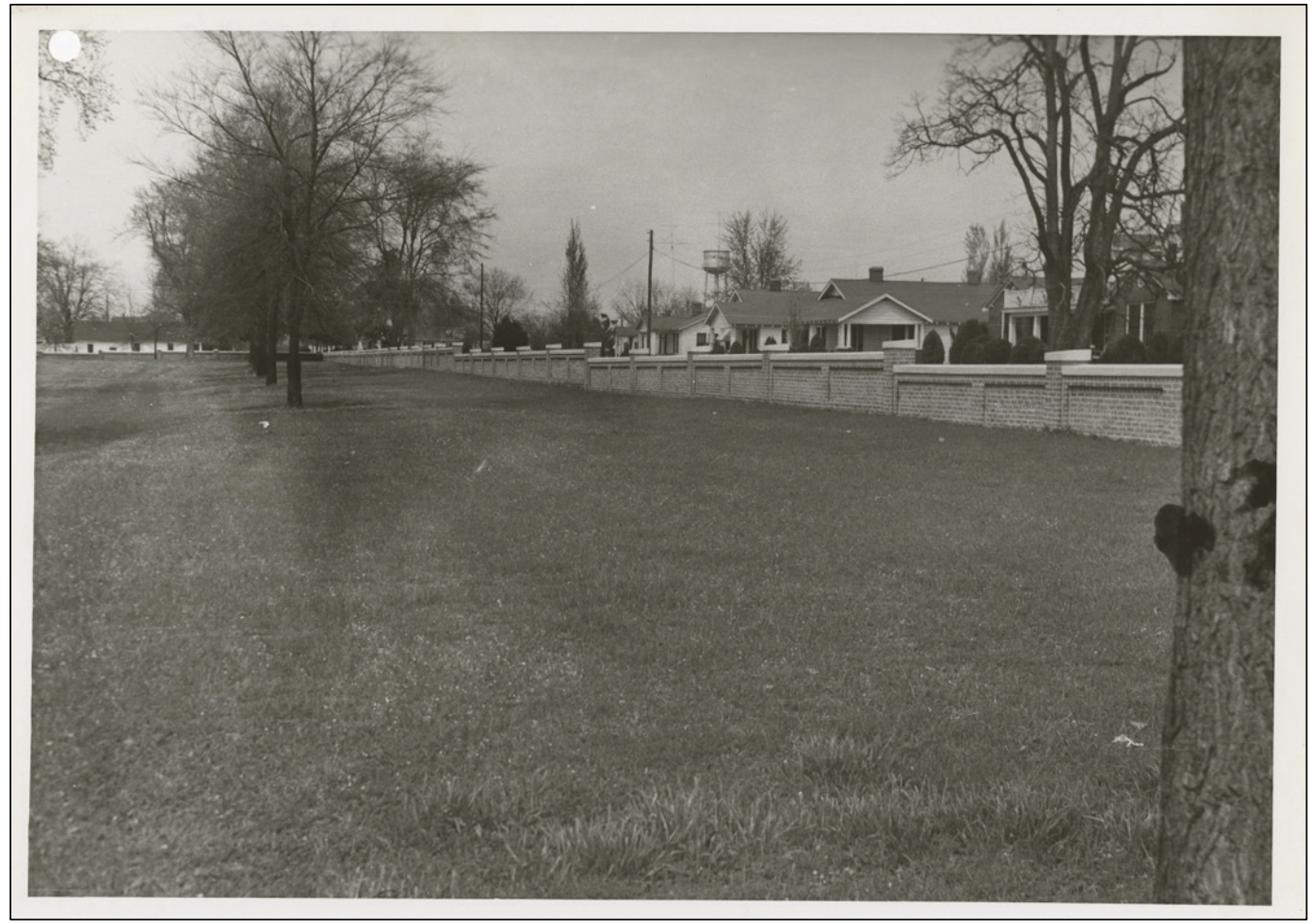

Figure 188 and Figure 189 show the changes made to the maintenance building and the surrounding area. The building had a high bay added to the south. The vegetation in the maintenance area was completely removed except for a few deciduous and evergreen trees.

Figure 190-Figure 194 show the lodge and surrounding area in the early 1950s. The mature vegetation in the area has been mostly removed. Small shrubs are planted around the lodge's foundation. There are no plants between the lodge and the maintenance building. The area between the lodge and Cemetery Drive has a few shrubs and larger trees. The Gettysburg plaque was attached near the front door of the lodge. 
Figure 188. West façade of the maintenance building and surrounding area at Corinth National Cemetery in July 1953 (NCA archives, Washington, DC).

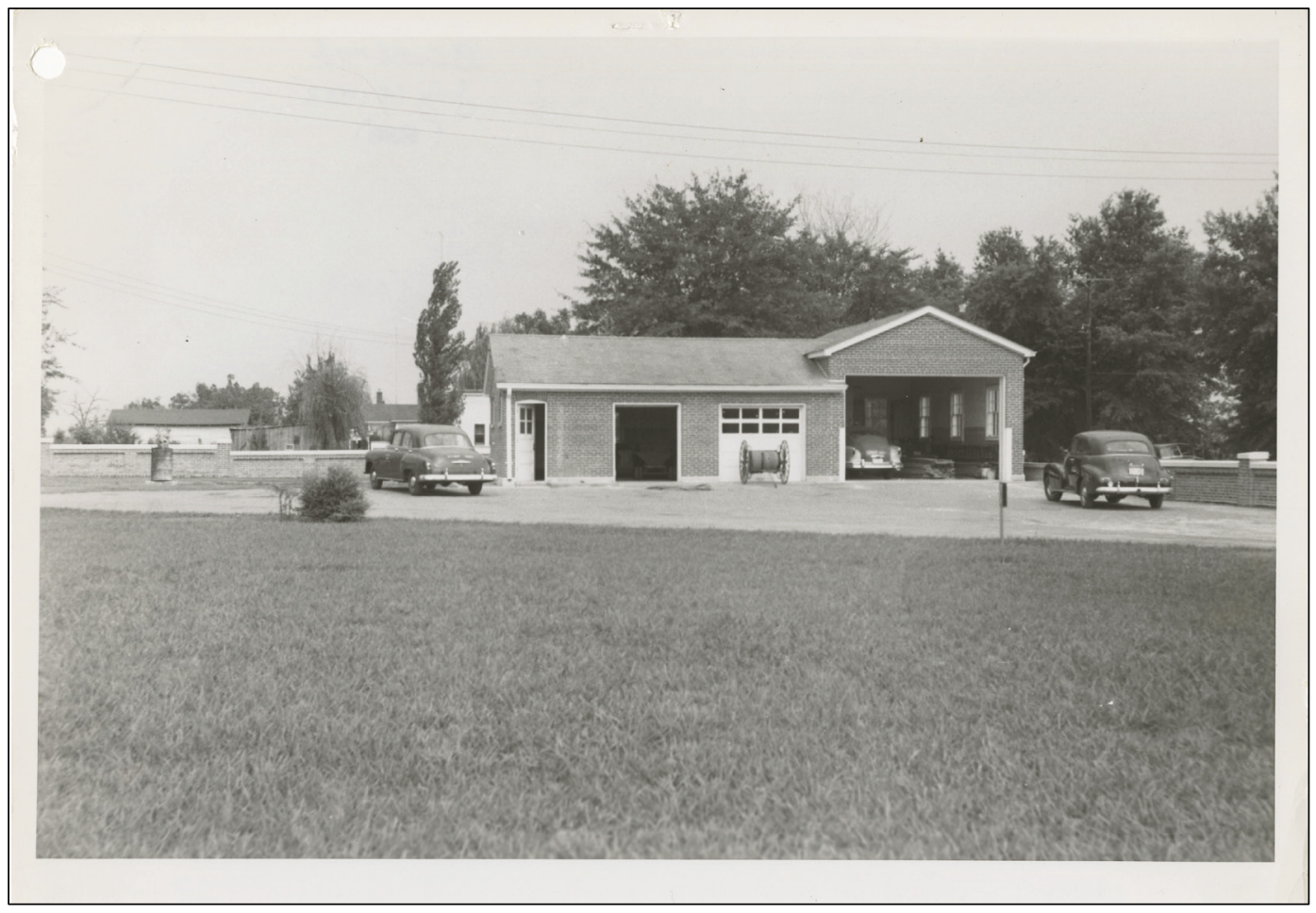

Figure 189. Rear of maintenance building at Corinth National Cemetery, with new addition in July 1953 (NCA archives, Washington, DC).

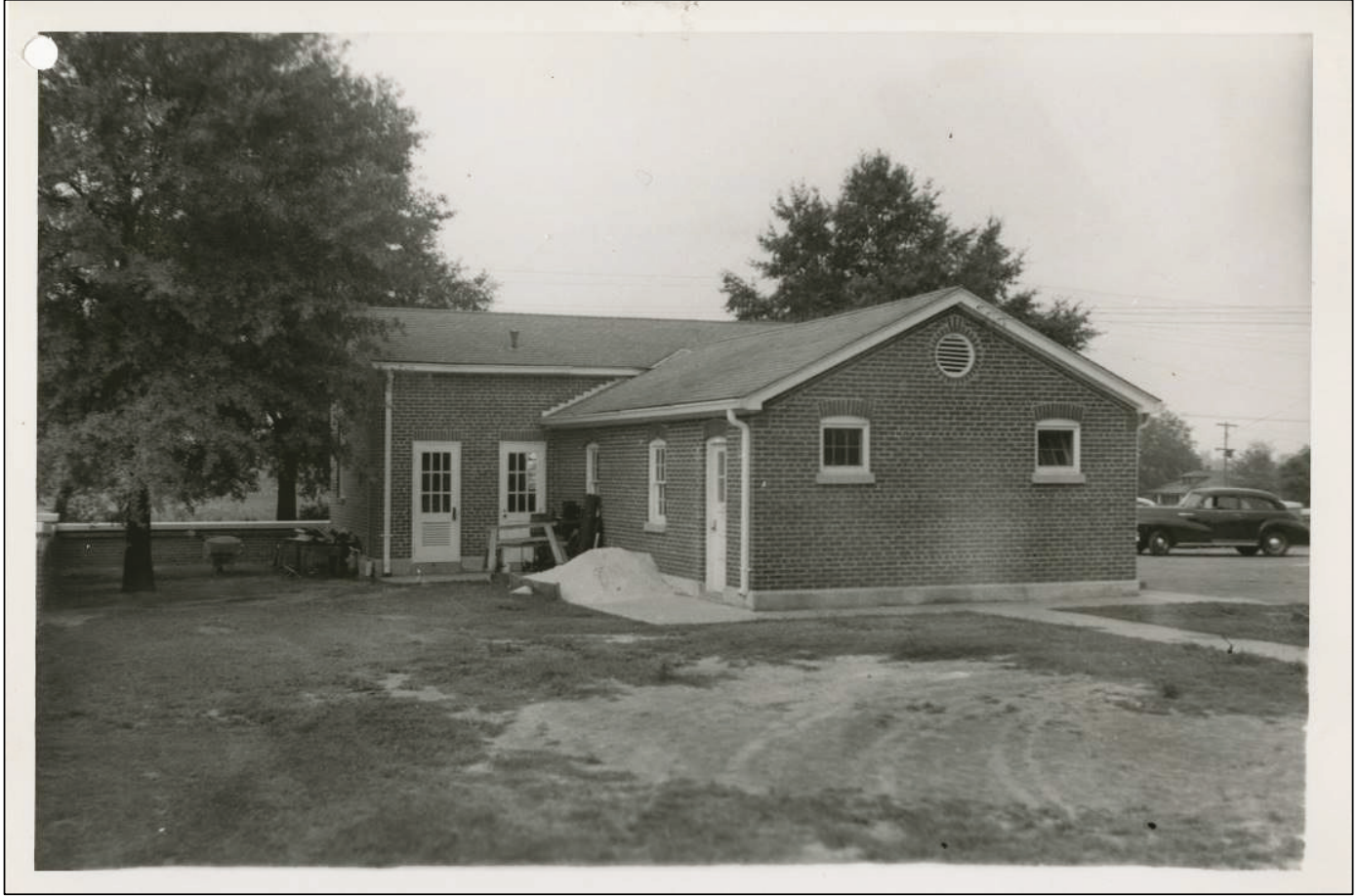


Figure 190. East elevation of the lodge at Corinth National Cemetery in July 1953

(NCA archives, Washington, DC).

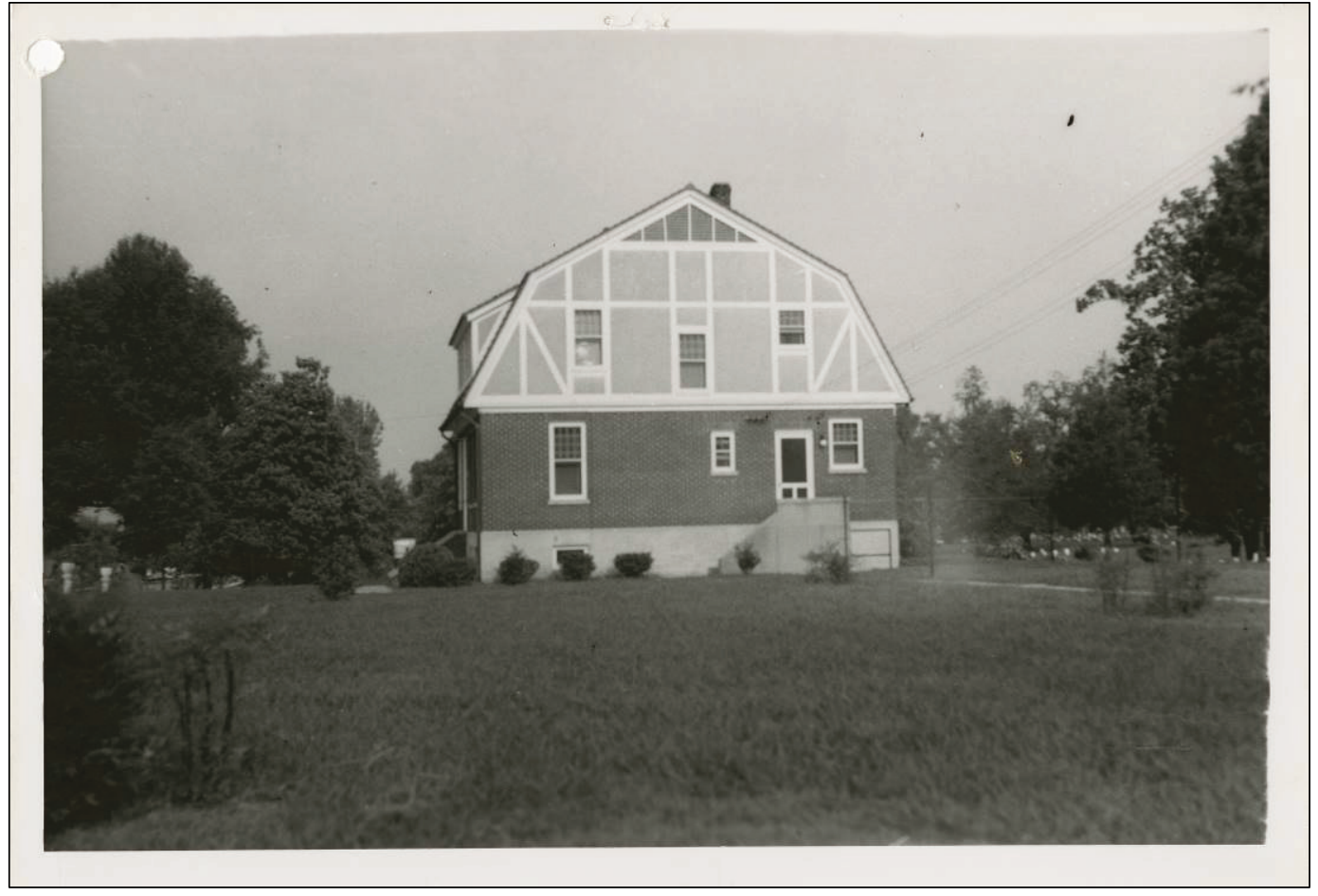

Figure 191. Concrete walk leading east from Cemetery Drive toward west side of the lodge, with newly planted shrubs lining the walk, July 1953 (NCA archives, Washington, DC).

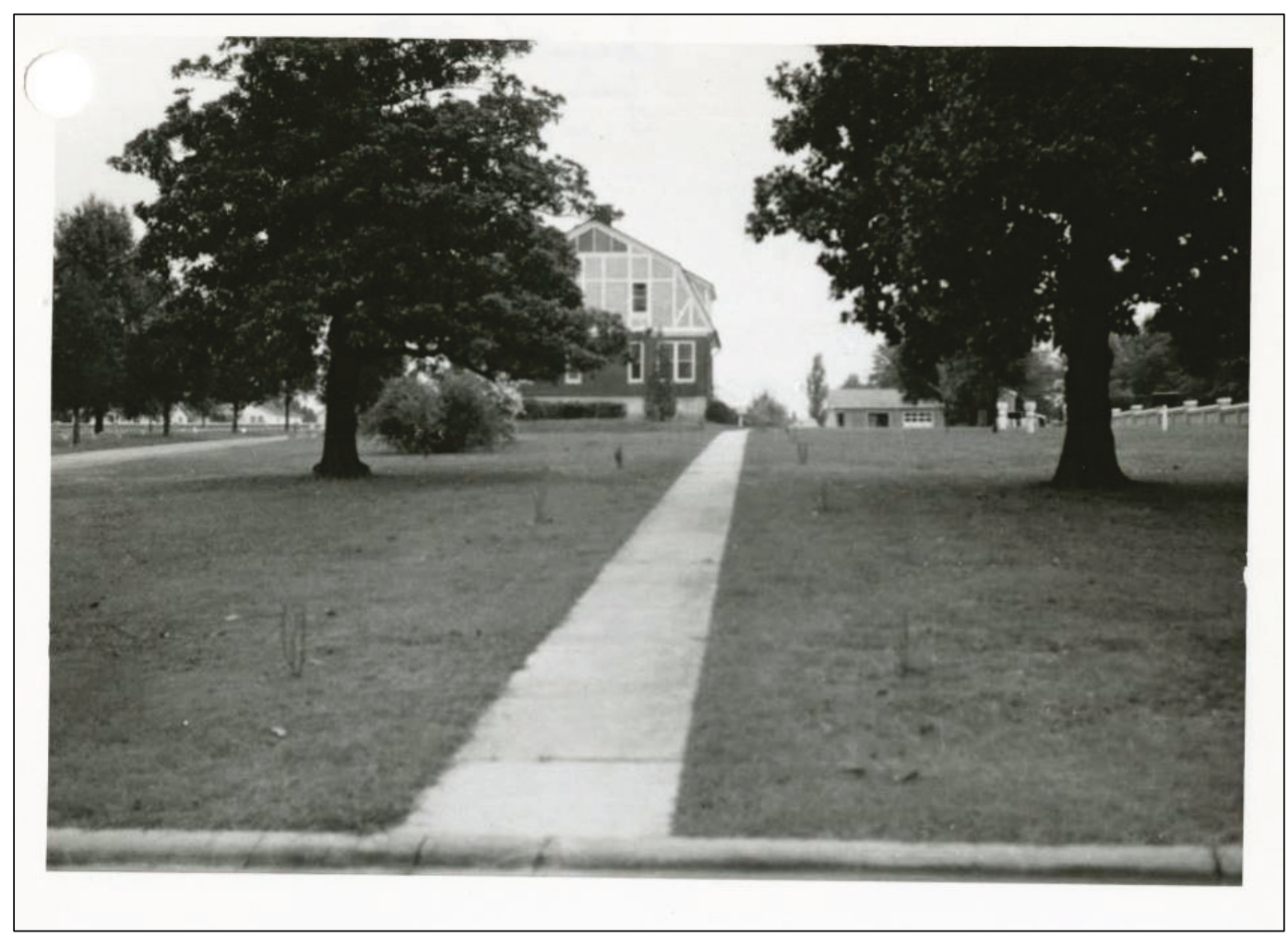


Figure 192. Looking southeast toward west side of the lodge and surrounding area at Corinth National Cemetery, April 1954 (NCA archives, Washington, DC).

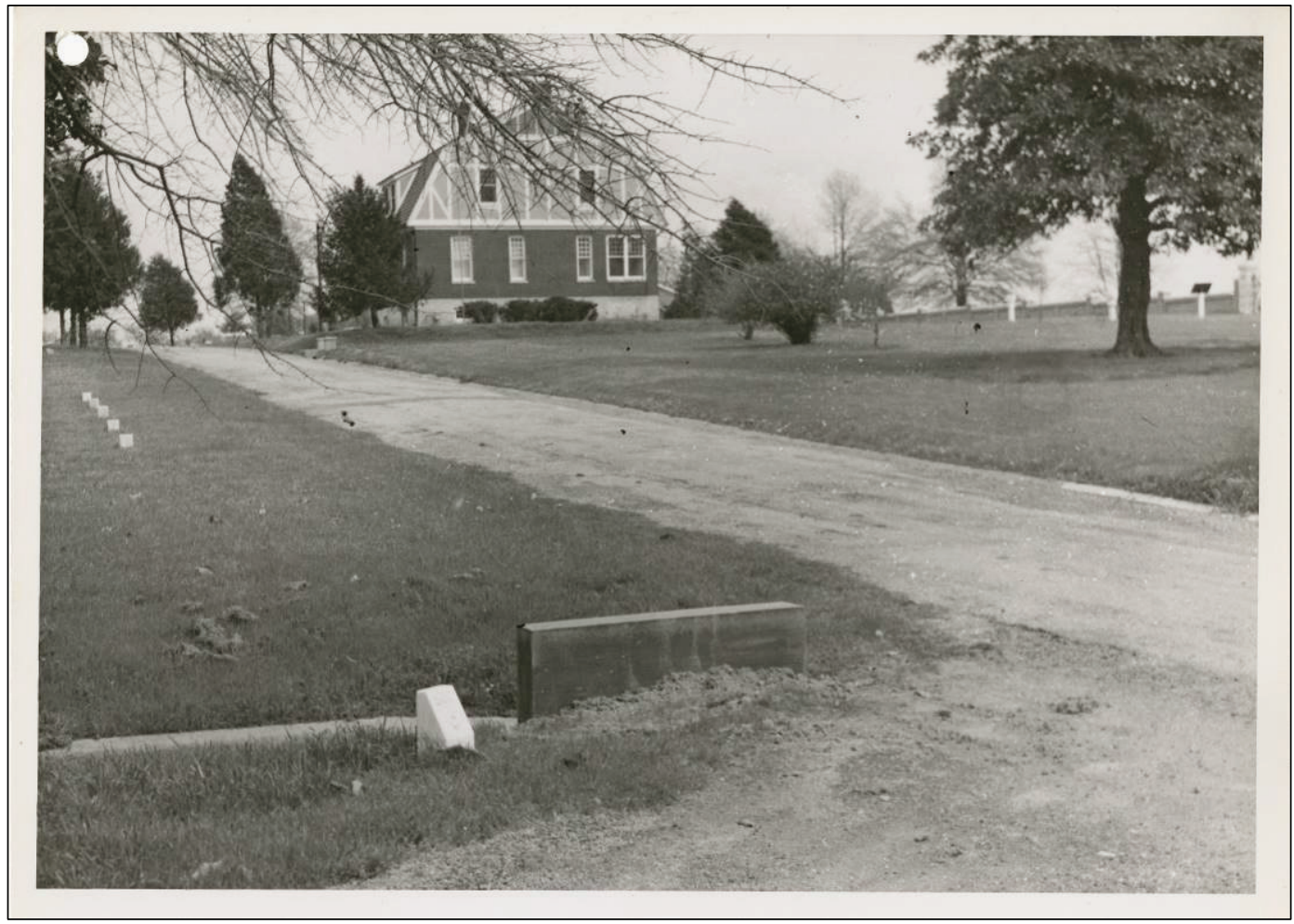

Figure 193. Northeast oblique of lodge at Corinth National Cemetery, April 1954 (NCA archives, Washington, DC).

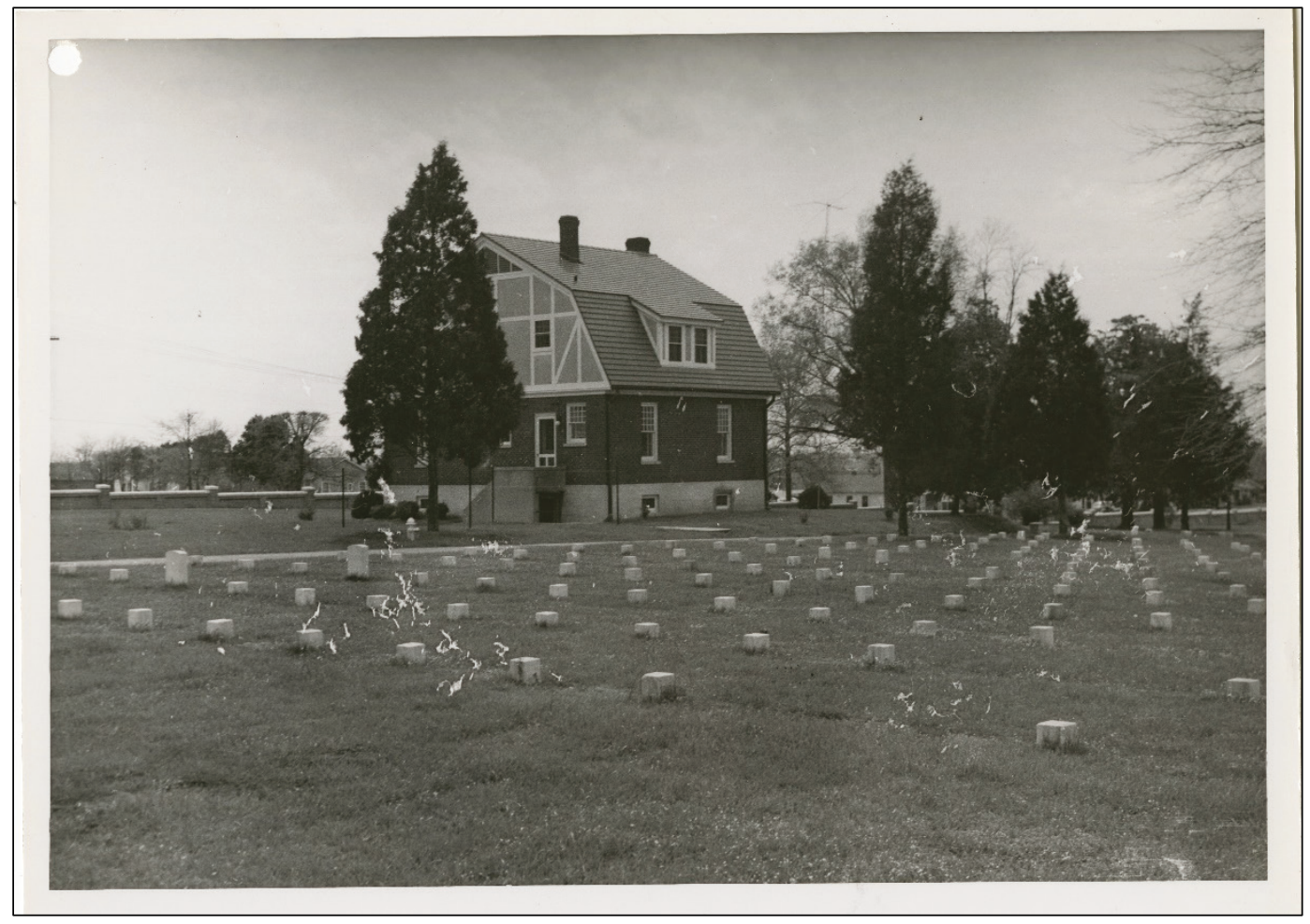


Figure 194. Metal tablet on south façade of lodge near the front door, July 1953, at Corinth National Cemetery (NCA archives, Washington, DC).

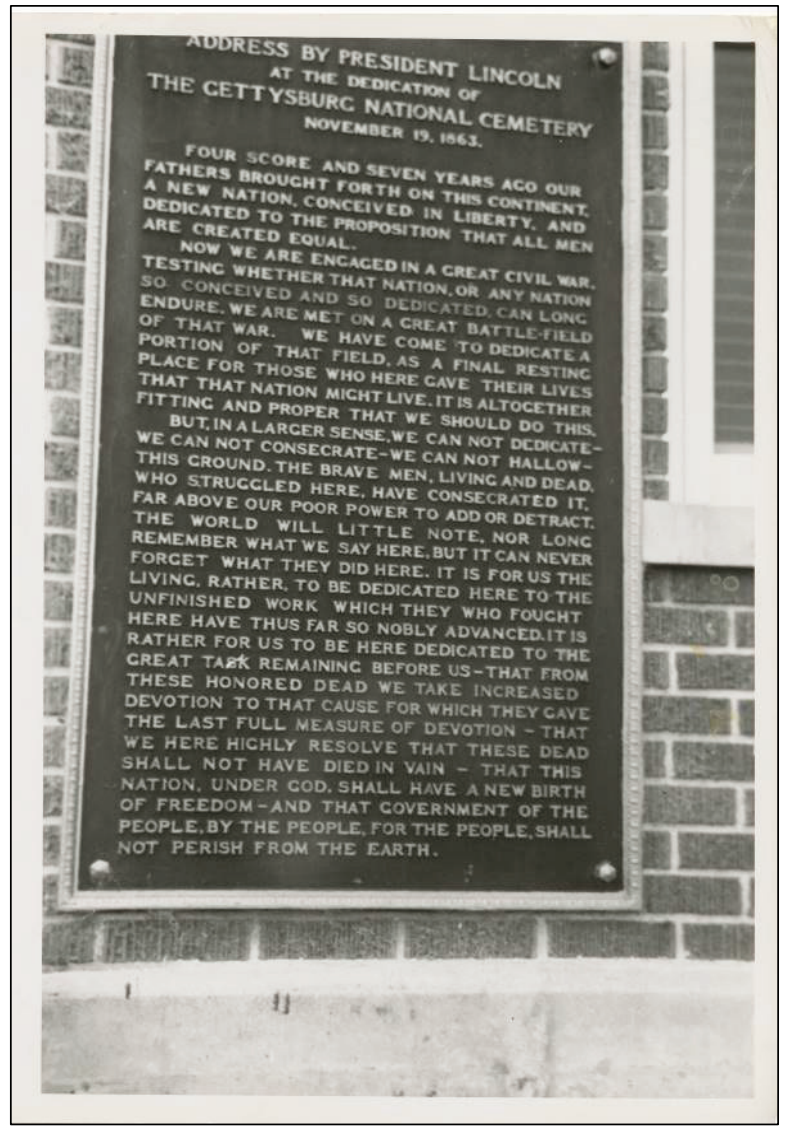

Figure 195, Figure 196, and Figure 197 show the concrete drainage ditch in the southeast quadrant. In these views, the open space and geometric headstone patterns in Section $\mathrm{C}$ are visible along with the young trees that were planted in this area. 
Figure 195. Concrete drainage ditch in the southeast quadrant of Corinth National Cemetery. View is looking west, July 1953 (NCA archives, Washington, DC).

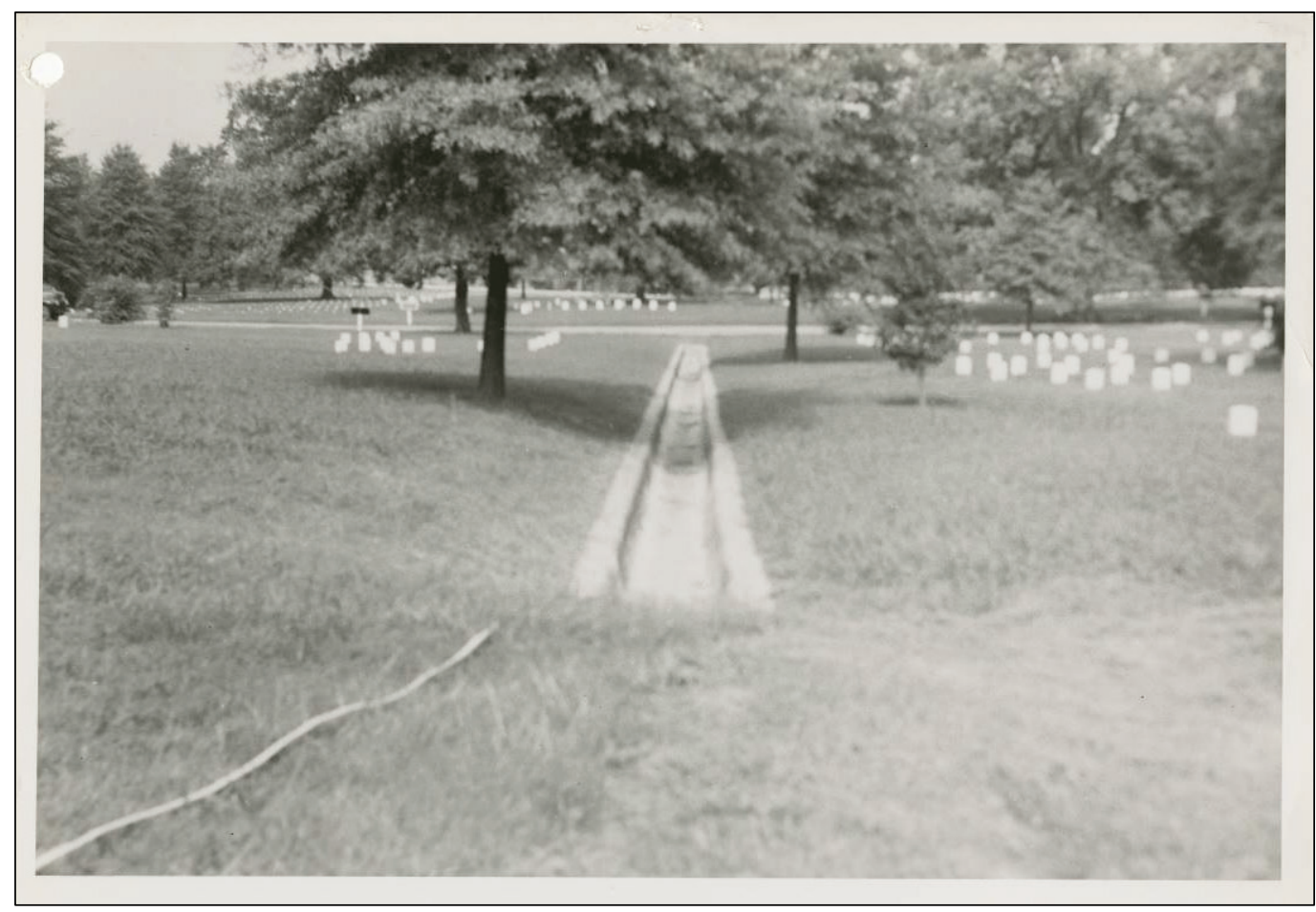

Figure 196. Drainage ditch along Cemetery Drive, looking north in Corinth National Cemetery, July 1953 (NCA archives, Washington, DC).

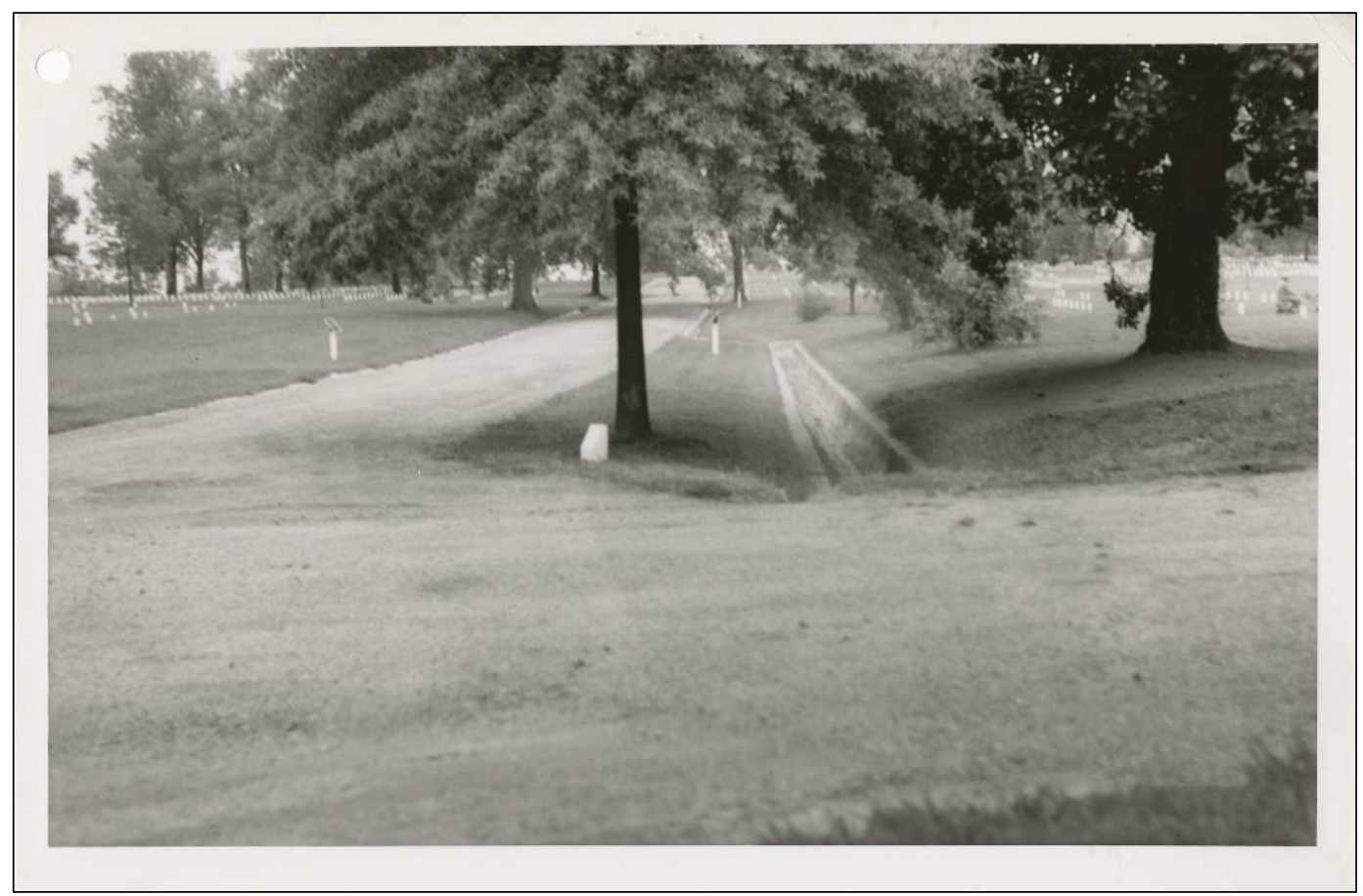


Figure 197. Drainage ditch in the southeast quadrant of Corinth National Cemetery, view looking east from Cemetery Drive in April 1954 (NCA archives, Washington, DC).

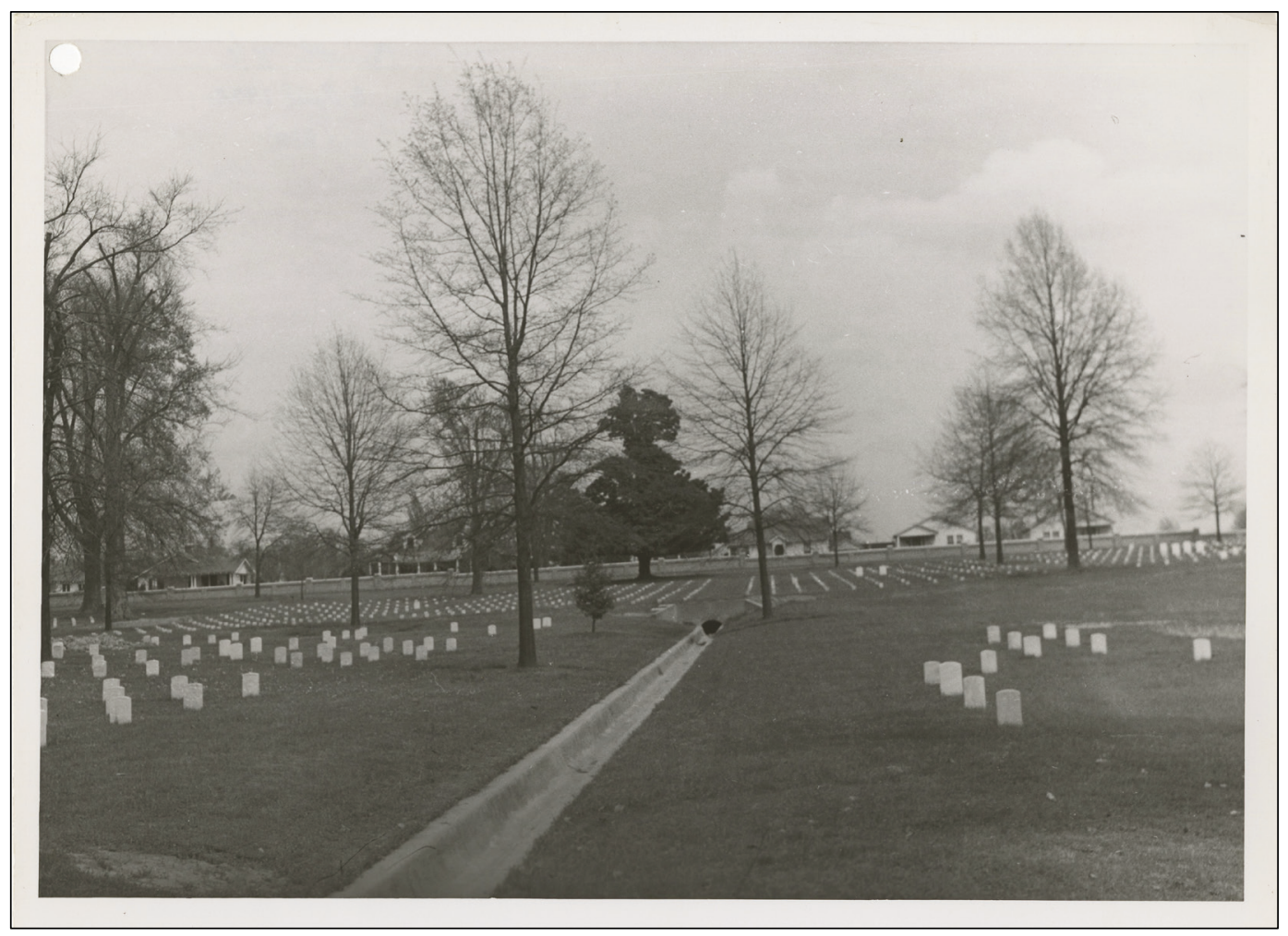

\subsubsection{1964 planting plan}

The 1964 planting plan for the southeast quadrant shows an array of deciduous and evergreen trees, smaller ornamental trees, individual shrubs, and shrubs planted to form hedges (Figure 198). In this plan, there was extensive planting of ornamental shrubs and hedges to surround the lodge and service yard. Crape myrtles lined the walk from the main road to the lodge, and Nandina were planted in the corners where the walks intersect west of the lodge. A line of Willow Oak trees has been planted outside the south perimeter wall.

Figure 198 shows the vegetation patterns in the southeast quadrant. Trees were scattered throughout the burial sections and line the inside of the perimeter wall. The lodge and maintenance areas also featured heavy vegetation. Of note, the lodge had extensive foundation plantings, and the maintenance area was screened from view by hedges. Exterior to the south wall was a line of Willow Oak trees. 
Figure 198. 1964 planting plan for the southeast quadrant of Corinth National Cemetery (NCA archives, Washington, DC).

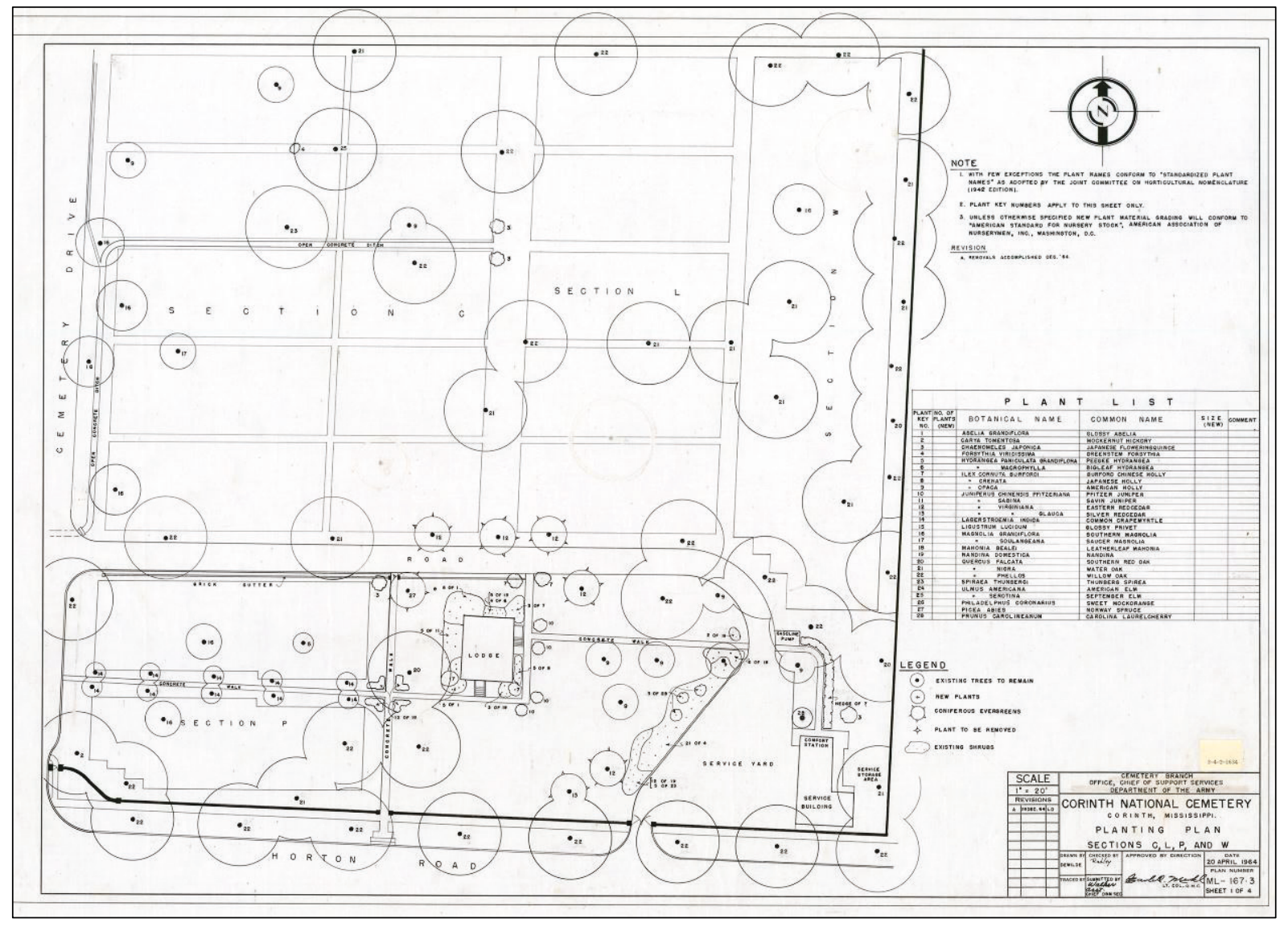

In 1964, Section C was planted with the following trees and shrubs: 2 Japanese Flowering Quince (Chaenomeles japonica), 1 Greenstem forsythia (Forsythia viridissima), 3 American holly (Ilex opaca), 4 Southern Magnolia (Magnolia grandiflora), 1 Saucer Magnolia (Magnolia soulangeana), 2 Eastern Redcedar (Juniperus virginiana), 3 Water Oak (Quercus nigra), 4 Willow Oak (Quercus phellos), 1 Thunberg Spirea (Spirea thunbergii), and 1 September Elm (Ulmus serotina).

In 1964, Section L was planted with the following trees and shrubs: 1 Eastern Redcedar (Juniperus virginiana), 2 Water Oak (Quercus nigra), and 2 Willow Oak (Quercus phellos).

In 1964, Section P was planted with the following trees and shrubs: 1 Mocknut Hickory (Carya tomentosa), 1 Peegee Hydrangea (Hydrangea paniculata grandiflora), 2 Southern Magnolia (Magnolia grandiflora), 1 Water Oak (Quercus nigra), and 6 Willow Oak (Quercus phellos). 
In 1964, Section W was planted with the following trees and shrubs: 1 Southern Red Oak (Quercus falcata), 1 Southern Magnolia (Magnolia grandiflora), 5 Water Oak (Quercus nigra), and 7 Willow Oak (Quercus phellos).

\subsubsection{1970s}

Images from the late 1970s show the changes made to the lodge and surrounding area. Figure 199 shows mature hedges around the foundation of the lodge. The first-story windows and front door had metal awnings added over them. Figure 200 shows the east side of the lodge. A wooden fence was added along the walk between the lodge and the maintenance area. Figure 201 shows the lodge's north elevation, which has shrubs around the foundation. An air-conditioning unit was added to this side, but awnings were not added to the windows on this side (Figure 201).

Figure 199. Southwest oblique of the lodge in 1977 (NCA archives, Washington, DC).

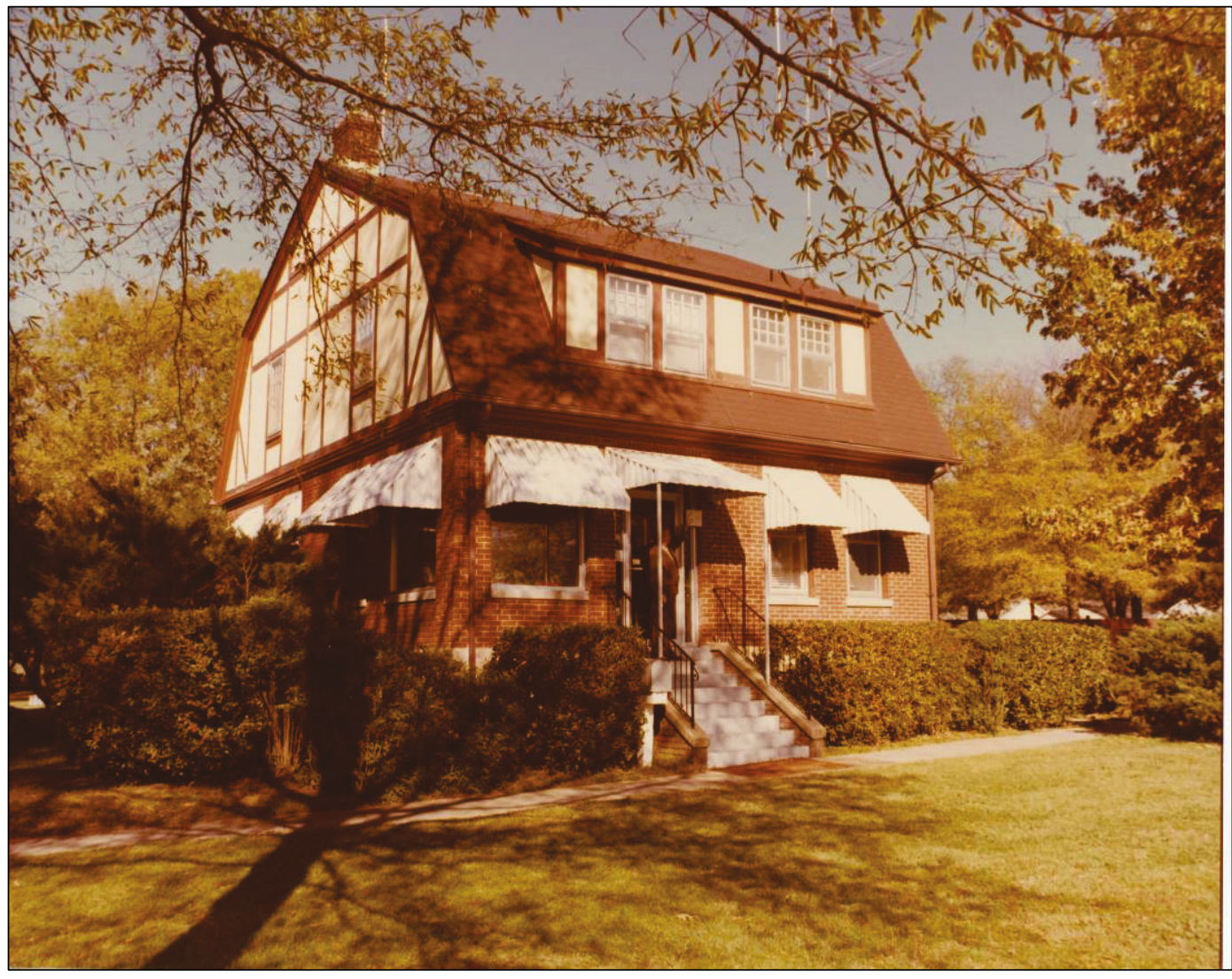


Figure 200. East elevation of lodge at Corinth National Cemetery in 1977 (NCA archives, Washington, DC).

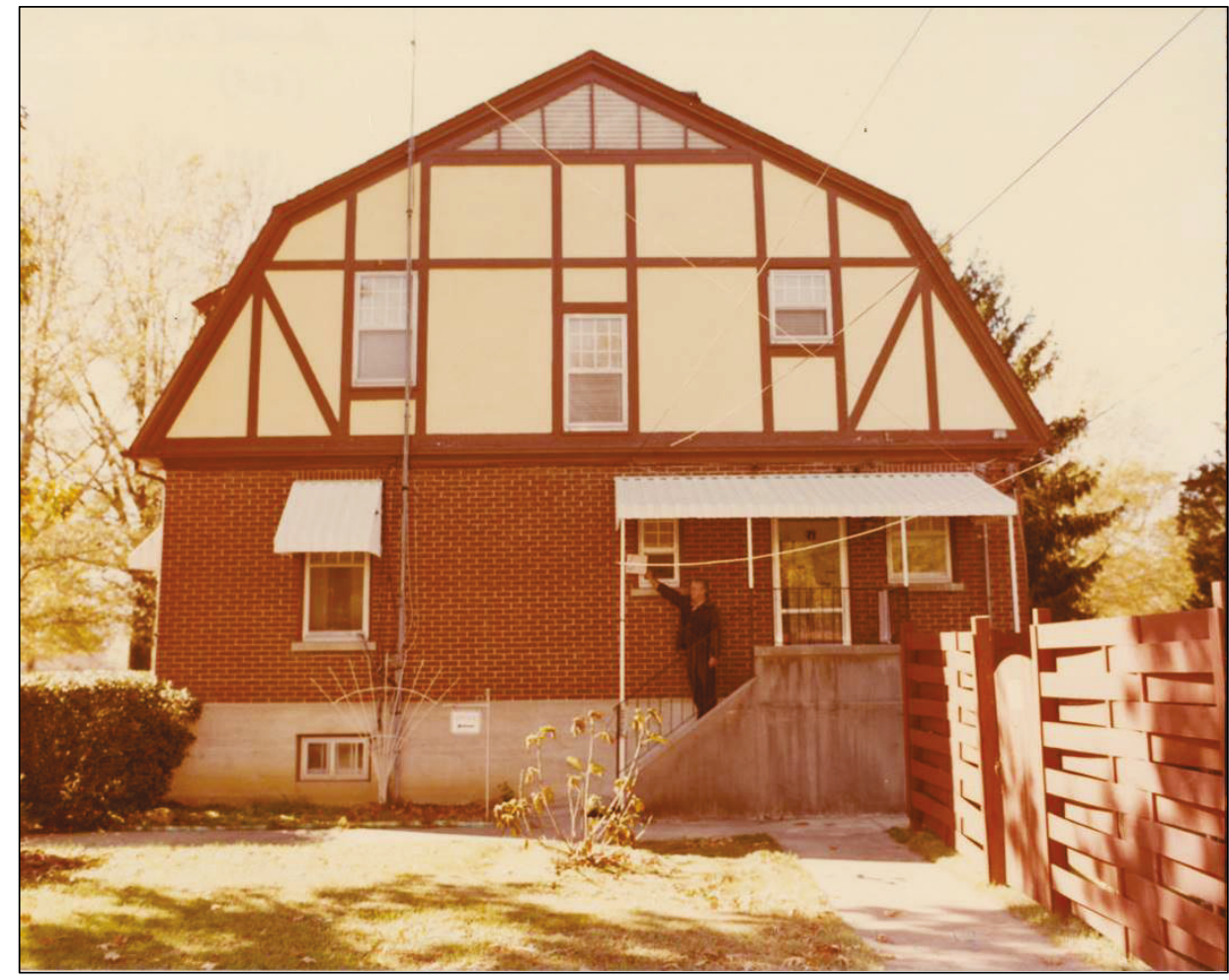

Figure 201. North elevation of lodge at Corinth National Cemetery, 1977 (NCA archives, Washington, DC).

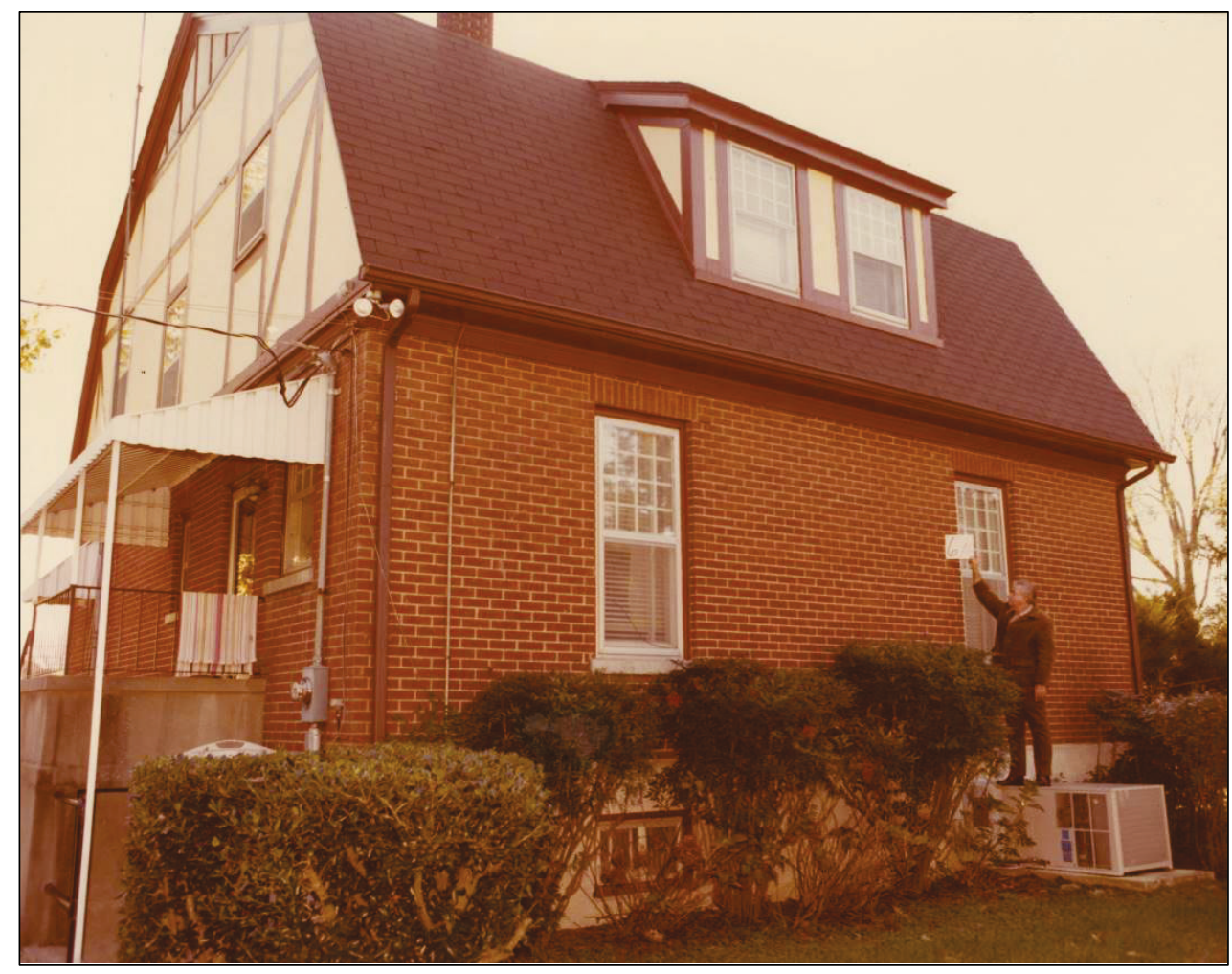




\subsubsection{1983 plan}

Figure 202 is the plan for the southeast quadrant in 1983. The plan is an updated drawing from 1954. Trees are shown as small black dots in the burial sections. Several graves were obstructed because of tree growth. The area around the lodge and maintenance areas still had many trees and shrubs. Sections P and W do not have burials in them. Figure 203 illustrates the density of vegetation in the southeast quadrant in 1983.

Figure 202. Burial plan for the southeast quadrant of Corinth National Cemetery, 1983 (NCA archives, Washington, DC).

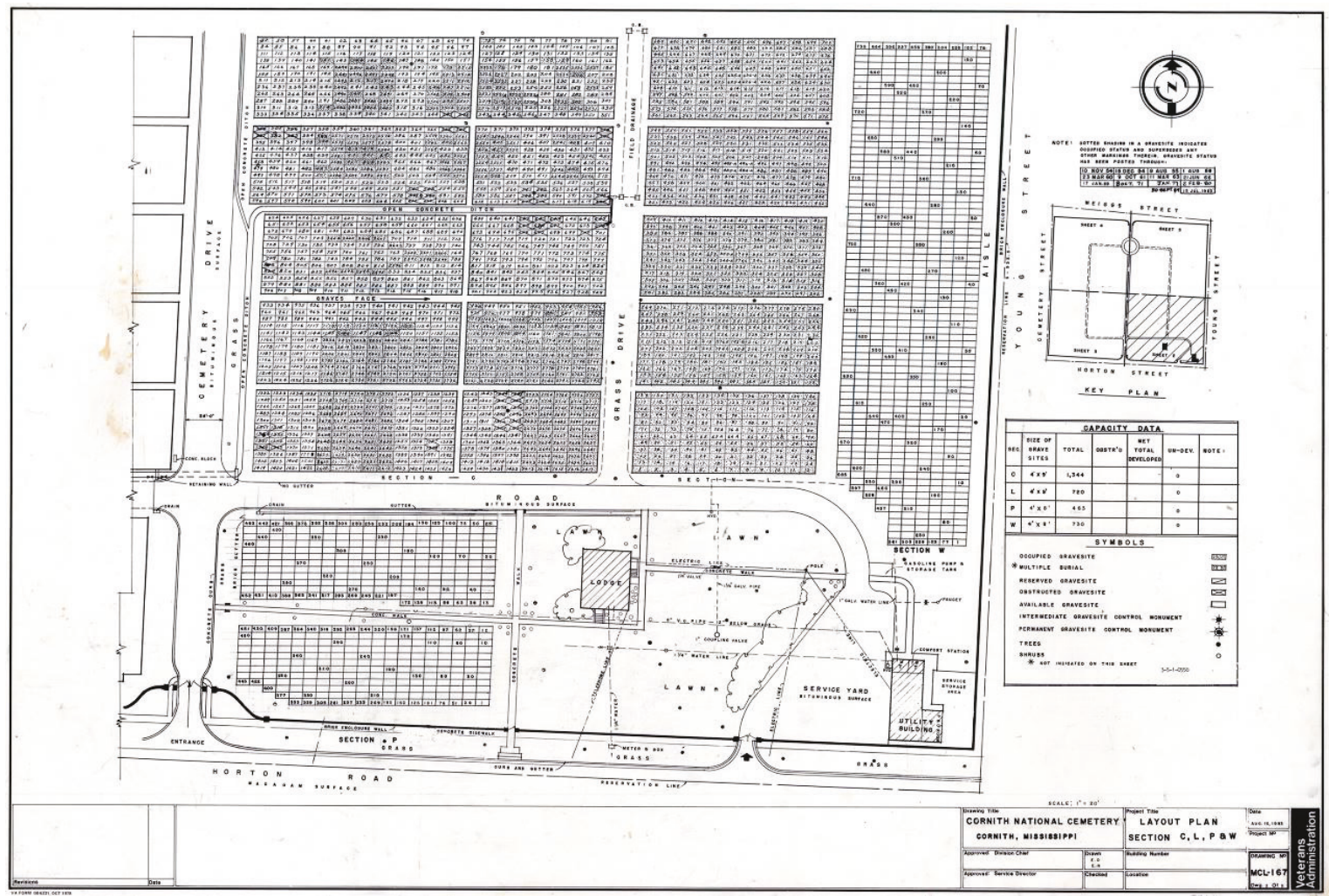


Figure 203. The tree and shrub maintenance plan from 1883 shows the density of vegetation throughout the southeast quadrant (NCA archives, Washington, DC).

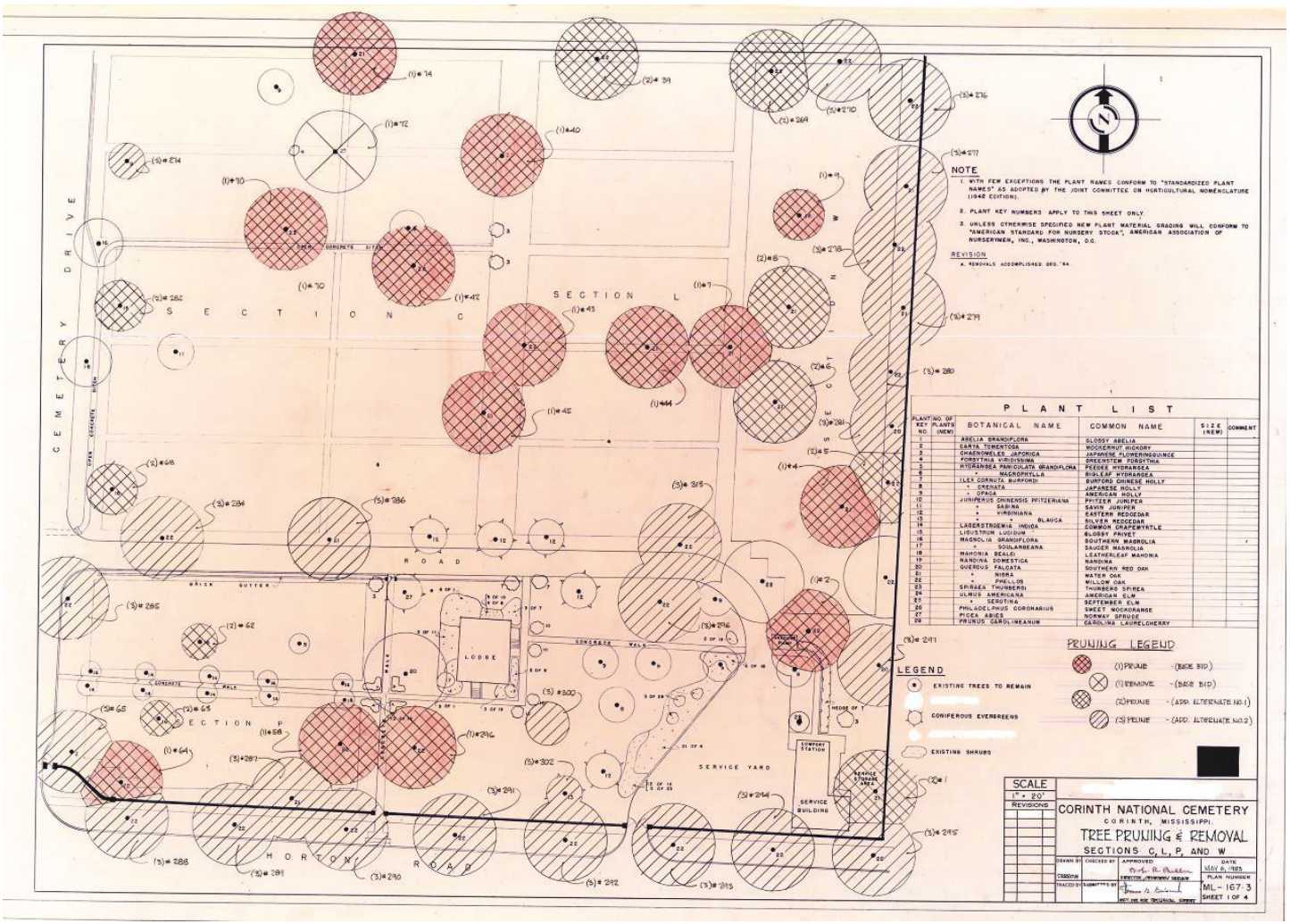

\subsubsection{2000s}

Observations in 2018 show that the open spaces in Section $\mathrm{C}$ defined the original geometric patterns of headstones were continuing to be filled in. Sections P and W still did not contain burials (Figure 204). There was a significant decrease in vegetation around the lodge and maintenance area. The lodge no longer had foundation plantings, and the maintenance area was screened from view with a slatted, chain link fence. 
Figure 204. The southeast quadrant burial plan in 2009

(NCA archives, Washington, DC).

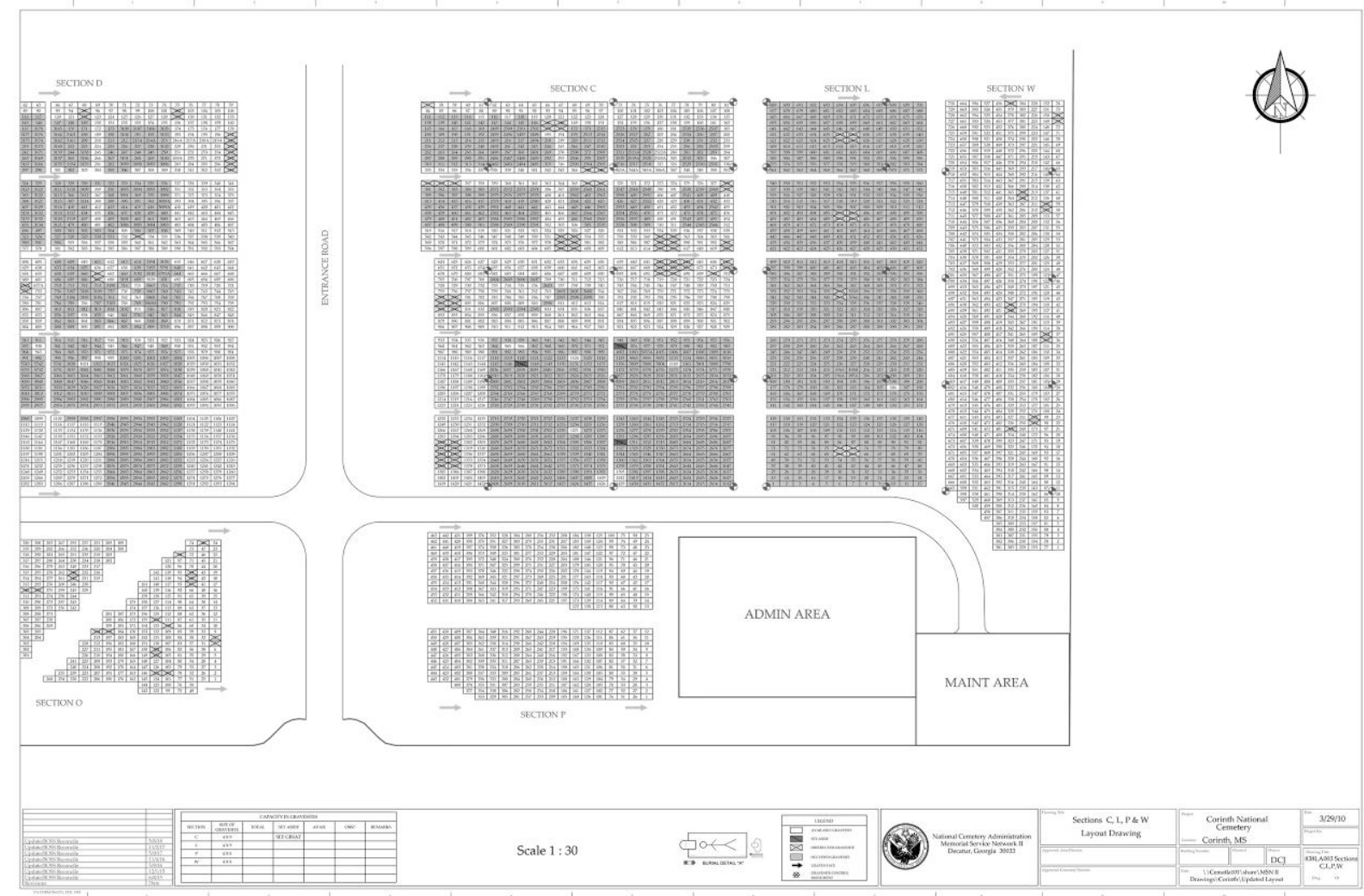

\subsubsection{Burial register summary}

According to burial register in spring 2018, there are 762 burials in Section $\mathrm{C}$ and 706 burials in Section L. Sections $\mathrm{P}$ and $\mathrm{W}$ do not have burials in them.

Of the 762 burials in Section C, there are 226 Unknown Soldiers. Of the known soldier deaths, there are 124 internments from the 1860s, 2 in the 1930s, 19 in the 1940s, 17 in the 1950s, 49 in the 1960s, 13 in the 1970s, 7 in the 1980s, 22 in the 1990s, 37 in the 2000s, and 234 from deaths in the 2010s. There are 9 known burials that do not list either a death or interment date for the soldier.

In Section L there are 691 Unknown Soldiers' graves. Of the known deaths, 4 graves are from deaths in the 1860 s, 1 from 1919, and 5 from the 1930 s. There are 4 known burials that do not have either a death or interment date listed. 


\subsubsection{Southwest quadrant}

\subsubsection{Preliminary plan (undated)}

In the undated preliminary design for Corinth National Cemetery (Figure 205), the southwest quadrant reflected the layout patterns of the southeast quadrant. Sections D and M are marked and mirror Sections C and L, respectively. Section D has the distinct circle path and wedge-shaped burial groupings. It is labeled Iowa. Section $\mathrm{M}$ is comprised of five rectangular burial groupings, each with a central grassed square. Section $M$ is marked Unknown. These burial sections are surrounded by wide grassed areas, and the undulating perimeter path runs to the south and then curves around the quadrant's west edge. The main road is laid out to the east of the sections, and the cemetery's entrance is marked in the center of the southern wall. The drainage channel is marked with a solid black line on Figure 205, running southwest from the southeast quadrant across the main road and then angling diagonally through the southern part of the southwest section. There appear to be two bridges or crossings over the channel where the main road and winding path intersect it. Between the entrance and the channel, the map marks an artesian well but the noted depth is unclear.

Figure 205. Undated preliminary design for the southwest quadrant of Corinth National Cemetery (NCA archives, Washington, DC).

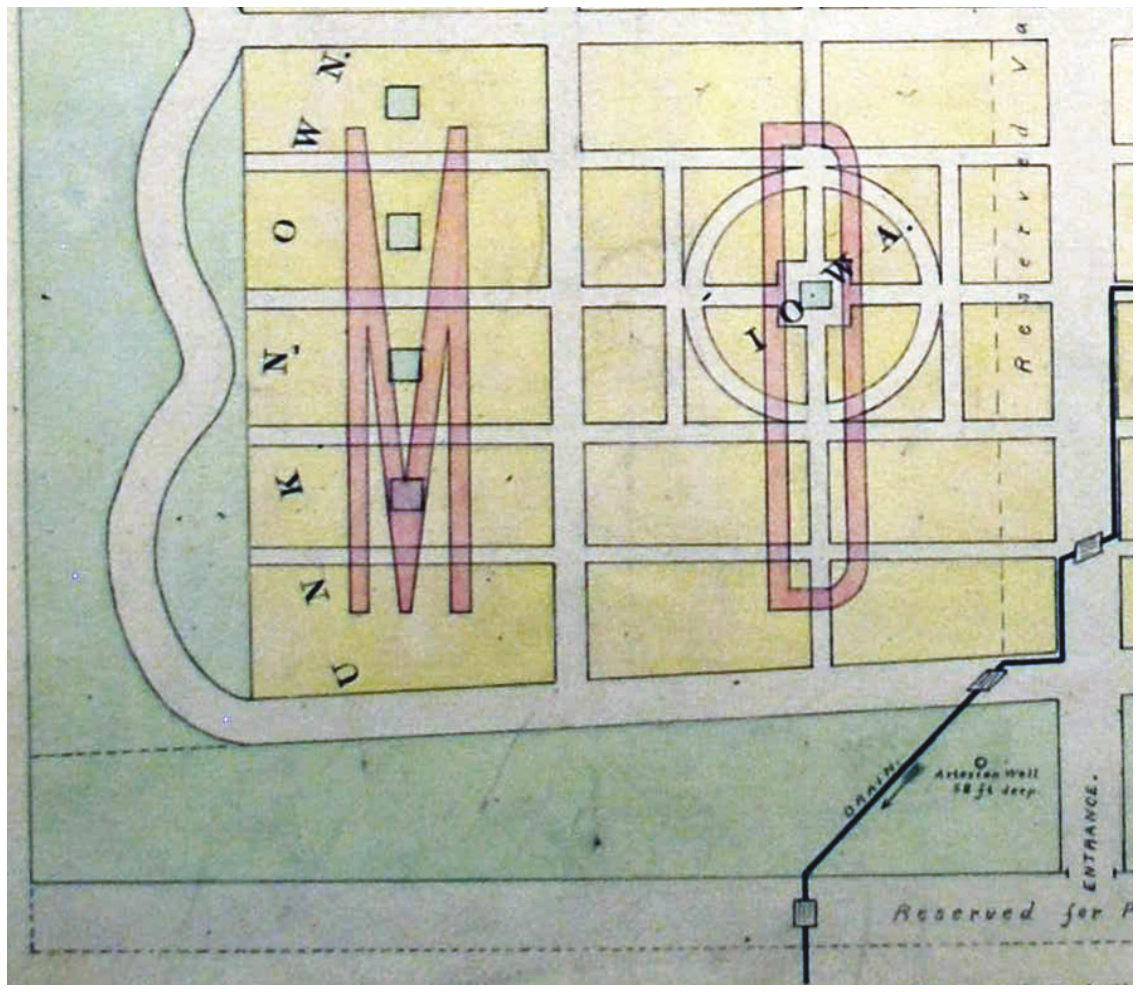




\subsubsection{1892 plan}

The 1892 plan of the southwest quadrant illustrates the changes that occurred between the design and construction of the cemetery. The overall layout was similar-two burial sections surrounded by grassed areas, but many of the details had changed. Section D was closest to the main road through the cemetery, and its layout was a close mirror image of Section C to the east. Section D had three burial groupings, and each featured distinct geometric patterns in the placement of headstones. These unique headstone arrangements were surrounded by abundant open space that emphasized the groupings. Like Section C, the northernmost grouping of headstones was rectangular, and the sequence of patterns was created by two squares, a circle, and then two more squares. The squared arrangements were similar, but not exact copies of each other. The squares closest to the road had more burials and larger open spaces in their interiors. The circular grouping of burials was defined by graves arranged in wedge shapes with an open aisle that crossed through the circle. In the middle of Section D there was a group of headstones arranged in a wide wishbone pattern. This plan shows 17 headstones with a wide field of open space around it. The third burial grouping in Section D was a wide rectangle composed of north-south rows of burials. The middle section on the south is left open and planted with a few trees. Figure 206 shows these arrangements clearly.

West of Section D is Section $\mathrm{M}-\mathrm{a}$ section having five rectangular burial groupings with rows running north to south. An aisle lined with trees separates the two sections. In Section M, a tree was placed in the middle of each of the five groupings (Figure 206).

Surrounding the burial sections to the south and west was open space, shown filled with trees and vegetation and the undulating perimeter grass drive. The southern portion of this quadrant had the Rostrum (Figure 207), drainage channel, and summer house. Additional drainage infrastructure is shown on the west side of the quadrant, with water diverted under the west perimeter wall (Figure 206). 
Figure 206. The 1892 plan of the southwest quadrant showing the spatial layout, headstone patterns of Sections $D$ and $M$, and the vegetation patterns

(NCA archives, Washington, DC).

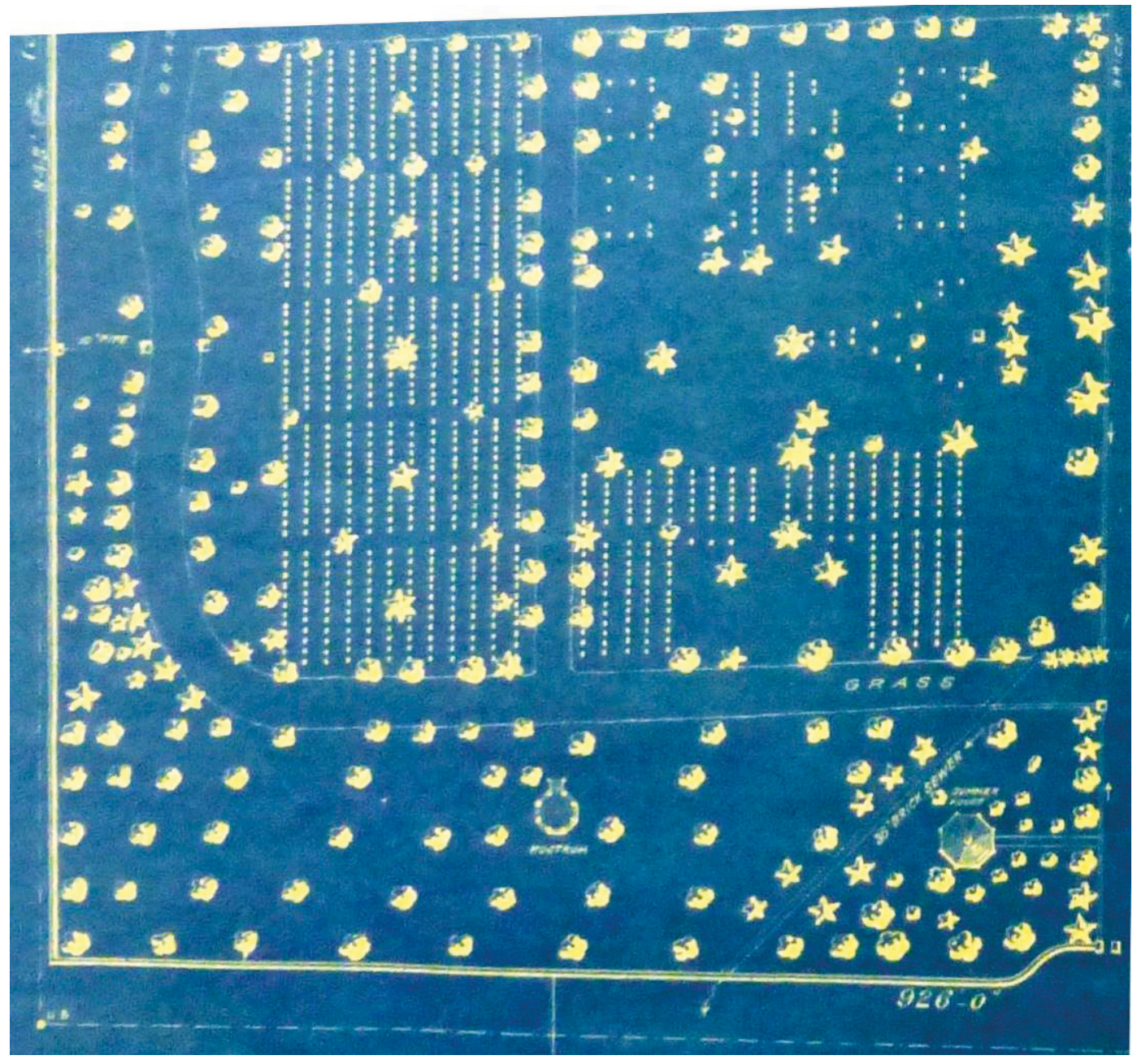

Figure 207 is a photograph from 1892 showing a view of the rostrum along with fairly young vegetation. There were several rows of deciduous trees aligned east to west and, in the background, evergreen trees and shrubs were arrayed throughout the area. 
Figure 207. View east toward the rostrum, 1892 (NARA, College Park, MD).

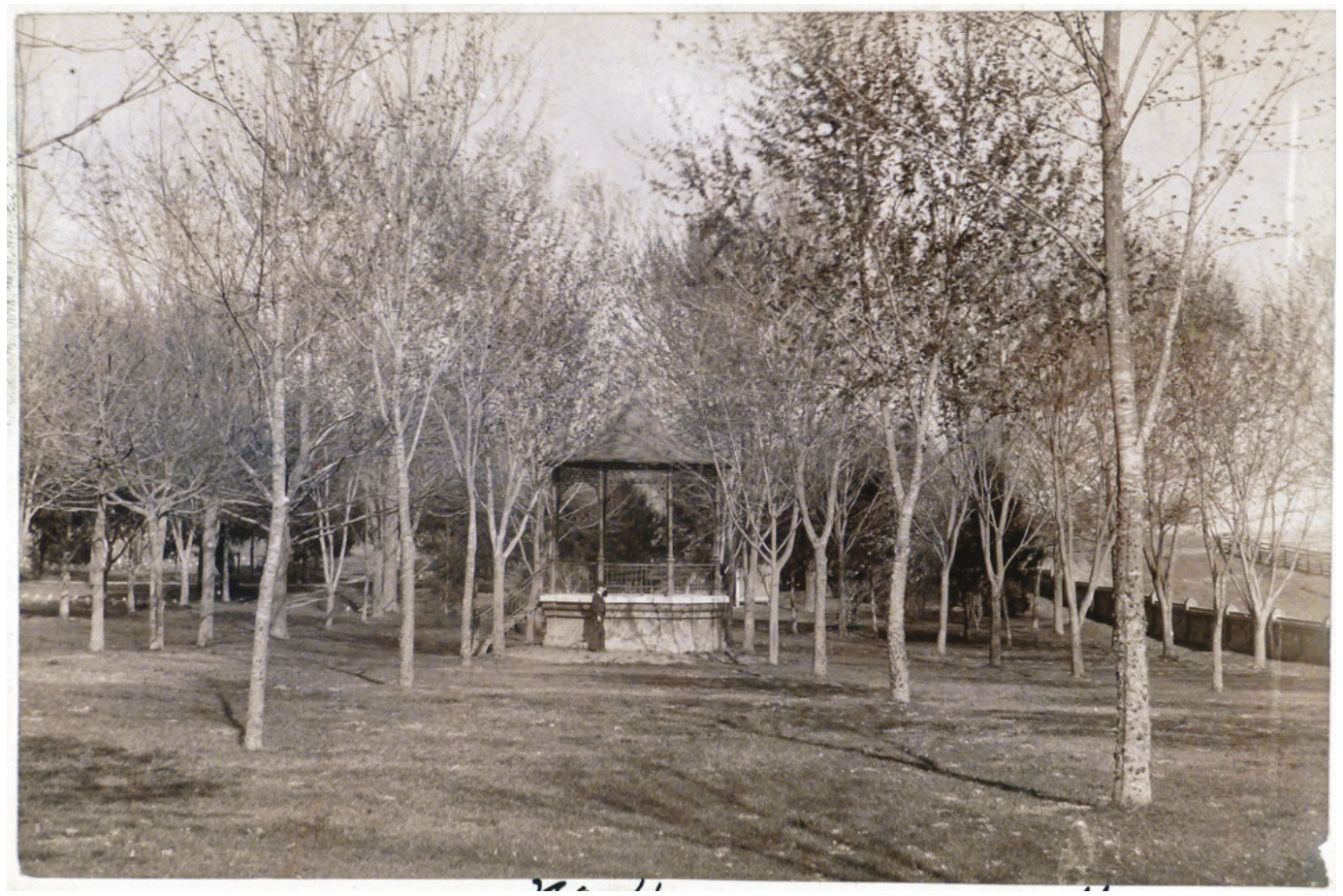

The 1892 plan shows the south entrance was articulated by two central piers with two other piers abutting the perimeter wall. This arrangement allowed for a wide, central gate to the road and two smaller pedestrian gates on either side (Figure 208).

Figure 208. Plan of the south entrance and surrounding area, 1892 (NCA archives, Washington, DC).

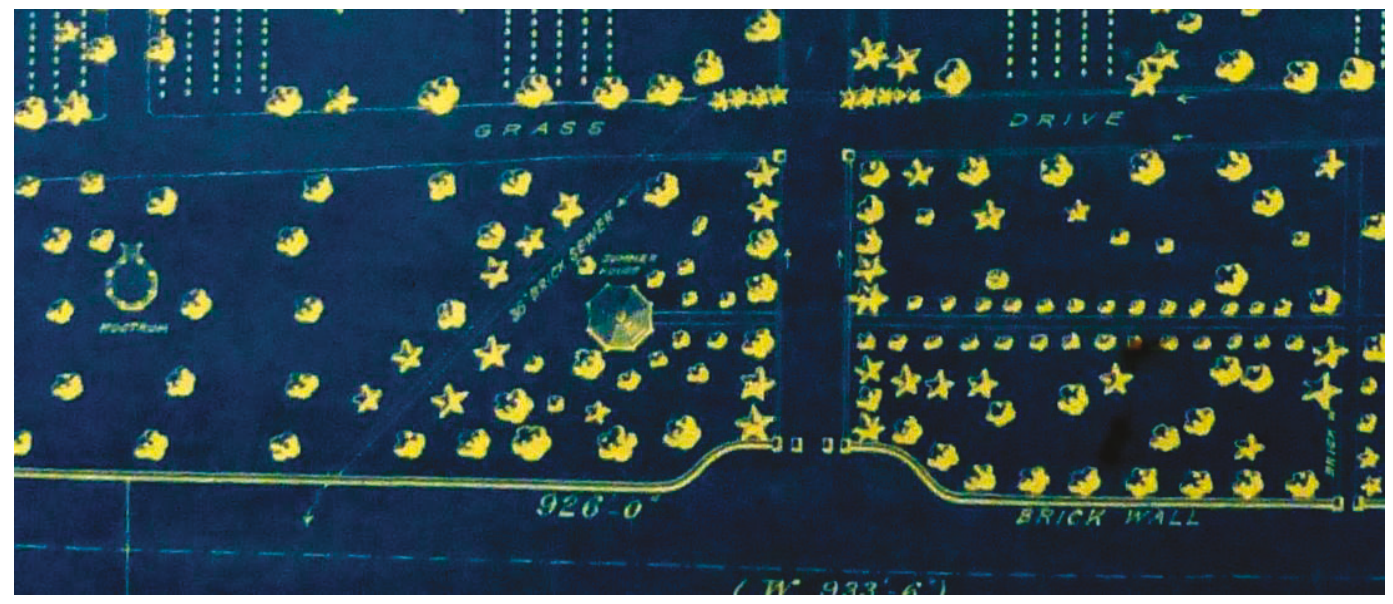

On this plan, the area inside the south entrance is heavily vegetated-trees lined the main road, shrubs lined the walk leading to the lodge, and other trees and shrubs were arrayed around the summer house. Figure 209 and 
Figure 210 are photographs taken around 1892 showing the conditions of the south entrance.

Figure 209. South entrance in 1892, with pedestrian gates on either side (NARA, College Park, MD).

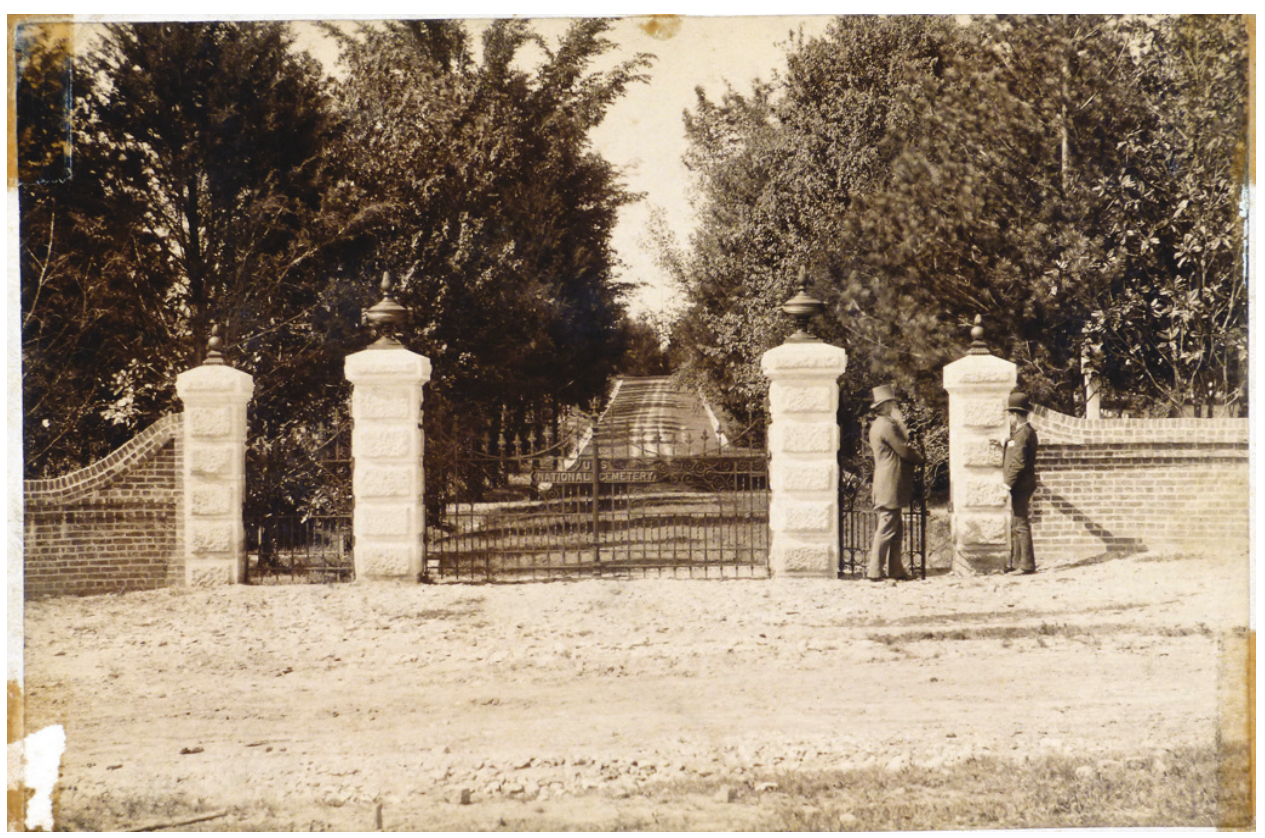

Figure 210.View east toward the lodge showing the cemetery's main road, brick walks, and vegetation around the south entrance, 1892 (NARA, College Park, MD).

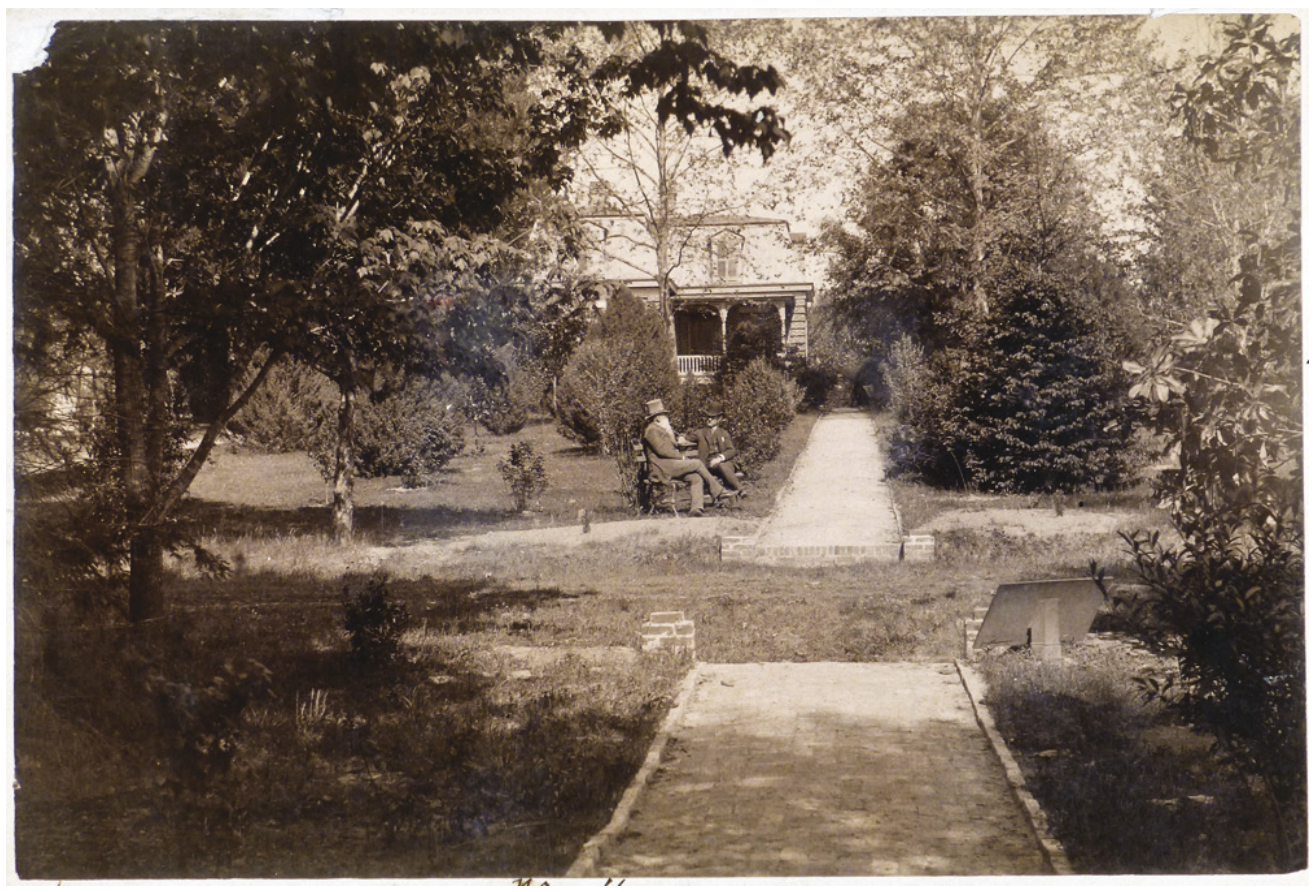




\subsubsection{1946}

Figure 211 shows the south entrance from Horton Street in 1946. The view was toward the northwest and showed dense vegetation in the cemetery. However, there were no trees in the verge between the city street and the cemetery's perimeter wall.

Figure 211. Old main gate in October 1946 (NCA archives, Washington, DC).

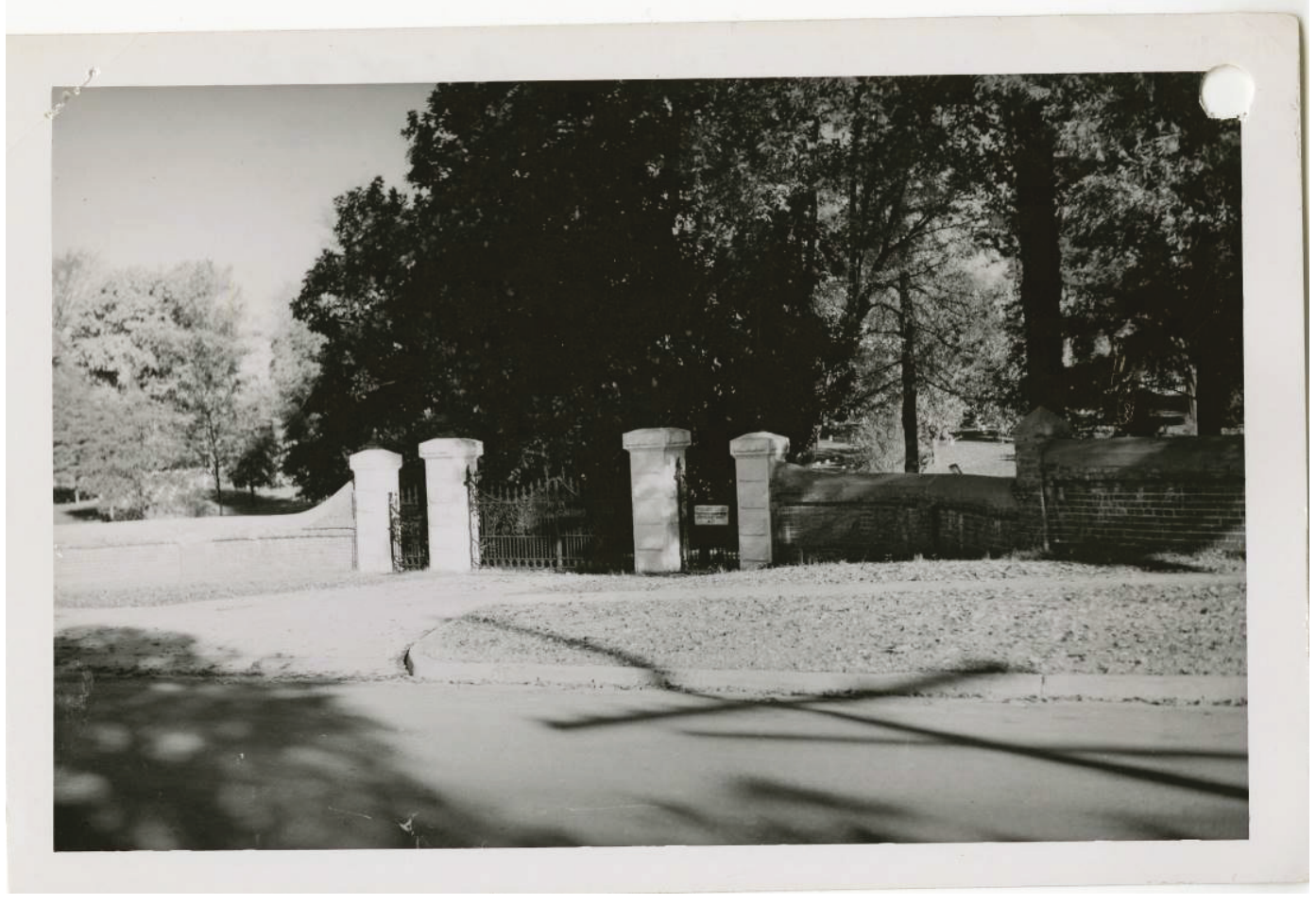

\subsubsection{1954 plan}

There's a gap in Corinth National Cemetery's historic spatial information. It is known that between 1892 and 1953, the headstones were reversed from facing west to facing east (an 1892 photo shows the headstones facing west while the 1954 plan shows them facing east). ${ }^{145}$ The date for this could not be determined due to the lack of archival material from this period (1909 is the most likely date due to the destructive impact of a storm that year). There are several major changes between the conditions documented on the 1892 cemetery plan and the 1954 plan. The first was the elimination of the winding grass perimeter drive and the inclusion of Sections $\mathrm{N}, \mathrm{O}$, and $\mathrm{R}$ in the southwest quadrant. Another significant change

\footnotetext{
145 The change in the direction that grave markers faced was noticed by ERDC-CERL researchers when studying historical photos onsite at Corinth National Cemetery, but no archival documentation was ever located regarding this change.
} 
was in Section D, where much of the open space around the geometric headstone patterns has been filled in with newer burials. The rostrum and summer house have been removed. On the 1954 plan, vegetation is shown as black dots for trees and lined circles for shrubs. There was an overall decrease in vegetation in this quadrant. Figure 212 is the 1954 plan of the quadrant that shows those changes.

Figure 212. 1954 burial plan for the southwest quadrant (NCA archives, Washington, DC).

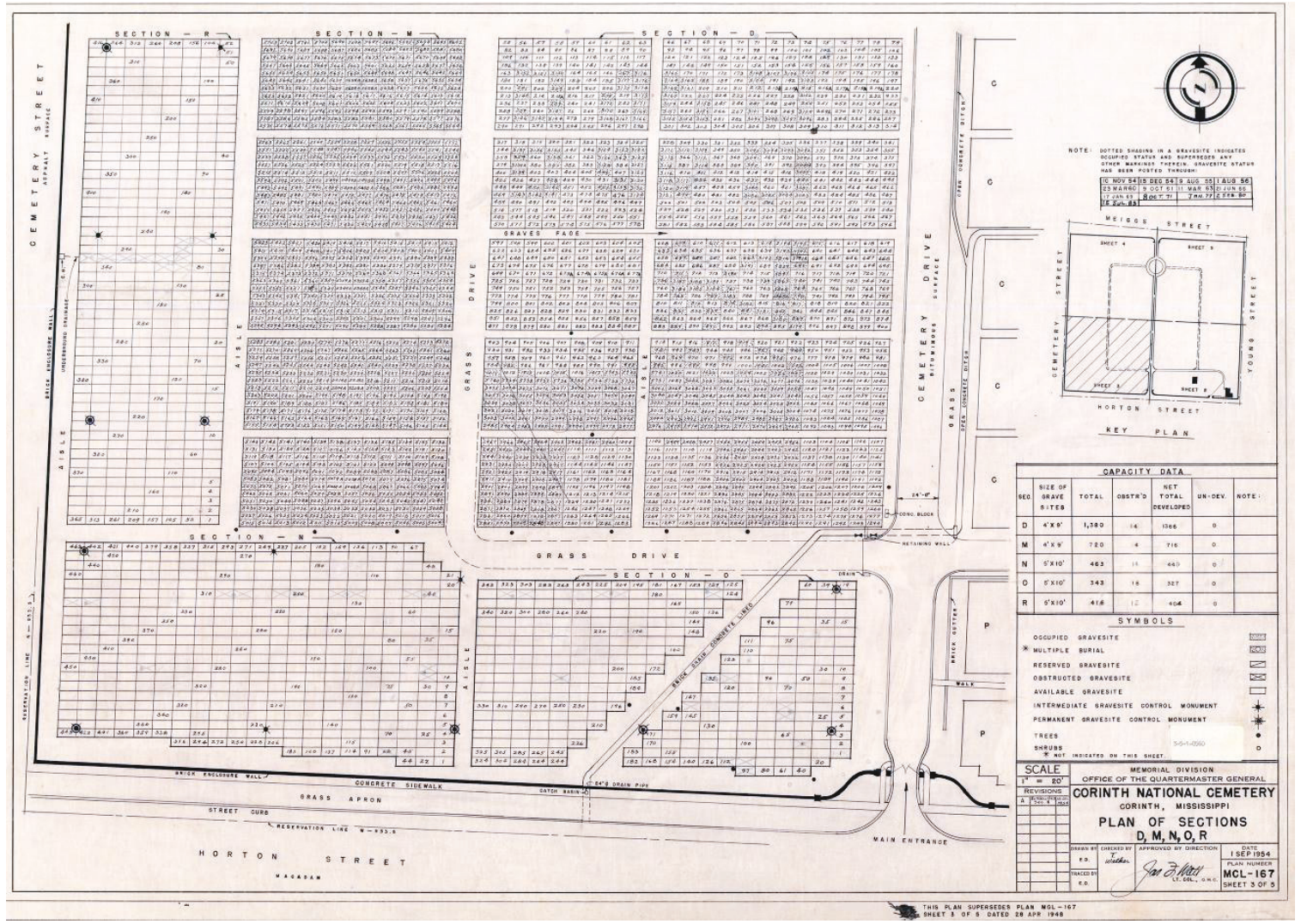

Photographs from the 1950 s show the cemetery with young vegetation. Figure 213 and Figure 214 show part of the southwest quadrant with a mix of older and younger vegetation. Of note, the trees lining the perimeter wall mostly have been removed. Figure 215 shows the drainage ditch in the southwest quadrant and the changes in vegetation throughout the area, along with the removal of the rostrum and summer house. 
Figure 213. Perimeter wall looking west along Horton Street, April 1954

(NCA archives, Washington, DC).

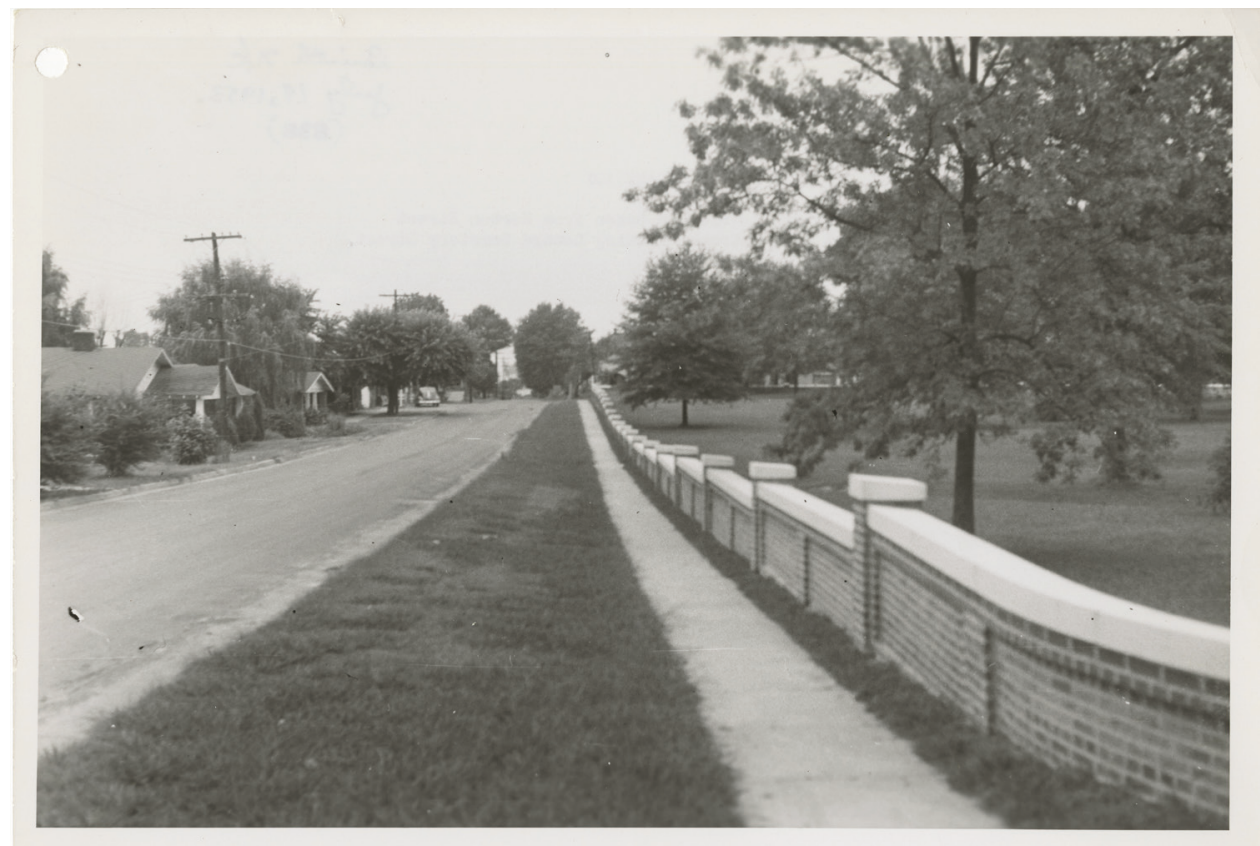

Figure 214. View toward the southwest corner of the cemetery in April 1954 (NCA archives, Washington, DC).

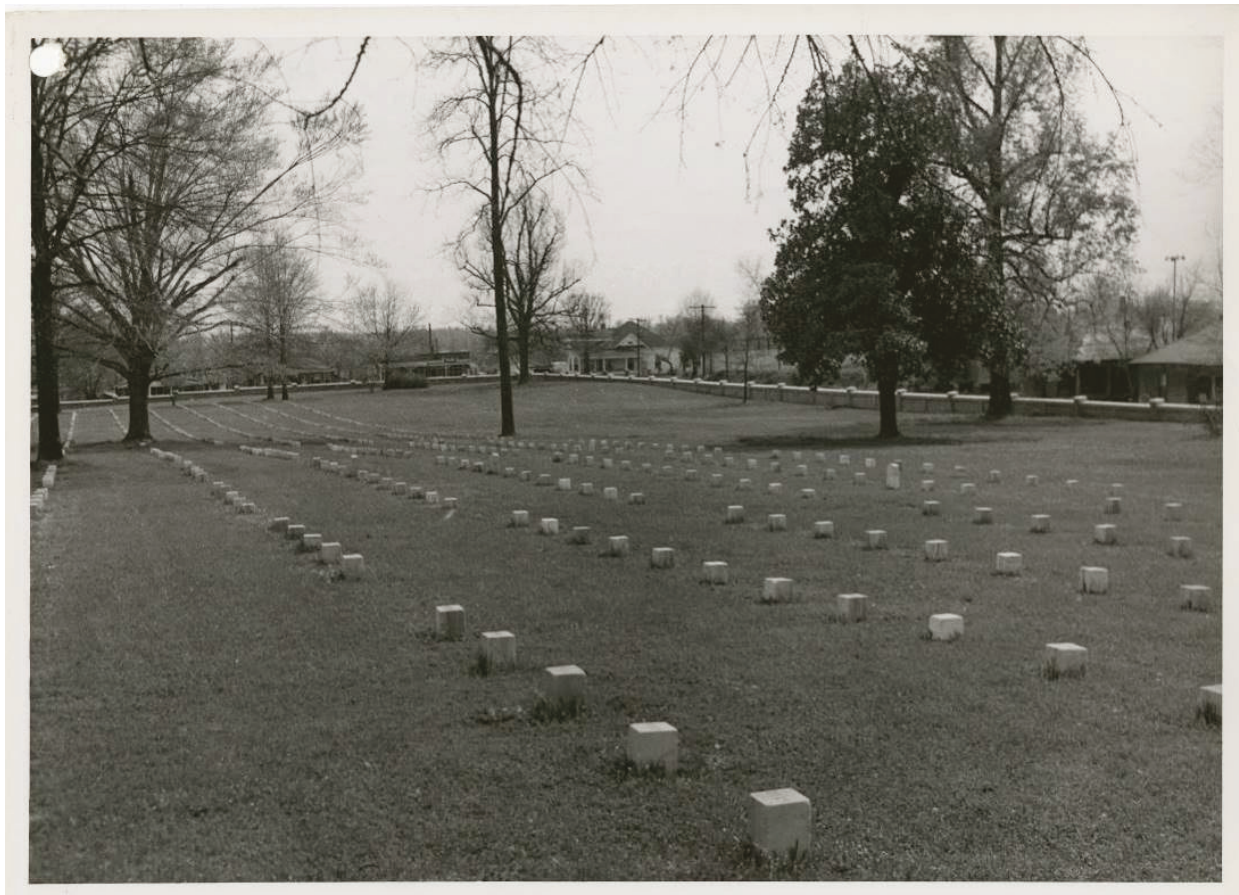


Figure 215. Drainage ditch running through the southwest quadrant. View looking south from Cemetery Drive, July 1953 (NCA archives, Washington, DC).

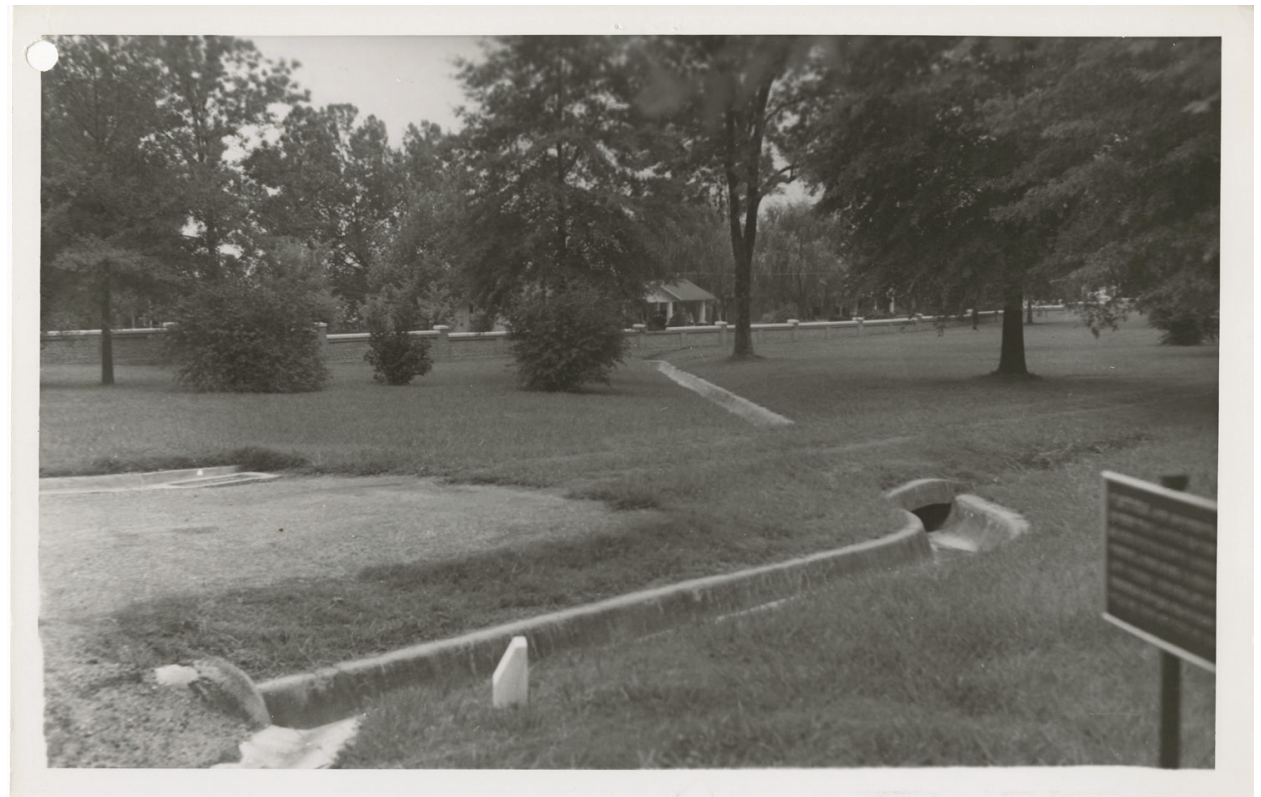

\subsubsection{1964 planting plan}

Between the 1954 burial plan and the 1964 planting plan were several changes. Large deciduous trees lined the interior of the perimeter wall and were scattered throughout Sections D and $\mathrm{M}$. The newer sections of $\mathrm{N}$ and O still featured a wide variety of vegetation including large deciduous trees, evergreens, small ornamental trees, and shrubs (Figure 216). 
Figure 216. Planting plan of the southwest quadrant in 1964 (NCA archives, Washington, DC).

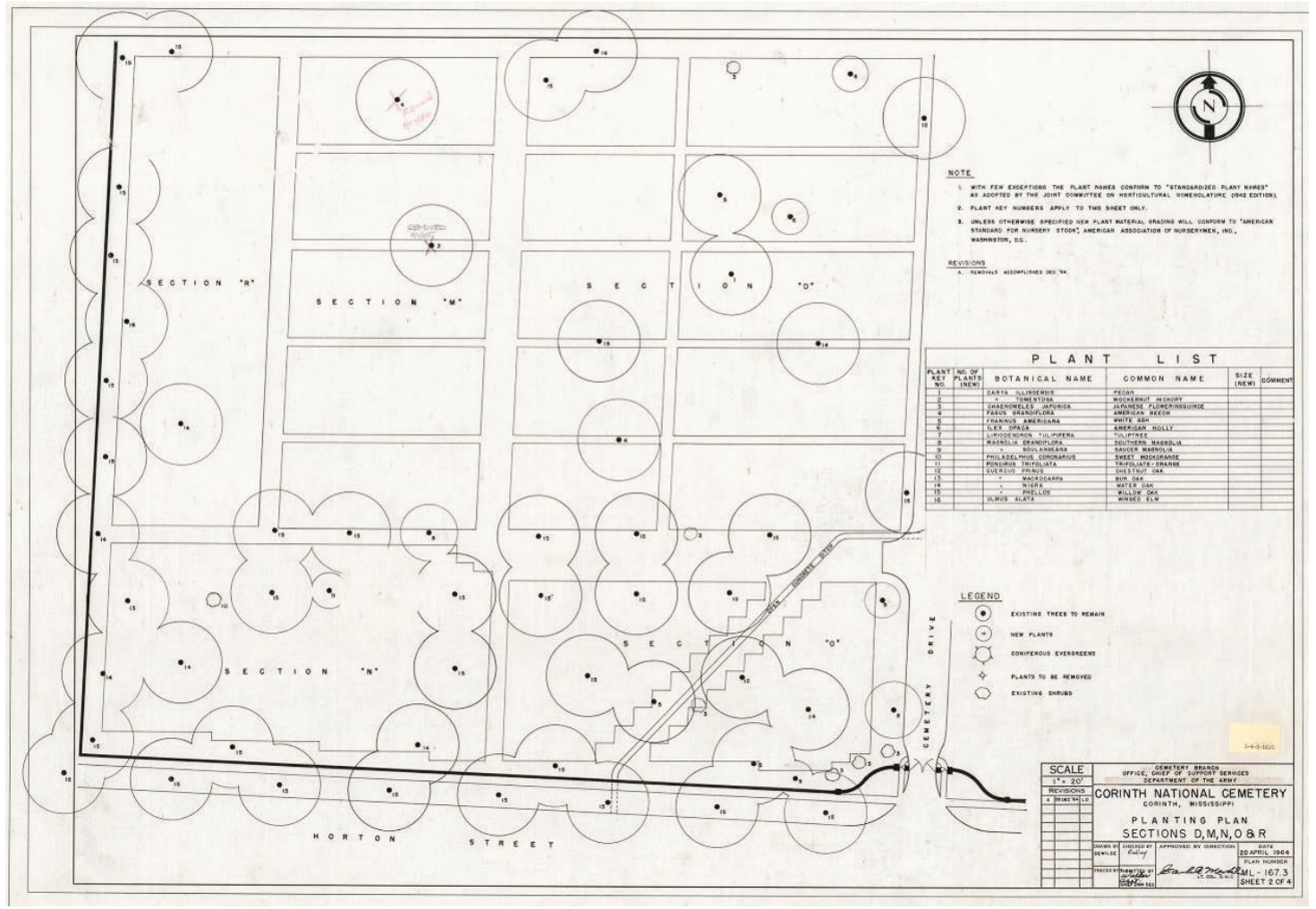

In 1964, Section D was planted with the following trees and shrubs: 1 Pecan (Carya illinoensis), 2 Japanese Flowering Quince (Chaenomeles japonica), 2 American Holly (Ilex opaca), 1 American Beech (Fagus grandiflora), 1 White Ash (Fraxinus americana), 1 Chestnut Oak (Quercus prinus), 2 Water Oak (Quercus nigra), and 6 Willow Oak (Quercus phellos).

In 1964, Section M was planted with the following trees and shrubs: 1 American Beech (Fagus grandiflora), 1 Mocknut Hickory (Carya tomentosa), 1 Southern Magnolia (Magnolia grandiflora), and 2 Willow Oak (Quercus phellos).

In 1964, Section $\mathrm{N}$ was planted with the following trees and shrubs: 1 Sweet Mockorange (Philadelphus coronarius), 1 Trifoliate Orange (Poncirus trifoliata), 1 Bur Oak (Quercus macrocarpa), 4 Water Oak (Quercus nigra), and 8 Willow Oak (Quercus phellos).

In 1964, Section O was planted with the following trees and shrubs: 4 Japanese Flowering Quince (Chaenomeles japonica), 2 White Ash (Fraxinus 
americana), 1 Southern Magnolia (Magnolia grandiflora), 2 Saucer Magnolia (Magnolia soulangeana), 1 Water Oak (Quercus nigra), and 10 Willow Oak (Quercus phellos).

In 1964, Section R was planted with the following trees and shrubs: 1 Water Oak (Quercus nigra), 6 Willow Oak (Quercus phellos), and 1 Winged Elm (Ulmus alata).

Figure 217 shows a view across Section D in the southwest quadrant. The vegetation is maturing, and large deciduous trees cast pockets of shade. In this view, the unique geometric groupings of headstones in Section D have not been filled in with newer graves.

Figure 217. View southwest across Section $D$, showing a fairly mature White Oak in the foreground, May 1964 (NCA archives, Washington, DC).

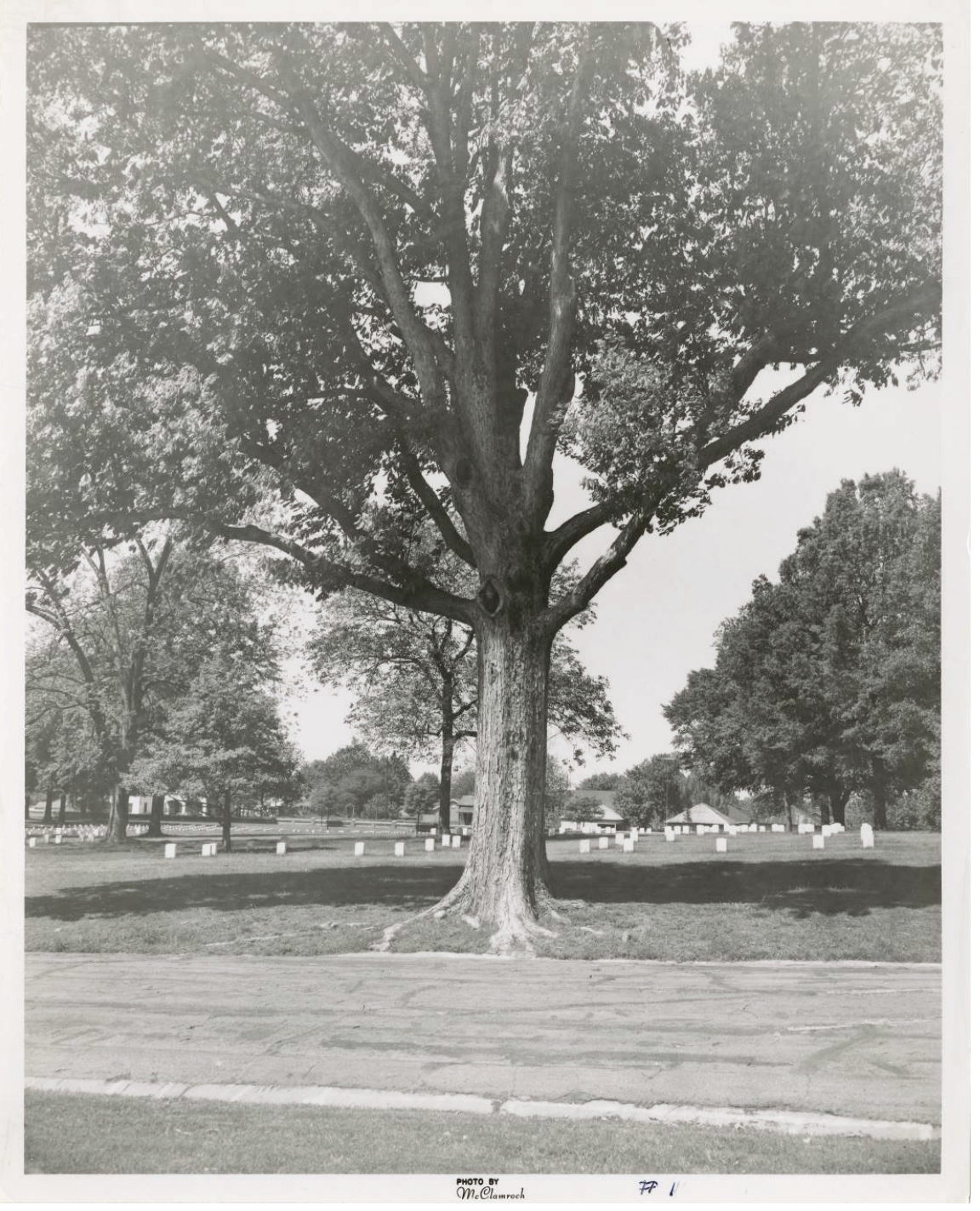




\subsubsection{1970s}

Figure 218 is a view northeast across the southwest quadrant. It shows dense and maturing vegetation.

Figure 218. Southwest corner looking northeast taken in June 1974 (NCA archives, Washington, DC).

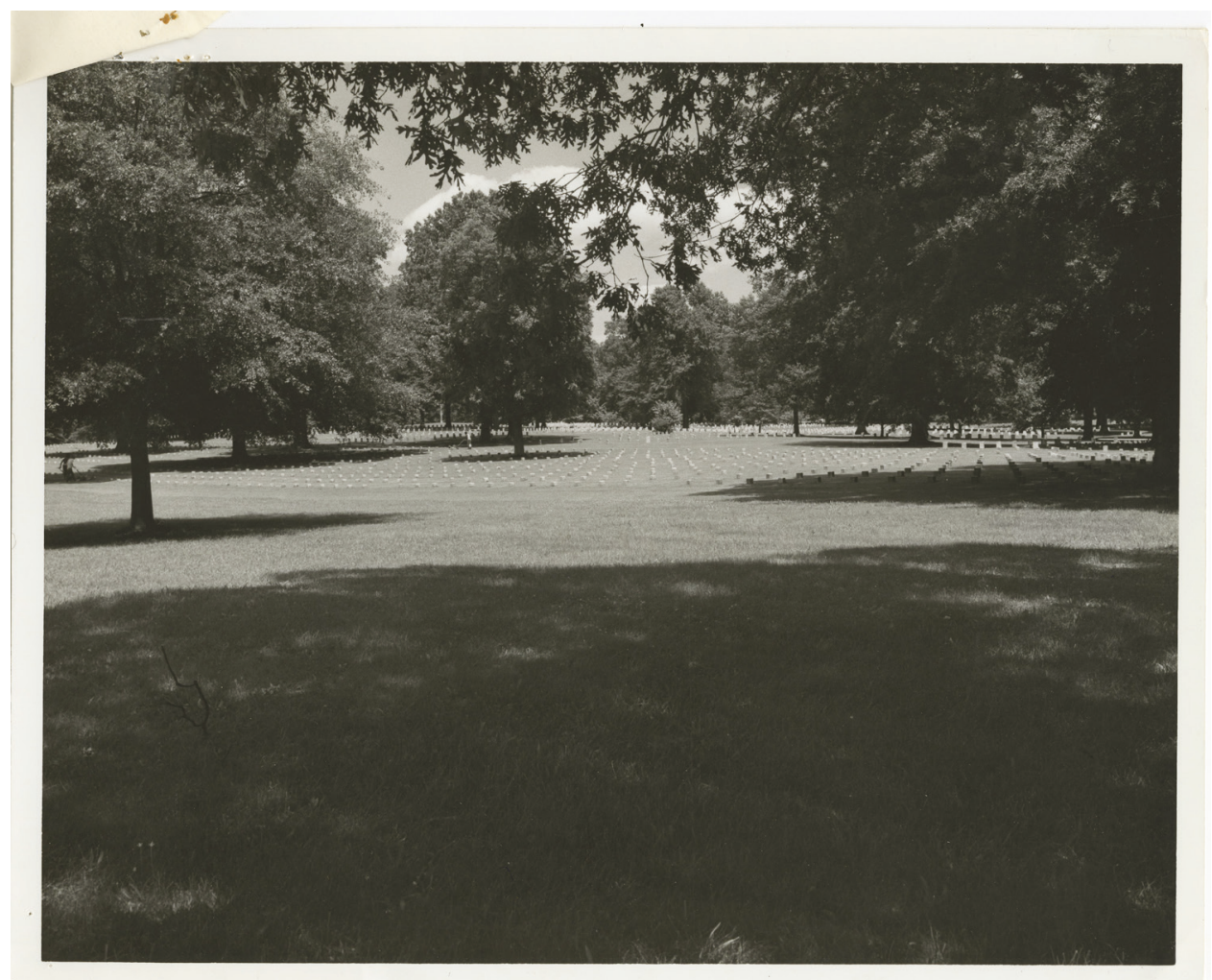

Figure 219 is a view of the main gates taken from outside the cemetery in June 1974. The vegetation near the entrance is mature and creates an enclosed feeling when passing through the gates. 
Figure 219. Main entrance gate in June 1974 (NCA archives, Washington, DC).

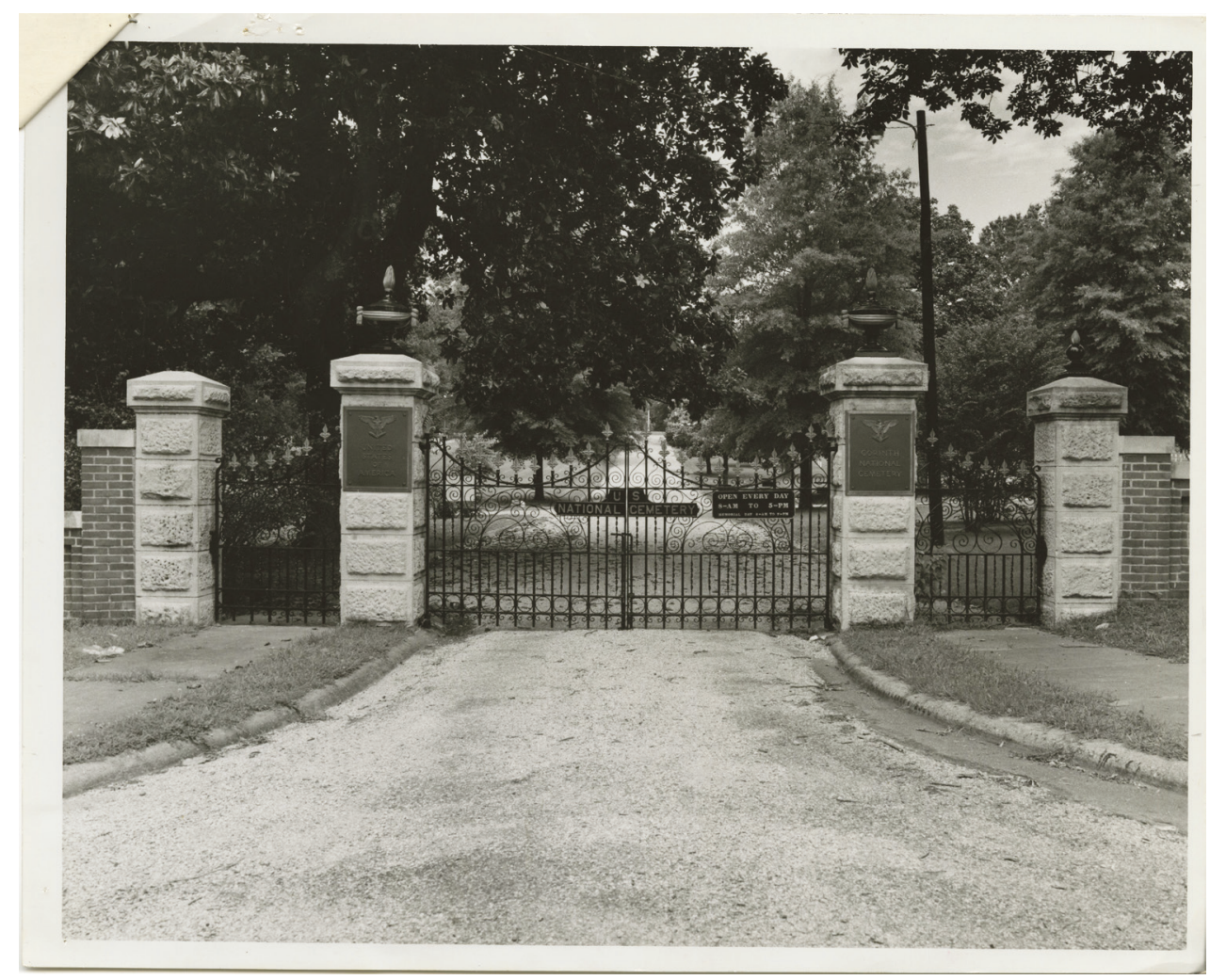

\subsubsection{1983 plans}

The burial and vegetation plans from 1983 show the major changes in the southwest quadrant were that newer burials were being incorporated into the open spaces in Section D (Figure 220). The vegetation plan shows that one tree in the southwest corner had been removed. Many other trees needed pruning. The quadrant still had large deciduous trees lining the inside of the perimeter wall, large deciduous trees scattered through the burial sections, and a higher density of trees and shrubs in Sections $\mathrm{N}$ and $\mathrm{O}$. Large deciduous trees lined the outside of the south perimeter wall (Figure 221). 
Figure 220. 1983 burial plan for the southwest quadrant of Corinth National Cemetery (NCA archives, Washington, DC).

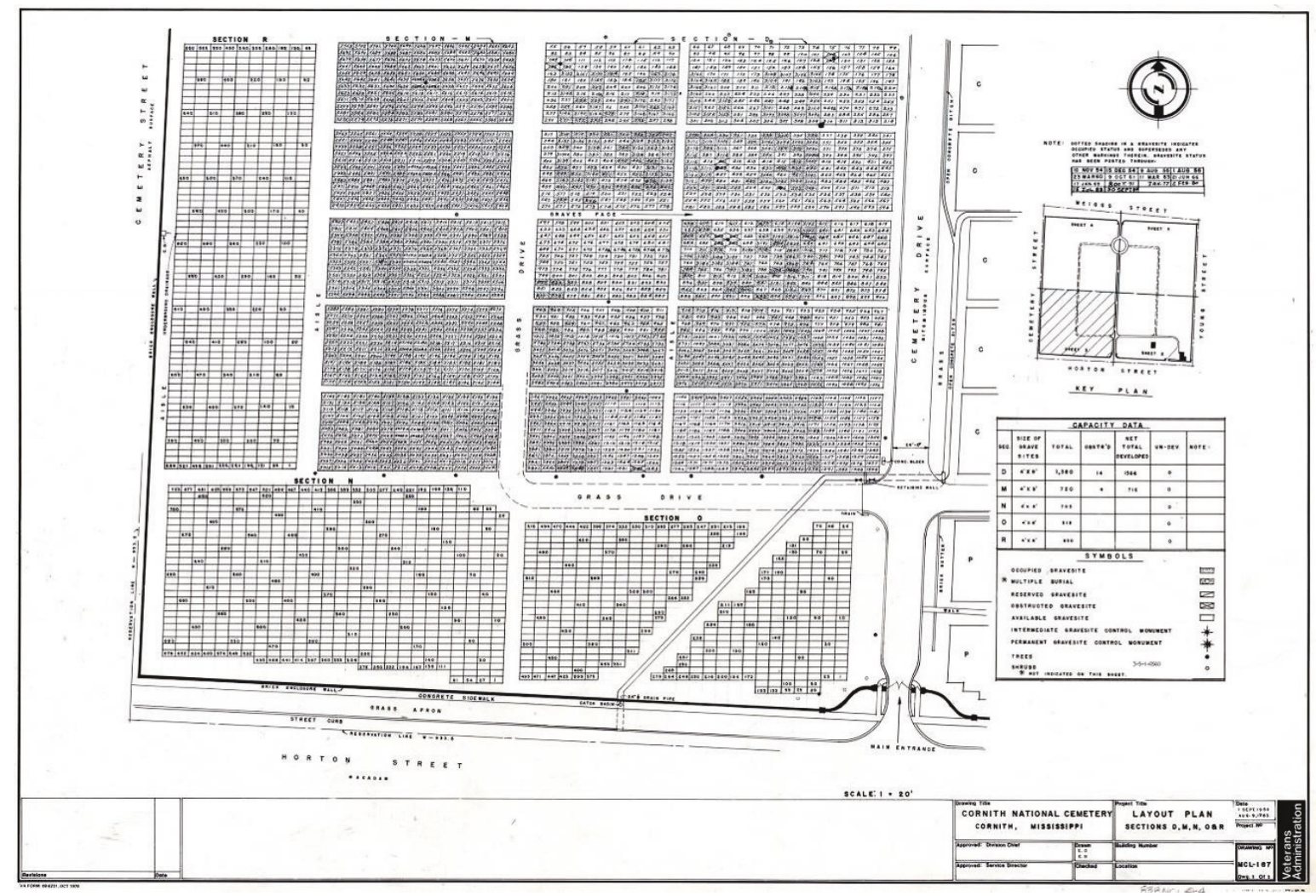

Figure 221. 1983 vegetation maintenance plan for the southwest quadrant (NCA archives, Washington, DC).

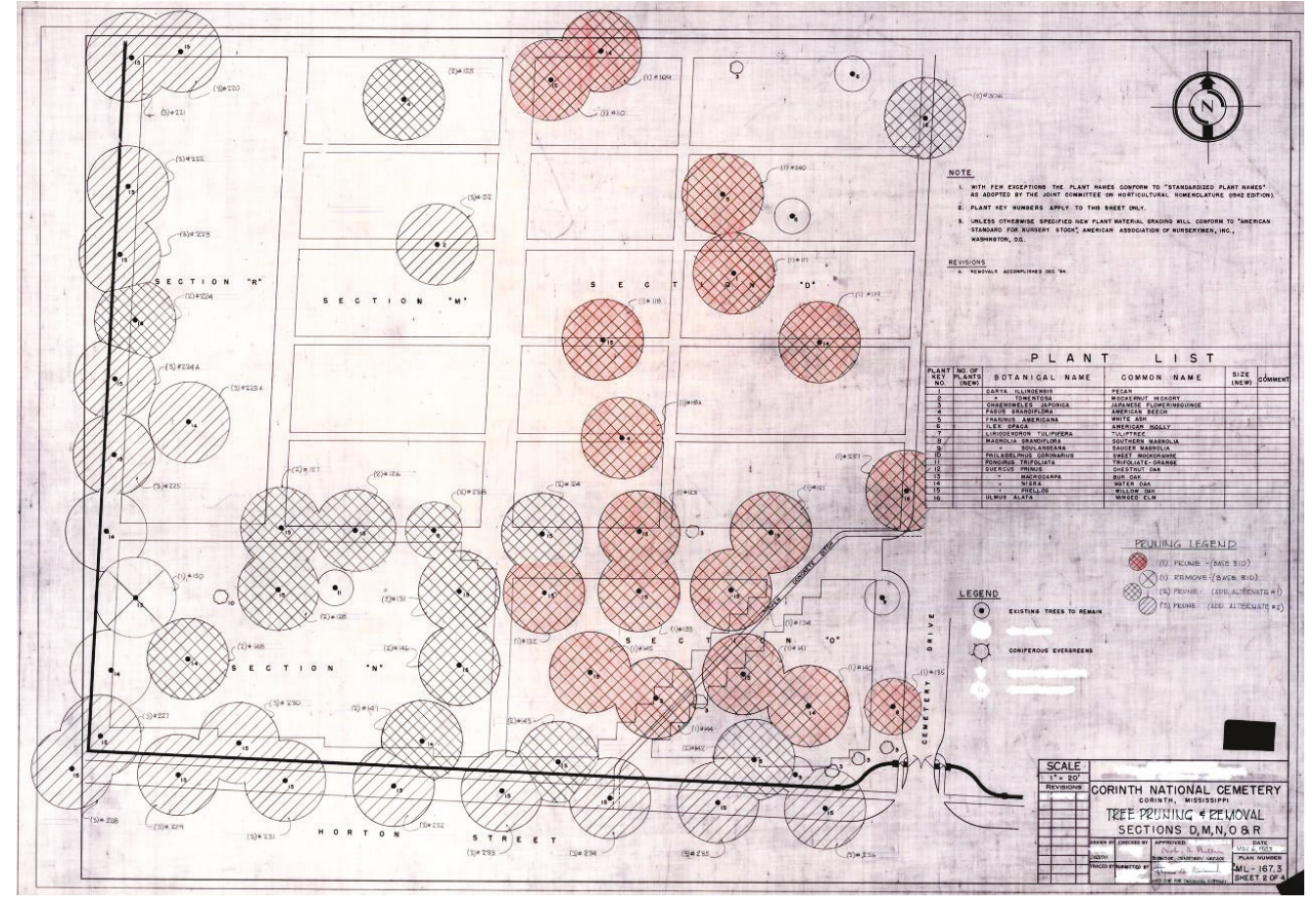




\subsubsection{2000s}

The major change to the southwest quadrant between the 1980s and the 2000 s was the gradual infilling with new graves of previously open space in Section D (Figure 222). Overall, the vegetation density decreased due to the removal of some trees in the southwest corner and the removal of shrubs around the main entrance.

Figure 222. 2009 burial plan of the southwest quadrant (Veteran's Administration).

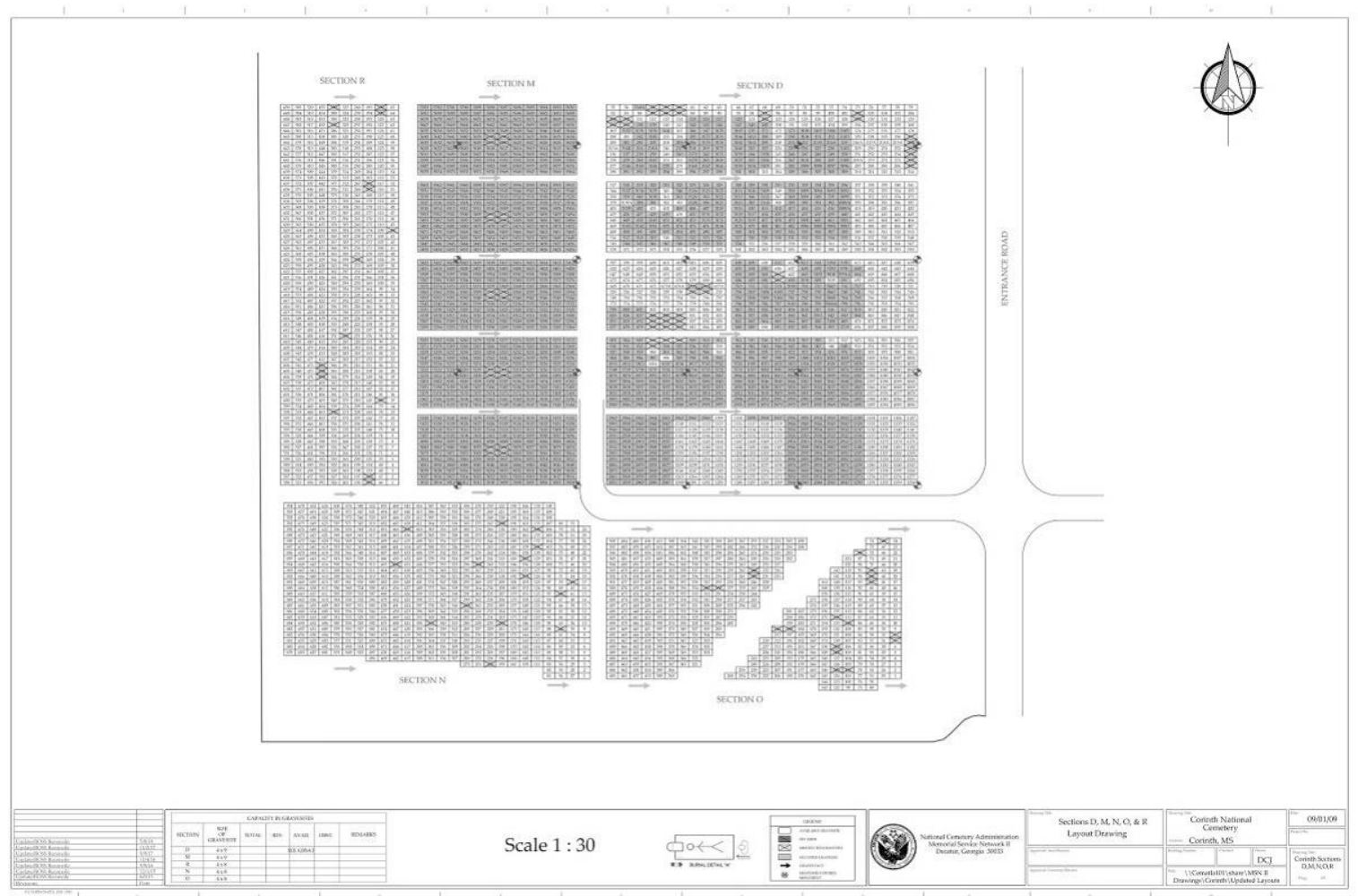

\subsubsection{Burial register summary}

The 2018 burial register lists 892 burials in Section D, and 700 burials in Section M. There are no burials in Section N, O, or R.

Of the 892 burials in Section D, there are 253 Unknown Soldier burials. 107 burials are from the 1860s, 1 burial from the 1900s, 3 from the 1910 , 6 from the 1940s, 2 from the 1950s, 3 from the 1960s, 1 from the 1970s, 221 from the 1980s, 74 in the 1990s, 124 in the 2000s, and 93 in the 2010s. There are 4 known burials without either a death or interment date listed. 
All of the 700 burials in Section M are for Unknown Soldiers and feature the cubed headstone.

\subsubsection{Northwest quadrant}

\subsubsection{Preliminary plan (undated)}

The northwest quadrant layout was a close mirror image to that of the northeast quadrant on the undated preliminary design for the cemetery. The northwest quadrant had burial Sections B, G, H, and K which were buffered from the perimeter wall by wide grassed areas. The undulating perimeter path wound through those grassed spaces. The burial groupings in Section B were the same as Sections A, C, and D and had a central circular path with wedge shaped groupings. That central geometry was labeled Ohio. Surrounding the central circular shape were rectangular burial groupings. One grouping in the northwest corner of Section B was labeled Missouri. Section $\mathrm{G}$ had two, roughly rectangular, burial groupings that were separated by an aisle and a central square grassed space. Section $G$ was labeled Miscellaneous. Section $\mathrm{H}$ had one roughly rectangular burial grouping and was labeled Unknown. Section $\mathrm{K}$ had five rectangular burial groupings with central open grassed areas in each. Section K was labeled Unknown. The cemetery's main road exited the north wall and was labeled gateway. Figure 223 shows the layout of this preliminary design. 
Figure 223. The layout of the northwest quadrant on the preliminary plan for the Corinth National Cemetery (NCA archives, Washington, DC).

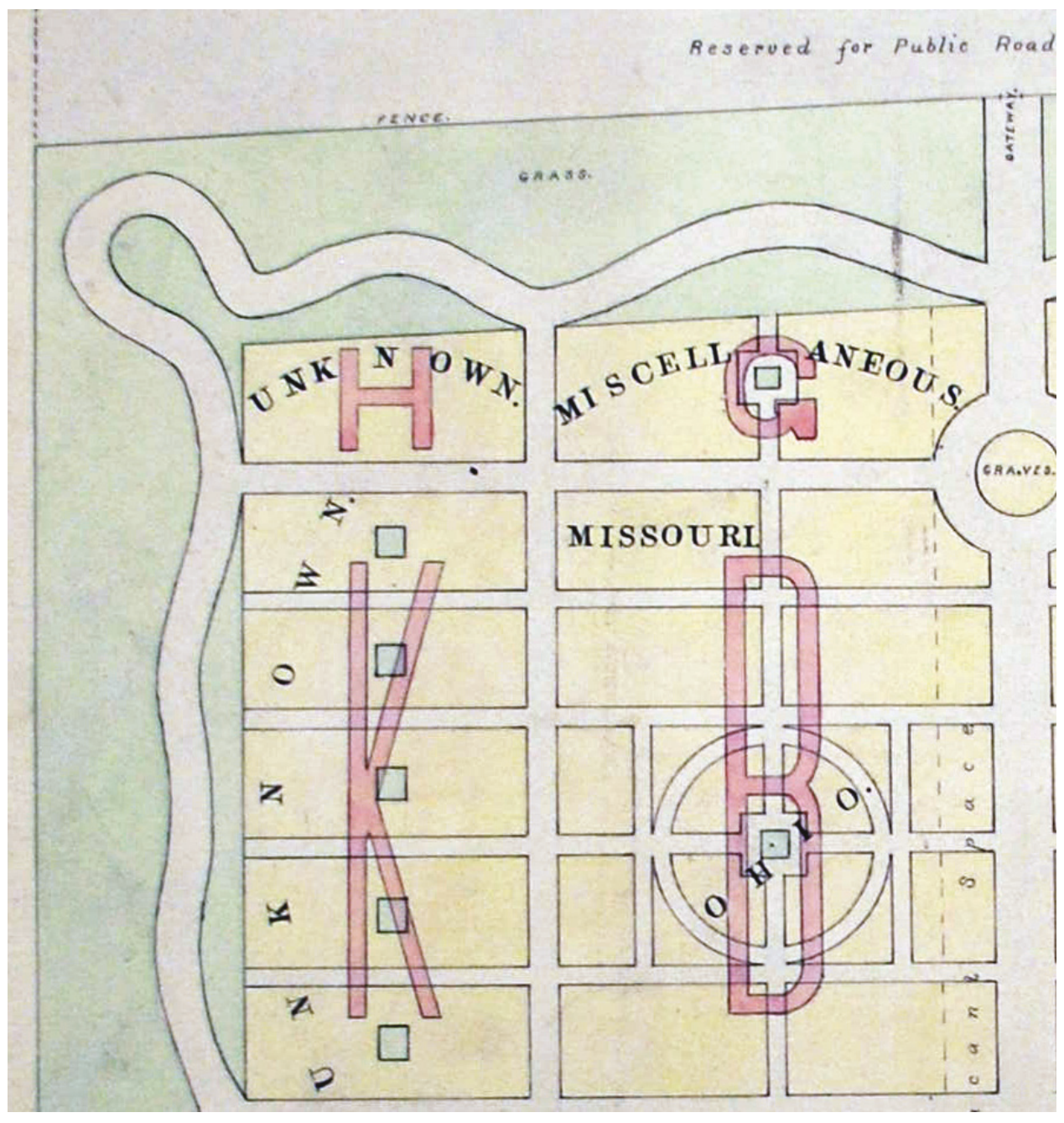

\subsubsection{1982 plan}

The 1892 plan for the cemetery shows the changes between the preliminary design and what was eventually constructed. The layouts for the burial sections closely mirrored those in the northeast quadrant, with a few differences in the geometric burial patterns in Section B. Overall, the quadrant featured an array of vegetation-deciduous and evergreen trees, small ornamental trees, and shrubs arranged throughout the area. The perimeter path was mostly lined by trees, and many of the burial groupings were lined with trees or had trees scattered through them.

Section B was the largest section in this quadrant. It fronted the main gravel road and on the plan, it has four main burial groupings. Two of the burial groupings were filled with regularly spaced headstones in rows that 
run north to south. However, two of the burial groupings featured arrangements of headstones that created fairly distinct patterns. The northernmost burial grouping was composed of two narrow rectangular areas. In those areas, the north-south aligned rows of headstones either spanned the entire area or had headstones removed from the sequence to create open spaces within the overall grouping. The burial grouping in the middle of Section B featured the most distinct headstone patterns. Moving east to west from the main road through the group, there were three main clusters of headstone geometries. The one closest to the road featured graves arranged to form two rectangles with large, open, interior spaces. The next cluster of graves were arranged to form a circular grouping with wide central aisles, and then the groupings farthest from the road were two rectangles that were defined by rows of graves with open interiors. Section B also had a gun monument.

Section $\mathrm{G}$ had two rectangular burial groupings, and both were filled with rows of graves running north to south. A grass drive separated Section $G$ from Sections B and H. To the north of Section $\mathrm{G}$ was its section marker and the undulating perimeter grass drive.

Section $\mathrm{H}$ had one rectangular burial grouping filled with rows of graves running north to south.

Section K had five rectangular burial groupings filled with rows of graves running north to south. In four of those groupings, a tree was planted in the middle. In the fifth grouping, where there should be a tree, there instead was an open space in which there were no burials.

Figure 224 shows the layout of the northwest quadrant on the 1892 plan of Corinth National Cemetery. 
Figure 224. Plan of the northwest quadrant of Corinth National Cemetery, 1892 (NCA archives, Washington, DC).

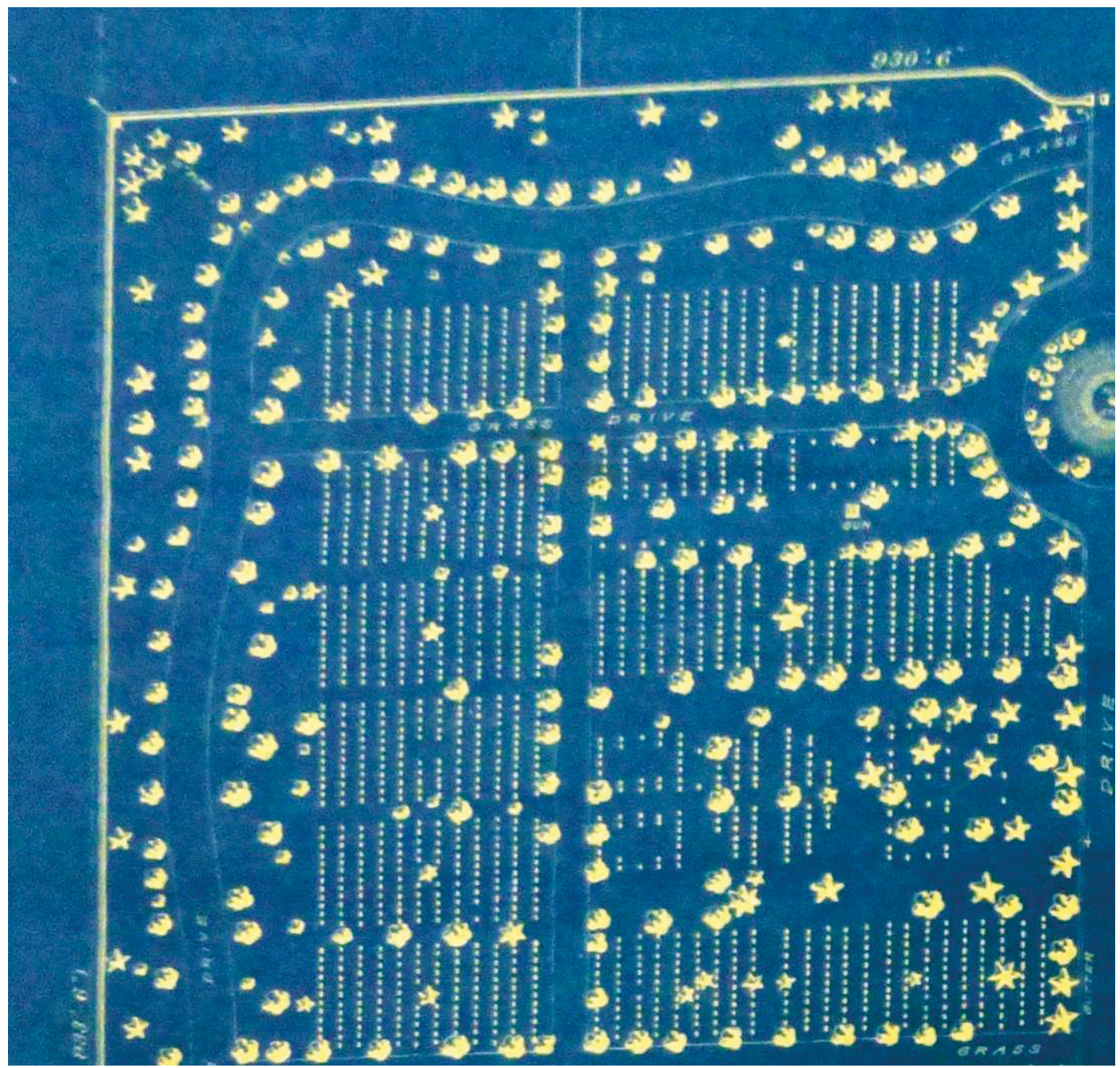

There was drainage infrastructure shown in the northwest corner of the site where water drains off the site. Along the gravel drive, brick gutters diverted water around the flagstaff mound (Figure 225). On this plan, the north entrance was the same layout as the south entrance and featured two columns, which were to create a wide main entrance flanked by two smaller openings. However, Figure 226 and Figure 227 show that the north gate's layout as built differed from the plan, with the main portion of the north entrance flanked by only one smaller opening. 
Figure 225. North entrance shown on the 1892 plan for Corinth National Cemetery (NCA archives, Washington, DC).

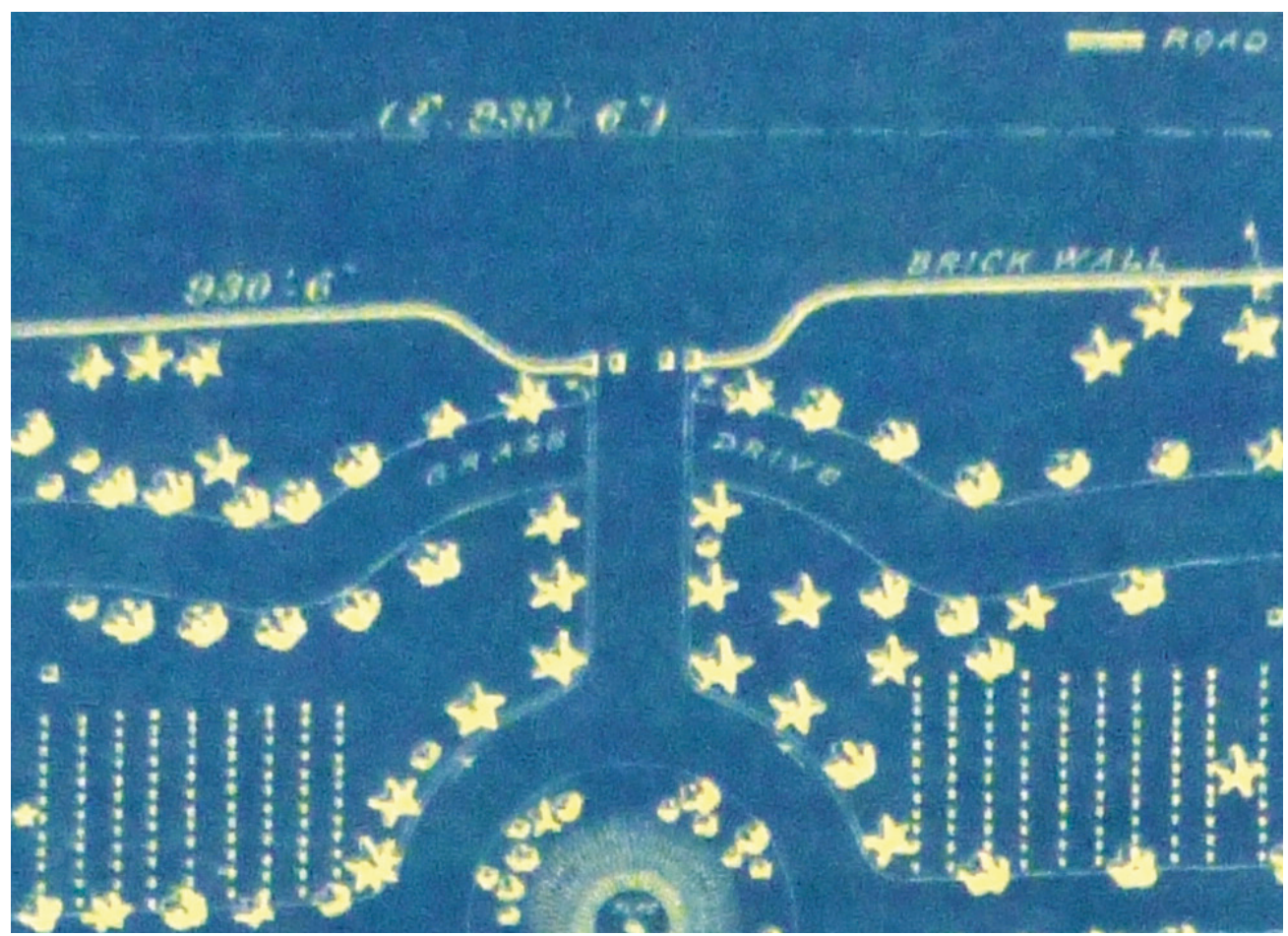

Figure 226. The layout of the north entrance gate at Corinth National Cemetery, as it appeared in 1892 (NARA, College Park, MD).

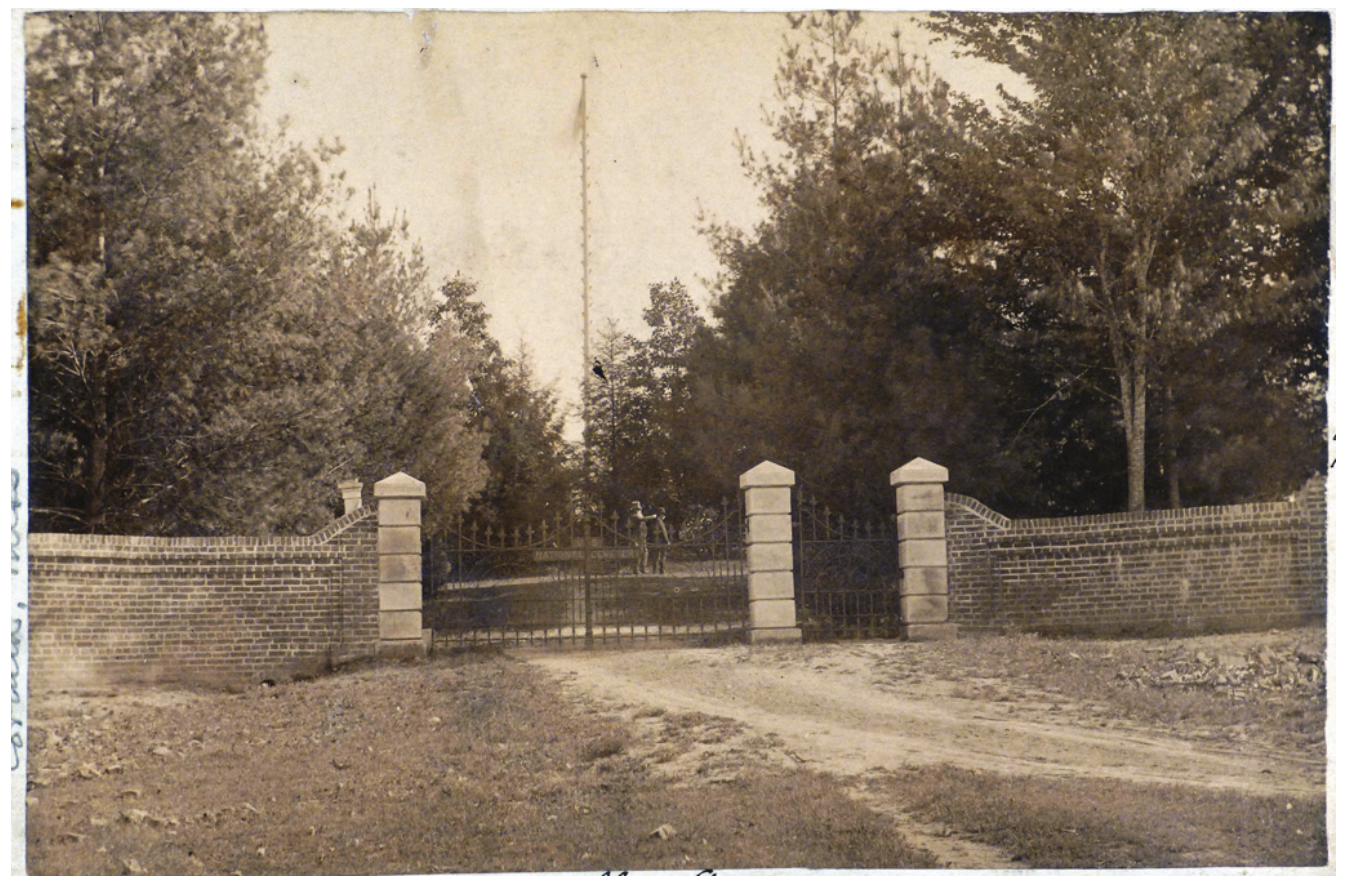


Figure 227. View of the north entrance at Corinth National Cemetery, unknown date (NARA, College Park, MD).

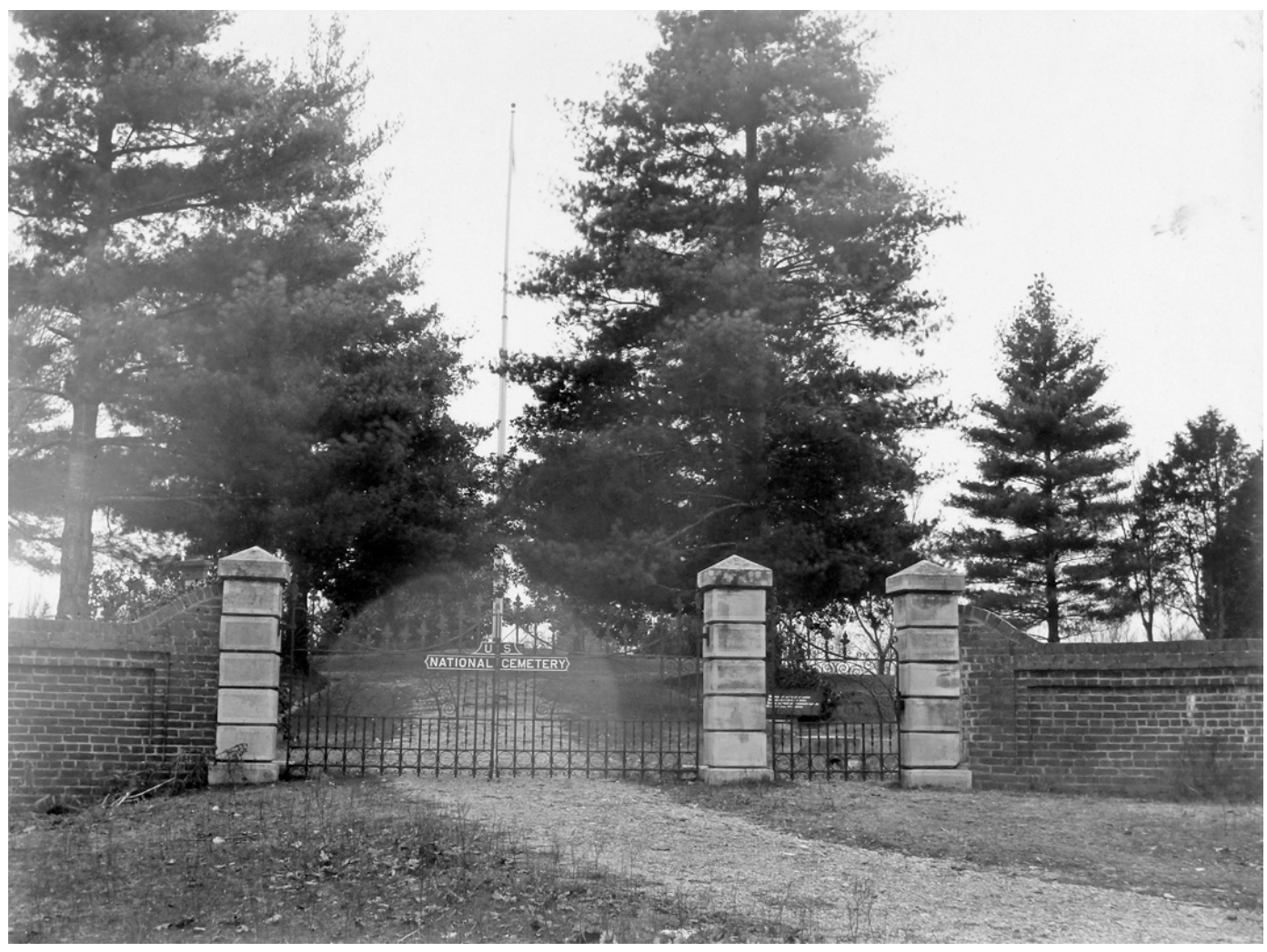

\subsubsection{1954 plan}

There were several significant changes made to the northwest quadrant between 1892 and 1954. Between 1892 and 1953, the headstones were reversed from facing west to facing east (an 1892 photo shows the headstones facing west while the 1954 plan shows them facing east). The date for this could not be determined due to the lack of archival material from this period (1909 is the most likely date due to the destructive impact of a storm that year). ${ }^{146}$ In addition, there was the removal of the grassed perimeter drive and the incorporation of two new sections where the perimeter drive was formerly (Sections $\mathrm{S}$ and $\mathrm{T}$ ). Another major change was made to Section B, where the open space surrounding the geometric headstone patterns was being filled in with newer burials. Figure 228 shows those changes.

\footnotetext{
146 The change in the direction that grave markers faced was noticed by ERDC-CERL researchers when studying historical photos onsite at Corinth National Cemetery, but no archival documentation was ever located regarding this change.
} 
In addition, photographs from the 1950 os showed the cemetery with little established vegetation, which was a significant change from photographs taken in the 1940s (Figure 229, Figure 230, and Figure 231).

Figure 228. 1954 burial plan for the northwest quadrant (NCA archives, Washington, DC).

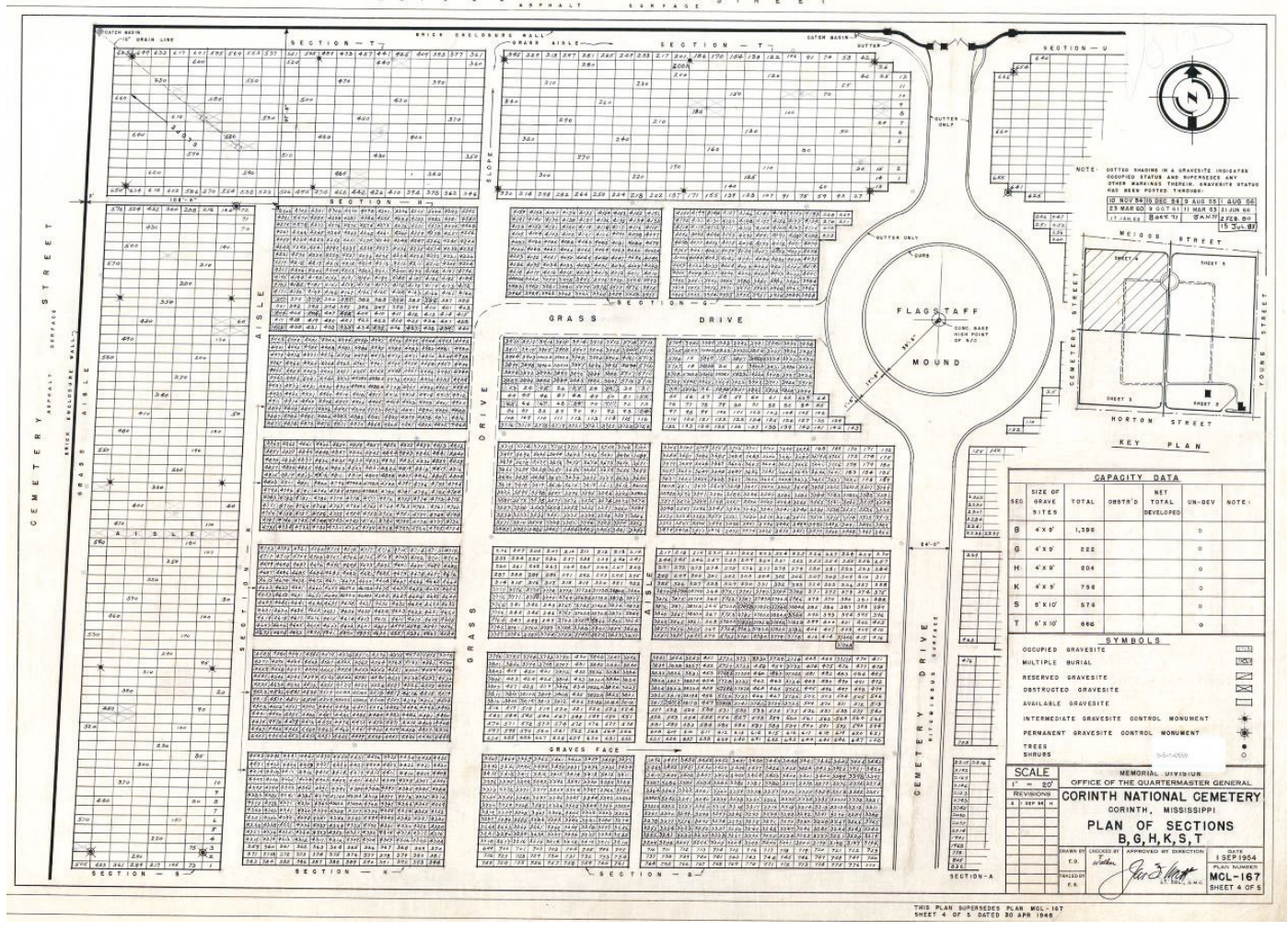


Figure 229. View northwest from the flagstaff mound in April 1954 (NCA archives, Washington, DC).

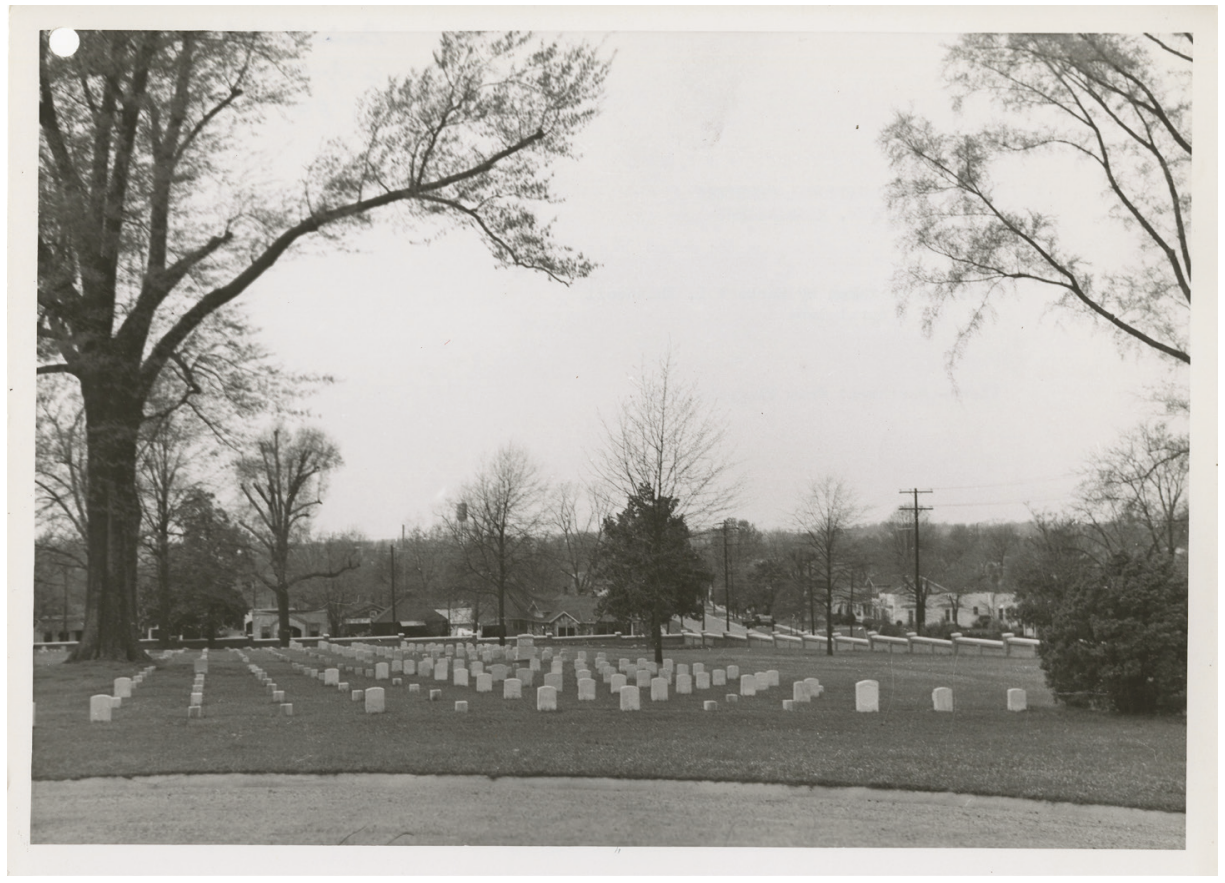

Figure 230. View west showing the north perimeter wall in April 1954 (NCA archives, Washington, DC).

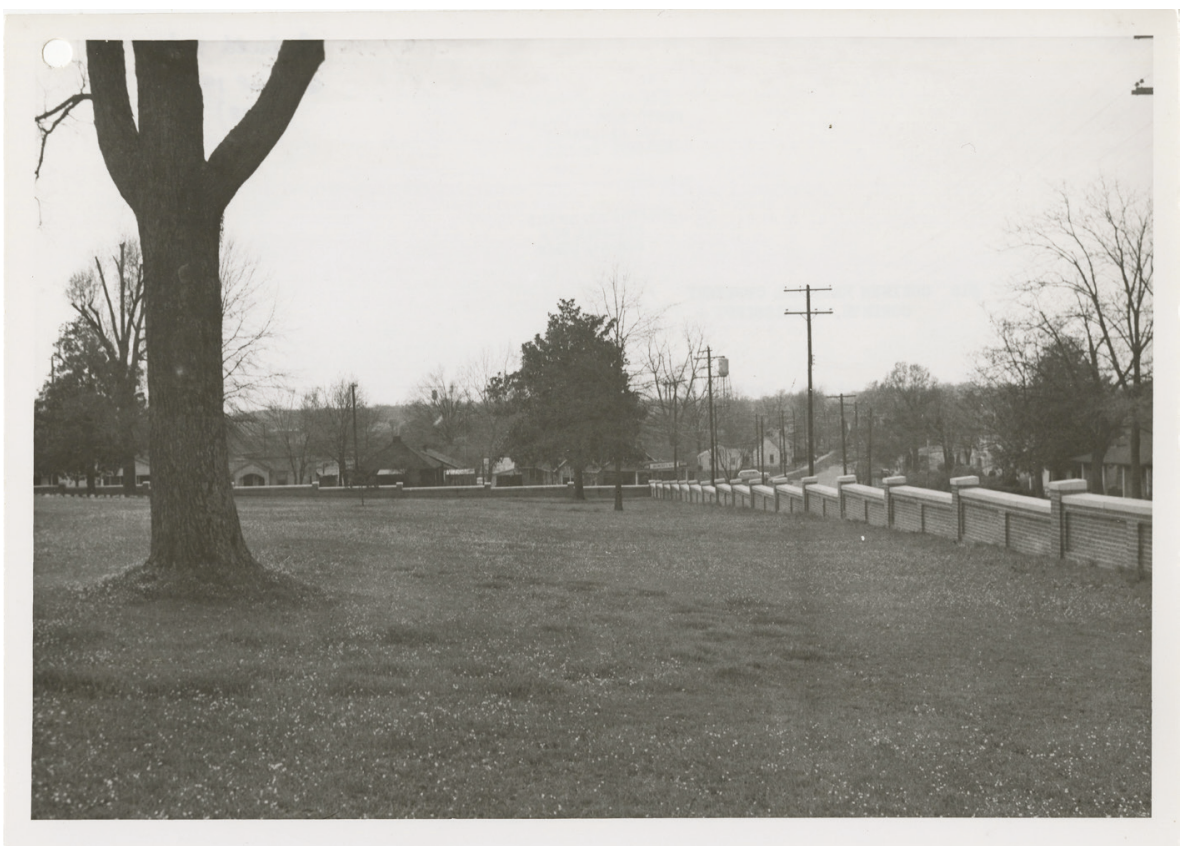


Figure 231. View of the northwest corner in April 1954 (NCA archives, Washington, DC).

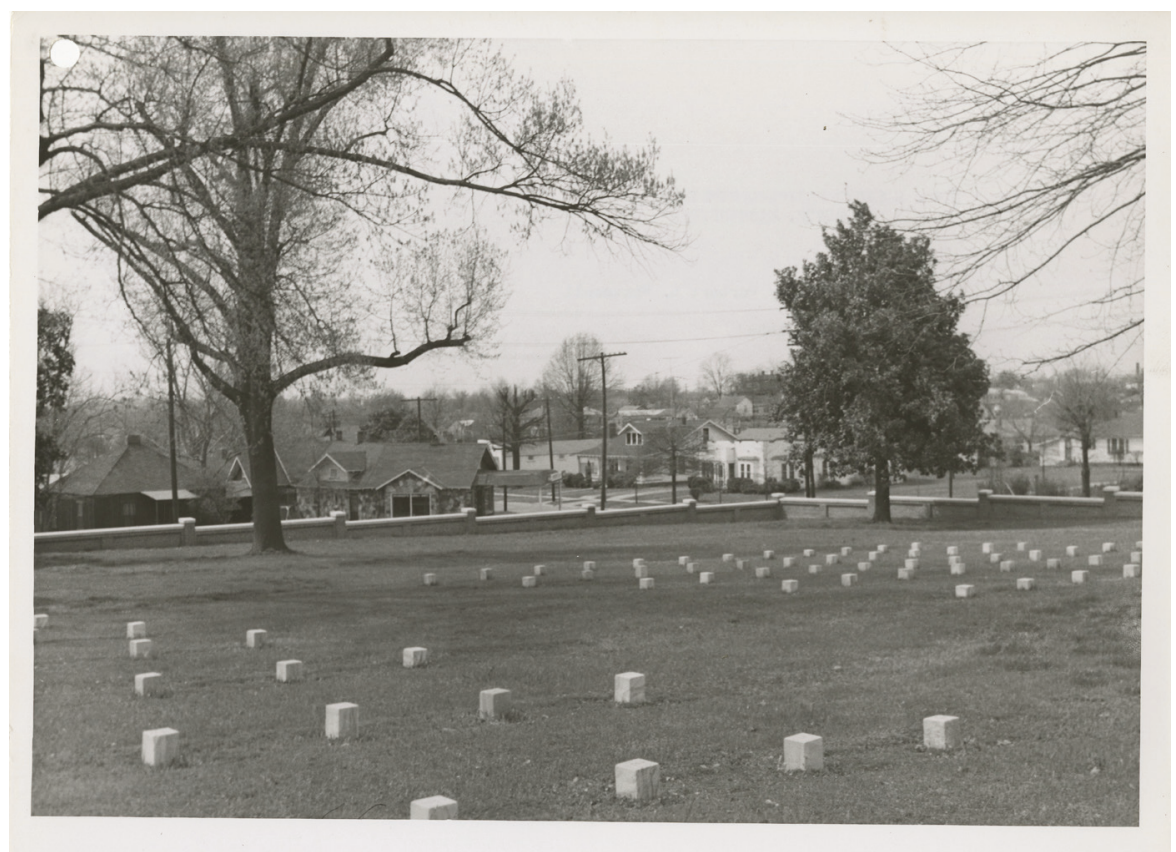

\subsubsection{1964 plan}

Between 1954 and 1964, there were several changes to the northwest quadrant. The most significant change was the addition of new graves to the open spaces in Section B. Deciduous trees lined the inner perimeter wall, but many trees were gone that had been shown arrayed throughout the burial sections in 1892 (Figure 232). The plan showed dogwoods lining the main road. Figure 233 shows a view west through Section B in 1964.

In 1964, Section B was planted with the following trees and shrubs: 4 Pecan (Carya illinoensis), 7 Flowering Dogwood (Cornus florida), 2 Water Oak (Quercus nigra), and 5 Willow Oak (Quercus phellos).

In 1964, Section $\mathrm{G}$ was planted with the following trees and shrubs: 1 Common Box (Buxus sempervirens), and 1 Water Oak (Quercus nigra).

In 1964, Section H was planted with 1 Southern Red Oak (Quercus falcata).

In 1964, Section K was planted with 2 Willow Oak (Quercus phellos).

In 1964, Section $S$ was planted with the following trees and shrubs: 3 American Holly (Ilex opaca), 5 Water Oak (Quercus nigra), 4 Willow Oak 
(Quercus phellos), 1 Swamp Chestnut Oak (Quercus prinus), and 1 White Oak (Quercus alba).

In 1964, Section T was planted with the following trees and shrubs: 2 Red Flowering Dogwood (Cornus florida), 1 American Holly (Ilex opaca), 2 Southern Magnolia (Magnolia grandiflora), 2 Southern Red Oak (Quercus falcata), 2 Water Oak (Quercus nigra), 2 Willow Oak (Quercus phellos), and 1 American Elm (Ulmus americana).

Figure 232. The vegetation plan in 1964 (NCA archives, Washington, DC).

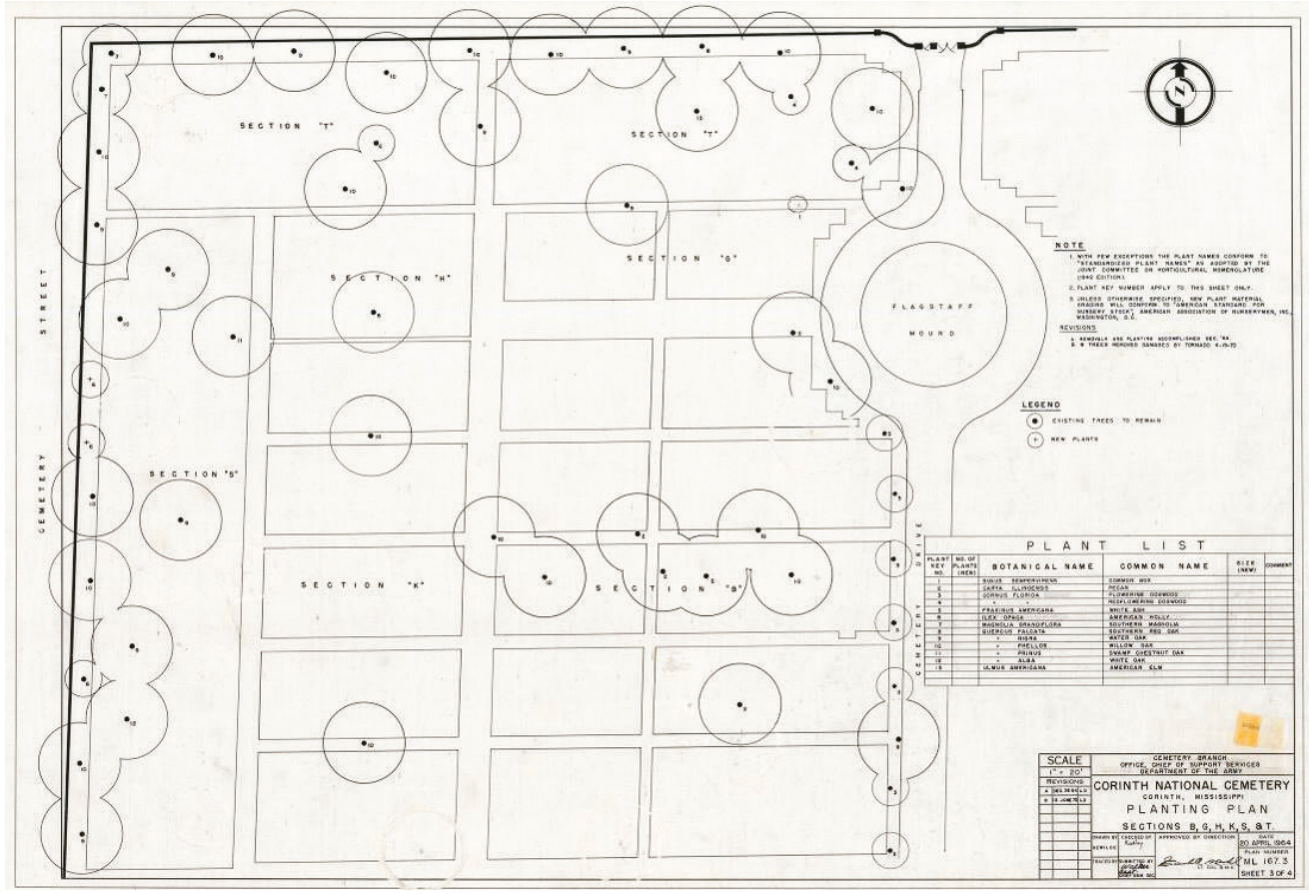


Figure 233. Elm tree in Section B looking west in May 1964 (NCA archives, Washington, DC).

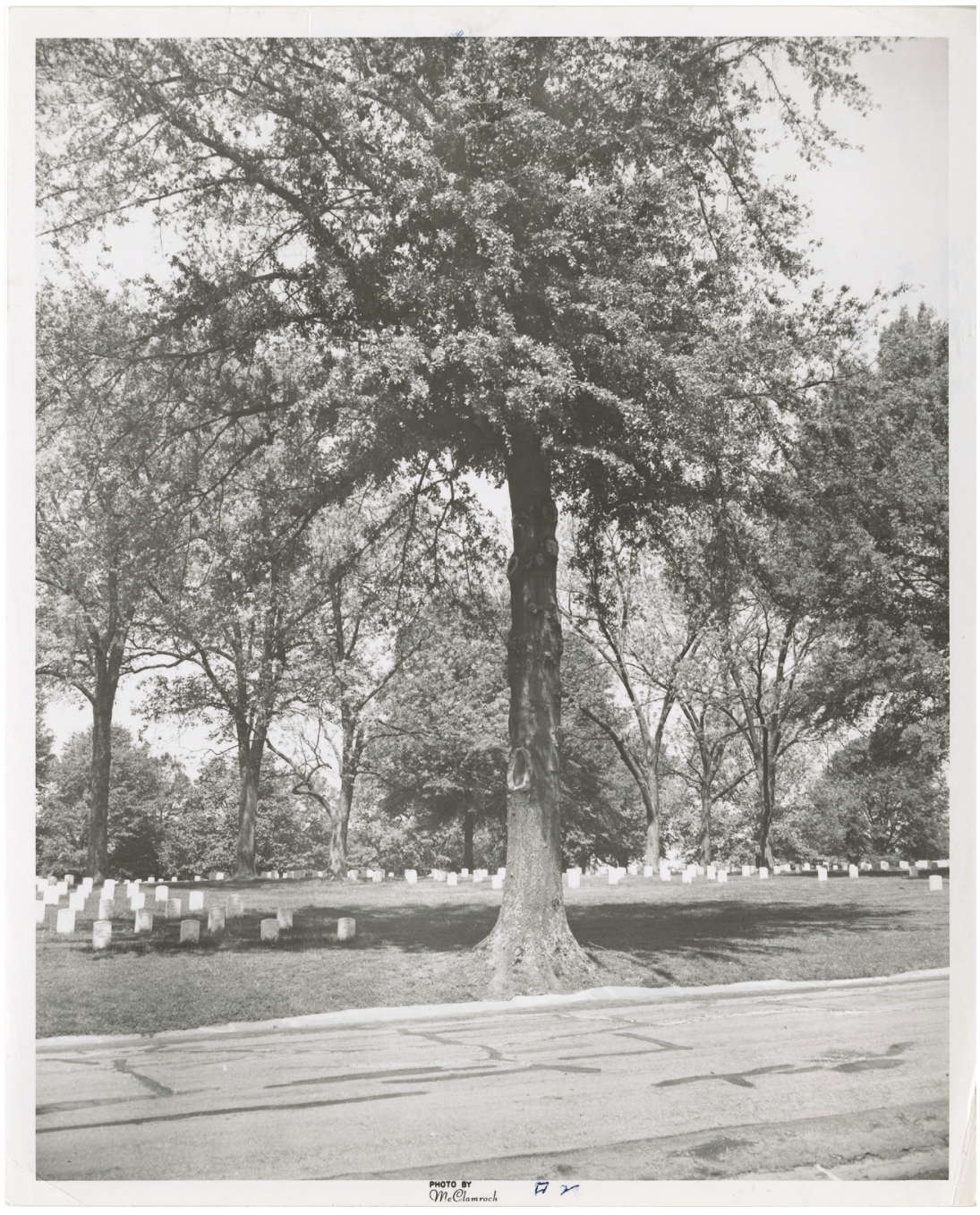

\subsubsection{1983 plans}

There were only a few changes to the northwest quadrant between the 1960 s and the 1980s. Mainly, Section B's open space continued to be filled with new graves. The vegetation density and arrangement remained fairly static (Figure 234 and Figure 235). 
Figure 234. Burial plan of the northwest quadrant in 1983

(NCA archives, Washington, DC).

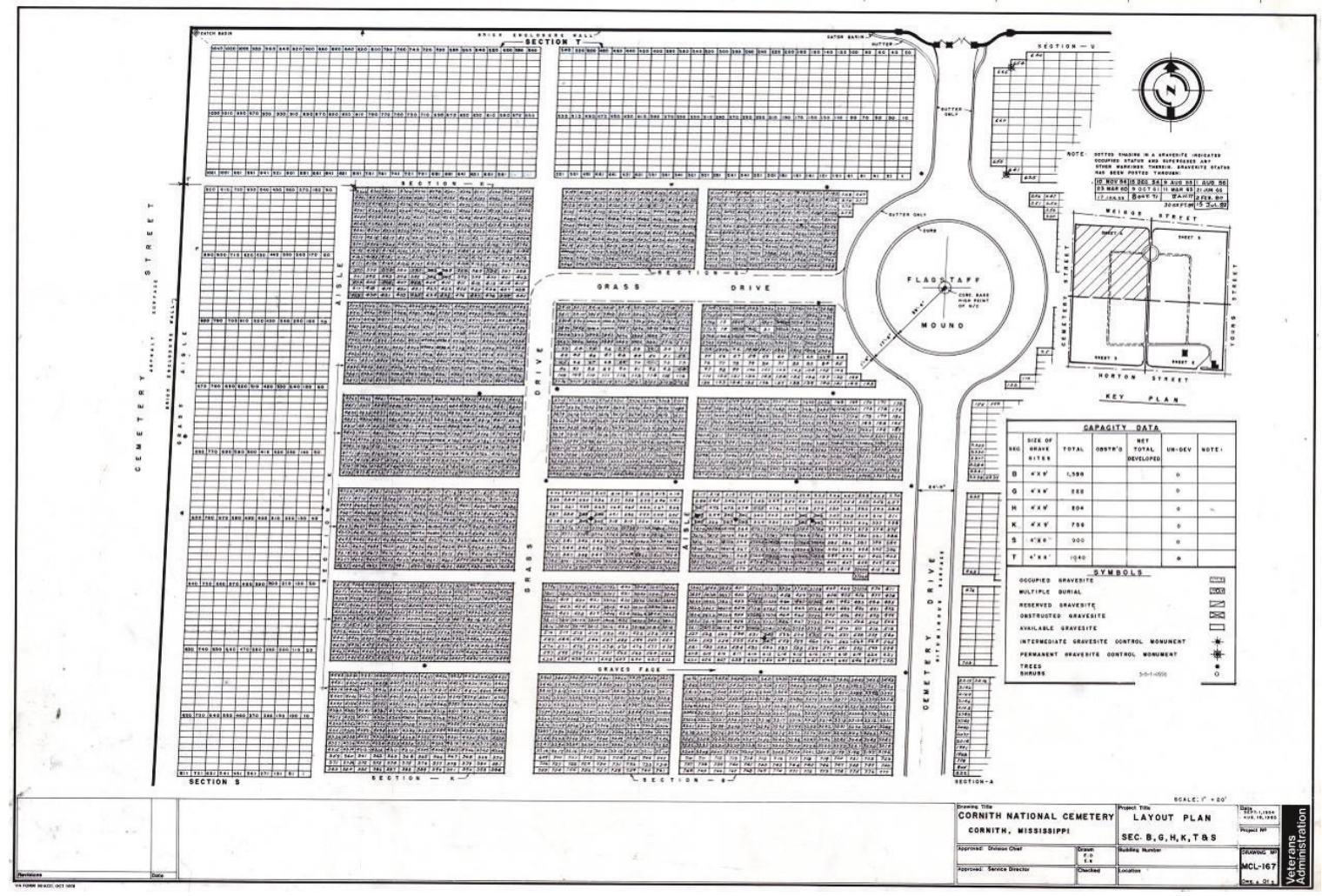


Figure 235. Vegetation plan of the northwest quadrant in 1983 (NCA archives, Washington, DC).

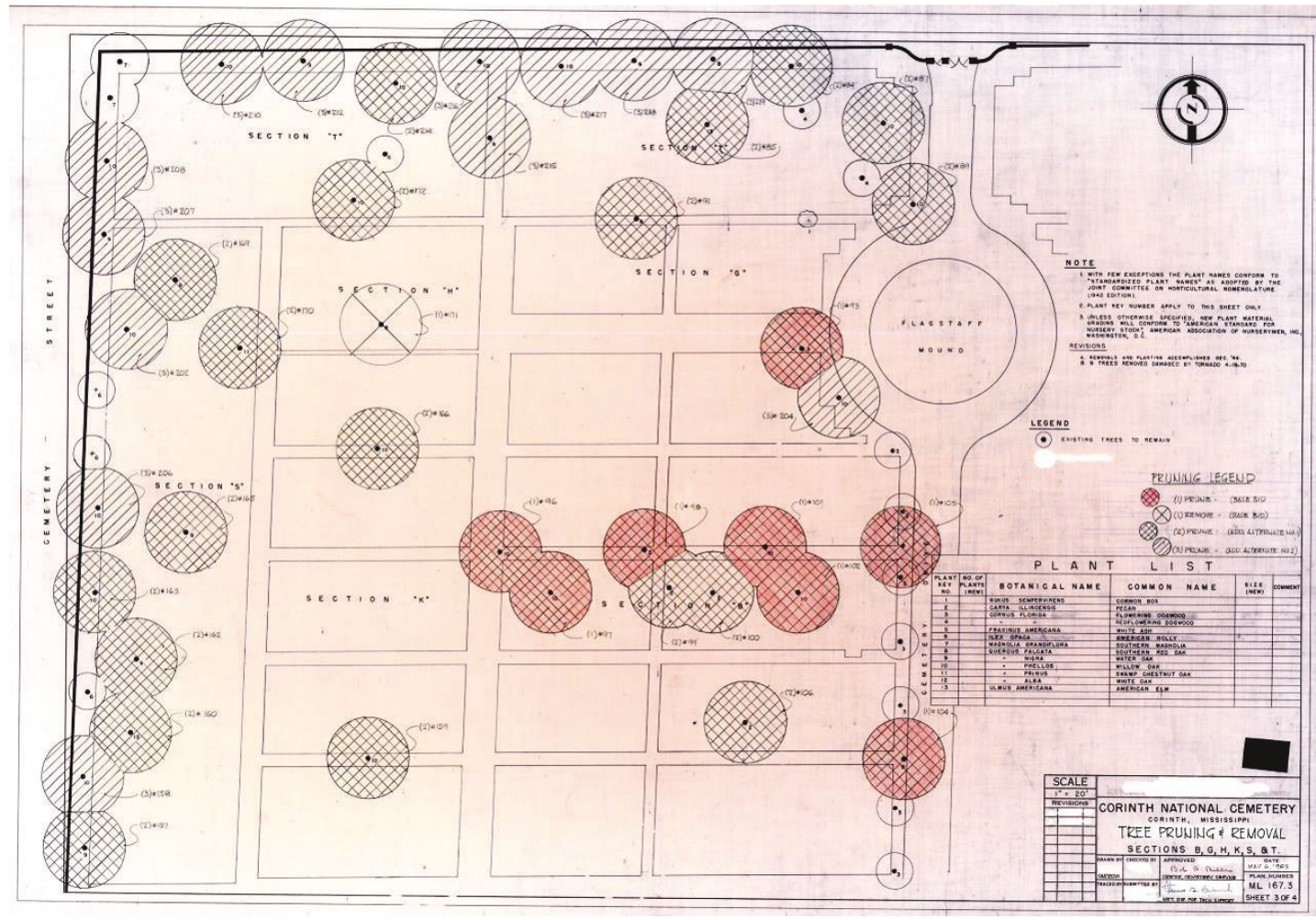

\subsubsection{2000s}

Between the 1980 s and early 2000s, there were few changes to the northwest quadrant. The open spaces in Section B had been filled with new graves (Figure 236). There was an overall decrease in vegetation density. The dogwoods that lined the main road were removed as well as were some dogwoods and holly in Sections $\mathrm{S}$ and $\mathrm{T}$. 
Figure 236. 2009 burial plan for the northwest quadrant (Veteran's Administration).

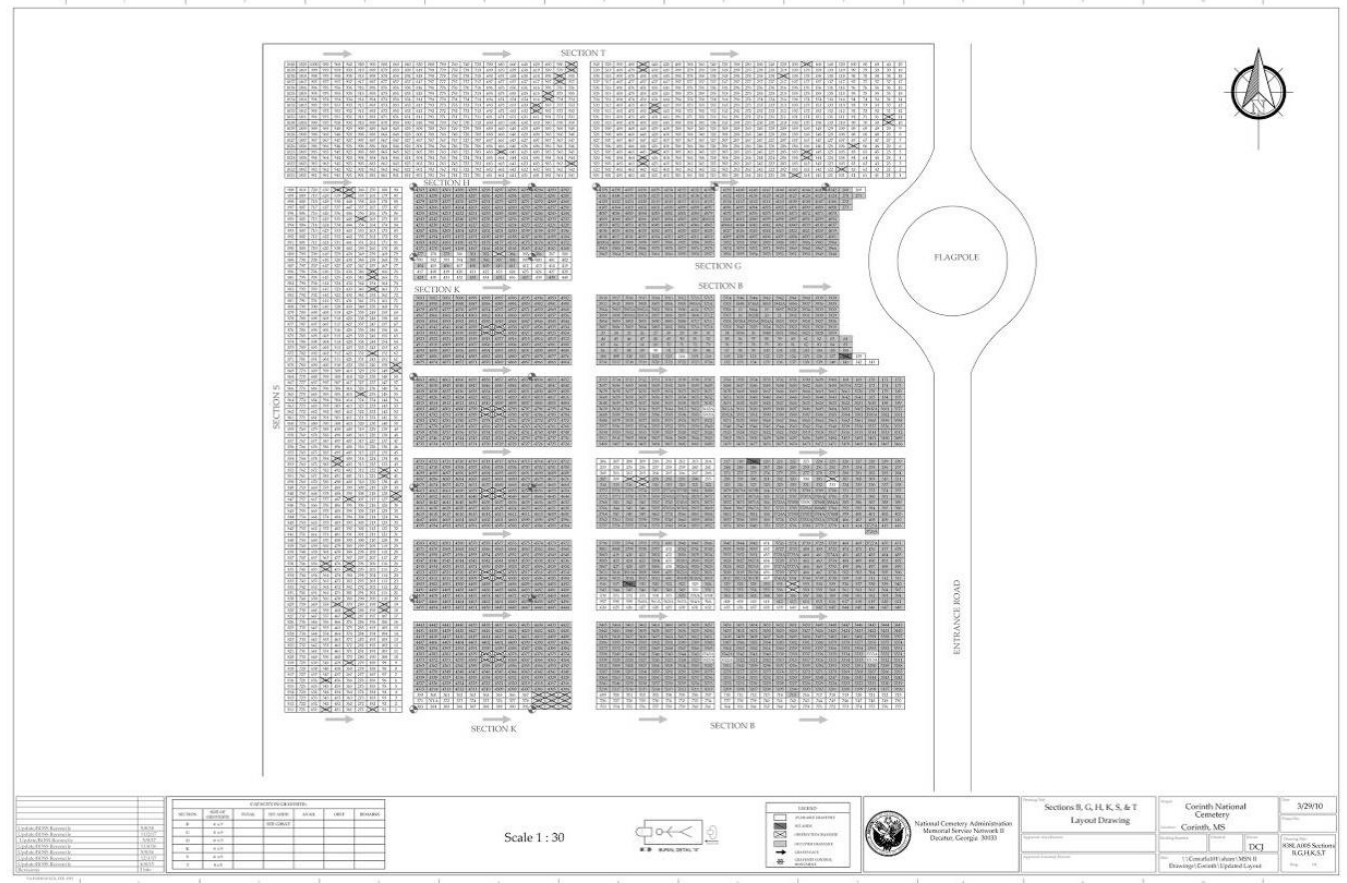

\subsubsection{Burial register summary}

The 2018 burial register lists 1,360 burials in Section B, 222 burials in Section $\mathrm{G}, 169$ burials in Section $\mathrm{H}$, and 700 burials in Section K. There are no burials in Sections $\mathrm{S}$ and $\mathrm{T}$.

Section B has 52 Unknown Soldier burials. There are 589 burials from the 1860 s, 2 from the $1870 \mathrm{os}, 7$ from the 1880 s, 7 from the 1890 s, 1 from the 1910s, 244 from the 1920s, 1 from the 1930s, 15 from the 1940 , 6 from the 1950s, 6 from the 1960s, 17 from the 1970s, 22 from the 1980s, 239 from the 1990 s, 198 from the 2000s, and 80 to date (2018) in the 2010s. There are 170 graves without either death or interment dates.

Section $\mathrm{G}$ has 107 Unknown Soldier burials. Of the remaining burials, 28 are from the 1860 s, 1 is from the 1910 s, and 3 are from the 1990 . There are 190 burials without either death or interment dates.

In Section H, there are 144 Unknown Soldier burials. The remaining 25 burials are from the twentieth and twenty-first centuries, with 12 burials in the 1970s, 1 burial in the 1990s, 5 in the 2000s, and 6 in 2010s. There are 145 burials without either death or interment dates. 
In Section K there are 696 Unknown Soldier burials. There are 4 known burials -3 are from the 1860 s and 1 does not have a date listed for either the death or interment of the soldier.

\subsubsection{Flagstaff mound}

\subsubsection{Preliminary plan}

The flagstaff mound at Corinth National Cemetery is located on the north side of the property. The main drive encircles the mound, and the main flagstaff is placed in the center of that circle. Early design schemes for the cemetery show a main road running north-south and bisected with a circle near the northern edge of the site (Figure 237). That road layout remained throughout the construction of the cemetery, with the use for the interior of the circle changed from graves to become the flagstaff mound.

Figure 237. The undated preliminary design for the roundabout in the main road at Corinth National Cemetery with specified graves for the interior circle (NCA archives, Washington, DC).

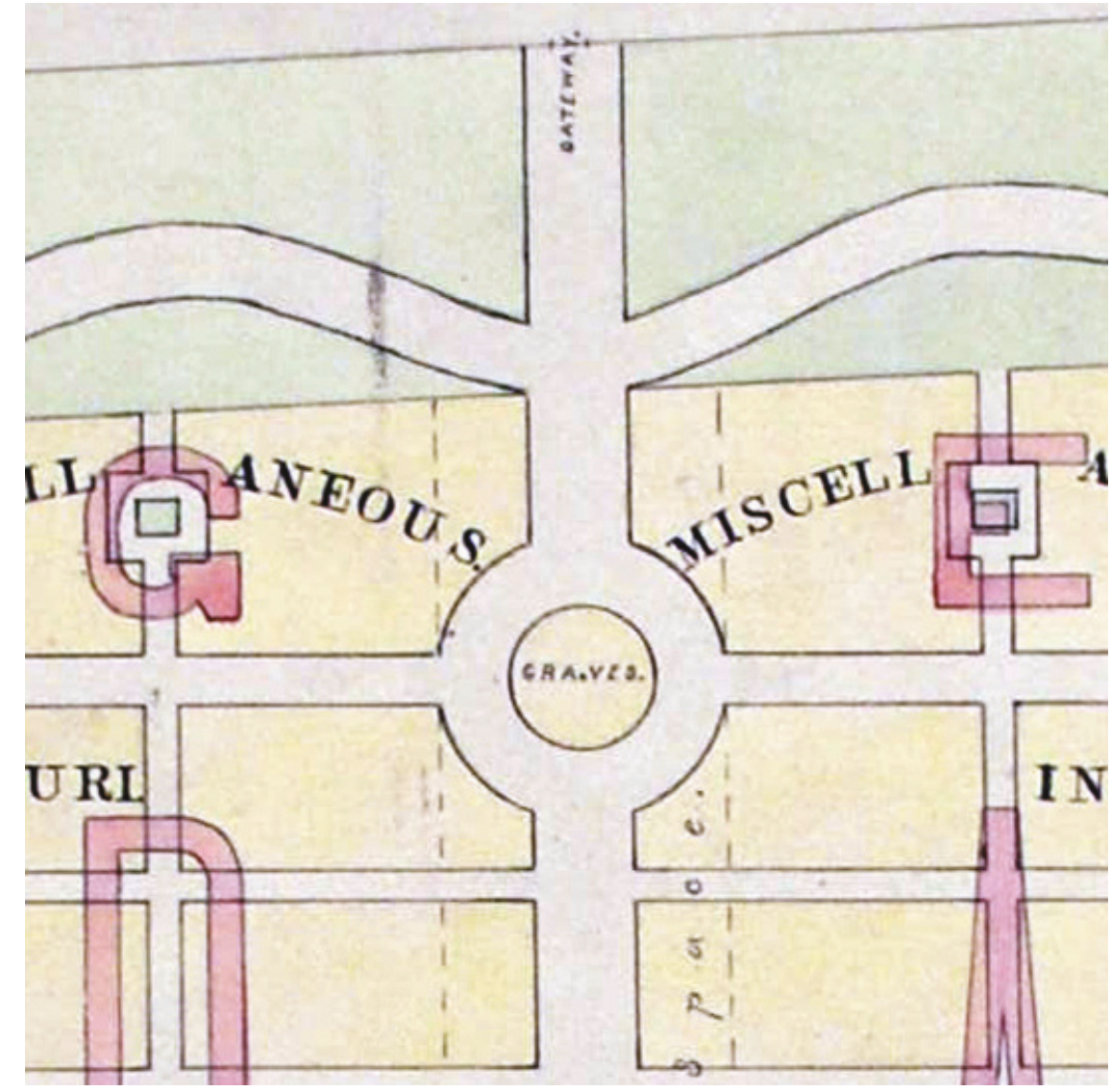




\subsubsection{1892 plan}

The early designs for the cemetery lack proposed vegetation but on the 1892 plan, vegetation around the flagstaff mound is documented. According to the plan's legend, the plants around the inner circle are a mix of evergreen and deciduous and because they are drawn smaller than the surrounding vegetation, it can be assumed they are shrubs. Across the road, the outer circle is lined with evergreen and deciduous trees. The main road in that plan is specified as gravel with brick gutters on either side. Water drained around the flagstaff mound to the north and south. To the east and west of the flagstaff mound are grass drives (Figure 238).

Figure 238. Plan of the flagstaff mound on the 1892 cemetery plan (NCA archives, Washington, DC).

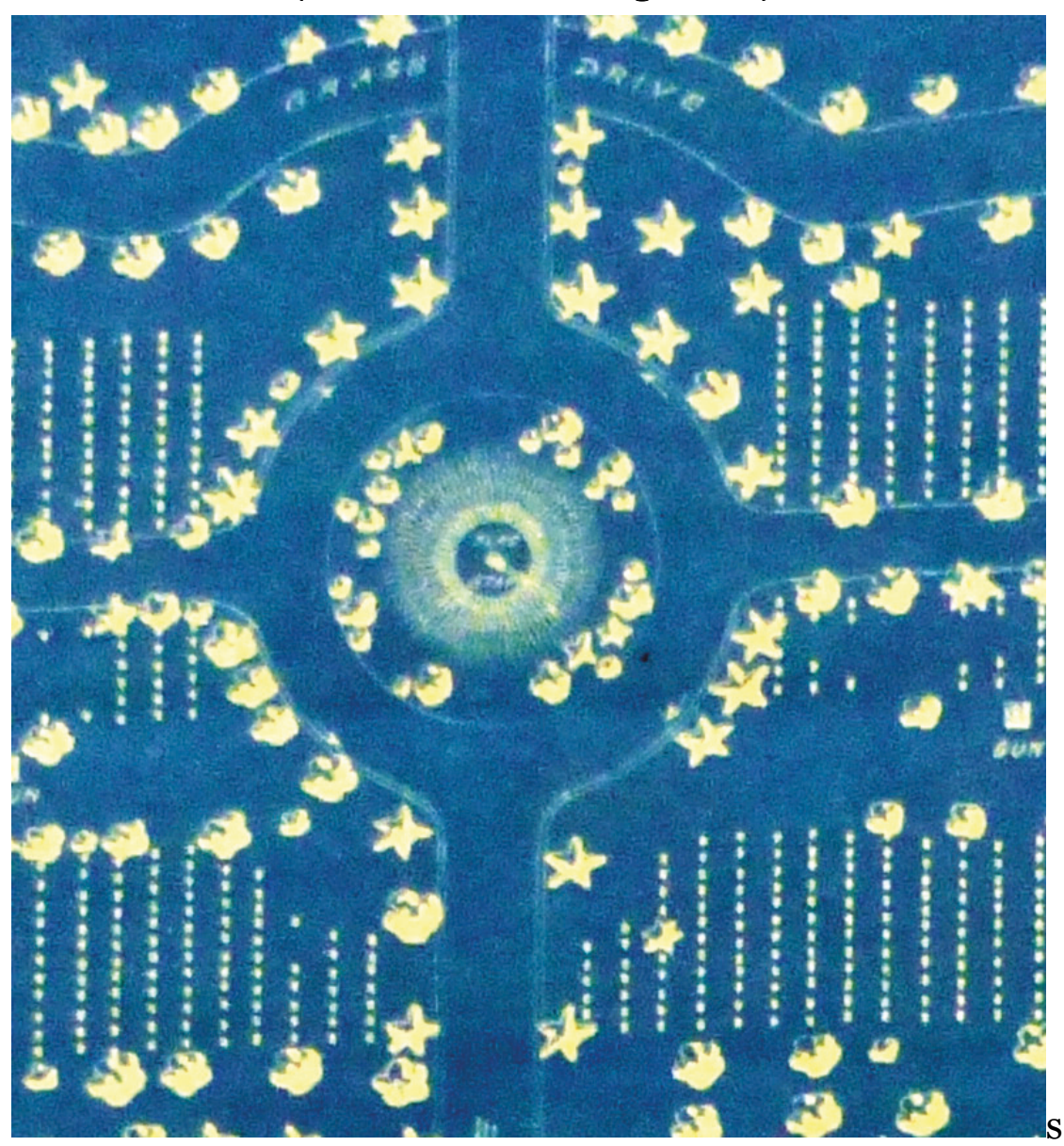




\subsubsection{1940s through 1970s}

In late December 1947, a new 75-foot flagpole was erected. By 1954, all vegetation around the flagpole had been removed (Figure 239). ${ }^{147}$

Figure 239. Flagstaff mound in 1954 (NCA archives, Washington, DC).

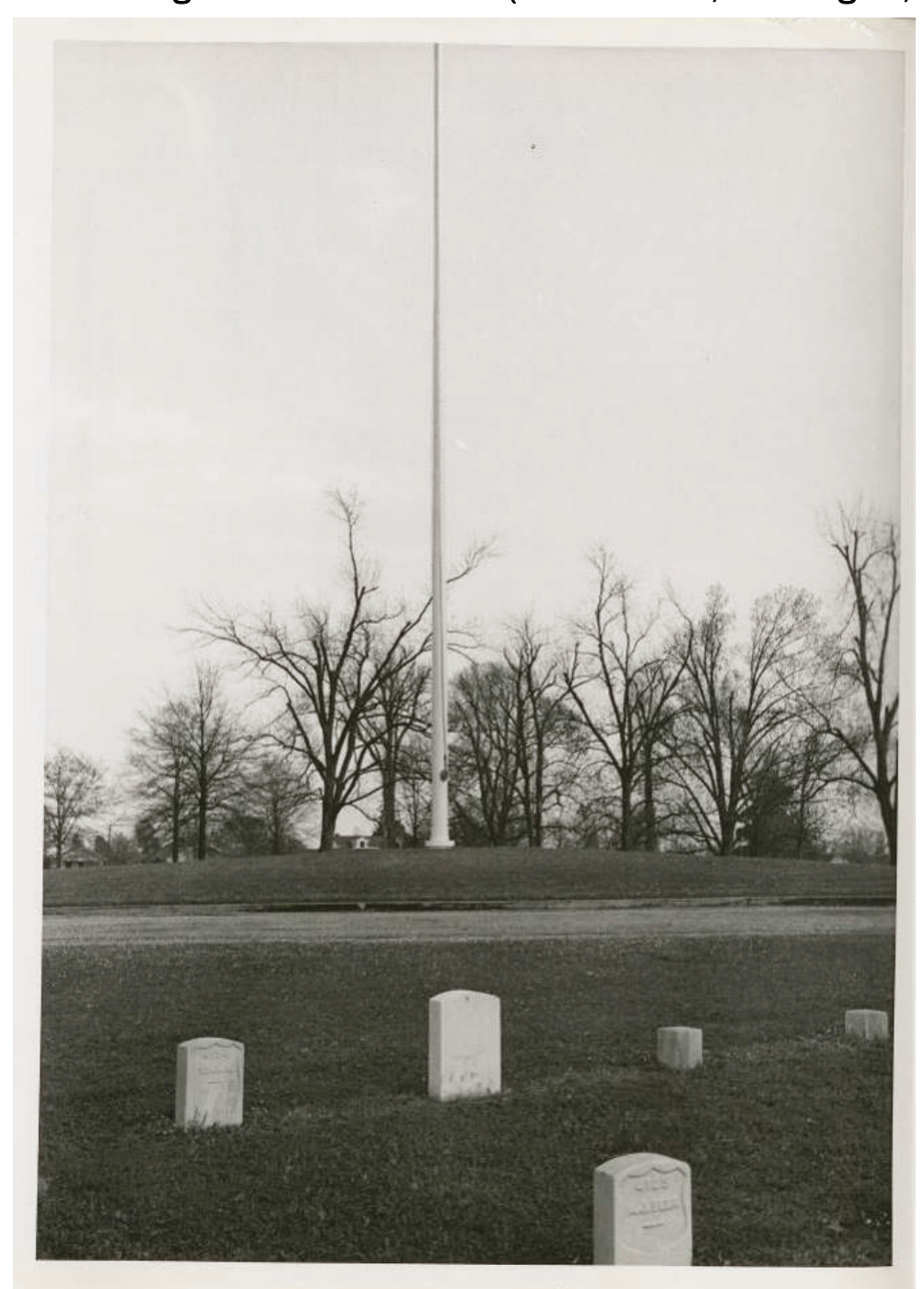

By the early 1950 s, the main road was paved with bituminous pavement and had concrete gutters running along it. The vegetation was never replanted around the mound. Figure 240-Figure 244 show that no further changes were made to the flagstaff mound and the surrounding area from the 1950 s through the early 1970 .

147 Corinth National Cemetery property card NARA CORI RG15 A1, Entry 25. 
Figure 240. View looking north toward the flagstaff mound in April 1954

(NCA archives, Washington, DC).

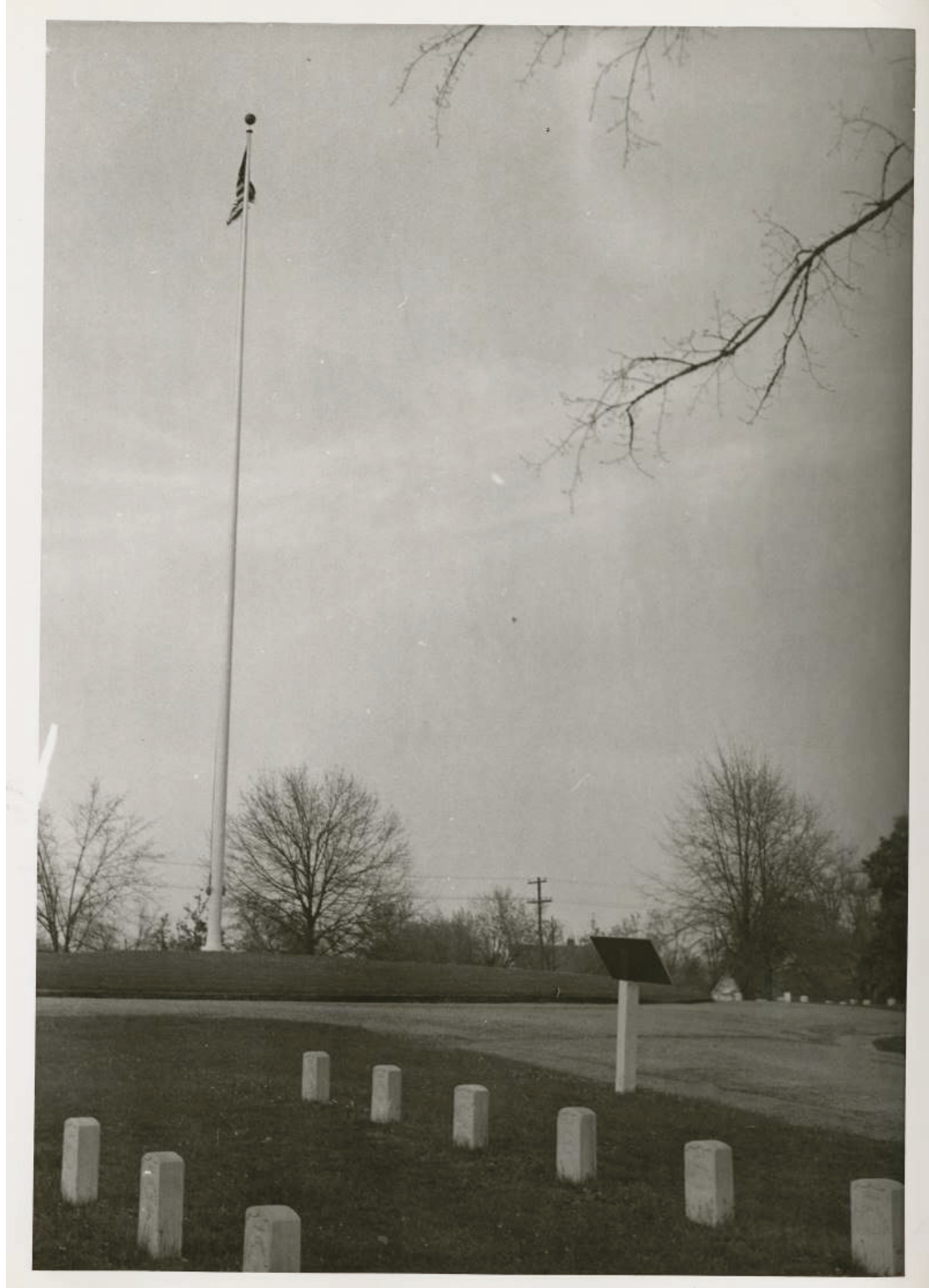


Figure 241. View looking north of the flagstaff mound from Cemetery Drive, April 1954 (NCA archives, Washington, DC).

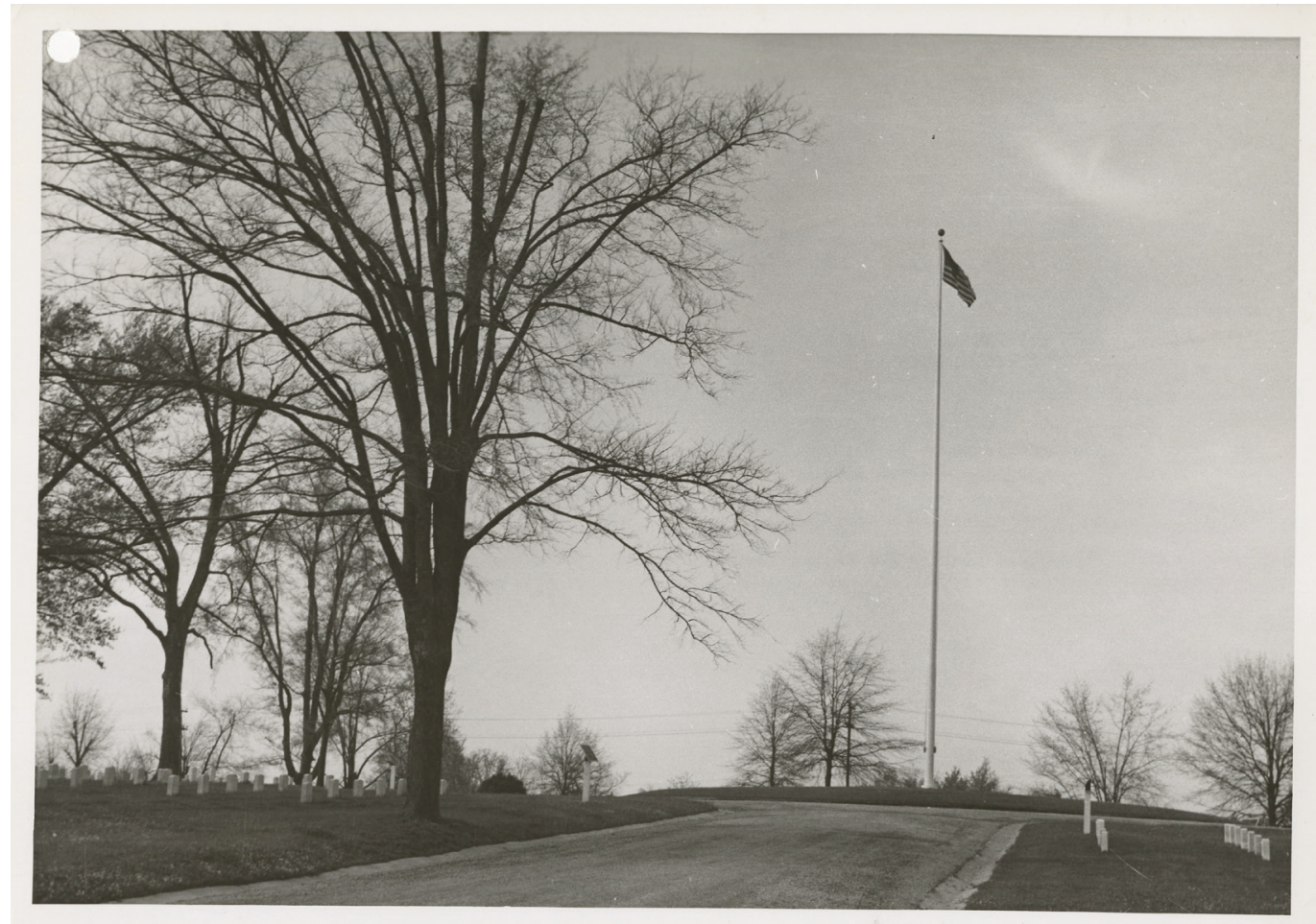

Figure 242. View from the flagstaff mound south to the main entrance in August 1963 (NCA archives, Washington, DC).

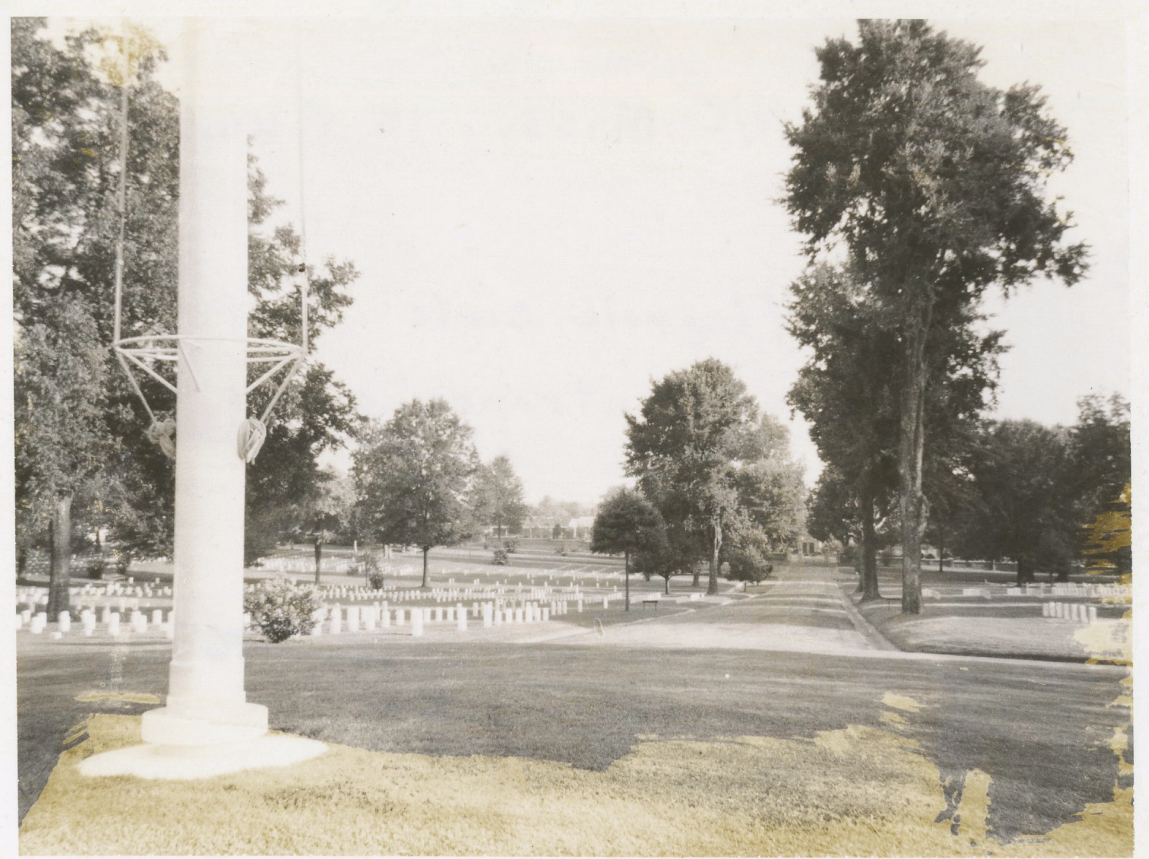


Figure 243. Flagstaff view to the south September 1974 (NCA archives, Washington, DC).

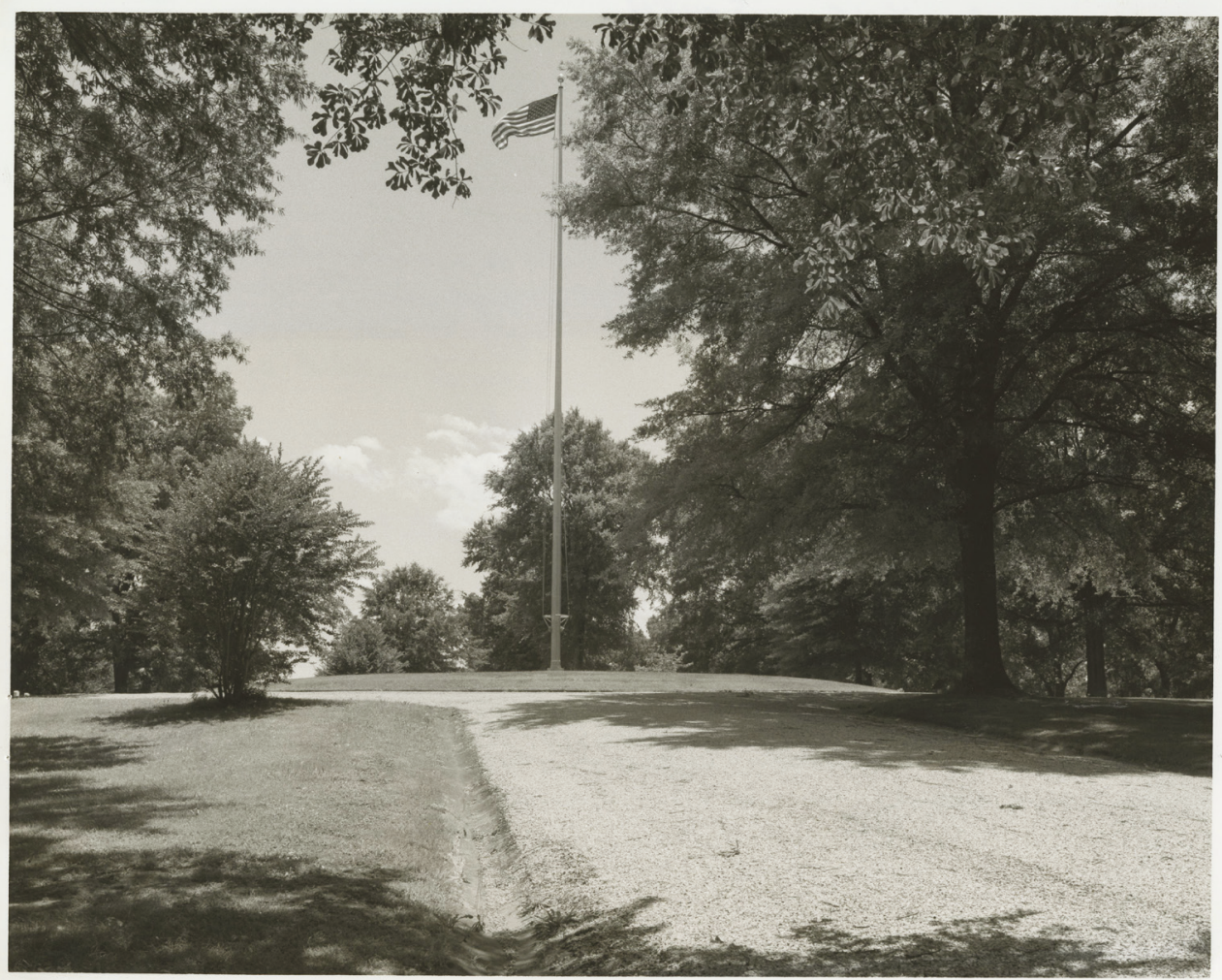


Figure 244. Flagstaff mound view to the north in September 1974 (NCA archives, Washington, DC).

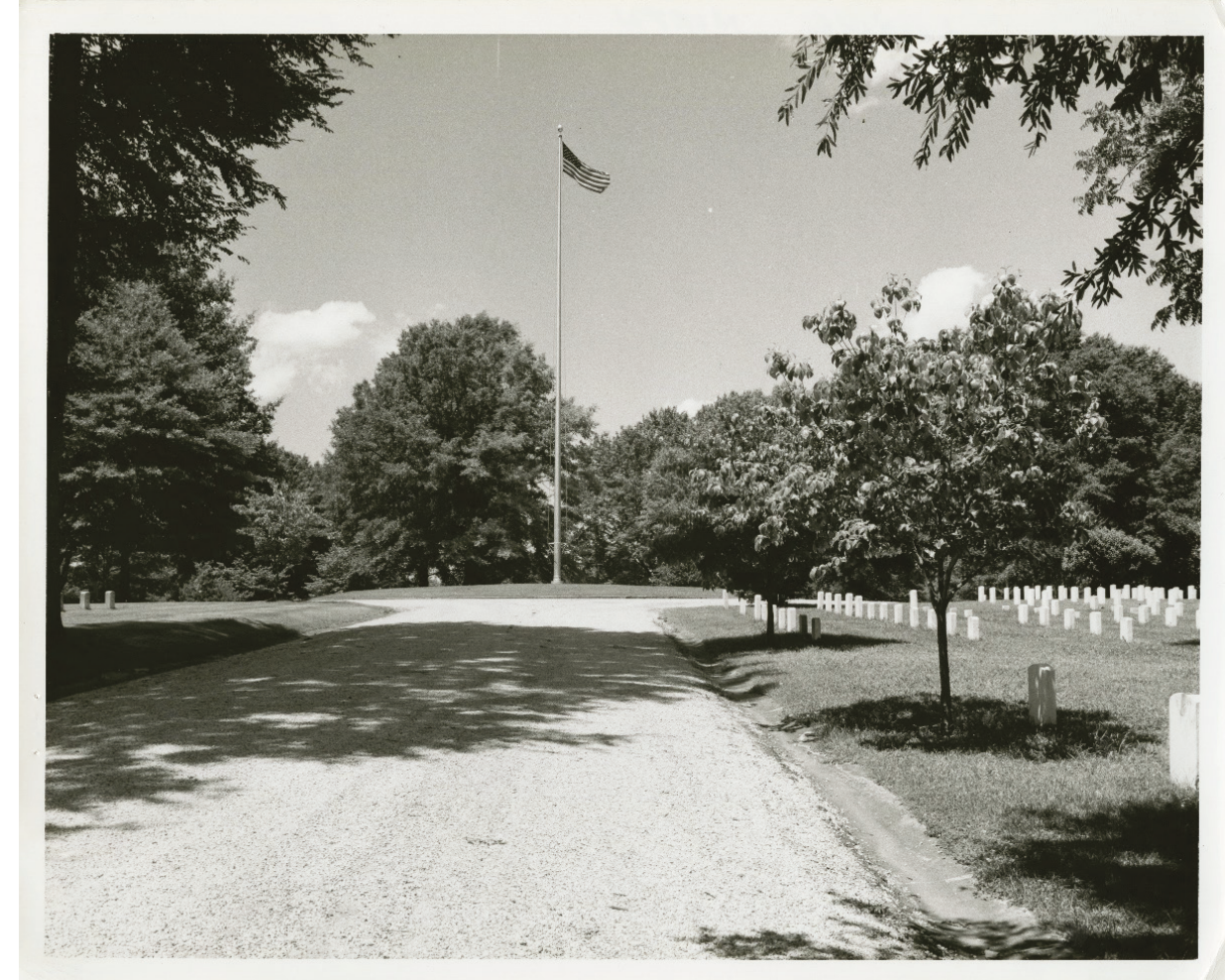

By 2018, a second, shorter flagpole has been placed west of the original main flagstaff in the center of the circle. Figure 245 was taken from the north looking south, and it shows the replacement flagpole in the center and the shorter, additional flagpole to the right. 
Figure 245. View of the flagstaff mound looking south from the north entrance, 2018 (ERDC/CERL).

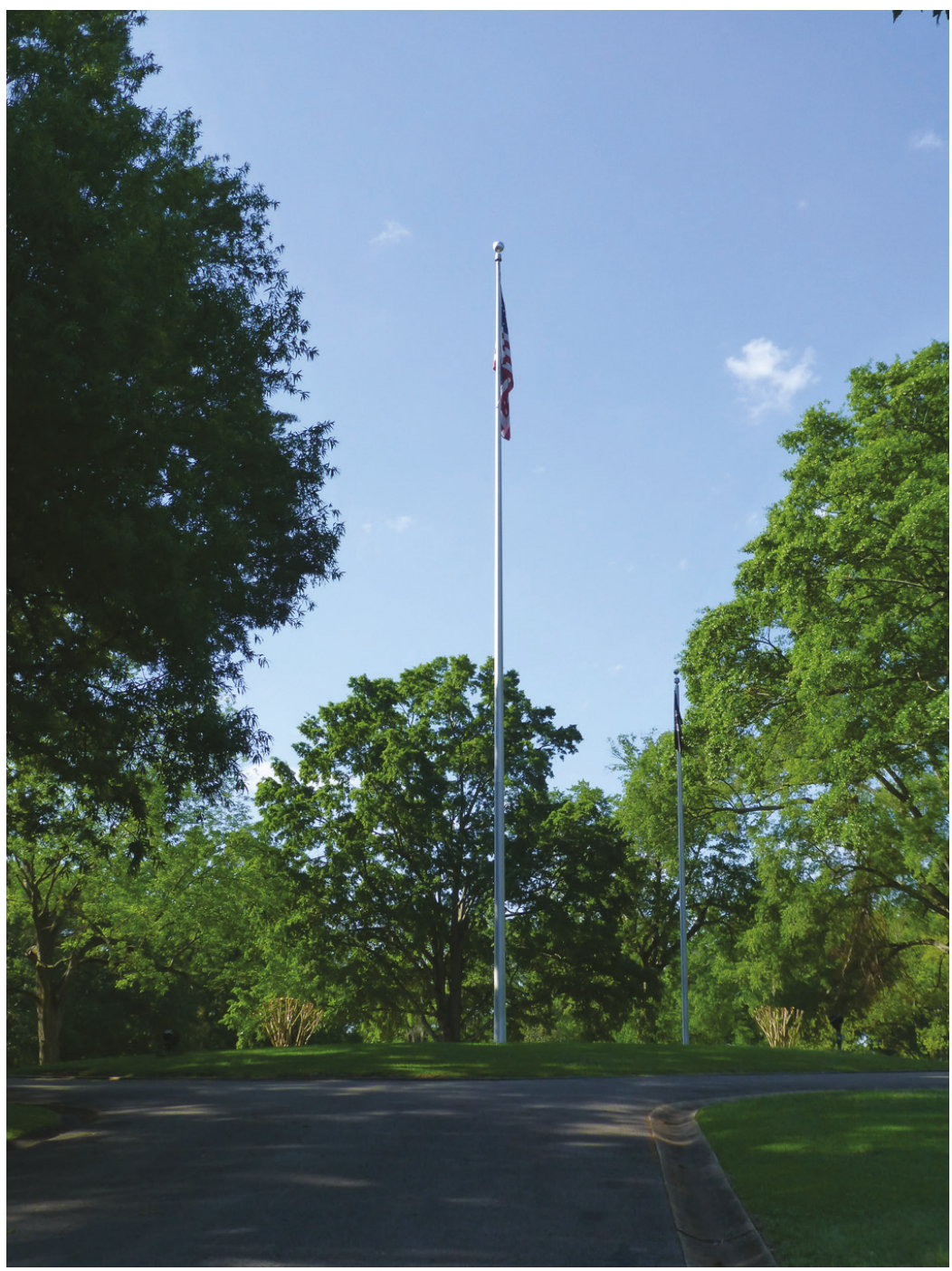

\subsection{Views and viewsheds}

Views of a site and viewsheds through a site are important components of historic landscapes. Views and viewsheds are how all landscape features are seen as a complementary whole. A landscape, such as Corinth National Cemetery, was designed to emphasize certain views of the site that had aesthetic qualities that would make them memorable. Corinth National Cemetery has four historically significant viewsheds: looking north through the main gate toward the flagstaff mound (Figure 246); looking south from the flagstaff mound toward the main gate (Figure 247); looking east toward the lodge (Figure 248); and looking north from where the rostrum was located through an allée of trees (Figure 249). These views show 
the uniform and regularly spaced headstones arrayed over the site's topography and the vegetation that creates areas of shade and light.

Figure 246. View north from the main gate in 1892 and 2018 (NCA archives, Washington, DC and ERDC-CERL).
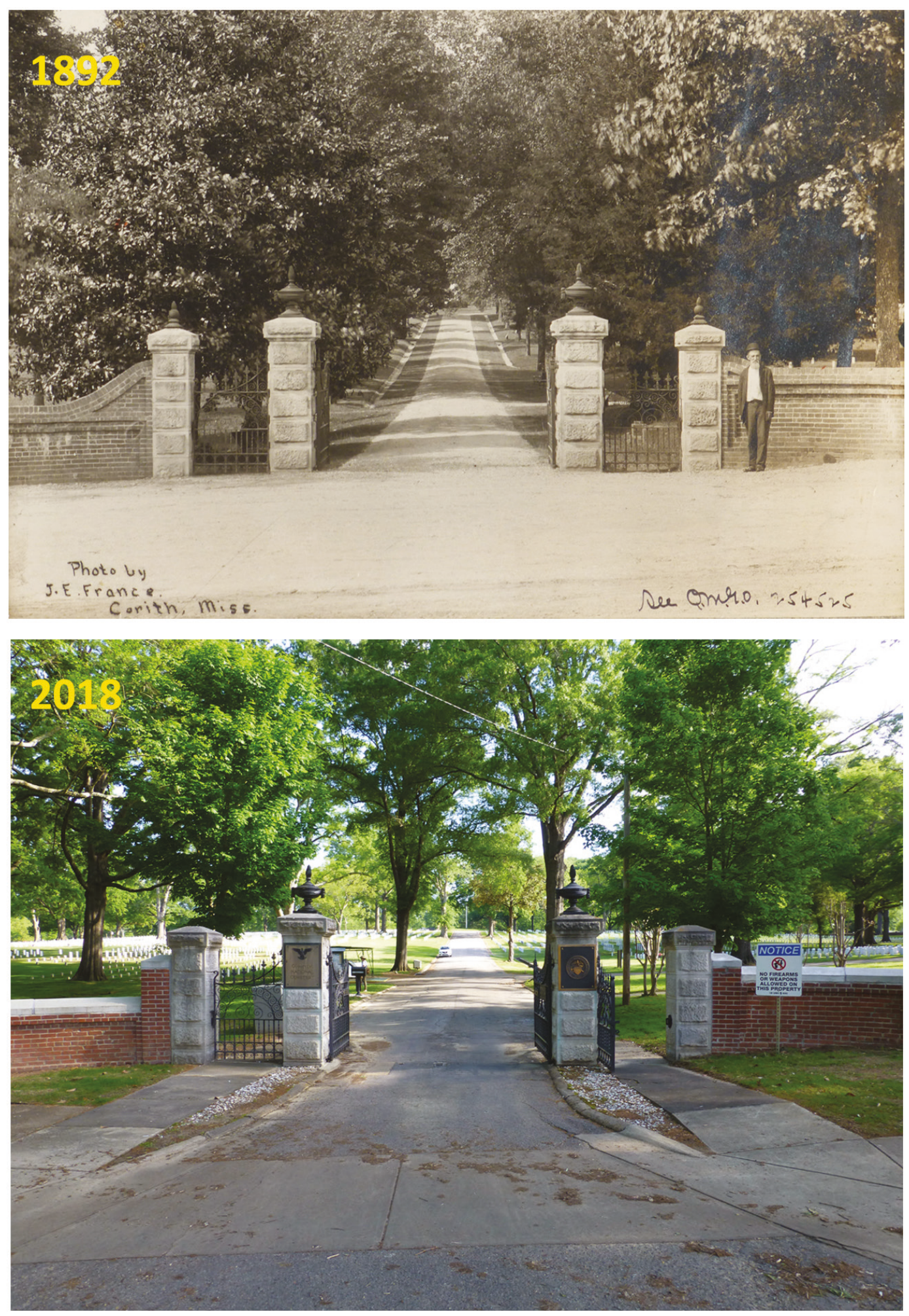
Figure 247. View south from the flagstaff mound toward the main gate in 1963 and 2018 (NCA archives, Washington, DC and ERDC-CERL).
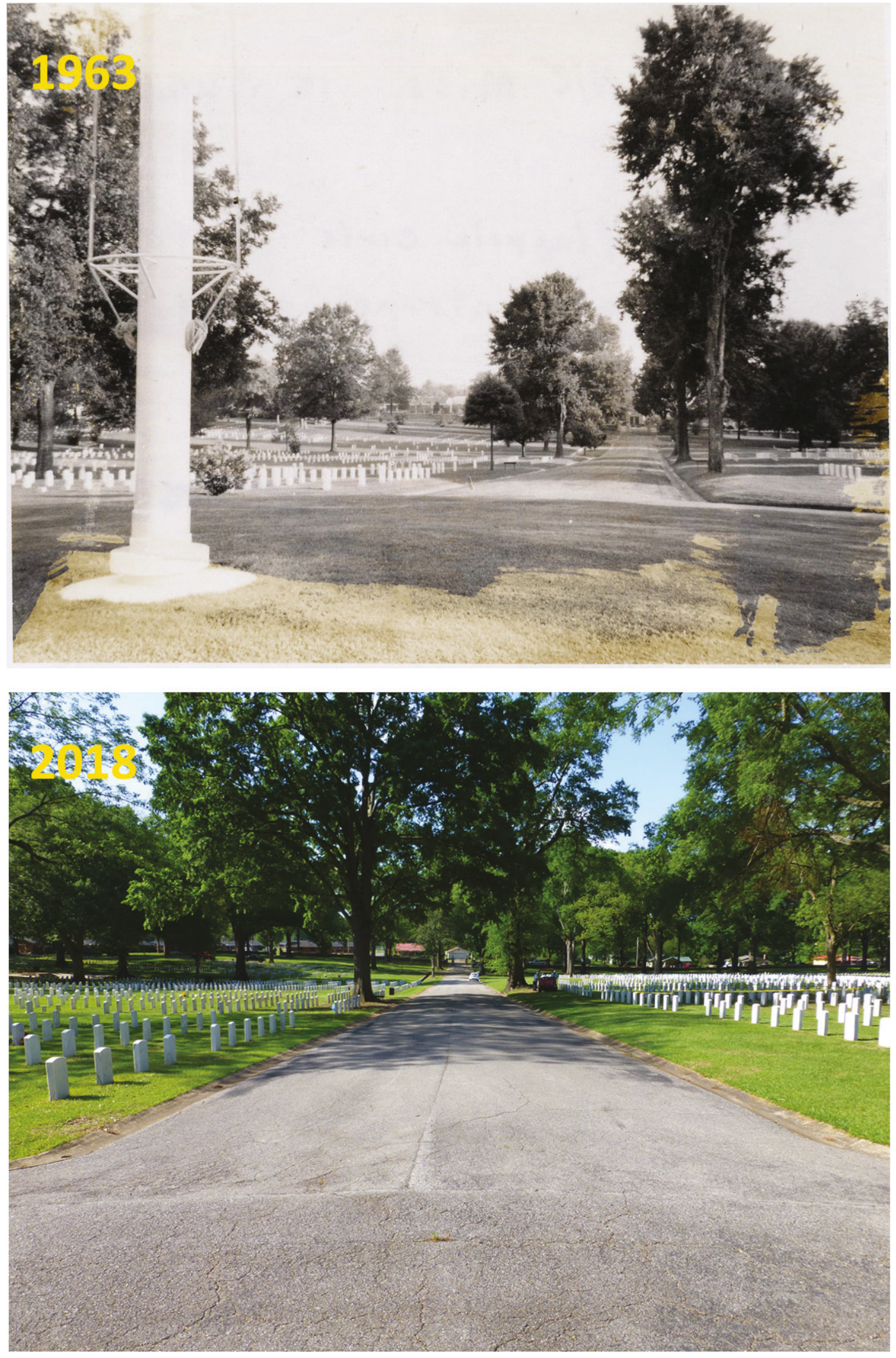
Figure 248. View east from the southwest corner of Corinth National Cemetery toward the lodge in 1892 and 2018 (NCA archives, Washington, DC and ERDC-CERL).
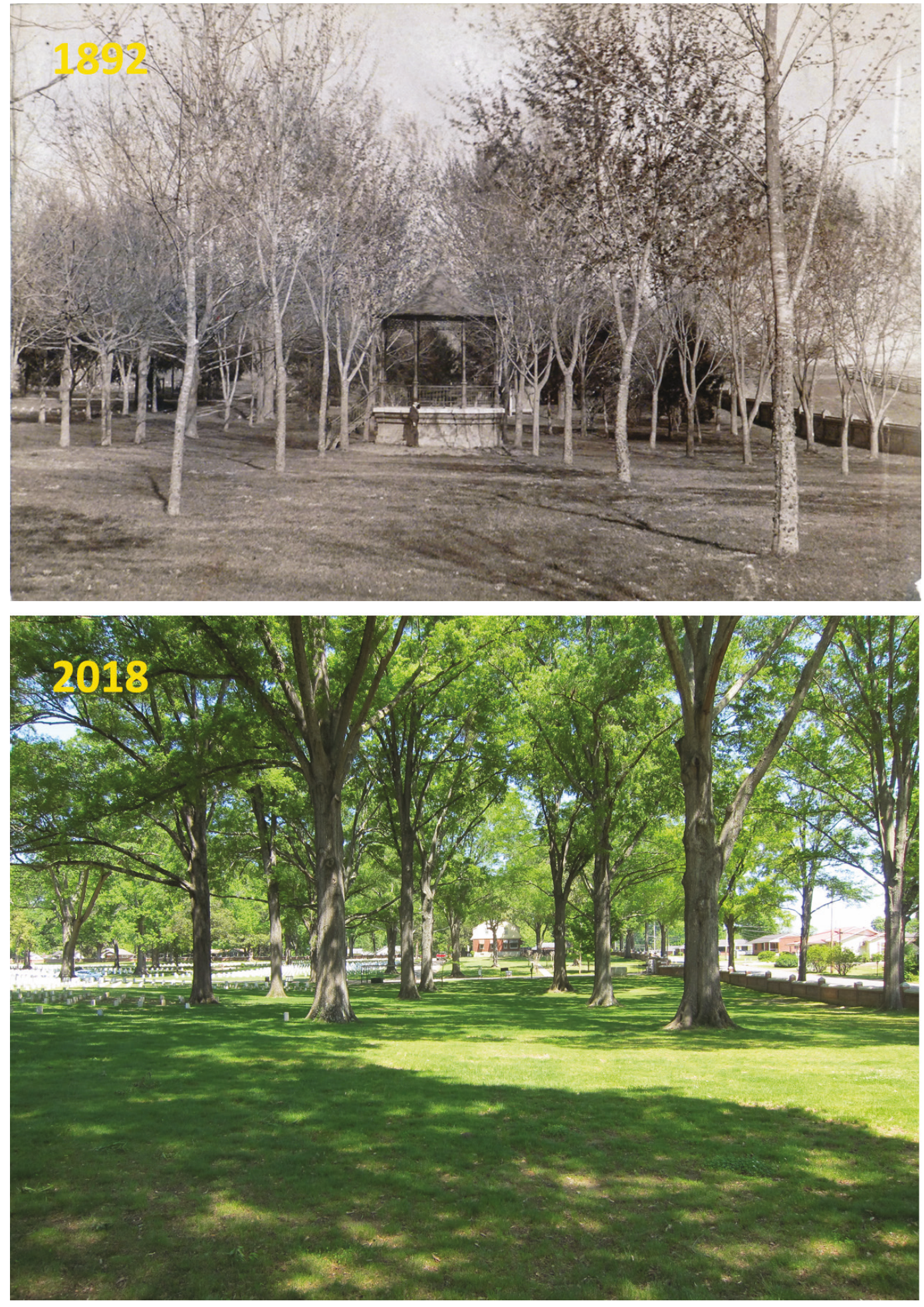
Figure 249. View north across the southwest quadrant between Sections $D$ and $M$ in 1892 and 2018 (NCA archives, Washington, DC and ERDC-CERL).
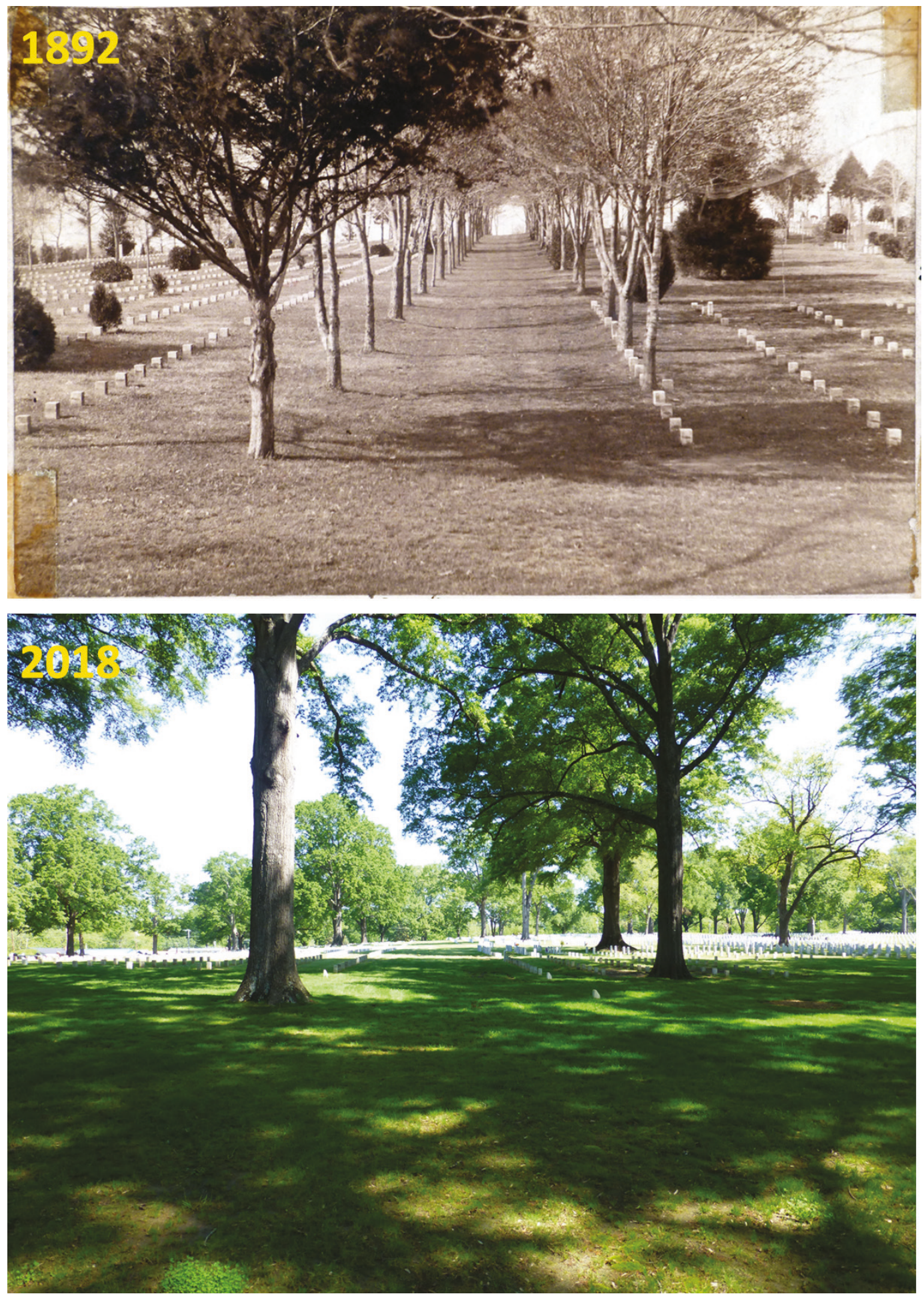
Figure 250. Views from same location showing headstone arrangement from 1892 and 2018 , using outlined photo as the reference point. Note that headstone facing direction has changed from west to east. (NCA archives, Washington, DC and ERDC-CERL).
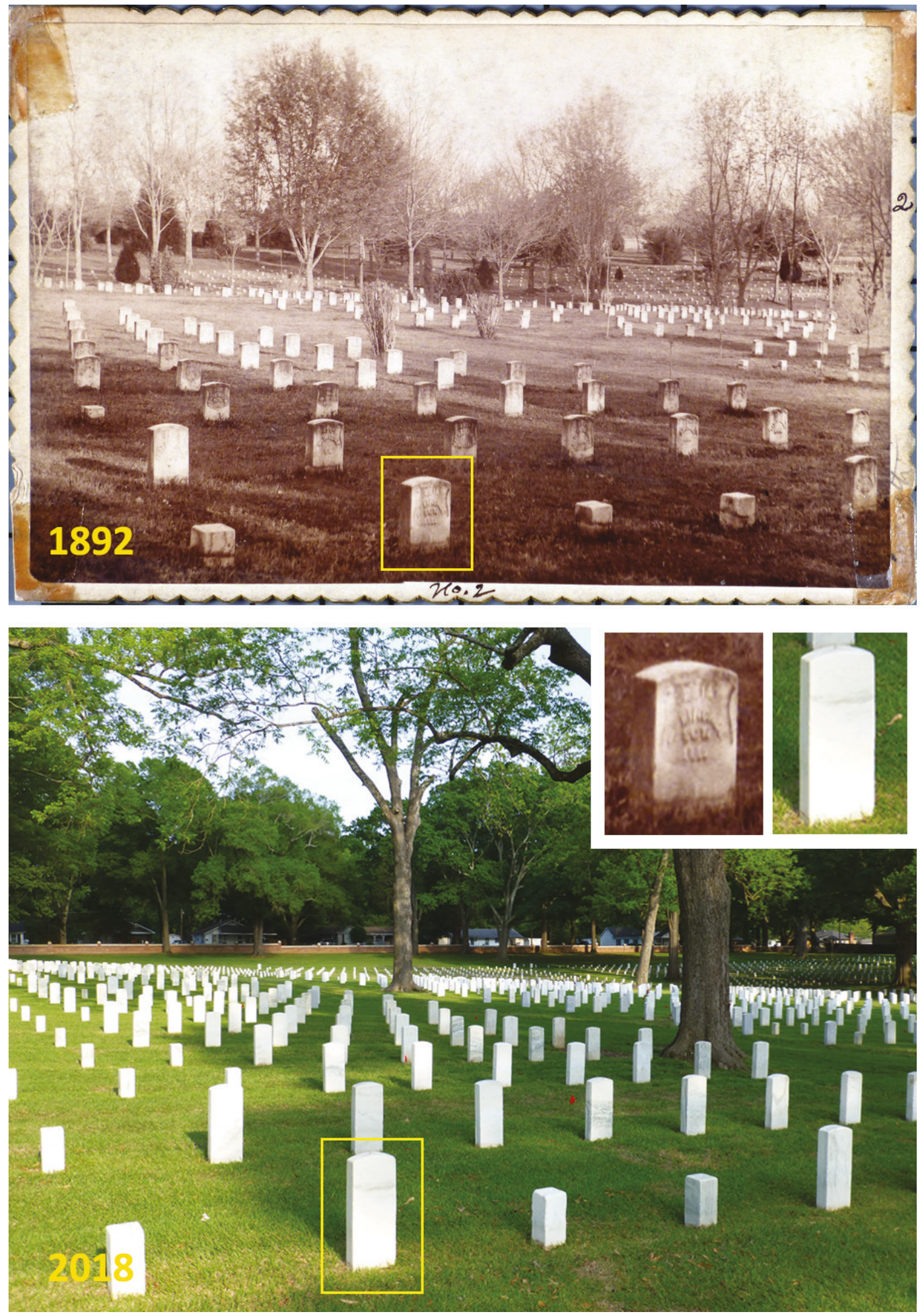
Figure 251. Two photos from another location within cemetery of historic photo from 1892 and a 2018 photo, showing comparison of headstone arrangement, using the outlined headstone as the reference point. Note that headstones were facing west and now face east. (NCA archives, Washington, DC and ERDC-CERL).
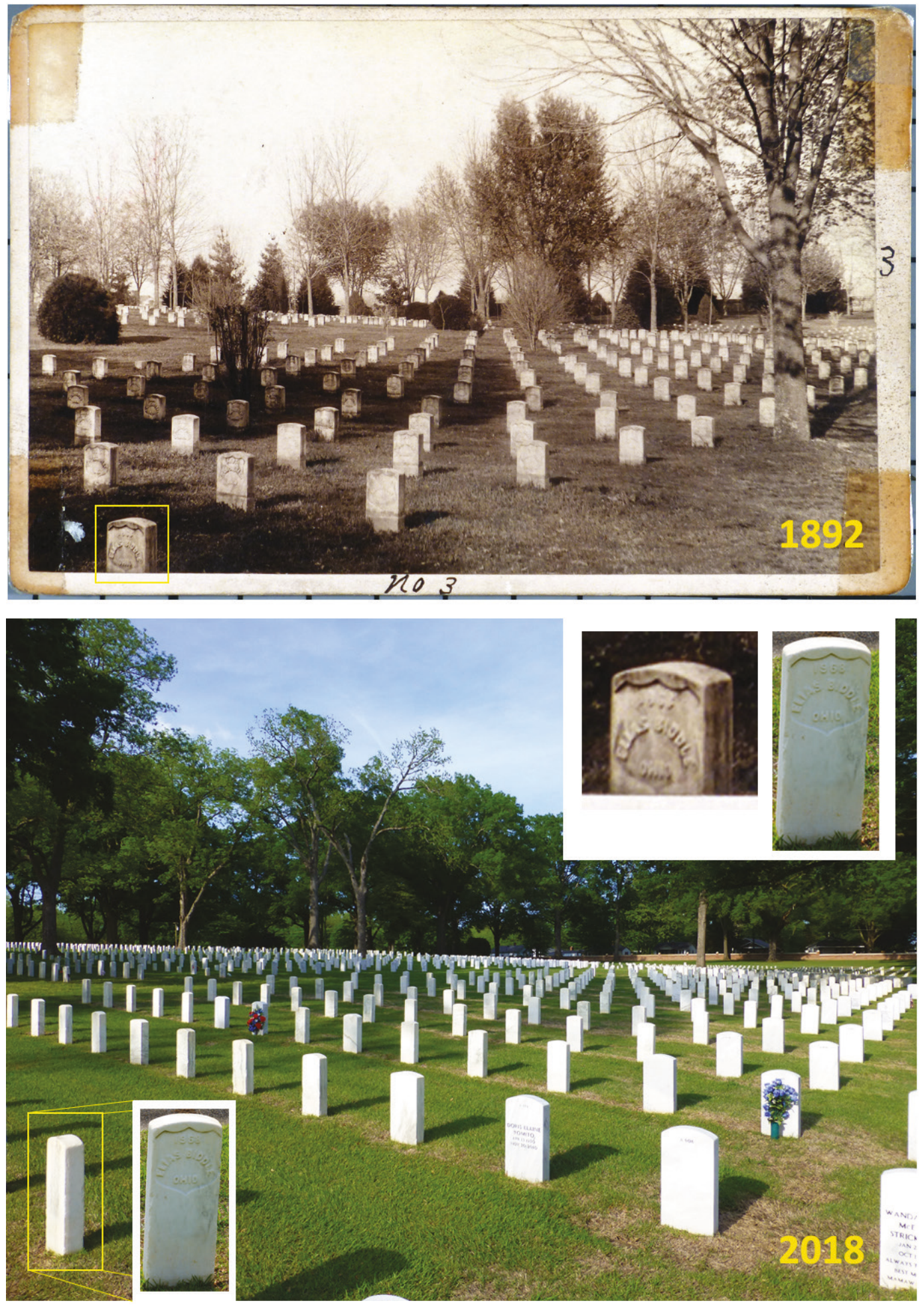


\subsection{Same-scale maps}

The development of Corinth National Cemetery can be read through plans and aerial images of the site. Figure 252 is a sequence of plans starting from left with the initial design proposal in 1864, an undated but similar design to the 1864 design, and then a plan from 1892 that shows the conditions of the cemetery several decades after it was built. Figure 253 is a sequence of aerial images from 1948 through 2015. The aerial images show overall changes to the cemetery landscape through six decades. Note that the 1968 and 1974 images show the site during fall or winter, when the leaves have fallen off the deciduous trees, and this difference makes a vegetation density comparison across the images somewhat difficult. 
Figure 252. Sequence of proposed designs for Corinth National Cemetery in 1864 through a plan of the cemetery in 1892 (NCA archives, Washington, DC).
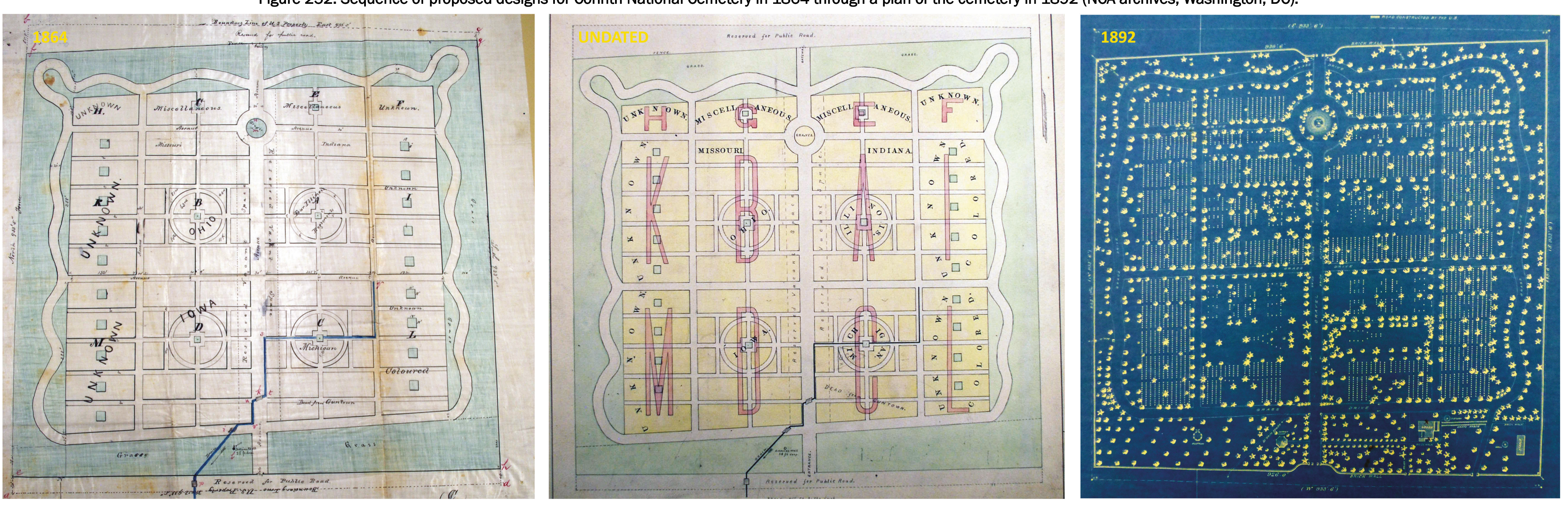
Figure 253. Sequence of aerial images from the late 1940s through 2015 (NCA archives, Washington, DC and Google Earth).

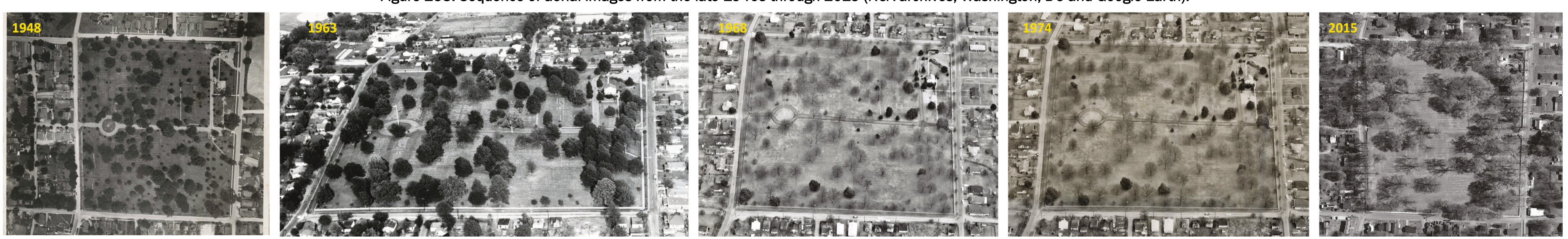




\section{Summary and Recommendations}

\subsection{Landscape features}

The Corinth National Cemetery was designed in 1866; however, the identity of the designer is uncertain. The original design was characterized by a rectangular grid of plots bisected by a north-south axial roadway. The burial plots were surrounded by a curvilinear perimeter roadway. The cemetery was bordered by a brick wall. The service areas were located in the southeast corner of the cemetery. The flagpole was located to the north on the central north-south axis at the highest elevation within the cemetery.

\subsubsection{Character-defining landscape features}

Key character-defining landscape features that reflect the original design intent of the cemetery include the following:

- The organization of programmatic areas within the cemetery: the bereaved support services clustered in the southeast quadrant, the visitor support areas in the southwest quadrant, and the memorial area near the flagpole on the central north-south axis.

- Rectilinear grid layout of the burial sections.

- North-south axial paved roadway that encircles the flagpole.

- Flagpole/flagstaff at the highest point in the cemetery.

- Grass paths that define individual burial sections.

- Deciduous trees arrayed throughout the site, providing areas of shade and the feeling of open and enclosed spaces.

- Uniform and regularly spaced white marble headstones.

- View from the main entrance north toward the flagpole.

- View from the north entrance south toward the flagpole.

- The screening of the service areas from public view due to the Superintendent's Lodge being located close to the main entrance with the maintenance building located behind the lodge. 


\subsubsection{Character-defining buildings and structures}

Key character-defining buildings and structures include the following:

- Superintendent's Lodge (1934, two story building, first floor brick, second floor clad in frame and stucco, gambrel roof)

- Utility building (1936, L-shaped, clad in brick, gable roofs, three garage bays, restrooms)

- Perimeter brick wall (peaked concrete coping along the wall segments and pillars)

- Main entrance gate located on the south wall (four granite piers support ornamented wrought-iron gates).

- North entrance gate located in the north wall (three granite piers that support ornamented wrought-iron gates).

- Pedestrian gate on south wall.

- Service/utility gate on south wall.

- Drainage channel that runs through the cemetery.

\subsection{Landscape treatment}

The Secretary of the Interior is responsible for establishing professional standards and providing advice on the stewardship of cultural resources listed on or as eligible for the NRHP. The Secretary's standards describe four basic approaches to the treatment of historic landscapes. ${ }^{148}$

\subsubsection{Restoration approach}

Restoration is the act or process of accurately depicting the form, features, and character of a property as it appeared at a particular period in time. This process includes reconstruction of missing features from the restoration period and removal of features from all other periods. The approach can be considered only when the property's significance during a particular period of time outweighs the loss of extant elements from other historical periods, and when there is substantial physical and documentary

148 National Park Service, The Secretary of the Interior's Standards for the Treatment of Historic Properties with Guidelines for the Treatment of Cultural Landscapes, edited by Charles A. Birnbaum with Christine Capella Peters. (Washington, DC: U.S. Department of the Interior, National Park Service, 1996), 3. 
evidence for the work, and when contemporary alterations and additions are not planned. 149

Restoration is not an appropriate approach for the Corinth National Cemetery since changes to the cemetery have occurred over an extended period of time (1866-present), and the period of significance extends in perpetuity.

\subsubsection{Reconstruction approach}

Reconstruction is the act or process of using new construction to depict a non-surviving site, landscape, building, structure, or object as it appeared at a specific period of time and in its historic location. The approach is appropriate only when the property's significance during a particular period of time outweighs the potential loss of extant features that characterize other historical periods. In addition, there must be substantial physical and documentary evidence for the work, and the work must be clearly identified as a contemporary re-creation. ${ }^{150}$

Reconstruction is a viable path for maintaining the Corinth National Cemetery since this report contains sufficient documentary evidence to reconstruct elements of the landscape that have changed or have been removed from the cemetery over the years-particularly the removed trees, allée of trees, shrubs, and other landscaping features such as benches and paving materials.

\subsubsection{Preservation approach}

Preservation involves applying measures to sustain the existing form, integrity, and materials of a historic property. This approach focuses on stabilizing and protecting extant historic resources, rather than replacing missing elements. It is appropriate when a historic property is essentially intact and does not require extensive repair or replacement; depiction at one particular period of time is not appropriate; and when continuing or new use does not require additions or alterations. ${ }^{151}$

\footnotetext{
149 NPS, The Secretary of the Interior's Standards, 1996, 89-90.

150 NPS, The Secretary of the Interior's Standards, 1996, 127-129.

151 NPS, The Secretary of the Interior's Standards, 1996, 17-18.
} 
Preservation is a potential management treatment for the Corinth $\mathrm{Na}-$ tional Cemetery due to the large amount of intact resources.

\subsubsection{Rehabilitation approach}

Rehabilitation allows repairs, alterations, and additions necessary to enable a compatible use for a property as long as the portions or features which convey the historical, cultural, or architectural values are preserved. This approach is appropriate when depiction at one particular period of time is not appropriate, repair or replacement of deteriorated features is necessary, and alterations or additions are needed for a new use. ${ }^{152}$

Rehabilitation is appropriate for Corinth National Cemetery as the landscape has changed over time, and repair/replacement has historically been necessary, particularly the brick perimeter wall.

\subsection{Management issues and recommendations}

The Corinth National Cemetery is federally owned and operated by the NCA, and the cemetery is listed on the NRHP and also is part of a National Historic Landmark district. As such, the NCA consults for all undertakings that affect the cemetery with the State of Mississippi Department of Archives and History (MDAH) Historic Preservation Division (HPD) and the National Historic Landmarks Program of the National Park Service. The HPD serves as the State Historic Preservation Officer (SHPO) for consultation purposes.

\subsubsection{Management issues}

Current landscape management issues include the following:

- Visitors are unaware of the landscape design history of the cemetery.

- Current policy of not replacing trees in-kind has negatively impacted the design and feel of the cemetery, especially between the burial sections and the perimeter wall.

- Removal of allée of trees has negatively impacted viewsheds of the grass paths.

- Filling in of grass paths with burial plots has negatively impacted the central grid of plots and the grass paths that define them.

152 NPS, The Secretary of the Interior's Standards, 1996, 47-48. 
- Removal of hedges and shrubs has negatively impacted the design and feel of the cemetery.

- Lack of plan listing tree species and age and estimated replacement date.

- Tree removal without replacement has led to a lack of tree diversity, and a lack of diversity can lead to massive loss from disease and/or pests.

- Lack of seating areas, which were provided historically.

- Lack of consistent signage in both placement and visual continuity.

- Seeming lack of a monuments and memorials placement plan/protocol and design standards.

- The vacancy of the Lodge detracts from the cemetery's story, whether used as office space or as a residence.

- Lack of a rostrum for a cemetery that previously had one also detracts from the cemetery's story.

\subsubsection{Historic landscape recommendations}

The following actions are recommended to address the issues outlined above in section 6.3.1:

- Locate future service buildings as near to current service buildings as possible.

- Develop a memorial and monument location plan.

- Develop a management plan that preserves the historic characteristics of the cemetery landscape and its features.

- Develop a planting plan based on historic vegetation planting patterns and plans.

- Review tree removal policy and consider renewing tree planting efforts.

- Review the Section 106 consultation procedures to make sure all undertakings that affect the landscape are included in the consultation process.

- Establish consistent maintenance guidelines for all buildings, structures, and objects.

- Develop a master plan for the next 25-year period.

- Update NCA real property and heritage asset list with corrected construction dates and NRHP eligibility codes.

- Find a use for the Lodge that will occupy the structure.

- Consider reconstructing the rostrum in its original location. 


\section{Bibliography}

\section{Publications}

Alcorn County Historical Association, The History of Alcorn County Mississippi, (Dallas, TX: National ShareGraphics, Inc., 1983), 18.

Article in The Weekly Clarion, 1 November 1866.153

"Congressman Candler Seeks Improvements for Local Cemetery," The Weekly Corinthian, 20 January 1916.

“Corinth National Cemetery." https://www.cem.va.gov/cems/nchp/corinth.asp.

The Grenada Sentinel, 25 December 1886.

Michael R. Harrison (historian), "National Cemeteries, Superintendent's Lodges," Historic American Buildings Survey (HABS) No. DC-46, (Washington, DC: National Park Service, 2013), 6, 17.

Michael R. Harrison (historian), "National Cemeteries, Rostrums," Historic American Buildings Survey (HABS) No. DC-47, (Washington, DC National Park Service, 2013), 28;

Hawke, Paul, Cecil McKithan, Tom Hensley, Jack Elliot, and Edwin C. Bearss. "Siege and Battle of Corinth Sites." National Register of Historic Places National Historic Landmark Nomination Form. Washington, DC: National Park Service, 1991.

Johnston, Jebb. “Toppled Tribute." Daily Corinthian, 23 June 2000, 1A-2A, in Corinth Vertical File, Washington, DC: National Cemetery Administration, U.S.

Department of Veterans Affairs.

Johnston, Jebb. "Work on Walls Surrounding Corinth National Cemetery is Completed." Daily Corinthian, 14 December 2001, 1A-2A. Washington, DC: Corinth Vertical File, National Cemetery Administration, U.S. Department of Veterans Affairs.

National Cemetery Administration. "150 th Anniversary National Cemeteries of the Civil War 2012 planner.” Washington, DC: National Cemetery Administration, U.S. Department of Veterans Affairs, 2011.

National Cemetery Administration. "Bivouac of the Dead." Washington, DC: National Cemetery Administration website, last updated 2015. https://www.cem.va.gov/history/bivouac.asp.

National Cemetery Administration. "History of Government Furnished Headstones and Markers." Washington, DC: National Cemetery Administration, U.S. Department of Veterans Affairs, 2015. https://www.cem.va.gov/history/hmhist.asp.

\footnotetext{
153 It should be noted that in some instances of newspapers from this era, articles were untitled and thus, no further information is available.
} 
National Cemetery Administration. "New Gettysburg Address Tablets for National Cemeteries to Honor Abraham Lincoln Bicentennial." Washington, DC: U.S. Department of Veterans Affairs, National Cemetery Administration, last updated 2015. https://www.cem.va.gov/history/LincBic.asp.

Navy Seabee Veterans of America. "Seabee Monument in Every National Cemetery Project." Can Do 28:3, 10. September 2018. https://www.nsva.org/pdf/CANDO.pdf.

NRHP (National Register of Historic Places). "National Register Eligibility of National Cemeteries-a Clarification of Policy." Washington, DC: NRHP, o8 September 2011.

https://www.cem.va.gov/CEM/pdf/Final Eligibility of VA cemeteries A Clarification of Policy rev.pdf.

Sammartino, Therese T. "Corinth National Cemetery." National Register of Historic Places nomination form. Washington, DC: National Park Service, 1996.

U.S. Secretary of War. “Annual Report of the Secretary of War." Report before the 43rd Congress, 1st Session. Ex. Doc. No. 1, Part 6. Washington, DC: Government Printing Office, 1873.

U.S. Department of Veterans Affairs. "Corinth National Cemetery: Historic Wall Repair, Reconstruction, and Restoration, Bid Documents.” Washington, DC: archival collection of the National Cemetery Administration, U.S. Department of Veterans Affairs, 12 March 2012.

Webb, Sandra M. "Corinth National Cemetery National Register of Historic Places Inventory - Nomination Form.” Draft, 8. Washington, DC: In Corinth Vertical File, National Cemetery Administration, U.S. Department of Veterans Affairs, 1974 .

\section{Archival resources}

\section{NARA}

Bingham to Quartermaster General. Letter in Record Group 92, Entry 576, Box 22. Washington, DC: NARA, 19 November 1881.

Carlton, Major C.H. 3rd Cavalry. Letter to Quartermaster General, in Record Group 92, Entry 576, Box 22. Washington, DC: NARA, 19 November 1881.

Dickey, James M., Superintendent, Corinth National Cemetery. Inspection report to Quartermaster General, Record Group 92, Entry 576, Box 23. Washington, DC: NARA, 18 January 1889.

Dickey, James M., Superintendent. "Status Report, Corinth National Cemetery," Record Group 92, Entry 576, Box 22. Washington, DC: NARA, 18 March 1909.

Dickey, James M., Superintendent, Corinth National Cemetery. Letter to the Chief Quartermaster, Department of the Gulf, Atlanta, GA. College Park, MD, 10 August 1909. 
Folsom, Brevet Colonel C. W., Assistant Quartermaster. "Report of an Inspection Made of Cemeterial Operations at Corinth, Mississippi," Record Group 92, Entry 576, Box 22. Washington, DC: NARA, 5 August 1867.

Gall Jr., James, Civil Engineer, War Department. Letter to Acting Quartermaster General, Record Group 92, Entry 576, Box 23. Washington, DC: NARA, 10 February 1876.

Gall Jr., James, Civil Engineer, War Department. Letter to Quartermaster General, in Record Group 92, Entry 576, Box 23. Washington, DC: NARA, 12 October 1874.

Gall Jr., James, Civil Engineer. Letter to General Benjamin C. Card, in Record Group 92, Entry 576, Box 23. Washington, DC: NARA, 8 January 1882.

Gall Jr., James, Civil Engineer. Letter to General Benjamin C. Card, Record Group 92, Entry 576, Box 22. Washington, DC: NARA, 25 March 1882.

Gall Jr., James, Civil Engineer. Letter to Acting Quartermaster General, Record Group 92, Entry 576, Box 22. Washington, DC: NARA, 10 April 1883.

Holabird, S.B., Quartermaster General. Letter to Major E.B. Kirk, Quartermaster, in Record Group 92, Entry 576, Box 22. Washington, DC: NARA, 31 October 1888.

“Inspection Report," Record Group 92, Entry 576, Box 23. Washington, DC: NARA, 25 June 1874 .

“Inspection Report," Record Group 92, Entry 576, Box 23. Washington, DC: NARA, November 1867.

Mack, Major Oscar A., Inspector National Cemeteries. Letter to Quartermaster General, in Record Group 92, Entry 576, Box 23. Washington, DC: NARA, 3 June 1873.

McGonnigle, Captain A. J., Depot Quartermaster, New Orleans, Louisiana. Letter to Quartermaster General, Record Group 92, Entry 576, Box 22. Washington, DC: NARA, 16 May 1881.

"National Cemetery Corinth Miss." Report circa 1968 or 1869, Record Group 92, Entry 576, Box 23. Washington, DC: NARA, undated.

Owen, W.H., Civil Engineer, Quartermaster Department. Letter to Lieutenant Colonel C.G. Sawtelle, Deputy Quartermaster General, in Record Group 92, Entry 576, Box 22. Washington, DC: NARA, 10 January 1888.

Owen, W. H. Letter to Quartermaster General, in Record Group 92, Entry 576, Box 22. Washington, DC: NARA, 16 January 1888.

Owen, W. H. Letter to Quartermaster General, Record Group 92, Entry 576, Box 22. Washington, DC: NARA, 14 May 1888.

Owen, W. H., Civil Engineer, Quartermaster Department. Letter to Quartermaster General, Record Group 92, Entry 576, Box 23. Washington, DC: NARA, 21 May 1888. 
Owen, W. H., Civil Engineer, Quartermaster Department, letter to Quartermaster General, in Record Group 92, Entry 576, Box 22. Washington, DC: NARA, 22 October 1888.

(Deputy) Quartermaster General, letter to Major E.B. Kirk, Quartermaster, in Record Group 92, Entry 576, Box 22. Washington, DC: NARA, 17 August 1888.

Quartermaster General's Office. Memo, Record Group 92, Entry 576, Box 23. Washington, DC: NARA, 25 March 1874.

Quartermaster General's Office, letter to Major E. B. Kirk, Quartermaster, Record Group 92, Entry 576, Box 22. Washington, DC: NARA, 22 March 1888.

"Repair of Wall and Drainage of Cellar at Corinth National Cemetery." Report in Record Group 92, Entry 576, Box 23. Washington, DC: NARA, DC, 25 March 1874.

Scully, J.W., Quartermaster. Letter to Quartermaster General, Record Group 92, Entry 576, Box 22. Washington, DC: NARA, 20 September 1890.

Superintendent, Corinth National Cemetery. Communication to Lt. K.B. Sarson, Huntsville, Alabama, Record Group 92, Entry 576, Box 23. Washington, DC: NARA, 22 May 1874.

Whitman, Brevet Major E. B., Assistant Quarter Master, "Reports on National Cemeteries, Department of the Cumberland, No. 6 Corinth, Miss.," Record Group 92, Entry 576, Box 22. Washington, DC: NARA, 4 November 1867.

Whitman, Colonel E.B. Letter to Brevet Major General Thomas Swords, Record Group 92, Entry 576, Box 22. Washington, DC: NARA, 5 August 1968.

\section{National Cemetery Administration collection}

"Cistern House, U.S. National Cemetery, Corinth, Mississippi." Real Property form, Corinth National Cemetery records. Washington, DC: NCA, U.S. Department of Veterans Affairs, 1932.

Clemons, John W., Superintendent. "Memorandum: Lighting of Flagpole," in Corinth Vertical File. Washington, DC: NCA, U.S. Department of Veterans Affairs, 30 September 1974 .

"Corinth National Cemetery." Typed manuscript in Corinth Vertical File, Washington, DC: NCA, U.S. Department of Veterans Affairs, undated.

"Corinth National Cemetery." Inspection report, in Corinth Vertical File. Washington, DC: NCA, U.S. Department of Veterans Affairs, 25 July 1959.

Enclosing Wall, U.S. National Cemetery, Corinth, Mississippi.” Real Property form, Corinth National Cemetery records. Washington, DC: NCA, U.S. Department of Veterans Affairs, 1965. 
"Entrance Gates, U.S. National Cemetery, Corinth, Mississippi." Real Property form, Corinth National Cemetery records. Washington, DC: NCA, U.S. Department of Veterans Affairs, 1960.

"Flagpole, U.S. National Cemetery, Corinth, Mississippi." Real Property form, Corinth National Cemetery records. Washington, DC: NCA, U.S. Department of Veterans Affairs, 1941.

"Flagpole, U.S. National Cemetery, Corinth, Mississippi." Real Property form, Corinth National Cemetery records, Washington, DC: NCA, U.S. Department of Veterans Affairs, 1958.

“Grounds, U.S. National Cemetery, Corinth, Mississippi.” Real Property form, Corinth National Cemetery records. Washington, DC: NCA, U.S. Department of Veterans Affairs, 1952.

"Grounds, U.S. National Cemetery, Corinth, Mississippi." Real Property form, Corinth National Cemetery records. Washington, DC: NCA, U.S. Department of Veterans Affairs, 1960.Historic American Landscapes Survey, "Lodges and Rostrums Data Recorded by HALS,” Excel spreadsheet, Washington, DC: NCA, U.S. Department of Veterans Affairs, as saved in 2015 by authors.

“Lodge, U.S. National Cemetery, Corinth, Mississippi.” Real Property form, Corinth National Cemetery records. Washington, DC: NCA, U.S. Department of Veterans Affairs, 1941.

“Lodge, U.S. National Cemetery, Corinth, Mississippi." Real Property form, Corinth National Cemetery records. Washington, DC: NCA, U.S. Department of Veterans Affairs, 1952.

"Lodge, U.S. National Cemetery, Corinth, Mississippi." Real Property form, Corinth Washington, DC: NCA, U.S. Department of Veterans Affairs, 1964.

Maynard, Mark E. "Corinth National Cemetery.” Visitor handout, in Corinth Vertical File, Washington, DC: NCA, U.S. Department of Veterans Affairs, undated.

"National Cemetery Data: Corinth." Real Property form, Corinth National Cemetery records. Washington, DC: NCA, U.S. Department of Veterans Affairs.

"Oil House, U.S. National Cemetery, Corinth, Mississippi." Real Property form, Corinth National Cemetery records. Washington, DC: NCA, U.S. Department of Veterans Affairs, 1933.

"Roads and Walks, U.S. National Cemetery, Corinth, Mississippi." Real Property form, Corinth National Cemetery records. Washington, DC: NCA, U.S. Department of Veterans Affairs, 1960.

"Road Repairs G.O.E. Maintenance \& Repairs - 1985." Veterans Administration plan. Washington, DC: NCA, U.S. Department of Veterans Affairs, 1985.

"Rostrum, U.S. National Cemetery, Corinth, Mississippi.” Real Property form, Corinth National Cemetery records. Washington, DC: NCA, U.S. Department of Veterans Affairs, 1941. 
"Stable, Tool House \& Public Toilet, U.S. National Cemetery, Corinth, Mississippi." Real Property form, Corinth National Cemetery records, Washington, DC: NCA, U.S. Department of Veterans Affairs, 1932.

United States War Department. "Corinth National Cemetery, Mississippi," Real Property report.in Corinth Vertical File. Washington, DC: NCA, U.S. Department of Veterans Affairs, 4 August 1937.

"Utility Building, U.S. National Cemetery, Corinth, Mississippi." Real Property form, Corinth National Cemetery records. Washington, DC: NCA, U.S. Department of Veterans Affairs, 1955. 


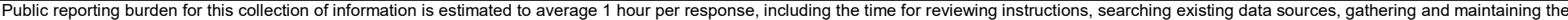

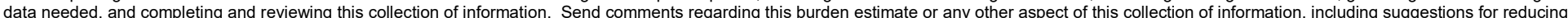

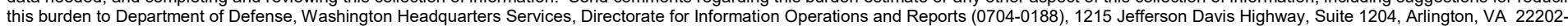

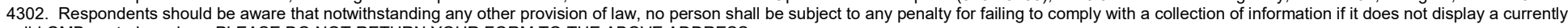
valid OMB control number. PLEASE DO NOT RETURN YOUR FORM TO THE ABOVE ADDRESS.
1. REPORT DATE (DD-MM-YYYY)
December 2018

\section{REPORT TYPE Final}

4. TITLE AND SUBTITLE

Historic Landscape Inventory for Corinth National Cemetery

3. DATES COVERED (From - To)

5a. CONTRACT NUMBER

5b. GRANT NUMBER

5c. PROGRAM ELEMENT NUMBER

5d. PROJECT NUMBER

H63F54

5e. TASK NUMBER

\section{5f. WORK UNIT NUMBER}

8. PERFORMING ORGANIZATION REPORT NUMBER

U.S. Army Engineer Research and Development Center (ERDC)

Construction Engineering Research Laboratory (CERL)

ERDC/CERL TR-18-37

PO Box 9005

Champaign, IL 61826-9005

\section{SPONSORING / MONITORING AGENCY NAME(S) AND ADDRESS(ES)}

U.S. Department of Veterans Affairs

National Cemetery Administration

Washington, DC 20420

11. SPONSOR/MONITOR'S REPORT NUMBER(S)

\section{DISTRIBUTION / AVAILABILITY STATEMENT}

Approved for public release. Distribution is unlimited.

\section{SUPPLEMENTARY NOTES}

\section{ABSTRACT}

This project was undertaken to provide the U.S. Department of Veterans Affairs National Cemetery Administration with a cultural landscape survey of Corinth National Cemetery. The 20-acre cemetery is located within the city limits of Corinth, Mississippi, and contains 7,892 burials. Corinth National Cemetery was placed on the National Register of Historic Places on 20 November 1996, as part of a multiple-property submission for Civil War Era National Cemeteries.

The National Cemetery Administration tasked the U.S. Army Engineer Research and Development Center-Construction Engineering Research Laboratory (ERDC-CERL) to inventory and assess the cultural landscape at Corinth National Cemetery through creation of a landscape development context, a description of current conditions, and an analysis of changes over time to the cultural landscape. All landscape features were included in the survey because according to federal policy on National Cemeteries, all national cemetery landscape features are considered to be contributing elements.

\section{SUBJECT TERMS}

National cemeteries--United States, Corinth (Miss.), Historic preservation, Landscape protection, Cultural property--Protection

\begin{tabular}{|c|c|c|}
\hline \multicolumn{3}{|c|}{ 16. SECURITY CLASSIFICATION OF: } \\
\hline $\begin{array}{l}\text { a. REPORT } \\
\text { Unclassified }\end{array}$ & $\begin{array}{l}\text { b. ABSTRACT } \\
\text { Unclassified }\end{array}$ & $\begin{array}{l}\text { c. THIS PAGE } \\
\text { Unclassified }\end{array}$ \\
\hline
\end{tabular}

\begin{tabular}{|c|c|c|}
$\begin{array}{c}\text { 17. LIMITATION } \\
\text { OF ABSTRACT }\end{array}$ & $\begin{array}{c}\text { 18. NUMBER } \\
\text { OF PAGES }\end{array}$ & 1 \\
& & \\
UU & 290 & $19 b$ \\
\end{tabular}

19a. NAME OF RESPONSIBLE PERSON

19b. TELEPHONE NUMBER (include area code) 